МІНІСТЕРСТВО ОСВІТИ І НАУКИ УКРАЇНИ

Харківський національний економічний університет імені Семена Кузнеця

MINISTRY OF EDUCATION AND SCIENCE OF UKRAINE

Simon Kuznets Kharkiv National University of Economics

\title{
ПСИХОЛОГО-ПЕДАГОГІЧНІ ПРОБЛЕМИ СТАНОВЛЕННЯ СУЧАСНОГО ФАХІВЦЯ
}

Збірник наукових статей

Матеріали міжнародної науково-практичної конференції (Україна, Харків, 11 - 12 червня, 2014 р.)

\section{PSYCHOLOGICAL AND PEDAGOGICAL PROBLEMS OF MODERN SPECIALIST FORMATION}

Collected articles

Materials of international scientific and practical conference

(11 - 12 June, 2014, Kharkiv, Ukraine)

Харків

"ХОГОКЗ"

2014 
УДК [37.015.3:167.1]-043.83-057.4(06)

ББК 88.40я431+88.840я431

П 86

Рекомендовано Вченою радою

Харківського національного економічного університету імені Семена Кузнеця (протокол № 09 від 22.04.2014 р.)

\section{Редакційна колегія:}

Колбіна Т. В. - д-р пед. наук, проф., завідувач кафедри іноземних мов та перекладу Харківського національного економічного університету (голова); Мельник Ю. Б. канд. пед. наук, доц., проф. кафедри військового навчання та виховання Академії внутрішніх військ МВС України (заступник голови); Бойчук Ю. Д. - д-р пед. наук, проф., завідувач кафедри здоров'я людини та корекційної освіти Харківського національного педагогічного університету імені Г.С. Сковороди, Україна; Большакова А. М. - д-р психол. наук, проф., завідувач кафедри соціальної психології Харківської державної академії культури, Україна; Борова Т. А. - д-р пед. наук. проф., завідувач кафедри іноземних мов Харківського національного економічного університету імені Семена Кузнеця, Україна; Галагузова М. А. - д-р пед. наук, проф., проф. кафедры социальной педагогики Института социального образования «Уральский государственный педагогический университет», Россия; Гриценко В. В. - д-р психол. наук, проф., заведующий кафедрой общей и социальной психологии Смоленского гуманитарного университета, Россия; Дмитренко Т. О. - д-р пед. наук, проф., проф. кафедри соціальної роботи та соціальної педагогіки Херсонського державного університету, Україна; Землянська О. В. - д-р психол. наук, проф., проф. кафедри соціології та психології факультету права та масових комунікацій ХНУВС, Україна; Искакова Л. Т. - д-р пед. наук, проф., директор филиала акционерного общества «Национальный центр повышения квалификации «Өрлеу», институт повышения квалификации педагогических работников по Южно-Казахстанской области, Казахстан; Кайдалова Л. Г. - д-р пед. наук, проф., завідувач кафедри педагогіки та психології Національного фармацевтичного університету, Україна; Нагаєв В. М. - д-р пед. наук, проф., директор Харківського наукового центру дидактики менеджмент-освіти, Україна; Пелепейченко Л. М. - д-р філол. наук, проф., проф. кафедри філології, перекладу та мовної комунікації Академії внутрішніх військ МВС України; Самохвалов В. Г. - д-р мед. наук, проф., завідувач кафедри фізіології Харківського національного медичного університету, Україна.

Психолого-педагогічні проблеми становлення сучасного фахівця : зб. наук. ст.,

П 86 матеріали міжнар. наук.-практ. конф., 11-12 черв. 2014 р. / Харк. нац. екон. ун-т. Х. : ХНЕУ; ХОГОКЗ, 2014. - 378 c.

До збірника увійшли кращі статті з науково-теоретичних і практичних питань педагогіки та психології, які подано до участі в міжнародній науково-практичній конференції "Психолого-педагогічні проблеми становлення сучасного фахівця“, Харків, 11 - 12 червня 2014 р. Адресований науковцям, викладачам ВНЗ, аспірантам, працівникам галузі педагогіки та психології, а також широкому кругу фахівців.

УДК [37.015.3:167.1]-043.83-057.4(06)

ББК 88.40я431+88.840я431

ISBN 978-966-97260-4-9

(c) Автори статей, 2014.

(c) Колбіна Т. В., вступна стаття, 2014.

(c) ХОГОКЗ, оформлення, 2014.

(C) XHEУ, 2014. 
3MICT

Колбіна Т. В. Теоретико-методологічні основи обгрунтування педагогічних умов професійного становлення сучасного фахівця 8 Абасалієва O. М. Роль визначення самості українського етносу у становленні сучасного спеціаліста.................................. 13 Алексєєва M. I. Формування коммунікативної компетентності на заняттях з іноземної мови........................................ Багаліка T. М. Післядипломна підготовка в рамках системи безперервної професійної освіти

Безугла I. В. Використання інформаційно-комунікаційних та дистанційних технологій навчання у процесі формування іншомовної компетенції.

Бондар О. $\boldsymbol{C}$. Візуальна організація інформації як метод ефективного запам'ятовування в навчальному процесі. Борисенко Д. В. Вплив інноваційних інформаційнокомунікативних технологій на формування сучасної творчої компетенції інженера-дизайнера.

Борова $\boldsymbol{T}$. $\boldsymbol{A}$. Електронне навчання у викладанні іноземної мови студентам ВНЗ: концепції, закономірності та принципи........... Бугайчук $\boldsymbol{K}$. Л. Значення курування контенту в умовах дистанційного навчання у вищих навчальних закладах МBC України.

Верховська М. В. Компоненти готовності сучасного вчителя фізичної культури до професійної діяльності у практиці роботи 3 учнями загальноосвітніх навчальних закладів

Вільчинська $\boldsymbol{T}$. В. Прислів'я та приказки української та латинської мов як джерело країнознавчої інформації у порівняльному аспекті.

Вознюк О. М. Взаємодія культур у професійній підготовці майбутніх фахівців залізничного транспорту.

Волошина I. В. Стандартизація програм професійної підготовки майбутніх фольклористів в університетах України та США....... Громова Н. М. Психологические особенности понимания газетных иностранных текстов будущими специалистами......... Груша Л. О. Особливості навчання іноземній мові студентів вищих медичних навчальних закладів.

Давидова Ж. В. Викладач як суб'єкт управління навчальною діяльністю студентів $з$ формування духовно-ціннісних орієнтацій у педагогічному процесі вишу.

Дмитренко T. О., Лаврик T. В. Педагогічні умови як компонент наукових основ дослідження. 
Дубовицкая Т. Д., Газизова Р. Р., Дубниченко В. Ю.

Формирование культуры отношения к клиенту у будущих

психологов на этапе обучения в вузе......................... 90

Eрастова-Михалусь I. Б. Міжкультурна толерантність як основа успішної професійної діяльності економіста................

Ерохов Р. А., Ковальчук Д. В. Понятие о телесности и телесных феноменах.

Свдокімова-Лисогор Л. А. Використання засобів сучасних інформаційно-комунікаційних технологій у процесі вивчення іноземної мови.

Заваруева И. И. Межкультурная коммуникация и использование невербальных средств в процессе обучения студентов иностранцев.

Заика $\boldsymbol{E}$. B. Тренинг мышления: поиск оснований для классификации слов на группы.

Zolotova S. H., Dyadechko A. M., Morozova I. A. The development of communicative competence of university teachers who work with foreign students

Ирчишина М. В. Особенности типов обращений в образовательной сфере.

Iваніzа O. B. Методи розвитку міжкультурної компетенції студентів на заняттях $з$ англійської мови......................

Кайдалова Л. Г. Теоретико-методичні аспекти компетнтнісного підходу у вищій освіті.

Калашник Л. $\boldsymbol{C}$. Підвищення рівня соціальної адаптивності сучасного спеціаліста системи державного піклування про дітей-сиріт в КНР

Камишний О. М. Розвиток комунікативної компетенції студентів медичного університету в сучасному навчальному процесі

Ключка $\boldsymbol{C}$. I. Інтерактивні технології навчання, як передумова розвитку творчого потенціалу майбутнього фахівця.

Коваль $\boldsymbol{A}$. C. Фізіологічні, психологічні та соціокультурні особливості студентського віку

Kondratska $\boldsymbol{L}$. A. Soteriologikal strategy of reforming of professional education.

Копилова С. В. Роль соціально-комунікаційних практик у функціонуванні соціально-педагогічної системи.

Костикова О. В. К проблеме адекватной самооценки личности учителя.

Костюченко О. В. Творчий потенціал як змістовий аспект професійності майбутнього дизайнера-стиліста перукарського мистецтва. 
Крайнова Т. И. Актуальные вопросы развития современной психотерапии как науки...........................................

Лanno B. B. Теоретико-методичні засади формування особистої й професійної гідності в процесі духовного розвитку майбутнього фахівця.

Ластовець $\boldsymbol{I}$. $\boldsymbol{B}$. Гармонізація особистісного розвитку курсанта як психологічна проблема.

Лукашова Л. В. Використання інформаційно-комунікаційних технологій для формування комунікативної компетентності студентів при вивченні іноземної мови

Луніна М. Л. Комунікативно-діяльнісний компонент

як один із важливих складників змісту МКК

Лютвієва Я. П. Використання мультимедійних технологій (відеофільмів) на заняттях з іноземної мови.

Малинівська Л. І. Інтеграція змісту психолого-педагогічної підготовки майбутніх педагогів.

Малихіна О. $\boldsymbol{E}$. Творче мислення як умова успішного професійного становлення майбутнього педагога................... Мельник Ю. Б. Психологічна служба ВНЗ.

Митроченко О. $\boldsymbol{E}$. К вопросу о повышении рефлексивности в познавательной деятельности студента

Нагаєв В. М., Абраменко П. О. Управління професійно-творчою компетентністю фахівців аграрної сфери: виховний аспект....... Оксенюк І. Л. Обгрунтування організаційно-педагогічних умов формування готовності до професійної діяльності магістрів 3 управління проектами.

Oleksenko O. O. Psychological and Pedagogical Aspects of Crosscultural Conflict Research...

Осьмук Н. $\boldsymbol{\Gamma}$. Характеристика предметного кола ключових компетенцій сучасного вчителя

Повстяна Ю. С., Радченко М. А. Інтерактивні методи навчання майбутніх фахівців.

Погорелова $\boldsymbol{T}$. Ф. Професійно важливі якості як ключовий фактор у формуванні професійної компетентності майбутнього фахівця.

Полежсаєва О. В. Впровадження новітніх засобів у процес навчання іноземним мовам: дистанційне навчання.

Полішцк В. М. Нормативні і ненормативні кризи у віковому розвитку.

Пономарьова Л. Ф., Осадча О. В. Роль міжкультурного компоненту у формуванні навичок іншомовного спілкування студентів 
Попович Н. М. Взаємодія діяльнісної і практичної складових у структурі професійно-особистісного досвіду майбутнього фахівця.

Посудиевская О. Р. Развитие «чувства языка» как компонент обучения иностранному язику.

Поуль В. С. Розробка проблеми волі в сучасній науці: конструювання вольової поведінки.

Птахіна О. М. Використання інформаційної технології WEB 2.0 в навчальному процесі вищого навчального закладу.

Россова М. М. Практичні рекомендації психологам, адміністрації школи та вчителям щодо особливостей застосування імпліцитного психологічного впливу в навчально-виховному процесі.

Савицька Л. В. Формування у студентів-економістів міжкультурної компетентності на основі аналізу ключових культурних концептів британської картини світу. ...

Самохвалов В. Г., Булынина О. Д., Васильева О. В. Особенности коммуникабельности студентов с различным типом функциональной асимметрии.

Святенко Т. П. Дослідження цінності «влада» у працівників, що займають керівну посаду в компаніях сфери Інтернеттехнологій

Сергієнко О. В. Основні компоненти інноваційної поведінки студентів спеціальності “Технології електронних мультимедійних видань".

Скринник I. О. Досвід використання методу проектів у формуванні професійної та ключових освітніх компетентностей майбутніх фахівців (на прикладі Харківського кооперативного торгово-економічного коледжу).

Станин Д. М., Ехалов В. В., Сединкин В. А. Использование юмора в процессе подготовки специалиста-медика.

Стосва Т. В., Кравченко Л. Г., Кривда Г. Ф., Лотиш Н. Г., Папінко P. М. Інтерактивні методи у професійній підготовці лікарів-інтернів.

Тесля Р. В. Вища освіта Франції в аспекті освіти дорослих........

Тинкалюк О. В. Відбір ефективних методів організації навчання іноземної мови професійного спілкування

Торяник Л. Б. Как понимать умения, навыки, знание иностранных языков.

Федорук Г. М. Мотиваційний аспект в структурі інформаційнокомунікаційної компетентності майбутніх учителів технологій... Фрицюк B. $\boldsymbol{A}$. Профессиональная самоактуализация будущего учителя. 
Хачатрян $\boldsymbol{C}$. Л. Розвиток мотивації щодо вивчення іноземної мови на основі використання соціокультурного компонента...... Ципіна Д. С. Концептуальні засади педагогічного дослідження формування риторичної компетентності майбутніх менеджерів... Черниш Л. М. Розвиток особистісних якостей майбутніх фахівців в сфері економіки ...

Шаповал Н. В., Заика Е. В. Память в учебном процессе: особенности проявления интерференции

Швець О. Г. Формування агроеконоосферної свідомості сучасного спеціаліста АПК при вивченні дисциплін хімічного циклу.

Шендерук О. Б. Сучасні підходи до визначення поняття "викладач".

Штученко І. $\boldsymbol{C}$. Особливості професійної мотивації студентів технічних ВНЗ у період навчання. 
УДК 378.147-027.21-021.51]316:37-027.561::116-057.86

(C) Колбіна Т. В., 2014.

Колбіна Тетяна Василівна

Харківський національний економічний університет імені С. Кузнеця

\section{ТЕОРЕТИКО-МЕТОДОЛОГІЧНІ ОСНОВИ ОБГРУНТУВАННЯ ПЕДАГОГІЧНИХ УМОВ ПРОФЕСІЙНОГО СТАНОВЛЕННЯ СУЧАСНОГО ФАХІВЦЯ}

Розглянуто теоретико-методологічні основи обтрунтування педагогічних умов у наукових дослідженнях з підготовки майбутнього фахівия. Доведено, щяо для визначення педагогічних умов доиільно проаналізувати особливості основних векторів педагогічного прочесу: організаиіі, управління, спілкування. Запропоновано механізм обтрунтування педагогічних умов, представлено інваріантні педагогічні умови (організаційно-педагогічні, психолого-педагогічні, дидактичні) в руслі сучасних парадигм педагогічної науки.

Ключові слова: педагогічні умови, організація, управління, спілкування, педагогічна система, педагогічна технологія.

Суспільні потреби української держави зумовлюють реформування професійної підготовки студентів, від кваліфікації та духовності яких у майбутньому залежать процвітання країни та добробут іiі громадян. В умовах інформаційно-комунікаційного суспільства вища школа має готувати студентів до майбутньої професійної діяльності таким чином, щоб вони могли на основі засвоєного соціального досвіду створювати нові знання та духовні цінності. Отже, основним завданням ВНЗ є підготовка творчого фахівця в процесі навчання - основної сфери діяльності студента, під час якої відбувається його інтелектуальний та духовний розвиток.

Для успішного навчання студентів необхідно створювати педагогічні умови, що уможливлюватимуть досягнення поставленої перед вищою освітою мети підготовки компетентного фахівця та гармонійно розвиненої особистості.

Мета статті полягає у визначені теоретико-методологічних основ обгрунтування педагогічних умов підготовки фахівців у вищій школі, що можливо через з'ясування їх сутності, а також механізму їх визначення.

Тривалий час у психолого-педагогічних дослідженнях розробляються питання, пов'язані з впливом на особистість різних умов, які стосуються основних аспектів навчально-виховного процесу. На сучасному етапі розвитку педагогічної науки спостерігається 
значне збільшення наукових робіт, присвячених дослідженню педагогічних умов щодо вирішення конкретних практичних завдань підготовки майбутніх фахівців, а саме організаційно-педагогічних, психолого-педагогічних, дидактичних та інших умов. Характерним при цьому $\epsilon$ те, що у переважній їх більшості педагогічні умови визначаються на основі емпіричного досвіду дослідника без належного теоретико-методологічного обгрунтування. Такий стан речей, як слушно зазначає Є. М. Хриков, «є проявом певних стереотипних уявлень та їх трансформації у традиційні підходи до проведення досліджень» [5]. Тож аналіз сутності, значення та місця педагогічних умов у структурі наукового знання, механізму їх визначення залишаються актуальним завданням педагогічних досліджень.

Розглянемо поняття «умова» у науковій літературі. У філософській категорії «умова» виражається відношення предмета до оточуючих його явищам, без яких він існувати не може. Сам предмет $\epsilon$ чимось зумовленим, а умови - як відносно зовнішне до нього різноманіття об’єктивного світу. На відміну від причини, що безпосередньо породжує те або інше явище чи процес, умови складають те середовище, обставини, в яких останні виникають, існують і розвиваються. Люди, пізнавши закони природи, можуть створювати сприятливі і усувати несприятливі умови своєї діяльності [2; 3; 4].

Посилаючись на довідкову літературу, виокремимо основні аспекти багатозначного поняття «умови», які $є$ важливими стосовно педагогічного процесу. Вважаємо, що сутність даного поняття розкривають наступні значення: 1) необхідні обставини, від яких щось залежить, оскільки вони уможливлюють здійснення, створення, утворення чого-небудь або сприяють чомусь; 2) вимоги однієї із сторін; 3) правила, які існують або встановлені в тій чи іншій сфері життя або діяльності для забезпечення нормальної роботи чого-небудь; 4) обставини, особливості реальної дійсності, в яких відбувається або здійснюється що-небудь; 5) сукупність даних (інформація), положення або вимоги, які лежать в основі чого-небудь і від яких необхідно відштовхуватися при вирішенні якоїсь проблеми (наприклад, умови завдання) [1; 2; 4].

Як видно, поняття «умова» безпосередньо пов'язане 3 поняттям «вимога», сутність якого можна зрозуміти за допомогою філософських категорій «можливість» та «дійсність». Будучи діалектично пов’язаними, вони відображають ступені розвитку предметів та явищ: можливість - це об'єктивна тенденція розвитку предмета або явища; дійсність - об’єктивно існуючий предмет або явище як результат реалізації певної можливості (в широкому розумінні - сукупність усіх реалізованих можливостей). Якщо в природі перехід можливого в 


\section{Збірник наукових статей}

реальне відбуваються стихійно, то в суспільстві такі процеси потребують свідомих перетворень, для яких необхідно створити певні умови. Це передбачає, що люди як соціально активні істоти серед різноманітних можливостей здійснюють вибір тих із них, що найбільше відповідають їхнім потребам, інтересам, ціннісним настановам, і діють відповідно до свого вибору над перетворенням можливого у реальне (дійсне). Але перехід можливого у дійсне відкриває шлях для появи наступної можливості вдосконалення предмета, явища, процесу тощо, тобто цей процес $\epsilon$ безкінечним [3, с. $237 ; 4$, с. 595-596].

Поняття «вимога» має такі значення: 1) норми, правила, яких необхідно дотримуватись; умови, обов'язкові для виконання; 2) внутрішні потреби, запити людини [1; 2]. Як бачимо, поняття «вимога» охоплює зовнішній об'єктивний аспект (обставини, зовнішні умови) і внутрішній особистісний стан людини як суб'єкта діяльності (iї потреби, запити). Важливим є те, що ці поняття обумовлюють одне одного, тобто є взаємооберненими.

Таким чином, педагогічний процес, до організації і здійснення якого висуваються певні вимоги, необхідно аналізувати із зовнішньої і внутрішньої сторін. Для визначення адекватних умов важливо усвідомлювати, що ззовні педагогічний процес пов'язаний 3 культурою суспільства, його основна функція - передача молоді культурного досвіду людства. Із внутрішнього боку педагогічний процес має сприяти навчанню, вихованню, соціалізації, розвитку i самовдосконаленню людини. Обидві сторони цілісного педагогічного процесу є взаємопов'язаними: розвиток людини не може відбуватися поза процесом передачі досвіду, але для їі творчого саморозвитку необхідно створити відповідні умови.

На наше переконання, визначення умов має стосуватися основних векторів педагогічного процесу: організації, управління, спілкування. 3 огляду на це, можна запропонувати інваріантні педагогічні умови організації, управлінні, спілкуванні.

Організація (від франц. organisation і пізньолат. organizo - надаю впорядкованого вигляду, влаштовую) педагогічного процесу необхідна для досягнення визначеності системи в зовнішніх і внутрішніх зв'язках і забезпечення стабільності їі функціонування у мінливому середовищі [4, с. 320-321]. Функція організації полягає в об’єднанні учасників навчальної діяльності для спільної праці і взаємодії, у створенні й вдосконаленні взаємозв'язків між компонентами педагогічної системи.

Педагогічні умови організації полягають у проектуванні педагогічної системи, компоненти якої (цілі, принципи, зміст, методи і організаційні форми навчальної діяльності) спрямовані на становлення суб'єктного потенціалу (мотивації, пізнавальної і комунікативної 
активності, рефлексивності) учасників педагогічного процесу (студентів і викладачів), розвиток професійно значущих особистісних якостей.

Педагогічні умови управління стосуються застосування педагогічної технології, спроектованої на основі концепції поетапного засвоєння професійних знань i формування наукових понять (П. Гальперін, В. Ляудіс, Н. Тализіна та ін.), створення креативного середовища під час навчальної i позанавчальної діяльності через проектування ситуацій спільної продуктивної діяльності викладача i студентів.

Педагогічні умови спілкування - це, насамперед, діалогізація педагогічного процесу на основі суб'єкт-суб'єктних відносин учасників педагогічного процесу (студентів i викладачів), комунікативна взаємодія на демократичних засадах.

Для оптимізації педагогічного процесу педагогічні умови необхідно постійно коригувати, що потребує внесення корективів компоненти педагогічної системи. Наочно це виглядає таким чином:

теперішні педагогічні умови $\rightarrow$ нові педагогічні умови.

Пропонуємо такий механізм визначення педагогічних умов: з'ясування нових вимог, щуо виникли у суспільстві ↔ аналіз актуальних умов педагогічного процесу (вихідної ситуації) $\leftrightarrow$ визначення утруднень та суперечностей $\leftrightarrow$ формулювання вимог $\leftrightarrow$ постановка цілей $\leftrightarrow$ визначення педагогічних принциипів $\leftrightarrow$ проектування компонентів педагогічної системи (змісту, методів, організаційних форм навчальної діяльності) $\leftrightarrow$ проектування педагогічної технологї $i$ визначення дидактичних засобів управління навчальною діяльністю ↔ проектування умов оптимізаиії майбутнього педагогічного процесу.

При обгрунтуванні педагогічних умов необхідно орієнтуватися на парадигми, що домінують у сучасній педагогічній науці, а саме: гуманістичну, знаннєву, культурологічну. Це дозволить визначити педагогічні цілі і принципи відповідно до особливостей актуальної соціокультурної ситуації, суспільних вимог до підготовки майбутнього фахівця. На такому підгрунті можливо виокремити умови, які забезпечать ефективність педагогічного процесу, а саме: умови щодо організації, управління ним, спілкування між його сучасниками. Згідно 3 основними векторами педагогічного процесу доцільно проаналізувати організаційно-педагогічні умови, що стосуються проектування педагогічної системи, яка моделює зміст професійної діяльності і соціальні відносини під час іiі здійснення; психологопедагогічні умови, які враховують особистісні характеристики суб'єктів навчальної діяльності (потреби, мотивацію, рівень наявних знань, умінь і навичок, особистісні якості та інше); дидактичні умови, 


\section{Збірник наукових статей}

які охоплюють дидактичні засоби, методи та організаційні форми їх застосування.

Отже, педагогічні умови - це необхідні обставини, які мають бути створені для організації та здійснення педагогічного процесу, управління ним і спілкування між його учасниками для досягнення запланованих результатів. Для організації та здійснення педагогічного процесу, спрямованого на формування творчої особистості майбутнього фахівця, необхідно проаналізувати існуючі педагогічні умови та створити нові педагогічні умови, що зможуть привести до досягнення поставленої мети (задоволенню вимог особистості та суспільства відповідно до нових об'єктивних вимог).

Умови організації педагогічного процесу мають відповідати вимогам до підготовки майбутнього фахівця в мінливих соціальних умовах, проектувати його професійну діяльність (зміст, методи, форми), а також соціальні відносини під час іiі здійснення. Умови цілісного педагогічного процесу мають забезпечити гармонізацію відносин студента 3 навколишнім соціокультурним середовищем i своїм внутрішнім світом.

Подальші дослідження спрямовані на визначення методологічних підходів до обгрунтування ролі і місця педагогічних умов у структурі наукового пізнання.

\section{Література}

1. Великий тлумачний словник сучасної української мови / Укл. і голов. ред. В. Т. Бусел. - К.; Ірпінь : ВТФ „Перун”, 2004. - 1440 с.

2. Ожегов С. И. Словарь русского языка / Под ред. чл.корр. АН СССР Н. Ю. Шведовой. - 19-е изд., испр. - М. : Рус. яз., 1987. - 750 с.

3. Советский энциклопедический словарь / Гл. ред. А. М. Прохоров. 2-е изд. - М. : Сов. энциклопедия, 1983. - 1600 с., ил.

4. Философский энциклопедический словарь / Редкол.: С. С. Аверинцев, Э. А. Араб-Оглы, Л. Ф. Ильичёв и др. - М. : Сов. энциклопедия, 1989. - 815 с.

5. Хриков С. М. Педагогічні умови в структурі наукового знання [Електронний ресурс] / Є.М. Хриков - Режим доступу : http://hrykov.luguniv.edu.ua. - Назва с титул. екрану.

Татьяна Колбина. Теоретико-методологическое обоснование педагогических условий профессионального становления будущего специалиста.

Рассмотрены теоретико-методологические основы обоснования педагогических условий в научных исследованиях по подготовке современного специалиста. Доказано, что для определения педагогических условий целесообразно проанализировать особенности основных векторов педагогического прочесса: организачии, управления, общения. Предложен механизм обоснования 
педагогических условий, представлены инвариантные педагогические условия (организационно-педагогические, психолого-педагогические, дидактические) в русле современных парадигм педагогической науки.

Ключевые слова: педагогические условия, организация, управление, общение, педагогическая система, педагогическая технология.

Tatiana Kolbina. Theoretical and Methodological Basis of Pedagogical Conditions of Future Specialist Formation.

Theoretical and methodological basis of pedagogical conditions in scientific research on modern specialist training is observed. It is proved that for determining pedagogical conditions it is worth analyzing the peculiarities of the main vectors of educational process: organization, management, communication. The mechanism of grounding the pedagogical conditions is proposed, invariant pedagogical conditions (organizational and pedagogical, psychological and pedagogical, didactic) are presented in the tideway of modern paradigms of pedagogy.

Key words: pedagogical conditions, organization, management, communication, pedagogical system, educational technology.

Стаття надійшла до редакційної колегії 12.05.2014

УДК 168.1:316.64(477)17.035.3-057.86

\section{Абасалісва Оксана Миколаївна}

(C) Абасалієва О. М., 2014.

Красноградський коледж Комунального закладу

«Харківська гуманітарно-педагогічна академія»

Харківської обласної ради

\section{РОЛЬ ВИЗНАЧЕННЯ САМОСТІ УКРАЇНСЬКОГО ЕТНОСУ У СТАНОВЛЕННІ СУЧАСНОГО СПЕЦІАЛІСТА}

Стаття містить аналіз сучасної проблематики в галузі етнічної свідомості украӥнців. Досліджено поняття самості украӥнського етносу та визначено його роль у становленні сучасного спеціаліста. Проблема визначення етнічної самості сучасного украӥния є безумовно значущою, оскільки є ключовою у формуванні його ідентичності. Щодо студентської молоді слід зазначити, що складові етнічної ідентичності наповнюються специфічним змістом в силу особливостей ї̈ розвитку на етапі професійного становлення у прочесі навчання у вищому навчальному закладі.

Ключові слова: самість етносу, самосвідомість, етнічна свідомість, етнічна ідентичність. 


\section{Збірник наукових статей}

Самість - це дуже місткий та багатозначний термін, який по різному сприймається різними дослідниками $\mathrm{i}$ його значення відрізняється в різних науках та школах. За К. Роджерсом самість - це уявлення людини про себе, яке виникає на основі минулого i теперішнього досвіду та очікувань майбутнього. За К. Г. Юнгом це архетип цілісності, що об'єднує свідоме і несвідоме, які взаємно доповнюють одне одного до цілісності. Розвиток самості - головна мета людського життя; самість об'єднує всі вияви душі. Розвиток особистості у процесі іiі індивідуалізації йде від свідомості до особистого несвідомого, а від нього до колективного несвідомого, центром якого є самість. Самореалізація, на думку Юнга, відбувається шляхом занурення у глибини колективного несвідомого.

Проблема визначення етнічної самості сучасного українця $\epsilon$ безумовно значущою, оскільки $є$ ключовою у формуванні його ідентичності. Мета статті полягає у вивченні поняття самості українського етносу та визначення його ролі у становленні сучасного спеціаліста.

Серед сучасних вітчизняних психологів проблеми етносу вивчали і вивчають: М. Шульга, П. Гнатенко, В. Павленко, С. Таглін, Л. Орбан, В. Хрущ, В. Москалець, М. Пірен, Л. Шкляр та інші. Крім того, видаються праці, написані українськими авторами в еміграції, які раніше були недоступні широкому українському загалу. Серед них можна назвати таких, як Г. Ващенко, I. Рибчин, О. Кульчицький, I. Мирчук, В. Янів, І. Ярема, а також Ю. Липа, О. Субтельний та інші. Говорячи про етнопсихологічні особливості українців, дослідники, перш за все, розглядають таке основоположне явище, як психічний склад українців, що характеризується як суб'єктивний психічний досвід нації, зафіксований у відносно стійких властивостях, рисах, у національній психології, які обумовлені усім суспільно-історичним ходом становлення і розвитку нації та специфікою соціальнопсихологічного відображення об'єктивних умов іiі існування. Соціально-політична ситуація, яку можемо спостерігати протягом останніх місяців в Україні, загострилася саме на конфлікті образів українського етносу та різного сприйняття власної етнічної самості, оскільки невирішеним залишається питання формування основи само ідентифікації: почуття соборності й української самості. Актуальним стає Шевченкове слово: „....та й спитайте тойді себе: що ми?...”.

Самосвідомість особистості - це усвідомлення людиною себе як індивідуальності. Одним із продуктів діяльності самосвідомості є «Яконцепція» особистості, що розглядається як система усвідомлюваних і неусвідомлюваних уявлень індивіда про себе, у поєднанні 3 їх емоційною оцінкою та відповідною поведінковою реакцією. Людина пізнає себе не лише за допомогою прямих самосприймань. Багато в 
чому індивід пізнає себе опосередковано, тобто за допомогою інших людей, досить часто представників свого етносу, сприймаючи їх реакції на власну поведінку та особистість. Сприймаючи думки i оцінки оточуючих про себе, індивід правильно чи неправильно пізнає себе, складає різноманітні уявлення про власне «Я», зокрема, й етнічні. Важливим джерелом розвитку таких уявлень виступають думки найбільш авторитетних для індивіда людей.

Уявлення особистості про себе як про представника якої-небудь етнічної групи належать до когнітивної складової „Я-концепції,, „Яобразу”. Етнічне „Я” - це уявлення людини про власну етнічну належність, що розвивається в результаті їі самоідентифікації з певним етносом.

Більшість дослідників виокремлюють етнічну самосвідомість на індивідуальному та груповому рівнях. Так, групові процеси виникають за тієї умови, що люди, які утворюють певну соціальну спільність (групу), зокрема, й етнос, здійснюють спільні дії та діяльність. У групі (етносі) 3'являються спільні для всіх іiі учасників психічні явища: почуття взаємозв'язку і належності до групи, ідентифікація з групою та почуття „ми”. Кожний індивід вважає себе членом етносу. Водночас, етнос як велика група набуває певних соціально-психологічних рис i характерних форм поведінки.

Етнічна самосвідомість на рівні особистості виступає як цілісна система уявлень про себе, що тісно пов'язана із сформованим у індивіда образом власного етносу. Людина може охарактеризувати свою етнічну спільність, іiі походження, мову, культуру, психологічні риси („національний характер”); а також власне місце в цій етнічній групі та ставлення до неї.

Джерелами етнічного „Я” чи етнічного „Я-образу” на рівні етносу виступають: свідомість людей-етнофорів, культурні пам'ятки, традиції, звичаї, ритуали і та інше. Етнічне „Я” на рівні етносу з'являється у результаті психічної діяльності багатьох людей, етносів та взаємодії між ними.

Одним 3 найважливіших етапів становлення фахівця є етап професійного навчання у вищому навчальному закладі. Адже саме студентський вік $\epsilon$ сензитивним для виявлення й розвитку професійного потенціалу, становлення професійної самосвідомості. Вищий навчальний заклад як соціальний інститут покликаний готувати своїх випускників до майбутнього соціально-професійного життя.

Становлення фахівця у процесі навчання у вищому навчальному закладі, як зазначає В. В. Рибалка, обов'язково передбачає розвиток: а) аксіологічної спрямованості і професійної свідомості; б) соціального і професійного інтелекту; в) емоційно-вольової сфери; г) позитивного 
ставлення до світу й до себе; д) самостійності, автономності і впевненості в собі; е) професійно важливих якостей і компетентності тощо.

Слід зазначити, що характерними ознаками студентської молоді $\epsilon$ відкритість до змін, філософське й творче ставлення до життя, пошук його сенсу й прийняття відповідальності за його здійснення та самовираження в ньому, розвиток професійно важливих якостей тощо. У зв'язку з цим постає питання, які ж риси своєї етнічності перенесуть і втілять в своїй власній родині i, загалом, у житті молоді люди? Чи позначиться це на успішності їх самореалізації не лише в сім’ї але й у професійному житті? Якими ж є складові їхньої етнічної ідентичності?

Етнічна ідентичність особистості загалом і студентської молоді, зокрема, - це відчуття належності до певної етнічної спільноти, однаковості 3 іншими їі членами внаслідок спільності історичної пам'яті, спогадів про єдиних предків та емоціональних зв'язків 3 батьківщиною, а також спільності основних компонентів культури, що звичайно виявляється у солідарності з членами цієї спільноти. Етнічна ідентичність особистості являє собою сукупність суспільних відносин, які об'єднують особу як носія етнічних ознак із іiі етнічним середовищем. Можна виокремити декілька рівнів соціальнопсихологічних чинників становлення етнічної ідентичності: макрорівень (соціальні норми, традиції, культура, що найяскравіше виявляються у процесах державотворення, в час військової мобілізації, релігії); мезорівень (рівень безпосередніх соціальних спільнот, у які включена особистість, насамперед, сім'я, професійні та неформальні об'єднання); мікрорівень (здатність особистості до наслідування, трансформації у власні установки пропонованих взірців і проявів національного характеру, специфіка міжетнічного сприймання особистості, яка визначається рівнем активності людини у процесі присвоєння значень суспільної етнічної свідомості).

Щодо студентської молоді слід зазначити, що ці складові етнічної ідентичності наповнюються своїм, специфічним змістом в силу особливостей іï розвитку на етапі професійного становлення у процесі навчання у вищому навчальному закладі. На наш погляд, науковці в своїх дослідженнях мають шукати оптимальний шлях об’єднання суспільства, розвитку національних традицій та їх запровадження в систему культурно-освітньої політики держави.

\section{Література}

1. Березін А. М. Психологічні чинники генезису національної самосвідомості особистості : дис. кандидата психол. наук: 19.00.07 / А. М. Березін. - К., 2002. - 208 с. 
2. Боднар М. Б. Вплив етнопсихологічних життєвих орієнтацій на самоактуалізацію студентської молоді: дис. кандидата психол. наук : 19.00.05 / Боднар Марія Богданівна. - К., 2004. - 216 с.

3. Лозова О. М. Ідилічний топос та етос української ментальності / О.М.Лозова // Науковий часопис Національного педагогічного університету імені М. П. Драгоманова: - Серія 12. Психологічні науки. - 2006. - № 2. - С. 26-33.

4. Мединська Ю. Я. Колективне несвідоме як глибинна детермінанта етнічного менталітету: Дис. канд. психол. наук / Ю. Я. Мединська. - Тернопіль, 2005. - 181 с.

5. Пірен М. І. Основи етнопсихології / М. І. Пірен. - К. : Наука, 1996. $-360 \mathrm{c}$.

6. Потебня А. А. Из записок по теории словесности // Слово и миф / А. А. Потебня. - М. : Правда, 1989. - С. 243-260.

7. Хотинец В. Ю. Этническое самосознание / В. Ю. Хотинец. СПб. : Алетейя, 2000. -311 с.

Оксана Абасалиева. Роль определения самости украинского этноса в становлении современного специалиста.

Статья содержит анализ современной проблематики в области этнического сознания украинцев. Исследовано понятие самости украинского этноса и определена его роль в становлении современного специалиста. Проблема определения этнической самости современного украинца является безусловно значимой, поскольку является ключевой в формировании его идентичности. Касательно студенческой молодежи следует отметить, что составляющие этнической идентичности наполняются специфическим содержанием в силу особенностей ее развития на этапе профессионального становления в процессе обучения в высшем учебном заведении.

Ключевые слова: самость этноса, самосознание, этническое сознание, этническая идентичность.

Oksana Abasaliyeva. The role of self determination ukrainian ethnicity in the formation of modern specialist.

The article includes an analysis of contemporary issues in Ukrainian ethnic consciousness. The concept of self Ukrainian ethnicity and defined its role in the development of the modern professional. The problem of ethnic self determination modern Ukrainian is certainly significant, because it is crucial in shaping his identity. As for the student youth should be noted that the components of ethnic identity are filled with specific content by reason of its development at the stage of becoming a professional in teaching in higher education.

Key words: self ethnicity, identity, ethnic consciousness, ethnic identity.

Стаття надійшла до редакційної колегії 12.05.2014 
(C) Алексєєва М. І., 2014.

\section{Алекссєва Марія Ігорівна}

Харківський національний економічний університет імені С. Кузнеця

\section{ФОРМУВАННЯ КОММУНІКАТИВНОЇ КОМПЕТЕНТНОСТІ НА ЗАНЯТТЯХ 3 ІНОЗЕМНОЇ МОВИ}

У статті розглянута навчальна дисиипліна «Іноземна мова» $у$ формуванні готовності до повночінного міжособистісного спілкування та формування комунікативної мовленнєвої компетениії.

Ключові слова: комунікативна компетенція, спілкування, іноземна мова.

У сучасних умовах активного прагнення країн до співробітництва та взаємозбагачення в усіх сферах життя особливого значення набувають міжкультурні зв'язки представників різних народів і держав. Отже, «Іноземна мова» як навчальна дисципліна має значний потенціал для навчання ефективного міжособистісного спілкування, формування впевненості у собі, уміння поводити себе природно під час спілкування з представниками інших країн.

Проблеми спілкування, міжособистісних стосунків вивчають вітчизняні і зарубіжні вчені, висвітлюючи їх багатоаспектність та значущість. Д. Уілкінс, Г. Уіддоусон, У. Літтлвуд, С. Тейлор, М. Ланг та інші підкреслюють широкі можливості навчальної дисципліни «Іноземна мова» щодо формування загальної комунікативної компетенції особи.

Метою статті $є$ розглянути трактування можливостей навчальної дисципліни «Іноземна мова» у формуванні готовності до повноцінного міжособистісного спілкування та формування комунікативної мовленнєвої компетенції.

Цілі і завдання в галузі навчання іноземних мов, визначені Радою Європи забезпечили ідеалогічну основу наукових і практичних досліджень: підтримка особистісної мобільності, спілкування, потреба в інтенсифікації міжнародного співробітництва, повага до прав людини, що, з одного боку, має на увазі розуміння і толерантне ставлення до культурного i лінгвістичного розмаїття як джерела взаємного збагачення, а $з$ іншого, веде до демократизації освіти, що пропонує навчання іноземних мов всіх студентів, незалежно від соціального статусу та походження і фокусується на студентові, його самостійності, активності [1, с. 30-32].

Слід зазначити, що у «Загальноєвропейських Рекомендаціях 3 мовної освіти: вивчення,викладання, оцінювання» зазначено, що комунікативна мовленнєва компетенція розглядається як така, що складається 3 лінгвістичного, соціолінгвістичного та прагматичного 
компонентів [2]. Отже лінгвістична, соціолінгвістична та прагматична компетенції, що формуються під час навчання іноземних мов значною мірою сприяють формуванню комунікативної мовленнєвої компетенції взагалі, оскільки оволодіння правилами ввічливості, нормами, які регулюють стосунки між поколіннями, класами та соціальними групами, лінгвістичними кодифікаціями деяких основних ритуалів у житті суспільства тощо пронизує весь процес спілкування між представниками як однієї, так і різних культур, навіть тоді, коли його учасники не усвідомлюють цього впливу. Розвиток цих компетенцій реалізується у виконанні різних видів мовленнєвої діяльності ( рецептивних і продуктивних; усних та писемних), залучення у які i становить провідну складову сучасного навчання іноземних мов на всіх освітніх рівнях.

Навчання у системі освіти повинно бути спрямоване на розвиток у майбутніх фахівців рис мультикультурної особистості: етнокультурного сприйняття, толерантності, емпатії, розуміння i поваги до проявів іншої культури, які дозволяють успішно контактувати 3 представниками будь-якої культури, вирішувати неминучі в міжкультурному спілкуванні етнолінгвокультурні конфлікти. Таким чином, вивчення засвідчує визнання суттєвого потенціалу навчальної дисципліни «Іноземна мова» для формування комунікативної компетенції, забезпечення готовності для міжособистісного спілкування у різних сферах.

\section{Лiтература}

1. Resolution of the Council and the Ministers of Education Meeting within the Council on the European Dimension in Education 88/C177/02// ATEE News/ - 1992/1993. - № 38/39. - P. 30-32.

2. Загальноєвропейські Рекомендації з мовної освіти: вивчення, викладання, оцінювання. - К. : Ленвіт, 2003. - 273 с.

Мария Алексеева. Формирование коммуникативной компетентности на занятиях по иностранному языку.

В статье рассмотрена учебная дисииплина «Иностранный язык» в формировании готовности $\kappa$ полноценному межличностному общению и формировании коммуникативной языковой компетенции.

Ключевые слова: коммуникативная компетенция, общение, иностранный язык.

\section{Mariya Alekseeva. Communicative competence formation within foreign languages teaching.}

The issues of foreign language teaching on training in adequate interaction and communicative competence formation have been observed in the article.

Key words: communicative competence, communication, foreign language.

Стаття надійшла до редакційної колегії 15.05.2014 
(C) Багаліка Т. М., 2014.

Багаліка Тетяна Михайлівна

Інститут Управління державної охорони України

Київського національного університету імені Тараса Шевченка

\section{ПІСЛЯДИПЛОМНА ПІДГОТОВКА В РАМКАХ СИСТЕМИ БЕЗПЕРЕРВНОЇ ПРОФЕСІЙНОЇ ОСВІТИ}

У статті розкрито сутність та основні ичілі категорії “безперервна професійна освіта”, виявлено ї̈ основні можливості, визначено функції та умови, що сприятимуть неперервному особистісному $i$ професійному розвитку $i$ саморозвитку особистості, професійній $i$ сочіальній мобільності, адаптаџійній гнучкості. Розглянуто складові безперервної професійної освіти, підкреслено доиільність оновлення, розширення, вдосконалення професійного досвіду або здобуття іншого фаху в умовах постійних змін.

Ключові слова: безперервна професійна освіта, післядипломна підготовка, професійна самореалізачія.

В попередні періоди історії відносно повільна еволюція суспільного виробництва обумовлювала і відносну постійність структури i змісту освіти. Фактично був сформований тип “остаточної” освіти, яка мала на меті навчити раз і назавжди всьому, що може знадобитись індивідууму впродовж усієї його соціальної $\mathrm{i}$ професійної діяльності. Однак, у сучасному суспільстві навчити на все життя неможливо, оскільки інформаційний потенціал, отриманий в рамках традиційної освіти, швидко втрачає актуальність і стає недостатнім для здійснення професійної діяльності протягом усього трудового життя. Російський вчений С. Р. Філонович відмітив, що у сучасному швидкозмінному суспільстві важливим $є$ не стільки обсяг отриманих в освітній системі знань, скільки розвиток здатності їх поновлювати та генерувати [4].

На сучасному етапі динамізм економічного і суспільного розвитку, що впливає на матеріальні і духовні сторони життя держави в цілому і кожної людини зокрема, тісний і постійний зв'язок науки i виробництва призводять до потреби постійної актуалізації отриманих в результаті освіти знань, до інтелектуалізації трудової діяльності. Це, в свою чергу, обумовлює певні вимоги до рівня освіти, появу концепції безперервної освіти, виникнення різних форм післядипломної освіти, наприклад, такого соціального інституту, як підвищення кваліфікації або отримання додаткової професійної освіти 
чи перепідготовка, що є ключовими сегментами моделі “безперервна професійна освіта”.

Умови сьогодення вимагають від фахівця XXI сторіччя бути зорієнтованим на необхідності подальшого навчання після отримання вищої освіти, підвищення кваліфікації чи перепідготовки в різних формах, самостійного отримання додаткової освіти. Разом із тим потребує дослідження проблема співвідношення умов післядипломної підготовки спеціалістів в структурі безперервної професійної освіти.

Постійна тенденція до диференціації i інтеграції наукових направлень у визнанні навчання як необхідної діяльності людини в усі періоди іiі життя і надання можливості для всіх людей різного віку застосовувати, поновлювати раніше набуті знання та вміння, отримувати спеціальність і вдосконалюватися в ній, набувати нову спеціальність, обумовлює появу системи безперервної професійної освіти, яка значною мірою стосується освіти дорослих i повина вирішувати проблеми перепідготовки кадрів, підвищення їхньої кваліфікації, отримання додаткової професійної освіти. Концепція безперервної професійної освіти відображає протиріччя між потребами індивідуумів в навчанні та умовами надання їм необхідних можливостей для реалізації актуальних освітніх запитів.

Дослідження в сучасній вітчизняній і зарубіжній педагогічній літературі, які присвячені розробці різних аспектів вирішення цих проблем (І. А. Зязюн, Н. Г. Ничкало, В. І. Луговий, М. М. Солдатенко, С. Я. Батишев, О. М. Новіков, П. І. Юнацькевич, В. І. Подобєд), призвели до створення системи безперервної професійної освіти в сучасному іiі розумінні. І. А. Зязюн підкреслює, що безперервну професійну освіту можна віднести до особистості, до освітнього процесу, до організаційних структур. У першому випадку це поняття означає, що людина вчиться постійно, без відносно довгих перерв в освітніх установах, чи займається самоосвітою. Залишаючись на одному й тому ж формальному рівні, вона удосконалює свою професійну кваліфікацію, свою майстерність, піднімається рівнями професійної освіти. Людина не лише продовжує освіту, але й змінює іiі профіль [1].

Метою статmі є 3'ясування сутності та функцій категорії “безперервна професійна освіта”; виявлення їі основних можливостей, визначення цілей i умов безперервної професійної освіти, що сприятимуть неперервному цілісному особистісному i професійному розвитку i саморозвитку особистості, професійній i соціальній мобільності, вдосконаленню, адаптаційній гнучкості.

Безперервна професійна освіта як світова тенденція формується у другій половині XX століття, а точніше з початку 70-х років. Саме в цей період посилюється міжнародне співробітництво в галузі 


\section{Збірник наукових статей}

професійної освіти [3]. Передусім йдеться про широку діяльність ООН, ЮНЕСКО, Міжнародної організації праці (МОП), які ухвалили винятково цінні документи 3 проблем професійного навчання різних категорій населення (Рекомендація щодо професійного навчання 1962 р., Рекомендація щодо професійного та технічного навчання 1974 р.). У цих документах чітко обгрунтовується потреба у неперервності професійного навчання, що відповідно закріплено у спеціально сформульованому принципі: навчання $\epsilon$ процесом, який триває протягом всього трудового життя людини відповідно до іiі потреб як індивідуума і члена суспільства [2].

В чому ж полягає сутність безперервної професійної освіти?

Безперервна професійна освіта - це сукупність цілеспрямованих дій (як формальних, так і неформальних), що застосовуються суб'єктами неперервно-дискретно з метою удосконалення, оновлення, розширення своїх професійних знань, навичок і компетенцій в межах існуючих різноманітних інституціональних та інших можливостей. В сутності категорії “безперервна професійна освіта" головним критерієм є функціональна специфіка знань, що отримуються, а головною рушійною силою $є$ мотивація.

Багато в чому таке розуміння безперервної професійної освіти співпадає 3 додатковою професійною освітою, оскільки вона також включає в себе регулярне підвищення кваліфікації і професійну перепідготовку. Відмінність полягає в тому, що додаткова професійна освіта, по суті, співвідноситься з основною, в той час як безперервна професійна освіта робить акцент на постійності процесу навчання в професійній сфері, але ніяк не пов'язує іiі з характером базової освіти.

Ця відмінність суттєва, оскільки вона вміщує різні уявлення про професійну кар'єру: за логікою додаткової освіти вона лінійна i пов'язана 3 лінійним розвитком технологій; за логікою безперервної професійної освіти вона не має лінійного характеру і обумовлена швидкою зміною технологій, необхідністю для працівника постійно змінювати сфери діяльності, а відповідно, і професії (або спеціальності) неодноразово упродовж професійної діяльності. До безперервної професійної освіти повинні відноситися всі програми професійної освіти, починаючи з рівня початкової професійної освіти, а також програми післядипломної і додаткової професійної освіти в інституціоналізованих i неінституціоналізованих формах 3 метою оновлення, розширення, вдосконалення професійного досвіду або здобуття іншого фаху в умовах постійних змін.

Н. Г. Ничкало виділяє низку важливих функцій, які виконує безперервна професійна освіта, зокрема: 1) соціокультурну, розвивальну; 2) загальноосвітню, компенсуючу; 3) адаптивну; 4) економічну [3, с. 13]. 
Враховуючи вищезазначені функції, безперервна професійна освіта повинна надавати можливості індивідам навчатися постійно, тобто брати участь в освітньому процесі безперервно; навчатися періодично, тобто включатися в освітній процес і виходити 3 нього в будь-який зручний час.

Це в свою чергу визначає головні цілі безперервної професійної освіти: забезпечення післядипломного навчання (підвищення кваліфікації, професійна перепідготовка, підвищення освітнього рівня, отримання додаткової освіти); вирішення проблем адаптації до швидкозмінних умов: навчання та перенавчання; забезпечення використання індивідами вільного часу, надаючи можливість відвідувати заняття з спеціальностей та направлень, що їх цікавлять; підбір кадрів, які здатні зрозуміти і виконати поставлені задачі.

Імплементація моделі “безперервна професійна освіта" може бути спрямована на вирішення триєдиної проблеми: неперервний цілісний особистісний, професійний розвиток і саморозвиток індивіда як суб'єкта діяльності протягом усієї професійної підготовки, оптимізація принципу функціональності в системі професійної підготовки та перепідготовки індивідуумів, удосконалення поліпрофесійних, загальнопрофесійних та спеціальних компетенції у сфері їхньої професійної діяльності.

Наразі можна виокремити умови в системі безперервної професійної освіти, інтеграція яких сприятиме особистісному i професійному розвитку і саморозвитку індивідуумів, їх професійній і соціальній мобільності, адаптаційній гнучкості:

- організаційно-змістова умова - створення та впровадження гнучких освітньо-професійних стандартів, програм i технологій підготовки, перепідготовки та підвищення кваліфікації кожного індивіда;

- соціально-психологічна умова - сприяння професійній i соціальній мобільності індивідуумів, їх здатності швидко адаптуватися до змінних умов; здійснення інституціоналізованими, неінституціоналізованими закладами освіти допомоги для перманентного розвитку індивідуума;

- іманентно-суб'єктивна умова - формування потребомотиваційно-діяльнісного комплексу та суб'єктивно образнопонятійної моделі діяльності через концептуальне усвідомлення індивідуумом набутих знань, саморегулююче застосування ним вмінь, навичок, а також готовність до самовизначеності, самоаналізу на основі професійно важливих здібностей та властивостей.

Всі ці умови повинні грунтуватися на принципах особистісної та професійної необхідності, системності, послідовності, безперервності. 


\section{Збірник наукових статей}

Висновки. На основі аналізу різних підходів до визначення поняття “безперервна професійна освіта", ми дійшли висновку, що в узагальненому вигляді суть безперервної професійної освіти представлена категорією неперервного цілісного особистісного, професійного розвитку i саморозвитку індивідуума як суб'єкта діяльності протягом усієї професійної підготовки. Основними компонентами, що доповнюють суть безперервної професійної освіти $€: 1)$ можливість багаторазових змін професійних і освітніх траєкторій індивідуума упродовж його трудової діяльності; 2) системний підхід до організації професійної освіти; 3) оптимізація підсистем післядипломого навчання (підвищення кваліфікації, професійна перепідготовка, підвищення освітнього рівня, отримання додаткової освіти); 4) спрямована орієнтація на самореалізацію та самовизначення особистості у житті, готовність до самоаналізу, самоконтролю.

Таким чином, безперервна професійна освіта повинна сприяти утвердженню особистості як найвищої цінності суспільства, функціонувати i розвиватися в ¥ї інтересах; надати можливість самореалізації індивідуума у освітньому середовищі та професійній діяльності; на практиці забезпечити організаційну і змістову єдність, наступність i взаємозв'язок усіх ланок професійної освіти, перепідготовки, підвищення кваліфікації; забезпечити повноцінний професійний розвиток особистості.

\section{Література}

1. Зязюн I. А. Неперервна освіта : концептуальні засади і сучасні технології / І. А. Зязюн // Творча особистість у системі неперервної професійної освіти : міжнародна наукова конференція, 16-17 травня 2000 р. / [за ред. С. О. Сисоєвої і О. Г. Романовського]. - Х. : ХДПУ, 2000. - C. 8-16.

2. Міжнародне законодавство про охорону праці, Конвенції та Рекомендації МОП. У 3т. - К. : Основа, 1997. - Т.2 - С. 407-409.

3. Ничкало Н. Г. Педагогіка вищої школи: крок у майбутнє / Сучасна вища школа: психолого-педагогічний аспект: Монографія / За ред. Н. Г. Ничкало. - К. : Видавництво “ВІПОЛ”. - 450 с.

4. Филонович С. P. Life-long learning: последствия для высшей школы / С. Р. Филонович // Вопр. образования. - 2009. - № 4. - С. 55 66.

Татьяна Багалика. Последипломная подготовка в рамках системы непрерывного профессионального образования.

В статье раскрыты сущность и основные цели категории “непрерывное профессиональное образование”, определены его основные возможности, функиии и условия, которые содействуют непрерывному личностному и профессиональному развитию, а также саморазвитию личности, профессиональной $и$ социальной 
Психолого-педагогічні проблеми становлення сучасного фахівця

Випуск 2014 мобильности, адаптациионой гибкости. Рассмотрены составные непрерьвного профессионального образования, подчеркнуто целесообразность обновления, расширения, усовершенствования профессионального опьтта либо преобретение другой специальности $в$ условиях постоянных изменений.

Ключевые слова: непрерывное профессиональное образование, последипломная подготовка, профессиональная самореализация.

Tetiana Bagalika. Postgraduate Training in System of Continuing Professional Education.

The article considers the main point of such category as "continuing professional education". Some aspects of its basic principles and core functions are studied. The aim of continuing professional education is characterized. Dimensions of continuing professional education are established. In terms of renewing, expanding and improvement of current professional experience and/or obtaining of supplemental occupation the necessity of postgraduate training for specialists is determined.

Key words: continuing professional education, postgraduate training, professional self-actualization.

Стаття надійшла до редакційної колегії 31.03.2014

УДК 378.147:004.78

Безугла Ірина Валентинівна

Харківський національний економічний університет імені С. Кузнеця

\section{ВИКОРИСТАННЯ ІНФОРМАЦЙНО-КОМУНІКАЦЙНИХ ТА ДИСТАНЦІЙНИХ ТЕХНОЛОГІЙ НАВЧАННЯ У ПРОЦЕСІ ФОРМУВАННЯ ІНШОМОВНОЇ КОМПЕТЕНЦІї}

Розглянуто питання, пов'язані із використанням інформаиійнокомунікаційних та дистанційних технологій навчання у процесі формування досвіду міжкультурної комунікаиіі майбутнього економіста. Розглянуто сучасні освітні тенденції, що сприяють формуванню іншомовної комунікативної компетенції, проаналізовано найбільш популярні інформаційно-комунікаційні технології.

Ключові слова: дистаниійні технології навчання, інформачійнокомунікаційні технології, іншомовна комунікативна компетенція.

Об'єктивною тенденцією у вищих закладах освіти, і зокрема у ХНЕУ, є пошук більш ефективних засобів навчання, які б виконували у навчальному процесі функції інформування, систематизування, контролю та мотивації. Таким вимогам можуть відповідати 


\section{Збірник наукових статей}

інформаційно-комунікаційні технології навчання, до яких належать Інтернет-технології, мультимедійні програмні засоби, офісне та спеціалізоване програмне забезпечення, електронні посібники та підручники, системи дистанційного навчання.

Досягнутий за останні роки прогрес у впровадженні інформаційно-комунікаційної технології навчання у процес формування іншомовної компетенції у вищій школі потребує глибокого наукового обгрунтування дидактичних і методичних основ їх використання, визначення концептуальних засад створення електронних посібників як для позааудиторного навчання (дистанційного), так і для аудиторного.

Проблеми розробки та створення умов впровадження інформаційно-комунікаційних технологій та дистанційних методів навчання розглядалися у ряді наукових праць вітчизняних та закордонних дослідників. Практичні аспекти використання дистанційних методів навчання досліджувалися у роботах О. Андрєєва, М. Моісєєвої, В. Мєськова, В. Вержбицького, С. Полат, В. Ізвозчикова, Р. Мильруд, Г. Фонтеней, Ф. Манжено та ін.

Mema cmammi - розкрити можливості використання інформаційно-комунікаційних та дистанційних технологій навчання у процесі формування досвіду міжкультурної комунікації майбутнього економіста.

Як форма організації навчальної діяльності дистанційне навчання виникло в 70-х роках у США. Воно здійснювалось в основному за допомогою листування між викладачем та учнем. 3 подальшим розвитком, дистанційне навчання, як різновид інтерактивного навчання залучало нові засоби передачі інформації: завантаження матеріалів навчального курсу з віртуальної аудиторії, по Intranet чи через Internet, за допомогою браузера Web; спілкування 3 викладачами та одногрупниками через переговорні кімнати, по електронній пошті, за допомогою дискусій-протоколів чи за допомогою аудіо зв'язку. Виникли нові форми роботи: участь у відеоконференціях, робота в інтерактивних лабораторіях $\mathrm{i} 3$ емуляторами, а також відновлення матеріалів навчального курсу в реальному часі. Отже, в наш час здобула популярності методика дистанційного навчання, що поєднує традиційні методи спілкування викладача і студентів на лекціях і семінарах в аудиторії, а також синхронні (одночасні) й асинхронні (із затримкою в часі) контакти через Інтернет.

Асинхронна форма навчання передбачає індивідуальний темп опрацювання навчального матеріалу, тобто, отримавши завдання, кожен студент сам вирішує, коли його виконати і надіслати результати (зрозуміло, у межах визначеного терміну). До асинхронних засобів 
відносять: друковані матеріали, аудіо / відеокасети, CD-ROM, електронна пошта, web-сторінки, FTP, web-форуми (електронна дошка оголошень), гостьові книги, телеконференції Usenet (підписка на групи новин). Синхронні засоби передбачають одночасну участь у процесі навчальних занять викладачів та студентів, до них відносять: web-чат, ICQ, Skype, IRC (Internet Relay Chat), інтерактивне TV, web-телефонія, телеконференції NetMeeting, Telnet.

Світовий досвід дистанційного навчання показує, що при такій методиці дистанційного навчання взаємодія тих, хто навчається, i викладачів на індивідуальній основі відбувається набагато частіше й ефективніше, ніж при інших формах [1, с. 54].

Розробка і впровадження електронних курсів у навчальний процес потребує комплексного вирішення таких дидактичних проблем, як розробка теорії та методики дистанційного навчання, технологій дистанційного навчання тощо. Для ефективної навчальної роботи необхідне якісне дидактичне забезпечення - комплекс взаємопов'язаних за дидактичними завданнями освіти та виховання різних видів змістовної навчальної інформації на різних носіях (у паперовому та електронному виглядах), розроблених з урахуванням вимог педагогіки, психології та інших соціогуманітарних наук.

Основною відмінною рисою дистанційної освіти від інших типів освіти $\epsilon$ широке використання телекомунікаційних технологій у навчальному процесі. Отже, дистанційне навчання - це навчання, що засноване на сучасних інформаційно-комунікаційних технологіях, або опосередковане навчання, яке належить до систем викладання й навчання, де головну роль відіграють високотехнологічні недруковані засоби. Воно здійснюється у двох основних формах:

- автономне (комп'ютеризоване) навчання (Computer-Based Training, CBT) - навчання в аудиторії під керівництвом викладача за допомогою комп'ютера або навчання під керівництвом та допомогою комп'ютера);

- за допомогою конференцій (наприклад, аудіо-, відео- i комп'ютерних).

Аудіоконференція (Audioconference) - електронна конференція, учасники якої перебувають у різних місцях, використовують телефони або спеціальне устаткування для аудіоконференций 3 метою спілкування в реальному часі. Кількість учасників може бути від трьох до ста та більше.

Відеоконференція (Desktop Videoconferencing) - зустріч, методичне засідання або розмова між людьми, які перебувають у різних місцях та використовують відеотехнології як основний канал зв'язку. При цьому надається двосторонній звук та одно- або двосторонне відео. 


\section{Збірник наукових статей}

Дистанційні технології навчання передбачають здійснення взаємозв'язку між учасниками навчального процесу як асинхронно, так і синхронно в часі, і спираються на використання електронних транспортних систем доставки навчальних та інших засобів інформаційних об'єктів, мультимедійних навчальних засобів та інформаційно-комунікаційних технологій. Сьогодні застосовуються такі основні технології дистанційного навчання:

- кейс-технологія - вид дистанційної технології навчання, яка заснована на використанні наборів (кейсів) текстових, аудіовізуальних та мультимедійних навчально-методичних матеріалів для їх самостійного вивчення слухачами, при організації регулярних консультацій у викладачів традиційним або дистанційним способом;

- ТВ-технологія - вид дистанційної технології навчання, що базується на використанні систем телебачення для доставки слухачам навчально-методичних матеріалів та організації регулярних консультацій у викладачів;

- мережева технологія - вид дистанційної технології навчання, що грунтується на використанні мереж телекомунікації для забезпечення слухачів навчально-методичними матеріалами та інтерактивної взаємодії з викладачем.

Дистанційна комунікація (Distance communication) можлива лише при використанні наступних телекомунікаційних технологій:

- електронна пошта (E-mail), основний інформаційний ресурс "offline", яким користуються всі, хто має доступ до дистанційного навчання;

- чат-заняття, навчальні заняття, що проводяться синхронно, в системі дистанційного діалогу "on-line“" у вигляді обміну письмовими репліками, які висвічуються на моніторах співрозмовників;

- веб-заняття, дистанційні уроки, конференції, семінари, ділові ігри, лабораторні роботи, практикуми та інші форми навчальних занять, що проводяться за допомогою засобів телекомунікацій та інших можливостей всесвітньої мережі Інтернет.

- комп'ютерні відеоконференції, відеоконференції із застосуванням персонального комп'ютера, що має швидке Інтернетз'єднання, мікрофон і цифрову відеокамеру;

- форум, інформаційний ресурс Інтернет, який називають мережевими новинами або електронними дошками оголошень і який реалізується за принципом “від одного - всім”.

Унікальність дидактичних властивостей комп'ютерних телекомунікаційних мереж щодо мети навчання іноземних мов полягає передусім у тому, що продуктивне навчання різних видів іншомовної мовленнєвої діяльності може здійснюватися дистанційно завдяки: 
- можливості індивідуального двобічного телекомунікаційного спілкування студента з викладачем та з партнерами за навчанням;

- доступу до численних джерел мовної навчальної інформації, яка зберігається у пам'яті мережевих комп'ютерів і розповсюджується через технічні засоби зв'язку.

Підхід до вибору технологій та методів навчання та викладання має представляти всі напрямки експліцитно та прозоро, та уникати упередженості та догматизму. Радою Європи у викладанні та дослідженні мов рекомендовано: методи, які мають найбільшу ефективність для досягнення цілей, узгоджених із завданнями та цілями навчання та їх соціальним контекстом. Ефективність їх застосування залежить від мотивації та рівня мовної підготовленості студентів, а також від особистісних та матеріальних ресурсів [2, c. 129].

Дистанційне навчання іноземної мови із використанням інформаційно-комунікаційних технологій має забезпечувати реалізацію таких завдань як:

- формування i розвиток умінь та навичок читання 3 безпосереднім використанням матеріалів мережі Інтернет;

- удосконалення умінь аудіювання на основі адаптованих та автентичних аудіотекстів;

- формування вмінь та навичок перекладу та реферування текстів за фахом;

- удосконалення вмінь монологічного та діалогічного мовлення;

- розширення активного та пасивного словників, ознайомлення 3 лексикою сучасної іноземної мови, яка відбиває певний етап розвитку культури даної країни, соціального та політичного устрою суспільства;

- формування елементів глобального мислення (діалог культур);

- формування стійкої мотивації пізнавальної діяльності, потреби використання іноземної мови у реальному спілкуванні;

- формування культури спілкування.

Дослідження підтверджують, що потенціал дистанційного навчання може бути найбільш ефективно використаний при вивченні іноземних мов, що передбачає обговорення, інтенсивну розумову активність та колективну діяльність, а також співпрацю викладача та студента як у формі позааудиторної (дистанційної) роботи, так і на контактних (аудиторних) заняттях. Дослідники в галузі використання електронних засобів інформації для навчання іноземних мов відзначають ефективність таких завдань, як робота в електронній мережі своєї країни та за кордоном, спілкування між викладачами i студентами, в малих групах за комп'ютером.

Сучасні інформаційні технології надають практично необмежені можливості в розміщенні, зберіганні, обробці та доставці інформації 
будь-якого обсягу та змісту на будь-які відстані. Ефективність будьякого виду навчання залежить від взаємодії викладача та студента, від зворотного зв'язку між ними, від застосованих при цьому педагогічних технологій і розроблених дидактичних матеріалів.

Успішність дистанційного навчання значною мірою залежить від організації та якості дидактичних матеріалів, а також від педагогічної майстерності викладача, що має бути активним учасником цього процесу й гнучко управляти процесом навчання своїх студентів.

\section{Література}

1. Андреев А. А., Солдаткин В. И. Дистанционное обучение: сущность, технология, организация. М. : МЭСИ, 1999. - 196 с.

2. Ніколаєва Ж. В. Навчання іноземних мов у ВНЗ у контексті Загальноєвропейських Рекомендацій 3 мовної освіти // Науковий вісник Миколаївського державного педагогічного університету. Педагогічні науки: Збірник наукових праць. Випуск 29. - Миколаїв : МДПУ, 2009. - С. 127-130.

3. MANGENOT, F. L'apport des TICE à l'enseignement/apprentissage du FOS. // Paris : Les cahiers de l'ASDIFLE. - 2003. - P. 145-156.

Ирина Безуглая. Использование информационнокоммуникационных и дистанционных технологий обучения в процессе формирования иноязычной компетенции.

Рассмотрены вопросы, связанные с использованием информационнокоммуникационных и дистанционных технологий обучения в процессе формирования навыка межкультурной коммуникации будущего экономиста. Рассмотрены современные образовательные тенденции, проанализированы наиболее популярные информационнокоммуникаиионные технологии.

Ключевые слова: дистанционнье технологии обучения, информационно-коммуникационные технологии, иноязычная коммуникативная компетенциия.

Iryna Bezugla. Information and communication technologies in the teaching and learning of foreign languages.

This article sets out to give a general overview of the availability of technology for foreign language teaching and learning today, to outline the various uses of information and communication technologies, to provide a few, selected studies of best practice, illustrating meaningful deployment of these resources. It highlights the importance and the role of the teacher in ICT-rich foreign language learning environment.

Key words: distance learning technologies, information and communication technologies, foreign language communicative competence.

Стаття надійшла до редакційної колегії 15.05.2014 
Бондар Оксана Євгеніївна

(с) Бондар О. Є., 2014.

Дніпропетровський національний університет імені Олеся Гончара

\section{ВІЗУАЛЬНА ОРГАНІЗАЦІЯ ІНФОРМАЦІЇ ЯК МЕТОД ЕФЕКТИВНОГО ЗАПАМ'ЯТОВУВАННЯ В НАВЧАЛЬНОМУ ПРОЦЕСІ}

Розглядається питання структурування інформащіі за допомогою карток пам'яті. Представлені погляди на розвиток теорії осмисленого навчання та ї̈ вплив на створення методу майндмеппінгу. Пропонується практичне застосування карток пам'яті для ефективного запам'ятовування інформачії у навчальному прочесі.

Ключові слова: картки пам'яті, візуальна організація, осмислене навчання, майнд-меппінг, асоціативне мислення.

Завданням сучасної вищої школи є пошук простих і ефективних методів активізації навчального процесу та втілення їх на практиці. Важливим на цьому етапі $\epsilon$ перехід від механічного заучування матеріалу, (що означає запам'ятовування понять, які майже не мають асоціацій 3 когнітивними структурами, що вже існують) до осмисленого навчання. Актуальною в наш час $\epsilon$ відома цитата видатного американського психолога Д. Аусубеля стосовно ідеології навчання: «Якби мені довелося сформулювати всю навчальну філософію у вигляді одного принципу, я би сказав, що на процес навчання найбільше впливає те, що учень уже знає. Потрібно тільки 3'ясувати це i, відповідно, учити. Найважливіше в навчанні є те, що учень уже знає» [3]. Основна ідея теорії осмисленого навчання, розробленої Д. Аусубелем, полягає у представленні нових понять чи концепцій через поняття, концепції та досвід, які людина вже має.

Вільям Джеймс у своїй книзі «Принципи психології» так описав осмислене навчання: «3 чим більшою кількістю фактів ми асоціювали даний факт, тим сильніше він затриманий нашою пам'яттю... Таємниця гарної пам'яті $\epsilon$, таким чином, мистецтво утворювати численні та різнорідні асоціації з усіляким фактом, який ми бажаємо утримати в пам'яті».

У 60-ті роки теорію осмисленого навчання розвивав професор Корнельського університету Джозеф Новак. Саме він розробив правила створення концепт-карт - інструмента візуалізації та створення нових ідей чи концепцій.

Подальший розвиток теорія отримала в роботах британського психолога Тоні Бьюзена [2]. У 1974 році він опублікував книгу 
«Працюй головою», в якій описав метод майнд-меппінгу (mind mapping). Виявляється, кожен біт інформації, що надходить із зовнішнього світу до нашого мозку (відчуття, спогади, думки тощо) може бути представлений у вигляді центрального сферичного об'єкту, від якого розходяться десятки, тисячі і навіть мільйони асоціацій.

В різноманітних українських джерелах можна знайти наступні варіанти перекладу цього методу: інтелект-картки, ментальні картки, картки розуму, концепт-картки, картки уявлень, картки знань, картки пам'яті, асоціативні картки. Ми будемо використовувати термін «картки пам'яті».

В основі концепції карток пам'яті лежать уявлення про принципи роботи мозку людини: асоціативне (нелінійне) мислення, візуалізація розумових образів, цілісне сприйняття. Для стимулювання асоціативного мислення застосовуються особливі «радіанні» діаграми, що являють собою дерево ідей. Побудова карток починається 3 центрального образу. Центральний образ - це завдання, яке необхідно розв'язати; ідея, яка потребує розвитку; проект, який необхідно виконати; інформація, яку треба запам'ятати. Центральний образ - це «стовбур» дерева, від якого розходяться гілки рішень. Від двох до десяти гілок цього дерева відповідають основним, базовим ідеям, що асоціативно пов'язані 3 центральним образом. Від них відходять другорядні ідеї-асоціації, а від другорядних «виростають» асоціації більш низького рівня тощо. Таким чином, у картці пам'яті реалізуються асоціативність та ієрархічність мислення - від загального до конкретного. Важливою особливістю таких карток $\epsilon$ їхня насиченість візуальними образами та ефектами. При підготовці карток пам'яті активно використовується колір, шрифт, малюнки, умовні позначки та абревіатури.

Давайте розглянемо, як можна застосовувати картки пам'яті у навчальному процесі.

1. Запам'ятовування нових слів. Цей спосіб набагато ефективніший ніж спосіб карток, коли на одній стороні пишеться слово, а на іншій - переклад, тому що багато англійських слів мають кілька значень, а також можуть бути різними частинами мови.

2. Розвиток мовленнєвих навичок. За допомогою дієслів та інших фраз, таких як «відомий як..., необхідний для..., залежить від..., $\epsilon$ результатом..., поділяється на... тощо» студенти вчаться зв'язувати окремі блоки картки у речення.

3. Вивчення граматики. За допомогою карти пам'яті можна уявити будь-яке граматичне правило або конструкцію. При цьому всі винятки, особливі випадки, а також приклади застосування можна виділити в окремі гілки і зробити на них акцент. 
4. Складання приміток (note-taking). Нотатки можна робити під час прослуховування лекцій, читання текстів або вивчення будь-якого матеріалу (статей, книг, підручників) і т.д. Наприклад, видання "Cambridge Preparation for the TOEFL Test" рекомендує робити нотатки під час проходження секції Listening методом карток пам'яті.

5. Перевірка та оцінювання знань. Завдяки тому, наскільки опрацьованою та гармонічною буде картка, створена студентами, можна оцінити, наскільки добре вони володіють основними поняттями теми, виділяють ключові питання теми та зв'язують їх між собою.

6. Складання плану занять. За допомогою даної технології можна скласти план своїх дій з вивчення англійської на цілий рік, місяць, тиждень або день. Можна зробити картку пам'яті зі списком справ.

Ознайомившись 3 технікою побудови карток пам'яті більш докладно, можна знайти ще безліч способів, як їх застосувати у вивченні іноземної мови. Це може бути підготовка до іспитів, складання плану твору або есе, виявлення слабких місць в граматиці, пояснення та обговорення словника та багато іншого.

Після закінчення роботи над карткою слід повернутися до неї через деякий час. Так, Т. Бьюзен рекомендує наступні інтервали часу: 10-30 хвилин, 1 день, 1 тиждень, 1 місяць, 3 місяці, 6 місяців. Такі звертання до картки дозволять подивитися на неї по-новому: побачити допущені помилки та пропуски, виправити або доповнити ії новою інформацією. Крім того, це дозволить краще запам'ятати інформацію на картці та перемістити іiі 3 короткострокової у довгострокову пам'ять [1].

Таким чином, карти пам'яті (Mind Maps) - це природний продукт діяльності нашого мозку. Складаючи такі карти, ми графічно висловлюємо процес нашого мислення. Карти пам'яті $\epsilon$ дуже потужним інструментом вивільнення потенціалу, прихованого в мозку. Тому цей метод може знайти застосування в будь-якій сфері людського життя, де потрібно вдосконалювати інтелектуальний потенціал особистості, а особливо при оволодінні іноземною мовою. Картки пам'яті - це ефективний інструмент структурування та аналізу інформації. Вони дозволяють прискорити процес вивчення навчальних матеріалів та підвищити ступінь запам'ятовування інформації.

\section{Література} $-320 \mathrm{c}$.

1. Бьюзен Т. Супермышление / Т. Бьюзен. - М. : Поппури, 2007

2. Бьюзен Т. Суперинтеллект / Т. Бьюзен. - М. : Поппури, 2005. $-412 \mathrm{c}$.

3. Ausubel D. The Psychology of Meaningful Verbal Learning / D. Ausubel. - New York : Grune \& Stratton. 
Оксана Бондарь. Визуальная организация информации как метод эффективного запоминания в учебном процессе.

Рассматривается вопрос структурирования информаџии с помощью карт памяти. Представлень взгляды на развитие теории осмысленного обучения и ее влияние на создание метода майндмэппинг. Предлагается практическое применение карточек памяти для эффективного запоминания информации в учебном процессе.

Ключевые слова: карты памяти, визуальная организачия, осмысленное обучение, майнд-мэппин, ассочиативное мышление.

Oksana Bondar. Visual organization of information as effective method of memorization in the educational process.

The problem of structuring information using mind-maps is considered. The views on the development of the theory of meaningful learning and its impact on the creation of mind-mapping method are presented. Practical application of mind-maps for information memorization in the learning process is suggested.

Key words: mind-maps,visual organization, meaningful learning, mindmapping, associative thinking.

Стаття надійшла до редакційної колегії 11.05.2014

УДК 001.895-042.3:004.9-043.83-047.22]:7.05-051-057.21

Борисенко Денис Володимирович

(C) Борисенко Д. В., 2014.

Українська інженерно-педагогічна академія

\section{ВПЛИВ ІННОВАЦЙНИХ ІНФОРМАЦІЙНО- КОМУНІКАТИВНИХ ТЕХНОЛОГІЙ НА ФОРМУВАННЯ СУЧАСНОЇ ТВОРЧОЇ КОМПЕТЕНЦЇ̈ ІНЖЕНЕРА-ДИЗАЙНЕРА}

Інноваційні навчальні технології характеризуються популярністю та широкою технічною підтримкою. Саме їх оновлення та поступове впровадження реалізує нову навчальну парадигму та перспективні кроки до майбутньої інтегративної освітньої системи. В статті розглянута інновачійна стратегія розвитку навчального процесу на прикладі підготовки інженерів-дизайнерів. Ставиться акцент на творчий компонент, який потребує більш досконального сучасного навчального вирімення. Представлені рекомендації впровадження інноваційної системи для інженерів-дизайнерів.

Ключові слова: інформачійно-комунікативні навчальні технології, інновачії, інженер-дизайнер, творча компетенція. 
Інформаційно-комунікативні технології замають провідне місце в інноваційному впровадженні та оновленні освітнього простору. Вони акцентують увагу на необхідність «переозброєння» наявного навчально-методичного комплексу, розгортання процесу якісного технічного опанування, створення новітніх моделей проведення лекційних, практичних, лабораторних та семінарських занять у вищих навчальних закладах. Досвід впровадження нових навчальних технологій демонструє перевагу їх розвитку саме в інженерних спеціальностях та в напрямах підготовки, пов'язаних з безпосереднім та частковою роботою 3 комп'ютером. Залишається менш технічно опанованим творчий комплекс навчальних дисциплін. Саме його на меті буде розглянуто в даній статті в рамках реалізації науководослідної роботи викладачами кафедри «Технологій i дизайну» Української інженерно-педагогічної академії «Розробка та впровадження інноваційних технологій викладання циклу спеціальних дисциплін для підготовки за напрямком «Професійна освіта. Дизайн».

Метою статті $є$ розгляд інноваційних надходжень та їх практичної ролі в формуванні творчої компетенції інженерадизайнера. Серед задач дослідження виділяється: аналіз теорій i практик впровадження інноваційних технологій, досліджень відомих науковців, методистів та педагогів-новаторів; аналіз реальної ситуації навчальної підготовки та виокремлення «прогалин»; розробка авторських рекомендації щодо впровадження інноваційних навчальнометодичних комплексів, методик та навчальних інформаційнокомунікативних технологій.

На сьогодні існує значна інформативна база щодо інноваційних навчальних зрушень та впровадження новітніх розробок. Так над проблематикою впровадження інноваційних навчальних технологій працювали I. Бом, Л. Ващенко, Л. Даниленко, О. Дусавицький, В. Живодьор та інші. Особливу плеяду науковців, які займалися саме в сфері підготовки дизайнерів, представляють: Л. Безмоздіна, Д. Джонсон, С. Новоселова, F. Gaviria, В. Ecugenia [1], Ф. Парамонов та інші. Формування творчої компетенції та розгляд ії проблематики висвітлено в роботах С. Батишов, S. Lester [2], П. Пучкова, А. Попов [3], В. Щукіної [4], А. Новікова та інших. Але серед більшості проаналізованих робіт науковців видаляється лише теоретичний аналіз без представлення практичних рекомендації інноваційних впроваджень. Ця невирішена проблематика частково буде представлена нижче.

Сучасна творча компетенція, яку повинні оволодіти студенти, майбутні інженери-дизайнери, на сьогодні включає крім традиційного компоненту також i інноваційний інформаційно-комунікативний спектр [4, с. 53]. До традиційного відносять з особливості методології 


\section{Збірник наукових статей}

ведення роботи, знання та вміння користуватися художніми техніками, стильовими напрямками, технікою виконання тощо. Інноваційний спектр включає використанні новітніх технологій, які повинні одночасно полегшити деякі етапи роботи та надати сучасний «інструмент», в тому числі і для формування дизайн-ідей.

При розробці нових методик та технологій, в тому числі i освітніх інформаційно-комунікативних компонентів, передує значний етап аналізу, оцінки, проведення експерименту на незначних групах, виявлення «негативних» ознак та їх виокремлення, а аж потім їх впровадження в навчальний процес. Методики - це створений педагогом перелік вимог до практичної реалізації освітньої розробки, який, в більшості за змістовним компонентом, має вже висвітлені аспекти технічних та експлуатаційних особливостей, загально дидактичні пункти та авторські побажання та рекомендації до спеціалізованого використання за певними предметними галузями використання або, навпаки, невикористання.

Підготовка інженера-дизайнера включає значну кількість навчальних дисциплін, в яких можливо застосувати інноваційні стратегії. Але для більшої доцільності та врахування розвитку сучасного творчого компоненту зорієнтуємося на викладі спеціальних дисциплін «Комп'ютерний дизайн» та «Основи формоутворення». В них буде виділимо своєрідний перелік дидактичних принципів використання освітньої розробки та представлені авторські рекомендації щодо особливостей застосування:

- за рахунок застосування комплексу програмованої, електронної в поєднанні з традиційними формами проведення занять зі студентами, опанування навчальним матеріалом в самостійному режимі, надання індивідуальним навчальних завдань 3 теоретичнотворчим змістом, впровадження часткового дистанційного забезпечення тощо реалізовується підвищення індивідуалізації та диференціації організації навчального процесу, що $є$ важливим для розвитку творчого компоненту майбутнього інженера-дизайнера;

- впровадження електронних засобів характеризуються присутністю поетапного вивчення навчального матеріалу, наявністю чітко виявлених навчальних доз та відповідних до них навчальних завдань 3 підвищенням складності при переході до найбільш поглибленого вивчення матеріалу та просування по тематикам навчальної програми. Це дозволяє виконувати ефективну та якісну навчально-методичну організацію освітньої підготовки майбутнього фахівця проектної діяльності;

- заміщення контролюючого комплексу спорідненням традиційних форм проведення контролю із збагачення його новими засобами, в тому числі електродних, дистанційних та мобільними; 
- знаходження вільного навчального часу, яке з'являється при використанні інноваційних навчальних засобів та контролюючих комплексів, та використання його для розвитку творчої діяльності студента;

- підвищення наочності, візуалізації навчального процесу, насамперед, представленого навчального матеріалу, активне використання демонстрації, включення навчальних презентацій, відеороликів та фільмів, а також заміщення статичних плакатів динамічними анімаційними засобами, застосування розгорнутих графічних ілюстрацій та переведення представленого навчального матеріалу в електронний вигляд, використання новітніх трьохвимірних технологій;

- використання модельованих та імітаційних навчальних систем в навчальному процесі при розгляді складних процесів формотворення та створення дизайн-продукту, проведенні дослідницьких проектів;

- при проведенні лабораторних та практичних робіт застосування комп'ютерних імітаційних програм створення формоутворюючих характеристик та створення дизайн-продукту, поєднання теоретичного викладу 3 практичною реалізацію в навчальній програмі;

- розробка, створення, використання та удосконалення інформаційних навчальних баз, надання відкритого доступу до їх використання студентам, а також надання студентам включатися в розробку навчальних систем, робити свій внесок в розробку окремих навчальних тем, навчальних завдань тощо; використання вітчизняного та зарубіжного досвіду при розробці та використанні навчальних електронних систем, користування вже існуючими прототипами;

- збільшення мотиваційного впливу на студента за рахунок впровадження ігровим навчальних моделей, які мають лише епізодичний аспект використання, лише на початкових стадіях освоєння, i подальше підкріплення іншими більш розвинутими та демократичними мотиваційними «механізмами»;

- надання кожному студенту інтерактивного плану та методики опанування навчальної дисципліни, навчальної завантаженості та необхідних сформованих вимог при проходженні лабораторних та практичних занять, обсягу комплексних навчальних завдань; підготовка студента до кожного послідующого заняття як в традиційній формі, так і в інноваційній дистанційно-мобільній, в якій реалізується більш повна та приближена для студента форма взаємодії та надання навчальної підтримки, виявлення теоретичних та практичних недоліків, надання додаткових ресурсних баз для досягнення поставленого рівня або підвищення знань та умінь 3 певних тематичних рубрик; 
- розвиток не лише теоретичних знать та певного виду мислення, а також при використанні інноваційних програмованих та комп'ютеризованих навчальних процесів реалізується комплексний підхід до сформування компетентних вимог до майбутнього спеціаліста, розширення меж творчої активності студента не лише в позаучбовий час, але й на самих практичних та лабораторних заняттях;

- формування у студентів системи критеріїв для прийняття швидких оперативних рішень, надання варіативних навчальних блоків для максимальної персоналізації протікання навчального процес.

Даний перелік рекомендацій можливо продовжувати ще сотнями пунктів для більш цілісного розуміння та конкретного визначення в певній навчальній ситуації. Але зосередимося на більш важливій особливості використання, яка пов’язана 3 наданням студенту максимально цілісного навчального процесу опанування теоретичними знаннями, сформування практичних умінь i навичок, професійних компетенцій. Саме досягнення максимальної цілісності навчального процесу, виключення «розриву» теоретичного навчального блоку від практичного, поєднання їх в один комплексний нерозривний навчальний комплекс - інформаційно-комунікативну навчальну базу, компоненти якої втілюють цілісність освітньої системи.

Модернізація освітньої сфери зачіпає одночасно не лише технічні особливості «переозброєння», які наглядно демонструються сьогодні вищими навчальними закладами, а й включає оновлення методологічного комплексу, застарілих традиційних методик викладання навчального матеріалу, проведення практичних та лабораторних робіт, особливо, для інженерних та творчих спеціальностей, серед яких i підготовка інженера-дизайнера. Перспективним стає акцент саме на авторські розробки, які стануть більш ефективним засобом для конкретних практичних цілей та завдань застосування в навчальному процесі та розвитку творчої компетенції фахівця. Вже сьогодні досвідчений викладач при використанні інноваційних навчальних програм звертає увагу не на масові показники впровадження та технічні характеристики, які також представляють важливу роль при застосовуванні, а на пї цілісність, простеження послідовності, методологічні особливості реалізації, а саме головне - практичну можливість використання в наявним навчальних умовах.

\section{Література}

1. Gaviria F. Technology-enhaced support for lifelong competence development in higher education / F. Gaviria, B. Ecugenia. - Girona: Universitat de Girona, 2012. -158 p. 
2. Lester S. Beyond knowledge and competence towards a framework for professional education / S. Lester // Capability. - 1995. T. 1. - № 3. - P. 44-52.

3. Пучков Н. П. Инновационные подходы к формированию творческих компетенций в системе обеспечения качества профессионального образования / Н. П. Пучков, А. И. Попов // Вопросы современной науки и практики. Университет им. В. И. Вернадского. - 2008. - Т. 1. - С. 165-173.

4. Щукина В. В. К проблеме развития дизайнерской компетентности студентов вузов / В.В.Щукина // Вестник ЧГПУ. 2004. - C. 52-55.

Денис Борисенко.

Влияние

инновационных информационно-коммуникативных технологий на формирование современной творческой компетенции инженера-дизайнера.

Инноваиионные учебные технологии характеризуются популярностью $u$ широкой технической поддержкой. Именно их обновление $u$ постепенное внедрение реализует новую учебную парадигму $u$ перспективные шаги к будущей интегративной образовательной системе. В статье рассмотрена инноваџионная стратегия развития учебного прочесса на примере подготовки инженеров-дизайнеров. Делается акиент на творческий компонент, который требует более досконального современного учебного решения. Представлены рекомендации внедрения инновачионной системы для инженеровдизайнеров.

Ключевые слова: информационно-коммуникативные учебные технологии, инновации, инженер-дизайнер, творческая компетенция.

Denis Borisenko. Influence of Innovative Information and Communicative Technologies on Formation of Modern Creative Competence of the Engineer-Designer.

Innovative educational technologies are characterized by popularity and broad technical support. Their updating and gradual introduction realizes a new educational paradigm and perspective steps to future integrative educational system. In article innovative strategy of development of educational process on the example of training of engineers-designers is considered. The emphasis on a creative component which demands more thorough modern educational decision is placed. Recommendations of introduction of innovative system for engineers-designers are submitted.

Key words: information and communicative educational technologies, innovations, engineer-designer, creative competence.

Стаття надійшла до редакційної колегії 05.05.2014 
Борова Тетяна Анатоліївна

(C) Борова Т. А., 2014.

Харківський національний економічний університет імені С. Кузнеця

\section{ЕЛЕКТРОННЕ НАВЧАННЯ У ВИКЛАДАННІ ІНОЗЕМНОЇ МОВИ СТУДЕНТАМ ВНЗ: КОНЦЕПЦІї, ЗАКОНОМІРНОСТІ ТА ПРИНЦИПИ}

У статті обгрунтовано основні конщепції, підходи та закономірності електронного навчання щодо викладання іноземної мови у вищому навчальному закладі. Подано результати аналізу основних принщипів електронного навчання іноземній мові студентів немовних спеціальностей вищих навчальних закладів. Виокремлено сутність застосування принципів електронного навчання у процесі викладання іноземної мови студентам немовних спеціальностей ВНЗ .

Ключові слова: електронне навчання, конщепції, закономірності, принщипи, іноземна мова, студенти вищого навчального закладу.

Сучасний період розвитку суспільства, 3 одного боку, характеризується суттєвим впливом комп'ютерних технологій, які пронизують усі сфери життя, утворюючи глобальне інформаційне середовище. 3 іншого боку, загальні інтеграційні процеси, і в першу чергу, прагнення України до вступу в СС зумовлюють необхідність підготовки майбутнього спеціаліста нового типу, здатного належним чином представляти країну в міжнародних стосунках і захищати іiі інтереси в межах міжнародного співробітництва. Таким чином, мовне навчання має стати елементом загальної модернізації системи підготовки майбутніх спеціалістів. У багатьох немовних вищих навчальних закладах під час вивчення іноземної мови немає можливості спілкування з носіями мови, відсутнє мовне середовище i, таким чином, умови навчання суперечать самій сутності дисципліни «Іноземна мова». Традиційне навчання має ряд недоліків, які впливають на рівень вивчення та володіння іноземною мовою студентами. У той же час постійно зростаючі вимоги суспільства і часу до рівня володіння іноземною мовою ставлять питання щодо підвищення якості навчання іноземним мовам.

У зв'язку з цим особливо гостро постає проблема пошуку нових, більш ефективних методик, методів і прийомів навчання іншомовній комунікації з метою підтримки зацікавленості студентів до вивчення іноземної мови.

В. Беспалько, Б. Гершунский, С. Зайцева, В. Іванов, С. Полат, В. Монахов, М. Скаткін, О. Мінькова, Г. Сєлєвко, І. Роберт та інші 
розглядали сучасні принципи педагогічного процесу з використанням інформатизованих систем навчання, а також методичні проблеми застосування комп'ютерних технологій у навчальному процесі. Ефективність використання інформаційно-комунікаційних технологій у процесі викладання іноземних мов вивчали такі провідні вчені як: О. Єрьоміна, І. Костікова, О. Мінькова, С. Полат, С. Петровска та інші. На тлі цих численних досліджень залишається недостатньо вивченим питання теоретико-методологічної основи застосування електронного навчання у процес викладання іноземної мови за професійним спрямуванням студентам немовних спеціальностей ВНЗ.

Метою статmі є обгрунтування теоретико-методологічної основи запровадження електронного навчання у процесі викладання іноземної мови студентам немовних вищих навчальних закладів. Завдання - проаналізувати основні підходи та концепції розвитку сучасного суспільства і визначити їх роль у застосуванні електронного навчання у вищому навчальному закладі, зокрема у ході викладання іноземної мови. Визначити основні закономірності та принципи електронного навчання у процесі викладання іноземної мови студентам немовних спеціальностей вищих навчальних закладів.

На початку XXI століття світ перейшов з індустріальної епохи до постіндустріальної або до інформаційного суспільства. У постіндустріальному суспільстві соціальна ефективність освіти стає більш високою. Основою побудови такого суспільства $\epsilon$ інформатизація, яка виявляється результатом розвитку інформаційних технологій. Головним фактором суспільного розвитку інформаційного суспільства визначено виробництво та використання науковотехнічної та іншої інформації (3. Бзежинський, Д. Белл, Дж. Пелтон, А. Тоффлер, Х. Еванс та інші) [4, с. 268-269].

Для постіндустріального суспільства характерною є концепція сталого розвитку. Концепція сталого розвитку $є$ основою теорії соціальної політики в умовах глобалізації. Основою сталого розвитку є системний підхід та сучасні інформаційні технології, які дають змогу дуже швидко моделювати різні варіанти напрямів розвитку, з високою точністю прогнозувати їхні результати та обрати найбільш оптимальний [1]. Таким чином, основними концепціями, які мають практичну реалізацію застосування сучасного навчання, зокрема електронного у сфері вищої освіти, можна визначити такі: концепція сталого розвитку та концепція інформаційного суспільства.

Поряд 3 системним підходом провідну роль відіграє синергетичний підхід (Г. Хакен, І. Пригожин, С. Курдюмов, В. Буданов), який є базою у моделюванні будь-яких систем. Зазначимо методологічні принципи синергетики у контексті взаємодії учасників навчально-виховного процесу: гомеостатичність, ієрархічність, 
нелінійність, незамкнутість (відкритість), нестійкість, динамічна ієрархічність (емерджентність) та спостерігальність [2]. Усі ці принципи також можуть бути покладені в основу електронного навчання, тому що відповідають за стабільність існування створеної системи електронного навчання.

Значне місце у системі електронного навчання відведено діяльнісному підходу, який $є$ основою будь-якої діяльності, зокрема вивчення іноземної мови. Дослідження особливостей педагогічної діяльності проводилося вітчизняними та зарубіжними науковцями (B. Блум, Т. Гускей, Н. Кузьміна, 3. Курлянд, Л. Подимова, В. Семиченко, В. Сластьонін).

Інший підхід, що $є$ важливим в електронному навчанні $\epsilon$ компетентнісний підхід. Тому що з використанням компетентнісного підходу компетенції розглядаються як результат освіти і виступають новим типом цілепокладання у ході проектування освітніх систем. Питанням компетентнісного підходу присвячені праці Н. Бібік, Л. Ващенко, Г. Єльникової, О. Локшина, О. Овчарук, О. Савченко, О. Пометун.

Зважаючи на виокремленні концепції та підходи в електронному навчанні, необхідно звернути увагу на основні закономірності навчання окремої навчальної дисципліни, які $\epsilon$ i у традиційному навчанні. До першої можна віднести - залежність основної мети та завдань навчання від рівня, темпів, потреб і можливостей суспільства, рівня розвитку педагогічної науки і практики. Зокрема, зосереджуємо увагу на інформаційному суспільстві, яке вимагає потужне використання інформаційно-комунікаційних технологій у навчальновиховному процесі вищої школи, електронне навчання буде відбивати дану закономірність.

Безумовно важливою закономірністю $є$ залежність результативності навчання від поєднання внутрішніх (особистісних) мотивів 3 зовнішніми (суспільно-економічними) умовами. У ході застосування електронного навчання у навчальний процес відбувається осучаснення викладання, зокрема іноземної мови, що підвищує вмотивованість і спрощує вивчення дисципліни студентами.

Наступною закономірність електронного навчання можна вважати залежність рівня продуктивності навчання від матеріальнотехнічного та методичного забезпечення навчального процесу, оптимального застосування засобів та методів навчання, форм його організації. Ця закономірність показує важливість оснащення навчального середовища сучасним обладнанням, зокрема у процесі навчання іноземній мові. Мається на увазі не тільки комп'ютери та мультимедійні засоби, а й сучасне програмне забезпечення. 
Ще однією важливою закономірністю електронного навчання $є$ обумовленість результативності навчання інтенсивністю зворотних зв'язків, врахування результатів попередніх етапів. Результати зворотного зв'язку повинні бути спрямовані на розвиток мовленнєвих вмінь студента, а навчальні результати необхідно заносити у мовний портфоліо студента. Такий підхід може прозоро та миттєво (запровадження електронних журналів) показувати реальні результати навчання з іноземної мови та спрямовувати студента на саморозвиток.

Звертаючи увагу на визначене вище, зауважимо, що електронне навчання може бути ефективними тільки тоді, на сучасному розвитку освіти, коли воно органічно поєднуються 3 традиційною системою навчання, яка містить такі принципи: спрямованість навчання на вирішення завдань освіти, розвитку й виховання; науковість навчання; систематичність і послідовність навчання; доступність навчання, врахування вікових особливостей; наочність навчання; зв'язок навчання 3 реальним життям; свідомість і активність у навчанні; міцність засвоєння знань, умінь та навичок.

У світлі зазначених вище принципів, зауважимо, що головною метою вивчення іноземних мов $€$ формування у студентів загальних та професійно зорієнтованих комунікативних мовленнєвих компетенцій (лінгвістичної, соціолінгвістичної і прагматичної) для забезпечення ефективного спілкування в академічному та професійному середовищі [3].

Технологічні можливості інформаційних технологій потужні та багатоаспектні, що дозволяє створити комунікативне середовище для навчання, розвивати зацікавленість до вивчення англійської мови за професійним спрямуванням, створити умови, які максимально приближені до реально мовного спілкування англійською мовою при відсутності природного мовного середовища.

Інформаційно-комп'ютерне навчальне середовище розглядається як організована сукупність інформаційно-комп’ютерних ресурсів, системного забезпечення, програмних засобів комп’ютерної комунікації та електронних засобів навчання, використання яких має на меті: забезпечити студента необхідними знаннями, сформувати компетенцій з відповідної дисципліни індивідуально або у співпраці $з$ іншими студентами. Все це дозволяе студенту обрати свою автономну траєкторію навчання щодо досягнення поставленої мети.

Вивчення мов з комп’ютерною підтримкою також реалізується на таких принципах, як: індивідуалізація, диференціація й інтенсифікація. Де комп'ютерні технології створюють мовне середовище, забезпечуючи провідний принцип вивчення мов принцип комунікативності. 


\section{Збірник наукових статей}

Багаторічні дослідження підтверджують той факт, що комп'ютерна комунікація дозволяє поєднати існуючі методи навчання іноземних мов шляхом використання мультимедійних технологій, що здатні моделювати лінгвістичну та комунікативну реальність, а також формувати компетенції в аудіюванні, говорінні, читанні та письмі. Мультимедіа дають змогу реалізувати принцип інтегрованого навчання усіх видів мовленнєвої діяльності.

За результатами застосування інноваційних інформаційних технологій на заняттях 3 англійської мови відбулися зрушення до більш прискореного формування у студентів таких якостей як вмотивованість, цілеспрямованість, конструктивність, комунікативність, оперативність та креативність. Інтерактивне навчання на основі інноваційних інформаційних технологій дозволяє більш повно реалізувати цілий комплекс методичних, дидактичних, педагогічних та психологічних принципів, робить процес навчання більш цікавим та творчим.

Отже, правильне врахування концепцій, підходів, закономірностей та принципів викладання іноземної мови на основі електронного навчання $\epsilon$ основою ефективного добору системи методів, засобів, організаційних форм, прийомів навчання іноземній мові.

Подальший науковий пошук буде здійснюватися в дослідженні ефективних методів навчання при дистанційній формі викладання та навчання англійської мови за професійним спрямуванням студентами BH3.

\section{Література}

1. Білорус О. Г. Глобальна перспектива і сталий розвиток: (Системні маркетол. досл.) / О. Г. Білорус, Ю. М. Мацейко. - К. : МАУП, 2005. - $492 \mathrm{c.}$

2. Буданов В. Г.

Методология синергетики B постнеоклассической науке и в образовании / В. Г. Буданов. - М. : Издательство ЛКИ, 2008. - 232 с.

3. Загальноєвропейські Рекомендації з мовної освіти: вивчення, викладання, оцінювання / Науковий редактор українського видання доктор пед. наук, проф. С. Ю. Ніколаєва. - К. : Ленвіт, 2003. - 273 с.

4. Социальная философия: учебник / [под ред. Андрущенко В. П., Горлача Н. И.]. - Киев. - Харьков : Изд. центр «Единорог», 2002. - $736 \mathrm{c.}$

Татьяна Боровая. Электронное обучение в преподавании иностранного языка студентам вуза: концепции, закономерности и принципы

В статье обоснованы основные концепции, подходы и закономерности электронного обучения в контексте преподавания иностранного 
Психолого-педагогічні проблеми становлення сучасного фахівця

Випуск 2014 языка в высшем учебном заведении. Подань результать анализа основных принципов электронного обучения иностранному языку студентов неязыковых специиальностей высиих учебных заведений. Выделена сущуность применения принципов электронного обучения в прочессе преподавания иностранного языка студентам неязыковых специильностей вуза.

Ключевые слова: электронное обучение, концеепции, закономерности, принцииы, иностранный язык, студенты высшего учебного заведения.

Tetyana Borova. E-learning in Foreign Language Teaching of Higher Educational Establishments' Students: Concepts, Approaches and Principles.

The article discusses the basic E-learning concepts and approaches in the context of foreign language teaching in higher educational establishments. Peculiarities of E-learning in foreign language teaching of students, pursuing the non-linguistic majors, have been analysed and the results substantiated. The essence implementing E-learning principles and concepts in foreign language teaching of students, pursuing the nonlinguistic majors, are grounded.

Key words: E-learning, concepts, approaches and principles, foreign language, higher educational establishments' students.

Стаття надійшла до редакційної колегії 12.05.2014

УДК 378.147

Бугайчук Костянтин Леонідович

Харківській національний університет внутрішніх справ

\section{ЗНАЧЕННЯ КУРУВАННЯ КОНТЕНТУ В УМОВАХ ДИСТАНЦЙНОГО НАВЧАННЯ У ВИЩИХ НАВЧАЛЬНИХ ЗАКЛАДАХ МВС УКРАЇНИ}

В статті досліджений зміст поняття «курування контенту» та його значення в умовах інформаційного суспільства та проведення дистанційного навчального процесу. Автором розглянуті основні функиї викладача ВНЗ МВС України, як куратора контенту, та запропоновано впровадження в систему підвищення кваліфікаиіі викладачів ВНЗ МВС навчального курсу «Куратор контенту».

Ключові слова: куратор контенту, викладач, дистанційне навчання, МВС України.

У сучасному навчальному процесі особливого значення набуває використання актуальної та достовірної інформації, яка відповідає 
вимогам часу. Усе частіше нам потрібно володіти швидкими й точними даними про предмет власної діяльності, причому своєчасність їх отримання стає надзвичайно важливою. У цей час найбільш зручним способом одержання й передачі різноманітної інформації $\epsilon$ використання всесвітньої комп'ютерної мережі Інтернет. Однією 3 переваг Інтернету є його різноманітність та відкритість - кількість і доступність інформації в мережі значно вища. Проте з розширенням глобальної комп'ютерної мережі, збільшенням кількості доступної інформації й послуг виникає проблема її обробки, систематизації, а також перевірки на достовірність.

В умовах проведення традиційного та дистанційного навчального процесу навчальні курси юридичної спрямованості у своїй більшості характеризуються швидкою зміною змісту, враховуючи постійну трансформацію чинного законодавства, появу нового контенту в мережі Інтернет - від прикладів правоохоронної діяльності до експертних оцінок того чи іншого нормативного акту. Bce частіше інформація про досягнення юридичної науки поширюється не тільки через традиційні друковані видання, але й електронні журнали, соціальні мережі, спеціалізовані портали, сайти освітніх установ, Інтернет-платформи співтовариств практики тощо. Зважаючи на це, для викладача та курсанта (студента, слухача) i просто для практикуючого юриста та правоохоронця виникає потреба у надбанні вмінь та навичок роботи із потоками «цифрової інформації» - куруванні контенту.

Сьогодні багато дослідників намагаються описати цей термін. Курування контенту - процес збору контенту, створеного іншими, цінного для вашої аудиторії, i публікація його на вашій платформі (Michael Brenner). Курування контенту - це процес вибору достовірної інформації відповідно до потреб читачів на певну тему фахівцем рівня редактора або куратора музею. Курування змісту це більше, ніж просто вибір інформації. Це монтаж, категоризація, коментування та подання кращого контенту (Heidi Cohen). Курування контенту - це процес визначення найбільш адекватного змісту по темі, просіювання i сортування інформації до стану, який буде забезпечувати найбільшу цінність для вашої аудиторії. (Kelly Hungerford) [1].

Отже в узагальненому вигляді курування контенту можна уявити, як діяльність фахівця по роботі з інформаційними потоками мережі Інтернет в рамках певної тематики [2].

Традиційно виділяють 5 моделей курування контенту у залежності від базової стратегії.

1. Агрегація - діяльність куратора щодо збору відповідної інформації з тієї чи іншої теми в одному місці (сайт, блог, мережеві 
агрегатори). Наприклад, останнім часом можна зустріти публікації на кшталт: «100 найкращих інструментів e-learning» або «25 найкращих додатків iPad».

2. Дистиляція - діяльність куратора щодо переводу інформації у більш спрощений або доступний формат в якому викладені основні ідеї або смисл інформації. Прикладами таких публікацій можна вважати конспекти або реферати з відповідної тематики, узагальнення схожої інформації з кількох різних мережевих джерел

3. Підвищення. Це аналіз змісту великої кількості джерел та визначення на цій основі загальних тенденцій. Це також може бути додавання власної точки зору до відповідної інформації у вигляді висновків, прогнозів тощо. Вважається, що це один з найскладніших видів курування контенту.

4. Змішування (mushup). На підставі обробки різних джерел інформації, які об'єднані в одному ресурсі, куратор контенту може створити нову інформацію, або просто надати читачам привід для роздумів та аналітичної діяльності.

5. Хронологія. Інформація розглядається та надається кінцевому споживачеві через еволюційну призму. Такий вид може бути корисним, для надання користувачам історичних (часових) уявлень про виникнення, зміну, поширення та сучасний зміст інформації 3 будь-якого питання [3].

Вміння працювати в умовах швидкої зміни інформації та інформаційного перевантаження дедалі стає для будь-якого педагогічного працівника основою його професійної діяльності. Завдяки таким вмінням фахівець здатен підтримувати високу актуальність власної навчальної дисципліни, оперувати найбільш свіжими та правдивими даними, надавати слухачам та студентам інформацію, що відповідає вимогам часу та ринку праці у відповідній галузі. Будь-який викладач має стати сьогодні куратором контенту в рамках власного предмету, а це буде означати розширення його традиційних функцій та зміни у стратегії навчальної діяльності.

Які ж функції виконує викладач, як куратор контенту?

1. Пошукова функиія. В ї̈ рамках куратор контенту:

- визначає місце пошуку інформації;

- вибирає інструменти пошуку інформації;

- здійснює пошук інформації в різних джерелах, базах, середовищах, репозіторіях.

2. Аналітична функиія. В ї̈ рамках куратор контенту:

- аналізує матеріал, вибирає релевантний;

- перевіряє матеріал на достовірність та актуальність;

- перевіряє дотримання авторських прав в цьому матеріалі;

- виділяє головну думку матеріалу. 


\section{Збірник наукових статей}

3. Функиія агрегації-публікаиії. В ї̈ рамках куратор контенту:

- класифікує матеріал за певними параметрами;

- розміщує матеріал у певних базах, на сайтах, платформах;

- поширює матеріал у соціальних мережах.

4. Творча функиія. В ї̈ рамках куратор контенту:

- реферує та коментує отриманий матеріал;

- доповнює вихідний матеріал своїми напрацюваннями;

- створює на базі знайденого новий матеріал.

5. Розвиваюча функиія. В ї̈ рамках куратор контенту:

- дає додаткові посилання до представленого матеріалу;

- пропонує шляхи розвитку курування за даною тематикою;

- рекомендує до підключення в мережу інших людей (кураторів).

6. Дослідницька функиія. В ї̈ рамках куратор контенту:

- досліджує роботи інших кураторів, вчених, користувачів мережі, включає їх напрацювання в свою діяльність, підключає нові вузли в свою персональну навчальну мережу;

- досліджує можливості нових інструментів курування контенту і застосовує їх у власній роботі [4].
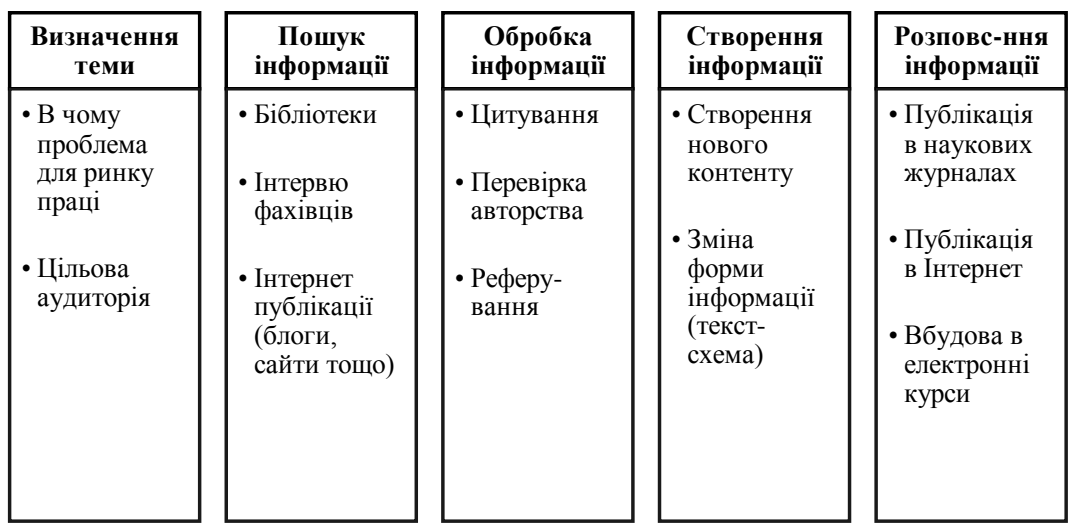

Мал. 1 Типовий алгоритм роботи викладача ВНЗ МВС Украӥни, як куратора контенту, в умовах дистанційного навчання.

Спираючись на вищевикладене, спробуємо проаналізувати основні причини чому курування контенту набирає актуальність в умовах дистанційного навчання у ВНЗ МВС України.

В навчальному процесі, в тому числі й дистанційному, викладач $\epsilon$ експертом з відповідної тематики, а 90\% інформації вже перейшло у «цифровий формат». Отже викладачу потрібні вміння роботи із цифровими потоками в мережі Інтернет для того щоб володіти та 
отримувати найсвіжішу та релевантну інформацію для власного навчального процесу. Юридична інформація швидко змінюється, постійно вдосконалюються практики правозастосувальної діяльності, отже відслідковування змін у правовому полі, встановлення нових міжпредметних зв'язків, включення до власної діяльності нових інформаційних потоків $є$ вимогою до сучасного науково-педагогічного працівника. Один із сучасних принципів дистанційного навчання формування персональної навчальної мережі та персонального навчального середовища. Інструментарій та функції роботи куратора контенту, дозволяють викладачеві знаходити нові джерела інформації та фахівців з відповідної тематики і включати їх у власну мережу, що, зрозуміло, може вдосконалити як зміст навчання так i його організацію, і це, безумовно, вплине на якість дистанційних курсів та інших навчальних матеріалів.

Для роботи 3 інформаційними потоками викладачеві треба володіти основними сервісами та інструментами курування: автоматичними та ручними агрегаторами, алгоритмами роботи в соціальних мережах, вміннями блоггінгу та створення цифрових ресурсів (сторінка сайту, підкаст, презентація, скрінкаст, інфографіка). Такі вміння сприяють, по-перше, можливості швидкого оновлення змісту навчального юридичного курсу, по-друге, викладач зможе заявити про себе як експерта у всесвітній мережі, а по-третє, викладач зможе інтегрувати у власний навчальний процес можливості сервісів web 2.0.

На підставі цього, вважаємо доцільним запровадити у вищих навчальних закладах МВС навчальний курс «Курування контенту». Навчальна мета курсу: здійснювати курування контенту в мережі Інтернет в рамках відповідної тематики.

Навчальна мета курсу досягається через вирішення навчальних завдань:

- перераховувати основні способи курування контенту описувати їх відмінності;

- планувати стратегію курування (терміни, інструменти, предметна область, сфера та місця пошуку, кінцеві продукти);

- формувати пошукові запити на отримання інформації i виконувати пошук інформації в різних базах даних, мережах, сховищах;

- визначати правовий статус авторства інформації, оцінювати іiі релевантність і достовірність на основі певних критеріїв;

- представляти інформацію в різних форматах (текст, графіка, звук, відео);

- класифікувати, синтезувати, реферувати отриману інформацію; 
- формувати пошукові запити на отримання інформації про «соціальні сервіси» курування, оцінювати їх функції в куруванні контенту, застосовувати ї можливості в конкретних ситуаціях курування: агрегація, дистиляція, підвищення, змішування.

Як висновок підкреслимо, що для сучасного юриста дуже важливо володіти вміннями та навичками роботи 3 цифровими інформаційними потоками в мережі Інтернет, - результати такої роботи позитивно відображаються на якості навчального процесу та проведенні наукових досліджень у відповідній сфері.

\section{Література}

1. Cohen Heidi Content Marketing Experts Define Content Curation [Електронний pecypc] / Heidi Cohen. - Режим доступу : http://heidicohen.com/content-curation-19-definitions. - Назва 3 титул. екрану.

2. Бугайчук К. Л. Курс «Курирование содержания» (защита) [Електронний ресурс] / К. Л. Бугайчук. - Режим доступу : http://bugaychuk.blogspot.com/2013/05/blog-post_22.html. - Назва 3 титул. екрану.

3. Бугайчук К. Л. Куратор контенту - нова роль викладача юридичних дисциплін в умовах дистанційного навчання / К. Л. Бугайчук // Сучасні педагогічні стратегії та технології у викладанні дисциплін гуманітарного циклу у технічному ВНЗ: Тези доповіді Всеукраїнської науково-методичної конференції (з міжнародною участю) 19-21 вересня 2012 р., Севастополь, СевНТУ, 2012. - C. 60-62.

4. Бугайчук К. Л. Курирование контента (Неделя № 4 Функции и компетенции куратора. Итог недели) [Електронний ресурс] / К. Л. Бугайчук. - - Режим доступу http://bugaychuk.blogspot.com/2013/04/4_11.html. - Назва 3 титул. екрану.

\section{Константин Бугайчук. Значение курирование контента в условиях дистанционного обучения в высших учебных заведениях МВД Украины.}

В статье исследовано содержание понятия «курирование контента» и его значение в условиях информачионного общества и проведения дистаниионного учебного прочесса. Автором рассмотрены основные функции преподавателя вуза МВД Украины, как куратора контента, предложено внедрение в систему повышения квалификации преподавателей вузов МВД учебного курса «Куратор контента».

Ключевые слова: куратор контента, преподаватель, дистанционное обучение, МВД Украиньл. 
Konstantin Bugaychuk. Value of content curation in terms of distance learning in higher educational institutions Ministry of Internal Affairs of Ukraine.

The article studied the concept of "content curation», its value in the information society and of distance learning process. The author considers the main functions of teachers in higher educational institutions Ministry of Internal Affairs of Ukraine, as content curator, proposed introduction in a system of training of higher educational institutions Ministry of Internal Affairs of Ukraine learning course "Content curation».

Key words: content curator, teacher, distance learning, Ministry of Internal Affairs of Ukraine.

Стаття надійшла до редакційної колегії 18.03.2014

УДК 373.55[37.091.12:005.963.5-057.87]:796.071.4

(C) Верховська М. В., 2014.

Верховська Марина Володимирівна

Дніпропетровський національний університет ім. Олеся Гончара

КОМПОНЕНТИ ГОТОВНОСТІ СУЧАСНОГО ВЧИТЕЛЯ
ФІЗИЧНОЇ КУЛЬТУРИ ДО ПРОФЕСІЙНОЇ ДІЯЛЬНОСТІ У
ПРАКТИЦІ РОБОТИ З УЧНЯМИ ЗАГАЛЬНООСВІТНІХ
НАВЧАЛЬНИХ ЗАКЛАДІВ

Одним із головних напрямків роботи загальноосвітніх навчальних закладів є діяльність, яка спрямована на збереження фізичного здоров'я дітей. Дбати про фізичне здоров'я, формувати розумові $i$ фізичні якості покликана фізична культура,спорт та кваліфіковані вчителя, від яких залежить не тільки проведення уроків, але і фізичне виховання учнів взагалі. Структурна модель готовності вчителя фізичної культури професійної діяльності практиці роботи з учнями загальноосвітніх навчальних закладів включае такі компоненти: психологічна готовність, науково-теоретична готовність, фізична готовність, практична готовність, психофізіологічна готовність.

Ключові слова: учитель фізичної культури, психологічна готовність, науково-теоретична готовність, фізична готовність, практична готовність, психофізіологічна готовність.

Розбудова незалежної України, становлення демократичної держави вимагає створення якісно нової системи національної освіти 3 метою забезпечення відродження інтелектуального та духовного потенціалу українського народу [1]. Поліпшення ефективності системи освіти, іiі впливу на соціальне, економічне та духовне життя 


\section{Збірник наукових статей}

суспільства значною мірою залежить від учителя: рівня його професійної майстерності, моральних і фізичних якостей. На жаль, професія учителя $є$ масовою, непрестижною, соціальна мотивація відсутня, професійна-педагогічна підготовка $\epsilon$ неякісною. Тому очікуваного рівня готовності здобуває зовсім незначна кількість учителів.

У зв'язку з цим проблема готовності учителя до професійної діяльності постійно привертає до себе увагу науковців.

Розробці моделі фахівців фізичного виховання присвятили свої роботи Я. А. Бельський, Е. С. Вільчковський, А. Б. Нурлибекова, О. О. Солтис. Формування готовності до професійної діяльності майбутніх учителів фізичної культури досліджували такі вчені, як В. І. Байдак, . В. Богініч, . Р. Генсерук, . П. Данилко, Р. П. Карпюк.

Mema cmammi. Теоретично обгрунтувати компоненти готовності учителя фізичної культури до професійної діяльності у практиці роботи з учнями загальноосвітніх навчальних закладів.

У суспільстві немає більш діалектичного й багатогранного явища ніж школа. Це інститут через який протягом десятка років проходить практично все населення України, незалежно від соціального статусу, національності, віросповідання. В останні роки загострилась проблема збереження здоров'я дітей. В наукових дослідженнях відмічено зниження рівня фізичної підготовленості учнів, їх здоров'я та працездатності. Подальша інтенсифікація i ускладнення процесу навчання в школі вимагає від учнів все більш великих психічних напружень та фізичних зусиль. Одним із головних напрямків роботи загальноосвітніх навчальних закладів є діяльність, яка спрямована на збереження фізичного здоров'я дітей. Дбати про фізичне здоров'я, формувати розумові і фізичні якості покликана фізична культура і спорт [2]. До готовності вчителя фізичної культури ставляться вимоги, які піднімають його на високий щабель суспільства: професіоналізм, розвинутий інтелект, високі моральні якості, психічне і фізичне здоров'я, мудрість. Він $є$ головним виконавцем і практиком всієї багатогранної роботи 3 фізичного виховання в школі. Від кваліфікації учителя залежить не тільки проведення уроків, але i фізичне виховання учнів взагалі [3; 4]. Сучасна критична ситуація із станом здоров'я дітей зумовлюють особливу значущість професійної діяльності вчителя фізичної культури, його майстерності. Професійна діяльність учителя фізичної культури це вирішення оздоровчих завдань, це вміння виконувати головну роль в організації активної рухової діяльності протягом навчального дня, формувати мотиви, виховувати звичку до систематичних занять фізичними вправами, здійснювати зв'язок 3 
сім'єю, спрямовувати і контролювати самостійну діяльність дітей, проводити навчальну та позакласну роботу тощо. Про це свідчать наукові роботи, які присвячені дослідженню змісту професійної діяльності вчителя фізичної культури.

Готовність учителя фізичної культури до професійної діяльності розглядається як цілісне явище, що включає позитивне ставлення до діяльності, установку на досягнення поставленої мети, особистісні якості, формування і розвиток спеціальних здібностей, навичок, умінь володіння способами та прийомами навчання і виховання, розвиток самоаналізу, самоконтролю, зацікавленість фахівця в передачі своїх знань, умінь іншим. Структурна модель готовності вчителя фізичної культури до роботи з учнями включає такі компоненти: психологічна готовність, науково-теоретична готовність, фізична готовність, практична готовність, психофізіологічна готовність.

Психологічна готовність розкриває мотиваційно-ціннісне ставлення до праці вчителя фізичної культури, що $\epsilon$ основою спрямованості на професійні цінності. Науковці трактують психологічну готовність як інтегральне утворення особистості, яке об'єднує в собі компоненти, знання, уміння, навички, особистісні якості, адекватні вимогам діяльності.

Науково-теоретична готовність визначається наявністю певного обсягу знань, які необхідні в здійсненні високопродуктивної професійної діяльності. В зміст готовності вчителя фізичної культури повинні бути включені відомості про закономірності процесу навчання та виховання, розвитку організму i рухових якостей дітей, які дозволять управляти фізичним розвитком учнів 3 використанням сучасних технологій, визначати необхідний обсяг засобів тренувального впливу, фізичного навантаження, інтервалів відпочинку, обов'язково теоретична підготовка 3 дисциплін медикобіологічного циклу. Практична готовність учителя фізичної культури до професійної діяльності передбачає наявність професійних умінь та навиків - специфічних рухових та власне педагогічних. Рухові уміння - це володіння технікою вправ шкільної програми, педагогічні - синтез теоретичних знань і практичних дій, прийомів навчання та виховання.

Практична готовність включає в собі вміння вчителя обгрунтовано визначати i раціонально застосовувати способи, які найбільш ефективно приводять до заданих виховних цілей в конкретних педагогічних ситуаціях.

Психофізіологічна готовність характеризує такий рівень професійної працездатності вчителя, який дозволяє йому достатньо тривало i ефективно займатись педагогічною діяльністю при оптимальному підвищенні функцій центральної нервової, серцевосудинної, дихальної систем, обміну речовин. 


\section{Збірник наукових статей}

Фізична готовність визначається відповідністю стану здоров'я і фізичного розвитку вимогам педагогічної діяльності. Для вчителя фізичної культури, який закладає основи здорового способу життя школярам, рівень різнобічного фізичного розвитку і підготовленості $\epsilon$ одним 3 найважливіших факторів педагогічної майстерності. В процесі проведення $з$ учнями різноманітних за формою і змістом занять фізичними вправами необхідною передумовою їх дієвості $\epsilon$ високий рівень фізичної підготовленості наставника. За допомогою фізичних вправ учитель передає знання, навчає рухових дій. Наукові дослідження показують, що в молодих учителів спостерігається тісний взаємозв'язок між фізичною підготовленістю і володінням руховими вміннями та навичками. Важливим фактором фізичної готовності вчителя до професійної діяльності є формування в нього потреби у фізичному самовдосконаленні і самовихованні.

Висновки. Сучасні учні повинні бачити вчителя фізичної культури працездатного, 3 гарною фігурою, загальним зовнішнім виглядом, впевненого в собі, готового до роботи, с гарним самопочуття. Крім академічних знань вчителю фізичної культури обов'язкові додаткові, кожен компонент готовності повинен бути розглянутий 3 врахуванням останніх досягнень у сфері педагогіки, психології, фізіології, фізичної культури та спорту, біології, медицини. Враховувати зарубіжний досвід, обсяг наукової інформації, отриманої за допомогою сучасних інформаційних і комунікаційних технологій, зокрема мережі Інтернет, та вміти іiі застосовувати в навчальновиховному та тренувальному процесах. Практично досліджувати шляхи, засоби, методи та етапи формування усвідомленої потреби у фізичному вдосконаленні, набуття навиків здорового способу життя на основі врахування вікових особливостей розвитку організму i фізичних якостей дітей.

\section{Література}

1. Національна доктрина розвитку освіти України в XXI столітті / Освіта України. - 2002. - 23 квітня.

2. Гонтаровська Н. Сприяння здоров'ю в діяльності навчального закладу / Н. Гонтаровська // Директор школи ліцею гімназії. - 2006. № 4. - C. $38-41$.

3. Москаленко Н. Педагогічні інновації у фізичному вихованні / Н. Москаленко // Спортивний вісник Придніпров’я. - 2009. - № 1. C. 19-22.

4. Москаленко Н. Готовність вчителів фізичної культури до інноваційної діяльності / Н. Москаленко // Молода спортивна наука України: зб. наук.праць. - Львів, 2006, - С. 299-301. 
Марина Верховская. Компоненты готовности современного учителя физической культуры к профессиональной деятельности в практике работы с учащимися общеобразовательных учебных заведений.

Одним из главных направлений работы общеобразовательных учебных заведений является деятельность, направленная на сохранение физического здоровья детей. Заботиться о физическом здоровье, формировать умственные и физические качества призвана физическая культура, спорт и квалифицированные учителя, от которых зависит не только проведение уроков, но и физическое воспитание учашихся в иелом. Структурная модель готовности учителя физической культуры к профессиональной деятельности в практике работы с учащимися общеобразовательных учебных заведений включает следующие компоненты: психологическая готовность, научно-теоретическая готовность, физическая готовность, практическая готовность, психофизиологическая готовность.

Ключевые слова: учитель физической культуры, психологическая готовность, научно-теоретическая готовность, физическая готовность, практическая готовность, психофизиологическая готовность.

Maryna Verkhovska. The components of modern Physical Training teacher's readiness for professional activity in practical work with secondary schools pupils.

One of the main tendencies of work at secondary schools is the activity which is focused on maintaining physical health of children. Physical Training, sport and qualified teachers, who influence not only the lessons, but also pupils' Physical Education in general, are aimed to care for physical health, to form mental and physical qualities. Structural model of Physical Training teacher's readiness for professional activity in practical work with secondary schools pupils includes the following components: psychological readiness, research and theoretical readiness, physical readiness, practical readiness, psychophysiological readiness.

Key words: teacher of Physical Training, psychological readiness, research and theoretical readiness, physical readiness, practical readiness, psychophysiological readiness.

Стаття надійшла до редакційної колегії 12.05.2014 


\section{Вільчинська Тамара Володимирівна}

(с) Вільчинська Т. В., 2014.

Хмельницький національний університет, Україна

\section{ПРИСЛІВ'Я ТА ПРИКАЗКИ УКРАЇНСЬКОЇ ТА ЛАТИНСЬКОЇ МОВ ЯК ДЖЕРЕЛО КРАЇНОЗНАВЧОЇ ІНФОРМАЦІЇ У ПОРІВНЯЛЬНОМУ АСПЕКТІ}

Стаття присвячена систематизачії прислів'їв та приказок украйнською та латинською мовами, що виступають складниками у прочесі лінгвокраӥнознавчого вивчення мови. Вони надають цінну культурну інформацію, акумулюють складний комплекс культури та психології даного народу, своєрідний та неповторний спосіб його мислення. Оскільки украӥнська та латинські мови належать до індоєвропейської групи мов, то культура, світогляд та менталітет ӥх носіїв є подібним.

Ключові слова: приказка, прислів'я, краӥнознавча інформація, традииії, мова, менталітет.

Кожен народ володіє багатющим запасом прислів'їв та приказок, які складають невід'ємну частину його духовної культури та мовних багатств. Людина, яка бажає опанувати будь-яку мову на високому рівні, обов'язково повинна ознайомитись також з мовними фразеологізмами (прислів'ями, приказками, афоризмами) відповідної мови.

Актуальність проведеного дослідження обумовлена широким використанням прислів'їв та приказок у всіх сучасних мовах, у тому числі й у латинській. Прислів'я та приказки $є$ дуже важливими складниками у процесі лінгвокраїнознавчого вивчення мови, оскільки несуть у собі культурну, історичну та іншу інформацію, що є типовою та зрозумілою лише для окремого народу, який їх вживає та у мові якого вони народилися.

Наукова новизна роботи пов'язана 3 тим, що вперше відбувається вивчення прислів їв та приказок латинської мови з точки зору відображення у собі країнознавчої інформації. Класифікація прислів 'їв та приказок за походженням та значимістю для історії та культури країни їх виникнення значно полегшить вивчення, а також допоможе краще зрозуміти їх зміст.

Головна мета лінгвокраїнознавства - забезпечити комунікативну компетенцію в актах міжкультурної комунікації, передусім через адекватне сприйняття промови співрозмовника i оригінальних текстів, що розраховані на носіїв мови. 
Лінгвокраїнознавство забезпечує розв'язання цілої низки проблем, зокрема головної філологічної проблеми - адекватного розуміння тексту. Ось чому воно виступає як лінгвістична основа не лише лінгводидактики, а й перекладу. Для лінгвокраїнознавства величезний інтерес становлять прислів'я та приказки, які, відображаючи в своїй семантиці тривалий процес розвитку культури народу, фіксують i передають 3 покоління в покоління культурні установки і стереотипи, еталони і архетипи. Це своєрідні мікросвіти, вони містять в собі «і етичний закон, і здоровий глузд, виражені в короткому вислові, що заповідали предки в керівництво нащадкам» [4, с. 23]. Це душа будьякої національної мови, в якій неповторним чином відображаються дух i самобутність нації, національна своєрідність історії, культури, традиційного образу життя народу - носія мови.

Прислів'я та приказки - це стійкі вислови у формі синтаксично завершеного речення, які породжуються усною народною творчістю або запозичуються з певних літературних джерел, втрачаючи зв'язок із цими джерелами [2]. Характерними прийомами узагальнення твердження виступають паралелізм, алітерація, асонанс, рима. Прислів'я та приказки найчастіше вживаються в абсолютно конкретній ситуації, але не позначають ii окремих елементів, а ставлять всю ситуацію у зв'язок 3 якою-небудь спільною та загальновідомою закономірністю, яку вони, власне, і виражають.

Прислів'я та приказки мають емоційне та стилістичне забарвлення, завдяки чому вони вдосконалюють комунікативну функцію мови. Їх часте вживання в усній та письмовій мові пояснюється, тим, що вони додають їй особливий колорит, роблять більш образною та виразною. Таким чином, виникає необхідність у порівнянні класифікацій, проведенні систематизації найбільш вживаних прислів”їв та приказок латинської та української мов.

Одним із найперших збирачів прислів”ї був відомий український поет другої половини XVII ст. Климентій Зиновіїв. Він зібрав понад півтори тисячі прислів 'їв і чимало їх використав у своїх віршах; у багатьох випадках він вводить їх у текст без зміни [3, с. 7074]. Вперше невелику добірку прислів 'їв (146 зразків) опублікував у своїй «Грамматике малороссийского наречия» (1818) О. Павловський. Вони служили матеріалом для вивчення української мови. Чимало нових прислів 'їв було в збірках А. Шашацького-Ілліча, В. Вислоцького, М. Комарова, І. Манджури, у «Працях етнографічностатистичної експедиції в Західно-Руський край». Упродовж 1901-1910 років у шести книгах «Етнографічного збірника» I. Франко опублікував 31091 прислів'я. Це було найбільше досягнення фольклористичної науки у галузі збирання і видання прислів'їв. Цінність праці І. Франка полягає не лише в публікації текстів, а й у 
тому, що великий учений прагнув 3'ясувати генезис кожного прислів'я чи приказки [5, с. 201-205].

Зв'язок української мови 3 латинською мовою не обмежується лише інтернаціоналізмами. Змістова схожість латинських та українських прислів”їв та приказок не $\epsilon$ випадковою, вона зумовлена тим, що обидві мови належать до індоєвропейської сім'ї. Таким чином, латинська мова допомагає нам багато чого вияснити й зрозуміти в українській мові, а українська - в латинській. Латинська мова допомагає більш енергійно та лаконічно виразити думку, ніж це можливо зробити будь-якою іншою європейською мовою $[1$, с. 75 113]. На відміну від інших жанрів прислів'я та приказки одержують найрізноманітніші аспекти дійсності, адже вони побутують у мові багатьох людей, будучи буденним жанром. Вони правдиво відтворюють життєві спостереження і дають оцінку певним явищам, тому вони легко запам'ятовуються [2, с. 74-83]. Великий цикл прислів 'їв та приказок породили різні соціальні та побутові явища. Ми вважаємо доцільним класифікувати їх за напрямками, що допоможе краще зрозуміти ментальність народів України та народів Древнього Риму, пізнати їх національно-виховне трактування. Отже, прислів'я та приказки, пов'язані з життєвою мудрістю, освітою, мораллю:

- Волос сивіє, а голова шаленіє. Сивина в бороду - біс в ребро.

- Barba crescit, caput nescit.

- Корінь навчання гіркий, а плід його солодкий.

- Doctrina est fructus dulcis radicis amarae.

- Борода не робить чоловіка мудрим.

- Barba non facit philosophorum.

- Потрібно вчиться, завжди згодиться.

- Studendum vero semper et ubique.

- Розумний учить, а дурний повчає.

- Sus Minerva docet (Свиня вчить Мінерву).

- Розумного пошли - одне слово скажи, дурня пошли - три скажи і сам за ним піди.

- Dictum sapient sat est.

- Вік живи - вік учись.

- Alit lectio ingenium (Читання постачає розум).

Поширеним серед прислів'їв та приказок був напрямок, оснований на трудовому досвіді. Вони супроводили все життя трудівників, передаючи повагу до праці, іiї результатів [2, с. 74-83]:

- Закінчивши діло, добре святкувати. Кінець діло хвалить.

- Finis coronat opus.

- Добрий початок - половина діла.

- Dimidium facti, qui coepit, facit.

- Коли працюєш час біжить, коли чекаєш - не спішить. 
- Labor fallit curas.

- Терпіння і труд все перетруть.

- Labor et patientia omnia vincunt.

Прислів'я та приказки сприяли формуванню у людей позитивних рис: сміливість, чесність, хоробрість, дружба. Наприклад:

- Вірний приятель - що найбільший скарб.

- Amici vitam ornant.

- Гусак свині не товариш.

- Inter dominum et servium nulla amicitia est (Між господарем i слугою дружби бути не може).

- Ситий голодному не товариш.

- Nummis praestat carere quam amicis.

- У лиху годину пізнай вірну людину.

- Amicus certas in re incerta cernitur.

- Чоловік без друга, що їжа без солі.

- Vitae sal amicitia est.

Здоровому способу життя завжди надавалося величезного значення. Свідком цього $є$ такі прислів'я та приказки:

- Без здоров'я нема щастя.

- Valetudo est bonum optium.

- Добрий лікар має орлине око, левине серце і жіночу руку.

- Officium medici est, ut tuto, ut celeriter, ut jucundo sanet.

- У здоровому тілі здоровий дух.

- Mens sana in corpore sano.

- Часник сім хвороб лікує.

- Fructus cape cum pane, si vis vivere sane. (Їж плоди з хлібом, якщо хочеш бути здоровим).

Потужним струменем у прислів'я та приказки увійшла тема сімейного життя, кохання, вірності. Часто характеризуються взаємини між молодими людьми, чоловіком та дружиною. Народ завжди підносить зразкове подружнє життя, чистоту почуттів, стосунків. Наприклад:

- 3 доброго тіста смачна паляниця, 3 гарної дівчини - гарна молодиця.

- Domi mansit, lanam fecit.

- Чоловік у домі голова, а жінка душа.

- Casta ad virum matrona parendo imperat.

- Кохання перемагає все.

- Amor vincit omnia.

- Кохання, вогню і кашлю ніде не сховаєш.

- Amor et tussis non caelantur.

- Краса лиця - це половина посагу.

- Formosa faciles multa commendation est. 


\section{Збірник наукових статей}

- Поганий на вроду, та гарний на вдачу.

- Forma viros neglata decet.

Практичне застосування нашої роботи $є$ у створенні підходу зацікавленості у виробленні паралелей, відображених у прислів'ях та приказках, які $\epsilon$ свого роду “криницею премудростей” народу, зберігають і відтворюють його менталітет, його культуру від покоління до покоління.

Підсумовуючи вищесказане, можна зробити висновок, що країнознавчі відомості, що містяться в семантиці прислів'їв та приказок, мають не лише загальноосвітне, але й виховне значення. Країнознавчоорієнтовані фразеологізми застосовуються для збільшення ємкості вислову, виражають емоційні та естетичні позиції того, хто говорить.

Лінгвокраїнознавство грає важливу роль i при навчанні перекладу та забезпечує адекватне розуміння тексту. Незнання того або іншого країнознавчого елементу, який знаходиться в основі образу прислів'я або приказки, може привести до невірного розуміння змісту вислову в цілому.

\section{Література}

1. Борсов С. В. Латынь на все случаи жизни / С. В. Борсов. - М. : АСТ; Транзиткнига, 2006. - С. 75-113.

2. Грицай М. С. Українська народно-поетична творчість / М. С. Грицай, В. Г. Бойко, Л. Ф. Дунаєвська. - К. : Вища школа, 1985. - С. 74-83.

3. Зіновіїв Климентій. Вірші. Приповісті посполиті / Климентій Зіновіїв. - К. : Наукова думка, 1971. - С. 70-74.

4. Корж Н. Г. Із скарбниці античної мудрості / Н. Г. Корж, Ф. Й. Луцька. - К. : Вища школа, 1988. - С. 20-24.

5. Франко І. Я. Етнографічний збірник / І. Я. Франко. - Львів, 1901, т. 10. -C. 301-612; 1905, т. 16. - С. 201-600.

Тамара Вильчинская. Пословицы и поговорки украинского и латинского язяков как источник краеведческой информации в сравнительном аспекте.

Статья посвящена систематизации послович $u$ поговорок в украинском $u$ латинском языках, которые выступают составляющими в прочессе лингвострановедческого изучения языка, поскольку они предоставляют иенную культурную информащию, аккумулируют сложный комплекс культуры и психологии данного народа, своеобразный и неповторимый образ его мышления. Поскольку украинский и латинские языки принадлежат к индоевропейской группе языков, то культура, мировоззрение $u$ менталитет их носителей подобен. 
Ключевые слова: пословица, поговорка, краеведческая информаџия, традиции, язык, менталитет.

Tamara Vilchynska. Ukrainian and Latin proverbs as a source of local history information in a comparative perspective.

The article is devoted to systemize proverbs and sayings in Ukrainian and Latin languages. They turn to be the linguistic components of language learning in country studying aspect as they provide a valuable cultural information, accumulate a complex of culture and psychology of a people, a peculiar and unique way of its worldview. As Ukrainian and Latin languages belong to Indo-European group of languages, the cultures of their speakers, way of thinking and mentality is similar.

Key words: proverb, saying, country studying information, traditions, language, mentality.

Стаття надійшла до редакційної колегії 30.03.2014

УДК [378.016:930.85]:652.2

Вознюк Оксана Миколаївна

Львівська філія Дніпропетровського національного університету залізничного транспорту імені акад. В. Лазаряна

\section{ВЗАЕМОДІЯ КУЛЬТУР У ПРОФЕСІЙНІЙ ПІДГОТОВЦІ МАЙБУТНІХ ФАХІВЦІВ ЗАЛІЗНИЧНОГО ТРАНСПОРТУ}

У статті висвітлено структурний склад формування професійної культури майбутніх фахівців залізничного транспорту (духовна, інформаиійна, екологічна, світоглядна, громадянська тощо). Обтрунтовано дочільність взаємодії иілей культурологічної освіти $i$ професійної підготовки, гуманітарної $і$ технологічної складової фахівців залізничного транспорту на різних рівнях.

Ключові слова: професійна культура, студенти вищих технічних навчальних закладів, культурологічна освіта, майбутні фахівці.

Формування професійної культури $€$ цілісним явищем, що охоплює процеси навчання, виховання та розвитку студента, має спрямовуватись на створення системи спеціальних культурологічних знань, опосередкованих змістом професійної діяльності фахівців залізничного транспорту; вироблення моделей поведінки спеціаліста, детермінованих потребами об'єкта його діяльності та кодексом честі працівника галузі. Професійна культура студентів ВНТЗ залізничної галузі формується на основі використання прогресивних ідей світового досвіду у вітчизняному просторі вищої освіти, що зумовлює 
необхідність грунтовного аналізу сучасних систем професійної підготовки в зарубіжних країнах та умов, які сприяють розвитку цих систем. Формування професійної культури розглядається нами як неперервний і цілісний процес, який охоплює множини структурних елементів, котрі діалектично взаємозумовлені, визначаються багатьма чинниками, провідним з яких є особистісний.

Формування професійної культури фахівців досліджувалося у різних аспектах (Ю. Безрученков, Г. Балл, Н. Дяченко, І. Лізан, Й. Ісаєв, А. Коломієць, Н. Костриця, А. Кочубей, В. Симоненко та ін.). Водночас, малодослідженою є проблема взаємодії різних культур та їх видів у професійній підготовці майбутніх фахівців залізничного транспорту.

У процесі формування професійної культури майбутніх фахівців залізничного транспорту виявляється складність та багатоаспектість цього поняття, скадовими якого $є$ різні види та аспекти культурологічної освіти (духовна, інформаційна, екологічна, світоглядна, громадянська тощо). Аналіз цих складових вимагає спеціального дослідження, причому на глобальному рівні взаємодіють відповідно матеріальна - духовна культура, загальна - професійна культура. Власне проблема їх оптимального поєднання і зумовила вибір тематики пропонованої статті.

Mета статmi - обгрунтування доцільності взаємодії культур у професійній підготовці фахівців та виявлення особливостей цієї взаємодії для майбутніх інженерів залізничного транспорту.

Необхідність формування загальної професійної культури у майбутніх спеціалістів є актуальним науково-педагогічним завданням, рішення якого дозволить прискорити входження в європейський освітній простір, відповідно 3 курсом на реалізацію Болонської конвенції. Соціально-економічні процеси нашого суспільства вимагають від вищої школи не лише підвищення рівня кваліфікації випускників, а й швидкого переходу до підготовки інженерів нового типу, здатних ефективно реагувати на зміни економічних, технічних і управлінських умов [3, с. 253]. Поняття «культура» $є$ складним феноменом людського буття. Воно належить до суспільних, соціальних психологічних явищ, і впливає на працю, побут, дозвілля, менталітет, спосіб життя усього суспільства. Процеси, які відбуваються в культурі, проходять через усі зазначені сфери i трансформуючись, утверджують нові культурні цінності. Особлива роль духовної культури полягає в тому, що вона пробуджує в людині особистість. Чим більшою мірою певна професія вимагає розв'язання творчих задач (а для багатьох професій такі вимоги стають дедалі вагомішими), тим примарнішим виявляється досягнення професійної 
компетентності без оволодіння (нехай не найвищому рівні) окресленими складниками професійної культури [1].

Професійна культура може ефективно формуватися на основі системи таких складових, якими виступають: певний рівень загальної культури людини; чесність, відповідальність і висока порядність працівника; висока духовність тощо. Під професійною культурою вчений має на увазі певну сукупність матеріальних i духовних цінностей, що виробляються людьми відповідної професії. Однією 3 підсистем культури, найбільш значущої для розкриття сутності повноцінного члена сучасного суспільства, $\epsilon$ професійна культура. А. Коломієць під професійною культурою розуміє «рівень оволодіння індивідом певною галуззю знань і діяльності як показник розвитку його загальної культури» [5, с. 89.]. С. Ісаєнко робить висновок, що „професійна культура - це цілісне особистісне утворення, сутністю якого $є$ діалектичний зв'язок усіх елементів культури індивіда, яке динамічно та нелінійно розвивається, специфічно проявляючись у сфері професійної діяльності і спілкування" [4, с. 28]. Різноманітність визначень цього поняття пов'язане зі складністю і багатовимірністю самого феномена, а також із наявністю різних наукових підходів до висвітлення його сутності.

Професійну культуру характеризують два основних поняття: "культура" і "професія", які, як підкреслює Н. Костриця [6] нерозривно пов'язанні 3 поняттям діяльність. Професійна культура відображає визначений етап становлення і розвитку професії; уявлення фахівця про неї як складову культури. На формування професійної культури впливають особливості самої професії. Залежно від обраної професії особистість засвоює різні моделі поведінки, а тому по-різному виявляється сутність професійної культури, яка включає сукупність спеціальних теоретичних знань та практичних умінь, пов'язаних із конкретним видом праці.

Однак на формування професійної культури майбутнього спеціаліста впливають не тільки особливості професії, а й інші фактори. Серед них ми виділяють особистісні та соціальні: стан системи освіти та якість освітніх послуг, культуру закладу освіти, розробку сучасних інноваційних технологій, престижність вибраної професії в суспільстві, ставлення особистості до навчання, рівень розвитку загальної культури тощо. Це дозволяє розуміти під професійної культурою різновид загальної культури суспільства та особистісне утворення, яке відображає ступінь оволодіння людиною спеціальних теоретичних знань та практичних умінь виконання визначеного виду діяльності, що здійснюється нею на основі сформованої системи певних ціннісних та духовно-моральних орієнтирів [2, с. 14]. 
Завдяки професійній культурі відбувається входження особистості у соціальні відношення. Важливим показником оволодіння професійною культурою $є$ прояв трудової активності особистості, інтенсивність іiі діяльності, налаштування на взаємодію з колегами, взаємодопомогу у виконані спільної праці тощо. Весь цей багатобічний процес, який носить назву „соціальне спілкування”, забезпечує взаєморозуміння між людьми, їх взаємозбагачення. Завдяки спілкуванню розповсюджується культура, що свідчить про взаємозв'язок між професійною та загальною культурою у суспільстві [2, с. 11]. Професійна культура набуває максимального прояву тільки тоді, коли специфічні способи й технології діяльності поєднуються 3 морально-психологічними рисами й якостями фахівця.

Взаємодія иілей культурологічної освіти та професійної підготовки фахівців залізничного транспорту випливає 3 ідеї цілеспрямованості та мотивації навчання культурологічних дисциплін у вищих навчальних закладах студентів технічних спеціальностей. Професійна спрямованість навчання культурологічних дисциплін реалізує єдність змісту, форм i методів навчання. Вона цільово орієнтує майбутніх фахівців залізничного транспорту на постійне використання отриманих культурологічних знань i вмінь для професійних цілей. Мотивація навчання культурологічних дисциплін майбутніх фахівців залізничного транспорту передбачає наявність сукупності мотивів, які спонукають і спрямовують його пізнавальну діяльність у процесі вивчення культурологічних дисциплін на формування, удосконалення та розвиток професійних знань і умінь. Складова змісту культурологічної освіти виступає як чинник мотивації навчання, цілеспрямованості освіти. Вона базується на положенні оптимального поєднання гуманізації освіти 3 iї професіоналізацією, оскільки культурологічна освіта $є$ важливою передумовою становлення фахівця-залізничника.

Взаємодія гуманітарної $і$ технологічної складової підготовки залізничника. Культурологічна підготовка слугує альтернативою, гальмом розгнузданих i аморальних поглядів сучасного (та й минулого) світу бізнесу і вигоди [6]. Творчість у професійній діяльності теж тісно пов'язана 3 рівнем культурологічної підготовки фахівця. Практично неможливо уявити безкультурну творчу особистість. Нині технологічна культура у значній мірі визначає світогляд сучасної людини [7]. В основі технологічної культури лежить трудова діяльність людини, в якій проявляються рівень іiі знань, умінь, навичок, трудової вихованості та культури праці, творчий евристичний підхід до справи. Значне місце у формуванні професійної культури майбутніх фахівців посідають предмети гуманітарного циклу для вибору духовних орієнтирів особистості, 
освоєння культурного досвіду людства, історичної пам'яті та можливості комунікацій. Формування культури в студентів вищих технічних навчальних закладів передбачає використання загальнокультурних, ціннісних, змістових, світоглядних можливостей дисциплін гуманітарного циклу. Не менш важливим є цикл професійно спрямованих та спеціальних дисциплін. Саме вони зорієнтують духовний потенціал майбутнього інженера на конкретний зміст його майбутньої професії, дозволять усвідомити нову, культуротворчу форму виконання посадових обов'язків та реалізації фахових функцій.

У сучасній зарубіжній освіті престижним вважають той ВН3, де значну кількість годин відведено на вивчення дисциплін гуманітарного блоку, незалежно від спеціальності. Це відкриває перспективи для розвитку особистості та відтворення моделі професійної діяльності. Основи професійної культури є значущими для фахової діяльності, особливо 3 надання послуг різним категоріям населення. Штучну віддаленість професійних, техніко-економічних від філософськолюдинознавчих дисциплін у технічних ВНЗ можна подолати тільки шляхом розширення гуманітарного впливу. Це пов'язано 3 тим, що будь-яка професія вимагає відповідної етичної форми і психологічного забезпечення. Мотивація професійного зростання обумовлює необхідність філософсько-світоглядної і психологічної підготовки до майбутньої діяльності.

Таким чином, у процесі формування професійної культури майбутніх фахівців залізничного транспорту доцільною є взаємодія цілей культурологічної освіти і професійної підготовки, гуманітарної і технологічної складової професійної культури на усіх рівнях від державних документів до конкретного навчального заняття. До подальших досліджень відносимо розробку теоретичних положень щодо взаємодії конкретних видів культур у професійній підготовці майбутніх інженерів залізничного транспорту.

\section{Література}

1. Балл Г. О. Категорія “культура особистості” в аналізі гуманізації загальної та професійної освіти / Г. О. Балл // Педагогіка i психологія професійної освіти: результати досліджень і перспективи: зб. наук. праць / за редакцією І. А. Зязюна та Н. Г. Ничкало. - К. : НТУ "ХПІ", 2003. - С. 51-61.

2. Безрученков Ю. В. Професійна культура фахівця: теоретичні аспекти / Ю. В. Безрученков // Вісник ЛНУ імені Тараса Шевченка. № 4 (239), 2012, Ч. II. - С. 10-16.

3. Дяченко Н. І. Особливості формування професійної культури студентів інженерних спеціальностей / Н. І. Дяченко // Проблеми інженерно-педагогічної освіти: збірник наук. праць: вид. 1 раз на 
квартал / Укр. інж.-пед. академія. - Вид. 3 квітня 2001 р. - Х. : УІПА, 2006. - Вип. 13. - С. 253-257.

4. Ісаєнко С. А. Формування професійної культури у студентів інженерно-технічних спеціальностей засобами іноземної мови / С. А. Ісаєнко. Дис... канд. пед. наук : $13.00 .04-$ К., 2009. - 227 с.

5. Коломієць А. М. Теоретичні та методичні основи формування інформаційної культури майбутнього вчителя початкових класів / А. М. Коломієць. Дис... д-ра пед. наук: 13.00.04. - Вінниця, 2008. $526 \mathrm{c}$.

6. Костриця Н. М. Культурологічна підготовка майбутніх фахівців аграрної галузі: [монографія] / Н. М. Костриця. - Київ, 2012. $420 \mathrm{c}$.

7. Симоненко В. Д. Технологическая культура и образование (культурно- технологическая концепция развития общества и образования) / В. Д. Симоненко. - Брянск : Изд-во БГПУ, 2001. - 214 с.

Оксана Вознюк. Взаимодействие профессиональной подготовке будущих специалистов железнодорожного транспорта.

В статье освещены структурный состав формирования профессиональной культуры будущих спечиалистов железнодорожного транспорта (духовная, информационная, экологическая, мировоззренческая, гражданская и др.). Обоснована иелесообразность взаимодействия иелей культурологического образования и профессиональной подготовки, гуманитарной $u$ технологической составляющей специалистов железнодорожного транспорта на различных уровнях.

Ключевые слова: профессиональная культура, студенты высших технических учебных заведений, культурологическая образование, будущие специалисты.

Oksana Voznyuk. Cultural interaction in the training of future specialists rail transport.

The article deals with the structural composition forming of future specialists rail transport (spiritual, informational, environmental, ideological, civil, etc.). The appropriateness of cultural interaction objectives of education and training, humanitarian and technological component of railway transportation professionals at different levels.

Key words: professional culture, students of higher technical education, cultural education, future professionals.

Стаття надійшла до редакційної колегії 10.05.2014 


\section{Волошина Ірина Василівна}

(C) Волошина I. В., 2014.

Хмельницький національний університет, Україна

\section{СТАНДАРТИЗАЦІЯ ПРОГРАМ ПРОФЕСІЙНОЇ ПІДГОТОВКИ МАЙБУТНІХ ФОЛЬКЛОРИСТІВ В УНІВЕРСИТЕТАХ УКРАЇНИ ТА США}

У статті досліджується проблема стандартизачії вищої освіти загалом та питання стандартизачії програм професійної підготовки майбутніх фольклористів зокрема. Проаналізовано вітчизняні ВНЗ, в яких відбувається професійна підготовка майбутніх фольклористів за різними освітньо-кваліфікаиійними рівнями. Проведено короткий порівняльний аналіз стандартизачії програм підготовки таких фахівиів у ВНЗ Сполучених Штатів Америки.

Ключові слова: майбутні фольклористи, фольклористика, стандартизачія, освітньо-кваліфікаційний рівень, система вищої освіти.

Входження України у світовий економічний, інформаційний, культурно-освітній простір актуалізує завдання вищої освіти щодо підготовки студентів до конкурентоспроможного професійного життя. Питання запровадження методів навчання, яке повинне враховувати всі основні складові дидактичної системи з урахуванням міжнародних стандартів якості навчання набуло актуальності. Після проголошення незалежності України 1991 року вища освіта зазнала певних змін відповідно до соціальних запитів суспільства та набула більш національно-орієнтованого відтінку. Саме тоді з'явилося декілька ВНЗ, які здійснюють підготовку майбутніх фольклористів. Тому постала проблема стандартизації програм їхньої підготовки.

Проблема стандартів у вищій освіті за останні роки все частіше досліджується з соціально-педагогічної, філософської точки зору такими вченими як I. Аннєнкова, В. Андрущенко, В. Байденко, В. Беспалько, І. Бех, А. Вулф, О. Ельбрехт, А. Зязюн, С. Кетрідж, М. Кісіль, В. Лутай, С. Маршал, Н. Ничкало, В. Петренко, С. Терепищий, Н. Фоменко, Х. Фрай. Зокрема, ними розглядаються основні підходи до розробки та обгрунтування стандартів у галузі вищої освіти, були визначені різні тенденції до проблеми стандартизації освіти в Україні та за кордоном [1; 4].

Загалом теоретичні витоки стандартизація освіти черпає 3 ідей теорії освіти щодо визначення вимог до програм навчання і змісту навчальних дисциплін. Проте існує система міжнародних стандартів 


\section{Збірник наукових статей}

освіти. Так, європейська асоціація забезпечення якості у вищій освіті розробила Стандарти і рекомендації щодо забезпечення якості вищої освіти в Європейському просторі [4]. Дотримання цього стандарту $є$ однією з умов приєднання до Болонського руху та надає рекомендації вищим навчальним закладам щодо підвищення якості освітніх послуг.Другим за вагомістю у світі $є$ американський стандарт ASQ Z1.11-2002 Стандарти забезпечення якості - Керівні вказівки щодо використання ANSI/ISO/ASQ Q9001-2000 в освітніх і навчальних організаціях [4].

Стандарти вищої освіти України були розроблені згідно 3 Законом України «Про вищу освіту» від 17.01.2002 р. № 2984, 3 урахуванням положень Постанови Кабінету Міністрів України «Про розроблення державних стандартів вищої освіти» від 07.08 .1998 р. № 2984, а також іншими нормативно-правовими актами, галузевими стандартами вищої освіти, вимогами Болонського процесу. У Законі України «Про вищу освіту» [2] подано таке визначення стандартизації освіти: «Стандарт вищої освіти - сукупність норм, які визначають зміст вищої освіти, зміст навчання, засіб діагностики якості вищої освіти та нормативний термін навчання».

Оскільки Україна активно підтримує політику інтеграції у міжнародні та європейські структури, 1993 року вона стала членом Міжнародної організації ISO. 3 метою удосконалення національної системи стандартизації, наказом Держспоживстандарту України 2008 року створено Технічний комітет стандартизації [4].

Згідно з поставною Кабінету Міністрів України від 24 травня 1997 p. № 507 у переліку напрямів та спеціальностей, за якими здійснюється підготовка фахівців у вищих навчальних закладах за відповідними освітньо-кваліфікаційними рівнями, знаходимо спеціальність «фольклористика», напрям підготовки - філологія, із шифрами спеціальностей для ОКР бакалавра -6.030500 , спеціаліста 7.030503 , магістра - 8.030503 [3]. За спеціальністю «фольклористика» за шифром 10.01.07 діє аспірантура та докторантура.

Як уже зазначалося, в Україні існує лише три університети, які здійснюють професійну підготовку майбутній фольклористів: це Київський національний університет імені Т. Г. Шевченка, Львівський національний університет імені I. Франка та Черкаський Національний Університет імені Б. Хмельницького. Далі у таблиці 1 наведені кваліфікації, які отримують випускники спеціальності «фольклористика» у цих ВНЗ за відповідними ОКР. Зазначимо, що також здійснюється підготовка за спеціальністю 10.01.07 «фольклористика» в аспірантурі та докторантурі. Відтак, аспірантура за спеціальністю 10.01.07 «фольклористика» діє у Київському національному університеті імені Т. Г. Шевченка, Львівському 
національному університеті імені I. Франка, Черкаському національному університеті імені Б. Хмельницького, Східноєвропейському національному університеті імені Лесі Українки, Донецькому національному університеті, Відділі фольклористики Інституту мистецтвознавства, фольклористики та етнології імені М. Рильського НАН України та Інституті народознавства НАН України. Докторантура за даною спеціальністю діє у Київському національному університеті імені Т. Г. Шевченка, Львівському національному університеті імені І. Франка, Відділі фольклористики Інституту мистецтвознавства, фольклористики та етнології імені М. Рильського НАН України та Інституті народознавства НАН України.

Наголосимо, що підготовка майбутніх фольклористів в університетах США здійснюється у близько двох десятках ВНЗ. У більшості з них даний напрям підготовки $є$ міждисциплінарним. Якщо в Україні спеціальність «фольклористика» діє лише на базі філологічних факультетів, то у США студент має право самостійно обирати власну освітню траєкторію. Так, кваліфікацію фольклориста можна отримати як додаткову, де фольклористика - другорядний, або ж навпаки - профілюючий предмет.

Таблиия 1

Кваліфікації, які отримують випускники ВНЗ спеціальності «фольклористика» за відповідними ОКР

\begin{tabular}{|c|c|c|c|}
\hline \multirow{2}{*}{$\begin{array}{c}\text { Назва } \\
\text { установи }\end{array}$} & \multicolumn{3}{|c|}{ Освітньо-кваліфікаційний рівень } \\
\hline & бакалавр & спеціал. & магістр \\
\hline $\begin{array}{l}\text { КНУ імені } \\
\text { Т. Шевченка }\end{array}$ & $\begin{array}{l}\text { Бакалавр } \\
\text { філології, } \\
\text { фахівець } 3 \\
\text { фолькло- } \\
\text { ристики }\end{array}$ & - & $\begin{array}{l}\text { Магістр фольклористики, } \\
\text { філолог-дослідник, викладач } \\
\text { ВНЗ (українська мова та } \\
\text { література та іноземна мова), } \\
\text { професіонал з фольклористики }\end{array}$ \\
\hline $\begin{array}{l}\text { ЛНУ імені } \\
\text { І. Франка }\end{array}$ & - & - & $\begin{array}{l}\text { Магістр філології, фольклорист, } \\
\text { викладач української мови та } \\
\text { літератури }\end{array}$ \\
\hline $\begin{array}{l}\text { ЧНУ імені } \\
\text { Б. Хмельни- } \\
\text { цького }\end{array}$ & - & - & $\begin{array}{l}\text { Магістр філології (українська } \\
\text { мова та література), } \\
\text { фольклорист, викладач ВНЗ }\end{array}$ \\
\hline
\end{tabular}

Схожа схема діє у низці інших університетах Сполучених Штатів. Часто до спеціалізації фольклориста може додаватися кваліфікація етномузиколога. За подібним принципом відбувається 
підготовка магістрів та докторів філософії у галузі фольклористики. У першому випадку після закінчення навчання студенти здобувають кваліфікацію магістра мистецтв у галузі фольклористики, у другому доктора філософії у галузі фольклористики.

Отже, диплом бакалавра мистецтв у галузі фольклористики можна отримати в Індіанському університеті та Університеті штату Пенсильванії. Диплом бакалавра мистецтв у певній галузі та додаткову спеціалізацію фольклориста можна отримати в Університеті Джорджа Мейсона, Університеті штату Джорджія, Гарвардському університеті, Університеті штату Айдахо, Індіанському університеті, Університеті штату Огайо, Університеті Північної Кароліни в місті Чейпел Хіл, Університеті Західного Кентукі, Університеті штату Пенсильванія, Університеті штату Орегон, Університеті Південної Каліфорнії, Університеті штату Міссурі, Конкордському університеті, Коледжі Колорадо, Університеті штату Юта. Диплом магістра в галузі фольклористики можна отримати в Індіанському університеті, Університеті штату Пенсильванія, Університеті штату Орегон, Університеті Каліфорнії в Берклі, Університеті штату Mіссурі, Університеті Північної Кароліни в Чейпел Хіл. Диплом магістра мистецтв у будь-якій галузі та додаткову спеціалізацію фольклориста можна отримати в Університеті Джорджа Мейсона, Університеті штату Огайо, Університеті штату Джорджія, Університеті Західного Кентукі, Університеті Техасу в Остіні, Університеті Аляски, Державному університеті Боулінг Грін, Університеті штату Юта. Ступінь доктора філософії в галузі фольклористики можна отримати в Індіанському університеті, Університеті Пенсильванії, Університеті штату Міссурі, Державному університеті Боулінг Грін. Ступінь доктора філософії у певній галузі та додаткову спеціалізацію фольклориста можна отримати в Університеті штату Огайо, Університеті Північної Кароліни в місті Чейпел Хіл, Університеті Вісконсин-Медісон, Університеті Техасу в Остіні, Університеті Аляски, Університеті штату Орегон, Університеті Каліфорнії в Берклі [5].

Звідси можем зробити висновок, що у більшості університетів «фольклористика» на різних рівнях підготовки пропонується як додаткова спеціалізація. Це може розглядатися як і з позитивного боку, так i 3 негативного. У першому випадку це свідчить про міждисциплінарну спрямованість підготовки фахівців у галузі фольклористики, що підвищує їхню гнучкість та конкурентоспроможність на ринку праці. У другому ж можуть виникати обвинувачення з приводу невузькопрофільності спецалізації, певної розмитості, неконкретності. Проте, не зважаючи на це, у США сформувалися всесвітньовідомі авторитетні фольклористичні наукові 
школи, що певною мірою може слугувати свідченням високого рівня підготовки випускників ВНЗ даного напряму.

Висновки. Питання багатоступеневої підготовки майбутніх фольклористів в Україні не можемо назвати остаточно вичерпаним, воно потребує розробок та затвердження галузевих стандартів підготовки майбутніх фольклористів. Під час їхнього проектування варто використовувати рекомендації міжнародних стандартів. Слід стандартизувати кваліфікації, які отримують випускники вітчизняних ВН3. Результативність і якість професійної підготовки майбутніх фольклористів можна забезпечити лише в межах цілісної трирівневої моделі навчання, де галузі знань упорядковані у раціонально побудовані цикли і курси. Це і буде напрямом для наших подальших досліджень.

\section{Література}

1. Ельбрехт О. М. Стандартизація вищої освіти як засіб удосконалення професійної підготовки фахівців / О. М. Ельбрехт // Краматорський економіко-гуманітарний інститут, Педагогіка i психологія. - 2011. - С. 38-42.

2. Закон України «Про вищу освіту» 17.01.2002 p. № 2984 [Електронний ресурс] / Режим доступу http://zakon1.rada.gov.ua/laws/show/2984-14. - Назва с титул. екрану.

3. Постанова кабінету міністрів України № 507 від 24.05.1997 [Електронний ресурс] / Режим доступу http://zakon0.rada.gov.ua/laws/show/507-97. - Назва с титул. екрану.

4. Рідей Н., Паламарчук С., Шофолов Д. Міжнародні стандарти як інструмент управління якістю освіти в Україні та США . Порівняльно-педагогічні студії № 3(13), 2012 [Електронний ресурс] / Режим доступу : $\quad$ http://journals.uran.ua/index.php/23065532/article/viewFile/18794/16518. - Назва с титул. екрану.

5. The American folklife center [Electronic resource] / Way of access : http://www.loc.gov/folklife/source/list_highered.php. - Name from screen.

Ирина Волошина.

Стандартизация

программ профессиональной подготовки будущих фольклористов в университетах Украины и США.

В статье исследуется проблема стандартизации выстего образования в иелом $u$ вопросы стандартизации программ профессиональной подготовки будущих фольклористов частности. Проанализированы отечественные вузы, в которых происходит профессиональная подготовка будущчих фольклористов по различным образовательно-квалификачионньм уровням Проведен краткий сравнительный анализ стандартизации программ подготовки таких специалистов в вузах США. 
Збірник наукових статей

Ключевые слова: будущие фольклористы, фольклористика, стандартизачия, образовательно-квалификационный уровень, система высшего образования .

Iryna Voloshyna. Standardization of training programs of future folklorists at the universities of Ukraine and the USA.

In this article the problem of standardization of higher education in general and standardization of professional training programs for future folklorists in particular has been researched. National universities where professional training of future folklorists at different educational levels where analyzed. A brief comparative analysis of the standardization of training programs for such professionals in the universities of the United States has been made.

Key words: future folklorists, folklore, standardization, education and qualification level, system of higher education.

Стаття надійшла до редакційної колегії 21.03.2014

УДК 159.922 .6

\section{Громова Наталия Михайловна}

(C) Громова Н. М., 2014.

Киевский университет имени Бориса Гринченко

\section{ПСИХОЛОГИЧЕСКИЕ ОСОБЕННОСТИ ПОНИМАНИЯ ГАЗЕТНЫХ ИНОСТРАННЫХ ТЕКСТОВ БУДУЩИМИ СПЕЦИАЛИСТАМИ}

Статья посвящена проблемам диалогического взаимодействия, аналитического чтения и понимания газетных текстов на английском языке студентами неязыковых вузов. Условиями успешного понимания иностранных текстов являются психологическая готовность $\kappa$ аналитическому чтению $u$ владение основными приемами диалогического взаимодействия с иностранными газетными текстами. Наблюдение показало, что сформированность у студентов приемов диалогического взаимодействия с иностранными текстами способствует их эффективному пониманию.

Ключевье слова: диалогическое взаимодействие, понимание, газетный текст, приемы, чтение, анализ.

В процессе обучения студентов иностранным языкам, особенно в неязыковых вузах, перед преподавателями часто возникает проблема психологической готовности к восприятию и пониманию студентами текстового сообщения, особенно из периодических изданий. Основной причиной возникновения такой проблемы является, убежденность студентов в сложности, скучности и утомительности чтения газетных 
материалов. К тому, же, современные темпы поступления информационных данных и их количество вызывают проблему качества восприятия читателями этих данных и умения их перерабатывать. Таким образом, вопрос готовности и умений студентов читать и понимать тексты из иностранных источников представляет интерес для исследователей из разных областей знаний: психологии, лингвистики, педагогики, журналистики, социологии.

Целью данного исследования является рассмотреть некоторые приемы формирования диалогического взаимодействия с иностранными текстами и их влияние на понимание текстов. В ходе работы были поставлены такие задачи: 1) определить основные признаки психологической готовности к аналитическому чтению иностранных текстов; 2) проанализировать основные приемы диалогического взаимодействия с текстами; 3) провести наблюдение с целью установить изменения в понимании иностранных текстов в связи 3 сформированностью у студентов приемов диалогического взаимодействия с текстами.

Проблемами обучения чтению занимались многие ученые в области психологии и педагогики (Г. И. Богин, А. А. Брудный, Н. С. Валгина, С. А. Васильев, Л. С. Выготский, Т. М. Дридзе, Н. А. Михальчук, С. Л. Рубинштейн, Н. В. Чепелева, Д. Б. Эльконин). Отдельный ряд работ рассматривает вопросы чтения и понимания газетных текстов (О.В.Дмитрук, Л. Р. Дускаева, Б. А. Зильберт, В. Л. Зливков, Л. В. Кудинова, О. О. Кучерова, А. В. Смирнова, Г. Я. Солганик). Несмотря на обширное освещение проблемы чтения и понимания текстов, недостаточно исследованной остается тема психологических особенностей аналитического чтения иностранной литературы будущими специалистами.

Аналитическое чтение предполагает в первую очередь психологическую готовность читателя к восприятию информации, как на родном, так и на иностранном языке. Неуверенность в собственных знаниях и способностях, низкий уровень владения иностранным языком, отсутствие навыков аналитического чтения, отсутствие мотивации изучения иностранного языка и предубежденность в сложности материала влияют на качество понимания иностранного сообщения. Таким образом, перед преподавателем стоит задача научить студентов преодолевать страх перед иностранным газетным текстом и вступать в диалогические отношения с его автором. Решением этой задачи является формирование у студентов приемов диалогического взаимодействия с иностранным текстом.

Проблема диалога и диалогического взаимодействия, а также диалогического мышления интересует ученых уже много десятилетий (А. Ю. Арутюнова, .А.Балл, М. М. Бахтин, С. М. Бондаренко, 


\section{Збірник наукових статей}

Г. Г. Граник, Л. П. Доблаев, Г. М. Кучинский, Л. А. Концевая, Л. В. Кудинова, Н. В. Чепелева, Х. Р. Яусс). Но большинство исследований проводилось на тему диалогического взаимодействия с текстами на родном языке, в то время как иностранные тексты рассматривались с точки зрения репрезентации в них автора.

Диалогическое взаимодействие с газетным текстом подразумевает взаимодействие нескольких элементов коммуникативной структуры: автора, читателя, текста и окружающей реальности. В таком диалоге с текстом важна активная позиция, как автора, так и читателя. Как известно из многочисленных исследований диалогичности газетных текстов, автор использует все возможные стратегии для того, чтобы донести до читателя необходимую информацию и идею с разными целями - от простого информирования до манипулирования общественным мнением $[1 ; 2 ; 4]$. Для того, чтобы пресечь попытки извне повлиять на его мнение, читатель должен овладеть приемами диалогического взаимодействия с текстом, которые способствуют развитию аналитического мышления. Одним из основных условий диалогического общения с текстом, по мнению исследователей, является осмысленное прочтение, которое предполагает выдвижение гипотез, постановку вопросов к автору текста и поиск ответов на них в тексте. Такой подход к чтению позволяет читателям почувствовать позицию автора, его намерения, что, в свою очередь, способствует развитию критического отношения к прочитанному.

Приемы, входящие в состав проблемного метода, способствуют развитию аналитического мышления читателей, их дискуссионных и диалогических умений. Наиболее эффективными приемами являются комментирование текста и сопоставление точек зрения на проблему, среди которых отдельное место занимает выявление авторской и читательской точек зрения. При их формулировании необходимым умением аналитического чтения считается умение выдвигать противоположное мнение и аргументировать свою позицию, приводить примеры и доказательства. Метод письменного комментирования включает в себя обучение приемам постановки диалогических вопросов, критического анализа и оценки прочитанного, обобщения содержания текста.

Наблюдения, проведенные на протяжении 2012-2013 учебного года над группой студентов, владеющих приемами диалогического взаимодействия с иностранными текстами (24 человека), и контрольной группой студентов (26 человек), показали существенные отличия в восприятии и понимании текстов. Студентам обеих групп на протяжении учебного года предлагалось прочитать и прокомментировать газетные тексты издания "KyivPost" на 
английском языке по специальности. Сформированность у студентов приемов диалогического взаимодействия определялась по таким критериям: 1) умения студентов выявлять в тексте разные смысловые позиции на проблемную ситуацию; 2) умения ставить диалогические вопросы к тексту и его автору; 3) умения выдвигать предположения о дальнейшем ходе событий в тексте; 4) умения высказывать собственное мнение и аргументировать его; 5) умения критически оценивать и анализировать текст; 6) умения составлять комментарий.

Письменные работы студентов, не владеющих приемами диалогического взаимодействия с иностранными текстами, содержали в основном категорические мнения за или против без приведения аргументов и доказательств. Данные и мнения автора статей упоминались в комментариях только 13\% испытуемых этой группы, что ставит под сомнение успешность понимания текстов статей большинством этих студентов. В отличие от них, студенты группы, владеющей диалогическими приемами, проявили навыки аналитической обработки информации. Они содержали не только апелляции к данным и мнениям авторов статей, но и продемонстрировали умения обосновывать собственное мнение о проблеме, ссылались на собственные знания и анализировали актуальность темы на сегодняшний день. С заданием написать комментарий к иностранной статье справились $88 \%$ студентов.

По результатам наблюдений можно сделать следующие выводы: 1) психологическая готовность к аналитическому чтению иностранных текстов характеризуется уверенностью читателя в собственных знаниях и способностях, наличием достаточного уровня владения иностранным языком, наличием навыков аналитического чтения, наличием мотивации изучения иностранного языка; 2) основными приемами диалогического взаимодействия с иностранными газетными текстами являются постановка диалогических вопросов, выдвижение гипотез и комментирование; 3) сформированность у студентов приемов диалогического взаимодействия с иностранными газетными текстами способствует лучшему пониманию текстов.

Таким образом, при обучении будущих специалистов чтению иностранных газетных текстов рекомендуется формировать у них основные приемы диалогического взаимодействия с текстами, поскольку это способствует развитию у их умений аналитического чтения, необходимого для существования и деятельности в современном информационном пространстве. 


\section{Литература}

1. Дмитрук О. В. Маніпулятивні стратегії в сучасній англомовній комунікації (на матеріалі текстів друкованих та Інтернетвидань 2000-2005 років) : автореф. дис. на здобуття наук. ступеня канд. філол. наук : спец. 10.02.04 «Германські мови» / О. В. Дмитрук. - К., 2006. $-24 \mathrm{c}$.

2. Дускаева Л. Р. Диалогическая природа газетных речевых жанров: автореф. дис. на соискание науч. степени докт. филол. наук: 10.01.10 / Л. Р. Дускаева. - Пермь, 2004. - 359 с.

3. Зимняя И. А. Ключевые компетенции - новая парадигма результата образования / И. А. Зимняя // Педагогика. - 2003. - № 3. C. 34-42.

4. Кудинова Л. В. Автор - Текст - Аудитория: проблемы диалога в публицистике: автореф. дис. на соискание науч. степени канд. филол. наук: спец. 10.01.10 «Журналистика» / Л. В. Кудинова. Воронеж, 2009. - 22 c.

5. Чепелєва Н. В. Психологія читання тексту студентами вузів / Н. В. Чепелєва. - К. : Либідь, 1990. - 100 с.

Наталія Громова. Психологічні особливості розуміння газетних іншомовних текстів майбутніми спеціалістами.

Стаття присвячена проблемам діалогічної взаємодї̈, аналітичного читання та розуміння текстів англійською мовою студентами немовних вузів. Умовами успішного розуміння іншомовних текстів $\epsilon$ психологічна готовність до аналітичного читання $i$ володіння основними прийомами діалогічної взаємодії з іншомовними газетними текстами. Спостереження показало, що сформованість у студентів прийомів діалогічної взаємодї з іншомовними текстами сприяє їх ефективному розумінню.

Ключові слова: діалогічна взаємодія, розуміння, газетний текст, прийоми, читання, аналіз.

Natalia Gromova. Psychological peculiarities of foreign newspaper texts understanding by future specialists.

The article deals with issues of dialogical interaction, analytical reading and understanding of foreign newspaper texts by students of non-linguistic universities. The factors of newspaper texts successful understanding are the following: psychological readiness to analytical reading and mastering the main methods of dialogical interaction with foreign newspaper texts. The observation proved that students' mastering methods of dialogical interaction with foreign texts contributes to their efficient understanding.

Key words: dialogical interaction, understanding, newspaper text, methods, reading, analysis.

Статья поступила в редакционную коллегию 01.04.2014 


\section{Груша Ляля Олександрівна}

(C) Груша Л. О., 2014.

Національний медичний університет імені О. О. Богомольця, м. Київ

\section{ОСОБЛИВОСТІ НАВЧАННЯ ІНОЗЕМНІЙ МОВІ СТУДЕНТІВ ВИЩИХ МЕДИЧНИХ НАВЧАЛЬНИХ ЗАКЛАДІВ}

У статті представлено до розгляду питання навчання іноземній мові студентів вищих навчальних закладів освіти та розглянуто особливості прочесу у вищих медичних навчальних закладах.

Ключові слова: іноземна мова, вищий медичний навчальний заклад, студенти-медики.

В складних умовах сьогодення українського суспільства висуваються серйозні вимоги до рівня підготовки сучасного спеціаліста. Важливим та суттєвим компонентом такої підготовки та одним 3 головних завдань, яке постає перед вищою школою, $\epsilon$ формування соціально затребуваної особистості. Участь у міжнародних конгресах, конференціях, семінарах, відвідування лекцій й проведення консультацій з іноземними фахівцями, стажування за кордоном стають розповсюдженими формами вищої професійної освіти, безперервного професійного розвитку та невід'ємною частиною життя висококваліфікованого фахівця будь-якої галузі, в тому числі, й медичної. Не підлягає сумніву, що забезпечення активного спілкування з іноземними колегами, участі у різних формах професійної діяльності, доступу до інформаційних ресурсів та сучасних баз даних, які, в переважній більшості, $\epsilon$ англомовними, актуалізує питання володіння студентами вищих медичних навчальних закладів іноземною мовою на належному рівні.

Метою статті $є$ розгляд особливостей процесу навчання іноземної мови студентів вищих медичних навчальних закладів.

3 огляду на особливості навчання іноземної мови як навчальної дисципліни у процесі підготовки студентів вищих медичних навчальних закладів, слід зазначити що мова являє собою, перш за все, освітню цінність, що розширює спектр подальших освітніх та професійних перспектив майбутніх фахівців. Безумовно, однією з іiі функцій $є$ забезпечення загального розвитку студента, збагачення знань про навколишній світ, суттєвого розширення його кругозору, формування власного світобачення [2]. Вивчення іноземної мови у ВНЗ сприяє й інтелектуальному розвитку за рахунок засвоєння нових соціально-історичних зразків та пластів культури. 
Водночас, вивчення іноземної мови в процесі підготовки спеціаліста не філологічного профілю, на нашу думку, ставить за кінцеву мету формування здатності володіння мовою у сфері побутової та професійної комунікації на рівні достатньому для здійснення певних видів професійної діяльності, а саме: пошуку інформації та користування сучасною додатковою літературою за спеціальністю; усного монологічного виступу у вигляді презентації, доповіді; усного діалогічного виступу на побутову або професійну теми; письмової комунікації. Тобто, досягнення рівня практичної підготовки володіння мовою достатнього для успішної майбутньої діяльності та життя в суспільстві в цілому.

Безперечно, традиційні методи навчання іноземної мови передбачають засвоєння знань у штучних ситуаціях, внаслідок чого не завжди чітко простежується міцний зв'язок між предметом та майбутньою професійною діяльністю та знижується мотивація навчання. Таким чином, існує потреба застосування на заняттях 3 іноземної мови не лише вивчення, повторення й закріплення професійно зорієнтованого лексичного матеріалу, але й імітації елементів професійної діяльності. Так, наприклад, спілкування діалог $з$ приводу професійної інформації, прочитаної іноземною мовою або отриманою із засобів масової інформації, аналіз реальних ситуацій лікувальної практики та виконання творчих завдань 3 профільним змістом забезпечуватимуть підвищення професійної спрямованості вивчення іноземної мови. Проте, як показує практика та зазначають фахівці, помітний ефект спостерігається лише за умов забезпечення системності застосування зазначених методів, що сприятиме формуванню комплексу відповідних умінь і навичок $[1 ; 3]$.

Звертаємо увагу на те, що в процесі навчання викладачу варто застосовувати всі доступні методи задля підвищення мотивації студентів. Інтерактивна взаємодія між студентом і викладачем, студентом і студентом, яка базується на позитивних відносинах, рівноправності партнерів, довірі й повазі один одного, сприяє цьому. Вона реалізується за допомогою колективних і групових способів організації навчальної діяльності. Навчальні заняття, організовані як безпосередній діалог, практичні заняття-диспути надають можливості студентам критично мислити, висловлювати власні думки, виражати почуття й оцінки. Завдання, запропоновані в ході проведення занять, змушують чути, сприймати та зважувати альтернативні думки й позиції, вирішувати складні проблеми на основі аналізу відповідної інформації і обставин, приймати власні рішення та, як наслідок, досягати відчутних результатів у вивченні іноземної мови.

Узагальнюючи вищезазначене вважаємо, що процес навчання іноземній мові студентів здійснюватиметься ефективно за умов: 
- забезпечення доступу тих, хто навчається, до різноманітних інформаційних джерел 3 метою отримання можливості всебічного дослідження тієї чи іншої проблеми;

- уникання пасивного оволодіння знаннями шляхом залучення кожного студента до активного пізнавального процесу і формування у нього власної аргументованої думки;

- не домінуючої, а корегуючої й консультативної ролі викладача, тобто такої, в якій викладач допомагає студенту, а не лише контролює рівень його знань;

- налагодження роботи у співробітництві при розв'язанні різноманітних проблем.

Висновки. Аналіз проблеми дозволяє зробити наступні висновки: навчання іноземній мові студентів вищих медичних навчальних закладів було та залишається актуальним у зв'язку 3 інтеграцією України до європейської спільноти. Водночас, навчання іноземній мові майбутніх лікарів $є$ невід'ємним компонентом їхньої освіти, без якої неможлива якісна підготовка фахівців, здатних компетентно здійснювати професійну діяльність та набувати конкурентоспроможності у світовому суспільстві.

\section{Література}

1. Веретенко Т. Г. Шляхи підвищення активності навчальнопізнавальної діяльності студентів : зб. наук. праць / Т. Г. Веретенко / Вісник Запорізького національного університету : Педагогічні науки. № 1. - Запоріжжя, 2008. - С. 52-57.

2. Шерстюк О. М. Сучасні підходи щодо викладання іноземних мов / О. М. Шерстюк // Інозем. мови, 2000. - С. 65-72.

3. Щукин А. Н. Обучение иностранным языкам: теория и практика / А. Н. Щукин. - М. : Филоматис, 2004. - 416 с.

Ляля Груша. Особенности обучения иностранному языку студентов высших медицинских учебных заведений.

B статье представлен $\kappa$ рассмотрению вопрос обучения иностранному языку студентов высших учебных заведений $u$ рассмотрень особенности прочесса в высших медицинских учебных учреждениях.

Ключевые слова: иностранный язык, высшее медицинское учебное заведение, студенть-медики.

Lialia Grusha. Peculiarities of teaching foreign language to students of higher medical educational institutions.

The article is devoted to the problem of teaching foreign language to students of higher educational institutions and peculiarities of the process in higher medical educational institutions.

Key words: foreign language, higher medical educational institution, medical students. Стаття надійшла до редакційної колегії 22.04.2014 


\section{Давидова Жанна Вадимівна}

(C) Давидова Ж. В., 2014.

Харківський національний економічний університет імені С. Кузнеця

\section{ВИКЛАДАЧ ЯК СУБ'СКТ УПРАВЛІННЯ НАВЧАЛЬНОЮ ДІЯЛЬНІСТЮ СТУДЕНТІВ 3 ФОРМУВАННЯ ДУХОВНО-ЦІННІСНИХ ОРІЕНТАЦІЙ У ПЕДАГОГІЧНОМУ ПРОЦЕСІ ВИШУ}

У статті розглянуто місие $і$ роль викладача у прочесі формування духовно-иіннісних орієнтаиій студентів. Проаналізовано головні професійні ци особистісні вимоги до викладача для забезпечення ефективності педагогічного процесу.

Ключові слова: духовно-ціннісні орієнтачії, професійна компетентність викладача, авторитетність викладача, діалогічна взасмодія.

Викладач $є$ організатором і керівником педагогічного процесу, творцем такого навчального середовища, що сприяє вільному духовному розвиткові студентів та особистістю, яка значно впливає на становлення їхньої ціннісної сфери та світогляду в цілому.

Його професійна компетентність передбачає сформованість в роботі викладача таких компонентів: ціннісні орієнтації, ідеали, внутрішні смисли праці викладача; клімат й атмосфера цієї праці; педагогічна діяльність - це “технологія” праці вчителя [4].

Особистість $є$ стрижневим фактором праці викладача, що визначає його професійну позицію в педагогічній діяльності та педагогічному спілкуванні. Особистість викладача розкривається в його професійно-педагогічній культурі, що $є$ інтегративною якістю педагога-професіонала. Вивчення робіт Ш. Амонашвілі, О. Барабанщикова, В. Гриньової, І. Ісаєва, В. Сластьоніна, С. Шиянова довело, що педагогічна культура $є$ найважливішою частиною загальної культури викладача, що виявляється в системі професійних якостей і специфіці педагогічної діяльності.

Метою статті є визначення головних професійних й особистісних вимог до викладача для забезпечення ефективності педагогічного процесу з формування духовно-ціннісних орієнтацій (ДЦО) студентів.

Формування ДЦО - складний процес, в якому завданням викладача $\epsilon$ введення студентів у світ культури, розкриття його багатогранності, створення умов для активного пізнання та інтеріоризації індивідуально значущих цінностей. 
При цьому особливого значення набуває рівень духовної культури викладача. В. Гриньова доводить, що духовність й духовна культура викладача $є$ підгрунтям як професійної, так і педагогічної культури [3]. Духовність знаходить вияв у гуманному ставленні до студентів, творчості, відданості своїй справі, незалежності у визначенні в світі культури. Позицією духовно розвиненого, гуманного викладача $є$ альтруїстична поведінка, що характеризується дотриманням норм, морально-етичних правил поведінки в суспільстві, виявленням соціальної відповідальності, співпереживання, співчуття, людської взаємності [5]. При формуванні ДЦО саме така позиція педагога, яка характеризується безкорисною спрямованістю на благо інших, а також його високий духовний розвиток, що виявляється у дотриманні ідеалів найвищих цінностей, можуть забезпечити досягнення результату.

Як свідчить практика, в навчально-виховному процесі педагогічні впливи є більш ефективними, якщо викладач користується довірою серед студентів, може їх зацікавити, а також $\epsilon$ вимогливим до себе й справедливим до учнів. У такому випадку можна стверджувати, що викладач користується авторитетом серед своїх учнів. Авторитетність педагога встановлюється на основі оцінки учнями його самостійності, вчинків, правил, особистісних якостей, життєвої позиції, професіоналізму, особистісного досвіду. При формуванні ДЦО такий викладач може стати дієвим посередником між суспільними цінностями та системою особистісних цінностей студентів. Викладач, який користується авторитетом серед студентів, стає взірцем для наслідування, з яким вони порівнюють свою життєву позицію, ціннісні орієнтації. Тому в процесі педагогічної взаємодії викладач постійно цілеспрямовано або не усвідомлено впливає на становлення особистості учня. Розуміючи головне завдання сучасної освіти сприяння духовному розвиткові особистості, викладач має постійно самовдосконалюватися як у професійному, так і в особистісному плані. У цьому зв'язку справедливо наголошує Ш. Амонашвілі: «Особистість виховується Особистістю» [1]. Особистісне самовдосконалення полягає у власній активності людини зі змінення себе, у розкритті, збагаченні своїх духовних потреб, творчості, всього особистісного потенціалу. Цей інтегративний процес включає розвиток усіх компонентів духовної сфери особистості (розуму, волі, почуттів, совісті). Особистісне і професійне самовдосконалення - це динамічний та неперервний процес самопроектування особистості викладача.

Діяльність викладача буде ефективною, якщо він створює в класі атмосферу тепла, природності, взаємної довіри [2]. Прийняття студента як унікальної особистості дозволяє викладачу будувати гуманні, демократичні взаємовідносини, в основі яких лежить 


\section{Збірник наукових статей}

діалогічна взаємодія. Проникнення у духовний світ студента дозволяє викладачеві осягнути безмежність кожного учня та знайти правильні шляхи впливу. I навпаки, якщо викладач байдужий до індивідуальності учнів, їхнього внутрішнього світу, то зворотний зв'язок $є$ дуже обмеженим, в результаті чого створюється напружена i формалізована атмосфера. За таких умов внутрішній світ особистостей залишається зачиненим для інших i для критичного сприйняття інформації щодо ДЦО, запропонованої викладачем.

Усвідомлення викладачем важливості духовного розвитку учнів вимагає перегляду організації педагогічного процесу. Відкритість до нового, що зумовлює високий рівень педагогічної майстерності, дозволяє дещо переглянути позицію та роль викладача. У процесі формування ДЦО викладач має створювати передумови для активізації пізнавальної діяльності учнів, оперативно реагувати, вільно оперувати змістом, методами, формами навчання. Визначення своєї ролі як співучасника, а не як лідера навчального процесу, передбачає постійну рефлексію щодо власної педагогічної діяльності, а також розвинення власного критичного мислення.

Таким чином, дослідження щодо місця й ролі викладача в процесі формування ДЦО студентів показали, що для забезпечення досягнення мети найважливішими характеристиками викладача $є$ його високий рівень духовної культури, альтруїстична позиція, авторитетність та спрямованість на самовдосконалення. Ефективне педагогічне спілкування при формуванні ДЦО досягається за рахунок установлення особистих, довірчих взаємин між учасниками педагогічного процесу. Головним завданням у діяльності педагога $\epsilon$ створення умов для ефективного формування ДЦО студентів.

\section{Література}

1. Амонашвілі Ш. О. Школа життя / Ш. О. Амонашвілі; пер. 3 poc. - Хмельницький : Подільськ. культурно-просвітительський центр ім. М. К. Реріха, 2002. - 172 с.

2. Анисимов О.С. Методологическая культура педагогической деятельности и мышления / О. С. Анисимов. - М. : Экономика, 1991. $415 \mathrm{c}$.

3. Гриньова В. М. Формування педагогічної культури майбутнього вчителя (теоретичний та методичний аспект) : монографія / В. М. Гриньова. - Х. : Основа, 1998. - 300 с.

4. Маркова А. К. Профессиональная компетентность учителя / А. К. Маркова // Психология труда учителя : Книга для учителя. - М. : Просвещение, 1993. - С. 6-11.
5. Рибалко Л. С.
Виявлення
мотиваційно-ціннісної спрямованості майбутнього вчителя на саморозвиток / Л. С. Рибалко // 
Психолого-педагогічні проблеми становлення сучасного фахівця

Випуск 2014 Вісник Харківської державної академії культури. - Вип. 27. - Х. : ХДАК, 2009. - С. 209-217.

Жанна Давыдова. Преподаватель как субъект управления учебной деятельностью студентов при формировании духовноценностных ориентаций в педагогическом процессе вуза.

B статье рассматриваются место и роль преподавателя при формировании духовно-ценностных ориентаций студентов. Проанализированы основные профессиональные и личностные требования $к$ преподавателю для обеспечения эффективности педагогического процесса.

Ключевые слова: духовно-цуенностные ориентации, профессиональная компетентность преподавателя, авторитет преподавателя, диалогическое взаимодействие.

Zhanna Davydova. Instructor as a Subject of Students' Educational Activity Management on Formation of Spiritual-Value Orientations in the Educational Process of University.

A place and a role of an instructor in the process of students' spiritualvalue formation is observed. The main professional and personality demands to an instructor are analyzed to provide the effective educational process.

Key words: spiritual-value orientations, professional competence of an instructor, instructor's authority, dialogue co-operation.

Стаття надійшла до редакційної колегії 15.05.2014

УДК $316.37: 001: 37$

(C) Дмитренко Т. О., Лаврик Т. В., 2014. Дмитренко Тамара Олександрівна

Херсонський державний університет

Лаврик Тетяна Володимирівна

Сумський державний університет

\section{ПЕДАГОГІЧНІ УМОВИ ЯК КОМПОНЕНТ НАУКОВИХ ОСНОВ ДОСЛІДЖЕННЯ}

У статті розглянуто сутність педагогічних умов як предмету дослідження з педагогіки. На основі аналізу педагогічних умов, які пов'язані, з одного боку, з проблемою дослідження, а з іншого - iз засобами ї̈ вирімення, обтрунтовано бінарний характер педагогічних умов. 3'ясовано функиії педагогічних умов.

Ключові слова: педагогічні умови, педагогічна система, наукове дослідження. 


\section{Збірник наукових статей}

Пріоритетним завданням вищої школи $є$ підготовка компетентного фахівця, здатного ефективно діяти за межами навчальних ситуацій, розв'язувати типові й проблемні завдання, що виникають в професійній діяльності. Реалізація поставлених завдань вимагає від педагогів створення відповідних педагогічних умов, що сприятимуть досягненню мети. Як засвідчив аналіз, у наукових дослідженнях 3 педагогіки розробляються різноманітні педагогічні умови, що спрямовуються на вирішення конкретного завдання (формування професійної спрямованості особистості студентів, управління самостійною роботою студентів тощо). Однак, на нашу думку, актуальними і недостатньо розробленими є питання, пов'язані зі структурою та функціями педагогічних умов, їх значенням у науковому дослідженні.

Метою статті є розгляд сутності, структури i функцій педагогічних умов у науковому дослідженні.

Філософське трактування поняття «умова» пов'язується 3 відношенням предмету до оточуючих його явищ, без яких він не може існувати $[5$, с. 98]. Тобто, сукупність конкретних умов предмету чи явища створюють середовище, в якому вони виникають, існують i розвиваються.

Під педагогічними умовами науковці розуміють фактори, які діють у навчальному процесі й впливають як на навчальну діяльність, так і на результати учіння [4, с. 95]. Аналіз показує, що умова пов'язана з процесом або системою і впливає на них. На нашу думку, доречним є саме таке родо-видове відношення: педагогічна умова фактор, що впливає і викликає необхідні зміни.

Розгляд педагогічних досліджень дозволив висновити стосовно функцій педагогічних умов, а саме, бути їх предметом. Зокрема, підтвердженням цьому $\epsilon$ дослідження $\quad$ В. Б. Бакатанової (1996), О. Л. Караман (2002), І. В. Кузнецової (2005), Л. Г. Харченко (2006), С. І. Редько (2007), Т. В. Лаврик (2013), Ж. В. Давидової (2013) та інші.

У цих дослідженнях педагогічні умови мають чітку спрямованість - на вирішення поставленої проблеми. Наприклад, у дисертації Т. В. Лаврик на тему «Педагогічні умови оптимізації системи дистанційного навчання бакалаврів галузі «Системні науки та кібернетика» в університеті» проблемою $\epsilon$ оптимізація системи дистанційного навчання, а педагогічні умови спрямовані на іiі вирішення [2].

Структура наукових основ дослідження 3 педагогіки включає такі компоненти:

1) актуальність проблеми, теми;

2) аналіз факторів, що впливають на педагогічну систему (об'єктивного - вплив навколишнього середовища; суб'єктивного - 
реакція суб'єктів системи на зовнішні впливи; особистісного - вплив характеристик суб'єктів на функціонування системи; людського - роль людини в системі як суб'єкта, який приймає рішення);

3) виявлення й аналіз суперечностей;

4) обгрунтування проблеми й теми;

5) мета, завдання, об’єкт, предмет, обмеження в об'єкті;

6) педагогічні умови вирішення проблеми;

7) застосування педагогічних умов для розробки компонентів педагогічної системи і педагогічного процесу.

Компоненти структури наукових основ педагогічного дослідження можна поєднати у три групи: перша включає з першого по п'ятий компонент; друга - шостий; третя - сьомий компонент. Метою такого поєднання $€$ обгрунтування значення шостого компонента - педагогічних умов - у наданій вище сукупності. На нашу думку, саме цей компонент займає центральне положення, тому що перші п’ять компонентів беруть участь у його розробці, а сьомий - у його застосуванні в практичній діяльності.

Розкриємо сутність деяких компонентів наукових основ на прикладі дослідження Т. В. Лаврик [2]. Від дії суб’єктивного фактора виникає головна суперечність: між необхідністю науково обгрунтованої оптимізації системи дистанційного навчання бакалаврів 3 інформаційних технологій в університеті та відсутністю чітко обгрунтованих умов оптимізації в зазначеному напрямі.

Для зниження дії суб'єктивного фактору визначено такі педагогічні умови: 1) забезпечення адаптації студентів до умов дистанційного навчання та сфери майбутньої професійної діяльності через дистанційний курс як засіб організації й управління; 2) організація самостійної пізнавальної діяльності студентів дистанційного навчання через робочий зошит у процесі професійної підготовки; 3) забезпечення фундаментальної підготовки бакалаврів 3 інформаційних технологій через комплекс дисциплін, що становлять теоретичні основи інформатики.

Отже, педагогічні умови є предметом дослідження, виходячи 3 того, що вони:

- спрямовуються на вирішення проблеми;

- обгрунтовуються через компоненти наукового апарату;

- впливають на компоненти педагогічної системи, а також педагогічний процес відповідно до критеріїв оптимізації й обмежень (здатність до самоорганізації й самоуправління; якість знань, умінь, навичок з дисциплін професійного циклу).

Особливості педагогічної системи дистанційного навчання складаються з особливостей їі компонентів [2, с. 7]. Аналіз структури зазначених вище особливостей показав, що кожна 3 них має дві 


\section{Збірник наукових статей}

складових: перша віддзеркалює питання, що вирішується, а друга надає ключ для його вирішення. Наприклад, цілі діяльності, які визначає викладач, є інваріантними стосовно форми навчання (очна, заочна), але постановка цілей суб'єктом навчальної діяльності (студентом) має підтримуватися через відповідні засоби й мати систематичний характер. Наявність у складі кожної особливості питання й ключа до нього дозволила науковцю застосувати їх для проектування засобу управління діяльністю - дистанційного курсу 3 робочим зошитом.

Виявлені особливості професійної підготовки бакалаврів галузі «Системні науки та кібернетика», зокрема, престижність професії, потреба у постійному навчанні, необхідність у фундаментальній підготовці з інформатики тощо, дозволили висновити, що здійснення професійної діяльності потребує вмінь організовувати свою діяльність і управляти нею.

Двосторонній характер особливостей системи дистанційного навчання й підготовки бакалаврів забезпечив обгрунтування критеріїв оптимізації, а саме - здатність студентів до самоорганізації й самоуправління, що відображає особливість дистанційного навчання, а також якість знань, умінь, навичок з дисциплін професійного циклу, що характеризує якість професійної підготовки.

Особливості системи дистанційного навчання дозволили розглянути таке обмеження в постановці завдання оптимізації тривалість роботи студента за комп'ютером, з навчально-методичними матеріалами до дисципліни.

Згідно 3 алгоритмом оптимізації у кібернетиці [1], особливостями системи дистанційного навчання, особливостями підготовки фахівців, критеріями оптимізації та обмеженнями розроблено педагогічні умови оптимізації [2, с. 10]:

- умова 1 - забезпечення адаптації студентів до умов дистанційного навчання та сфери майбутньої професійної діяльності через дистанційний курс як засіб організації й управління;

- умова 2 - організація самостійної пізнавальної діяльності студентів дистанційного навчання через робочий зошит у процесі професійної підготовки;

- умова 3 - забезпечення фундаментальної підготовки бакалаврів з інформаційних технологій через комплекс дисциплін, що становлять теоретичні основи інформатики.

Аналіз педагогічних умов показав, що вони $є$ бінарними, тобто мають дві сторони свого розгляду (двохвимірні, двохаспектні). Перша сторона кожної умови пов'язана 3 проблемою, що вирішується (адаптація студентів до умов дистанційного навчання й майбутньої професійної діяльності; організація самостійної пізнавальної 
діяльності студентів дистанційного навчання; забезпечення фундаментальної підготовки бакалаврів), а друга сторона - із засобами вирішення проблеми (вступний очно-дистанційний курс, навчальний дистанційний курс з робочим зошитом, комплекс дистанційних курсів 3 дисциплін).

Якщо розглянути сукупність педагогічних умов як їх послідовне поєднання на підгрунті застосування засобів для вирішення проблем, то буде реалізовано принцип наступності: вступний очнодистанційний курс, навчальний дистанційний курс 3 робочим зошитом, комплекс дистанційних курсів 3 дисциплін. Підгрунтям наступності між вступним очно-дистанційним курсом і навчальним дистанційним курсом є знання, які дозволяють сформувати вміння самоорганізації й самоуправління через вирішення завдань, а також перейти до вивчення інших дисциплін навчального плану відповідного напряму підготовки, що становлять теоретичні основи інформатики.

Принцип ієрархічності, на нашу думку, реалізується в процесі вирішення проблем. Так, на базовому рівні ієрархії розглядається проблема адаптації, без вирішення якої неможливо перейти до організації самостійної діяльності, а тим більше - забезпечення фундаментальної підготовки майбутніх фахівців. Якщо принцип наступності сприяє набуттю досвіду професійної діяльності, то принцип ієрархічності дозволяє сформувати відношення студента до цього процесу.

Висновуємо, що сукупність педагогічних умов оптимізації $\epsilon$ бінарною системою, яка задовольняє принципам наступності та ієрархічності, що є взаємооберненими (взаємодоповнюваними).

Розглянемо сутність, структуру і функції педагогічних умов оптимізації. У сучасній філософії сутність означає сукупність посутніх властивостей i якостей речі, субстанціональне ядро самостійного сущого [3, с. 1008].

Аналізуючи наведені вище педагогічні умови оптимізації системи дистанційного навчання бакалаврів, зазначимо, що їх основними властивостями $є$ : універсальність, інструментальність, спрямованість на вирішення проблеми, ієрархічність, наступність, інтегративність, технологічність.

Універсальність педагогічних умов означає спрямованість на теорію і практику. Спрямованість на теорію полягає у тому, що їх підгрунтям є теорія оптимізації, розроблена в кібернетиці, а саме алгоритм як послідовність вирішення завдання оптимізації [2, с. 10]. Спрямованість на практику полягає у тому, що педагогічні умови використовуються для розробки компонентів системи дистанційного навчання відповідно до критеріїв оптимізації й обмежень. Отже, через педагогічні умови реалізується зв'язок теорії оптимізації з практикою. 
У цьому сенсі субстанціональним ядром педагогічних умов є їх вплив на практику навчання через компоненти педагогічної системи $\mathrm{i}$ технологію. Теоретичний аспект розгляду педагогічних умов дозволив розробити визначення: педагогічні умови оптимізації - це взаємопов'язана сукупність необхідних факторів, що впливають на педагогічну систему для досягнення поставлених цілей відповідно до критеріїв оптимізації та обмежень [2, с. 8$]$.

Інструментальність педагогічних умов полягає у тому, що вони спрямовані на вирішення проблеми дослідження - оптимізація педагогічної системи через зміни іï компонентів відповідно до критеріїв та обмежень.

Бінарність педагогічних умов виявляється також у тому, що, 3 одного боку, вони $є$ інтегрованими, а з іншого, виступають підгрунтям інтеграції наукових основ дослідження.

Інтегративність педагогічних умов є результатом їх інтеграції на підгрунті підготовки фахівця. Тривимірна система педагогічних умов включає три аспекти - адаптацію, організацію й управління, в той же час, як організація й управління - системоутворювальні фактори, а адаптація - умова їх здійснення. Педагогічні умови сприяють інтеграції наукових основ дослідження, тому що частина 3 них використовується в процесі розробки умов, а інші - втілення їх в практику оптимізації педагогічної системи дистанційного навчання.

Важливою характеристикою педагогічних умов $\epsilon$ ïx технологічність. Вони виступають ланкою зв'язку парадигм, методологічних i теоретичних засад дослідження 3 педагогічною системою дистанційного навчання як об'єктом оптимізації, з одного боку, і умовою здійснення педагогічного процесу, з іншого.

Обгрунтовані характеристики педагогічних умов дозволяють визначити їх функції: універсальність - зв'язок теорії оптимізації $з$ практикою; інструментальність - засіб (інструмент) вирішення проблеми дослідження; інтегративність - засіб інтеграції наукових основ дослідження; технологічність - вплив на технологію 3 метою підвищення ефективності процесу дистанційного навчання.

Отже, на основі аналізу наукових досліджень 3 педагогіки обгрунтовано педагогічні умови як предмет дослідження, виходячи 3 того, що вони спрямовані на вирішення проблеми дослідження й виявлені через компоненти наукового апарату, а також застосовуються для розробки компонентів педагогічної системи і педагогічного процесу. Встановлено, що педагогічні умови у дослідженні за своєю структурою являють бінарну систему, яка задовольняє принципам наступності та ієрархічності. Визначено їх основні функції, а саме універсальність, інструментальність, інтегративність, технологічність. Відповідно обгрунтованих положень щодо структури та функцій 
педагогічних умов у подальшому передбачається проаналізувати та застосувати їх до наукових досліджень, предметом яких є педагогічні умови.

\section{Література}

1. Коршунов Ю. М. Математические основы кибернетики: учеб. пособие для вузов / Ю. М. Коршунов - М. : Энергоатомиздат, 1987. $495 \mathrm{c}$.

2. Лаврик Т. В. Педагогічні умови оптимізації системи дистанційного навчання бакалаврів галузі «Системні науки та кібернетика» в університеті: автореф. дис. ... канд. пед. наук / Т. В. Лаврик. - Запоріжжя, 2013. - 20 с.

3. Новейший философский словарь / под ред. А. А. Грицанова. Мн. : Интерпрессервис; Книжный дом, 2001. - 1280 с.

4. Самостійна робота студентів: (навчальний посібник) / В. І. Свдокимов, Л. Д. Покроєва, Т. П. Агапова, В. В. Луценко - Х. : ХДПУ ім. Г. С. Сковороди, 2004. - 140 с.

5. Философский энциклопедический словарь / Е. Ф Губский., Г. В. Кораблева, В. А. Лутченко - М. : ИНФРА-М, 2007. - 576 с.

Тамара Дмитренко, Татьяна Лаврик. Педагогические условия как компонент научных основ исследования.

В статье рассмотрена сущность педагогических условий как предмета исследования по педагогике. На основе анализа педагогических условий, которые связаны, с одной стороны, с проблемой исследования, а с другой - со средствами ее решения, обоснован бинарный характер педагогических условий. Уточнены функиии педагогических условий.

Ключевые слова: педагогические условия, педагогическая система, научное исследование.

Tamara Dmitrenko, Tetjana Lavryk. Pedagogical conditions as a component of scientific research.

The article considers the essence of pedagogical conditions as the subject of research of pedagogy. Based on the analysis of pedagogical conditions are substantiated their binary character. The functions of pedagogical conditions are clarified.

Key words: pedagogical conditions, pedagogical system, scientific research.

Стаття надійшла до редакційної колегії 14.05.2014 
Збірник наукових статей

УДК 008-043.83-052]:37.091.12:159-051"376"

(C) Дубовицкая Т. Д., Газизова Р. Р., Дубниченко В. Ю., 2014.

Дубовицкая Татьяна Дмитриевна

Башкирский государственный педагогический университет

им. М. Акмуллы, Россия

Газизова Регина Расиховна

Стерлитамакский филиал

Башкирского государственного университета, Россия

Дубниченко Варвара Юрьевна

Донецк, Украина

\section{ФОРМИРОВАНИЕ КУЛЬТУРЫ ОТНОШЕНИЯ К КЛИЕНТУ У БУДУЩИХ ПСИХОЛОГОВ НА ЭТАПЕ ОБУЧЕНИЯ В ВУЗЕ}

Вводятся понятия: «отношение психолога к клиенту», «культура отношения психолога к клиенту». Содержится структура культуры отношения психолога $\kappa$ клиенту, включающая перцептивнокоммуникативный, эмоционально-регулятивный, поведенческий компоненты. Дается характеристика их содержания, модель и программа формирования культуры отношения психолога к клиенту, результаты их практического внедрения в работе со студентами будущими психологами.

Ключевые слова: отночение, психологическая культура, культура отночения психолога к клиенту, эмпатия, границь общения.

Последние десятилетия характеризуются возрастанием интереса людей к психологической службе и пониманием необходимости обращения за психологической помощью. Психолог становится востребованным специалистом, потребность в котором осознается в самых различных сферах человеческой деятельности: медицине, образовании, политике, экономике и т.д. В этой связи актуальным является повышение эффективности профессиональной подготовки будущих психологов на этапе обучения в ВУЗе. Одной из важных составляющих психологической помощи (наряду с психологической теорией и набором методов и техник) является отношение психолога к клиенту. Особенности данного отношения отражены в работах представителей практически всех направлений прикладной психологии, но еще не стали предметом целенаправленного формирования у студентов-психологов.

Цель статьи. В статье представлена разработка условий и программы формирования культуры отношения к клиенту у студентов-психологов. Для достижения поставленной цели необходимо было решить следующие задачи: 1) уточнить понятие 
культуры отношения психолога к клиенту, определить ее психологические компоненты, охарактеризовать критерии и показатели сформированности; 2) провести эмпирическое исследование сформированности культуры отношения к клиенту у студентов-психологов; 3) разработать модель и программу формирования культуры отношения к клиенту у студентовпсихологов; 4) проверить эффективность разработанной модели и программы формирования культуры отношения к клиенту у студентов-психологов.

Наиболее глубокая разработка категории «отношение» представлена в концепции В. Н. Мясищева [2, с. 48], согласно которому отношения человека представляют сознательную, избирательную, основанную на опыте психологическую связь его с различными сторонами объективной действительности, выражающуюся в его действиях, реакциях и переживаниях. И именно качество этой связи обуславливает характер и эффективность взаимодействия людей. В структуре отношения В. Н. Мясищев выделяет «эмоциональную», «оценочную» (когнитивную, познавательную) и «конативную» (поведенческую) стороны. Теоретический анализ основных направлений практической психологии позволил констатировать тот факт, что все они признают полезность установления позитивных, эмпатических отношений с клиентом, но при этом сохраняющих определенные границы. Так, по мнению 3. Фрейда [5], психолог должен создавать условия для максимального проявления бессознательного в человеке, в то же время, никак не вовлекаясь в отношения с клиентом. Психолог, работающий в русле когнитивно-поведенческого направления [6], выступает в четко определенной роли учителя и наставника, он должен проявлять эмпатию, устанавливать доверительные отношения и раппорт, но при этом ему следует воздерживаться от выражения чрезмерной теплоты и любви к клиенту, сохранять объективную позицию. В экзистенциально-гуманистическом направлении [4; 5] психолог выступает в роли помощника клиента. Ф. Перлз различает понятия «эмпатия» и «симпатия», в характеристике последней отсутствует контактная граница, в результате терапевт отождествляется с клиентом, что лишает его возможности смотреть на проблемы клиента со стороны.

Опора на идеи В. Н. Мясищева, позволила определить понятие «отношение психолога к клиенту» как психологическую связь психолога с клиентом, обусловливающую характер профессионального межличностного взаимодействия и психологической помощи клиенту. В содержании отношения психолога к клиенту были выделены следующие базовые 
психологические составляющие: 1) образ клиента и его жизненной ситуации/проблемы; 2) эмоционально-чувственное переживание; 3) действия психолога по отношению к клиенту [1].

Культура отношения психолога к клиенту рассматривается как составная часть психологической культуры психолога, заключающаяся в способности создавать целостный образ клиента и его проблемы, эмоциональной саморегуляции и направленности психолога на развитие личности клиента при условии сохранения границы в общении с ним.

Основными компонентами культуры отношения психолога к клиенту являются: перцептивно-коммуникативный (способность создавать целостный образ клиента и его проблемы), эмоциональнорегулятивный (способность к эмоциональной поддержке клиента, а также к саморегуляции своего эмоционального состояния в ситуации взаимодействия с клиентом), поведенческий (направленность психолога на развитие личности клиента при условии сохранения границы в общении с ним).

Каждый из названных компонентов характеризуется набором специфических умений и свойств личности, диагностируемых с помощью специальных методик. Перцептивно-коммуниктивный компонент включает следующие умения и свойства: владение средствами невербальной психодиагностики; Умение понимать соответствие вербального сообщения человека его действительным желаниям и стремлениям; проникающая способность к эмпатии; способность вызывать доверие. Эмоционально-регулятивный компонент включает: способность к эмпатии, социальный интерес, комфортность в межличностных отношениях, умение регулировать эмоциональное состояние. Поведенческий компонент включает: направленность на развитие личности клиента, тактичность в отношениях, удовлетворенность межличностным взаимодействием, самоценность отношений, конструктивность и диалогичность отношений.

Формирование культуры отношения к клиенту у студентовпсихологов моделируется как единство и взаимообусловленность целевого, диагностического, содержательно-деятельностного, практического и результативного блоков. Целевой блок определяет цели и задачи предложенной модели, обосновывает психологические компоненты, условия и механизмы, обусловливающие эффективность формирования культуры отношения к клиенту; диагностический блок направлен на выделение критериев и показателей сформированности культуры отношения, определение диагностического комплекса для исследования культуры отношения психолога к клиенту, констатацию сформированности культуры отношения к клиенту у студентов- 
психологов; содержательно-деятельностный блок характеризует осваиваемые компетенции и формы работы со студентами через изучение специального курса «Культура отношения психолога к клиенту», дисциплины «Концепции и методы оказания психологической помощи», работу психологической службы ВУЗа; практический блок включает реализацию освоенных знаний, сформированных умений и свойств личности и соответствующих компетенций в ходе психолого-педагогической практики; результативный блок направлен на констатацию изменения сформированности культуры отношения к клиенту у студентовпсихологов.

Программа предложенного спецкурса состоит из теоретической и практической частей. Изучение теоретической части направлено на ознакомление студентов с понятиями «отношение», «отношение психолога к клиенту», «культура отношения психолога к клиенту», компонентами культуры отношения психолога к клиенту и т.д. Практическая часть направлена на осознание студентами важности, ценности и значимости отношений в процессе взаимодействия с клиентом. Также обеспечивается формирование доброжелательного, открытого и искреннего отношения к клиенту, способности к актуализации его внутренних ресурсов, эмпатии, тактичности и взаимопонимания, осознания роли провокации, вербальных и невербальных средств общения в отношении с клиентом, умения поддерживать психологическую границу и в то же время доверительные отношения с клиентом, умения выбирать адекватные, конструктивные формы самоконтроля эмоционального состояния.

В качестве психолого-педагогических условий формирования культуры отношения психолога к клиенту выступают: опора на диагностику сформированности психологических компонентов культуры отношения к клиенту; введение в учебный процесс специально разработанного курса «Культура отношения к клиенту»; последовательное вовлечение студентов в различные виды деятельности (в учебную деятельность по овладению теорией и методами психологической помощи, основ психологического консультирования, культуры отношения к клиенту; квазипрофессиональную деятельность в виде тренингов, ролевых и деловых игр; учебно-профессиональную деятельность в виде практической реализации освоенных знаний и сформированных умений в ходе психолого-педагогической практики); проведение индивидуальной и групповой консультативно-коррекционной работы со студентами-психологами в рамках психологической службы ВУЗа.

Bblводы, перспективы. Реализация заявленных условий осуществлялась в работе со студентами третьего курса - будущими 
психологами, готовящимися к выходу на свою первую психологическую практику. На основе использования методов математической статистики проверена и доказана эффективность разработанной программы по формированию культуры отношения психолога к клиенту, что позволяет рекомендовать ее для внедрения в системы профессиональной подготовки и повышения квалификации психологов. Проведенное исследование не исчерпывает все стороны проблемы отношения и заслуживает дальнейшей разработки. В качестве перспективных направлений дальнейшего исследования может выступать выявление и формирование индивидуального стиля культуры отношения психолога к клиенту. Психологическая коррекция деструктивных отношений и формирование конструктивных отношений между людьми могут служить психологической профилактикой многих негативных явлений в обществе.

\section{Литература}

1. Дубовицкая Т. Д., Газизова Р. Р. Проблема отношения психолога к клиенту [Электронный ресурс] / Р. Р. Газизова, Т. Д. Дубовицкая // Современные проблемы науки и образования. 2012. - № 2. - 0,4 п.л. - Режим доступа: http://www.scienceeducation.ru/102-5869. - Название с титул. экрана.

2. Мясищев В. Н. Психология отношений / Под ред. А. А. Бодалева. - M. : Издательство «Институт практической психологии», Воронеж: НПО «МОДЭК», 1995. - 356 с.

3. Перлз Ф. Гештальт-подход и свидетель терапии [Электронный ресурс] / Ф. Перлз // Режим доступа: http://www.koob.ru. - Название с титул. экрана.

4. Роджерс К. Консультирование и психотерапия / К. Роджерс. Изд-во Института Психотерапии. - 2008. - 512 с.

5. Фрейд 3. Психоаналитические этюды / Составление Д. И. Донского, В. Ф. Круглянского. - Мн. : ООО «Попурри», 1998. $608 \mathrm{c}$.

6. Эллис А. Практика рационально-эмоциональной поведенческой терапии / А. Эллис, У. Драйден. - 2-е изд. СПб. : Издательство «Речь». - 2002. - 352 с.

Tatyana Dubovitskaya, Regina Gazizova, Varvara Dubnichenko. The formation of a culture of respect for the customer in the future psychologists at the stage of study at the University.

Introduce the concepts of "psychologist attitude to the client," "psychologist, cultural attitudes to the client." Contained cultural structure relationship psychologist to the client, which includes perceptualcommunicative, emotional, regulatory, behavioral components. We give a description of their content model and the program of building a culture 
psychologist relationship to the client, the results of their practical implementation in the work with the students - future psychologists.

Key words: attitude, psychological culture, culture relationship psychologist to the customer, empathy, communication borders.

Статья поступила в редакционную коллегию 10.03.2014

УДК 33:303.446.2:316.647.5

Срастова-Михалусь Інна Борисівна

Харківський національний економічний університет імені С. Кузнеця

\section{МІЖКУЛЬТУРНА ТОЛЕРАНТНІСТЬ ЯК ОСНОВА УСПІШНОЇ ПРОФЕСІЙНОЇ ДІЯЛЬНОСТІ ЕКОНОМІСТА}

Обтрунтовано міжкультурну толерантність як професійно значущу якість економіста, необхідну для успішного здійснення економічної діяльності. Розглянуто поняття “толерантна особистість" з точки зору економічної теорії толерантності.

Ключові слова: толерантність, міжкультурна толерантність, економічна теорія толерантності, толерантна особистість, інтолерантна особистість.

На сучасному етапі основною тенденцією розвитку суспільства $\epsilon$ процес глобалізації, для якого характерно розширення кордонів, встановлення більш тісних міжкультурних зв'язків у всіх сферах життєдіяльності людини. В умовах ринкового суспільства глобалізація особливо впливає на економічну сферу. Сучасний світ неможливо уявити без співпраці 3 іноземними партнерами, встановлення економічних зв'язків, спільного 3 іншими країнами виробництва товарів. У таких обставинах економісту для успішної реалізації завдань економічної діяльності, спрямованої на підвищення ефективності та рентабельності підприємства, необхідно наряду 3 інтересами своєї компанії враховувати комерційні інтереси партнерів по бізнесу, зважати на міжкультурні відмінності, поважати культуру країни-партнера.

Мета статті полягає в обгрунтуванні міжкультурної толерантності як професійно значущої якості фахівця з економіки для здійснення успішної економічної діяльності.

Зміни у суспільстві, які пов'язані з процесом глобалізації та розширенням міжкультурних зв'язків, необхідність показати, що толерантне ринкове суспільство $є$ більш економічно ефективним, зумовили необхідність розробки економічної теорії толерантності, авторами якої є вчені-економісти Дж. Корнео та О. Жане. Питання 
економічної ефективності толерантності розглядається також у працях Є. Сабурова, Н. Кузьміної, О. Котельникової, G. Becker, A. Bisin, T. Verdier та ін. Однак, незважаючи на значну кількість публікацій стосовно цієї проблеми, у країнах Західної Європи, США та Росії, у нашій державі це питання не отримує належної уваги.

Основна ідея економічної теорії толерантності полягає у тому, що риси характеру та стилі поведінки людини набувають символічної цінності, а система цінностей, в свою чергу, має певну корисність для суспільства. Поєднання поведінки та систем цінностей людини сприяє формуванню поваги по відношенню до індивіда. На думку авторів (Дж. Корнео та О.Жане), толерантність як повага до відмінностей забезпечує мирне співіснування різних груп, захист меншин, підтримує розвиток талантів та самореалізацію, що укріплює демократичні права людини та сприяе повному використанню ринкових можливостей суспільства [4, с. 691]. Толерантна особистість - це особистість, яка наділяє символічною значущістю не тільки власні характеристики, але й характеристики інших людей, вона має диверсифіковані цінності та сприймає факт наявності різних точок зору. Інтолерантна особистість не схвалює диверсифікацію цінностей та вважає прийнятним тільки один тип поведінки, таким чином рівень корисності такої людини знижується, тому що така особистість не здатна ефективно співпрацювати 3 людьми, які не відповідають іiі поглядам. Згідно з цією теорією, політика у суспільстві, яка сприяє розвитку толерантності, $є$ більш економічно ефективної, тому що повної мірою використовує таланти та здатності людини, не зважаючи на іï відмінності.

На думку відомого американського вченого Ф. Фукуями, ефективність економіки країн Західної Європи та США пояснюється високим рівнем довіри між суб'єктами господарювання [3, с. 20-23]. У цих країнах набагато легше зрозуміти інтереси сторін, погодитись на спільні дії та передбачити ризики. Слід зазначити, що у сучасній економіці під словом “довіра" мається на увазі здатність розуміти, поважати одне одного та забезпечувати прозорість дій. Визначені умови можна схарактеризувати одним словом - толерантність, результатом якої є довіра [2].

Наступним аргументом на підтримку прояву міжкультурної толерантності у процесі професійної діяльності економіста є той факт, що одним із найважливіших умінь фахівця економічного профілю $\epsilon$ уміння вести переговори, які створюють основу успішної співпраці в інтересах обох сторін. Належне ведення переговорів не допускає відсутність готовності поважати думку "Іншого" або інакший прояв інтолерантності, який може призвести до негативних наслідків та значних фінансових втрат. 
Таким чином, міжкультурна толерантність являє собою складний феномен, що складається із соціокультурних, політичних, психологічних та економічних елементів. Це $\epsilon$ однією із найважливіших професійно значущих якостей економіста, яка дозволяє ефективно виконувати завдання, пов'язані з підвищенням ефективності й рентабельності підприємства, розширенням міжнародних контактів на основі взаємоповаги та взаємовигоди, що сприятиме якісному зростанню ефективності економіки нашої держави.

\section{Література}

1. Кузьмина Н. Г., Котельникова О. В. Толерантность как проявление экономической свободы / Н. Г. Кузьмина // Современные исследования социальных проблем. - 2012. - № 11 (19). [Электронный pecypc]. - Режим доступа : http://cyberleninka.ru/article/n/tolerantnostkak-proyavlenie-ekonomicheskoy-svobody. - Название с титул. экрана.

2. Сабуров Е. Толерантность и мир современной экономики / Е. Сабуров // Русский журнал. - 17 февраля 2003. [Электронный pecypc]. - Режим доступа : http://old.russ.ru/ist_sovr/20030217_sabpr.html. - Название с титул. экрана.

3. Фукуяма Ф. Доверие: социальные добродетели и путь к процветанию: Пер. с англ. / Ф. Фукуяма. - М. : ООО «Издательство АСТ»: ЗАО НПП «Ермак», 2004. - 730 с.

4. Corneo Giacomo, Jeanne Olivier A theory of tolerance / G. Corneo // Journal of Public Economics. - Elsevier, 2009. - P. 691-702.

Инна Ерастова-Михалусь. Межкультурная толерантность как основа успешной профессиональной деятельности экономиста. Обоснована межкультурная толерантность как профессионально значимое качество экономиста, необходимое для успешного осуществления экономической деятельности. Рассмотрено понятие “толерантная личность" с точки зрения экономической теории толерантности.

Ключевые слова: толерантность, межкультурная толерантность, экономическая теория толерантности, толерантная личность, интолерантная личность.

Inna Yerastova-Mikhalus. Cross-cultural tolerance as a basis of the successful professional activity of an economist.

Cross-cultural tolerance as a professionally important quality of an economist, which is necessary for a successful realization of the economic activity, is grounded. The concept "tolerant personality" in terms of economic theory of tolerance is considered.

Key words: tolerance, cross-cultural tolerance, economic theory of tolerance, tolerant personality, intolerant personality.

Стаття надійшла до редакційної колегії 15.05.2014 
УДК 159.955.2:159.9.016.1]::001.12

(C) Ерохов Р. А., Ковальчук Д. В., 2014.

\section{Ерохов Роман Александрович}

Межрегиональная академия управления персоналом

Ковальчук Дарья Васильевна

Национальный педагогический университет имени М. П. Драгоманова

\section{ПОНЯТИЕ О ТЕЛЕСНОСТИ И ТЕЛЕСНЫХ ФЕНОМЕНАХ}

B cтатье представлень теоретические обоснования понятий «телесность» $и$ «телесный феномен». Раскрывается структура телесности через механизм биопсихической обратной связи. Описываются свойства телесности и ее компоненты. Аргументируется принцип появления $u$ особенности функиионирования телесного феномена.

Ключевые слова: телесность, телесный феномен, здоровье, самость, Я-кониеепияя.

Отношение к душе и телу в разные эпохи и в разных культурах было различным. Множество философов и психологов пытались в научных трудах теоретически описать и обосновать свой взгляд на сложившееся противоречие. Так, по мнению Аристотеля, « душа есть форма тела». Бихевиористы и материалисты и вовсе утверждали, что души не существует; на их взгляд, есть только непрерывная последовательность психических феноменов. Однако, не взирая на огромное количество научного материала в данном вопросе, на сегодняшний день не существует единого подхода и категориального аппарата, который бы позволил описать феномен соотношения души и тела. Попытки дать определение роли тела и души в жизни человека приводят к вопросам, связанным с понятием о телесности.

«Я - это мое тело в той мере, в которой я могу понимать его», писал М. Мерло-Понти.

Понятие «тело» обозначает материальное образование, которое можно описать в категориях формы, веса, структурности и функциональности.

Телесность есть интегральная характеристика бытия субъекта, свидетельствующая о формах его связи с миром» $[1 ; 2]$.

В телесности отражены формы отношения человека к своему телу, то есть к своему «Я» и формы, выражающие процесс взаимодействия человека с социумом. По средствам биопсихической обратной связи, которой наделена телесность, человек способен регулировать и определять для себя функции и значение тела в процессе коммуникации с социумом. 
Биопсихическая обратная связь телесности представлена непрерывной цепочкой чувственных ощущений, которые мы получаем в виде информации о том, что происходит во внешней среде и в теле, движений, совершаемых по отношению к себе и в отношении внешнего мира и, наконец, в отражении происходящего в сознании посредством наделения знаком или символом, например, словом. Когда человек способен назвать или описать в доступных для него формах то, что с ним происходит в контексте протекания внутренних процессов и внешней ситуации, он способен совершать осознанную саморегуляцию на любом уровне в биопсихической цепи.

Элементы биопсихической системы телесности настолько интегрированы, что при возникновении каких-либо изменений, например, ухудшается физическое самочувствие, система, пытаясь найти оптимальный механизм регуляции, будет задействовать все наличные компоненты. Таким образом, изменение состояния одного компонента системы телесности влечет за собой изменение всей системы по биопсихичской обратной связи. Нарушение движения влечет за собой нарушение восприятия пространства, что, в свою очередь, влияет на осознанную включенность в отношении происходящего.

Саморегуляция - свойство системы сохранять внутреннюю стабильность через непрерывный процесс коммуникации с внешней средой. Телесность, как часть целостной системы личности, наделена способностью к саморегуляции. И в тоже время телесность есть особой формой, которая отражает непрерывный процесс взаимодействия системы личности с внешней средой в каждый момент времени.

Таким образом, телесность есть интегрированная целостная саморегулирующаяся биопсихическая система, отражающая формы непрерывной коммуникации человека со средой и формы коммуникации человека с самим собой.

Обычно человек не обращает внимания на свое психофизическое состояние, которое способно саморегулироваться без активного участия сознания до того момента, пока система не дает сбой. Плохое самочувствие, тревога, болезнь, ухудшение взаимоотношений, многое другое есть наличным показателем того, что система не способна к саморегуляции, как это происходило раньше. Такая ситуация, когда система не способна к само- регуляции, а новый способ еще не найден (оптимальный для этой системы), называется «переходной» (термин П. В. Лушина). И именно в этой переходной ситуации разного рода «симптомы» есть временное, самое оптимальное решение в сложившихся обстоятельствах, которое не позволяет системе разрушиться. В этом смысле телесность выступает 
как лакмусовая бумажка, посредством которой проявляется переходная ситуация в виде «переходных состояний», продолжая диалог с внешним миром на понятном для системы языке. Опираясь на наше определение понятия «телесность», можно предположить, что переходные состояния относятся к кризису в отношении человека к самому себе и в отношении к миру в форме телесных проявлений или «телесных феноменов».

Мы воспринимаем события на когнитивном уровне в виде ментальных представлений через систему своих убеждений и ценностей. Центральным образованием, которое интегрирует систему представлений и убеждений человека о себе и мире есть «Я». Тело есть форма «Я», то есть в процессе взаимодействия с миром и самим собой «Я» через сложившуюся умозрительную картину определяет характер этих отношений, влияя на телесность как биопсихическую систему. Таким образом, происходит самоопределение в системе и, как результат, система генерирует особую форму как ответ на сложившиеся обстоятельства - телесный феномен.

Телесный феномен есть уникальное явление, продукт взаимодействия единоличной, неповторимой системы личности с внешней средой в попытке найти механизм саморегуляции в изменяющихся, непривычных условиях.

Телесный феномен - это уникальная реакция тела на не стандартную ситуацию, возникающую при активном участии «Я». Одни и те же телесные реакции, как объективно наблюдаемые изменения в теле, могут нести за собой абсолютно иной опыт и значение для субъекта. Вписываясь в систему личности и порождаясь ею, телесный феномен наделен всеми свойствами целостной системы и выражает всю своеобразность и неповторимость внутреннего пространства человека.

Если в нашем преставлении ситуация расценивается как угрожающая, на телесном уровне срабатывает механизм защиты, сжимая переднюю поверхность тела, например, рефлекс «Красного света» Т. Ханни. В такой ситуации, когда система не способна к саморегуляции, то есть, автоматические реакции включаются непроизвольно, безконтрольно и неадекватно предъявляемым стимулам, происходит попытка найти способ разрешить ситуацию, устранить «переходное состояние» (зажимы, болезни, раздражительность) с помощью контроля «Я». Человек начинает задавать себе вопросы, пытаясь разобраться, что с ним происходит и почему. Самым простым способом решения проблем, особенно тех, которые связаны с телесными проявлениями (плохое самочувствие, болезни, телесные деформации), есть физическое устранение (таблетки, хирургия). Устранение симптома не разрешит сложившийся 
конфликт, т. к. по-прежнему система не нашла новый способ саморегуляции в сложившихся условиях, а значит возникнет новый механизм в системе телесности для поддержания переходного состояния до «лучших времен».

На наш взгляд, одной из черт, свидетельствующих об уникальности человека, это его одновременное пребывание в позиции объекта и субъекта. Для врачей и других специалистов человек есть объект, биологическое тело, в котором они усматривают те или иные патологии. Но никто, кроме самого человека, не может чувствовать и знать, что происходит изнутри. Таким образом, субъектом человек становится для самого себя через проживание и преобразование своего телесно-душевного бытия.

Особенности проживания человеком своего внутреннего мира отражаются в формах телесных проявлений и определяют возникновение телесных феноменов как уникальных реакций на уровне тела и психики в противовес телесным реакциям, которые воспринимаются другими и зачастую мгновенно интерпретируются.

Таким образом, если человек относится к себе как к объекту, пытаясь устранить или избавиться от телесных проявлений, вызывающих дискомфорт, он отчуждается от самого себя, отдаляется от своей самости. Его система теряет естественную целостность, и ей становится чрезвычайно сложно найти способ саморегуляции. Старый механизм изжил себя и адекватно не удовлетворяет условий наличной ситуации, а новый возможно выстроить, опираясь на собственный опыт телесно-душевного бытия, который и есть уникальным ключом к своей системе, основой, на которой система генерирует телесные феномены. В итоге человек страдает душевно и телесно, находясь в бесконечном поиске нового способа саморегуляции, все дальше отдаляясь от своей истинной сущности.

Игнорируя опыт, приобретенный через тело, в том числе игнорируя телесный феномен как важный элемент системы, человек строит ложные представления о себе и мире, потому что такой опыт не подкреплен практическим испытанием, реальностью.

Такое знание «не работает» точно так, как и все получаемые рецепты врачей и советы терапевтов, потому что получаемая информация извне остается частью иной системы и не имеет отношения к субъективному пространству человека.

Из этого можно сделать вывод об уникальности приобретенного телесно-душевного опыта человеком в процессе его жизни и о том исключительном значении этого истинного знания, которое по сути и есть ресурсом для преодоления «переходных состояний» в системе телесности и ключом в интерпретации телесных феноменов. По своей 


\section{Збірник наукових статей}

сути разворачиваемый процесс есть показателем развития и перехода на качественно иной уровень в самопознании

Таким образом, мы приходим к выводу о том, что телесность есть открытая, целостная, интегральная, саморегулирующая система, которая разворачивается как процесс в непрерывном диалоге человека с внешним миром и своим внутренним бытием и как форма в виде телесных реакций и телесных феноменов.

Телесный феномен - форма реакции системы личности на телесном уровне, особенности протекания которой обусловлены своеобразием внутреннего бытия человека и значение которой определяется наличным опытом, приобретенном в процессе взаимодействия человека с внешним и своим внутренним миром.

\section{Литература}

1. Никитин В. Н. Онтология тилесности: Смислы, парадокси, абсурд / В. Н. Никитин. - М. : Когито-Центр, 2006. - 320 с.

2. Нікітін В. Н. Психология телесного сознания / В. Н. Нікітін. M., 1998.

3. Cash T. F. (2012). Cognitive-behavioral perspectives on body image. In T. F. Cash (Ed.), Encyclopedia of Body Image and Human Appearance (pp. 334-342). London, UK, and San Diego, CA: Academic Press (Elsevier).

4. Cash T. F. (2004). Body Image: Past, present and future (editional). Body Image: An international Journal of Research, 1, 1. - 5. Provides the editors perspective on the field for the journals inaugural issue, which includes nine review articles on core topics about body image.

5. Elone J., Sedory J. (2005). Diagnostic Criteria foe Body Dysmorphic Disorder and Muscle Dismorphic Disorder. Journal of Athletic Training, 40 (4). - C. 352- 359.

6. Fisher S. (1990). The evolution of psychological concepts about the body. In T. F. Cash \& Pruzinsky (Eds), Body Image: Deveopment, deviance and change (p. 3-20). - New York: Guilford Press. - An excellent historical view of the body image construct from an influential scholar in the field.

7. Grogan S. (2008). Body image: Understanding body dissatisfaction in men, women and children $\left(2^{\text {nd }}\right.$ ed.). East Sussex, UK : Routledge. - Offers an extensive and detailed overview of the field.

8. Shontz F. C. (1990). Body image and physical disability. In T. F. Cash\& T. Pruzinsky (Eds), Body images: Development, deviance, and changes (p. 149-169). - New York: Guilford Press. - Summarizes the history of body image concepts and their applications to physical disabiities. 
Роман Єрохов, Дарія Ковальчук. Поняття про тілесності і тілесних феноменах.

В статті представлені теоретичні обгрунтування понять «тілесність» та «тілесний феномен». Розкривається структура тілесності через механізм біопсихічного зворотнього зв'язку. Подається описання властивостей тілесності $i$ ï компонентів. Аргументується принции появи $i$ особливості функціонування тілесного феномену.

Ключові слова: тілесність, тілесний феномен, здоровіє, замість, ЯКониепиія.

Roman Erohov, Daria Kovalchuk. The concept of telesnosty and telesnыh phenomena.

In this paper, the theoretical underpinnings of the "corporeality" concepts and "bodily phenomenon" are presents. Disclosed corporeality structure through the mechanism of biopsychic feedback. The properties of corporeality and its components. Argued the principle of appearance and features of the functioning of bodily phenomenon.

Key words: corporeality, bodily phenomenon, health, Self.

Статья поступила в редакционную коллегию 07.05.2014

УДК 81'243:004

(С) Євдокімова-Лисогор Л. А., 2014.

Свдокімова-Лисогор Леся Анатоліївна

Харківський національний економічний університет імені С. Кузнеця

\section{ВИКОРИСТАННЯ ЗАСОБІВ СУЧАСНИХ ІНФОРМАЦЙНО- КОМУНІКАЦІЙНИХ ТЕХНОЛОГІЙ У ПРОЦЕСІ ВИВЧЕННЯ ІНОЗЕМНОЇ МОВИ}

У статті розглянуто використання сучасних інформаційнокомунікаиійних технологій (IКT) під час викладання іноземної мови. Охарактеризовано напрямки використання IКT у процесі викладання іноземної мови у вищих навчальних закладах України.

Ключові слова: сучасні інформаційні технології, інформачійнокомунікачійні технології, мультимедійні засоби навчання, комп 'ютерні навчальні програми, глобальна мережа Інтернет.

Інформатизація істотно вплинула на процес придбання знань. Розвиток комп'ютерних технологій, особливо Інтернет-технологій, дає потужний імпульс розвитку всього людства. Усвідомлюючи цей факт викладач прагне активно використовувати нові технічні досягнення в навчальних цілях. Нові технології навчання на основі інформаційно- 


\section{Збірник наукових статей}

комунікаційних дозволяють збільшити швидкість сприймання, розуміння та глибину засвоєння знань. Інформаційна технологія виступає як система, складовими якої $\epsilon$ учасники педагогічного процесу (викладачі й студенти) та система теорій, ідей, засобів і методів організації навчальної діяльності для ефективної міжкультурної комунікації, що охоплює усі аспекти засвоєння знань i формування практичних навичок, а інформаційні технології спонукають до постійної самоосвіти, більш того процес навчання дає можливість відчути практичні результати. Можна визначити, що ІКТ це сукупність різноманітних технологічних інструментів і ресурсів, які використовуються для забезпечення процесу комунікації, а також створення, розповсюдження, збереження та управління інформацією.

Ряд сучасних наукових досліджень присвячено вивченню особливостей використання ІКТ в освіті. Наукові праці В. Олійника направлені теоретико-методологічним основам дистанційної освіти дорослих, В. Кухаренка - теоретичним та методичним засадам дистанційного навчання у ВНЗ, досліджував у своїх працях В. Редько. Проблеми використання IКТ в освіти розглядали також В. Бикова, М. Жалдака, С. Ракова, Л. Калиндрузь, В. Анака, О. Войченко, А. Солопо, В. Базурін, І. Закомірний, В. Іштуків, Л. Ястребов.

Інформаційні технології найбільше задіяні під час міжкультурної комунікації, що $є$ середовищем взаємодії двох або декількох комунікаційних партнерів, які належать до різних культур, причому інша культура пізнається за допомогою образів рідної культури та усвідомлюється і переосмислюється в процесі пізнання чужої культури за допомогою Інтернет-ресурсів. При цьому сам процес комунікації $\epsilon$ передумовою для виникнення діалогу культур у свідомості окремого індивіда. Для здійснення міжкультурної комунікації студенти повинні оволодіти міжкультурною комунікативною компетентністю, яка передбачає засвоєння: етнографічної інформації, відбиває найбільш значущі історичні події, відомості про загальні національні особливості країни, відомих особистостей та ін.

Викладання іноземної мови за допомогою інформаційнотехнічних засобів визначається такими цілями: сприяти підвищенню ефективності навчального процесу; забезпечувати негайне і постійне підкріплення правильності навчальних дій кожного студента; підвищувати усвідомленість та інтерес до вивчення мови; забезпечувати оперативний зворотний зв'язок i поопераційний контроль дій всіх студентів; створювати можливість швидкого застосування відповідей без довготривалого їх кодування.

Досить багато уваги приділяється питанням, що стосуються критеріїв визначення доцільності використання IКТ для вирішення 
комунікативних та дидактичних завдань на занятті з іноземної мови в цілому, окремих його етапів, впливу використання IКТ на підвищення інтересу, мотивації студентів до навчальної діяльності.

Ефективність застосування нових інформаційних технологій на заняттях обумовлена наступними факторами: різноманітність форм представлення інформації; висока ступінь наочності; моделювання за допомогою комп'ютера різноманітних об'єктів і процесів; організація колективної та індивідуальної дослідницької роботи; можливість диференціювати роботу студентів в залежності від рівня підготовки, пізнавальних інтересів та ін., використовуючи сучасні інформаційні технології; організувати комп'ютерний оперативний контроль і допомогу 3 боку викладача; можливості комп'ютера дозволяють студенту активно брати участь у процесі пізнання.

У практичній діяльності ІКТ безпосередньо використовуються на різних етапах підготовки та проведення заняття іспанської мови. В узагальненому вигляді дані щодо використання програмних засобів, надбудов для використання в Microsoft Word (макросів), тестових оболонок подано у таблиці 1.

Таблицяя 1.

Використання програм при підготовці та проведенні занять з іспанської мови

\begin{tabular}{|c|c|c|}
\hline Етап заняття & Мета етапу & Програмні засоби \\
\hline Організаційний & $\begin{array}{l}\text { мобілізувати студентів до } \\
\text { навчання; активізувати їхю увагу; } \\
\text { створити робочу атмосферу для } \\
\text { проведення заняття. }\end{array}$ & $\begin{array}{l}\text { Презентація Power Point, } \\
\text { Podcast }\end{array}$ \\
\hline $\begin{array}{l}\text { Мотиваційно- } \\
\text { стимулюючий }\end{array}$ & $\begin{array}{l}\text { формування потреби та навчання } \\
\text { мотивації вивчення конкретного } \\
\text { навчального матеріалу. }\end{array}$ & $\begin{array}{l}\text { Power Point, Podcast, } \\
\text { Youtube, Slideshare }\end{array}$ \\
\hline $\begin{array}{l}\text { Обговорення } \\
\text { проблем, винесених } \\
\text { на заняття }\end{array}$ & $\begin{array}{l}\text { обговорення і керування процесом } \\
\text { розгляду основних сюжетів заняття } \\
\text { відповідно до обраного виду і } \\
\text { методики його проведення. }\end{array}$ & Podcast, Youtube, Flickr \\
\hline $\begin{array}{l}\text { Діагностика } \\
\text { правильності } \\
\text { засвоєння } \\
\text { студентами знань }\end{array}$ & $\begin{array}{l}\text { з'ясування причин нерозуміння } \\
\text { певного елементу змісту } \\
\text { навчальної інформації, невміння чи } \\
\text { помилковості виконання } \\
\text { інтелектуальної або практичної дії. }\end{array}$ & $\begin{array}{l}\text { Blogger, Wiki, } \\
\text { Bookmarks, Hot Potatoes, } \\
\text { Glogster }\end{array}$ \\
\hline $\begin{array}{l}\text { Підведення } \\
\text { підсумків }\end{array}$ & $\begin{array}{l}\text { повідомлення у стислій формі про } \\
\text { виконання запланованої мети, } \\
\text { завдань заняття. }\end{array}$ & Power Point, Slideshare \\
\hline $\begin{array}{l}\text { Організація } \\
\text { позаадиторної } \\
\text { самостійної роботи } \\
\text { студентів }\end{array}$ & $\begin{array}{l}\text { пояснення щодо змісту завдання, } \\
\text { методики його виконання, джерел } \\
\text { інформації, пропозиції щодо } \\
\text { виконання індивідуальних завдань }\end{array}$ & Power Point \\
\hline
\end{tabular}


Як видно з представленої таблиці, використання ІКТ можливе на будь-якому етапі заняття. Вибір конкретного засобу залежить щонайменше від таких факторів: технічне забезпечення навчальновиховного процесу в конкретному закладі освіти; рівень підготовки викладача і студентів до використання ІКТ; стабільність роботи програми, збереження результатів діяльності студентів та викладача.

Аналіз досвіду дозволив виявити такі труднощі: використання IКТ у системі навчальної роботи на заняттях з іноземної мови потребує від викладача значних витрат часу в порівнянні 3 традиційним заняттям; вибір технічних засобів ускладнюється відсутністю науково обгрунтованого комплексного аналізу їх використання та відповідних методичних рекомендацій.

Використання мультимедійних засобів у навчанні передбачає основні напрямки реалізації педагогічної діяльності, які можна розподілити відповідно до ролі студентів при проектуванні та створенні комп'ютерних засобів навчання. До першої групи слід віднести ті освітні продукти, які розробляються викладачем для подання змісту навчального матеріалу, при роботі з ними студентам надається лише пасивна роль отримувача навчальної інформації. До другої групи належать інтерактивні освітні засоби, оскільки вони передбачають активну роль студента, який при їх використанні самостійно обирає розділи в рамках навчальної теми, визначаючи послідовність їх вивчення.

Загальновідомо, що сприятливим середовищем для оволодіння мовою $є$ сприятливим середовище країни мова, якої вивчається. Завдяки Інтернету та комп'ютерним технологіям, стало можливим створення штучної мовного середовища. Кожен викладач прагне зацікавити студентів, створюючи на заняттях web-квести, інтерактивні плакати Glogster та ін. На основі власного досвіду, сучасним студентам набагато цікавіше попрацювати в мережі Інтернет, вирішуючи поставлені перед ними завдання, ніж вивчати іноземну мову більш традиційними способами. Викладач має розвиватися та передавати свої знання студентам у нових Інтернетформатах, застосовувати візуалізовані засоби представлення інформації в електронній формі; збирати інформацію, отриману з різних джерел ретельно перевіряти та застосовувати іiї на своїх заняттях. Для цього викладач використовує можливості комп'ютерних мереж, які забезпечують користування засобами обміну інформацією і колективного використання апаратних, програмних та інформаційних ресурсів [1].

Найефективнішими 3 огляду на розвиток навичок мислення, пізнавальної діяльності студентів та навичок самостійної дослідницької діяльності є засоби, які проектуються та розробляються самими студентами при вивченні навчального матеріалу. Презентація $\epsilon$ 
творчою роботою студентів. Студентські мультимедійні презентації доцільно використовувати як для представлення порівняння результатів проведених досліджень, проектів, самостійної роботи, так і для виконання випереджуючих завдань як засіб ознайомлення 3 новою інформацією. За кількістю студентів, які планують, проектують, розробляють, демонструють презентації можна розглядати презентації: індивідуальні - розробляються і створюються одним студентом; групові - розробляються і створюються малою групою студентів, або які створено всією групою.

Впровадження та застосування комп'ютерних навчальних програм на заняттях іноземної мови це: ефективний допоміжний технічний наочно-слуховий засіб; допоміжний засіб пізнавальної діяльності студентів; засіб підвищення мотивації та бажання вивчати мову; швидкий та ефективний засіб оцінювання та контролю знань, вмінь та навичок; засіб підвищення інтерактивної та комунікаційної діяльності Тож, застосування на заняттях комп'ютерних навчальних програм - це досить ефективний та доцільний засіб у навчанні студентів іноземної мови, спрямований на розвиток комунікаційних здібностей школярів. Крім цього використання комп'ютерних технологій у викладанні іноземної мови дозволяє відійти від традиційних форм навчання й підвищити індивідуалізацію навчальної діяльності студентів, оптимізувати засвоєння мовних структур та граматичних правил, а також подолати монотонність заняття при формуванні мовленнєвої та комунікаційної компетенції студентів при навчанні іноземній мові. Використання IKT надають можливість скористатися перевагами сьогодення та позитивно впливають на вивчення іноземної мови.

\section{Література}

1. Волкова Н. П. Професійно-педагогічна комунікація: навч. посіб. / Н. П. Волкова. - К., 2006. - 256 с.

2. Ястребов Л. Й. Создание мультимедийных презентаций в программе Microsoft Power Point, Вопросы Интернет-образования, № 41 [Электронный ресурс]. - Режим доступа : http://vio.fio.ru/vio_41/cd_site/Articles/glava-00/02.htm. . - Название с титул. экрана.

Леся Евдокимова-Лысогор. Использование средств современных информационно-коммуникационных технологий в процессе изучения иностранного языка.

В статье рассмотрено использование современных информационнокоммуникационных технологий (ИКТ) во время преподавания иностранного языка. Охарактеризованы направления использования ИКТ в прочессе преподавания иностранного языка в высших учебных заведениях Украины. 
Збірник наукових статей

Ключевые слова: современные информачионные технологии, информационно-коммуникационные технологии, мультимедийные средства обучения, компьютерные обучающие программы, глобальная сеть Интернет.

Lesya Yevdokimova-Lisohor. The use of contemporary informative-communicational means of technologies in the process of studying foreign language.

The employment of modern information and communication technologies in the process of teaching foreign language is considered in the article. The ways of wing of establishments of Ukraine are characterized.

Key words: modern information technologies, information and communication technologies, multimedia teaching aids, computer syllabi, internet.

Стаття надійшла до редакційної колегії 15.05.2014

УДК 008-024.63:316.28]::316.772.2-045.7-04:376-054.62

(С) Заваруева И. И., 2014.

Заваруева Инна Ивановна

Днепропетровский национальний университет железнодорожного транспорта имени академика В. Лазаряна

\section{МЕЖКУЛЬТУРНАЯ КОММУНИКАЦИЯ И ИСПОЛЬЗОВАНИЕ НЕВЕРБАЛЬНЫХ СРЕДСТВ В ПРОЦЕССЕ ОБУЧЕНИЯ СТУДЕНТОВ ИНОСТРАНЦЕВ}

В статье рассматривается проблема использования невербальных компонентов в преподавании русского языка как иностранного, анализируются особенности невербальных средств коммуникации, служащих для создания, передачи и восприятия сообщений $в$ межкультурной коммуникации.

Ключевые слова: невербальные средства коммуникации, коммуникация культур, языковая и концептуальная картина мира, семантика невербальних средств общения.

На страницах научной литературы большое внимание уделяется проблеме межкультурного общения в профессиональнопедагогической деятельности. Одним из аспектов данного направления является изучение невербальных средств общения, которые играют существенную роль в процессе межкультурного взаимодействия, поскольку известно, что различные средства невербального общения (жест, мимика, поза, взгляд, дистанция) оказываются в некоторых случаях более выразительными и действенными, чем слова. В 
современном языкознании, культурологии, в методике преподавания иностранных языков межкультурная коммуникация является объектом пристального внимания ученых. Среди работ в области коммуникации культур следует назвать труды Е. Верещагина, И. Игнатовой, В. Костомарова, О. Митрофановаой, В. Фурманова, М. Бахтина, С. Тер-Минасовой, И. Афанасьевой, А. Бусыгина, А. Грекова и другие.

По мнению С. Тер-Минасовой, в основе любой коммуникации лежит „обоюдный код”, обоюдное знание реалий, знание предмета коммуникации между участниками общения [5], поэтому изучение и преподавание иностранного языка должно осуществляться в тесной связи с миром носителей изучаемого языка, в неразрывном единстве с культурами народов, использующих эти языки в качестве средства общения. Только таким образом можно обеспечить изучающим иностранные языки необходимые фоновые знания, без которых невозможно реальное общение. В каждой стране люди общаются поразному: в соответствии со своими обычаями, традициями, менталитетом. В процессе общения важная роль принадлежит культуре общения, к которой относится не только форма речи, но и её невербальная составляющая (телодвижения, мимика, жесты и т.п.). Невербальные компоненты есть важнейшими составляющими коммуникации, поскольку именно они выступают важнейшими носителями значений сообщения. Чаще всего невербальная передача происходит одновременно с вербальной и может или усиливать, или изменять содержание слов. По мнению психологов 60-80\% коммуникации происходит за счет невербальных средств и только 40$20 \%$ - за счет вербальных. Это мнение подтверждается и исследованиями ученных в области коммуникации культур, по данным приведенным в книге С. Тер-Минасовой „Война и мир языков и культур", общение состоит с: 7\% собственно вербальных средств, 38\% фонетического оформления языка, 55\% невербальных средств [4, c. 93].

Существенный вклад в проблему изучения невербального общения внесли отечественные и зарубежные ученные А. Пиз, М. Коццолино, Т. Николаева, Б. Успенский, В. Морозов.

Актуальность темы данной работы обусловлена потребностями коммуникативно-деятельностной методики преподавания русского языка как иностранного. Цель исследования заключается в комплексной лингвострановедческой интерпретации невербальных средств коммуникации. Важность для методики преподавания РКИ представляют проблемы, связанные с изучением языковой и концептуальной картины мира русского человека, познанием через язык аксиологии, эмоциональной и этической сфер русских. Все это позволяет приблизиться к пониманию русского народа, способствует 
более успешной межкультурной коммуникации, формирует особое отношение к культуре страны изучаемого языка.

Иностранный студент, впервые оказавшийся в новой социокультурной среде, ещё не зная языка, может инстинктивно (на уровне жестов и мимики) воспринимать определенную информацию. Нередко мимика или жест воздействуют на адресата сильнее всяких слов - побуждают к действию или, наоборот, к релаксации. Жест сообщает то, что находится между строк и делает общение более полным и ярким.

Одним из важнейших качеств педагога является его умение организовать взаимодействие с учащимися не только вербально, но и невербальными средствами. При организации обучения русскому языку иностранных учащихся следует учитывать, что речевые жесты национально и социально обусловлены: у разных народов разные жесты служат для выражения одного чувства, а одно и то же движение руки может обозначать разное - от гнева до изумления; жест, принятый в определенной социальной среде, может вызвать осуждение или непонимание в других коллективах. Учет этого фактора имеет значение и для правильной организации общения преподавателя с иностранными студентами, а также является неотъемлемым компонентом овладения русским языком иностранными студентами. Таким образом, во избежание недоразумений параллельно с другими аспектами русского языка, необходимо знакомить иностранных учащихся с характерными для русских жестами и мимикой. При включении национальнокультурного компонента в содержание обучения иностранному языку нужны адекватные средства для его усвоения. Такими средствами могут быть, прежде всего, аутентичные материалы: литературные и музыкальные произведения, предметы реальной действительности и их иллюстративные изображения, которые больше всего могут приблизить учащегося к естественной инокультурной среде. Нет сомнения, что бессловесный язык позы, жеста, взгляда, пространственной композиции живописного полотна и кинокадра еще недостаточно изучен. Благодаря исследованиям в области семиотики, социолингвистики и теории коммуникации вопросы изучения жестового языка привлекают внимание ученых. Конечно, преподавателю русского языка как иностранного необходимо учитывать, что существуют национальные различия в использовании жестов. В иностранной аудитории особенно важно как понимание преподавателем жестов, используемых учащимися, так и использование невербальных средств преподавателем, адекватно воспринимаемых аудиторией. При межнациональном общении становятся особенно значимыми вопросы семантики жестов. Ошибки в 
интерпретации происходят в основном при формальном их совпадении: сходному жесту придается то значение, которым он обладает в своей культуре (хрестоматийный пример неверного истолкования при формальном совпадении жестов - противоположное движение головой при утверждении и отрицании у русских и болгар; в немецком и украинском коммуникативном поведении существует различие, когда немец начинает считать, то согнутые пальцы левой руки разгибают пальцами правой руки, начиная с большого пальца, у нас наоборот, пальцы сгибают начиная с мизинца). Преподавателю следует также помнить и о том, что в иностранном коммуникативном поведении есть жесты, отсутствующие в родном языке (например, жест постукивания косточками пальцев по столу, выражающий одобрение и удовлетворение от удачно прочитанной лекции или доклада на конференции). Неглубокое проникновение в среду изучаемого языка приводит к ошибкам, комическим ситуациям. Различают общие нормы жестикуляции, принятые у разных народов (от сдержанной у северян до темпераментной у южан), некоторые специфические различия в жестовом словаре имеют социальные, профессиональные и конфессиональные группы. Все эти факты должны учитываться преподавателями на занятиях. Знание жестовых словарей иностранных студентов позволит преподавателю получать обратную связь при подаче материала и по ходу занятия корректировать подаваемую информацию. Но, тем не менее, не зная языка другой страны, он может объясниться с иностранными студентами именно с помощью жестов. Значит, существуют какие-то общие правила их применения и расшифровки. Каждому, например, понятно, что поднятая рука означает призыв к вниманию, хлопанье в ладоши - одобрение, кивок головой - согласие, угрожающее потрясание кулаком - гнев, пожимание плечами - отсутствие интереса, пассивность, зевок - скуку, движение рукой ладонью к себе - просьбу подойти и т.д.

Из-за недостаточного владения лексикой, иностранные студенты, впервые оказавшиеся в новой социальной среде, испытывают чувство тревоги, беспокойства, связанные с рядом психологических причин, о которых они не всегда могут рассказать преподавателю. Красноречивее слов будут их жесты. Нужно только уметь замечать посылаемые сигналы. Внимательный преподаватель по жестикуляции студентов может определить их эмоциональное состояние. Каждая эмоция по-особому влияет на телодвижения, замедляя или ускоряя их. Например, радость, приподнятое настроение делают движения быстрыми, экспансивными, ритмичными, выразительными. При депрессии, наоборот, движения человека становятся медленными, нерешительными, приступ гнева проявляется 


\section{Збірник наукових статей}

в задержке дыхания и смыкания губ. Различными способами могут также выражаться недовольство, досада или отвращение. Наличие подобных жестов и телодвижений у студента свидетельствует о возникновении перед ним психологических барьеров.

Неправильная интерпретация совершенно безобидных жестов иногда приводит к печальным недоразумениям. Преподавателю русского языка как иностранного необходимо это учитывать и выработать свою определённую стратегию и тактику, которая поможет снять психологические трудности, создать условия, при которых студенты будут чувствовать себя психологически комфортно в инокультурном окружении. Знание культурно-обусловленных сценариев поведения (норма, которой носители языка, принадлежащие к определенной культуре, обычно руководствуются при коммуникации) [1] дает возможность расшифровать увиденное и услышанное, помогает понять окружающих. В отсутствие невербальных средств общения процесс коммуникации оказывается неполноценным.

Таким образом, следует сказать о том, что невербальная коммуникация имеет огромное значение в кросс-культурных отношениях. Изучая иностранный язык, необходимо учить и его безмолвный вариант. Правильно читая язык тела и пользуясь им, общение между представителями разных культур может быть успешным и плодотворным. Лингво-культурологический аспект при изучении иностранного языка предусматривает выделение языковых единиц и знаков, имеющих особенности вербального и невербального оформления в родном и изучаемом языке, этичные нормы общения, которые отражают менталитет данной культурно-языковой общности, позволяют оформить высказывание адекватно конкретной ситуации. И тогда понимание будет везде: и на улицах Лондона, и на Ближнем и Дальнем Востоке.

Итак, используя невербальные средства общения, преподаватель повышает эффективность учебного процесса, создаёт положительный тонус общения, устанавливает и сохраняет контакт, влияет на речевую активность учащихся, способствует запоминанию учебного материала.

\section{Литература}

1. Вежбицкая А. Язык. Культура. Познание / Анна Вежбицкая. M., 1996. - C. 291-325.

2. Морозов В. Искусство и наука общения: невербальная коммуникация / В. Морозов; [под ред.В.И. Медведева]. - М. : ИПРАН, 1998. - 164 с.

3. Николаева Т. Языкознание и паралингвистика / Т. Николаева, Б. Успенский // Лингвистические исследования по общей и славянской типологии. - М. : Наука, 1966. - С. 63-65. 
4. Пиз А. Язык жестов: как читать мысли других людей по их жестам / Алан Пиз. - М. : Ай-Кью, 1995. - 257 с.

5. Тер-Минасова С. Война и мир языков и культур / С. ТерМинасова. - М. : Астрель. Хранитель, 2007. - 286 с.

6. Тер-Минасова С. Язык и межкультурная коммуникация (Учебное пособие) / С. Тер-Минасова. - М. : Слово/Slovo, 2000. 264 c.

Інна Заварусва. Міжкультурна комунікація і використання невербальних засобів в процесі навчання іноземних студентів.

В статті досліджується проблема використання невербальних компонентів при викладанні російської (украӥнської) мови як іноземної дається аналіз особливостей деяких невербальних засобів комунікації, щзо слугують для створення, передання та сприйняття повідомлень у міжкультурній комуникацї.

Ключовые слова: невербальні засоби комунікації, комунікація культур, мовна $і$ концептуальна картина світу, семантика невербальних засобів спілкування.

Inna Zavaruyva. Intercultural communication and the use of non-verbal means in learning foreign students.

The problem ofthe use ofnon-verbalcomponentsin teachingRussianas a foreign language, analyzes the features ofnon-verbal communicationthat are used tocreate, sendmessagesand perceptionsincrossculturalcommunication.

Key words: nonverbal communication, communication culture, language andconceptualpicture of the world, the semantics of nonverbalcommunication.

Статья поступила в редакционную коллегию 09.04.2014

УДК 159.9.954

(C) Заика E. B., 2014.

Заика Евгений Валентинович

Харьковский национальный университет имени В. Н. Каразина.

\section{ТРЕНИНГ МЫШЛЕНИЯ: ПОИСК ОСНОВАНИЙ ДЛЯ КЛАССИФИКАЦИИ СЛОВ НА ГРУППЫ}

В русле разрабатьваемого автором игрового тренинга познавательных процессов предложен комплекс упражнений для развития логического мышления. Упражнения базируются на поиске оснований (причин, признаков), по которым некоторая совокупность объектов уже разделена на две или более групп. Используется 


\section{Збірник наукових статей}

материал как словесный, так и образный. Рассчитано на школьников 12-19 лет.

Ключевые слова: логическое мынление, игровой тренинг познавательных процессов, разделение объектов на группы.

Для развития мышления учащихся в рамках игрового коллективного тренинга познавательных процессов предложено немало как целостных комплексов, так и отдельных игр и упражнений [3]. Многие из них либо основаны, либо включают в себя такие операции и приемы мышления, как установление причинноследственных связей, классификация, поиск общих и различных признаков, пересечение признаков, исключение лишнего объекта и др.; при этом акценты делаются на работу как со стандартными, так и нестандартными признаками и на поиск как одного-единственного верного ответа, так и принципиальной множественности возможных решений. Однако этих упражнений явно не достаточно (с учетом сложности и разнообразия проявлений мышления, возрастных особенностей учащихся, сложившихся их тематических интересов и т.П.).

В связи с этим ощущается необходимость создания и использования новых вариантов тренинга мышления, в особенности основанных не столько на развитии отдельных интеллектуальных операций или даже их сочетаний, сколько на формировании целостных их сочетаний, их синтетических «сгустках». Это требует нахождения или построения некоторых весьма ёмких в этом плане заданий и ситуаций, разрешение которых предполагало бы включение и активизацию таких «сплавов» мыслительных операций (некоторые задачи такого рода представлены в [2]). Задание по поиску оснований для разделения объектов на группы и выступают, с нашей точки зрения, одним из вариантов таких емких ситуаций и являются чрезвычайно перспективными для развития различных аспектов мышления учащихся.

Цель статьи - описать входящие в интеллектуальный тренинг различные игры и упражнения, базирующиеся на поиске оснований (критериев) разделения объектов на группы. В плане научной преемственности статья продолжает наши предыдущее разработки [35] и в данном случае основывается на представлениях о структуре и функциях мышления, описанных в литературе [2].

Ситуация поиска оснований для разделения объектов на группы в некотором смысле противоположна хорошо известным процедурам классификации и группировки объектов. Предположим, ряд объектов разделили, в простейшем случае, на две группы, используя для этого некоторый неявный, неочевидный признак, обычно замаскированный 
несколькими другими, более яркими признаками. Теперь, имея разделённость на группы как факт, нужно найти тот или те признаки, которые использовались для этого разделения.

Предположим, имевшиеся у нас десять треугольников мы делим на две группы по признаку наличия или отсутствия тупого угла (в одну группу - треугольные, в другую - иные: остро- и прямоугольные). При этом треугольники различаются ещё и по ряду других, маскирующих признаков: размеру (большие - малые), положению (вверх вершиной или стороной), цветом (красные - зеленые), наличием или отсутствием элементов внутри фигуры (с точкой внутри - без точки). Теперь, глядя на имеющиеся две группы нужно четко выделить искомый признак (тупоугольность), «пробившись» к нему сквозь «туман» маскирующих его несущественных для данной разбивки признаков.

В такой процесс поиска активно включается цельй ряд мыслительных операций: сравнение (нахождение общих признаков внутри каждой группы и различных между группами), обобщение (объединение нескольких объектов по общим для них признакам), абстрагирование (отвлечение от второстепенных, несущественных признаков), а также: анализ, синтез, противопоставление, разделение признаков на существенные и несущественные и т.п. Кроме того эти комплексы мыслительных операций «прокручиваются» многократно, что связано с последовательными циклами «выдвижение гипотезы - её проверка».

Для этого с необходимостью активизируются и процессы внимания (его нужно концертировать, распределять, переключать и т.п.), памяти (надо удерживать в голове рассматриваемые признаки, а также использовать результаты предшествующих действий для организации последующих), воображения (надо перебирать в качестве гипотез любые мыслимые признаки, привлечение которых способствовало бы нахождению ответа).

Предлагаемые в нашем тренинге задания на поиск оснований для разделения объектов чрезвычайно разнообразны. Их можно расклассифицировать так:

1) по используемому материалу (объектам): вербальный (на карточках напечатаны слова) - образный (рисунки); в свою очередь в вербальном материале используются либо единичные слова (и тогда надо ориентироваться на представленные в них понятия о предметах или явлениях: живое - неживое, округлое - продолговатое, или особенности словесной формы: местоположение ударения, иностранные - русские), либо целостные предложения; в образном материале используются либо рисунки объектов (дом, дерево, корова), либо абстрактные фигуры (треугольники, эллипсы с линиями внутри, медузоподобные формы и т.д.); 


\section{Збірник наукових статей}

2) по типу группировки: простая (например, все объекты делятся на живые и неживые или на крупные и мелкие) иерархическая (после первого такого разделения объекты продолжают делиться и далее, например, живые - на растения и животные; неживые - на природные и рукотворные; а затем, в свою очередь, например, животные делятся на пресмыкающихся и млекопитающих);

3) по количеству выделяемых групп: обычно две (как в приведенных выше примерах), но может быть и три-четыре (например фигуры типа треугольника, многоугольника или эллипсоидной формы; или с внутренней штриховкой вертикальной, горизонтальной и косой);

4) с изначально заданным набором объектов (например, имеется по три объекта в каждой из двух групп - и по ним следует отыскать критерий такого разбиения) или с постепенным добавлением новых объектов (так, если по трём объектам испытуемый не может дать ответа, то вводится новый, четвертый объект как некая дополнительная информация; если недостаточно и этого, то вводится новый, пятый, и так несколько раз);

5) по отсутствию или наличию одного лишнего сбивающего с толку объекта; в последнем случае испытуемому говорится, что в наборе имеется один «ошибочный» объект, который в него попал по недосмотру, но нужно, не смотря на это затруднение, всё же задачу решить правильно (например, при делении объектов на природные и рукотворные в группу природных попадает «по ошибке» один рукотворный);

6) с одним-единственным заранее заданным ответом (как в приведенных выше примерах) - или «открытые», не имеющее заранее однозначного ответа, а предполагающее их множество, различные варианты (и в этом случае нужно дать как можно больше разных ответов);

7) по содержанию материала: либо бытовой и игровой (окружающие, хорошо знакомые объекты) - либо учебный и научный (объекты физики, географии, лингвистики и т.п.); в первом случае преимущество заключается в возможности акцентировать именно состав и процедуры мышления «в чистом виде», не замутненном сложностью самого материала; во втором - в возможности увязать эти операции с реальным учебным материалом, с которым ученик постоянно взаимодействует, и научить его использовать их именно в учебно-познавательных целях.

Приведем примеры некоторых предлагаемых в ходе тренинга заданий. Вот некоторые задания на вербальном материале (приведён только их общий «костяк», а многочисленные нюансы, связанные со способом их предъявления, а также с изменением их сложности: упрощением или усложнением - могут варьировать): 
1) на картинке слева напечатаны в столбик слова: мотоцикл, паровоз, самосвал, - а справа: тачка, телега, велосипед; здесь основание для разделения следующие: первая группа объектов приводится в движение силой пара, вторая - мускульной силой живых существ; в случае затруднений можно сделать такие добавления: в первую группу - вездеход, во вторую - конка; в более сложном варианте можно ввести ещё и третью группу объектов: трамвай, троллейбус, электрокар (движутся силой электричества);

2) даны такие группы слов: а) перрон, касса, вокзал, б) полка, купе, тамбур; здесь первая группа объектов - наземные, вторая - части поезда; можно добавить и две новые группы: в) бельё, чай (они в поезде, но не части поезда), г) носильщик, проводник (сотрудники);

3) слева: ложка, бревно, пила, спичка; справа: кастрюля, ранец, колесо; здесь ориентация на смысл не приводит к четкому однозначному решению; ориентироваться надо на форму этих объектов: первые - вытянутые (удлиненные), вторые круглые или квадратные;

4) слева: пейзаж, галерея, натюрморт; справа: выставка, краски, картина; в случае затруднения добавляем: в первую группу - барокко, во вторую - показ; здесь надо ориентироваться не на сами описываемые явления, а на особенности их обозначающих слов: первая группа - слова иностранного происхождения, вторая - русские;

5) слева: телевизор, телефон, магнитола; справа: пылесос, тостер; при затруднениях добавляем: в первую - компьютер, во вторую - кондиционер, микроволновка; слева - приборы информационного назначения, справа - прагматического; для затруднения задания в первую группу можно ввести «запутывающий» объект: холодильник (или вентилятор);

6) слева: булка, колбаса, торт; справа: арбуз, яйцо, молоко; добавляющими словами в первую группу могут быть слова: паштет, чипсы; вторую - виноград; здесь слева продукты требующие сложной технологии приготовления из исходного сырья, справа - готовые продукты;

7) слева: холодец, ложка, пенал, розетка; справа: вилка, бюст, нож; в одни может быть что-то положено, налито, насыпано, вставлено, в другие - нет; в качестве «запутывающего» объекта вводим во вторую группу: портфель (или сумка);

8) слева: синус, точка, периметр; справа: угол, объем, линия; здесь левые слова - иностранного происхождения (кроме «запутывающего» слова точка), справа - русские.

Bblвoдbl: 1. Ситуация поиска (выделения) оснований (критериев) для разделения объектов на две (или более) групп является чрезвычайно «ёмкой» в смысле концентрированности в ней различных 
мыслительных операций и приёмов, и поэтому она может использоваться в игровом тренинге мышления учащихся.

2. В рамках этой ситуации можно успешно организовать работу учащихся с различным материалом (вербальным и образным) и различными процедурными нюансами (в частности, с всевозможными дозированными подсказками, актуализирующими зону ближайшего развития мышления ребёнка).

\section{Литература}

1. Бонгард М. М. Проблема узнавания / М. М. Бонгард. - М. : Наука, 1967. - 320 с.

2. Вертгеймер М. Продуктивное мышление: Пер. с англ. / М. Вертгеймер. - М. : Прогресс, 1987. - 336 с.

3. Заика Е. В. Комплекс игр для развития мышления учащихся / Е. В. Заика // Вопр. Психологии, 1990. - № 6. - С. 86-92.

4. Заика Е. В. Комплекс игр для развития воображения / Е. В. Заика // Вопр. Психологии, 1993. - № 2. - С. 54-62.

5. Заика Е. В. Игры для развития внутреннего плана действия школьников / Е. В. Заика // Вопр. Психологии, 1994. - № 5. - С. 60-67.

\section{об'єктів на групи. \\ Євген Заїка. Тренінг мислення: пошук підстав для поділу}

В руслі розроблюваного автором ігрового тренінгу пізнавальних прочесівзапропонований комплекс вправ для розвитку логічного мислення. Вправи базуються на пошуку підстав (причин, ознак), за якими деяка сукупність об'єктів вже розділена на дві або більше груп. Використовується матеріал як словесний, так і образний. Розраховані на школярів 12-19 років.

Ключові слова: логічне мислення, ігровий тренінг пізнавальних прочесів, поділ об'єктівна групи.

Eugene Zaika. Training of thinking: the search for reasons for the separation of objects into groups.

In the context of a gaming training developed by the author of the training of cognitive processes proposed a set of exercises for the development of logical thinking. The exercises are based on the search for reasons (causes, symptoms) in which a set of objects is divided into two or more groups. Material is used as a verbal and figurative. Designed for schoolchildren 1219 years of age.

Key words: logical thinking, game coaching cognitive processes, the division of objects into groups.

Статья поступила в редакционную коллегию 12.05.2014 
УДК 316.28-047.22"71"]::37.091.12.011.3-051:376-054.62

(C) Zolotova S. H., Dyadechko A. M., Morozova I. A., 2014.

Zolotova Svitlana Hryhorivna,

Dyadechko Alla Mykolaivna,

Morozova Iryna Anatoliivna

Sumy State University

\section{THE DEVELOPMENT OF COMMUNICATIVE COMPETENCE OF UNIVERSITY TEACHERS WHO WORK WITH FOREIGN STUDENTS}

The methodological principles of teaching foreign language for working in the groups with foreign students are presented. The main aspects necessary to form communicative competence are described. The peculiarities of cooperation of EL teachers with their non-language colleagues at classes are given. Some recommendations as for the development of public speaking skills are offered.

Key words: professional communication, communicative competence, public speaking skills, non-language teachers.

Ukraine has proclaimed the course towards the Euro-integration. Thus the role of foreign languages in the teaching process for foreign students in the structure of curricula has substantially grown. The National ESP Curriculum aims to provide students with the integrated language skills: to develop their general and professionally- oriented communicative language competences in English [2].

In the process of growing international academic mobility this level opens up the opportunity for Ukrainian universities to join the European Higher Education Area. More and more students from different countries come to study at Ukrainian universities. Both students and teaching staff happened to be involved into this new communication process. While students and language teachers are immediate participants of the English language activities, non-language staff cannot avoid performing a supporting role which may cause changes in the University language environment.

The paper focuses on a particular language project, initially launched at Sumy State University in 2008. Teachers from different departments of SSU have already completed or are taking a special English language program because they are expected to teach foreign students in English. Special two-year courses of English have been provided for such teachers. The tasks of the program are numerous: to teach students academic communication, to enlarge their English language professional vocabulary, to master fundamentals of presenting specific knowledge and information, 


\section{Збірник наукових статей}

etc. A new sort of classroom environment where English language staff have to teach their colleagues from other departments requires the statement of new teaching and learning aims as well as looking for innovative technologies that could result in transformation of teachers' knowledge and skills which will enable them to reach the European standards of professional communication.

In the system of Bologna process university teachers are expected to be not only the specialists with firm theoretical knowledge, but also the progressive, capable of thinking independently teachers who have skills of search and processing the information, possess the skills of communicating in English with foreign students: can deliver his ideas, participate in arguments, express their points of view and use English for academic purposes easily. The EL teachers have to work out special methodology to provide these teachers with appropriate English necessary to organize classes for foreign students. The essence of the new programmes of teaching foreign language for specific purposes can be defined as training future specialists to form and formulate their ideas by means and ways of a foreign language.

L. Chayka, denotes some professional features which may be identified as necessary for those teachers who are going to work in group with foreign students. They must:

- have fundamental knowledge in professional sphere;

- establish connection between professional knowledge and other spheres of life;

- have a technique of scientific knowledge;

- possess skills of oral and written academic communication in English;

- can apply advanced achievements in modern technologies while conducting their own classes [1].

Teachers who work with foreign students often underestimate their abilities in English and consider their communicative skills not good enough to speak to foreigners. Thus, their teachers of English face the problem of undertaking drastic measures to eliminate the fear that they will fail at the lessons with foreign students.

Nowadays a lot of researchers in the field of Linguistics and Psychology try to find the best ways to solve the problem. Developing public speaking skills is one of the ways to increase self-confidence of teachers who work with foreign students. Modern educators Steven R. Lewis, Wendy Russell devoted a lot of their works to this subject. They provide the discussion about the psychology and mechanics of speaking that should be useful for future lectures, conferences, presentations and talks (including job talks), etc. In academic training, speaking skills are rarely taught in any formal sense, which may increase anxiety and discomfort. Yet 
public speaking is one of the most important skills for scholars, and hence a skill which is commonly tested-from lectures to formal research presentations [3].

One of the goals of an EL teacher is to provide some core materials one can use to begin the journey of becoming comfortable with speaking in public. English language teachers are permanently working on special training system which helps to make public speaking less frustrating. Here three questions need to be discussed. First, to what degree are there clear procedures for consistent and systematic use of the language training system and its products by the intended users, and to what extent are they appropriate? Second, to what degree does the language training system offer a continuing capability and capacity to identify and meet consistently and effectively language training needs? Third, to what degree are there adequate opportunities to ensure continuity of personal implementing the language training system?

The answer to each of these questions should give a fairly reliable indicator of the stability of project effects. The effects depend on the EL teacher's methodology competence, the methods they provide in educational process and their professional knowledge. How to teach should depend on who you are teaching. University teachers of different subjects have different level of proficiency in English. Learners (teachers of different subjects) must be guided by clear understanding that the skills they develop and acquire will become their basic instrument in running classes to foreign students. They must be able not only to teach a particular subject: maths, computer sciences, finance or marketing, but also to practice English language in a variety of communicative situations: classroom management, presenting a course, delivering lectures or running practical classes, testing and providing students' knowledge assessment. These situations are never easy to predict and master as a teacher has to deal with another cultural environment that his or her students bring into the classroom. Teaching English to non-language colleagues has turned to be a new kind of professional collaboration in which all its participants should feel and act on equal terms as they have common aims and interests. Special features of the students taught specify a list of aspects which must be considered and followed while organizing a teaching process with a focus on the communicative competences:

- meeting the students' needs due to the purpose of the course;

- raising the students' motivation towards a higher level of practical English;

- granting students more and more initiative and stimulating their active and responsible participation in the speaking classes while treating their groupmates as potential students; 


\section{Збірник наукових статей}

- keeping up with a variety of the English language resources, learning materials and computer assisted technologies in particular;

- understanding the necessity of non-stop improvement of the personal English language skills needed for professional communication.

With all above enlisted components in mind a language teacher is able to bring his/her students to a higher level of readiness to perform their professional activities and English language communication, to talk to foreign students, to do research, to take part in the international conferences, to cooperate with foreign partners, etc.

At the end of two-year course of English non-language teachers should have an Intermediate level. Since the goal is to help learners to get the most from classes, it is important to adopt a variety of approaches. Whatever the level of the students might be, the list of the common approaches that a language teacher has to provide includes the following typical points:

- the development of a new kind of curricula which corresponds to the level and needs of students;

- bringing the classroom atmosphere as close to real life as possible;

- offering students communicative situations they could commonly play and practice;

- allowing students to give their feedback in all possible ways in order to involve them in designing and developing classes and classroom activities;

- looking for innovative teaching and learning approaches and technologies on part of the language teachers;

- trying new ways of sharing personal language and teaching experience.

\section{References}

1. Chayka L. On the role of foreign languages in training specialists of new generation / L. Chayka // IATEFL Ukraine Newsletter, 2004, № 26, - p. 16-17.

2. English for Specific Purposes (ESP). National Curriculum for Universities / [національна програма] - К. : Ленвіт, 2005. - 107 с.

3. Lewis S. R.. Speaking with confidence / S. R. Lewis. [Електронний pecypc] / Режим доступу : http://www.unce.unr.edu/publications/files/cd/2000/cm0008.pdf. - Назва с титул. екрану.

4. Russel W. Better English Public Skills = Better Presentations/ W. Russel.- [Електронний pесурс] / Режим доступу : http://presentationsoft.about.com/od/ powerpointinbusiness/tp/120904better-public-speaking-skills.htm. - Назва с титул. екрану. 
Світлана Золотова, Алла Дядечко, Ірина Морозова. Розвиток комунікативної компетенції викладачів університету, які працюють 3 іноземними студентами.

Представлено методичні засади прочесу навчання іноземної мови викладачів різних предметів університету для роботи в групах 3 іноземними студентами. Визначені основні аспекти, необхідні для формування іншомовної комунікативної компетенції. Набуття слухачами навичок публічних виступів визначається як принщиповий момент у процесі підготовки викладачів до вільного спілкування $з$ іноземними студентами англійською мовою.

Ключові слова: професійна комунікація, комунікативна компетенція, навички публічного говоріння, викладачі-предметники.

Светлана Золотова, Алла Дядечко, Ирина Морозова. Развитие коммуникативной компетенции преподавателей университета, которые работают с иностранными студентами.

Представлены методические основы прочесса обучения иностранному языку преподавателей различных предметов университета для работы в группах с иностранными студентами. Определены основные аспекты, необходимые для формирования коммуникативной компетенции. Принципиальным моментом в процессе подготовки преподавателей к свободному общению с иностранными студентами на английском языке есть развитие навыков публичных выступлений.

Ключевые слова: профессиональная коммуникация, коммуникативная компетенция, навыки публичных выступлений, преподавателипредметники.

Статья поступила в редакционную коллегию 09.05.2014

УДК 124.4-021.321(042)::37.046:005.9

Ирчишина Марина Витальевна

Днепропетровский национальный университет им. О. Гончара

\section{ОСОБЕННОСТИ ТИПОВ ОБРАЩЕНИЙ В ОБРАЗОВАТЕЛЬНОЙ СФЕРЕ}

B статье рассмотрень наиболее распространенные способы обращения преподавателей $\kappa$ учащиися $c$ целью выявления закономерностей. Способы обращения $\kappa$ студентам считаются показателем культурного и педагогического уровня преподавателя $u$ его или ее спосібностей устанавливать взаимоотнотения $c$ учашимися. Целью исследования является выявление закономерностей u взаимосвязей между различными формами обращения $u$ возможными ассоциациями, а также результаты использования 


\section{Збірник наукових статей}

разнообразных обращений. Приведены примеры происхождения некоторых наиболее распространенных слов, входящих в состав обращения. Результатом исследования является выявление того, что выбирая правильное обращение, преподаватель может изменять рабочую атмосферу в соответствии с иелями диалога.

Ключевые слова: обращение, адресат, нормы поведения, речевой етикет.

В традиционной педагогике теория воспитания всегда считалась ведущей. Метод воспитания - специфическое воздействие воспитателя на воспитанника, имеющее своей целью формирование определенных качеств его личности. К методам воспитания в педагогике относят изучение норм поведения, требование, разъяснение, убеждение, приучение, принуждение, поощрение и наказание. Изучение норм поведения часто рассматривают как задачу обучения, предшествующую воспитанию, поскольку человек не может соблюдать то, что ему неизвестно. Требование соблюдения изученных норм заставляет учащихся обращать внимание на свое поведение, корректировать его в соответствии с этими нормами, формирует при многократном повторении навыки культурного поведения и общения [4]. Однако соблюдение норм является обязательным не только для учащихся, но и для преподавателей, так как зачастую именно преподаватель задает тон всему занятию, создавая для себя и студентов благоприятную атмосферу доверия и подготавливая тем самым почву для успешного усвоения материала и дальнейшей мотивации.

Темой данного исследования являются особенности употребления распространенных форм обращения в образовательной сфере, в частности, преподавателей к студентам.

Цель исследования - установить закономерности между формой и содержанием различных форм обращения.

Одной из неотъемлемых норм поведения является обращение преподавателя к учащимся. Само по себе обращения является самым ярким этикетным знаком, ведь французское слово "etiquette" первоначально имело значение “этикетка", “ярлык”. Называя собеседника, мы как бы выбираем для него наиболее походящий к случаю “ярлык". Во всех языках есть великое множество обращений, которые употребляются в самых разных ситуациях с различной целью. Основная функция обращения - привлечение внимания, призыв собеседника - дала ему определенную оформленность, специфическую звательную форму, существующую в ряде славянских языков и имевшуюся в древнерусском языке и в современном украинском [2]. Тема данного исследования также рассматривалась в 
работах выдающихся лингвистов: "Речевой этикет нашем обществе", "Обращение" Н. И. Формановской, "Специализированные средства контакта в современном русском языке" Р. М. Гайсина, "Обращение: теоретические проблемы" В. Е. Гольдина, "Обращение как способ установления межъязыковой профессиональной коммуникации» Ю. В. Ильиной, «Преподавание и воспитание в высшей школе» Ю. Г. Фокина и другие источники.

Вторым важным свойством обращений является обозначение адресата. Обращения в образовательной сфере возникают на базе словназваний, которые указывают на наиболее ярко выраженные признаки. Наиболее распространенные приемлемые конструкции, которые используются в обращении к группе учащихся в целом, можно условно распределить на такие группы, для которых в приоритете:

1) возраст адресата в соотношении с возрастом говорящего: “дети”, "ребята”, “уважаемые ребята”;

2) личные качества адресата как объекта эмоционального воздействия и оценки со стороны говорящего: “дорогие ребята/студенты";

3) профессия, род занятий адресата: “товарищи/уважаемые юристы/историки/журналисты/филологи”, “первый/второй/третий и т.д. курс";

4) функция адресата в данной ситуации: “уважаемые студенты”, “господа студенты”, “товарищи студенты”.

Стоит уделить особое внимание старым формам обращений “товарищи” и "господа", которые все еще не сдают полностью своих позиций в речевом употреблении [1]. Обращение “товарищи” стало популярным во времена Советского Союза и использовалось применительно как к мужчинам, так и женщинам. Стойкость этих форм объясняется тем, что они прочно вошли в речь представителей старшего поколения, которые пользуются ими активно до сих пор. Вовторых, на смену устаревшим обращениям все еще не пришли новые формы обращений, которые были бы однозначно приняты всеми членами общества.

Использование слова “господин” несет излишне официальный и формальный оттенок, да и сфера его употребления чрезвычайно ограничена: “господином" в наше время можно назвать только человека, который является владельцем крупного производства, на которого работают наемные работники. Однако в сфере правительственных кругов, в официальной речи это обращение находит вполне логичное и обоснованное употребление: "господа депутатьы", “господин министр”, “господин Президент” [3].

Довольно часто при открытии собрания, заседания, конференции в речи ведущих довольно часто используется именно эта 
привычная форма обращения, несмотря на то, что в приветственном слове их организаторы используют обращение "господа", а затем незаметно для себя переходят к “товарищам”. По-видимому, это можно объяснить не только сложившейся за многие годы речевой традицией или официальной окраской возрожденного обращения “господa”, но и тем, что во время проведения заседания, конференции налаживаются некие межличностные связи, люди знакомятся с выступающими, их взглядами, поэтому их отношения приобретают некую более конкретную, личную окраску, и переход к обращению “товарищи” связан с новым этапом становления взаимоотношений между членами определенного сообщества.

Таким же образом, преподавателям следует обращать внимание на цели, которых они хотят достичь, употребляя те или иные конструкции и какие ассоциации могут вызвать те или иные слова у учащихся. Первые две группы обращений, представленных в данной работе, акцентируют внимание на личности учащихся и используются c целью создания установки уважительных, но достаточно дружественных и доверительных отношений, разрушения «барьера» между преподавателем и студентами. Последние две группы обращений употребляются для установки дружественной, однако несколько официальной обстановки и состоят из слов, указывающих на профессии, род занятий и функции.

Кроме того, владение речевым этикетом способствует приобретению авторитета, порождает доверие и уважение, а знание правил норм поведения, их соблюдение позволяет человеку чувствовать себя уверенно и непринужденно. Уровень владения речевым этикетом определяет степень профессиональной пригодности человека. Соблюдение норм обращения людьми лингвоинтенсивных профессий имеет, кроме того, воспитательное значение, способствует повышению как речевой, так и общей культуры общества.

\section{Литература}

1. Гольдин В. Е. Обращение: теоретические проблемы : учебное пособие для вузов / В. Е. Гольдин. - Саратов : Книжный дом "Либроком", 1987. - 125 с.

2. Ильина Ю. В. Обращение как способ установления межъязыковой профессиональной коммуникации / Ю.В.Ильина. [Электронний peсурс]. - Режим доступа: julia.ilina.90@bk.ru. Название с титул. экрана.

3. Смирнов И. Б. Влияние общественно-политических изменений на употребление обращений в современном русском языке / И. Б. Смирнов. [Электронний ресурс]. - Режим доступа: http://festival.1september.ru/articles/625345. - Название с титул. экрана. 
4. Фокин Ю. Г. Преподавание и воспитание в высшей школе: Методология, цели и содержание, творчество: Учеб.пособие для студ. высш. учеб. заведений. - М. : Издательский центр "Академия", 2002. $224 \mathrm{c}$.

Марина Ірчишина. Особливості типів звернення в освітній сфері. У роботі розглядаються найуживаніші засоби звернення викладачів до студентів. Засоби звернення до студентів вважсаються показником культурного та педагогічного рівня викладача та його здібностей до встановлення відносин зі студентами. Метою дослідження $\epsilon$ виявлення закономірностей та взаємозв'язків між різними формами звернення та можливими асоціаціями та наслідками, які вони можуть викликати. Розглянуто походження найуживаніших слів, які використовуються при зверненні. Результатом дослідження $\epsilon$ виявлення закономірності, щзо обираючи відповідну форму звернення, викладачі можуть змінювати робочу атмосферу відповідно до мети діалогу.

Ключові слова: звернення, адресат, норми поведінки, мовленнєвий етикет.

\section{Maryna Irchyshyna. Peculiarities of ways of addressing in educational field.}

In this paper the most common ways of how lecturers may address students are considered. Ways of addressing students are supposed to be the indicator of the cultural and pedagogical level of the lecturer and his or her abilities to establish relations with students. The purpose of this research is to find out the regularities and correlations between different forms and possible associations and results of using various ways of addressing. The origins of some words commonly used in addressing are given. The result of the research is that by choosing appropriate addressing construction lecturers may change working atmosphere according to the purpose of the dialogue.

Key words: addressing, addressee, norms of behavior, speech etiquette. Статья поступила в редакционную коллегию 13.05.2014

УДК $316.77: 378.14$

\section{Іваніга Орина Валеріївна}

Харківський національний економічний університет імені С. Кузнеця

\section{МЕТОДИ РОЗВИТКУ МІЖКУЛЬТУРНОЇ КОМПЕТЕНЦІЇ СТУДЕНТІВ НА ЗАНЯТТЯХ 3 АНГЛІЙСЬКОЇ МОВИ}

У статті розглянуто сутність явища міжкультурної компетениії та методи комунікативно-орієнтованого викладання.

Ключові слова: міжкультурна комунікачія, викладання, краӥнознавчий. 


\section{Збірник наукових статей}

Викладання іноземної мови останніми роками набуває особливу роль в реалізації принципу культурного різноманіття (плюралізму), на якому будується міжнаціональне спілкування у всіх сферах життя, включаючи професійну. У зв'язку з цим, підготовка викладача повинна відповідати вимогам нових реалій і включати, разом 3 іншими, міжкультурну компетенцію (МКК). Як і інші види компетенції, МКК повинна постійно удосконалюватися. Для цього існують наступні причини:

1. Зміна культурного середовища у сфері професійного спілкування.

2. Зміна і розвиток професійних потреб студентів.

3. Розбіжність між реальною підготовкою викладача і такою підготовкою, якою він повинен володіти в даний момент.

Усвідомлене ігнорування соціокультурних знань властиве не тільки викладачам, але і студентам, які, якщо їм надати вибір, у переважній більшості вважатимуть за краще виконати граматичні тести, а не культурні. Це, можливо, пояснюється глибоко укоріненою думкою про те, що мовна неграмотність $є$ більш неприваблива, ніж неграмотність культурна, внаслідок чого важливіше витратити час на вивчення, наприклад, вживання дієслівних часів і способів, ніж на вивчення регіональних особливостей якого-небудь регіону. Але це не означає, що МКК виходить на перший план, принижуючи роль лінгвістичної і комунікативної компетенцій. Із зсувом уваги до МКК, кваліфікація викладача повинна необхідним чином мінятися $\mathrm{i}$ розвиватися.

У терміні «міжкультурний» поняття «культура» використовується як синонім цивілізації, як сукупність поглядів, переконань і типів поведінки груп індивідуумів в повсякденному і суспільному житті, як література і мистецтво.

МКК, яка $\epsilon$ ядром комунікативної компетенції, може розрізнятися як єдність соціально-культурної компетенції (СКК), 3 одного боку, і соціально-лінгвістичною компетенцією (СЛК) - 3 іншого. СКК припускає наявність культурних знань в широкому значенні, співвіднесених з ситуацією спілкування, тоді як СЛК пов'язана із знанням правил мовної поведінки і взаємодії в різних сферах спілкування (повсякденній, діловій, науковій та ін.).

У змістовому плані міжкультурна компетенція викладача іноземної мови відноситься до предметної компетенції, або предметної площини кваліфікації викладача, в якій він виступає як фахівець. Таким чином, предметна площина повинна включати, разом 3 вузькоспеціальними знаннями, знання загальнокультурного плану, включаючи знання національної культури. Соціально-культурна, або країнознавча інформація повинна відображати основні сутнісні 
характеристики країни і включати наступні елементи: 1) інформацію енциклопедичного характеру (історія, географія, державний лад та ін.); 2) знакові історичні дати, які представляють найважливіші історичні події, факти сучасної реальності (система освіти, економіка, засоби масової інформації); 3) назви пам'ятників культури, імена видатних осіб, основні події сучасного культурного і суспільного життя, імена відомих людей сучасності (письменники, актори, журналісти і т.д.); 4) основні види дозвілля, основні цінності і риси суспільної психології, стереотипні уявлення про націю і країну.

Оскільки навчання міжкультурної компетенції припускає порівняння студентами двох культур - своєї і чужої, викладач повинен уміти навчати представляти на іноземній мові свою країну, або уміти «представлятися» в широкому значенні слова. Порівняння цих двох елементів можливе лише у тому випадку, коли обидва вони добре відомі. Проте освітня практика показала, що в свідомості студентів другий елемент (соціально-культурна інформація про свою країну) виявляється сукупністю неясних і не завжди вірних уявлень, неточних фактів або суперечністю думок. У цій ситуації викладач зустрічається з проблемою пошуку, відбору і систематизації документів, що містять соціально-культурну інформацію про свою країну для ії уявлення у формі вправ, таблиць, текстів, різних завдань. Одна з вимог, на наш погляд, повинна відповідати відбору необхідної інформації - це їх знаковий характер, який забезпечує інформування про найважливіше, істотне. Ця вимога витікає 3 особливостей сприйняття одержувача інформації: знакова інформація легше сприймається і легко піддається порівнянню. Дуже важливо також, щоб відібраний матеріал містив символи, або знаки, які представляють характерну абстрактну ідею або характерну реальність. Серед фактів, які відображають реалії, слід виділяти і ті, які включали б національну екзотику. Слід помітити, що поняття «екзотика» розширилося за останні два десятки років, про що свідчать визначення тлумачних словників. Якщо раніше екзотичним вважалося все те, що не належало західним цивілізаціям і походило 3 далеких країн, то в наші дні екзотикою є те, що належить чужій країні або походить 3 неї. До екзотики повсякденного життя, як правило, відносять національні блюда, напої, іграшки, музичні інструменти та ін. При відборі країнознавчої інформації слід ураховувати, з одного боку, чинник ㄲi мінливості, який припускає необхідність оновлення застаріваючих даних, i чинник постійності, 3 другого боку, що відноситься до знакових фактів і символів.

Серед мовних засобів передачі соціально-культурної інформації всі дослідники відзначають певні групи лексичних одиниць, які мають особливу семантику, оскільки служать для номінації явищ навколишнього світу, відносяться до культури, або мають додаткове 


\section{Збірник наукових статей}

значення (конотацію), свідчать про наявність суб'єктивної оцінки. До них відносяться:

1) безеквівалентна лексика, яка включає реалії i деякі абревіатури;

2) слова з конотативним значенням, у тому числі абревіатури;

3) мена власні, у тому числі абревіатури.

Щодо застосування соціально-лінгвістичної компетенції, то володіння нею означає знання мовних актів, які актуалізуються в різних сферах спілкування (повсякденне, ділове, наукове і т.п.), а також знання лексичних одиниць, які мають стилістичне, конотативне забарвлення.

Порівняння правил мовної поведінки носіїв іноземної і рідної мов тут відіграє другорядну роль і представляється доцільним у разі порушення паралелізму.

Деякі правила мовленнєвої поведінки у сфері повсякденного спілкування описані в учбовій літературі і відомі викладачам. Так, при знайомстві $з$ жінкою не слід задавати питання про ії вік і сімейний стан. У співрозмовників однієї статі не прийнято питати про їх прибутки і про місце в соціальній ієрархії, до якої політичної партії належать, як відносяться до смертної кари. У зворотному випадку співбесідник буде шокований, і розмова не отримає розвитку [3]. Проте часто виділяється такий парадокс: деякі теми розмов, що, зазвичай, уникають співвітчизники «природним чином» обговорюються між представниками різних культур [4].

Проте викладач зустрічається 3 деякими труднощами, які не вичерпуються списком що приводиться:

1. Неможливо описати у вигляді правил практично усі мовні поведінки наперед.

2. Не всі випадки і правила можуть бути проілюстровані. Наприклад, ввічлива поведінка має безліч виявів.

Отже, для викладача проблема змісту МКК полягає в забезпеченні правильного повного тематичного змісту, адекватного функціонального змісту i, у меншій мірі, мовного змісту.

Специфіка методичної сторони, на наш погляд, полягає не в особливих методах, а в правильному дидактичному забезпеченні. Для взаємодії зі студентами протягом тривалого часу викладач користується підручником.

Аналіз підручників англійської мови як іноземної, виданих у Британії за останнє десятиріччя, показує, що в змісті з'явився розділ, озаглавлений як «соціокультурний аспект» або країнознавство [5]. Англійські методисти констатують зниження методичного рівня унаслідок прагнення відповідати кон'юнктурі ринку, але слід 
зазначити основні переваги таких підручників, які дозволяють навчати MKK.

По-перше, підручники є опорою для соціокультурної інформації завдяки великій кількості друкарських i образних документів (фотографії, репродукції картин, малюнки, комікси).

По-друге, мовний матеріал для навчання говоріння поданий у формі діалогічних сцен, який максимально точно відповідає потребі формування СЛК, оскільки відображає культуру повсякденного життя (вітання, життя удома, їжа, покупки, дозвілля і т.п.). Підкреслимо, що тільки підручник може запропонувати «мозаїку» діалогічних сцен повсякденного життя, які з'єднані одним загальним соціокультурним контекстом.

Носіями соціокультурної інформації $є$ документи. До них відносяться статті 3 преси, рекламні тексти, ділові і дружні листи, уривки $з$ літературних творів, таблиці, тексти пісень та ін. Їх об'єднує одна загальна перевага: здатність пропонувати сучасну і актуальну соціокультурну інформацію у вигляді конкретних фактів, які дозволяють уникати формування стереотипних, банальних i помилкових уявлень про чужу культуру.

Англійські підручники розраховані на широкий круг студентів i не ураховують ні програмних вимог конкретного курсу, ні профіль університету, нарешті, вони не орієнтовані на конкретні умови національного характеру. Тому викладач, на додаток до підручника, вимушений сам створювати корпус автентичних документів, оновлюючи їх у разі втрати ними актуальності. Таким чином, він бере на себе функції документаліста, або фахівця, в обов'язки якого входить пошук, відбір, класифікація, використання i розповсюдження документів [6].

Можна також доповнити, що необхідність пошуку i вибору нових документів $є$ не тільки об'єктивною вимогою політичної, соціальної і культурної реальності, що змінюється, але вона викликана наявністю величезної кількості і багатої різноманітності документів.

У результаті аналізу інформаційної цінності, комунікативної, лінгвістичної і соціокультурної доцільності, передбачуваної ефективності використовування документи класифікуються за метою навчання, по рівню навчання та за тематичним змістом. Що стосується друкованих документів, то прийнято вважати, що при відборі текстів слід керуватися принципом доступності тексту бути зрозумілим, у тому числі в соціокультурному плані. Проте, на нашу думку, повчальною функцією володіють саме тексти, які містять труднощі соціокультурного характеру, деякі 3 яких традиційно відносять до категорії лексичних (імена власні, абревіатури, безеквівалентна 
лексика), хоча, як вже мовилося вище, ці слова передають соціокультурну інформацію.

Задача викладача полягає в тому, щоб мову документа зробити мовою для вивчення, інакше кажучи, побачити одиниці, які є носіями соціокультурної інформації. Така задача входить до числа задач прикладної лінгвістики, напрями мовознавства, які займаються «розробкою методів вирішення практичних задач, пов'язаних 3 використанням мови», зокрема, відбором «мовного матеріалу в цілях удосконалення викладання мови» [1]. Отже, викладач повинен володіти навичками прикладної лінгвістики, щоб на основі результатів лінгвістичного аналізу розробляти матеріали, які відповідали б поставленій цілі навчання.

Завдання i тести, що розробляються, повинні відповідати загальним вимогам, які пред'являються до навчальної діяльності: вони повинні допомагати економити час навчання, тобто не вимагати багато часу для виконання. Також завдання повинні бути сформульовані ясно і дієво.

Для набуття досвіду МКК може використовуватися також методика проекту, наприклад, створення студентами словникадовідника лексичних одиниць - носіїв соціокультурної інформації.

Як культурний медіатор, викладач може займати активну суспільно-політичну позицію. Така роль викладача вимагає від нього певної сміливості і упевненості в собі, оскільки він ризикує бути залученим в конфлікт. Але така позиція прийнятна, коли викладач виступає за соціальні інтереси і ідеали всього суспільства, наприклад, ідеї гуманізму. Розрізняючи функціональний і тематичний зміст МКК, викладач повинен звернути увагу на двосторонність останнього, а саме: знання i порівняння двох культур (своєї i чужої). Для дидактичного забезпечення навчання МКК викладач повинен мати навички роботи документаліста i знати прийоми прикладної лінгвістики; виконуючи роль міжкультурного медіатора, викладач проявляє себе як особа (з активною соціально-політичною позицією або без неї), яка реалізує зі студентами відносини партнерства, в яких шляхом постійного i ретельного аналізу долаються міжособові проблеми, здійснюється досягнення мети навчання.

\section{Література}

1. Болдырев Н. Н. Лингвистические основы коммуникативных методов обучения иностранным языкам / Н. Н. Болдырев. Иностранные языки в школе. - 1998. - № 3. - С. 15.

2. Бухбиндер В. А. О системе упражнений - Общая методика обучения иностранным языкам: Хрестоматия / В. А. Бухбиндер. - М. : Рус. яз., 1991, - С. 210. 
Психолого-педагогічні проблеми становлення сучасного фахівця

Випуск 2014

3. Введение в коммуникативную методику обучения английскому языку. Пособие для учителей в России. - Oxford University Press, 1997. - C. 48.

Арина Иванига. Методы развития межкультурной компетенции студентов на занятиях английского языка.

B статье рассматривается сущность понятия межкультурная коммуникация $и$ методы коммуникативно-ориентированного преподавания.

Ключевые слова: межкультурная коммуникация, преподавание, страноведческий.

Oryna Ivaniga. Development of students' cross-cultural competence in the lessons of English language.

The article deals with the development of cross-cultural competence as well as methods of communicatively-oriented teaching.

Key words: cross-cultural communication, teaching, culture studies.

Стаття надійшла до редакційної колегії 15.05.2014

УДК 37.691.33.-027.21:111.5-047.22]:378

Кайдалова Лідія Григорівна

Національний фармацевтичний університет

\section{ТЕОРЕТИКО-МЕТОДИЧНІ АСПЕКТИ КОМПЕТНТНІСНОГО ПІДХОДУ У ВИЩІЙ ОСВІТІ}

Висвітлено теоретико-методичні аспекти компетентісного підходу у підготовці майбутніх фахівців у вищзому навчальному закладі. Виокремлено групи компетентностей, серед яких ключові (життєві), професійні, комунікативні та соціальні.

Ключові слова: компетентність, компетентнісний підхід, ключові (життєві) компетентності, професійна компетентність, комунікативна компетентність, сочіальна компетентність.

Упровадження ідей компетентнісного підходу обумовлено процесами інтеграції світової економіки і європейської системи освіти, у т.ч. вітчизняної вищої фармацевтичної освіти, зміною освітньої парадигми. У рамках Болонського процесу європейські університети по-різному опановують та сприймають компетентнісний підхід, який розглядається як своєрідний інструмент посилення соціального діалогу вищої школи зі світом праці, засіб поглиблення. 


\section{Збірник наукових статей}

Метою статті є висвітлення теоретико-методичних аспектів компетентнісного підходу у підготовці майбутніх фахівців у вищих навчальних закладах.

За визначенням міжнародних експертів, поняття „компетентність” охоплює задані навички (вимога виконувати певні індивідуальні завдання); використання знань і вмінь на робочому місці на рівні встановлених вимог (стандартів); здатність відповідально виконувати обов'язки і досягати запланованих результатів; здатність знаходити рішення у нестандартних ситуаціях; здатність застосовувати знання і вміння у нових умовах виробничої діяльності [1].

Компетенція, за Європейською системою кваліфікацій (ССК), є інтегративним поняттям і виражає здатність людини самостійно застосовувати в певному контексті різні елементи знань та вмінь i містить: когнітивну компетенцію, яка передбачає використання теорії і понять, а також „приховані” знання, надбані досвідом; функціональну компетенцію (уміння та ноу-хау), саме те, що людина повинна вміти робити; особистісну компетенцію, яка передбачає вміння поводитись у конкретній ситуації; етичну компетенцію, що передбачає наявність певних особистісних і професійних цінностей

Для європейського виміру України визначені загально життєві компетенції, що вважаються необхідними для кожного європейця, а саме: самостійність - здатність приймати необхідні рішення та відповідати за них, вміти жити та діяти в певному соціумі, зберігаючи власне самовизначення, враховуючи свою свободу і безпеку та маючи свою громадянську позицію; орієнтуватись у політичному, економічному, культурному та правовому контекстах; мобільність уміння пристосуватися до ситуації, змінювати напрями діяльності, володіти декількома європейськими мовами, спілкуватись та взаємодіяти з іншими, поважаючи їх права, культуру, самобутність, коректно розв'язувати конфлікти; професійна підготовленість прагнення до професійної досконалості, здатність до навчання упродовж усього життя, вміння отримувати необхідну інформацію, уміння працювати в команді [3].

Ключові компетентності $є$ основою моделі випускника будьякого ВНЗ. Вони не $\epsilon$ професійно обумовленими. Зазначеними компетентностями повинні володіти всі сучасні фахівці незалежно від сфери їхньої діяльності, оскільки вони є підгрунтям для професійних компетентностей. Навіть у тому випадку, коли виникає потреба змінити професію, вони дають можливість успішно реалізувати себе в інших професіях.

Ми поділяємо точку зору тих авторів, які відзначають, що в основі успішної професійної діяльності лежать: сукупність компетентностей, які передбачають володіння знаннями, вміннями та 
навичками в певній галузі діяльності; уміння застосовувати набуті знання та вміння для вирішення професійних завдань; готовність до аналізу проблемних ситуацій та пошуку шляхів їх вирішення; уміння працювати самостійно та в групі тощо. Тобто професійна діяльність фахівця є успішною тоді, коли він ще під час навчання у ВНЗ набуває досвіду практичної діяльності. Зауважимо, що професійна компетентність розглядається як показник готовності тих, хто навчається до здійснення конкретної професійної діяльності на певному рівні виконання [2].

Для більшості фахівців важливою $є$ комунікативна компетентність, яку слід розглядати здатність встановлювати i підтримувати необхідні контакти 3 іншими людьми. До комунікативних умінь та навичок відносяться: уміння встановлювати контакти; уміння спілкуватись 3 різними людьми; уміння висловлювати власні думки; уміння слухати; уміння знаходити у співрозмовника найбільш сильні його сторони і вселяти йому віру в себе; проявляти терпіння з партнерами по спілкуванню; уникати та вміти розв'язувати конфлікти (підхід до проблеми 3 точки зору партнера, подолання особистої неприязні тощо); здатність взаємодії 3 іншими людьми (за віком, статусом, родом діяльності); уміння будувати партнерські стосунки.

Соціальна компетентність необхідна як у професійній діяльності, так i в повсякденному житті людини. Соціальну компетентність розглядаємо як здатність та готовність особи співпрацювати 3 людьми певним чином, розуміти їх інтереси та соціальне становище.

Таким чином головним завданням компетентнісного підходу у вищій освіті є підготовка кваліфікованого фахівця, який є професійно компетентним, здатним ефективно працювати на рівні вітчизняних, світових i європейських стандартів, готового до постійного професійного росту та самовдосконалення, соціальної та професійної мобільності.

Перспективи подальших досліджень полягають у вивченні та впровадженні заходів щодо формування найбільш важливих компетентностей майбутніх фахівців у вищих навчальних закладах.

\section{Література}

1. Державні стандарти професійної професійної освіти: теорія та методика : монографія // [за ред. Н. Г. Ничкало]. - Хмельницький : ТУП, 2002. - 334 с.

2. Компетентнісний підхід у сучасній освіті: світовий досвід та українські перспективи : Бібліотека з освітньої політики / Під заг. ред. О. В. Овчарук. - К. : „К.І.С”, 2004. - С. 3-21. 
Збірник наукових статей

3. Key Competencies. A developing concept in general compulsory education. Eurydice. The information network on education in Europe. 2002. $-28 \mathrm{p}$.

Лидия Кайдалова. Теоретико-методические аспекты компетнтносного подхода в высшем образовании.

Освящены теоретико-методические аспекты компетентосного подхода в подготовке будущих специалистов в высшем учебном заведении. Выделены группь компетентностей, среди которых: ключевые (жизненные) профессиональные, коммуникативные $и$ сочииальные.

Ключевые слова: компетентность, компетентностный подход, ключевые (жизненные) компетентности, профессиональная компетентность, коммуникативная компетентность, социальна компетентность.

Lydia Kaydalova. The theoretical-methodological aspects kompetentnostnogo approach in higher education.

Consecrated theoretical-methodological aspects kompetentnostnogo approach in training of future specialists in higher educational institution. The selected group of competencies, which include: key (life) professional, communicative and social.

Key words: competence, competence approach, key (life) the competence, professional competence, communicative competence, social competence.

Стаття надійшла до редакційної колегії 09.04.2014

УДК $37.018 .1(510)$

Калашник Любов Сергіївна

Інститут вищої освіти

Національної академії педагогічних наук України

\section{ПІДВИЩЕННЯ РІВНЯ СОЦІАЛЬНОЇ АДАПТИВНОСТІ СУЧАСНОГО СПЕЦІАЛІСТА СИСТЕМИ ДЕРЖАВНОГО ПІКЛУВАННЯ ПРО ДІТЕЙ-СИРІТ В КНР}

Стаття присвячена актуальним питанням сучасної педагогічної науки - підвищенню рівня соціальної адаптивності молодого фахівия. В умовах глобалізаиії освітнього простору, наявності у молодих людей можливостей працевлаштування за кордоном сочіальна адаптивність (здатність до швидкої адаптації у новому суспільстві) стає однією з вимог, які висуваються до фахівия. Система освіти КНР накопичила певний досвід з означеного питання, який у вітчизняній літературі репрезентується вперше. 
Ключові слова: сочіальна адаптивність, здатність до адаптації, система освіти, КНР, система державного піклування.

Зміна зовнішніх факторів життя веде до зміни внутрішнього світу людини і навпаки. Низький ступінь соціальної адаптованості веде за собою виникнення у людини внутрішнього конфлікту, загострення емоційного фону, що нерідко призводить до психічних і фізичних захворювань, неадекватних проявів, суїцидів. Реалії сьогодення обумовлюють необхідність розширення базових вимог, які висуваються до сучасного спеціаліста: разом 3 його фаховою підготовкою, гостро стоїть питання про психологічну готовність спеціаліста до виконання своїх обов'язків, підвищення рівня його стресоопору, пристосування до нових реалій (як соціального, так i економічного, географічного та культурологічного характеру), тобто питання про підвищення рівня соціальної адаптивності молодої людини.

Метою статті $\epsilon$ репрезентувати досвід системи освіти КНР щодо підвищення рівня соціальної адаптивності молодих спеціалістів на прикладі майбутніх спеціалістів галузі соціального піклування про дітей-сиріт в країні.

Завданнями статті є:

- визначити соціальну адаптивність молодих фахівців як соціокультурну проблему сучасного китайського суспільства;

- нарисово окреслити основне спрямування заходів щодо підвищення рівня адаптивності молодих спеціалістів в КНР на прикладі системи підготовки майбутніх працівників системи соціального піклування про дітей-сиріт.

Питання підвищення рівня соціальної адаптивності сучасного спеціаліста $\epsilon$ досить новою для сучасної української педагогічної науки. Окремі питання, пов'язані з цією проблемою, розроблялися такими фахівцями, як I. Трубавіна (соціальна адаптивність прийомних дітей та батьків), К. Юр'єва (полікультурність як передумова соціальної адаптивності молодого фахівця), С. Чолій та С. Грабовська (соціальна адаптивність як чинник соціальної активності особистості), I. Галецька (психологічні чинного соціальної адаптивності). Цікавими для нашого дослідження $є$ праці Л. Горюнової та О. Шпектаренко (соціальна адаптивність як складова процесу професіоналізації державних службовців), Н. Калашник (підвищення рівня соціальної адаптивності державних службовців засобами самоосвіти) тощо. Нажаль китайський досвід підвищення рівня соціальної адаптивності молодих фахівців в системі освіти дотепер не був репрезентований у вітчизняній фаховій літературі, а, отже і не піддавався аналізу. 


\section{Збірник наукових статей}

Соціальна адаптація це взаємний процес досягнення рівноваги між людиною і суспільством: 3 одного боку існують відносини між особистістю і соціальним середовищем (відносини ієрархічні, в яких людина повинна адаптуватися до соціальних умов, що постійно змінюються, до прийнятих в даному суспільстві соціальних і поведінкових норм), з іншого боку - відносини між компонентами соціального середовища (держава, суспільство, сім'я, людина, виробничий колектив тощо), де кожен з вище перелічених компонентів $\epsilon$ рівним і всі зміни відбуваються в горизонталі.

Сьогодні питання підвищення соціальної адаптованості молодих фахівців є дуже важливими для цієї країни. У зв'язку 3 активними міграційними процесами всередині країни, які обумовлені виробничим бумом 3 одного боку та державними проектами щодо залучення фахівців для роботи і життя в економічно нерозвинених і відсталих регіонах країни, Китай зіткнувся з необхідністю вирішення проблеми низького рівня соціальної адаптованості випускників закладів освіти, зокрема і фахівців в галузі соціального піклування про окремі категорії населення. На практиці окреслена проблема, з одного боку, має форму неприйняття «чужаків» місцевими громадами в сільських районах $\mathrm{i}$ призводить до їх ізоляції та самоізоляції, байкотуванню роботи та ініціатив «прийшлих», а 3 іншого - веде до відтоку висококласних фахівців 3 числа тих, хто приїхав за державними програмами та ініціативами. В якості головної причини такого становища сьогодні китайські ЗМІ сьогодні називають психологічних дискомфорт переселенців і труднощі в адаптації до місцевого товариства (як і місцевої громади до «нових» людей). Все це, надумку китайського уряду, гальмує державні програми з подолання бідності та підвищення рівня життя населення на селі.

Сьогодні освітня система КНР приділяє велику увагу питанням соціальної адаптивності населення. Для цих цілей в навчальних закладах країни всіх рівнів впроваджуються спеціальні курси та тренінгові заняття, які мають форму лекцій, бесід-роз'яснень. Подібні заходи також проходять і на виробництвах. Власники приватного бізнесу всіляко стимулюються до впровадження подібних практик для своїх співробітників на робочих місцях. Робота 3 підвищення соціальної адаптивності молодих фахівців в системі освіти КНР проходить за наступними напрямками:

Розуміння навколишнього середовища. Основним постулатом $є$ те, що для того, щоб розуміти, як адаптуватися до нових життєвих умов, людина повинна розуміти, що відбувається з навколишнім середовищем, які відбуваються якісні зміни навколишнього середовища в глобальному масштабі і на локальному рівні, які $\epsilon$ відмінності природних та екологічних умов життя даного регіону і чим 
вони відрізняються від тих умов, в яких людина виросла. У Китаї досить популярні громадські програми (як правило, вони ініціюються муніципальною владою або самі жителями) з прибирання власного міста/двору, роздільного викиду сміття, висадки молодих дерев. На підприємствах, у навчальних закладах широко обговорюються екологічні проблеми, проводяться лекції та дискусії. Трудові колективи відраховують частину зароблених грошей в якості екологічного податку, гроші від якого також йдуть і на організацію парків, державні програми по збереженню рідкісних тварин тощо. ЗМІ постійно звертають увагу людей на досягнення КНР в галузі екологічної безпеки, а також випадки запобігання контрабанди тварин, незаконної вирубки лісу;

Взаємовідносини з іншими. Основні принципи взаємовідносин в китайському суспільстві (як між суспільством і окремою особистістю, так і між людьми) були сформульовані ще мислителями глибокої давнини i знайшли своє відображення в китайській «політиці обличчя». У більш сучасному варіанті в тезовому формулюванні вони прозвучали в промовах Мао Цзедуна: «Суворість до себе і м'якість по відношенню до інших». Мао сформулював основні «вимоги» до особистості сучасної людини: кожен повинен бути позитивним, активним, відданим колективу, чесним до себе i до інших. Також частиною даного напрямку роботи з підвищення адаптивності молодих фахівців зокрема системи соціального піклування $є$ роз'яснювальна робота, яка знайомить людей із звичаями і традиціями представників інших національностей, які населяють Китай, прищеплення слухачам поваги до представника будь-якої національності, підкреслюючи що «всі національності КНР є рівними і вносять свій рівний внесок в розвиток країни». Даний напрямок роботи $є$ особливо важливим для майбутніх фахівців системи соціального піклування про дітей-сиріт, оскільки, внаслідок особливостей розташування закладів державної опіки про дітей-сиріт, вони мають працювати здебільшого в сільських регіонах, місцях компактного проживання національних меншин, економічно занедбаних та територіально віддалених районах країни.

Розвиток власних позитивних якостей особистості. Характер людини, темперамент, виховання та інші характеристики особистості впливають на якість людських відносин i ступінь адаптивності людини. Традиційно китайське суспільство вітало в людині прояв таких якостей, як доброзичливість, чесність, милосердя, здатність розуміти інших, комунікабельність, живий розум, увага до людей; нелюдимість, упертість, дурість, жорстокість, підозрілість, зазнайство засуджувалися i висміювалися як у старовину, так i в сучасному суспільстві. Сучасна система освіти в Китаї націлює своїх студентів на розвиток позитивного мислення i ставлення до життя, вчить 
розраховувати на власні сили, поважати суспільство і людину як частину суспільства і виробничого колективу.

Об'єктивна оцінка реальності і власної особистості. Основною тезою даного напрямку практичної роботи з молодими фахівцями є те, що мрії людини та їі очікування повинні мати під собою реальну базу. Апріорі нездійсненні мрії, недосяжні результати несуть розчарування i негативно відбиваються як на самій особистості, так і на їі взаєминах 3 оточуючими. Адекватно оцінені власні можливості допомагають людині отримати визнання оточуючих, домогтися успіху, підвищити власну самооцінку.

Для досягнення позитивних результатів у галузі об'єктивного самооцінювання та побудови адекватних взаємин 3 іншими, що $\epsilon$ ознакою високого рівня соціальної адаптивності, китайські психологи і педагоги виділяють 3 аспекти діяльності:

- в галузі самосвідомості: самоспостереження і самооцінка;

- в галузі емоційного стану: само-переживання і самовідношення;

- в галузі самоврядування: самоконтроль, самовиховання, самостимулювання, самомотивація, прагнення до самовдосконалення.

У середніх (починаючи 3 8-го класу) і вищих навчальних закладах учні кожен семестр мають заповнювати анкети, оцінюючи себе i анонімно оцінюючи своїх однокласників. Дані анкет обробляються i результати обговорюються 3 учнями. Основним критерієм визначення рівня соціалізованості учня i показником ступеня його інтегрованості в колектив є відсоток збігу оцінок, які учень/студент собі поставив сам, i йому виставили однокласники/одногрупники: чим відсоток вище - тим більше соціально адаптованим вважається даний учень.

Також в обов'язки вчителя-вихователя (аналог класного керівника чи куратора) входить оцінювати динаміку виправлень конкретного учня (або їі відсутність), допомагати йому долати власні психологічні та поведінкові бар'єри. Слід зазначити, що даний вид роботи з молоддю, хоча і вважається прогресивним, використовується переважно у вищих навчальних закладах та зразково-показових школах. Подібне анкетування проходять також вчителі та викладачі як державні службовці при підвищенні категорії. Результати «перевірки особи» кандидата на більш високу посаду (категорію, звання тощо) складають 30\% від процедури прийняття позитивного рішення 3 даного питання.

Китайська психолого-педагогічна практика сьогодні приділяє значну увагу підвищенню рівня соціальної адаптивності молодих фахівців, вбачаючи це запорукою забезпечення кваліфікованими кадрами усіх без винятку регіонів країни. Досвід КНР з означеного 
питання може бути корисним для України за умов його всебічного вивчення та адаптування до вітчизняних реалій та потреб.

\section{Література}

1. 杨彦平, 金瑜.中学生社会适应量表的编制 // 心理发展与教育. - 2007. - № 4. - p. 106-114 (Ян Янпин, Тин Ю. Развитие школьников: аспект социальной адаптации // Психологическое развитие и образование. - 2007. - № 4. -C. 106-114).

\section{2. 社会学概论新修 (第三版) - 郑杭生 主编.}

中国人民大学出版社. - 2012. - 516 p. (Введение в социологию (издание третье). - под ред. Чжен Ханьшен. - Изд-во : Китай Жэньминь University Press, $-2012 .-516$ с.).

3. 才源源. 心理健康的社会适应性标准. 人民教育出版社 . 2012-129 р. (Цай Юаньюан. Социальная адаптивность как показатель психического здоровья личности. - Изд-во : Китай Жэньминь University Press, 2012. - 129 c.).

\section{Любовь Калашник. Повышение уровня социальной адаптивности современного специалиста системы государственной опеки о детях-сиротах в КНР.}

Статья посвящена вопросам повышения уровня социальной адаптивности молодого специалиста. В условиях глобализации образовательного пространства, наличия $y$ молодых людей возможностей трудоустройства за рубежом сочиальная адаптивность (способность к быстрой адаптащии в новом обществе) становится одним из требований, предъявляемых к специалисту. Система образования КНР накопила определенный опьт в данном вопросе, который в отечественной литературе представляется виервые.

Ключевые слова: сочиальная адаптивность, способность $\kappa$ адаптации, система образования, КНР, система государственной опеки.

Lyubov Kalashnyk. Ways of icreasing social adaptability of modern specialists of public care system for orphaned children in China.

This article focuses on issues of increasing the level of social adaptability of the young specialist. In the context of globalization of educational space, young people abroad employment opportunities social adaptability (the ability to quick adaptation to a new society) becomes one of the requirements for a specialist. China's education system has accumulated some experience over the problem mentioned, which in the Ukrainian literature appears for the first time.

Key words: social adaptability, ability to adaptation, education system, China, system of public care.

Стаття надійшла до редакційної колегії 28.04.2014 
Камишний Олександр Михайлович

Запорізький державний медичний університет

\section{РОЗВИТОК КОМУНІКАТИВНОЇ КОМПЕТЕНЦІЇ СТУДЕНТІВ МЕДИЧНОГО УНІВЕРСИТЕТУ В СУЧАСНОМУ НАВЧАЛЬНОМУ ПРОЦЕСІ}

У статті акцентовано увагу на особливостях формування комунікативної компетенції студентів у процесі викладання мікробіології в медичних університетах як однієї зі складових професійної компетентності майбутніх фахівиів.

Ключові слова: медичний університет, комунікативна компетентність студентів.

На сучасному етапі розвитку інформаційного суспільства в Україні перед колективами вищих навчальних закладів гостро постають завдання не тільки здійснення ефективного професійного навчання майбутніх фахівців, але й виховання грамотних, конкурентоспроможних, духовно багатих, національно свідомих, творчих особистостей, рівень знань котрих відповідав вимогам суспільства, що постійно підвищуються $[1 ; 6]$. Потреба у розв'язанні важливих соціально-психологічних, економічних i культурнопросвітницьких проблем ставить нові вимоги до мовної освіти й мовленнєвої підготовки майбутніх фахівців у вищій школі, оскільки обов'язковою умовою успішної навчальної і майбутньої фахової діяльності студентів $є$ знання логічних основ різних видів спілкування, володіння культурою ділового, професійного мовлення [6]. У контексті професійної підготовки медичного працівника ці знання й уміння набувають особливого значення, тому проблема формування комунікативної компетентності як однієї з ключових компетентностей майбутніх фахівців i професійних якостей лікаря, не втрачає актуальності до сьогодні [5; 6].

Частина студентів у процесі навчання у ВНЗ відчувають труднощі комунікативного характеру, зокрема це стосується несформованості навичок вільного спілкування рідною або іноземною мовами, комунікативних бар'єрів у зв'язку з фрагментарним знанням фахової термінології. Це зумовлює необхідності вдосконалення навчального процесу відповідно до нових тенденцій у науці і практиці в аспекті розвитку особистості, яка володіє комунікативною компетенцією [2]. Отже, мета статті полягає у розкритті особливостей 
формування комунікативної компетенції студентів на прикладі кафедри мікробіології, вірусології та імунології ЗДМУ.

Тема культури спілкування, професійного мовлення фахівців медичної галузі надзвичайно широка, складна, делікатна. Протягом різних досліджень доведено, що хвора людина не завжди надає перевагу професійній компетенції лікаря, а, насамперед, душевним якостям, здатності співчувати, вмінню вислухати, заспокоїти. Без оптимального душевного спілкування діяльність навіть висококваліфікованого медика може дати негативний результат $[3,6]$. Тому формування комунікативної компетенції студентів, яке здійснюється в університеті в рамках викладання фундаментальної дисципліни, зокрема «Мікробіології, вірусології, імунології» здатне зробити внесок у розв'язання проблеми багатоаспектного розвитку особистості майбутнього сучасного фахівця.

Володіючи умовами, що ініціюють самовдосконалення, комунікативний розвиток студентів $\epsilon, 3$ одного боку, процесом становлення й удосконалення особистісних якостей особи, яка навчається, іiі комунікативних умінь, ціннісних орієнтацій і соціальних навичок. 3 іншого боку, воно сприяє формуванню готовності i здатності особистості до саморозвитку, отриманню нового знання, його перетворенню й застосуванню за рахунок постійного вибору викладачем засобів, форм, методів, прийомів активізації комунікативного потенціалу студента. 3 цих позицій очевидне значення формування комунікативної компетенції студента в умовах сучасного медичного вишу [3; 6].

Удосконалення навчального процесу 3 метою розвитку комунікативності та підвищення професійних якостей майбутнього лікаря-мікробіолога, лікаря-імунолога $\epsilon$ пріоритетним завданням кафедри мікробіології, вірусології та імунології. Вдале поєднання традиційних методик викладання навчального матеріалу 3 мікробіології, вірусології та імунології у медичних вишах 3 ефективнішим використанням активних форм i методів навчання, підвищує інтерес цієї дисципліни, збільшує інтенсивність й активізує навчально-пізнавальну діяльність.

Наприклад, на практичних заняттях 3 мікробіології використовується ігрове моделювання як один із методів проблемноорієнтованого навчання з використанням комп'ютерних технологій. У межах методики відбувається відбір проблемного змісту і подальше його відтворення студентами у різних ситуаційних завданнях 3 мікробіологічної діагностики окремої інфекційної хвороби після перегляду навчальних тематичних відеофільмів, ілюстрацій електронних підручників або 3 використанням мультимедійних презентацій. 


\section{Збірник наукових статей}

Досягненню мети формування комунікативної компетенції у студентів на кафедрі мікробіології, вірусології та імунології сприяли впровадження у навчальний процес інтерактивних форм і методів навчання, які дають змогу формувати знання, професійні вміння i навички студентів 3 вивчення запропонованої дисципліни шляхом залучення їх до інтенсивної пізнавальної діяльності. Так, широко використовується ситуативне моделювання, «мозковий штурм», дискусії, повідомлення, робота в малих групах. Інтерактивне навчання дозволяє вирішувати одночасно кілька завдань, головним із яких $€$ розвиток комунікативних умінь і навичок. Таке навчання допомагає встановити емоційні контакти між студентами, забезпечуючи, насамперед, виховний процес, оскільки привчає працювати в групі, прислухатись до думки товаришів, сприяе високій мотивації, творчості, комунікабельності, взаємоповазі й демократичності [3; 6].

Співробітники нашої кафедри, спираючись на кращий досвід роботи аналогічних педагогічних колективів кафедр інших ВНЗ [2; 5; 6], працюють, розвиваючи такі компоненти комунікативного розвитку студентів як:

Мотиваційно-ціннісний компонент, який передбачає усвідомлення студентами значущості професійного мовлення у майбутній фаховій діяльності, а також сформованість системи цінностей, що сприяє зацікавленому розвитку i використанню моральних ресурсів особистості для досягнення цілей комунікації.

Комунікативно-операційний - уміння використовувати мовні засоби відповідно до мети, умов, ситуації спілкування; опанування базових професійно-мовленнєвих умінь, необхідних для медичної галузі.

Когнітивний компонент - знання норм сучасної української літературної мови, вільне користування медичною термінологією та професійною лексикою, знання особливостей усного й писемного професійного мовлення медичної галузі, культура і спосіб комунікації, розуміння можливостей застосування цих знань на практиці; готовність до пізнання; знання переваг і недоліків як власних, так i співрозмовника, а також форм і методів подолання проблем, що виникають під час спілкування.

Конативний (поведінковий) компонент - сформованість свідомості суб'єкта у вигляді мотивів, цілей, спрямувань, намірів і готовності до здійснення медичної діяльності, уміння вести діалог або полілог, які сприяють продуктивному професійно спрямованому обміну інформацією [6]. Перед викладачами постає завдання визначити правила спілкування відповідно до створеної навчальної ситуації, котра моделює реальний процес спілкування. 
Емоційний компонент - гуманістична установка на спілкування, інтерес до іншої людини, готовність вступати 3 нею в особистісні, діалогічні взаємини, інтерес до власного внутрішнього світу; розвинуті емпатія та рефлексія; високий рівень ідентифікації з виконуваними професійними та соціальними ролями; адекватні вимогам професійної діяльності психоемоційні стани); здатність використовувати вербальні та невербальні (жести, міміка тощо) засоби спілкування, які $\epsilon$ необхідною умовою комунікативної діяльності студентів-медиків [5; $6]$.

Отже, рівень комунікативної компетенції медичного працівника відображає соціально-психологічну атмосферу суспільства, стан суспільної моралі, успіх професійної діяльності. Ця компетенція забезпечує управління системами рольової та міжособистісної взаємодії суб'єктів лікувального процесу.

Висновки. Серед численних проблем сучасної освіти в медичному виші особливої актуальності набуває проблема розвитку та вдосконалення комунікативної компетенції майбутніх фахівців у сфері медицини. Тому формування комунікативної компетенції студентів як психолого-педагогічного компоненту професійної діяльності майбутнього фахівця у всій різноманітності його внутрішніх зв'язків, властивостей і взаємовідносин $є$ надзвичайно важливим, і весь процес навчання мікробіології, вірусології та імунології будується за принципом системного підходу 3 урахуванням індивідуальних особливостей кожного учасника навчального процесу.

\section{Література}

1. Вища освіта України i Болонський процес: Навчальний посібник / За редакцією В. Г. Кременя. Авторський колектив :

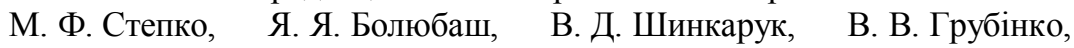
I. І. Бабин. - Тернопіль : Навчальна книга "Богдан". - 2004. - 384 с.

2. Денисова О. Ю. Роль педагога в формировании мотивации обучения / О. Ю. Денисова // Профессиональное образование. - 2009. № 6.

3. Ефремичева Н. В. Компетентностная модель подготовки педагогов в условиях модернизации профессионального образования / Н. В. Ефремичева // Профессиональное образование. - 2008. - № 1.

4. Зеер Э. Ф. Психология профессионального развития Учебное пособие для студентов ВУЗов / Э. Ф. Зеер. - Академия, 2007.

5. Корнілова А. Ключові кваліфікації компетентності особистості у вищих навчальних закладах/ А. Корнілова // Шлях освіти. - 2005. - № 3. - С. 18-22.

6. Лісовий М. І. Формування професійного мовлення майбутніх медичних працівників у вищих медичних навчальних закладах / М. І. Лісовий. Дис....канд. пед. наук: 13.00.04. - Вінниця, 2006. - 192 с. 
Збірник наукових статей

Александр Камышный. развитие компетенции студентов медицинского университета в современном учебном процессе.

В статье акцентировано внимание на особенностях формирования коммуникативной компетенции студентов в прочессе преподавания микробиологии в медицинских университетах как одной из составляющих профессиональной компетентности будущих специиалистов.

Ключевые слова: медицинский университет, коммуникативная компетентность студентов.

Alexander Kamyshnyy. development of communicative competence of students medical university in modern educational process.

In article we discusses some aspects of microbiology teaching in medical high school. It covers the formation of the communicative competence of students in education. It is one of the components of professional competence of future specialists.

Key words: medical high school, communicative competence of students.

Стаття надійшла до редакційної колегії 10.05.2014

УДК 37.015.31-024.63-026.12"71":355.343

Ключка Світлана Іванівна

(C) Ключка C. I., 2014.

Черкаський державний технологічний університет

\section{ІНТЕРАКТИВНІ ТЕХНОЛОГІЇ НАВЧАННЯ, ЯК ПЕРЕДУМОВА РОЗВИТКУ ТВОРЧОГО ПОТЕНЦІАЛУ МАЙБУТНЬОГО ФАХІВЦЯ}

Обгрунтовано інтерактивне навчання як обов'язковий компонент педагогічного процесу вищої школи. Висвітлено використання відповідних підходів в освітньому прочесі, як передумову розвитку творчого потениіалу майбутнього фахівия. Увага акиентована на активізації пізнавальної діяльності студентів, формуванні вмінь розв'язувати нестандартні завдання на прикладі ділових ігор. Змістову лінію склала робота, спрямована на усвідомлення студентами психологічних закономірностей у виробничому колективі, формування індивідуальних иінностей, оцінно-рефлексивної діяльності, зміџнення сочіально спрямованих мотивів у професійній сфері та поведіниі.

Ключові слова: інтерактивні технології, педагогічний прочес, творчий потенціал, особистісно-орієтований підхід. 
В сучасній педагогіці актуальним питанням $є$ виховання i навчання особистості, яка здатна до виконання будь-якого завдання, а також вміє знайти свій власний нестандартний варіант вирішення проблеми. Креативний фахівець виступає двигуном прогресу, тому першочерговим завданням педагога є виховання людини здатної діяти в змінених виробничих та життєвих ситуаціях. Творчий підхід до розв'язання необхідних завдань передбачає наявність певних особистісних якостей, в яких відображається вміння швидко та конструктивно приймати відповідні зважені рішення. Формування вищезгаданих рис забезпечується завдяки активній позиції індивіда. Виховання соціально активної особистості потребує запровадження відповідних форм педагогічної взаємодії. Серед таких форм виділяють інтерактивне навчання, як ефективну передумову розвитку творчого потенціалу майбутнього фахівця.

Питання впровадження інтерактивних технологій у вищій освіті $€$ об'єктом вивчення багатьох вчених (А. Алексюк, І. Богданов, В. Бондар, П. Воловик, О. Дубасенюк, О. Свдокімов, Г. Сазоненко). Значний внесок в запровадження інтерактивного навчання в педагогічну діяльність вищої школи зробили науковці А. Алексєєнко, Д. Брунер, А. Вербицький, І. Дичківська, О. Пометун, Л. Пироженко, О. Савченко, Г. Щукіна та ін. Ці автори у своїх працях обгрунтовують ідею необхідності активізації пізнавальної діяльності студентів в будьяких напрямах підготовки, систематизують та вдосконалюють окремі методи активізації навчально-виховного процесу, тощо. Сьогодні освіта все більше орієнтується на «вільний розвиток», високу культуру, творчу ініціативу, самостійність, мобільність майбутніх спеціалістів, що вимагає якісно нового підходу до формування майбутнього фахівця [1]. Однією 3 передумов пізнання людиною оточуючої дійсності та набуття нею творчих якостей виступають інтерактивні технології навчання.

Метою статті $є$ висвітлення інтерактивних технологій навчання в процесі становлення творчих рис особистості на прикладі ділових ігор.

Лише активна пізнавальна діяльність людини $\epsilon$ умовою іiі успішного професійного становлення, розвитку ऑiі креативного потенціалу, набуття необхідних життєвих та виробничих вмінь та навичок. Існують різноманітні класифікації форм діяльності (духовна, матеріальна, виробнича, трудова, нетрудова). 3 точки зору творчої ролі діяльності в соціальному розвитку особливе значення має розподіл іiі на репродуктивну (спрямовану на отримання уже відомого результату відомими засобами) і продуктивну діяльність, або творчість, пов'язану 3 виробленням нових цілей і відповідних їм засобів або з досягненням відомих цілей за допомогою нових засобів. Сучасна дидактика, 


\section{Збірник наукових статей}

звертаючись до активних форм навчання, справедливо вбачає в них можливості ефективної взаємодії педагога та студентів, продуктивної форми їх спілкування 3 наявними елементами змагання, безпосередності, природного інтересу. В своїй роботі, під час викладання дисциплін гуманітарного блоку, ми акцентували увагу на такі психолого-педагогічні ділові ігри, як “Виховання комунікативних якостей особистості”, “Студент і викладач”, “Подолання комплексу неповноцінності”, “Фобії в нашому житті”, “Шляхи подолання стресових ситуацій”, “Студентська група”, “Емоції і почуття в повсякденні”. Використання інтерактивних технологій забезпечувало, насамперед, комплексність впливу на емоційно-ціннісну, когнітивну, діяльнісну сферу особистості. Беручи активну участь у пропонованих завданнях, студенти знаходили шляхи вирішення в психологічних ситуаціях, приймали рішення, брали на себе відповідальність за той чи інший випадок, тощо. Ігровий процес вимагав від учасників максимальної віддачі енергії, мобілізації їх інтелектуальних здібностей, винахідливості, витримки, самостійності. При цьому враховувались вікові особливості аудиторії, соціальний досвід молоді. Ділова гра дозволяє створити комфортні умови залучення студентів до діяльності, спрямованої на вирішення особистісних проблем, пов'язаних із знанням i його застосуванням в суспільстві. Використання ділових ігор в навчальному процесі, особливо в умовах дефіциту часу, відведеного на дисципліни гуманітарного циклу, відкриває широкі можливості для вдосконалення психологічних знань студентів. Виконання учасниками правил гри i дотримання професійних норм - необхідна передумова індивідуальних і спільно прийнятих рішень в рамках відведеної кожному ролі. Учасники створюють, розігрують і вирішують проблемні ситуації, спілкуючись один 3 одним та фахівцями 3 обраної проблематики. Ділова гра забезпечує не тільки закріплення знань і використання їх у практичній діяльності, а й набуття професійних умінь і навичок, сприяє адаптації студента, формуванню вміння вирішувати складні професійні завдання. Реалізація пізнавальної діяльності в середовищі ділових ігор викликає зацікавленість у вивченні предмета, націлює студентів до ділової активності. Ділові ігри навчають колективному опрацюванню проблем, створюють атмосферу колективної роботи, призначені для вироблення і прийняття самостійних рішень. Застосування ігрового моделювання в процесі підготовки майбутніх інженерів дозволяє імітувати конкретну ситуацію, у якій доводиться знаходити правильне рішення, наближене до реальних обставин. При цьому, зазвичай, використовується не тільки програмний матеріал, але, що особливо важливо, виробляються уміння та навички системного мислення, пробуджується прагнення до пошуку нових ідей, творчості та 
колективної взаємодії. У ході проведення ділових ігор та колективного обговорення їх результатів формуються важливі соціальні установки, виробляються професійні практичні навички i вміння. Гра $\epsilon$ надзвичайно динамічним процесом, розвиває навички прийняття рішень, аналізу ситуацій i зворотних зв'язків, планування дій на тривалу перспективу. Окрім того, ділові ігри сприяють розвитку у майбутніх фахівців психологічної етики, емпатії. Так, під час навчально-виховного процесу ми апробували різні види таких ділових ігор, як “Керівник і підлеглий”, “Конфлікт на виробництві”, “Допоможи товаришеві” та ін. Ділова гра передбачає урахування таких логічно пов'язаних компонентів: постановка проблеми, висунення гіпотези, перевірка іiі на підставі аналітичних дій. Виховний аспект творчої ділової гри полягає в єдності психологічних знань з власними творчими можливостями студентів, сприяє розвитку науковості. Особливе значення мають підсумкові ігрові заходи, оскільки головним ix завданням $\epsilon$ систематизація i поглиблення знань студентів 3 попередніх тем, узагальнення вивченого матеріалу, розвиток логічного мислення і вміння чітко висловлювати думки. Під час проведення рольових ігор виявляється підвищений інтерес студентів до означеної проблеми, їх активність впродовж всього педагогічного процесу. Учасники виступають в ролі дослідників, а також набувають досвіду поведінки в подібних ситуаціях під час виробничої практики чи професійної діяльності. Виховний потенціал ділової гри полягає у розвитку творчих здібностей особистості, використання необмеженої кількості можливих варіантів вирішення завдань, в тому числі формування психологічної готовності до професійної діяльності. Такі види роботи сприяють підготовці до прийняття зважених рішень у майбутніх життєвих та професійних ситуаціях, що виникають в системі “людина - людина”, формують досвід відповідної поведінки, засвоєння моральних норм і правил взаємодії з соціумом. Особливістю гри є те, що вона супроводжується станом захопленості, творчої ініціативи, сформованістю мотивації. Одночасно розвиваються вміння аналізувати, синтезувати, узагальнювати та прогнозувати дії у майбутній професійній ситуації. Під час гри в студента з'являється можливість усвідомити свої обов'язки в професійній діяльності, виховати вміння доводити, переконувати, вислуховувати протилежні аргументи, відстоювати свою позицію, оцінювати дії інших, робити висновки.

Таким чином, впровадження інтерактивних технологій в навчально-виховний процес вищої школи забезпечує різнобічне висвітлення ситуації на основі підготовчої роботи (студенти попередньо опрацьовують добірки статей, або готують мікро-виступ на певну тему, попередньо продумують психологічні ситуації та 


\section{Збірник наукових статей}

проектують шляхи їх вирішення тощо). Імітаційні ігри супроводжувались комп'ютерними програмами, в яких рельєфно було представлено конкретну ситуацію. Застосування такого підходу у процесі навчання сприяло поглибленню знань, розширенню світогляду студентів. Інтерактивні технології навчання передбачають постановку мети, спрямованої на засвоєння відповідного змісту освіти, виокремлення необхідних методів та форм навчально-пізнавальної діяльності, взаємодії педагога та студентів. Першочерговим завданням інтерактивних технологій $є$ формування в майбутніх фахівців уміння вдало поєднувати здобуті теоретичні знання 3 відповідною практичною діяльністю. Оволодіння необхідним досвідом відбудеться в тому випадку, коли студент самостійно в достатній мірі виявлятиме інтерес до знань і докладатиме відповідних зусиль, гармонійно поєднуючи теоретичний матеріал 3 вирішенням конкретних виробничих та життєвих завдань. Подальші перспективи досліджень вбачаємо в напрямку виявлення умов формування особистісних якостей студентської молоді в навчально-виховному процесі вищої школи.

\section{Література}

1. Савченко О. П. Компетентнісний підхід у сучасній вищій школі / е-журнал «Педагогічна наука: історія, теорія, практика, тенденції розвитку» Режим доступу: http://www.intellectinvest.org.ua/ukr/pedagog_editions_e-magazine_pedagogical_science / Випуск № 3 [2010] / О. П. Савченко. Компетентнісний підхід у сучасній вищій школі. - Назва с титул. екрану.

Светлана Ключка. Интерактивные технологии обучения, как условие развития творческого потенциала будущего специалиста.

Обоснованно интерактивное обучение, как обязательный компонент педагогического прочесса высшей иколь. Освещены использования соответствующих подходов в образовательном процес се, как условие развития творческого потенцииала будущего специалиста. Внимание акцентировано на активизации познавательной деятельности студентов, формировании умений решать нестандартные задачи на примере деловых игр. Содержательную линию составила работа, направленная на осознание студентами психологических закономерностей в производственном коллективе, формирование индивидуальных иенностей, оценочно-рефлексивной деятельности, укрепление социиально направленных мотивов в профессиональной сфере и поведении .

Ключевые слова: интерактивные технологии, педагогический прочесс, творческий потенциал, личностно-ориентированый подход. 
Svetlana Klyuchka. Interactive technologies of education as a term for the development of creative potential future professional.

Interactive teaching as on obligatory component of pedagogical process of high school is well grounded. The use of appropriate approaches in education as a prerequisite for the development of the creative potential of future specialists. Attention is accented on activation of cognitive activity of students, forming of abilities to decide the not ordinari tasks, business games. A semantic line was made by the work directed on the awareness by the students of psychological conformities in the term, forming of individual values, evaluativ and reflective activity, strengthening of the socially directed reasons of professional activity and conduct.

Key words: interactive technology, teaching process, creativity personality, personality-oriented approach.

Стаття надійшла до редакційної колегії 07.05.2014

УДК 378.147.111.015.3

Коваль Аліна Сергіївна

(C) Коваль А. С., 2014

Харківський національний економічний університет імені С. Кузнеця

\section{ФІЗІОЛОГІЧНІ, ПСИХОЛОГІЧНІ ТА СОЦІОКУЛЬТУРНІ ОСОБЛИВОСТІ СТУДЕНТСЬКОГО ВІКУ}

Студентство можна розглядати як соціально-демографічну групу, або як особливу фазу, стадію соиіалізації (студентські роки), яка характеризується специфічними рисами. При роботі зі студентами потрібно враховувати закономірності та психологічні механізми їх особистісного розвитку, які зумовлені як своєрідністю соџіальної ситуачії розвитку студентства, так $і$ основними психологічними та фізіологічними особливостями юнацького віку.

Ключові слова: студентство, соиіалізація, розвиток, особистість.

Викладач повинен враховувати індивідуальні особливості кожного студенту. Студентство треба розглядати як соціальну групу в системі вищого навчального закладу, яка має свою мету, свої специфічні особливості і яка готується до виконання соціальних ролей i функцій інтелігенції. Допомогти у цьому студентам повинні викладачі-педагоги, тому що студент $є$ об'єктом педагогічної діяльності. Продукти діяльності педагога матеріалізуються у психологічному соціокультурному відображенні іншої людини - у іiі знаннях, уміннях, навичках, рисах характеру. Своєрідність даного об'єкта полягає в тому, що він одночасно є суб'єктом діяльності, проте 


\section{Збірник наукових статей}

не педагогічної, а навчальної, ігрової, дослідницької, комунікативної, тоді як об'єктом діяльності студента $є$ наукова, теоретична і практична інформація, якою він має оволодіти. Продуктами його діяльності $\epsilon$ відповіді: усні, письмові, графічні.

При організації викладачем впливу на свій об'єкт потрібно враховувати те, що студент ніколи не розвивається у прямій залежності від педагогічного впливу на нього, а за своїми законами, властивими його психіці - особливостями сприймання, розуміння, запам'ятовування, становлення волі, характеру, формування загальних i специфічних здібностей. Студент не народжується суб'єктом діяльності, а стає ним під впливом виховання і в процесі навчальної діяльності.

Дослідженням даної проблеми займалися наступні вчені: Б. Г. Ананьєв, І. С. Кон, Ю. А. Самарін, К. Д. Ушинський.

Mema cmammi - розглянути фізіологічні, психологічні та соціокультурні особливості студентського віку.

Студентство - це мобільна група, метою існування якої $\epsilon$ організована за певною програмою підготовка до виконання професійних і соціальних ролей у матеріальній і духовній сферах.

При вихованні й навчанні студентів варто враховувати те, що кожному періоду життя, кожному віку людини притаманні властивості духовного й фізичного розвитку. Завдання педагога полягає у тому, щоб пізнати особистість студента, виявити загальні психічні риси психології групи, розкрити індивідуальні особливості кожного студента. Успіх у навчанні можна досягти лише при розумінні викладачем інтересів і цілей, які ставить перед собою молодь, при врахуванні особливостей духовного й фізичного розвитку, що властиві молодим людям.

Студентство як окрема вікова й соціально-психологічна категорія виділено в науці ще в 1960-х роках ленінградською психологічною школою під керівництвом Б. Г. Ананьєва при дослідженні психофізіологічних функцій дорослих людей. Як вікова категорія студентство співвідноситься 3 етапами розвитку дорослої людини, i визначається як «перехідна фаза від формування до зрілості» [1], пізня юність - рання дорослість (18-25 років). Виділення студентства всередині епохи зрілості - дорослості засновано на соціально-психологічному підході.

К. Д. Ушинський вважав період життя людини від 16 до 22-23 років найбільш вирішальним. Як зазначав науковець, саме тоді завершується період утворення окремих уявлень, і якщо не усі вони, то значна частина їх групуються в одну мережу, досить широку, щоб надати вирішальну перевагу тому чи іншому уявленню [5]. 
Ю.О.Самарін виділив ряд характерних рис та протиріч соціально-психологічного характеру, що мають місце у розвитку студентської молоді. У цей період молода людина здійснює вибір професії, оволодіває нею і починає випробувати себе в інших сферах життя, самостійно планує свою діяльність і поведінку, активно відстоює самостійність суджень і дій. У цьому віці формуються світогляд на основі синтезу наявних знань, життєвого досвіду (який ще $\epsilon$ недостатнім), самостійних міркувань і дій, багато 3 яких зі сфери теоретичних уявлень переходять у сферу практичних здійснень (кохання, шлюб, створення власної сім'ї). Однак, у зв'язку 3 матеріальною залежністю від батьків та необхідністю підкорятися існуючому в навчальному закладі розпорядку виникає економічне протиріччя між різноманітністю бажань і можливістю їх здійснення. Таке протиріччя студент іноді намагається розв'язати додатковим заробітком, який завжди шкідливо відбивається на навчальній діяльності [4].

Студентський вік, за твердженням Б. Г. Ананьєва [1], $€$ сенситивним періодом для розвитку основних соціогенних потенцій людини. Вища освіта впливає на психіку людини, розвиток іiї особистості. За час навчання у ВНЗ, при наявності сприятливих умов у студентів відбувається розвиток усіх рівнів психіки. Вони визначають спрямованість розуму людини, тобто формують склад мислення, що характеризує професійну спрямованість особистості. Для успішного навчання у ВНЗ необхідний досить високий рівень загального інтелектуального розвитку, зокрема сприйняття, пам'яті, мислення, уваги, рівня володіння певним колом логічних операцій.

Психічний стан людей такого віку є складним і суперечливим, через що поведінка молодих людей не завжди буває послідовною. В одних умовах вони проявляють високу зрілість, дисциплінованість, а в інших - порушують елементарні норми. Ці особливості, як фізіологічні, так і психологічні, викладачеві треба виявити й використати. Завдання викладача полягає не тільки в озброєнні студентів певною системою знань, навичок, спеціальних умінь, але й у всілякому розвитку їхніх розумових сил, у формуванні загальних інтелектуальних умінь: самостійно здобувати нові знання, вирішувати нестандартні завдання, знаходити оригінальні способи рішень, раціонально працювати з різними джерелами інформації.

Дослідження психологів показали, що в другий період юності розвиток таких важливих для навчання психічних процесів, як мислення, пам'ять, увага, відбувається нерівномірно. Особливо помітні «спади» i «підйоми» у розвитку мислення і пам'яті. «Підйоми» у розвитку мислення припадають на вік 20, 23 і 25 років. «Спади» спостерігаються у 22 і 24 роки. «Підйоми» у розвитку пам'яті 
припадають на 18, 23 і 24 роки; «спади» - на 22 і 24 роки. Як видно 3 наведених даних, існує тимчасова розбіжність «підйомів» $\mathrm{i}$ «спадів» у розвитку пам'яті і мислення. Зміни в пам'яті мов би підготовляють зміни в розвитку мислення [2].

У віці від 18 до 21 року рівень уваги стабільний; пізніше коливання виражені більш інтенсивно. 19, 22 і 25 років $є$ оптимальним віком для розвитку інтелекту. У 18 -літньому віці студент може запам'ятати досить великий обсяг навчальної інформації, що збільшився на другому курсі, але не може здійснити розумову переробку всього отриманого матеріалу, оскільки мислення відстає від пам'яті. Таким чином можна пояснити, чому значна кількість студентів на екзаменаційній сесії за третій семестр має нижчу успішність, ніж у перших двох.

За своїм суспільним станом студентство ближче стоїть до інтелігенції, $є$ іiї резервом і призначене в майбутньому до занять висококваліфікованою працею в різних галузях соціальної сфери, науки, техніки, управління, культури. Соціальна функція студентства зумовлюється суспільною необхідністю забезпечувати приток фахівців до названих галузей.

Не зважаючи на відмінності свого соціального походження і матеріальних спроможностей, студентство об'єднує спільний вид діяльності і воно являє єдину соціально-професійну групу. Спільна діяльність породжує в студентства певну спільність інтересів, групову самосвідомість, специфічну субкультуру і спосіб життя, причому це доповнюється і підсилюється віковою однорідністю, якої не мають інші соціально-професійні групи. Соціально-психологічна спільність закріплюється діяльністю в різноманітних політичних, культурнопросвітницьких, спортивних студентських організацій.

У вихованні якостей першорядну роль відіграє викладач. Від його кваліфікації значною мірою залежить стан усього навчальновиховного процесу. Високий рівень організації навчання й виховання студентів забезпечується педагогами, які мають високу культуру, глибоко знають свій предмет і добре знайомі із суміжними галузями науки, практично розбираються в питаннях загальної й особливо студентської психології, досконало володіють методами викладання й виховання.

Інколи викладач не розуміє цього і бачить студента лише через свій викладацький стіл: як студент відвідує заняття, виконує завдання, слухає і відповідає. Інше ж в особі вихованця деяких викладачів не цікавить. А це «інше» - частина ядра особистості студента - його багатство або бідність у прагненнях i задумах, духовність або бездуховність, моральність або аморальність, гідність або рабська 
покірливість і пристосуванство, сила духу або слабкість характеру, працьовитість або лінощі й апатія, корисливість або безкорисливість.

Студентський вік характеризується ще й тим, що в цей період досягаються оптимуми розвитку фізичних сил. Це час спортивних рекордів, початок художніх, технічних і наукових досягнень. Але часто проявляються протиріччя між цими можливостями та їх дійсною реалізацією. Безперервно зростаючі творчі можливості, розвиток інтелектуальних і фізичних сил, які супроводжуються й розквітом зовнішньої привабливості, приховують у собі також ілюзії, що це зростання сил буде тривати «вічно», що краще життя ще попереду».

3 фізіологічної точки зору студентський вік характеризується найвищим рівнем таких показників, як м'язова сила, швидкість реакцій, моторна спритність, швидкісна витривалість та ін. Як прийнято говорити, це вік фізичної досконалості людини. Однак, як свідчать дані Всесвітньої організації охорони здоров'я, саме студенти характеризуються гіршими показниками фізіологічних функцій у своїй віковій групі. Вони лідирують за числом хворих гіпертонією, тахікардією, діабетом, нервово-психічними порушеннями. Причини, як показують дослідження, криються в тім, що в процесі вузівського навчання студенти відчувають сильну психічну напругу, часто руйнівну для здоров'я.

Навчання у виші вимагає великих витрат часу й енергії, що обумовлює деяку затримку становлення студентів у порівнянні 3 іншими групами молоді. Сучасна студентська молодь закінчує свою освіту в основному тільки у 22-23 роки, тому настання зрілості як індивіда (фізична зрілість) й як особистості (громадянська зрілість) не співпадають у часі. Дисгармонія фізичного і психічного розвитку проектується молодою людиною на навколишній світ, який сприймається нею як особливо напружений і конфліктний.

Таким чином, студентство можна розглядати як соціальнодемографічну групу, або як особливу фазу, стадію соціалізації (студентські роки), яка характеризується специфічними рисами. Провідний вид діяльності в студентському віці - процес навчання, накопичення нових знань, засвоєння нових умінь i навичок. Новоутвореннями зрілого юнацького віку є професійна спрямованість, формування мотивів і цілей, намірів і цінностей, вироблення власного світогляду, становлення нового рівня розвитку самосвідомості. Для студентства характерне подолання вікової кризи, протягом якої в особистості відбуваються процеси отримання дорослої ідентичності і нового ставлення до світу. У зоні найближчого розвитку - професійна підготовка 3 обраної спеціальності, професійне випробування i "проектування" себе у професії. 


\section{Література}

1. Ананьев Б. Г. К психофизиологии студенческого возраста / Б. Г. Ананьев // Современные психолого-педагогические проблемы высшей школы. - Л. : ЛГУ, 1974. - 328 с.

2. Винославська О. В. Психологія: Навчальний посібник. - К. : IHКОC, 2005. - $352 \mathrm{c}$.

3. Подоляк Л. Г. Психологія вищої школи: Навчальний посібник для магістрантів і аспірантів / Л. Г. Подоляк, В. І. Юрченко, К. : ТОВ “Філ-студія", 2006. - 320 с.

4. Самарин Ю. А. Очерки психологии ума / Ю. А. Самарин. М. : Издательство академии педагогических наук РСФСР, 1962. $504 \mathrm{c}$.

5. Ушинський К. Д. Вибрані педагогічні твори / К. Д. Ушинський. - К. : Радянська школа, 1949. - 416 с.

Алина Коваль. Физиологические, психологические и социокультурные особенности студенческого возраста.

Студенчество можно рассматривать как социальнодемографическую группу, стадию сочиализачии, которая характеризируется специфическими особенностями. При работе со студентами нужно учитывать закономерности и психологические механизмы их личностного развития, которые обусловлень физиологическими, психологическими и соииокультурными особенностями юношеского возраста.

Ключевые слова: студенчество, сочиализачия, развитие, личность.

Alina Koval. Physiological, psychological and socio-cultural peculiarities of student age.

The students can be considered as socio-demographic group or special phase (the student days) which is characterized with special features. Working with students it's needed to take into account psychological mechanisms of their individual development, which are caused by social development and psychological and physiological peculiarities of student age.

Key words: the students, socialization, development, individual.

Стаття надійшла до редакційної колегії 15.05.2014 


\section{Kondratska Ludmila Anatoliyivna \\ Volodymyr Hnatiuk Ternopil National Pedagogical University
SOTERIOLOGIKAL STRATEGY OF REFORMING OF PROFESSIONAL EDUCATION

(C) Kondratska L. A., 2014

The article deals with the problem of the actuality and contents of epistemic strategy of future specialists' personal development, revelation of epistemological status and methodological grounds for the future specialists' cognition of the essence in the context of clear demarcation between philosophical and humanitarian discourse. The clarification of the prospects and abilities of perfect (apocatastasive) responsibility of a cognitive person, analysis the theory of the essence interpretation and methodological application of modern interpretive strategies of professional education; revealing the contents and stages of the development of epistemological competence of future specialists, defining the structural and functional model of educational technologies of future specialists' epistemological self-correction and analysis the ways of its fulfillment are reflected.

Key words: epistemic strategy, soteriological discourse, world view apperception, intuition of co-message, cognitive and corrective technology.

The descriptive methodology doubtlessly plays an important role in achieving possible success in the area of modern professional education. Being a catalyst for previous achievements and neglects in educational process (of classical, non-classical, post-non-classical types), it immutably makes the participants of pedagogical interaction change the main context of cognition of the essence of professional objectness. The range of these changes is impressive: from admitting logical and methodological standards of experimental verification of one professional theory and denying this approach as a means to learn the truth with the help of competing different theories to counterinduction that suggests the possibility of explaining theoretical facts of one discipline from the point of view of another and the search for the alternative mutual explanation and, therefore, new understanding of valuable and purposeful position of the particapants of the cognitive activity and their personal features.

The last post-positive vector has activated in educators' memory the opposition of two significant positions. According to the first position, the guarantee of observing the Aletheia is the development of serious creative thinking. According to the second position, the mystery of Sphinx is humbly accepted by a heart of a creative person only in the case of intuitive awareness-unity (transcendental expectation) and not awareness-discovery. 


\section{Збірник наукових статей}

For altitude of thoughtful human activity (on the level of sense making) ends beyond the scope of the activity theory, and the joint of introspective mediation is situated in the single semantic field (B. Bratus) or supraindividual schemes of humanity (L. Vyhotsky). So, mediation as an act of thinking tends to be not incorporation (interiorisation) of information by a person but co-existence with other people's ideas and in their world. This understanding is especially important in modern multicultural environment.

All the said above gives grounds to suggest that the aim of the article is the problem of pedagogical epistemology as a means of educational reforming. This aim requires discussing such issues as:

- revealing epistemological status and methodological grounds for the future specialists' cognition of the essence in the context of clear demarcation between philosophical and humanitarian discourses;

- defining the subject and object of the cognition of the essence and the main directions of its epistemological research;

- clarifying the prospects and abilities of perfect (apocatastasive) responsibility of a cognitive person;

- analysing the theory of the essence interpretation and methodological application of modern interpretive strategies of professional education;

- revealing the contents and stages of the development of epistemological competence of future specialists;

- defining the structural and functional model of educational technologies of future specialists' epistemological self-correction and analysing the ways of its fulfillment.

The paradox of "readiness but unability" of future specialists to comprehend the essence (in case of developed frustrated tolerance of choice, the decision to "concretize" and even substitute it) is objective since being in the situation of voluntary solitude in "Plato's cave", they consider the aim of their epistemological activity to be simply the comprehension of the ways of self-presence in the "otherness" without existential experience of transcendental expectation of meeting the "otherness".

However, professor O. Ukhtomsky underlines that "individuals will not comprehend the essence as a categorical principle until they are centered and speak on their own unless they get rid of their twin - arrogant and self-sufficient intellect" [3]. This position was supported by Russian philosopher I. Kireyevsky who states: "Real essence does not correspond to the image or conclusion drawn on deduction by a comprehending person. Intellectual contemplation of the essence functions sensibly but while reflecting, it separates the very essence from its independent existence and sense (energy)" [2, p. 99]. S. Horuzhy stresses that even the position of a "live participant of the event-being", the position of an "inner-outer observer", the position of a person who experiences the ontological 
existence, who tries to keep the unity, reliability and meaningfulness of the description does not give the expected result [5, p. 75]. He says: "Each attempt to get not only the form but the whole world of knowledge from the "pure self" even regarding as an absolute participant of transcendental apperception is fatal because in the process of scientific interference the dual nature of the essence and its independent existence will elude the observers, limiting itself on the pantheist belief" [5, p. 302]. So, "the essence is revealed in such a way that people have deserved it (italics by L. K.) by their past and present" [3, p. 77].

So, the final comprehension and arguments for the reality or unreality of the proposed in the text variant of modeling the essence of objectness ("its sign") of the professional information implies world view apperception what means redirecting future specialists from the belief in power of intellect to realising their creative inability and to belief in higher wisdom and hope (humble expectation) for help to comprehend the essence. The mechanism of this "contextual reframing" appears to be affective intellectual revelation of the greatness of God's creation. The spiritual entasy which humbles "Faust's spirit" lasts only few minutes. But I. Ilin argues that this short-lasting energetic connection with the truth appears for a person "a forgotten air by means of which the objectness of things reveals in a different way" [1, p. 89]. It brings about "the confidence in the invisible and realisation of the expected" [Свр., 11:1], hence it actualizes conscience belief in the light of God's grace, hope (expecting feeling) for its spiritual, life giving effect and finally - for the feeling of love" [3, p. 467]. That is why the scientist stresses that the highest level of humanitarian knowledge development is love [3, p. 469].

So, the awareness of the essence of objectness (as the objective signified) requires spiritual dedication. This supra-situational activity is directed to achieve "the norms of soul spirituality" [4, p. 284] and causes the phenomena which is described by O. Ukhtomsky as "passing through the self" and creating "a distance in advance" what means the distance from the person who contemplates to the one who accepts thankfully the essence of the objectness as a result of the lasting transcendental expectation, energetic connection and "instantaneous meeting with the pure". It is caused by such epistemic characteristics as "intuition of co-message" (O. Ukhtomsky) and the ability to co-exist thoughtfully with the essence which is being comprehended.

In the context of the declared epistemological competence of future specialists, the intuition of co-message proves a means of revealing and defining the essence of objectness and also the grounds for or basis or beginning of further comprehension of "the existence mystery of the world and people" [1, p. 24]. The educational and informational situation of postmodernism and post-structuralism is not an exception as we can read in 
the statement: "Reading is not an objective process of revealing the meaning but making the text meaningful because it doesn't have any meaning itself" [1, p. 187]. In the era of total crisis the desire to justify the supra-sensitivity makes the following characteristics of the future specialists' intuition of co-message evident. They are conscientious faith (I. Ilin) and the will to the sacred (M. Khrenov).

The definition to Ilin's declared notion "conscientious belief" is best given by saint Feofan Zatvornyk ("Recluse"). He says: "It is the vital need to revive godlike sense in learning the truth" [6, p. 461], and to be more exact - "the vital need in true knowledge which lightens scared awareness with hope and love" [4, p. 458]. By the way, this formula for wisdom (Sophia consists of Faith, Hope and Love) is invented by V. Soloviov in his research work "Philosophical Principles of Integral Knowledge" where he revives the idea of Platonic love (eros) as a way to learn the truth.

So, conscientious faith is an ability to perceive everything around with the help of a pure soul so that the inner sense of things (invisible for the "blind") will get revealed with its immortal aspects [3, p. 68], it is a unique way to get into irreal prophetic spirit of time and space continuum that is on the edge of dreams and children's mentality.

Another aspect of the so called intuition of co-message is the will to the sacred which, on M. Khrenov's opinion, is a characteristic of a creative person of a marginal type who obligatory, in each transitional epoch (especially in the contemporary epoch of POST), has to make a choice between the life for death's sake and the death for life's sake. The new methodology of co-existence with the truth caused by the mentioned facts implies future specialists as creative individuals to have an ability in adaptive maximum and synaisthesis (from Greek - co-feelings, sympathy, empathy) that is a systemic ability of human perception and a characteristic of recapitulation of all spiritual and soul strengthes.Both characteristics of future specialists - the ability in adaptive maximum and synaisthesis correspond with patristical understanding of direct inclusion of the professional act into "existence-event" of the nature (as a complete unity) and life (as multiple view). In our theory they complete the structural contents of the epistemological competence of future specialist.

Verifying the comprehension of the professional subject essence requires from students not only actualization but correction (amplification) of their own cognitive, emotional, affective, psycho-motion resources in the direction of their self-perfection. That means that acquiring professional knowledge is not the final aim but a means of future specialists' personal development. One of the ways of technical provision of this transformational process, as it gets clear from the experience, can be the strategy of future specialists' epistemological self-correction. Its modeling is based on the existential understanding of activity as the act of defining 
the sense (D. Leontiev, G. Deleuze, O. Karpov), and on cognitive theories of identical elements (S. Dmytriev), contemplation as learning (M. Bershadsky, V. Huzeiev), phenomenological reduction (E. Husserl, P. Prechtl, M. Mamardashvili). We have distinguished effective pedagogical conditions to implantation of this educational strategy:

- to make decent and intellectual surrounding of seeking the truth("transintellectual life obsessed with the truth" K. Levin);

- to motivate epistemological self-correction of the participants of pedagogical interaction;

- to provide free self-defining and to activate future specialists' personal resources;

- to perform epistemological concept in teaching professional subjects.

The realization of these conditions is based on the regularities of mutual dependence:

- development of the inborn cognitive activity and the effectiveness of its involvement in the process of seeking the truth;

- future specialists' comprehension of their spiritual state and development of their ability to relegational functioning as personalities;

- the experience gained by individuals concerning their responsible choice and the character of pedagogical accompaniment of their educational activity as spiritual development.

Functioning of these regularities is determined not only by didactic but also special principles such as spirituality of the educational process; integral (sobornost) and hierarchy of the educational process; providing the freedom of choice for future creative personalities of their own personal educational direction; personal responsibility and educational reflection; spiral and concentric search for epistemological reference; creative and dialogical interaction; contemplation as spiritual perfection. So, technological model of future specialists' epistemological self-correction suggests providing the readiness for the verification of the essence of the professional knowledge what points to spiritual self-perfection in order to fulfill effectively their soteriological mission in post cultural society. In condition of modern environmental educational situation its providing will help young thinking people to distinguish real and specific measures of true independence.

\section{Literature}

1. Ильин И. А. О сопротивлении злу силой / И. А. Ильин. - М. : Даръ. $-2005 .-464$ с.

2. Киреевский И. В. О характере просвещения Европы и о его отношении к просвещению России. Письмо к гр. Е. Е. Комаровскому / И. В. Киреевский, П. В. Киреевский. Полн.собр соч.: в 4-х т.- Т. 1. Калуга : ИПЦ «Гриф», 2006. - 242 с. 
3. Ухтомский А. А. Интуиция совести / А. А. Ухтомский. СПб. : Петербургский писатель, 1996. - 502 с.

4. Феофан Затворник. Христианская психология / Феофан Затворник. - М. : Даниловский благовестник, 2005. - С. 403-483.

5. Хоружий С. С. Феноменология аскезы / С. С. Хоружий. - М. : Изд-во Братства во имя святого кн. Александра Невского, 2000. $180 \mathrm{c}$.

Людмила Кондрацька. Сотеріологічна стратегія реформування професійної освіти.

У статті розглядається проблема актуальності $i$ змісту епістемічної стратегії реформування професійної освіти, яка спрямована не лише на розвиток дизайнового мислення, але й на сутнісну видозміну самого суб'єкта пізнання. Пропонується характеристика структури світоглядної аппериепиії студента та педагогічні умови ї̈ реалізації.

Ключові слова: епістемічна стратегія, сотеріологічний дискурс, світоглядна аппериеепџія, інтуїція со-вісті, когнітивно-корекційна технологія.

Людмила Кондрацкая. Сотериологическая стратегия реформирования профессионального бразования.

В статье рассматривается проблема актуальности и содержания эпистемической стратегии реформирования профессионального образования, которая предполагает не только развитие дизайнового мышления, но и сущностное преображение самого субъекта познания. Предложена характеристика структуры мировоззренческой апперцепции студента и педагогические условия ее реализачии.

Ключевые слова: эпистемическая стратегия, сотериологический дискурс, мировоззренческая апперцепџия, интуиция совести, когнитивно-коррекционная технология.

Статья поступила в редакционную коллегию 30.04.2014

УДК 37.013

Копилова Світлана Вікторівна

Херсонський державний університет

\section{РОЛЬ СОЦІАЛЬНО-КОМУНІКАЦІЙНИХ ПРАКТИК У ФУНКЦІОНУВАННІ СОЦІАЛЬНО-ПЕДАГОГІЧНОЇ СИСТЕМИ}

Взаємодія суб'єктів у педагогічній системі розглядається як соиіокультурне явище, механізм набуття досвіду, фактор професійної соиіалізації. Соціальна взаємодія в освіті характеризується єдністю 
ціннісно-оріснтаційної, пізнавальної, перетворювальної, комунікативної сторін і може бути забезпечена через організацію, управління, спілкування.

Ключові слова: сочіальна взаємодія, педагогічна взаємодія, соціальнопедагогічна система, організачія, управління, спілкування.

Необхідність підвищення якості й ефективності педагогічного процесу змушує переосмислювати теоретичні положення. У традиційних підходах до розглядання соціально-педагогічних систем увага науковців зосереджувалася на структурі особистості й діяльності; залежно від обраної позиції перевага надавалась особистісно-орієнтованим чи діяльнісним концепціям, хоча деякі автори вказують на особистісно-діяльнісний підхід. Поза увагою науковців залишались важливі соціальні феномени - процеси комунікації та форми соціальної взаємодії, які мають визначальне значення у будь-якій сфері людської діяльності, насамперед, педагогічній.

Мета: на основі аналізу характеру взаємозв'язку соціального і педагогічного в явищах освіти теоретично обгрунтувати роль соціально-комунікаційних практик у функціонуванні соціальнопедагогічної системи. Досягнення поставленої мети може бути здійснене на міждисциплінарній основі. Проблема соціальної й педагогічної взаємодії стала предметом осмислення в соціології (С. Карепова, В. Болгаріна), педагогічній психології (Н. Салміна, Г. Глотова), педагогіці (Т. Дмитренко, Т. Колбіна, Т. Лаврик).

Взаємодія у словниках тлумачиться і як взаємна підтримка, і як взаємний зв'язок явищ [4]. Взаємодія - філософська категорія, що відбиває процеси впливу об'єктів один на одного, їх взаємну зумовленість та породження одним об'єктом іншого. У загальній соціології «соціальне» тлумачиться як сукупність соціальних відносин між індивідами чи групами людей під час їхньої взаємодії між собою; воно виявляється у ставленні один до одного, до себе i свого становища в суспільстві, до свого оточення, до тих чи інших ситуацій, конкретних подій і явищ тощо [5]. Оскільки у будь-якій системі суспільних відносин типи взаємодій завжди характеризуються яскраво вираженим соціальним аспектом, то й педагогічна взаємодія у педагогічному процесі уособлює соціальне, що виникає між суб'єктами. Певний інтерес представляє дослідження С. Кареповою історичної еволюції поглядів на соціальну взаємодію у працях класиків соціологічної думки. Взаємодія розглядається як сукупність зв'язків, що об'єднують та притягують людей, володіють специфічними ознаками (Е. Дюркгейм); як основа людської трудової діяльності (К. Маркс); детермінанта людських вчинків (М. Вебер); взаємні впливи людей зумовлені цілями й інтересами (Г. Зиммель). 


\section{Збірник наукових статей}

Поняття соціальної взаємодії в дослідженнях провідних теоретичних шкіл XX століття розглядається як [3]: мікромодель соціальної системи; комунікація 3 однаковою системою символізування; передумова інтегрованості системи; передумова конфлікту; механізм створення нової реальності; соціальні практики, що формують структуру суспільства. Висновуємо, що процеси соціальної взаємодії активізують комунікацію в системі, а їх тривалість і частота забезпечують узгодженість та інтегративність системи. У педагогічній науці, 3 одного боку, взаємодія розглядається як соціокультурне явище, 3 другого - як механізм набуття досвіду в педагогічному процесі, з третього - як чинник соціалізації особистості. Розглянемо зазначені аспекти. Поняття «соціальна взаємодія» $є$ ключовим у сфері дослідження навчально-виховного процесу. Такий підхід, на думку П. Сорокіна, $є$ правомірним лише за умови, якщо йдеться про значиму, свідому взаємодію двох або більше індивідів, яка у процесі впливу суб'єкта на іншого стає ціннісно значущою. Процес значущої людської взаємодії складається з трьох компонентів: суб'єктів, що свідомо мислять і діють; цінностей і норм, які складають основу цієї взаємодії; відкритих дій i матеріальних носіїв, за допомогою яких об'єктивуються і соціалізуються цінності й норми [5]. Вплив у результаті взаємодії здійснюється за умови усвідомленості, цінності для об'єкта впливу та прояву відповідної активності. Основними ознаками педагогічної взаємодії $\epsilon$ : фактори, що зумовлюють діяльність; рівень готовності виконавців до діяльності, особистість виконавців. Саме через взаємодію педагогів 3 індивідуальним i колективним суб'єктами здійснюється викладання та учіння як види соціокультурної діяльності.

У семіотико-психологічних дослідженнях людина розглядається як знак, а у ¥ї формах життєдіяльності відбитий закріплений оточуючий природний та соціальний світ; саме ці форми життєдіяльності виражаються у формі різних зовнішніх властивостей людини - міміці й пантоміміці, тембрі голосу, діях і вчинках, у всьому, що доступне безпосередньому чуттєвому сприйняттю. Описана вище сукупність властивостей утворює особливу семіотичну систему, яку можна назвати природною семіотикою життя людини. Носієм способів та механізмів людської життєдіяльності є людина. Мотиви діяльності, способи емоційного реагування на різні життєві ситуації, загальнолюдські моральні норми переважно засвоюються через декодування іншої людини як знаку засвоєних ним способів та механізмів життєдіяльності; ті, хто навчаються, розпредмечують i привласнюють їх. У взаємодії 3 іншими людьми кожна людина реалізує як мінімум чотири взаємопов'язані семіотичні функції: а) бути знаком для іншої людини; б) бути знаком для самого себе; 
в) ставитися до іншої людини як до знаку; г) ставитися до себе самого як до знаку [1].

Змістове наповнення процесу соціальної взаємодії в освіті має характеризуватися наявністю кількох сторін: пізнавальної, що забезпечує формування, збереження та функціонування необхідних зразків (моделей реальності); ціннісно-орієнтаційної (цілемотиваційний аспект); комунікативної, пов'язаної зі спілкуванням суб'єктів, суб'єкта 3 соціумом; перетворювальної (технікотехнологічної). Отже, традиційні педагогічні підходи, які головний акцент у педагогічному процесі роблять на пізнавальній діяльності, $\epsilon$ обмеженими. Вважаємо, що забезпечення ціннісно-орієнтаційної складової можливе через організацію, комунікативної - через спілкування, перетворювальної - через управління. Найважливішою стороною педагогічної взаємодії $є$ діяльнісні відносини суб'єктів освіти. Деякі дослідники визначають сутність педагогічної взаємодії як зв'язок, що опосередковує взаємовідносини суб'єкта й об'єкта виховання у педагогічній системі. Педагогічна взаємодія містить у собі співвідношення педагогічного явища i його активного сприйняття, власну активність вихованця, що виявляється у відповідних впливах як на самого себе, так і на педагога. Тому виділяють суб'єкт-суб'єктні (міжсуб'єктні) і суб'єкт-об'єктні (особистісно-діяльнісні) стосунки, які взаємопов'язані i взаємозумовлені. Викладач має цінувати у навчальній діяльності не лише те, як він передає студенту знання, як вчить його правилам поведінки тощо. Дуже важливо, чи спосіб життя самого педагога відповідає тим нормам, дотримання яких він вимагає від студента, як особистість педагога-вихователя виявляється у діяльності. Суб'єкт-суб'єктні взаємозв'язки впливають на суб'єктоб'єктні, розширюючи і збагачуючи їх зміст. Лише завдяки духовній спільності педагога й студентського колективу навчання не зводиться до передачі знань, а виливається в багатогранні взаємини: кожного викладача пов'язує зі студентами система різноманітних інтересів.

Т. Колбіна розглядає проблему соціальної взаємодії з позицій формування досвіду міжкультурної комунікації. Процес навчання $є$ спільною діяльністю педагога i студентів, а діалог між ними $\epsilon$ звичайним способом взаємин, а не штучно створеною формою комунікації. Підкреслюється, що діалогічність навчання допомагає особистості відшукувати свої цінності i смисли, а також усвідомлювати їх під час комунікації з іншими учасниками навчальної взаємодії в атмосфері відкритості, вільного обміну думками та емоціями [2, с. 19].

Важливим завданням педагога є організація взаємодії суб'єктів навчального процесу на основі спілкування, у процесі якого відбувається взаємний вплив та їхнє взаємне збагачення завдяки тому, 


\section{Збірник наукових статей}

що духовне надбання однієї людини стає спільним надбанням суб'єктів спілкування. Інший аспект дослідження взаємозв'язку соціальних і педагогічних процесів полягає в обгрунтуванні соціальної взаємодії як механізму набуття досвіду. Л. Виготський обгрунтовує соціальний механізм детермінації i регуляції набуття досвіду як продукту учіння. Учений доводить, що в онтогенезі під час взаємодії індивіда 3 об'єктом відбувається перехід від біологічної до соціальної детермінації через оволодіння культурно-історичним досвідом, основним засобом якого $\epsilon$ мова. Інтеріоризація опосередкованих мовою соціальних відносин, перехід від виконання пізнавальної діяльності на зовнішньому, соціальному рівні до внутрішнього - в плані індивідуальної свідомості - лежить в основі розвитку вищих психічних функцій. 3 позицій знаково-символічного підходу, взаємодія розглядається як чинник особистісного розвитку суб'єктів педагогічної системи у процесі оволодіння досвідом. Об'єктивні істини знаходять відображення у сфері суб'єктивного світу і після опредмечування у символах стають придатними для введення до навчально-виховного процесу. Вторинна суб'єктивація істини відбувається під час навчальної діяльності, причому іiі розвивальна функція реалізується лише за умови такої організації взаємодії викладачів і студентів, за якої студент виступає у ролі співучасника відкриття, що дозволить розпредметити істину; у протилежному випадку символи лише перейдуть у сферу пам'яті i не набудуть смислового значення.

Третій аспект пов'язаний з розгляданням педагогічної взаємодії як засобу й фактору соціалізації особистості (у тому числі, професійної). Саме завдяки їй індивід накопичує соціальний досвід, адаптується до умов середовища, стає соціально зрілою особистістю, готовою до співжиття у суспільстві. Система суспільних відносин впливає на життєдіяльність особистості на чотирьох рівнях. Першим і чи не найважливішим є загальні умови життєдіяльності, створені суспільством, другим - умови діяльності у сфері освіти, третім - умови групового спілкування (група, колектив, команда), четвертим проблемні ситуації, в які потрапляє індивід. Аналіз розглянутих підходів дозволяє констатувати: розв'язання головної суперечності педагогічного процесу щодо узгодження суспільних вимог та індивідуальних потреб суб'єктів педагогічного процесу, можливе на основі урахування закономірностей зв'язку соціального й педагогічного в явищах освіти. У педагогічній системі, яка за своїм смислом орієнтована на поведінку інших, визначальне значення мають форми соціальної взаємодії та комунікації.

Висновки. Взаємодія суб'єктів у педагогічній системі є соціокультурним явищем, механізмом набуття досвіду, фактором 
професійної соціалізації. Соціальна взаємодія передбачає наявність: суб'єктів, що свідомо мислять і діють; цінностей і норм, які складають основу цієї взаємодії; відкритих дій і матеріальних носіїв, за допомогою яких об'єктивуються і соціалізуються цінності і норми. У педагогічній взаємодії набувають значення фактори, що зумовлюють діяльність; рівень готовності виконавців до діяльності, особистість виконавців. Змістове наповнення процесу соціальної взаємодії в освіті характеризується наявністю кількох сторін: пізнавальної, що забезпечує формування, збереження та функціонування необхідних зразків (моделей реальності); ціннісно-орієнтаційної (цілемотиваційний аспект); комунікативної, пов'язаної зі спілкуванням суб'єктів, суб'єкта 3 соціумом; перетворювальної (технікотехнологічної), що забезпечується через організацію, управління, спілкування. Організація взаємодії суб'єктів навчального процесу здійснюється на основі спілкування, у процесі якого відбувається взаємний вплив і їх взаємне збагачення. Через організацію досягається і узгодженість взаємодії. При проектуванні соціально-педагогічних систем доцільно враховувати не тільки діяльнісний та особистісний підходи, а й брати до уваги закономірності соціальної взаємодії, які представлені в соціально-комунікаційній парадигмі. Осмислення іiі положень становить інтерес для подальших досліджень у галузі соціальної педагогіки.

\section{Література}

1. Глотова Г. А. Человек и знак: Семиотико-психологические аспекты онтогенеза человека / Г. А. Глотова. - Свердловск : Урал. унта, 1990. $-256 \mathrm{c}$.

2. Колбіна Т. В. Формування у студентів досвіду міжкультурної комунікації: монографія / Т. В. Колбіна. - Х. : «ІНЖЕК», 2012. - 168 с.

3. Карепова С. Г. Социальное взаимодействие: исторический и современный аспект социологического знания: авт. канд. социол. наук / С. Г. Карепова. - Москва, 2011. - 20 с.

4. Ожегов С. И. Толковый словарь русского языка С. И. Ожегов, Н. Ю. Шведова. - М. : Аз, 1996. - 928 с.

5. Педагогічна соціологія / В. Болгаріна та ін. - Тернопіль : Підручники і посібники, 1998. - 144 с.

Копылова Светлана. Роль социально-коммуникационных практик в функционировании социально-педагогической системы.

Взаимодействие субъектов в сочиально-педагогической системе рассматривается как социокультурное явление, механизм приобретения опыта, фактор сочиализации. Социальное взаимодействие в образовании характеризуется единством ценностно-ориентационной, познавательной, преобразовательной, 
Збірник наукових статей

коммуникативной сторон и может быть обеспечена через организацию, управление, общение.

Ключевые слова: сочиальное взаимодействие, педагогическое взаимодействие, социально-педагогическая система, организация, управление, общение.

Kopylova Svitlana. The role of social communication practice in the functioning of the social pedagogical system.

Interaction of subjects in social pedagogical system is exemind as a social cultural phenomenon, the mechanism of gaining of experience factor of professional socialization. Social interaction in the education is characterized by unity of value-orientation, cognitive, transformative, communicative parties. It can be achieved through the organization, management and communication.

Key words: social interaction, pedagogical interaction, social pedagogical system, organization, management, communication.

Стаття надійшла до редакційної колегії 13.05.2014

УДК 159.923.2:37.011.3-051]:167.1-022.253-047.44

(C) Костикова О. В., 2014.

Костикова Ольга Владимировна

Харьковский национальный педагогический университет

им. Г.С. Сковороды

\section{К ПРОБЛЕМЕ АДЕКВАТНОЙ САМООЦЕНКИ ЛИЧНОСТИ УЧИТЕЛЯ}

В статье рассматриваются некоторые возрастные аспекты самосознания личности, динамика формирования самооценки у детей и школьников. Анализируются результаты изучения самооченки личности студентов - будущих учителей. Приводятся выводы и рекомендации.

Ключевые слова: самооценка, самосознание, личность, возраст, студенты, учитель.

Наше внимание привлекла проблема самооценки личности у студентов как будущих преподавателей. Как известно, адекватная самооценка личности учителя, в комплексе, конечно, с рядом профессионально значимых и нравственных качеств личности, является определенной гарантией того, что такой учитель сформирует устойчивую высокую адекватную бесконфликтную самооценку у своих учеников. Именно адекватная высокая самооценка способна обеспечить уверенное поведение личности, самоуважение, гармоничное соотношение в осознании возможностей, способностей 
человека и его уровня притязаний в постановке достижимых конструктивных целей при социально-адекватном поведении.

Целью статьи явился теоретический анализ возрастной динамики формирования самооценки личности и анализ результатов психодиагностического исследования самооценки личности у студентов ХНПУ им. Г. С. Сковороды.

Проблема самооценки личности привлекала внимание многих психологов, работающих над исследованиями, как в области общей психологии, психологии личности, так и возрастной и педагогической, социальной психологии (Р. Бернс, М. Кле, И. Кулагина, А. Петровский). Такой интерес закономерен, так как самооценка является основой самосознания личности, а самосознание определяет «Я-концепцию» личности. Целесообразным является и продолжение исследований по данной проблеме, углубление и уточнение психолого-педагогических условий по формированию высокой адекватной самооценки личности молодого поколения. Очень своевременной нам представляется изучение самооценки личности у будущих учителей на современном этапе, ориентируясь на актуальный лозунг «Освіта - збереже Україну».

В контексте проблемы исследования самооценки личности и необходимой компетентности в этой области знаний будущих учителей считаем целесообразным отметить ряд возрастных аспектов в динамике развития самосознания личности.

Вспомним, что в раннем возрасте при интенсивном развитии психических функций возникают основы самосознания и к трем годам появляется исключительно эмоциональная, завышенная самооценка. Данный феномен обусловлен потребностью ребенка в эмоциональной безопасности, принятии и объясняется глубокой связью самосознания с развитием эмоционально-потребностной сферой в раннем детстве.

В дошкольном возрасте возникают рациональные компоненты самооценки, осознание некоторых личностных качеств и поведения, согласующегося с требованием взрослых. Несмотря на интенсивное личностное развитие, дошкольники оценивают себя оптимистично, но поверхностно. В целом высокая самооценка дошкольника помогает ребенку осваивать новые виды деятельности, проявлять социальную активность и без тревожности включаться в занятия учебного типа. При этом завышенная самооценка, характерная для большинства шестилетних детей, приводит к сложности понимания педагогической оценки, так как оценка учебной работы ассоциируется у таких детей с оценкой личности.

У младших школьников самооценка личности становится более адекватной и дифференцированной, мнение о себе более обоснованным. Дети младшего школьного возраста различают свои 


\section{Збірник наукових статей}

физические и духовные качества, оценивают свои способности и поведение, сравнивают себя со сверстниками. Новый аспект самосознания - чувство компетентности, которое зависит от результативности учебной деятельности, осознания младшими школьниками как способностей так и своих умений качественно выполнять различные задания и отражается на самооценке ребенка, его самоуважении и самопринятии.

Подросток открывает для себя собственный внутренний мир. Возникает особая форма самосознания - чувство взрослости отношение подростка к себе как к взрослому, очень субъективное представление. Объективно подросток не способен включиться во взрослую жизнь не физически, не психологически, не социально, но активно стремится и претендует на определенные права и статус. После поисков себя и личностной нестабильности у подростка формируется «Я-концепция» - целостная система внутренне согласованных представлений о себе, образов «Я», важнейший этап в развитии самосознания.

Старшеклассники в большей степени в целом принимают себя, чем подростки, их самоуважение выше. Старшеклассник должен не только представлять свое будущее в общих чертах, а осознавать способы достижения поставленных целей. Осознание временной перспективы и построение жизненных планов требуют от старшеклассника уверенности в себе, в своих силах и возможностях, самоуважения. Юность - период стабилизации личности, формирования мировоззрения, профессионального и личностного самоопределения. Высокая самооценка в ранней юности выступает как необходимое условие решения жизненно важных задач.

Для нас особый интерес, в возрастной динамике формирования самооценки личности, представляла информация о специфике личностных особенностей в юношеском возрасте. В качестве испытуемых в нашем исследовании участвовали юноши и девушки студенты специализаций хореография и музыка. После выполнения методики «Самооценка личности» анализ результатов показал, что у $50 \%$ (!) участников психодиагностики была выявлена неадекватно завышенная самооценка, 37,5\% студентов - показали оптимальный результат - самоцценка высокая адекватная и у 12,5\% студентов самооценка оказалась выше среднего. Другие показатели вариантов самооценки отсутствовали, в частности, «низкая самооценка», что положительно. Но фактически половина респондентов нашего исследования продемонстрировали самооценку высокую, но неадекватную. Такой «результат» потребует от личности студентов определенной внутренней работы, самопсихокоррекции и участия в социальном психотренинге. Так как известно, что неадекватность в 

оценке собственной личности может спровоцировать дезорганизацию деятельности вследствие нарушений в самоменеджменте, определенную социальную дезадаптацию, так как личность с неадекватной завышенной самооценкой склонна считать, что ее недооценивают окружающие, проявляя некоторое высокомерие и недостаточную самокритичность.

Работа над собственной самооценкой личности обязательна для студентов - будущих учителей, так как их будущая педагогическая направленность деятельности, как преподавателей хореографии и музыки требует большой ответственности для формирования высокой адекватной самооценки у их учеников. Мы надеемся, что наши студенты - будущие учителя для развития у детей высокой адекватной самооценки и чувства компетентности будут создавать в учебном процессе положительный эмоциональный фон, атмосферу психологического комфорта и поддержки. Наши будущие преподаватели хореографии и музыки будут сочетать содержательную оценку в психолого-педагогической деятельности с положительными ожиданиями для каждого учащегося. Оценивать конкретную работу, но не личность, не сравнивая детей между собой. Ориентировать учеников на индивидуальные достижения - чтобы работа завтрашняя была лучше вчерашней, конструктивно сочетая критику и одобрение.

\section{Литература}

1. Залесский Г. Е. Психология мировоззрения и убеждений личности / Г. Е. Залесский. - М., 1994.

2. Кулагина И. Ю. Возрастная психология (Развитие ребенка от рождения до 17 лет): Учебное пособие. - 4-е изд. / И. Ю. Кулагина. М. : Изд-во УРАО, 1998. - 176 с.

\section{Ольга Костікова. Щодо проблеми адекватної самооцінки особистості вчителя.}

Y статті розглядаються деякі вікові аспекти самосвідомості особистості, динаміка формування самооиінки у дітей $i$ иколярів. Аналізуються результати вивчення самоочінки особистості студентів - майбутніх учителів. Наводяться висновки і рекомендації. Ключові слова: самоочиінка, самосвідомість, особистість, вік, студенти, вчитель.

Olga Kostikova. To the problem of adequate self-appraisal, the personality of the teacher.

This article discusses some age-related aspects of consciousness of the person, the dynamics of formation of self-esteem in children and schoolchildren. Analyzes the results of a study of the self-identity of the students - future teachers. Provides conclusions and recommendations.

Key words: self-esteem, identity, personality, age, students, teacher.

Статья поступила в редакционную коллегию 12.05.2014 


\section{Костюченко Олена Вікторівна}

(c) Костюченко О. В., 2014.

Київський національний університет культури і мистецтв

\section{ТВОРЧИЙ ПОТЕНЦІАЛ ЯК ЗМІСТОВИЙ АСПЕКТ ПРОФЕСІЙНОСТІ МАЙБУТНЬОГО ДИЗАЙНЕРА-СТИЛІСТА ПЕРУКАРСЬКОГО МИСТЕЦТВА}

Означені складові у структурі професійності дизайнера-стиліста перукарського мистецтва, підкоряючись загальним закономірностям творчого розвитку його особистості, серед яких розумова, когнітивна, мотивачійна, особистісна, творча. Розглянуто складові та принципи когнітивних моделей осмислення художньої иілісності створюваного актуального образу моделі, як продукту творчої діяльності та гнучкої естетичної конщепџї̈ дизайнера перукарського мистецтва.

Ключові слова: творчий потенціал, складові професійності дизайнера

У будь-якій педагогічній i психологічній системі постає проблема формування творчої особистості та включення ï в певну діяльність для реалізації творчого потенціалу, стимулюючи пошук ефективних засобів і методів розвитку афективної, особистісної, соціальної та когнітивної сфер особистості. I це зрозуміло, тому що підвищення вимог соціального середовища до творчого сприймання, нестандартного бачення у відомому нових можливостей його функціонування, продукування необмеженої кількість ідей, гнучкості мислення й поведінки, самостійності, готовності розраховувати тільки на самого себе, до відкритості новим формам самореалізації та особистісної життєтворчості ставлять вимогу впровадження технологій з творчої активації особистості майбутнього фахівця.

В аналізі даної проблеми ми спираємося на дослідження творчої діяльності, у яких вивчалися закономірності творчості (Л. С. Виготський, Я. О. Пономарьов, О. М. Матюшкін та ін.); етапність творчого процесу (В. О. Моляко, Я. О. Пономарьов, В. А. Роменець та ін.); процес реалізації творчих стратегій та практик (В. О. Моляко, Я. О. Пономарьов, А. Б. Коваленко та ін.), умови становлення творчої особистості та розвитку творчих здібностей (П. Торренс, В. С. Юркевич, В. С. Чудновський та ін.), впливу креативності на прояви й становлення творчості як суб'єктивного, індивідуального стилю діяльності особистості (Дж. Гілфорд, Ф. Баррон, Е. Торренс, М. О. Холодна та інші). 
На нашу думку, найбільш продуктивне визначення творчого потенціалу пропонується в рамках діяльнісного підходу. Під цим поняттям розуміється властивість, що характеризує міру можливостей особистості здійснювати творчу діяльність (Г. С. Альтшуллер, Г. Х. Валеєв, В. М. Жураковський, Ю. Н. Кулюткін, Н. В. Мартинович,

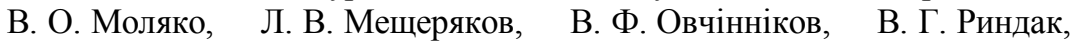
О. К. Чаштигін). Причому прихильники даного підходу відзначають, що при дослідженні творчого потенціалу надзвичайно важливо розглядати не лише сукупність властивостей, що становлять його структуру, а й характер та інтенсивність їх взаємозв'язку.

Розвиток творчих здібностей особистості майбутнього фахівця у будь-якій сфері здійснюється через залучення його до різних видів творчої діяльності, зокрема художньої творчості, яка охоплює весь процес роботи і включає в себе художню діяльність, художнє освоєння об'єктивної складної та багатогранної дійсності, відбираючи ті іiі сторони i прояви, які 3 найбільшою силою розкривають власний внутрішній світ, світогляд, смаки, мистецьку позицію. Серед основних ознак художньої творчості є: новизна й оригінальність діяльності або іiі результату, художнього продукту; суспільна значимість результатів творчості, збагачення досвіду попередників та прогресивний характер діяльності.

Серед видів синтетичного мистецтва чільне місце належить перукарському мистецтву, основою якого є дизайн і стилістика, де втілюється глибина авторської думки через пластику, точність та узгодженість рухів, здатність до інтерпретації, активізацію сенсомоторних, перцептивних, мнемічних, імажинативних, мисленнєвих i комунікативних здібностей, які тісно пов'язані 3 загальною спрямованістю особистості, 3 мірою стійкості схильності фахівця до певної діяльності. В структурі професійності особистості дизайнеру стилю важливими $\epsilon$ такі складові: розумовий компонент (високий рівень пізнавальної активності і цікавість, швидкість i точність виконання розумових операцій, що обумовлена стійкістю уваги і оперативної пам'яті, сформованістю навичок логічного мислення i чіткий алгоритм дії, багатство активного словника, швидкість виникнення i оригінальність візуальних i вербальних асоціацій, виражена установка на творче виконання завдання, розвиток творчого мислення і фантазії, бажання навчатися $[1 ; 4 ; 5]$ ); когнітивний компонент (розуміння матеріалу, його осмислення, образне мислення); якості (емпатія, вольові якості творче ставлення особистості до тієі діяльності, що виконується, психологічна готовність навчатися і працювати, усвідомлення своїх здібностей, критичність, мотивація і самостійність їх оцінки [2]); особистісний художньо-естетичний досвід (ціннісне ставлення до перукарського 
мистецтва, художньо-естетичні знання і професійні вміння, що забезпечує формування естетичних смаків i почуттів, естетичного світосприймання і поглядів) та здатність до творчості [3]. Арсеналом професійних методів фахівців у сфері дизайну має базуватися на досвіді креативного арт-впливу, художніх засобах самореалізації експресивної діяльності, вираження назовні сприйнятої та опрацьованої інформації та трансформування піi відповідно до свого індивідуального досвіду.

Творча за своєю суттю діяльність дизайнера-стиліста перукарського мистецтва не завжди може мати видатні результати, однак участь у творчій діяльності має позитивний вплив на особистість через удосконалення власних якостей майбутнього фахівця саме як творчої особистості, емоційну заглибленість у діяльність, загальне й естетичне задоволення від процесу і продуктів діяльності; розуміння суті проблеми, задачі, ситуації; несвідоме, інтуїтивне розв'язання проблеми («поза логічне»); стратегіальність в інтелектуальній поведінці (особистісні можливості продукувати проекти); багатоваріантність рішень; швидкість рішень, оцінок, прогнозів; мистецтво знаходити; вибирати (винахідливість).

Когнітивні моделі перукарського мистецтва базуються на візуальному сприйманні, яке враховує динамічний аспект переробки інформації. Воно грунтуються на принципі «від загального до часткового», який забезпечує актуальне становлення образу, коли сприймання відбувається від цілого до все більш диференційованих структур. Творчим $\epsilon$ таке сприймання, в якому автоматично відбувається фіксація нового в об'єкті, ситуації, взаєминах між сприйманими зовнішніми параметрами об'єкта дизайну. Для створення певних образів важливою складовою є здатність їх уявляти.

Дизайнери-стилісти у своїй діяльності керуються принципом творчого комбінування, реконструювання та аналогізування ідей, образів і засобів. Особливістю цього способу є осмислення художньої цілісності створюваного затребуваного образу та гнучкої естетичної концепції дизайнера - як професійної оцінки у поєднанні 3 відповідністю образу естетичним вимогам та творчою імпровізацією. Багатомірність і багатофункціональність образів, що формуються у дизайнера стилю протягом його діяльності, з'являються у ході активного здобуття й обробки інформації, $\epsilon$ специфічним сплавом відображення реального об'єкта, сприйнятого суб'єктом, i попереднього досвіду суб'єкта щодо сприйняття подібних об'єктів і взаємодії з ними, тобто виявленою структурою внутрішнього відображення дійсності [3].

Теоретичний аналіз проблеми дозволив сформулювати такі висновки: 
1) структура професійності підкоряючись

загальним закономірностям творчого розвитку особистості майбутнього дизайнера-стиліста визначається поєднанням ряду складових, до яких відносять розумову, когнітивну, мотиваційну, особистісну, творчу;

2) сенсорно-перцептивні процеси забезпечують виділення найважливіших для розв'язання конкретного завдання аспектів, здійснюють таку обробку інформації від органів чуття, яка веде до побудови образу, адекватного як предметові, так i завданням діяльності;

3) активізація творчого сприймання та творчого осмислення дизайнера-стиліста сприятиме його творчій діяльності і навпаки у творчо-пізнавальній діяльності виникає нове сприймання об'єкту для реалізації творчих задумів, що виникає внаслідок внутрішньої роботи 3 опанування емоційно-психологічного, інформаційного, культурного впливу.

\section{Література}

1. Дмитренко Н. Рефлексивне мислення в контексті теоретичного та емпіричного пізнання психічної реальності / Н. Дмитренко // Психологія і суспільство. - 2005. - № 4. - С 93-97.

2. Здібності, творчість, обдарованість: теорія, методика, результати досліджень / За ред. В. О. Моляко, О. Л. Музика. Житомир : Рута, 2006. - 320 с.

3. Костюченко О. В. Рекреаційні аспекти активних творчих методів сенсорно-перцептивної активації для дітей підліткового та юнацького віку / О.В.Костюченко // Проблеми сучасної психології: 3б. наук. пр. Кам'янець-Подільського національного університету ім. I. Огієнка, Інституту психології ім. Г. С. Костюка НАПН України / За ред. акад. С. Д. Максименка, Л. А. Онуфрієвої. - Вип. 19. - Кам'янецьПодільський : Аксіома, 2013. - 860 с. - С. 313-323. $114 \mathrm{c}$.

4. Лук Л. М. Мышление и творчество / Л. М. Лук. - М., 1976. -

5. Матюшкин А. М. Основные направления исследований мышления и творчества / А. М. Матюшкин // Психологический журнал. - 1984. - Т. 5. - № 1. - С. 9-17.

Елена Костюченко. Творческий потенциал как содержательный аспект профессионализма будущего дизайнерастилиста парикмахерского искусства.

Обозначены составляющие в структуре профессионализма дизайнерастилиста парикмахерского искусства, подчиняясь общим закономерностям творческого развития его личности, среди которых интеллектуальная, когнитивная, мотивационная, личностная, творческая. Рассмотрены составляющие и принципь когнитивных моделей осмысления художественной целостности создаваемого 
Збірник наукових статей

актуального образа модели, как продукта творческой деятельности и гибкой эстетической концеепции дизайнера парикмахерского искусства.

Ключевые слова: творческий потенциал, составляющче профессионализма дизайнера

Olena Kostyuchenko. Creative potential as a substantial aspect of professionalism the future of the designer-stylist hairdressing art. Above mentioned components in the structure of professionalism of the designer-stylist hairdressing obeying the General principles of the creative development of his personality, among which mental, cognitive, motivational, personal, creative. Considered the components and principles of cognitive models of understanding the artistic integrity of the created actual image model, a product of the creative activity and flexible aesthetic concept of the designer of hairdressing art.

Key words: creativity, components of professionalism of the designer.

Стаття надійшла до редакційної колегії 05.04.2014

УДК 161.221.2-021.121-043.86:[615.851:001]

Крайнова Татьяна Ивановна
Украинский союз психотерапевтов, Харьков, Украина

(С) Крайнова Т. И., 2014.

\section{АКТУАЛЬНЫЕ ВОПРОСЫ РАЗВИТИЯ СОВРЕМЕННОЙ ПСИХОТЕРАПИИ КАК НАУКИ}

Статья посвящена становлению психотерапии как самостоятельной научной дисииплины. Рассматриваются вопросы научного обоснования прочессов психотерапевтического взаимодействия, выявляются проблемы, возникаюшие в прочессе становления психотерапии как науки, отмечаются возможности внесения психотерапией своего вклада в междисииплинарное понимание природы человеческой психики.

Ключевье слова: научность психотерапии, психотерапия как наука, психотерапиелогия, психотерапевтическое лечение, эволючионные трудности.

В соответствии со Страсбургской декларацией, психотерапия является независимой научной дисциплиной, практическая деятельность в которой представляет собой независимую и свободную профессию. 
Говоря о развитии психотерапии как самостоятельной научной дисциплины, можно представить ее в двух аспектах: научная психотерапии и психотерапия как наука.

Целью статьи является определение характера междисциплинарных взаимодействий современной научной психотерапии, то есть ее научности, а также выявление сложностей в процессе становления психотерапии как науки.

Современная научная психотерапия базируется на использовании в своих процессах знаний, полученных в других научных дисциплинах (философия, медицина, психология, когнитивная наука, нейрофизиология, антропология, психолингвистика и другие). Эти знания о человеке и человеческих взаимоотношениях имеют признанный научный статус и принимаются мировым научным сообществом как таковые. В таком случае психотерапевтические процессы могут считаться научно обоснованными.

Что же касается психотерапии как науки, то этот вопрос требует особого внимания. Сложность приобретения научного в академическом смысле статуса заключается в том, что психотерапия состоит из двух частей, первая из которых имеет базовый характер субъективности, что не свойственно современному понятию о научности. Первая, и на сегодняшний день наиболее развитая часть психотерапии, это живой динамический процесс взаимодействия двух (или более) людей. Он представляет собой неповторимый мир взаимных психотерапевтических переживаний и мыслительных процессов, возникающих между психотерапевтом и человеком, который обратился к нему за помощью. Назвать этот процесс наукой в прямом смысле этого слова нельзя. Более того, зачастую «научность» или «наукообразность» не приветствуется и самими практикующими психотерапевтами. Прибегая к классике, они утверждают, что невозможно «поверить алгеброй гармонию».

С другой стороны, читая книги основоположников психотерапии, участвуя в конференциях и психотерапевтических семинарах, мы не можем назвать эти явления собственно процессом психотерапии. В итоге, там, где преобладает процесс психотерапии, научное теоретизирование практически неуместно. Там же, где предпринимается попытка теоретического научного обоснования, тонкое, почти неуловимое, ощущение живой психотерапии исчезает, оставляя досаду потери и холод научной терминологии. Cumуацияя названия двух, по сути противоположных процессов одним словом «психотерапия» становится критической, и, возможно, даже тупиковой. 


\section{Збірник наукових статей}

Но, если выйти из эгоцентрического феноменального фрагмента психотерапии и посмотреть шире, то можно заметить, что выход в подобных ситуациях давно уже найден. Например, не является собственно наукой процесс осмотра пациента терапевтом или хирургом. Но есть наука, то есть медицина, которая является основанием этих действий. (В то же время, она получает материал от практического взаимодействия врача и пациента и для своего собственного научного развития). Не может быть наукой в прямом смысле живая человеческая речь, но существует наука, изучающая ее. Это лингвистика. Не может считаться академической наукой художественное творчество, например, поэзия или проза, но может быть наука, его изучающая. Это литературоведение. Это перечисление можно продолжить, и по аналогии предположить, что, вероятнее всего, должна существовать наука, например психотерапиелогия, которая будет изучать общие объективные закономерности процессов взаимодействия между пациентом и психотерапевтом, субъективно протекающих в терапевтической комнате, а также находить их место в общечеловеческом социокультурном контексте. Существующие книги и учебники по психотерапии, в которых авторы раскрывают, систематизируют, обобщают ее процессы, и являются началом создания такой науки о психотерапии. Или, подойдя с другой стороны, необходимо называть процесс взаимодействия психотерапевта и пациента «Психотерапевтическое лечение», «Психотерапевтическое развитие», a научную часть, с еe строгой объективной упорядоченностью, собственно «Психотерапия». Важно, чтобы эти два разнородных процесса имели два различающихся названия.

В любом случае, должна быть выделена часть, которая, не смешивалась бы с субъективно протекающими в психотерапевтической комнате процессами.

В таком случае, актуальными становятся следующие вопросы:

1. Кто будут эти люди - ученые, исследователи, изучающие процессы психотерапии?

2. Достаточно ли материала для подобных исследований, и каков характер этого материала?

Расширяя первый из этих вопросов можно спросить о том, будет ли допущен к этому закрытому процессу, которым является сегодня психотерапия, кто-либо «чужой», то есть человек, сам не являющийся психотерапевтом? Таким специалистом потенциально может быть, например, философ, социолог, нейрофизиолог или представитель развивающейся науки - коммуникологии. С одной стороны, эта позиция невовлечения в процесс дает шанс быть более беспристрастным, а значит, объективным и научным. С другой, сможет ли такой человек, ученый, понять и почувствовать все 
особенности такого тонкого, можно даже сказать тончайшего явления, как психотерапевтические отношения? Или этим исследователем всетаки может оставаться только сам психотерапевт, при условии развития определенных профессиональных качеств? Возможно ли сочетание того и другого? Ответы на эти вопросы может дать только опыт практического взаимодействия в поле междисциплинарного пространства.

Далее встает вопрос о материале, который подлежит научному изучению. На сегодняшний день, ни пациент, ни терапевт, ни их терапевтические отношения не могут непосредственно стать объектом наблюдения. Научному миру может предстать только клинический материал, переданный психотерапевтом в ходе его супервизионной или интервизионной деятельности. Позиция пациента в этой ситуации может быть представлена минимально: он всего лишь имеет возможность обратиться в этическую комиссию с личной претензией к терапевту и его деятельности, или, в положительном варианте, выразить свою благодарность руководителю клиники или Центра, в котором работает его психотерапевт. C позиций же научного материала, представленного другой стороной психотерапевтического процесса, то есть пациентом, информация безнадежно утрачивается, о чем нельзя не сожалеть. Выход из этого положения может лежать в области предоставления пациентам возможности высказать свое мнение (при сохранении конфиденциальности) о ходе психотерапии более подробно.

Проблемной является еще одна часть психотерапевтического материала, являющегося объектом научного изучения. Это теперь уже не практический, а теоретический материал. В настоящее время современная психотерапия состоит из множества направлений. Возможно, они достаточно развиты в отношении наличия собственной теоретической базы, но не имеют общей методологической платформы. Несомненно, что в своей теоретической части современная психотерапия (или психотерапиелогия) могла бы более успешно развиваться как самостоятельная наука, если бы различные направления объединили свои усилия в поисках единой научнопсихотерапевтической парадигмы. Работа в этом направлении уже начата. Примером может служить книга Б. Д. Карвасарского «Психотерапия», [1] но проблема требует дальнейших научнопсихотерапевтическх исследований в пространстве профессионального взаимодействия представителей paзличных напрвлений.

В связи с актуальностью этих и других вопросов, возникающих в процессе становления современной психотерапии как самостоятельной научной дисцииплины, в харьковском отделении 


\section{Збірник наукових статей}

Украинского союза психотерапевтов в 2012 году была создана Секция научно-психотерапевтических исследований. Областью ее текущих и ближайших научных интересов является дальнейший поиск научного обоснования психотерапевтических прочессов, в основе которого лежит связь с другими науками о человеке. Так, например, современная неврология [2] дает возможность объективно рассматривать ранние взаимодействия матери и новорожденного ребенка. Это способствует отходу от тех психотерапевтических утверждений, которые предполагают наличие у младенцев тех психических функций, которые не соответствуют текущему состоянию их психических функций [3]. Таким образом, поиск профессиональных путей «примирения» в спорных моментах теоретических гипотез, например, в психоаналитической психотерапии, лежит в плоскости неоспоримых на сегодняшний день научных фактов.

Также исследования ведутся в области становления современной психотерапии как науки. Научно-исследовательская группа, состоящая из представителей нескольких психотерапевтических направлений, продолжает уже начатый поиск общих факторов в различных психотерапевтических подходах. Такое профессиональное сотворчество является последовательным продвижением к формированию единой научно-психотерапевтической парадигмы.

Творческий диалог с представителями философии, психологии, педагогики, которые могут увидеть процесс психотерапии, как изнутри, так и с отстраненной позиции другого научного направления, дает возможность дальнейшего развития, как для самой психотерапии, так и для таких направлений, как Философия психотерапии, Психотерапевтически ориентированная педагогика, Психотерапевтически ориентированная психология.

Создание журнала «Современная научная психотерапия», даст возможность публиковать не только результаты этих и других исследований в области современной психотерапии, но и возможность людям, обращавшимся к психотерапевту за помощью, выразить свои мысли и чувства в рубрике «Я проходил психотерапию».

Большое внимание в данной научно-психотерапевтической исследовательской группе уделяется особенностям обучения психотерапевтов. В этом плане «психотерапиелогия», как формирующаяся наука, может быть полезной не только для развития психотерапии, но и внести свой вклад в общенаучное пространство. Только в таком случае она может не только надеяться на научный статус, но и быть принятой в мировое научное сообщество.

Таким образом, становление современной психотерапии как самостоятельной научной дисциплины имеет свои эволюционные 
трудности. В данной статье был представлен опыт частичного преодоления некоторых из них. Была затронута только небольшая часть тех проблем, которые встают на пути ее развития и требуют творческого коллективного и междисциплинарного решения .

\section{Литература}

1. Карвасарский Б. Д. Психотерапия / Б. Д. Карвасарский // Учебник для студентов медицинских ВУЗов. - Спб. : Питер, 2002. $672 \mathrm{c}$.

2. Скворцов И. А. Неврология развития / И. А. Скворцов // Руководство для врачей. - М. : Издательство Литтерра, 2008.

3. Klein M. A contribution to the theory of anxiety and guilt. In The writings of Melanie Klein. Vol. 3. - London : Hogarth, 1975, - P. 25-42.

\section{Тетяна Крайнова. Актуальні питання розвитку сучасної психотерапії як науки.}

Стаття присвячена становленню психотерапії як самостійної наукової дисципліни. Розглядаються питання наукового обтрунтування процесів психотерапевтичної взаємодії, виявляються проблеми, щчо виникають у процесі ставлення психотерапії як науки, відзначаються можливості внесення психотерапією свого внеску в міждисциплінарне розуміння природи людської психіки.

Ключові слова: наочність психотерапії, психотерапія як наука, психотерапіелогія, психотерапевтичне лікування, еволюиійні труднощі.

Tatiana Krainova. Topical issues of the development of modern psychotherapy as a science.

The article is dedicated to formation of psychotherapy as independent scientific discipline. Issues of scientific grounding of the processes of psychotherapeutic interaction came under review, problems in the process of formation of psychotherapy as a science are revealed, and possibilities of psychotherapy to make a contribution to interdisciplinary understanding of the nature of human psyche are mentioned.

Key words: scientific character of psychotherapy, psychotherapy as a science, science of psychotherapy, evolutionary difficulties.

Статья поступила в редакционную коллегию 01.01.2014 
Лаппо Віолетта Валеріївна

(c) Лаппо В. В., 2014.

Коломийський інститут ДВНЗ «Прикарпатський

національний університет імені Василя Стефаника»

\section{ТЕОРЕТИКО-МЕТОДИЧНІ ЗАСАДИ ФОРМУВАННЯ ОСОБИСТОЇ Й ПРОФЕСІЙНОЇ ГІДНОСТІ В ПРОЦЕСІ ДУХОВНОГО РОЗВИТКУ МАЙБУТНЬОГО ФАХІВЦЯ}

У статті розкрито сутність категорії "культура гідності особистості". 3'ясовано історико-філософське підгрунтя та психолого-педагогічний зміст ї̈ тлумачення. Доводиться теза про важливість формування як особистої так і професійної гідності в умовах сучасного ВНЗ. Наголошено на ефективності залучення рефлексивно-експліцитного методу у різні форми організації виховної роботи зі студентською молоддю.

Ключові слова: культура гідності, особиста гідність, професійна гідність, студентська молодь, рефлексивно-експліичтний метод.

Зміна ціннісних пріоритетів сучасного українського суспільства обумовлює нові вимоги до виховання підростаючого покоління. Закони України "Про освіту", "Про вищу освіту”, Національна доктрина розвитку освіти України у XXI столітті, Програма виховання дітей та учнівської молоді в Україні й інші державні та нормативні документи передбачають створення системи виховання, яка забезпечила б можливості для постійного духовного самовдосконалення особистості, формування інтелектуального та культурного потенціалу як найвищої цінності нації. 3-поміж провідних духовних цінностей чільне місце посідає гідність. Означене почуття повинно бути притаманним кожній людині. Життя людини в культурі гідності звеличить іï як у власних очах, так і в очах усього суспільства.

Гідність - це, насамперед, відчуття людиною своєї цінності. Кожній людині притаманні цінності, які сукупно утворюють феномен гідності: особистісна гідність - цінність конкретної особистості. Відтак професійна гідність - цінність, детермінована професійною діяльністю.

Гідність передбачає загальнообов'язкове визнання самоцінності людини, іiі здатності бути моральним суб’єктом. Потенційна наявність гідності визнається за усіма людьми. Проте збереження гідності (як особистої, так і професійної) вимагає здійснення особливих моральних вчинків і відмови від аморальних [1]. 
Витоки інтерпретування гідності беруть свій початок в античності. Аристотель, Платон, Протагор, Цицерон, Сократ пов'язували гідність особистості 3 виваженими судженнями, правильними вчинками, законослухняністю. В їхніх працях знаходимо врахування індивідуальних особливостей та особистісних цінностей у вихованні.

Саме в епоху античності людина була вперше проголошена “мірою всіх речей” (Протагор) і розглядалась як вище творіння природи. Сократ стверджував, що пізнати світ людина може, тільки пізнавши себе, свою душу, свої дії та вчинки. Він пов'язував гідність людини з розвитком іiі моральної самосвідомості [5, с. 12-13].

Для Аристотеля почуття власної гідності означало ставлення людини до інших. Він підкреслював, що хто зважає на інших, але ні перед ким не принижується, а з людьми гідними тримається належним чином, той гордий.

Особливе значення для розуміння категорії гідності мають теоретичні розробки I. Канта. Визнання цінності i високого призначення людини незалежно від ії станової належності, соціального походження, раси, нації - основа трактування категорії гідності великого мислителя. Кант виступав 3 вимогою поважати гідність людини і стверджував, що людина повинна бути не засобом, а лише метою [3].

У вітчизняній педагогіці та психології проблема виховання гідності висвітлювалась у роботах І. Д. Беха, А. С. Макаренка, В. О. Сухомлинського, О. А. Захаренка, І. О. Синиці, С. В. Удовицької, Н. В. Чиренко, Ю. М. Зайцева; у зарубіжній - Д. Дьюї, Я. Корчака, М. Монтессорі, С. Френе, які визначали гідність як право дитини на повагу.

Аналіз сучасних психологічних досліджень дозволяє уточнити поняття гідності як складного інтегративного особистісного утворення, яке характеризується цілісним самоствердженням на основі рефлексійно-емоційної настанови на повагу до іншої людини та самоповагу. Вона $є$ умовою виховання духовного потенціалу особистості, що дозволяє їй нормативно діяти в різноманітних соціальних ситуаціях. Гідність стимулює свідому саморегуляцію та самовиховання. Гідність визначається сформованими в особистості світоглядом, установками, звичками; підлягає цілеспрямованому вихованню й самовихованню та поєднує у собі емоційно-ціннісний, когнітивний, поведінково-діяльнісний компоненти [4, с. 21].

Визначення сутності досліджуваного феномену спирається на сентенцію про те, що культура гідності здебільшого залежить від сучасного розвитку права й етичної культури. Це відповідає базовому розумінню культури особистості як гармонії знань, умінь і ставлень. 
Знання й уміння опосередковують ставлення. Ставлення - це реальний дійсний зв'язок, який встановлює людина із суб'єктами і об'єктами навколишньої дійсності у своїй свідомості. Це зв'язок “Я - Я”, “Я Ти", “Я - суспільство, нація". Показниками ставлення особистості є iï якості, які опосередковано несуть у собі значуще для людей - цінність.

В означеному контексті перед сучасною вищою школою постає завдання - формувати професійну гідність майбутнього спеціаліста в процесі опанування фаховими знаннями і вміннями.

Позаяк формування культури гідності особистості є проблемою не лише надзвичайно важливою, але й складною, тенденцією сьогодення $\epsilon$ впровадження рефлексивно-експліцитного методу, розробленого І. Д. Бехом [2]. Реалізація названого методу апелює до позитивного поведінкового досвіду молодої людини, сприяє глибинному зануренню в особистісну самосвідомість вихованця.

Назва цього методу походить від слів “рефлексія" (лат. reflexio вигин, відображення) - мислення, яке особа спрямовує на свій внутрішній світ, самоаналіз; та експліцитний (від лат. exsplicitus розгорнутий) - явний, чіткий, доступний зовнішньому спостереженню і розумінню.

Суть методу полягає в тому, щоб через атмосферу довіри педагога до вихованця, упевненість у наявності в молоді основ шляхетності, самоповаги, їхній орієнтації на добро, удосконалення повсякденного життя, спонукати студентство до грунтовного усвідомлення свого внутрішнього світу (емоцій, почуттів, мотивів, цінностей, потреб, інтересів, бажань, прагнень, ідеалів). Адже без розуміння цієї психічної сфери неможливо вести мову про вихованця як суб'єкта духовної діяльності, на основі якої відбувається особистісний саморозвиток та боротьба зі своїм егоїстичними потягами. Рефлексія виступає основою самосвідомості.

Процес занурення вихованця у свої душевні глибини, їх осмислення і перебудова здійснюється під керівництвом педагога, який активізує рефлексивне мислення вихованця та сприяє винесенню його результатів назовні, тобто готує їх експлікацію з метою більшого усвідомлення і надання їм індивідуальної значущості.

Метод застосовується у такій послідовності:

- глибоке ознайомлення зі змістом духовної цінності, яка буде виховуватись;

- визначення засобів формування, механізму виховання якості чи цінності;

- усвідомлення, як зазначений феномен вплине на стимулювання позитивної спрямованості вихованця (Я доброцентроване); 
- усвідомлення, як предмет виховання вплине на зменшення егоїзму учня (Я - егоцентроване);

- як якість чи цінність діє на іншого, на суспільне життя?;

- як вона вплине на майбутню професійну діяльність?;

- як вона оцінюється людьми?;

- чим вона винагороджується?;

- яка альтернатива певної чесноти?;

- які обставини можуть до неї призвести?;

- якими засобами можна цього уникнути?

Основна перевага рефлексивно-експліцитного методу полягає в тому, що вихованець не відчуває себе об'єктом педагогічного впливу, "рабом" моральної норми, не переживає стану підкорення моральним істинам, а сприймає їх, як власний вільний вибір.

Означений метод передбачає також розуміння педагогом i вихованцем свого внутрішнього світу: світу емоцій, почуттів, мотивів, цінностей, потреб, інтересів, прагнень, ідеалів.

Основу (базис) цього методу становлять:

1) віра педагога у духовний потенціал студента (довіра);

2) доброцентрованість вихованця;

3) наявність у нього шляхетності, самоповаги;

4) урізноманітнення форм, методів i засобів поза аудиторної виховної роботи.

Водночас унікальність цього методу вбачаємо у тому, що його застосування може посилити виховну ефективність більшості форм та методів становлення особистості: бесід, круглих столів, дискусій, диспутів, мозкового штурму, педагогічних ситуацій, ділових ігор тощо. Приміром застосування рефлексивно-експліцитного методу під час проектної діяльності зумовило позитивні зміни у ставленні до обраного професійного шляху. Участь у проекті "Світочі нашої професії сприяла вихованню в студентів других-четвертих курсів Коломийського інституту ДВНЗ «Прикарпатський національний університет імені Василя Стефаника» культури особистісної, професійної та національної гідності. При цьому значно зросла ініціативність, активність молоді, позитивна мотивація до пізнавальної діяльності. Студенти вчилися працювати самостійно, досягаючи мети проекту, а також дослухалися до порад куратора та однокурсників під час обговорення етапів виконання проекту. Учасники проекту робили власний вибір об'єктів для дослідження (не лише відомих та маловідомих історичних постатей, які прославили певну професію).

Зважаючи на ефективність рефлексивно-експліцитного методу в умовах вищої школи подальшого дослідження й розробки потребує система заходів, спрямованих на ознайомлення педагогів (насамперед кураторів академічних груп) з виховними можливостями означеного 
методу та способами його залучення в процес духовного розвитку особистості студента.

\section{Література}

1. Бех І. Д. Гідність як духовний геном особистості / I. Д. Бех // Педагогіка і психологія. - 2009. - № 1 (62). - С. 76-89.

2. Бех І.Д. Рефлексивно-експліцитний метод у вихованні особистості / І. Д. Бех // Рідна школа. - 2012. - № 12. - С. 3-7.

3. Кант И. О характере и образе мыслей / И. Кант // Соч. в 6-ти т. - Т. 6. - М. : Мысль, 1966. - С. 540-588.

4. Маценко Ж. М. Духовність: феномен психології та об'єкт виховання / Ж. М. Маценко. - К. : Освіта України, 2010. - 100 с.

5. Помиткін Е. О. Психологія духовного розвитку особистості: монографія / Е. О. Помиткін.-К. : Наш час, 2005. - 126 с.

Виолетта Лаппо.

Теоретико-методические

основы формирования личного и профессионального достоинства в процессе духовного развития будущего специалиста.

В статье раскрыта сущуность категории "культура достоинства". Установлено историко-философские предпосылки и психологопедагогический смысл ее толкования. Обосновано тезис о важности формирования как личного, так и профессионального достоинства $в$ условиях высшей иколь. Отмечено эффективность привлечения рефлексивно-эксплицитного метода в различные формы организации воспитательной работы со студенческой молодежью.

Ключевые слова: культура достоинства, личное достоинство, профессиональное достоинство, студенческая молодежь, рефлексивно-эксплициитный метод.

Violetta Lappo. Theoretical and methodological basis for the formation of personal and professional dignity in the process of spiritual development of the future expert.

The article reveals the essence of the category " Culture dignity." Set of historical and philosophical background of Psychology and Education and the meaning of its interpretation. Substantiated the thesis about the importance of both personal and professional dignity in high school. Noted the effectiveness of attracting reflexive- explicit method in various forms of educational work with students.

Key words: culture of dignity, dignity, dignity of professional, students, reflexive-explicit method.

Стаття надійшла до редакційної колегії 22.04.2014 


\section{Ластовець Ігор Володимирович}

(C) Ластовець I. В., 2014.

Національна академія внутрішніх справ, м. Київ

\section{ГАРМОНІЗАЦІЯ ОСОБИСТІСНОГО РОЗВИТКУ КУРСАНТА ЯК ПСИХОЛОГІЧНА ПРОБЛЕМА}

Розглянуто проблему гармонізачії особистісного розвитку курсантів вищих навчальних закладів МВС України. Проведено аналіз понять «розвиток», «особистісний розвиток», «гармонійний розвиток», «гармонізація». Виділено психологічні компоненти процесу гармонізаиії особистісного розвитку курсантів (когнітивний, мотиваційний, суб'єктно-діяльнісний, рефлексивний), визначено ӥх психологічний зміст.

Ключові слова: особистісний розвиток, гармонізація, курсанти, вищий навчальний заклад, Міністерство внутрішніх справ.

Об'єктивний процес формування в Україні нової правової системи та системи правоохоронних органів обумовлює гостру потребу в підготовці юридичних кадрів на фундаментальній науковій і правовій основі з урахуванням сучасного вітчизняного та зарубіжного досвіду. Це припускає переорієнтацію юридичної освіти з переважно інформативного типу навчання на навчання, яке дозволяє виявляти $\mathrm{i}$ розвивати у курсантів якості, що забезпечують ефективну професійну діяльність майбутніх правоохоронців та їх безперервний особистісний i професійний розвиток. Особливо актуальним стає питання гармонізації особистісного розвитку курсантів ВНЗ МВС України.

Як відомо, соціальна ситуація розвитку майбутніх працівників ОВС характеризується тим, що вони не тільки навчаються у відомчих вищих навчальних закладах МВС України, а й водночас несуть службу. I якщо специфіка професійного розвитку курсантів досить ретельно досліджена у психологічній літературі, то процеси особистісного розвитку, в тому числі його гармонізації вивчені недостатньо.

Існують різні точки зору на поняття «розвиток», «особистісний розвиток», «гармонійний розвиток». Деякими авторами розвиток розглядається як процес безповоротних, спрямованих по висхідній, закономірних змін, що призводять до виникнення кількісних, якісних $\mathrm{i}$ структурних перетворень психіки і поведінки людини. Інші під розвитком розуміють тільки процес якісних змін, закономірний перехід з одного якісного своєрідного ступеня розвитку на інший. При 
цьому кількісні зміни розглядаються в межах поняття «особистісного росту» $[1 ; 4]$.

Суть гармонійного розвитку людини розкрито, насамперед, в дослідженнях психологів гуманістичного напряму (Е. Фром, А. Маслоу, Р. Ассаджолі, К. Роджерс). Вони звернулися до вивчення психологічно благополучних осіб, які мають здатність відчувати щастя, задоволення від процесу творчої самореалізації, розвитку власних ресурсів і потенціалу. Згідно гуманістичної етики, мета розвитку зрілої особистості - бути самим собою, а умова досягнення цього - бути «людиною для себе», яка реалізує свій життєвий інтерес. Це, насамперед, означає відсутність байдужості до власного «Я» (а звідси і до інших людей), знання своїх істинних потреб, прийняття відповідальності за своє життя і поведінку. Така особистісна позиція приводить до стану плодючості, реалізації можливостей, активізації потенційних сил людини, яка має перспективне і об'єктивний погляд на реальність, що передбачає звільнення від внутрішніх деструкцій [2].

Частіше за все гармонійний розвиток людини у психологічній науці розглядають як збалансований розвиток чотирьох основних сфер: фізичної, емоційно-вольової, інтелектуальної та духовної. Розвиненість емоційно-вольової сфери проявляється у багатстві емоцій та почуттів та вмінні керувати власними станами, що проявляється у поведінці та спілкуванні як ввічливість, тактовність, толерантність, вміння знаходити спільну мову з іншими. Високий рівень розвитку інтелектуальної сфери передбачає уважність, гарну пам'ять, винахідливість, нестандартність мислення тощо. Духовний розвиток знаходить відображення, насамперед, у розвиненій свідомості людини, iii спрямованості на примноження краси, добра та істини. Така людина допомагає іншим, відчуває свою причетність до всіх подій і явищ у світі [3].

Щодо гармонізації процесу особистісного розвитку, то Г. К. Зелинська розуміє під цим збіг суб'єктивної позитивної оцінки свого «Я» і об'єктивної, зовнішньої оцінки даної людини. Суб'єктивна оцінка проявляється по типу «мені добре»; об’єктивна оцінка - по типу «він успішний, він приємний, він корисний» [5].

Розглядаючи гармонізацію як педагогічний процес, I. Г. Іванова вказує, що остання являє собою збалансований, комплексний i взаємозбагачувальний розвиток якостей людини, який сприяє формуванню гармонійної особистості. Структурними компонентами цього процесу $є$ психофізичне, інтелектуальне, духовно-моральне i художньо-естетичне виховання особистості. Рівень сформованості компонентів процесу гармонізації вона визначає за наступними критеріями: когнітивний, емоційний та діяльнісний критерій [5]. 
Формування цілей статті - визначити психологічні компоненти процесу гармонізації особистісного розвитку курсантів ВНЗ МВС України.

На підставі нашого емпіричного дослідження було визначено основні компоненти процесу гармонізації особистісного розвитку курсантів, а саме: когнітивний, мотиваційний, суб'єктно-діяльнісний, рефлексивний. Когнітивний компонент складається 3 придбання курсантами знань про гармонію, гармонійний розвиток, гармонійну особистість. Мотиваційний компонент відбиває актуалізацію у курсантів мотивації до гармонійного розвитку, яка включає в себе мотивацію на здоровий спосіб життя, внутрішню професійну мотивацію, мотивацію до самоактуалізації та саморозвитку. Суб'єктно-діяльнісний компонент передбачає розвиток здатності до діяльності, тобто переносу знань про гармонійний розвиток у конкретні дії. Рефлексивний компонент гармонізації пов'язаний із розвитком саморозуміння, відповідальності за свій особистісний розвиток та життя в цілому.

Висновки. Проведене дослідження дало можливість визначити основні психологічні компоненти процесу гармонізації особистісного розвитку курсантів ВН3 МВС України. Подальше дослідження психологічних умов гармонізації особистісного розвитку курсантів ВНЗ МВС України стане основою для визначення засобів такої гармонізації, розробки програми з оптимізації процесу розвитку та формування гармонійної особистості курсантів МВС України.

\section{Література}

1. Братченко С. Л. Личностный рост и его критерии / С. Л. Братченко, М. Р. Миронова // Психологические проблемы самореализации личности. - СПб., 1997. - С. 38-46.

2. Волков Б. С. Психология развития человека : учеб. пособие для вузов / Б.С. Волков, В. Н. Волкова. - М. : Академический Проект, 2009. -223 c.

3. Додонов Б. И. Гармоническое развитие и типологическое своеобразие личности // Психология формирования и развития личности / Под ред. Л. И. Анцыферовой. - М. : Наука, 1981. - С. 284304.

4. Психология развития. Методическое пособие / сост. доцент, канд. психол.наук Егорова Э. Н. - Изд-ние 3-е, испр. и дополн. Харьков : ИППС, 2006. - 144 с.

5. Степаненко Л. В. Проблема гармонійного та дисгармонійного розвитку особистості в психолого-педагогічній літературі / Л. В. Степаненко // Вісник Харківського державного педагогічного унту ім. Г. С. Сковороди. Психологія. - Харків : ХДПУ, 2002. - Вип. 8. C. $175-179$. 
Збірник наукових статей

Игорь Ластовец. Гармонизация личностного развития курсанта как психологическая проблема.

Рассмотрена проблема гармонизачии личностного развития курсантов высших учебных заведений МВД Украины. Проведен анализ понятий "развитие», «личностное развитие», «гармоничное развитие», «гармонизачия». Выделены психологические компоненты прочесса гармонизации личностного развития курсантов (когнитивный, мотивационный, субъектно-деятельностный, рефлексивный), определено их психологическое содержание.

Ключевые слова: личностное развитие, гармонизачия, курсанты, выстее учебное заведение, Министерство внутренних дел.

Igor Lastovets. Cadets' personal development harmonisation as a pshychological problem.

The article considers the high-educational cadets' problem of personal development harmonization in Ukrainian MIA universities. The analysis of such concepts as: "development", "personal development", "harmonious development", "harmonization" was done. Were also highlighted the psychological components of the cadets' personal development's harmonization process (they were: cognitive, motivational, activitysubjective, reflexive). Their psychological content was defined as well.

Key words: personal development, harmonization, cadets, higher education institution, the Ministry of Internal Affairs.

Стаття надійшла до редакційної колегії 14.05.2014

УДК 004.77:81'243

(C) Лукашова Л. В., 2014

Лукашова Людмила Василівна

Харківський національний економічний університет імені С. Кузнеця

\section{ВИКОРИСТАННЯ ІНФОРМАЦІЙНО-КОМУНІКАЦІЙНИХ ТЕХНОЛОГІЙ ДЛЯ ФОРМУВАННЯ КОМУНІКАТИВНОӤ КОМПЕТЕНТНОСТІ СТУДЕНТІВ ПРИ ВИВЧЕННІ IHOЗЕМНОÏ МОВИ}

Представлено результати дослідження можливостей застосування інформаиійно-комунікаиійних технологій (IКT) на заняттях 3 іноземної мови. Розглянуто можливі шляхи застосування World Wide Wеb на заняттях з ділової німецької мови.

Ключові слова: мультимедійні засоби, сайти, інтерактивні навчальні посібники. 
Враховуючи стрімкий розвиток комп'ютерної техніки та при наявності всесвітнього Інтернет-павутиння, а також 3 метою підвищення зацікавленості студентів та ефективності навчального процесу особливо актуальним стає використання можливостей інформаційно-комунікаційних технологій (IКТ) при вивченні студентами вузів іноземних мов.

Метою статті є дослідження можливостей використання IКТ та Інтернету на заняттях з іноземної мови.

Інформаційно-комунікаичійні технології - це загальне поняття, що описує різні пристрої, механізми, засоби, алгоритми обробки інформації. Найважливішим сучасним пристроєм ІКТ $є$ комп'ютер, оснащений відповідним програмним забезпеченням, та засоби телекомунікацій разом з розміщеною на них інформацією.

Розглянемо основні напрями використання ІКТ для формування комунікативної компетентності у процесі вивчення іноземних мов. Це, насамперед, використання комп'ютерних навчальних програм та електронних навчальних посібників, можливості таких засобів навчання дозволяють тренувати різні види мовленнєвої діяльності, допомагають краще зрозуміти мовні конструкції. За їх допомогою студенти можуть самостійно пройти тести та визначити рівень володіння іноземною мовою, що сприяе формуванню лінгвістичних навичок, розвитку комунікативних умінь у різноманітних ситуаціях спілкування. Отже, використання ІКТ завдяки автоматизації процес мовної підготовки забезпечує реалізацію індивідуального підходу та інтенсифікацію самостійної роботи студентів.

Використання таких програм, як Power Point, Camtasia, Captivate, при створенні презентацій для введення лексичного, граматичного, країнознавчого матеріалу, створенні інтерактивних підручників робить процес навчання привабливим i легким для розуміння і засвоєння.

Широке використання Інтернет-ресурсів дає можливість доступу до найбагатших джерел іншомовної інформації, що сприяє розвитку комунікативної компетентності. При вивченні німецької мови їх можна використати 3 метою занурення студентів в німецькомовне середовище в позааудиторній і самостійній роботі.

Дослідження Л. С. Нигай [1] i власний досвід педагогічної діяльності довів, що для цього доцільно використовувати ресурси, які будуть схарактеризовані нижче.

Онлайн-версї зарубіжних газет та журналів. Студентам цікавіше і корисніше читати та обговорювати статті й актуальні новини у світі, розміщені на сайтах іноземних газет та журналів, ніж працювати із друкованими виданнями із застарілою інформацією. Перевагою роботи $з$ такими матеріалами $є$ те, що новини в Інтернеті 


\section{Збірник наукових статей}

постійно оновлюються. 3 часом студенти набувають певних навичок та можуть вільно орієнтуватися в широкому колі подій. Найчастіше використовуються такі німецькомовні сайти: www.wirtschaftswoche.de; www.spiegel.de; www.vitamin.de.

Мультимедійні матеріали дають змогу студентам, наприклад, на мові оригіналу слухати пісні, концерти відомих виконавців, інтерв'ю цікавих та відомих людей, дивитися відеоролики за темою, трансляцію популярних телевізійних каналів, останні новини, фільми. Серед студентів найпопулярнішими сайтами $є$ www.youtube.com; www. vkontakte.ru (zpyna deutsch-online); www.google.de; www.zdf.de.

Довідники та енциклопедї допомагають студентам знаходити потрібну інформацію та орієнтуватися в інформаційному Інтернетпросторі. Студенти використовують цей ресурс найчастіше при підготовці до занять та презентацій, написанні рефератів. Найчастіше використовуються сайти: www.wikipedia.de; www.wirtschaftsdeutsch.de; www.lernen.de.

Електронні словники дуже популярні серед студентів, вони зручні в користуванні, з наявних можна вибрати словник, що краще всього підходить для конкретного перекладу, $є$ також спеціалізовані словники, серед таких можна порекомендувати словник для Windows Multitran. За допомогою деяких словників, як наприклад Promt, можна перекладати навіть тексти.

Для підготовки до занять 3 використанням IKT викладачеві, звичайно, потрібно значно більше часу, ніж для підготовки до занять за традиційною технологією. Крім того важко знайти підручник, що оптимально відповідає вимогам програми, тому в навчальному процесі викладачам часто доводиться користуватися кількома підручниками, 3 цієї причини все більшої популярності набувають інтерактивні навчальні посібники, авторами яких $є$ саме викладачі. Щоб створити такий підручник, необхідно мати певні навички та знання.

3 метою підвищення кваліфікації викладачів у Харківському національному економічному університеті імені С. Кузнеця були організовані курси 3 інтерактивних елементів Moodle для створення інтерактивних підручників. Висококваліфіковані викладачі факультету економічної інформатики проводять змістовні теоретичні та практичні заняття. По закінченні курсів кожен з викладачів-слухачів курсів створює фрагмент інтерактивного підручника за однією 3 тем дисципліни, яку він викладає, та презентує свою розробку на екзамені. Набуті знання дають змогу в подальшому створювати авторські інтерактивні підручники, що відповідають вимогам навчальних програм у вищих навчальних закладах України. При створенні підручників застосовуються програми PowerPoint, Camtasia та 
Captivate. Можливості, які надають ці програми, вражають своєю різноманітністю, наочністю та цікавістю.

Слід відзначити, що такі підручники дійсно підвищують зацікавленість студентів та впливають на результати вивчення теми. Правда, при відсутності чи перервах в роботі Інтернету робота 3 інтерактивними підручниками на заняттях ускладнена. Створенню та актуалізації інтерактивних підручників передує значна та ретельна робота, але це - потреба часу. При викладанні курсу ділової німецької мови прагнення до актуальності, автентичності та спеціалізації набагато більше, ніж при викладанні основного курсу німецької мови. Можливості використання World Wide Web на таких заняттях дуже різноманітні. Вони дозволяють студентам та викладачам роздрукувати актуальні статті з преси, статистичні дані та графіки про ринок праці, інформацію про розвиток бізнесу в регіоні, місті чи на фірмі, адаптувати їх для заняття; знайти тексти про історію розвитку СС та пояснення найважливіших економічних термінів; провести пошук літератури з економічних наук та замовити іiі у видавництві; замовити безкоштовно інформаційний матеріал та публікації різних фірм та установ; знайти інформацію про реквізити банків, телефонні коди, вартість телефонних переговорів, про розклад руху поїздів та польотів літаків; знайти інформацію про адреси фірм певної галузі або будьякого населеного пункту; знайти місця для проведення практики та ознайомитися 3 оголошеннями про наявність вільних робочих місць; знайомитися з актуальними біржовими курсами та брати участь в іграх на біржі; знайомитися з актуальним календарем ярмарок та виставок $\mathrm{i}$ одержувати вичерпну інформацію про них; подати безкоштовне оголошення в Інтернеті; отримати детальну інформацію про мовні курси з ділової німецької мови тощо.

Через брак часу та значне навантаження на викладачів використання Інтернету для більшості 3 них $є$ дуже складним. Щоб полегшити пошук інформації, в інституті міжкультурної комунікації (Дюссельдорф, ФРН) було розроблено та розміщено в Інтернеті «Інтернет-бібліографію 3 ділової німецької мови 3 коментарями», 3 якою можна ознайомитися за адресою: http://www.wirtschaftsdeutsch.de/webliographie/.

Такі бібліографічні матеріали можуть використовуватись не тільки викладачами, але й студентами. Огляд прикладів та вправ для вивчення іноземних мов, в тому числі англійською, французькою та німецькою мовами, можна знайти за адресою: http://www.ualberta.ca/ german/present.htm.

Разом 3 цим слід підкреслити, що використання IKT у навчальному процесі не виключає традиційні методи навчання, а 
гармонійно поєднується 3 ними на усіх етапах вивчення іноземної мови: ознайомлення, тренування, застосування, контроль.

Отже, використання ІКТ дозволяс не лише значно підвищити ефективність навчання, але й залучати студентів до подальшого самостійного вивчення іноземної мови.

Подальші дослідження будуть присвячені вивченню досвіду застосування ІКТ при викладанні іноземної мови за кордоном.

\section{Література}

1. Нигай Л. С. Использование ИКТ для формирования коммуникативной компетентности на уроках английского языка / Л. С. Нигай // Педагогическое мастерство: материалы III междунар. науч. конф. (г. Москва, 2013 г.). - М. : Буки-Веди, 2013. - С. 117-119.

2. Jung M. Internet und Computer im Unterricht Wirtschaftsdeutsch / M. Jung// Didaktik der Wirtschaftsfremdsprachen- und Fernunterricht. Vorträge der Fachtagung in Budapest 18.11. - 19.11.1996, Budapest 1997.

Людмила Лукашова. Использование информационнокоммуникационных технологий (ИКТ) для формирования коммуникативной компетентности студентов при изучении иностранного языка.

Представлены результаты исследования возможностей применения информационно-коммуникационных технологий (ИКТ) на занятиях по иностранному языку. Рассмотрень возможные пути применения World Wide Web на занятиях по деловому немецкому языку.

Ключевые слова: мультимедийные средства, сайты, интерактивные учебные пособия.

Ludmila Lukashova. The use of ICT for forming of communications competence of students at foreign language lessons.

The article presents the results of the research into possibilities of information and communication technologies (ICT) at foreign language lessons. The possibilities of the World Wide Web application at business German lessons are also considered.

Key words: multimedia, website, interactive training manual.

Стаття надійшла до редакційної колегії 15.05.2014 


\section{Луніна Марина Леонідівна}

(C) Луніна М. Л., 2014.

Харківський національний економічний університет імені С. Кузнеця

\section{КОМУНІКАТИВНО-ДІЯЛЬНІСНИЙ КОМПОНЕНТ ЯК ОДИН ІЗ ВАЖЛИВИХ СКЛАДНИКІВ ЗМІСТУ МКК}

У статті розглядаються особливості змісту МКК як основного компоненту педагогічної системи формування досвіду МКК. Особлива увага приділяється комунікативно-діяльнісному складнику МКК, який передбачає володіння спеціалістом комунікативною компетенцією $i$ певними професійними вміннями задля успішного здійснення фахової діяльності. Комунікативно-діяльнісний підхід до навчання іноземної мови визначається як провідний у системі мовної підготовки фахівия. Ключові слова: міжскльтурна комунікачія, зміст, комунікативнодіяльнісний компонент, комунікативна компетенція, комунікативнодіяльнісний підхід.

Процеси інтеграції України в європейське та світове товариство, сучасні соціально-економічні умови розвитку суспільства висувають усе вищі вимоги до підготовки фахівців у галузі освіти. 3 огляду на це важлива роль у навчально-виховному процесі ВНЗ відводиться формуванню багатомовної особистості, яка володіє досвідом міжкультурної комунікації і поєднує в собі цінності рідної та іншомовної культур.

Одним із шляхів оновлення змісту освіти та узгодження його із сучасними потребами інтеграції до європейського та світового освітніх просторів $\epsilon$ орієнтація навчальних програм на набуття ключових компетентностей та на створення ефективних механізмів їх досягнення. Основні положення щодо вивчення мов, оцінювання мовленнєвої підготовки особистості знаходимо у Загальноєвропейських Рекомендаціях 3 мовної освіти (2005) [2], які передбачають різні підходи до опанування лінгвістичними одиницями.

Mema cmammi - дослідити особливості міжкультурної комунікації студентів-економістів та розглянути комунікативнодіяльнісний підхід до навчання іноземних мов. Отже, основним елементом педагогічної системи МКК $є$ зміст, який викладачеві необхідно відібрати для того, щоб належно організувати педагогічний процес, а студенту - засвоїти інформацію задля набуття досвіду в певній сфері людської діяльності. Науковець В. С. Безрукова пропонує одне $з$ найбільш вдалих, на нашу думку, визначень поняття «зміст», а саме: «Зміст - це та частина суспільного досвіду поколінь, що 
відбирається відповідно до поставленої мети розвитку людини і у вигляді інформації передається їй» [1, с. 52].

Визначення і обгрунтування змісту освіти є однією з основних проблем сучасної педагогіки, над якою працюють вітчизняні та закордонні вчені й викладачі-практики. Наукові засади формування змісту освіти, зокрема і професійної, розробляються у працях філософів, педагогів, психологів та вчених інших напрямів (С. Батишев, Б. Гершунський, С. Гончаренко, І. Зязюн, В. Краєвський, В. Лєднєв, І. Лернер, М. Махмутов, Н. Ничкало та інші). Питання змісту МКК досліджуються, насамперед, у роботах 3 теорії та методики викладання іноземних мов (О. Бердичевський, І. Бім, I. Воробйова, Н. Гальскова, Н. Гез, Г. Слізарова, Є. Пассов, Ј. House, А. Knapp-Potthoff, M. Liedke та інші).

На сьогодні існує декілька концепцій, які мають значення для визначення змісту МКК. Найбільш відомі концепції запропоновані такими вченими, як I. Лернер, М. Скаткін, В. Краєвський, В. Безрукова, П. Підкасистий, В. Лєднєв та інші. Незважаючи на всі відмінності існуючих концепцій змісту освіти, спільним для них є те, що аналогом змісту науковці пропонують вважати соціальний досвід у певній сфері діяльності людини, який викладач повинен передати, а студент має засвоїти.

Вітчизняний науковець Т. Колбіна слушно зауважує, що особливого значення набуває в цьому зв'язку теоретичне обгрунтування змісту МКК, виокремлення його інваріантних елементів, які слугуватимуть орієнтирами для викладачів у виборі навчальної інформації для організації педагогічного процесу.

Складність визначення змісту МКК полягає в тому, що культура кожного народу постійно розвивається, зумовлюючи тим самим зміни змісту МКК. Сучасні навчальні матеріали, які апелюють до досвіду студентів, розширюють i уточнюють його, допомагають молоді орієнтуватися в контексті іншої культури і відповідним чином будувати свою комунікативну поведінку.

У своїх дослідженнях Т. Колбіна в змісті МКК умовно виділяє наступні компоненти:

1) когнітивний компонент (знання та засвоєна інформація стосовно МКК мають допомагати людині зорієнтуватися в іншій культурі);

2) емоційно-ціннісний компонент (потреби та мотиви людини здійснювати МКК зумовлюють ціннісне ставлення до об'єкта пізнання i перетворювання, а також формування необхідних особистісних якостей);

3) комунікативно-діяльнісний компонент (засвоєні способи діяльності, набуті навички та вміння МКК забезпечують відтворення 
людиною об'єкта пізнання і дозволять у процесі творчої діяльності його подальше перетворення) [3].

Усі компоненти складають цілісну систему, оскільки їх єдність дає можливість сформувати нову якість особистості, якою є готовність до міжкультурної комунікації.

Особливості змісту МКК у педагогічній системі ВНЗ, вважає науковець, полягають, насамперед, у приналежності учасників МКК до різних культур (лінгвокультурних спільнот). Кожний з них є:

1) індивідуумом, носієм тільки йому притаманних рис, ознак, знань, уявлень, емоцій, вмінь, способів діяльності тощо;

2) членом певної професійної групи;

3) представником певної національно-культурної спільноти;

4) представником людства [3].

Отже, у змісті МКК мають бути представлені індивідуальноособистісний зміст, професійний зміст, культурно зумовлений національний зміст, універсальний зміст.

3-поміж названих складників змісту МКК особливу увагу викладачів-практиків привертає саме комунікативно-діяльнісний компонент, який передбачає володіння спеціалістом комунікативною компетенцією і певними професійними вміннями, що дозволяє йому успішно здійснювати фахову діяльність, професійно-ділове й міжособистісне спілкування. Міжкультурна комунікативна компетенція $є$ невід'ємною складовою професійної діяльності й містить у собі здатність особистості використовувати іноземну мову для досягнення професійно значущих цілей [3].

Комунікативно-діяльнісний компонент змісту МКК нерозривно пов'язаний із комунікативною компетенцією. Розробляючи проблему комунікативної компетенції в підготовці фахівців, зарубіжні й вітчизняні вчені (Ю. Пассов, О. Соловова, Т. Колбіна, Р. Мільруд, В. Сафонова, Н. Гальскова, А. Богуш, С. Ніколаєва та ін.), наголошують на важливості цієї компетенції в професійній діяльності фахівця й визначають у їі складі такі компоненти, як лінгвістичний, дискурсивний, соціокультурний, стратегічний. До цього переліку складників деякі дослідники додають прагматичний, соціолінгвістичний, мовленнєвий та соціальний компоненти.

Таким чином, комунікативна компетенція забезпечує не лише формування й функціонування одиниць мовлення, а й здатність спеціаліста організовувати власну мовленнєву й немовленнєву поведінку відповідно до завдань спілкування.

Найбільш вдало усі компоненти змісту МКК реалізуються за умови використання комунікативно-діяльнісного підходу до навчання іноземних мов. 


\section{Збірник наукових статей}

Сучасні педагоги вважають, що комунікативно-діяльнісний підхід передбачає дотримання принципу цілісного вивчення мови i мовлення іє одним із основних у навчанні іноземної мови. При його використанні процес оволодіння мовленням має здійснюватися в ході розв'язання усних i письмових завдань, розташованих у порядку наростання їх складності.

Комунікативно-діяльнісний підхід у навчанні передбачає переорієнтацію навчання з традиційного засвоєння і запам'ятовування готових форм знань на процес їх отримання i функціонування; формування основних видів діяльності (спілкування, пізнавальної і навчальної діяльності), співвідношення i пріоритет яких змінюватимуться впродовж навчання; цілеспрямоване формування основних умінь і навичок як розумових дій на основі поетапного їх відпрацювання. Він дає можливість розглядати процеси спілкування, пізнання і учіння як діяльності, а також прослідкувати їх розвиток від практичного рівня до знаково-символічного.

Можна виділити декілька характеристик діяльнісної позиції студента в навчальному процесі: стійка навчальна мотивація (пізнання, спілкування у формі співробітництва); здатність формулювати мету та визначати умови іiі досягнення (цілепокладання та цілеутримання); володіння діями (предметними та мисленнєвими), які дозволяють вирішувати навчальні завдання (тобто досягти мети); здатність до самоконтролю та самооцінки результатів навчальної діяльності тощо.

Методологія діяльнісного підходу дозволяє представити процес навчання як чітко сплановану систему засвоєння студентами навчально-професійної діяльності, надає простір для розширення i посилення навчання знаннями, вміннями і навичками творчої праці на практико-дослідницькому, науково-дослідницькому й інноваційнодослідницькому рівнях, активно працювати над розвитком мовленнєво-мисленнєвих здібностей, формувати діяльнісне ставлення до процесу навчання. Діяльнісний підхід висуває на перший план комунікативний аспект мови та інтеграцію різних сторін, пов'язаних 3 процесом спілкування.

Аналіз лінгвістичних праць М. Вашуленка, М. Львова, М. Пентилюка, К. Плиско та інших дозволяє зазначити, що суть комунікативної спрямованості мовної освіти полягає у навчанні студентів розв'язувати комунікативні завдання, що сприяє оволодінню творчим мисленням та вільному спілкуванню іноземною мовою. Саме лінгвістичний аспект у комунікативному підході до навчання передбачає оволодіння мовою іншої країни як одним з найважливіших засобів в усіх видах мовленнєвої діяльності, що дозволяє студенту на цій основі створювати власні тексти, будувати діалоги i 
висловлювання (осмислювати мету, планувати і контролювати своє висловлювання), формує культуру спілкування.

Комунікативна спрямованість навчання активізує формування всіх видів мовленнєвої діяльності: вміння слухати, говорити, читати, писати. Так, мова розглядається не просто як один 3 предметів навчального процесу, а як універсальний засіб спілкування на основі знакової системи, що відображає світ.

Отже, для сучасної педагогічної науки визначення i обгрунтування змісту МКК $є$ однією 3 важливих проблем, яку намагаються розв'язати вчені й викладачі-практики. Відбір навчального матеріалу для організації педагогічного процесу МКК має забезпечувати цілісність усіх його інваріантних компонентів. Серед визначених науковцями складників МКК - когнітивного, емоційноціннісного та комунікативно-діяльнісного - особливого аналізу, на нашу думку, потребує останній компонент, адже досвід ціннісного ставлення людини до об'єктів інтелектуальної або практичної діяльності, засобів діяльності, навколишнього світу, до себе та інших людей виявляється у іiі практичній діяльності й комунікативній поведінці.

\section{Література}

1. Безрукова В. С. Педагогика. Проективная педагогика / В. С. Безрукова. - Екатеринбург : Деловая книга, 1996. - 342 с.

2. Загальноєвропейські Рекомендації 3 мовної освіти [Електронний ресурс]. - Режим доступу http://www.twirpx.com/file/612403. - Назва с титул. екрану.

3. Колбіна Т. В. Формування міжкультурної комунікації майбутніх економістів: теоретико-методологічний аспект : монографія / Т. М. Колбіна. - Х. : ІНЖЕК, 2008. - 392 с.

Марина Лунина.

Коммуникативно-деятельностный компонент как один из важных составляющих содержания МКК.

B cтатье рассматриваются особенности содержания МКК как основного компонента педагогической системы формирования опыта МКК. Особенное внимание уделяется коммуникативнодеятельностному компоненту МКК, который предусматривает владение специалистом коммуникативной компетенцией $u$ определенными профессиональными навыками для успешного выполнения профессиональной деятельности. Коммуникативнодеятельностный подход $к$ обучению иностранным языкам определяется как основной в системе языковой подготовки специналиста.

Ключевье слова: межкультурная коммуникация, содержание, коммуникативно-деятельностный компонент, коммуникативная компетенция, коммуникативно-деятельностный подход. 
Marina Lunina. Communicative and activity approach as one of the most important components of the content of cross-cultural communicative competence.

The article deals with peculiarities of the content of cross-cultural communicative competence as the key component of pedagogical system. Peculiar attention is focused on communicative activity which helps a specialist to master communicative competence and acquire specific professional skills. Communicative and activity approach to learning foreign languages is determined as the main one in linguistic preparation system of future specialists.

Key words: cross-cultural communication, content, communicative and activity component, communicative competence, communicative and activity approach.

Стаття надійшла до редакційної колегії 15.05.2014

УДК 81’243:37.018.43:004.738.5

Лютвісва Ярослава Павлівна

Харківський національний економічний університет імені С. Кузнеця

\section{ВИКОРИСТАННЯ МУЛЬТИМЕДІЙНИХ ТЕХНОЛОГІЙ (ВІДЕОФІЛЬМІВ) НА ЗАНЯТТЯХ 3 ІНОЗЕМНОЇ МОВИ}

У статті розглянуто можливості використання автентичних художніх відеофільмів як засобу формування комунікативної компетенцї студентів, створення та застосування методичних рекомендачій для опрачювання відеофрагментів фільмів. Показано приклади завдань, спрямованих на навчання студентів адекватного розуміння відеофільму на основі загальних знань, щзо сприяє підвищенню їхнього мовленнєвого рівня.

Ключові слова: комунікативний підхід, відеофільм, завдання, методика використання.

Підвищення якості вищої освіти визначається використанням нових методів i засобів навчання. Активне навчання потребує залучення студентів у навчальний процес. Широке застосування мультимедійних технологій здатне значно підвищити ефективність активних методів навчання для всіх форм організації навчального процесу.

Сьогодні невід'ємною частиною вивчення іноземної мови $є$ міжкультурні знання, які дуже важливі як на початковому, так і на високому рівні володіння мови. Знання іноземної мови для фахівця 
економічного профілю $є$ одним 3 основних компонентів професійної компетентності, вони допомагають налагоджувати ділові відносини 3 іноземними партнерами, знайомитися зі світовими досягненнями у сфері професійної діяльності і використовувати їх у професійній практиці. Формування міжкультурної компетентності спрямовано на підвищення здатності студентів ефективно вирішувати міжнародні ділові завдання, оскільки професіонал, успішний в своєму рідному, знайомому йому соціокультурному середовищі, не обов'язково буде мати успішну діяльність в новому середовищі з відмінною культурою.

Метою статmі є розгляд методу використання відеофільму як можливого засобу розвитку пізнавальної мотивації студентів до набуття міжкультурної комунікативної компетентністю, що сприяє розвитку позитивної мотивації до вивчення іноземної мови.

Сучасна різноманітність засобів навчання англійської мови надає викладачам можливість вибору того чи іншого навчального посібника, що значно розширює спектр здійснення професійної педагогічної діяльності.

Однією 3 необхідних умов підвищення ефективності процесу вивчення іноземної мови $є$ те, що серед сучасних допоміжних засобів навчання необхідно знайти такі, які б допомогли викликати у студентів інтерес до іншомовної мовленнєвої діяльності. Таким засобом можуть слугувати відеофільми, які належать до групи сучасних допоміжних засобів навчання, які здійснюють насамперед емоційний вплив на студентів, відповідають їхнім інтересам. Обстановка, дія , емоції, жести, які студенти можуть спостерігати у відеофільмі, забезпечують важливі візуальні стимули для мовленевої практики. Слід також підкреслити велику пізнавальну цінність автентичних відеоматеріалів. Використання відеофільмів іноземною мовою у процесі навчання студентів поглиблює соціокультурні знання про країну. Емоційний вплив, реактивність, пізнавальна цінність автентичних відеоматеріалів викликають інтерес у студентів до іноземної мови, тобто сприяють формуванню пізнавальної мотивації студентів до іноземної мови в цілому.

Відомо, що мотивація навчання буває зовнішня і внутрішня. Внутрішня мотивація навчання є найбільш природною і провідною для досягнення найкращих результатів у процесі навчання. При цьому до внутрішніх мотивів учення відносять, звичайно, власне пізнавальні інтереси, безпосередню зацікавленість студента в реалізації процесу i досягненні результату вчення. Таким чином, дуже важливо на заняттях прагнути, щоб у студентів переважала саме пізнавальна мотивація при набутті міжкультурної комунікативної компетентності.

Мотиваційно-розвиваюча роль аудіовізуальних засобів інформації висуває їх на одне 3 перших місць серед технічних засобів 
навчання. Такі засоби стимулюють розвиток внутрішнього мовлення як основи мовленнєво-розумової діяльності, взаємопов'язують функціонування таких механізмів мовленнєвої діяльності, як мислення, сприйняття, увага та пам'ять, підтримують інтерес, стимулюють іншомовну мовленнєву діяльність та створюють мотивацію. Тільки аудіо-візуальні засоби поєднують у собі мовний тапозамовний елементи.

Визначивши потенційні можливості відеофільмів і спираючись на основні вимоги до процесу навчання іноземної мови взагалі, можна виділили такі принципи відбору фрагментів відеофільму для навчання: соціокультурна орієнтованість інформації; тематична різноманітність змісту; стилістична диференціація мовного та мовленнєвого оформлення змісту; естетична цінність. При роботі з будь-яким текстом в методиці навчання іноземним мовам прийнято виділяти три основні етапи: дотекстовый етап (pre-viewing); текстовий етап (viewing); післетекстовый етап (post-viewing).

Дотекстовый етап може включати такі типи завдання як: перегляд частини фільму без звуку; визначення нових слів 3 дефініціями, питання або правдиві/ неправдиві твердженнях. Наприклад, студентам пропонують подивитися відеофільм 3 вимкненим звуком. Потім їм дається завдання написати свій власний сценарій і продемонструвати його. Після виступу студентів відеофільм переглядається зі звуком, і вирішується, яка група була найцікавіша або найближча до оригіналу. Для такої роботи найкраще підходять відеофільми з великою кількістю жестів, що стимулює уяву студентів.

Текстовый етап може включати такі типи завдань: підберіть англійські еквіваленти до наступних слів та виразів; заповніть пропуски в реченнях потрібними словами та виразами; вибудуйте частини тексту в логічній послідовності; встановіть причиннонаслідковий зв'язок та ін.

Досліджено, що під час перегляду відеофільму деякі студенти здатні слідкувати за подіями і слухати; інші тільки слухати. Тому використовуються різноманітні вправи, які дозволяють студенту заповнити пропущену інформацію. Студентів поділяють на дві групи. Перша група - очевидці подій, інші - журналісти, які працюють на радіостанції і повинні проводити інтерв'ю в прямому ефірі. Студентів не просять звертати увагу на конкретний діалог, але відновити події які вони щойно спостерігали.

Післятекстовый етап може включати такі типи завдань: проектну роботу, пов'язану з підготовкою аналогічних відеосюжетів; рольові ігри, в основу яких покладений сюжет або ситуації відеофільму. Наприклад, студентам пропонують подивитися відеофільм, насичений подіями, після чого дається завдання написати 
газетну статтю про ті події, свідками яких вони стали. Завдання попереднього перегляду та завдання, які виконуються під час перегляду, дозволяють студентам опрацювати нову лексику, а завдання, яке виконується після перегляду спрямовано на відпрацювання граматичного матеріалу і вироблення вміння описувати події послідовно.

Таким чином, можна дійти висновку, що мультимедійні засоби навчання дозволяють: підвищити інформативність лекції; стимулювати мотивацію навчання; підвищити наочність навчання за рахунок структурної надмірності; здійснити повтор найбільш складних моментів навчання; реалізувати доступність і сприйняття інформації за рахунок паралельного представлення інформації в різних модальностях: візуальної і слухової; здійснити повтор (перегляд, коротке відтворення) матеріалу попередніх уроків; створити викладачу комфортні умови роботи на уроках.

Отже, відеоматеріали надають практично необмежені можливості для проведення аналізу, побудованого на порівнянні i зіставленні культурних реалій i особливостей комунікативної поведінки людей у різних ситуаціях міжкультурного спілкування(за умови, якщо відібрані відеотексти створюють необхідну основу для такого порівняння).

Мультимедійні засоби навчання $є$ перспективним i високоефективним інструментом, що дозволяє надати інформації у більшому об'ємі, ніж традиційні джерела інформації, i в тій послідовності, яка відповідає логіці пізнання i рівню сприйняття конкретного контингенту студентів.

\section{Література}

1. Бобильова О. А. Комунікативний метод як метод активізації творчих можливостей особистості / О. А. Бобильова // Англійська мова та література. - 2005. - № 26. - С. 16-18.

2. Маркова А. К. Формирование мотивации учения: кн. для учителя / А. К. Маркова, Т. А. Матис, А. Б. Орлов. - М. : Просвещение, 1990. -192 c.

Ярослава Лютвиева. Использование мультимедийных технологий (видеофильмов) на занятиях по иностранному языку. В статье рассмотрень возможности использования аутентичних видеофильмов как средства формирования коммуникативной компетенции студентов. Показаны примерь заданий, направленных на обучение студентов адекватного понимания видеофильма на основе общих знаний, что способствует повыиению речевого уровня. Ключевые слова: коммуникативный подход, видеофильм, упражнения, методика использования. 
Yaroslava Lyutviyeva. The use of multimedia technologies (video) in the foreign language classroom.

The article deals with the possibility of using authentic films as a means of communicative competence of students, creating and using guidelines for processing video fragments of movies. Examples of tasks aimed at practising students in an adequate understanding of a film on the basis of general knowledge as well as improving their speech level are presented.

Key words: communicative approach, video film, exercises, methodology of usage.

Стаття надійшла до редакційної колегії 15.05.2014

УДК 37.015.3-044.247-043.61]:37.091.12-057.86

(C) Малинівська Л. І., 2014.

Малинівська Людмила Іванівна

Житомирський державний університет імені Івана Франка

\section{ІНТЕГРАЦІЯ ЗМІСТУ ПСИХОЛОГО-ПЕДАГОГІЧНОЇ ПІДГОТОВКИ МАЙБУТНІХ ПЕДАГОГІВ}

У статті розглянутий зміст педагогічної підготовки майбутніх педагогів, проаналізовані особистісно орієнтований $i$ компетентнісний підходи в освіті та способи їх застосування $з$ метою удосконалення саме педагогічної складової педагогічної освіти.

Ключові слова: особистісно орієнтований та компетентнісний niдхід, особистість, структура особистості, спрямованість особистості, компетентність.

Входження освіти України до єдиного європейського та світового освітнього і наукового простору обумовлює певні зміни у державній політиці щодо розвитку вітчизняної вищої освіти. «Основною метою державної політики в галузі освіти є створення умов для розвитку особистості і творчої самореалізації кожного громадянина України, оновлення змісту освіти та організації навчально-виховного процесу відповідно до демократичних цінностей, ринкових засад економіки, сучасних науково-технічних досягнень» [5].

На основі цього у Національній доктрині розвитку освіти [1] серед пріоритетних напрямів державної політики щодо розвитку вищої освіти значаться такі:

- особистісна орієнтація вищої освіти;

- формування національних і загальнолюдських цінностей;

- створення для громадян рівних можливостей у здобутті вищої освіти; 
- постійне підвищення якості освіти, оновлення iї змісту та форм організації навчально-виховного процесу;

- запровадження освітніх інновацій та інформаційних технологій;

- формування в системі освіти нормативно-правових i організаційно-економічних механізмів залучення i використання позабюджетних коштів;

- розвиток освіти як відкритої державно-суспільної системи;

- інтеграція вітчизняної вищої освіти до європейського та світового освітніх просторів.

Реалізація зазначених завдань в галузі педагогічної освіти вимагає пошуку та застосування нових, більш ефективних підходів до формування іiі змісту, використання технологій навчання 3 урахуванням специфіки професійної діяльності майбутніх педагогів.

Погляди закордонних авторів (В. Джемс, Е. Шпрангер, 3. Фройд, К. Юнг, А. Адлер, К. Горні, Г. Салліван, Е. Фромм, Е. Еріксон, К. Роджерс, Г. Олпорт, А. Маслоу, Е. Дюркгейм, П. Жане, В. Франкл, В. Мішел) найчастіше зводяться до пошуку провідної риси чи якості людини, що на їх думку дозволяє вже про неї говорити як про особистість. При цьому, як правило, ця риса чи якість визначається в процесі встановлення відношень людини із соціумом.

У роботах вітчизняних дослідників (Б. Г. Ананьєв, Л. С. Виготський, П. А. Гончарук, К. С. Дрозденко, А. Г. Ковальов, Г. С. Костюк, О. М. Леонтьєв, А. В. Морозов, Р. С. Немов та інших) наряду 3 тим, що також здійснюються спроби виявити ті якості, властивості, риси, які роблять людину особистістю, також простежується спроба побудувати 3 них ієрархію, яка може зватися структурою особистості. При цьому частіше за все вказуються як структурні такі елементи: спрямованість; звички, знання, уміння, навички, які можуть у своїй єдності становити досвід; особливості психічних процесів; біопсихічні властивості; характер; темперамент; можливості; емоційно-вольова сфера; спілкування; задатки; здібності та ін.

Слід відразу ж обмовитися, що з виділенням виховного аспекту підготовки в окрему самостійну складову складно погодитися. Виховання, як процес формування людини, який здійснюється педагогами у навчально-виховних установах i спрямований на розвиток особистості, є тим, що спеціально організується та керується. 3 цього видно, що виховання містить як етап підготовки, так і етап здійснення. Таким чином, за своїми етапами виховний процес нічим не відрізняється від дидактичного і, тим самим, має разом з ним поділяти проектувальну і технологічну функції діяльності. А у тому, що в стандарті освіти виховна функція винесена на один рівень 3 іншими, 
нами вбачається, скоріше, спроба повернути у вищих навчальних закладах, перш за все - педагогічних, виховання на такий високий рівень, якого воно було майже зовсім позбавлене внаслідок докорінних змін, що відбулися останнім часом в економічному та політичному житті України.

Такий набір складових професійної діяльності, дійсно, дозволяє охопити іiі різні прояви 3 урахуванням передбаченого працевлаштування фахівця 3 вищою освітою. За діяльнісним підходом кожна із зазначених складових знаходить втілення у змісті навчання, як на загальному рівні (рівні всієї підготовки), так і частковому рівні (рівні тематики навчальних дисциплін). 3 рештою вимога удосконалення змісту підготовки зводиться до включення у кожну існуючу навчальну дисципліну тем, які точніше, за думкою викладача, відбивають зміст тих же незмінних видів діяльності. В результаті численні дублювання навчального матеріалу, які вимагають невиправданого додаткового часу на засвоєння. А зовсім нові змістовні блоки можуть потрапити до навчальної дисципліни тільки в тому разі, якщо виділяються нові напрями (види) в професійній діяльності майбутнього фахівця.

Мета статmі проаналізувати особистісно орієнтований i компетентнісний підходи в освіті та отримати способи їх застосування 3 метою удосконалення саме педагогічної освіти.

Особистісна орієнтація вищої освіти, зокрема - педагогічної, вимагає в першу чергу визначитися зі змістом таких понять, як «особистісно орієнтований підхід», «структура особистості».

Особистісно орієнтований підхід в освіті на сьогоднішній день $€$ дуже популярним, тому що, на думку дослідників, дозволяє вирішити багаточисленні проблеми, пов'язані із вихованням, навчанням та розвитком людини. Саме тому до цього підходу спостерігається неоднозначне ставлення. Серед трактувань, які найбільш часто зустрічаються, А. В. Морозов та Д. В. Чернилевський вказують наступні:

1. Особистісний підхід в освіті на рівні буденної, наймасовішої педагогічної свідомості розуміється як етико-гуманістичний принцип спілкування педагога і вихованців.

2. Особистісний підхід розглядається як принцип синтезу напрямів педагогічної діяльності навколо їі головної мети - особистості.

3. Особистісний підхід тлумачиться як пояснювальний принцип, що розкриває механізм особистісних новоутворень в педагогічному процесі. Значення цього принципу у тому, що ніякі зміни в життєдіяльності людини не можуть бути пояснені без розуміння їх місця і ролі в самореалізації особистості. 
4. Даний підхід трактується як принцип свободи особистості в освітньому процесі в значенні вибору нею пріоритетів, освітніх маршрутів», формування власного, особистісного сприйняття змісту, що вивчається (особистісного досвіду).

За кожним 3 цих трактувань стоїть певна модель педагогічної діяльності, по-своєму виправдана i ефективна в тій або іншій соціокультурній ситуації.

Стосовно даного дослідження, найближчим є останнє 3 визначень особистісно орієнтованого підходу, коли він не обмежується певним вирішенням окремих педагогічних ситуацій, поведінкою педагога чи усвідомленням учнем себе як особистості, а охоплює всі напрями та рівні становлення педагога, підкоряючи принципам розвитку особистісних властивостей людини формування та взаємодію всіх елементів педагогічної системи.

Щоб отримати складові змісту педагогічної підготовки майбутніх педагогів, необхідно визначитися із структурою особистості та оптимальним стосовно даного дослідження іiі педагогічним трактуванням.

Враховуючи предмет даного дослідження, інтерес представляють ті складові особистості, на які можна впливати у вищому навчальному закладі 3 метою їх розвитку та формування в напрямі професійного становлення викладача. Цій вимозі задовольняє структура особистості, запропонована К. К. Платоновим: спрямованість, досвід, особливості психічних процесів, біопсихічні властивості. Зокрема, Е. Ф. Зеєр [3], розглядаючи особистість як суб'єкт соціальних відносин i активної діяльності, а також грунтуючись на уявленні про структуру особистості К. К. Платонова, спроектував чотирьохкомпонентну структуру особистості педагога професійної школи.

Спрямованість особистості - це сукупність стійких мотивів, які спрямовують поведінку й діяльність людини відносно незалежно від конкретних умов. Характеризується домінуючими потребами, інтересами, схильностями, переконаннями, ідеалами, світоглядом (К. С. Дрозденко [2]). У психології спрямованість особистості окремий елемент по відношенню до досвіду, якостей, фізіологічних властивостей тощо.

Компетентність як структурний елемент особистості сьогодні зосередила на собі увагу багатьох учених, бо у контексті вирішення поставлених державою завдань є втіленням досвіду якісно нового, більш високого рівня. Це дало поштовх до утворення та розвитку компетентнісного підходу до навчання. 


\section{Збірник наукових статей}

За енциклопедіями, тлумачними словниками та словниками іноземних мов компетентний - це знаючий, обізнаний, авторитетний в якій-небудь галузі фахівець або той, хто володіє компетенцією.

Таким чином, аналіз показав, що зараз немає встановленого, постійного набору компетентностей, компетенцій; в кожному окремому дослідженні наводяться відмінні від інших компетентності та компетенції, назви яких продиктовані потребами держави, суспільства, людини взагалі чи конкретного фахівця.

Висновки. У статті обгрунтована актуальність удосконалення змісту професійної педагогічної підготовки майбутніх педагогів. Наведені результати аналізу праць закордонних та вітчизняних учених 3 приводу структури особистості, застосування особистісноорієнтованого, компетентнісного та кваліфікаційного підходів до навчання. Запропоновано способи побудови змісту підготовки, в результаті застосування яких у студентів формуватимуться професійна спрямованість, креативність мислення, гнучкість професійно необхідних умінь. Реалізація даного підходу на рівні всієї педагогічної підготовки майбутніх педагогів повинна сприяти гнучкості, міцності професійних вмінь та удосконаленню їх упродовж життя.

\section{Література}

1. Болонський процес: Нормативно-правові документи / Укладачі: 3. І. Тимошенко, І. Г. Оніщенко, А. М. Грехов, Ю. І. Палеха. - К. : Вид-во Європ. ун-ту, 2004. - 102 с.

2. Дрозденко К. С. Загальна психологія в таблицях і схемах : навч. Посібник / К. С. Дрозденко. - К. : ВД «професіонал», 2004. 304 c.

3. Зеер Э. Ф. Психология личностно ориентированного профессионального образования / Э. Ф. Зеер. - Екатеринбург : Изд-во Урал. гос. проф.-пед. ун-та, 2000. - 258 с.

4. Коваленко О. Е., Брюханова Н. О., Мельниченко О. О. Концепція професійно-педагогічної підготовки студентів інженернопедагогічних спеціальностей / О. Е. Коваленко, Н.О.Брюханова, О. О. Мельниченко // Проблеми інженерно-педагогічної освіти: Зб. наук. праць - Х. :УІПА, 2005, № 10, - С. 7-20.

5. Козаков В. А. Самостоятельная работа студентов и ее информационно-методическое обеспечение: Учеб. Пособие / В. А. Козаков. - К. : Вища шк. - 1990. - 248 с.

6. Леднев В. С. Содержание образования: учеб. пособие / В. С. Леднев. - М. : Высш. шк. $-1989 .-360$ с.

7. Модернізація вищої освіти України і Болонський процес: Матеріали до першої лекції / Уклад. М. Ф. Степко, Я. Я. Болюбаш, К. М. Левківський, Ю. В. Сухарніков; відп. ред. М. Ф. Степко. - К. : Узд., 2004. - 60 с. 
Людмила Малиневская. Интеграция содержания психологопедагогической подготовки будущих педагогов.

B cтатье рассмотрен содержание педагогчческой подготовки будущзи педагогов, проанализированы личностно ориентированный и компетентностный подходы в образовании и способы их применения с цุелью усовершенствования именно педагогической составляющей педагогического образования.

Ключевые слова: личностно ориентированный и компетентностный подход, личность, структура личности, направленность личности, компетентность.

\section{Lyudmila Malinovsky. Integrating content psycho-pedagogical training of future teachers. \\ The article reviewed the content and pedagogical training of future teachers, analyzed personality oriented and competence-based approach in education and how they use it to improve educational component of teacher education.}

Key words: learner-focused approach and competence, personality, personality structure, personality orientation, competence.

Стаття надійшла до редакційної колегії 14.03.2014

УДК 159.954.4-027.233-027.561:116]:37.091.12-057.86

Малихіна Олена Свгенівна

(C) Малихіна О. С., 2014.

Харківський національний педагогічний університет

імені Г. С. Сковороди

\section{ТВОРЧЕ МИСЛЕННЯ ЯК УМОВА УСПІШНОГО ПРОФЕСІЙНОГО СТАНОВЛЕННЯ МАЙБУТНЬОГО ПЕДАГОГА}

У статті творче мислення розглядається як важлива властивість особистості майбутнього педагога та як умова його успішного професійного становлення. Проаналізовано підходи до вивчення творчого мислення та його особливості, а також виокремлено деякі умови його формування.

Ключові слова: вчитель, професійне становлення, творче мислення, особливості творчого мислення, умови розвитку творчого мислення.

Зміни, що відбуваються у сучасному суспільстві та освітньому просторі, а саме: збільшення інформаційного потоку, широке застосування інформаційних технологій, вільний доступ до різноманітної інформації, зміни у способах здобування знань, 


\section{Збірник наукових статей}

зумовлюють нові, підвищені вимоги до творчого потенціалу особистості не лише учня, а й педагога. Складовою творчого потенціалу особистості педагога $є$ творче мислення як здатність до генерування нових ідей та прийняття нестандартних, оригінальних рішень.

Meта статmi полягає у теоретичному дослідженні особливостей творчого мислення як важливої психологічної умови професійного становлення майбутнього педагога та виявленні деяких умов його формування.

У психологічній літературі (І. О. Зимня, В. А. Крутецький, Н. В. Кузьміна, А. К. Маркова, Р. С. Немов та ін.) проблема дослідження властивостей педагога, що визначають ефективність педагогічної діяльності, стала предметом спеціального теоретичного та експериментального вивчення. Вченими виокремлено такі головні вимоги до особистості педагога, як любов до дітей, до педагогічної діяльності; наявність спеціальних знань у галузі предмета, який він викладає; ерудиція; педагогічна інтуіція; високорозвинений інтелект; високий рівень загальної культури; професійне володіння методами навчання та виховання дітей. Багато дослідників вказують на необхідність наявності в педагога вмінь швидко реагувати на різні ситуації, що постійно виникають у навчанні та вихованні, але в той же час не розглядають творче мислення в якості його важливої професійної властивості.

У дослідженнях Є. О. Клімова [2] усе різноманіття профессій класифікується за такими критеріями, як предмет праці, мета праці тощо. Виходячи з першої класифікації професія педагога належить до соціономічних професій, що передбачають взаємодію людей між собою. Людині цієї професії притаманні такі властивості: вміння керувати, слухати, широкий кругозір, мовленнєна культура, рішення нестандартних ситуацій та ін. За другим критерієм професії поділяються залежно від мети, яку ставить перед собою суб'єкт: гностичної, перетворення або пошуку. Відповідно педагогічна діяльність передбачає наявність у iї суб'єкта вмінь ставити та розв'язувати завдання перетворення i пошуку нових способів вирішення цих завдань. Виходячи 3 вимог, що висуваються до педагогічної професії, можна констатувати, що творче мислення $\epsilon$ професійно значущою властивістю.

На важливість творчого мислення в діяльності педагога вказував А. В. Брушлінський, стверджуючи, „що психологічні закономірності мислення як процесу відкриття нового перш за все розповсюджуються на мисленнєву діяльність вчителя" [1, с. 89]. У практичній діяльності педагога дуже часто несподівано виникають або цілеспрямовано створюються нові життеві ситуації, тому йому 
доводиться швидко та правильно оцінювати вчинки учнів; розроблювати нові методичні прийоми; виясняти причини конфлікта між учнями. Також А. В. Брушлінський розглядає творче мислення вчителя як умову його успішного професійного становлення, оскільки ,оволодіваючи основами педагогічних та психологічних знань, вчитель закладає фундамент своєї професійної майстерності. Водночас, ані психологія, ані педагогіка не дають вчителю готових рецептів, що допомагають легко та швидко розв'язати будь-яку практичну проблему. Психологія і педагогіка закладають систему фундаментальних та прикладних знань та методів роботи, на підставі яких кожен вчитель у конкретній ситуації творчо використовує та розвиває методичні прийоми, що найбільш підходять для даного випадка" [1, с. 90].

Для подальшого розгляду даної проблеми потрібно зупинитися на особливостях творчого мислення. Аналіз психологічних досліджень показує, що поняття творчого мислення не має однозначного визначення та існують різні підходи до його вивчення: психодинамічний (3. Фройд, А. Адлер), прагматичний (Е. де Боно), психометричний (Дж. Гілфорд, Е. П. Торренс), особистісний $\begin{array}{lll}\text { (С. Д. Максименко, } & \text { В. А. Роменець), прцесуальний }\end{array}$ (Д. Б. Богоявленська, Л. С. Виготський, Я. О. Пономарьов), стратегіально-діяльнісний (В. О. Моляко, О. Л. Музика), структурноінтегрований (М. О. Холодна, В. Ф. Моргун). У своїх дослідженнях О. С. Кущ [3] підсумовує, що творче мислення розглядається як властивість мислення та як особистісна характеристика. Він визначає творче мислення як „вид мислення, що характеризується впорядкованим багатовимірним ієрархічним взаємосполученням властивостей мислення як психічних новоутворень різних рівнів ускладнення, що включає лабільність, уміння встановлювати логічні закономірності, логічно-понятійне мислення та вміння утворювати складні аналогії, креативність мислення, значущу конструктивність" [3, с. 16].

Аналіз характеристик творчого мислення зумовлює необхідність формулювання психологічних умов (детермінант) його розвитку, які за характером перебігу процесу мислення $є$,„зовнішніми” і „внутрішніми”. До ,зовнішніх” психологічних умов розвитку творчого мислення відносять діяльність як реагування особистості на систему впливів оточуючого середовища, зокрема - організованої навчальної діяльності. Дослідниками розроблені окремі методи розвитку творчого мислення: метод мозкового штурму (А. Осборн), сінектика (В. Дж. Гордон), метод ТРВ3 (Г. С. Альтшулер), метод КАРУВ (В. О. Моляко), розв'язання творчих завдань (Р. Крачфілд), метод імпровізації (Н. В. Рождественська), ігрові технології 


\section{Збірник наукових статей}

(О. С. Кущ, В. О. Моляко) та ін. До „внутрішніх” психологічних умов відносять індивідуально-психологічні характеристики особистості.

Для успішного професійного становлення майбутніх педагогів необхідно створювати спеціальні умови для розвитку у студентів творчого мислення. Нашу особливу увагу привертає експериментальне дослідження О.С. Куща [3] щодо розвитку творчого мислення старшокласників у процесі впровадження спеціальної навчальної технології із застосуванням системи ділових i рольових ігор. Використання ігор, на думку автора, дозволяє особистості не тільки розвинути складові мислення, отримати навички i побудувати конструктивні стратегії розумової діяльності, здійснити перехід від стану проблемної невизначеності, ситуативної дезадаптованості до стану творчого мислення і конструктивної діяльності, а і врахувати в навчанні взаємодію „зовнішніх” та „внутрішніх” психологічних умов. Крім того, як зазначає автор, юнацький вік $є$ сензитивним для розвитку творчого мислення, що також створює сприятливі умови для його формування у майбутніх педагогів.

Висновки. Творче мислення $є$ важливою умовою успішного професійного становлення майбутнього педагога, оскільки дозволяє швидко орієнтуватися в умовах, що постійно змінюються, обирати оптимальні для кожного окремого випадка методи і засоби навчання та виховання. Для розвитку творчого мислення у майбутніх педагогів необхідно у процесі навчальної діяльності створювати сприятливі умови, застосовувати спеціальні методи, зокрема, використання ділових та рольових ігор. Перспективи подальших досліджень вбачаємо у поглибленому вивченні специфіки творчого мислення як професійно значущої властивості педагога.

\section{Література}

1. Брушлинский А. В. Субъект: мышление, учение, воображение / А. В. Брушлинский. - Москва : Издательство „Институт практической психологии”; Воронеж : НПО „Модэк”, 1996. - 392 с.

2. Зимняя И. А. Педагогическая психология: Учеб. пособие / И. А. Зимняя - Ростов на/ Д. : Изд-во „Феникс”, 1997. - 480 с.

3. Кущ О. С. Психологічні умови розвитку творчого мислення старшокласників засобами рольових ігор: автореф. дис. на здобуття наук. ступеня канд. психол. наук: спец. 19.00.07 „Педагогическая и возрастная психология" / О. С. Кущ. - Київ, 2011. - 20 с.

Елена Малыхина. Творческое мышление как условие успешного профессионального становления будущего педагога.

$B$ статье творческое мышление рассматривается как важное свойство личности будущего педагога и как условие его успешного профессионального становления. Проанализировань подходы $\kappa$ 
изучению творческого мышления и его особенности, а также выделены некоторые условия его формирования.

Ключові слова: вчитель, професійне становлення, творче мислення, особливості творчого мислення, умови розвитку творчого мислення.

Olena Malykhina. Creative thinking as a condition of becoming a successful professional future teachers.

The article creative thinking is seen as an important feature of future teacher and as a condition of his successful professional development. The approaches to the study of creative thinking and its features, but also singled out some of the conditions of its formation.

Key words: teacher, professional development, creative thinking, creative thinking features, terms of creative thinking.

Стаття надійшла до редакційної колегії 11.05.2014

УДК $331.485 / 711.57$

\section{Мельник Юрій Борисович \\ Академія внутрішніх військ МВС України

\section{ПСИХОЛОГІЧНА СЛУЖБА ВНЗ}

(C) Мельник Ю. Б., 2014.

Висвітлено тендениіі розвитку та сучасний стан психологічної служби в Україні та інших державах. Проаналізовано нормативноправову базу щодо організаиії психологічної служби у ВНЗ України. 3'ясовано сутнісні характеристики психологічної служби. Виявлено особливості психологічної служби у ВНЗ. Введено до наукового обігу поняття «психологічна служба ВНЗ».

Ключові слова: психологічна допомога, особливості психологічної служби, психологічна служба ВНЗ.

Гуманізація системи освіти сприяла виникненню у вищій школі нового напряму діяльності, який забезпечує психолого-педагогічний супровід навчального процесу. Так у вищих навчальних закладах (далі - ВНЗ) створюються психологічні служби, соціально-психологічні центри тощо. Сьогодні розвиток психологічної служби ВНЗ у значній мірі зумовлений потребами самого закладу освіти, якому він підпорядкований. Ця діяльність повинна здійснюватися у відповідності до завдань, які поставлені перед ВНЗ, а також має регламентуватися статутом цього закладу, нормативно-правовою базою і керівними документами в галузі освіти. Проте, залишається чимало невирішених питань, які постають перед ВН3, а саме: професійна назва роботи фахівців, які здійснюють цей психолого- 


\section{Збірник наукових статей}

педагогічний супровід; нормативи чисельності психологів або практичних психологів, або соціальних педагогів; напрями діяльності цих служб/центрів та ін.

Ціль статті - висвітлити тенденції розвитку та сучасний стан психологічної служби в Україні та інших державах, 3'ясувати сутнісні характеристики психологічної служби та виявити особливості психологічної служби у ВНЗ, ввести до наукового обігу поняття «психологічна служба ВНЗ».

Історія психологічної служби ВНЗ в Україні нетривала. Переважна більшість психологічних служб або центрів у ВНЗ України створені лише на початку цього століття, тоді як світова практика свідчить про інтенсивний розвиток таких служб/центрів у США, Канаді, Великобританії, Франції, Японії ще у другій половині XX століття, система ж психологічної допомоги в спеціальних службах та центрах має більш ніж вікову історію. Вперше така система з'явилася в Великобританії та США, що було зумовлено соціально-економічним контекстом розвитку цих держав. У 1870 році у Великобританії прийнятий Закон про освіту (Education Act), який став базовим документом для створення психологічних служб/центрів у освітніх закладах цієї країни. У 1896 році при Пенсильванському університеті в США створено першу психологічну клініку для діагностики дітей, а в 1915 році їх чисельність уже становила двадцять. У цей час в США зароджується і шкільна психологія, з'являються аналогічні клініки при державних школах. Їх основні завдання полягали в дослідженні індивідуальних відмінностей між дітьми, впливу цих відмінностей на навчання та поведінку [1]. Отже, психологічні центри створюються в освітніх закладах і стають важливою їх складовою, що здійснюють дослідження індивідуального розвитку особистості та забезпечують психологічний супровід процесу навчання.

Незважаючи на інтенсивний розвиток психології та відкриття психологічних центрів у закладах освіти англомовних держав, перша спроба створення подібних центрів в Україні відбулася лише в 30х роках 20 сторіччя, яка на той час входила до складу СРСР. Це відбулось завдяки розвиткові педології - науки, що поєднувала анатомо-фізіологічний, біологічний, психологічний та соціальний підходи до вивчення дітей. 31933 року, після прийняття постанови Наркомпроса РСФСР про педологічну роботу, в дитячих садках i школах починають проводитися широкомасштабні психологічні консультування, педологи в своїй діяльності активно застосовують психологічні та корекційні методи психології. Проте, вже у 1936 році виходить інша постанова ЦК ВКП(б), у якій критикується педологія, що спричиняє закриття цих центрів, лабораторій тощо. Це привело до «замороження» цього наукового напряму на довгі роки (з цього 
моменту траєкторії розвитку психологічної допомоги у нас і за кордоном різко розійшлися) і лише в 1970-1980 рр. почали створюватися умови для відродження практичної психології в освітніх закладах [1]. Відновлення організації діяльності психологічної служби освіти в нашій країні пов'язані 3 введенням ставки практичного (шкільного) психолога в навчально-виховних установах, переважно загальноосвітніх закладах. Ця діяльність спочатку була регламентована Постановою Державного комітету СРСР від 1988 р., а згодом, Положенням про психологічну службу в системі освіти України (Наказ Міністра освіти України № 230 від 01.07.1993р.), у якому визначені загальні положення, зміст діяльності, структура та управління психологічною службою в системі освіти; а також змінами, внесеними згідно з Наказами Міністерства освіти і науки України № 439 від 07.06.2001 р. та № 616 від 02.07.2009 р., у яких зроблено уточнення вищенаведених розділів та висвітлені основні завдання, права та обов'язки практичного психолога/соціального педагога навчального закладу, фінансування діяльності психологічної служби, запропоновано формулу для розрахунку кількості ставок посад практичних психологів та соціальних педагогів у малокомплектних навчальних закладах [2; 3; 4]. Саме в останньому документі (2009 р.) наведено положення, які регламентують діяльність психологічної служби ВН3, зокрема: «Структура та штатний розпис психологічної служби вищого навчального закладу III-IV рівнів акредитації визначаються вищим навчальним закладом та фінансуються за рахунок власних коштів цього навчального закладу. Психологічна служба вищого навчального закладу III-IV рівнів акредитації підпорядковується керівнику або одному 3 його заступників, а у частині науково-методичного забезпечення - Українському науковометодичному центру практичної психології і соціальної роботи» [4]. Втім цей документ не дає відповіді на поставлені питання.

Отже, ВН3 змушені інтенсивно напрацювати власний практичний досвід i розробляти чимало документів i методичних матеріалів, які регламентуватимуть їх діяльність у певній сфері задля вирішення поставлених питань і забезпечення потреб навчального закладу. Яскравим прикладом організації системи діяльності психологічної служби в розробці інструктивно-методичної бази $\epsilon$ військові ВНЗ. Зокрема в Академії внутрішніх військ МВС України психологічна служба здійснює свою діяльність згідно 3 такими інструкціями: про порядок організації та здійснення психологічного супроводження військовослужбовців строкової служби; про порядок обліку і звітності діяльності психологічної служби внутрішніх військ МВС України; про роботу з військовослужбовцями, віднесеними до групи посиленої психологічної уваги; про порядок організації та 


\section{Збірник наукових статей}

здійснення психологічного вивчення військовослужбовців внутрішніх військ, які допускаються до несення служби зі зброєю та ін.

Однак далеко не кожний ВН3, у якому діє психологічна служба, має таку інструктивно-методичну базу. Слід зазначити, що відсутність наказів та інструкцій адміністрації ВНЗ щодо організації діяльності психологічної служби має як негативну, так і позитивну сторони. 3 однієї сторони невизначеним залишаються напрями діяльності та норми часу, які відводяться для тієї чи іншої роботи, до цього ж результативність цієї роботи в значній мірі залежить від професіоналізму психолога, який змушений на власний розсуд обирати зміст, форми та методи діяльності, з іншої сторони - це надає змогу психологу бути більш мобільним у виборі актуальних напрямів діяльності, враховувати соціальне замовлення та запити студентів, сприяє розвиткові його творчості, професійної майстерності.

Питанням наукового обгрунтування, практичної організації та функціонування психологічної служби в системі освіти присвятили свої праці Ю. Гільбух, К. Гуревич, І. Дубровіна, Ю. Забродін, К. Обозов, Р. Овчарова, В. Панок, А. Прихожан та інші науковці. Роботи цих вчених стали для нас основою з узагальнення досвіду в області створення та розвитку психологічної служби, зокрема у ВНЗ.

Розглянемо більш грунтовно суть психологічної служби. Однозначного розуміння структури та функцій психологічної служби немає. Вважаємо, іiі можна розглядати в широкому та вузькому значенні. На цей час виділено два найбільш загальних визначення, які відображають суть психологічної служби, ії цілі, завдання та шляхи їх вирішення.

В широкому значенні, психологічна служба являє собою психологічне забезпечення різних соціальних сфер: освіти, здоров'я, виробництва та ін. Тобто, це особлива сфера психологічних послуг, яка використовується для вирішення комплексних завдань психологічної діагностики, консультації, корекції, експертизи в сферах освіти, охорони здоров'я, правопорядку, виробництва, транспорту i т.д.

У вузькому значенні психологічна служба це складова системи спеціальних установ, що створюються в різних соціальних інститутах та організаціях, покликаних надавати кваліфіковану психологічну допомогу особам, які іï потребують, здійснювати соціальнопсихологічну адаптацію в навчальній або професійній діяльності, підвищувати рівень психологічної культури всіх суб'єктів, проводити тренінгові заняття тощо. Основні цілі такої психологічної служби надання психологічної допомоги, забезпечення задоволення попиту на ті чи інші види психологічної допомоги. 
Психологічна допомога представляє собою систему спеціальних заходів, спрямованих на попередження, пом'якшення або подолання різного роду труднощів, що виникають у студентів або педагогічних працівників, методами практичної психології, зазвичай у формі діагностики, консультування, психокорекції та психотерапії, що базуються на психологічній (немедичній) моделі.

Аналіз сучасної вітчизняної та іноземної наукової літератури щодо здійснення психологічної допомоги психологічними службами/центрами [5] дозволяє дійти висновку, що сьогодні майже немає жодної області людського життя, в якій людина залишалася б без такої допомоги. А. Бондаренко [6] виділяє такі головні області застосування психологічної допомоги: 1) в психічному (і духовному) розвиткові дитині (сприяння у виборі ціннісних і моральних норм, особливо в критичні періоди розвитку тощо); 2) в подоланні екзистенціальних й особистісних проблем підлітка (допомога в подоланні почуття неповноцінності, сексуальних проблем, боротьба за особистісний та соціальний статус тощо); 3) в питаннях взаємовідносин у родині та шлюбі (подружні й батьківські конфлікти, сімейні кризи); 4) в проблематиці психічного й особистісного здоров'я (превентивна й поточна допомога при психічних i соматичних захворюваннях, духовних стражданнях, пов'язаних 3 розладами настрою, алкоголізмом, наркоманією, життєвими стресами, конфліктами, прикордонними станами тощо); 5) психологічна допомога вмираючому i психотерапія горя (це одна 3 найважчих проблем психологічної допомоги, яка сьогодні активно розробляється американськими психотерапевтами); 6) в подоланні проблем літнього віку (вироблення адекватного світогляду, задоволення емоційних запитів, відгук на виникаючі релігійні проблеми, регулярний патронаж і допомога в організації відповідного способу життя); 7) психологічна допомога в пенітенціарних закладах, лікарнях, казармах, студмістечках (проблеми особистості, спілкування, психічного стану тощо); 8) психологічна допомога й підтримка в кризових ситуаціях (раптова смерть, спроба суїциду, згвалтування, зрада, втрата любові, роботи тощо); 9) шкільне консультування (проблеми відносин учителів й учнів, учнів між собою, питання відносин з батьками, проблеми шкільної успішності, відхилення в поведінці, розвитку здатностей тощо); 10) професійне консультування (загальне орієнтування у виборі тієї або іншої професії, складання «резюме», пошук роботи тощо); 11) психологічна допомога в кросскультурній проблематиці (бар'єри в адаптації, подолання етнічних забобонів і стереотипів у емігрантів тощо); 12) управлінське консультування (допомога в прийнятті управлінських рішень, відстеження й рішення конфліктів, робота 3 персоналом тощо). 


\section{Збірник наукових статей}

Деякі $з$ вищезазначених областей застосування психологічної допомоги базуються на медичній моделі, інші на - психологічній. На наш погляд діяльність психологічної служби ВНЗ має забезпечуватися немедичними працівниками (психотерапевтами, психологами), а практичними психологами та соціальними педагогами. Щодо розрахунку нормативів чисельності практичних психологів та соціальних педагогів у ВНЗ зазначимо, що у вирішенні цього питання адміністрація ВНЗ має керуватися «Положенням про психологічну службу системи освіти України» [4], що відповідатиме нормативноправовій базі $[2 ; 3 ; 4]$, а також особливостям діяльності фахівців психологічної служби у ВНЗ.

Для 3'ясування особливостей психологічної служби ВНЗ розглянемо основні напрями і методи іiї діяльності, які сьогодні впроваджуються у вищій школі.

Чисельність ВНЗ, де організована і діє психологічна служба як в Україні, так і за кордоном, дуже велика. Серед розмаїття напрямів $\mathrm{i}$ методів діяльності психологічних служб ВНЗ, переважна більшість їх зводяться до напрямів, які зазначені у вищенаведених документах $[2 ; 3 ; 4]$. Зокрема це: діагностика (психологічне обстеження та моніторинг студентів та ін.); корекиія (психологомедико-педагогічні заходи задля усунення відхилень у психофізичному та інтелектуальному розвитку і поведінці, схильності до залежностей та правопорушень та ін.); реабілітація (психологопедагогічна допомога студентам, які перебувають у кризовій ситуації, адаптації до умов навчання і життєдіяльності та ін.); профілактика (попередження відхилень у становленні особистості, міжособистісних стосунках, запобігання конфліктним ситуаціям у освітньому процесі та ін.); прогностика (проектування змісту і напрямів індивідуального розвитку студентів і складання на цій основі життєвих планів, визначення тенденцій розвитку груп та міжгрупових відносин та ін.) [4]. Існують і досить екстравагантні методи, які використовуються в роботі зі студентами ВНЗ. Наприклад, в ЛНУ імені Тараса Шевченка проводять психологічні тренінги: „Початковий курс йоги з елементами самосугестії”, „Еріксонівський гіпноз” та ін.

Досліджуючи сутнісні характеристики психологічної служби та особливості іiі діяльності у ВНЗ, привертає увагу робота Е. Зеєра [7], в якій автор розглядаючи діяльність психологічної служби у ВНЗ розуміє її як психологічний супровід студентів у професійній освіті. В цілому ми поділяємо цю думку, оскільки на наш погляд, одним 3 головних завдань психологічної служби є психолого-педагогічний та соціальний супровід освітнього процесу. Це теоретичне підгрунтя дозволило Е. Зеєру розробити технологію, що спрямована на 
вирішення завдань психологічного супроводу студентів у ВН3 за такими етапами: адаптація, інтенсифікація, ідентифікація.

На етапі адаптації (перший курс) - завдання психологічної служби полягає в наданні допомоги студентові в адаптації до нових умов життєдіяльності. Зокрема в технологічну програму входять: 1) діагностика готовності до навчально-пізнавальної діяльності, мотивів навчання, ціннісних орієнтацій, соціально-психологічних установок; 2) допомога в розвитку навчальних умінь і регуляції своєї життєдіяльності; 3) психологічна підтримка першокурсників у подоланні труднощів самостійного життя і вибудовуванні комфортних взаємин 3 однокурсниками i педагогами; 4) консультування першокурсників, що розчарувалися у вибраній спеціальності; 5) корекція професійного самовизначення при компромісному виборі професіï.

На етапі інтенсифікації (другий i третій курси) завдання психологічної служби зводяться до діагностики особистісного i інтелектуального розвитку, наданню допомоги у вирішенні проблем, що виникають у взаєминах 3 іншими студентами і викладачами, а також в особистих стосунках. У технологічну програму входять методи розвиваючої діагностики, психологічного консультування, корекції особистісного і інтелектуального профілів.

На етапі ідентифікації (четвертий і п’ятий курси) завдання психологічної служби полягають «у фінішній діагностиці професійних здібностей, допомозі в знаходженні професійного поля реалізації себе, підтримці в знаходженні сенсу майбутньої життєдіяльності. Головне допомогти випускникам професійно самовизначитися і знайти місце роботи» [7].

На підгрунті аналізу сутнісних характеристик психологічної служби та відповідно до особливостей упровадження цієї діяльності у ВНЗ введемо поняття «психологічна служба ВНЗ».

Психологічна служба ВНЗ - це складник системи державної охорони психологічного здоров'я громадян, як структурний підрозділ ВНЗ, здійснює психолого-педагогічний та соціальний супровід освітнього процесу, має чітку цілеспрямованість на надання фахової психологічної допомоги студентам, професорсько-викладацькому складу та адміністрації навчального закладу.

Таким чином, сьогодні організація психологічної служби ВН3 є важливим напрямом діяльності, який спрямований на формування спеціальних та загальних компетенцій особистості студентів, забезпечує розвиток особистісного, інтелектуального та професійного потенціалу суспільства. Найважливішими умовами ефективності роботи психологічної служби ВНЗ є професійна взаємодія між усіма суб'єктами освітнього процесу в єдиній педагогічній системі. 


\section{Література}

1. Психологические центры: Организация, содержание деятельности, документация / под ред. С. Б. Малых. - М. : Генезис, 2007. - (Психология в образовании). -248 с.

2. Положення про психологічну службу в системі освіти України : наказ Міністерства освіти України. - № 230 від 01.07.1993 p. [Електронний pecypc]. Режим доступу : http://zakon.rada.gov.ua/cgibin/laws/main.cgi?nreg=z0101-93. - Назва з титул. екрану.

3. Положення про психологічну службу в системі освіти України : наказ Міністерства освіти України. - № 127 від 03.05.1999 p. [Електронний ресурс]. Режим доступу http://ukraine.uapravo.net/data2008/base58/ukr58398.htm. - Назва з титул. екрану.

4. Про внесення змін до Положення про психологічну службу системи освіти України : наказ Міністерства освіти і науки України. № 616 від 02.07.2009 p. [Електронний ресурс]. Режим доступу : http://news.yurist-online.com/laws/5714/. - Назва 3 титул. екрану.

5. Мельник Ю. Б. Організація роботи соціально-психологічного центру / Ю. Б. Мельник // Вісник Інституту розвитку дитини. Сер. : Філософія, педагогіка, психологія : зб. наук. пр. - К. : НПУ ім. М.П. Драгоманова, 2011. - Вип. 19. - С. 134-140.

6. Бондаренко А. Ф. Психологическая помощь : теория и практика / А. Ф. Бондаренко. - 3-е изд., испр. и доп. - М. : Независимая фирма «Класс», 2001. - 336 с.

7. Зеер Э. Ф. Психология профессий: Учеб. пособ. для студентов вузов / Э. Ф. Зеер. - М. : Академический проект; - Екатеринбург : Деловая книга, 2003. - 336 с.

Юрий Мельник. Психологическая служба ВУЗа.

Освещень тендениии развития $u$ современное состояние психологической службы в Украине и других странах. Проанализирована нормативно-правовая база по организаиии психологической службы в ВУЗах Украины. Выяснены сущностные характеристики психологической службы. Выяялены особенности психологической службы в ВУЗе. Введено в научный оборот понятие «психологическая служба ВУЗа».

Ключевые слова: психологическая помощь, особенности психологической службы, психологическая служба ВУЗа.

\section{education.}

Yuriy Melnyk. Psychological center institution of higher Illuminating development trends and modern state psychological center in Ukraine and other's countries. Analyzed the legal and regulatory framework for the organization psychological center in the institution of higher education of Ukraine. Finding the essential characteristics of 
psychological center. The features of psychological center in the institution of higher education. Permission for into scientific circulation concept of "psychological center of the institution of higher education».

Key words: psychological assistance, features psychological center, psychological service of the institution of higher education.

Стаття надійшла до редакційної колегії 17.01.2014

УДК 159.953.5+159.9.072

\section{Митроченко Ольга Евгеньевна}

Харьковский национальный университет имени В. Н. Каразина

\section{К ВОПРОСУ О ПОВЫШЕНИИ РЕФЛЕКСИВНОСТИ В ПОЗНАВАТЕЛЬНОЙ ДЕЯТЕЛЬНОСТИ СТУДЕНТА}

Рассмотрены вопросы содержания современного университетского образования. Особое внимание уделено изучению соотношения таких компонентов обучения, как собственно содержательный и компонент формирования необходимых учебных и профессиональных навыков будущуего спецуиалиста. Сделан вывод о необходимости постановки отдельной задачи повышения рефлексивности познавательной деятельности студента. Описана процедура по повышению рефлексивности при овладении ресурсами внимания, которая предполагает теоретическую, диагностическую и тренинговую составляюшие.

Ключевые слова: рефлексивность познавательной деятельности, задачи университетского образования, ресурсы внимания.

Цель статьи заключается в рассмотрении и уточнении задач университетского образования, особенно в области освоения навыков учебной и профессиональной деятельности. На современном этапе развития общества, традиционно именуемом постиндустриальным, задачи университетского образования постоянно пересматриваются. В основном это связано с тем, что роль человека в информационном поле стремительно изменяется. И в условиях производства, и в условиях обучения задача накопления и переработки информации передается компьютерам, сам же человек выполняет задачи ориентировки в информационном хаосе, его критической оценки и принятия решения об уместности информации в определенных условиях. Существует мнение, что образование в содержательном плане - система консервативная, что указывает на то, что та информация, которая выносится на изучение, не отвечает новейшим 


\section{Збірник наукових статей}

достижениям науки. Особенно это касается молодых динамичных наук, в частности гуманитарных. Таким образом, студенты усваивают знания, которые отчасти утратили свою актуальность. Эта ситуация не может быть изменена: оценить вклад новейших достижений в науку можно часто спустя лишь некоторое время, что мешает их непосредственному непромедлительному внедрению в учебный процесс. Этот замкнутый круг необходимости тщательного отбора сведений для учебной программы и ее быстрого устаревания наталкивает на мысль, что не информация сама по себе должна быть основным содержанием образования. В этом же русле рассуждают приверженцы так называемого непрерывного образования R. H. Dave [1] и O. П. Мещанінов [3] указывая, что образование, кроме базовых знаний, должно формировать проблемное аналитическое мышление, социально-психологическую компетентность, интеллектуальную культуру и морально-духовные ценности. Сложно согласиться, что морально-духовные ценности должны быть сформированы в рамках университетского образования, поскольку это роль традиционно отводится дошкольному и школьному образованию. Однако все остальные требования, описанные авторами, не вызывают возражений. Действительно, если опираться на понимание университетского образования, как призванного подготавливать специалистов, которые имеют ряд важнейших практических навыков и могут быстро реагировать на изменения условий труда, тогда следует выделять как минимум два компонента обучения: собственно содержательный и компонент овладения собственными интеллектуальными, мотивационными и эмоционально-волевыми ресурсами.

Таким образом, представляется необходимым выделение отдельной самостоятельной задачи обучения - повышения рефлексивности в познавательной деятельности студента. Высокая рефлексивность предполагает понимание значимости конкретного изучаемого материала для будущей специальности, осознание своих способностей и способов наилучшего использования собственных когнитивных ресурсов, а также высокую интеллектуальную культуру. Под интеллектуальной культурой обычно понимают комплекс знаний и умений в области умственного труда: умение определять цели познавательной деятельности, планировать ее, умение выполнять мыслительные операции различными способами, работать с источниками [2]. Повысить рефлексивность познавательной деятельности можно за счет специальных мероприятий по изучению собственных когнитивных ресурсов. Такие мероприятия должны иметь две основные формы: диагностическую - для констатации так 
называемой зоны актуального развития, и формирующую - для изучения когнитивного потенциала.

Нами была предпринята попытка проведения таких мероприятий для овладения студентами их аттенционными ресурсами. В качестве основного свойства внимания была рассмотрена его дистрибуция. Именно дистрибуция внимания, проявляющаяся в его переключении и распределении, позволяет современному человеку выполнять многозадачную деятельность, которая для него характерна, а также ориентироваться в разнообразных потоках информации. Были разработаны компьютерные методы для диагностики особенностей дистрибуции внимания, на основе которых были выделены ее типы [4]. Также были проведены тренинговые мероприятия. В их состав входило ознакомление с информацией об устройстве дистрибуции внимания, а именно об ее динамическом характере, который проявляется в форме смены последовательной и параллельной обработки информации. Были раскрыты субъектные и объектные факторы, которые влияют на характер дистрибуции, например особенности содержания задачи, влияние опыта разрешения определенного рода задач, индивидные характеристики человека и прочее. Были также проведены собственно тренинговые упражнения, которые вскрывали алгоритм управления собственным вниманием, а именно выделение главных и второстепенных элементов задач, регуляция интенсивности внимания при совмещении действий, выработка ритма деятельности и прочее. Успешность проведенных мероприятий доказывает возможность овладения аттенционными способностями, а также их применимость по отношению к студентам.

Подводя итоги, следует отметить, что наработки современной педагогики и психологии должны быть непременно внедрены в современное университетское образование для повышения гибкости будущих специалистов. Постановка отдельной задачи по повышению рефлексивности познавательной деятельности позволит расставить соответствующие акценты в планировании учебных и воспитательных программ.

\section{Литература}

1. Dave R. H. Lifelong Education and School Curriculum / R. H. Dave. - Hamburg : UNESCO Institute for Education, 1973. - 90 p.

2. Иванова В. П. Феноменология интеллектуальной культуры: общие характеристики / В. П. Иванова // Вестн. Том. гос. ун-та. 2010. № 334. - С. 132-137.

3. Мещанінов О. П. Основні ознаки та проблеми розвитку університетської освіти / О. П. Мещанінов // Наукові праці. - Т. 46. Вип. 33. Педагогічні науки. - Миколаїв : Вид-во МДГУ ім. П. Могили, 2006. - С. 7-13. 
Збірник наукових статей

4. Митроченко О. Є. Діагностика атенційного потенціалу 3 метою вивчення адаптивності студентів / О.С. Митроченко // Психологія в суспільстві, що трансформується, квітень 2010 р. : тези доповіді. - Х., 2010. - С. 302-305.

Ольга Митроченко. До питання про підвищення рефлексивності у пізнавальній діяльності студента.

Розглянуті питання змісту сучасної університетської освіти. Особливу увагу приділено вивченню співвідношення таких компонентів навчання, як власно змістовний та компонент формування необхідних навчальних та професійних навичок майбутнього спеиіаліста. Зроблено висновок про необхідність постановки окремої задачі підвищення рефлексивності пізнавальної діяльності студента. Описана прочедура по підвищенню рефлексивності при оволодінні ресурсами уваги, яка передбачає теоретичну, діагностичну та тренінгову складові.

Ключові слова: рефлексивність пізнавальної діяльності, задачі університетської освіти, ресурси уваги.

Olga Mytrochenko. To the issue of increasing reflexivity in cognitive activity of the students.

The questions of content of modern university education have considered there. Special attention has been payed on studying of relation between such components like informative and formation of necessary studying and professional skills of future specialists. The conclusion about necessity of separate setting the problem of increasing level of reflexivity of student's cognitive activity. The procedure of increasing reflexivity in case of attentional resources acquirement which contain theoretical, diagnostic and training elements has been described.

Key words: reflexivity of cognitive activity, tasks of university education, resources of attention.

Статья поступила в редакционную коллегию 15.05.2014

УДК $378.02: 372.8$

(C) Нагаєв В. М., Абраменко П. О., 2014.

Нагаєв Віктор Михайлович, Абраменко Павло Олексійович

Харківський національний аграрний університет ім. В. В. Докучаєва

\section{УПРАВЛІННЯ ПРОФЕСІЙНО-ТВОРЧОЮ КОМПЕТЕНТНІСТЮ ФАХІВЦІВ АГРАРНОЇ СФЕРИ: ВИХОВНИЙ АСПЕКТ}

Розглянуто теоретичні, методичні та методологічні аспекти виховного процесу підготовки спеціалістів сільськогосподарського 
виробництва в умовах формування їхньої професійно-творчої компетентності. Проаналізовано результати педагогічних експериментів з визначення впливу компонентів пропонованої виховної системи на рівень сформованості соціального досвіду майбутніх фахівиів аграрної сфери.

Ключові слова: професійно-творча компетентність, виховна творча діяльність, управління виховною творчою діяльністю.

XXI століття висуває до освіти нові вимоги. Пріоритетом розвитку сучасної освітньої галузі $\epsilon$ виховання творчої особистості майбутнього фахівця. В процесі виховання студенти опановують духовні і культурні цінності людства, формують моральну основу свого соціального досвіду. Виховання робить людину гармонійно розвинутою, пристосованою до громадського життя [5]. Успіхи цього процесу залежать насамперед від активної виховної діяльності не лише з боку професорсько-викладацького складу, а й з боку самих студентів на основі розвитку творчих компонентів самовиховання особистості.

Проблему формування професійно-творчої компетентності аграріїв розглянемо крізь призму методологічних основ оптимізації виховної системи вищого навчального закладу. Саме виховна система в умовах оновлення усіх сфер громадського життя $\epsilon$ базисом, що формує педагогічний процес за критерієм творчості i сприяє досягненню освітніх цілей у вигляді сформованості соціального досвіду фахівців.

Виховання студентів - процес творчий, зорієнтований на проблеми, пов'язані зі специфікою розвитку професійної галузі. В ідеальній перспективі вищі навчальні заклади освіти мають стати школою саморозвитку, самоуправління, самодисципліни, свідомої відповідальності, співробітництва й творчості викладача й студента [6]. Останнє положення визначає активну роль суб'єктів педагогічного процесу - викладачів і студентів. Саме викладач повинен організувати умови якісної виховної роботи, створивши творче освітнє середовище, а студент відповідно до індивідуальних потреб, інтересів і мотивів - спланувати особистісну стратегію такої діяльності.

Досягнення вищенаведених цілей неможливо без систематичного удосконалення виховної системи. П. Г. Лузан зазначає, що в сучасних умовах для підвищення якості вищої аграрної освіти i забезпечення на цій основі конкурентоспроможності випускників необхідно суттєво перебудувати навчально-виховний процес. До основних напрямів такої модернізації слід віднести: впровадження нових педагогічних технологій; реалізацію відповідної системи підготовки та перепідготовки викладачів; цілеспрямоване, 


\section{Збірник наукових статей}

системне формування навчально-пізнавальної творчої активності студентів в умовах зростаючої ролі самоврядування та самоуправління виховною діяльністю [2, с. 75, 82]. Виходячи 3 цього для підготовки кадрів сільськогосподарського виробництва пропонуємо запровадити у навчальному процесі інноваційну концепцію виховання на основі управління навчально-виховною діяльністю студентів.

Mema cmammi полягає в удосконаленні традиційних дидактичних підходів щодо управління якістю виховної роботи студентів на основі технологізації процесу підготовки кадрів в умовах проектування виховної системи творчого рівня освіти.

Виховна творча діяльність (ВТД) нами розглядається як об'єкт системного вивчення на основі об'єктивності аналізу, інтерпретації джерельної бази 3 позицій цілісності, єдності, науковості, безперервності професійної підготовки фахівців і формування творчої особистості фахівця-аграрія за умов управління і самоуправління різноманітними видами виховної діяльності студентів. Однією 3 якісних критеріальних ознак ВТД $є$ ї самостійність i децентралізований вплив з боку викладача. У сучасному виші виховна творча діяльність - $є$ обов'язковою складовою педагогічної діяльності i являє собою цілеспрямовану високо мотивовану комбінаторну діяльність людини 3 елементами управління i самоуправління у педагогічній системі, яка спрямована на формування високого рівня соціально-творчого досвіду майбутніх фахівців в умовах професійної підготовки кадрів. М. І. Лазарєв у педагогічних дослідженнях зазначає, що у процесі створення технологій навчання та виховання об'єктивно постає проблема розробки ефективного, керованого процесу формування у студентів цілей навчально-виховної діяльності [1].

Авторами пропонується удосконалена виховна система підготовки кадрів, яка грунтується на впровадженні управлінських функцій у педагогічне середовище, реалізації креативної системи підготовки кадрів, високому рівні інформаційного забезпечення i технологізації виховного процесу. Розглядаємо виховну систему за критерієм цілісності, за яким у навчальному процесі є два елемента управління: 1) педагоги (виконують функції управління); 2) студенти (виконують функції самоуправління). При цьому вищою ланкою в ієрархії управління повинен бути педагог, а нижніми - самокеровані дії студентів та відповідні інформаційні засоби [4, с. 249].

Пропонована нами виховна система є динамічною структурою, в якості системоуворюючого компонента якої виступає виховна творча діяльність в умовах функціонального управління. ВТД є керованим об'єктом з боку викладачів і студентів, а також інформаційних засобів виховання, які опосередковують управлінські функції. ВТД організовується за усіма методами, видами і формами освітньої роботи 
i виступає складовою частиною загальних виховних процесів підготовки кадрів. Професійна компетентність за критерієм творчої сформованості фахівців-аграріїв $\epsilon$ кінцевим результатом функціонування пропонованої системи.

Виховні процеси протікають на підставі цільової функції змісту освіти 3 урахуванням соціально-психологічних умов та потреб особистості. При цьому ВТД реалізується у різноманітних педагогічних підсистемах: «студент-викладач», «студент-студент», «студент-навчальна група», «студент-неформальна група», «студентінформаційні засоби виховання», «студент-студентське самоврядування», «студент-соціальна інфраструктура» та ін., де знаходять своє відображення виховна, навчально-творча, соціальна, наукова, виробнича, громадська та інші види діяльності.

Даній виховній системі притаманні визначені функціональні підсистеми, що забезпечують эї стійке функціонування: підсистема планування (забезпечується цілями виховання відповідно професійнокваліфікаційної моделі фахівців); підсистема організації (визначається концепцією виховної роботи); підсистема мотивації (визначається відповідними методами стимулювання студентів); підсистема контрою (забезпечується різноманітними засобами діагностики рівня досягнення сформованості соціального та творчого досвіду фахівців).

Результати дослідження в ХНАУ ім. В. В. Докучаєва засвідчили підвищення соціальної активності студентів i, як наслідок їх рівня сформованості соціального досвіду [3]. Наприклад, при оцінці креативних, когнікативних та оргдіяльнісних якостей студентів експериментальних груп, викладачі засвідчили значно ширший діапазон їх рівня розвитку ніж у студентів контрольних груп. Так, якщо проаналізувати компонент планувальної діяльності студентів експериментальних груп, можна визначити їх вміння розробляти i корегувати індивідуальну стратегію самоуправління виховною роботою 3 визначенням ієрархії цілей досягнення освітнього результату. При цьому студенти контрольних груп у більшості випадків обмежувалися лише вибором мети індивідуального завдання iз запропонованого викладачем виховного напряму.

Висновки. Удосконалена виховна система вишу творчого рівня освіти $є$ динамічною структурою, в якості системоутворюючого компонента якої виступає виховна творча діяльність в умовах функціонального управління. Виховна творча діяльність i процес формування соціального досвіду кадрів аграрної сфери визначається насамперед програмованим блоком управління, який включає елементи управління і самоуправління. Самоуправління $є$ наслідком регуляторної діяльності з боку викладача i результатом суб'єктсуб'єктної взаємодії викладача зі студентом. 


\section{Література}

1. Лазарєв М. I. Полісистемне моделювання змісту технологій навчання: Монографія / М. І. Лазарєв. - Х : НФаУ, 2003. - 326 с.

2. Лузан П. Г. Теоретичні і методичні основи формування навчально-пізнавальної активності студентів у вищих аграрних закладах освіти: Дис... д-ра пед. наук: 13.00.04 / П. Г. Лузан. - К., 2004. - C. 75-82.

3. Нагаєв В. М. Дидактичні критерії навчально-творчої діяльності студентів за технологією «менеджмент-освіта» / В. М. Нагаєв // Новий колегіум. - № 1, 2007. - С. 34-39.

4. Нагаєв В. М. Дидактичні основи формування творчої особистості аграрного менеджера в умовах Болонського процесу: Монографія / В. М. Нагаєв. - Х. : ХНАУ, 2006. - 525 с.

5. Сухомлинський В. А. О воспитании / Сост. С. Соловейчик. 3-изд. - М. : Политиздат, 1979. - С. 168.

6. Чернілевський Д. В. Духовна культура особистості: навчальний посібник / Д. В. Чернілевський, П. М. Таланчук, М. Б. Свтух та ін. - Вид. 3-є. - Вінниця : Глобус-Прес, 2013. - 416 с.

Виктор Нагаев, Павел Абраменко. Управление профессионально-творческой компетентностью специалистов аграрной сферы: воспитательный аспект. Paсcмотрень теоретические, методические и методологические аспекты воспитательного прочесса подготовки специалистов сельскохозяйственного производства в условиях формирования их профессионально-творческой компетентности. Проанализированы результаты педагогических экспериментов по определению влияния компонентов воспитательной системь на уровень сформированности соичиального опыта будущих специиалистов аграрной сферы.

Ключевые слова: профессионально-творческая компетентность, воспитательная творческая деятельность, управление воспитательной творческой деятельностью.

Viktor Nagaev, Pavlo Abramenko.

Management the professionally-creative competence of specialists of agrarian sphere: educator aspect. The theoretical, methodical and methodological aspects of educator process of preparation of specialists of agricultural production are considered in the conditions of forming of professionally-creative competence of specialists. The results of pedagogical experiments are analysed from determination of influence of components of the offered educator system on the level of formed of social experience of future specialists of agrarian sphere.

Key words: professionally-creative competence, educator creative activity, management educator creative activity.

Стаття надійшла до редакційної колегії 11.05.2014 


\section{Оксенюк Ірина Леонідівна}

(C) Оксенюк І. Л., 2014.

Національний авіаційний університет, м. Київ, Україна

\section{ОБГРУНТУВАННЯ ОРГАНІЗАЦІЙНО-ПЕДАГОГІЧНИХ УМОВ ФОРМУВАННЯ ГОТОВНОСТІ ДО ПРОФЕСІЙНОЇ ДІЯЛЬНОСТІ МАГІСТРІВ 3 УПРАВЛІННЯ ПРОЕКТАМИ}

В статті проаналізовано необхідні організаційно-педагогічні умови для формування готовності до професійної діяльності магістрів 3 управління проектами в технічному університеті. Представлено власне трактування поняття «організаційно-педагогічні умови».

Ключові слова: організаційно-педагогічні умови, диференційоване навчання, інновачійна діяльність, проектна технологія, фахівець 3 управління проектами, самостійна робота магістра.

Аналіз соціально-економічних і професійних вимог до фахівців 3 управління проектами свідчить, що їх професійна підготовка потребує удосконалення організаційно-педагогічних умов навчальновиховного процесу з метою забезпечення відповідності підготовки сучасним потребам у тих видах діяльності, де доводиться мати справу з управлінням складними процесами.

Результати аналізу наукових джерел свідчать, що поняття „Педагогічні умови” широко розглядається багатьма авторами (О. Богданюк, В. Матвійчук, О. Михайлишин, О. Пономаренко, С. Сінкевич), а поняття “організаційно-педагогічні умови” зустрічається в науковій літератур віднедавна, зокрема у працях таких авторів: І. Зайцева, О. Мельничук, І. Підласий, Н. Логінова та інші.

Метою даної статті є авторське формулювання необхідних організаційно-педагогічних умов для формування готовності до професійної діяльності магістрів 3 управління проектами та обгрунтування даних в ході дисертаційного дослідження.

Науковці все частіше застосовують організаційний аспект у педагогічних умовах та пов'язують його з ефективністю процесів, що досліджуються досить актуально [2, с. 162-164]. Наші дослідження свідчать про те, що впроваджувати організаційно-педагогічні умови слід як цілісну систему. При вивченні даної проблематики ми сформулювали власне визначення організаційно-педагогічних умов взаємопов'язані способи та обставини організації педагогічного процесу, які утворюють відповідну систему та визначають ефективність його функціонування (педагогічного процесу). 
Обгрунтуємо організаційно-педагогічні умови, що були нами визначені.

Перша: забезпечення позитивної внутрішньої мотивації в процесі професійного становлення магістрів. В якості мотиваційних факторів навчальної діяльності можуть виступати: важливість предмета для професійної підготовки; інтерес до предмету; якість викладання; співвідношення між труднощами оволодіння відповідним предметом і особистісними здібностями; взаємостосунки з викладачем $[1$, c. 267]. Забезпечити їх можна шляхом вивчення особливостей кожного магістра: рівня засвоєних знань, ступеню прояву здібностей, потенційних можливостей, темпераменту, певної типологічної групи тощо.

Друга організаційно-педагогічна умова: здійснення професійної підготовки майбутніх фахівиів з управління проектами з урахуванням інтегрованого характеру їх практичної діяльності. Інноваційні процеси в економічній діяльності підприємств будь-якої індустрії, що використовує проектну технологію (будівельна, IT) в умовах ринкових перетворень вимагають впровадження ринкових важелів виробництва, що зумовлює інтегрований характер професійної діяльності майбутніх фахівців. Інтегровані наукові знання мають таку важливу ознаку, як системність, тобто це не просте накопичення розрізнених знань, а взаємопов'язана система, що грунтується на відповідних положеннях і закономірностях.

Проте, аналіз начальних планів підготовки фахівців 3 управління проектами в технічних університетах України свідчать, що ряд навчальних курсів, здебільшого, включаючи великий об'єм інформації і враховуючи традиційні технології, не сприяють науковообгрунтованому засвоєнню, а лише хаотично накопичуються у магістрів i не в повному обсязі стають засобом формування студентами відповідних професійних компетентностей.

Третьою організаційно-педагогічною умовою ми розглядаємо використання та реалізація проектних технологій та окремих їх елементів для створення проектів, що формують складові компоненти ключових компетентностей.

Під проектуванням ми розуміємо процес створення проекту, а проектну діяльність ми визначаємо як сукупність певних дій та операцій, які здійснює суб'єкт у процесі проектування. Крім того, в нашому дослідженні ми користуємося поняттям „проектна технологія" як упорядкованою сукупністю дій, операцій, процедур і методів (дослідницьких, пошукових, проблемних), навчальнопізнавальних прийомів, що зорієнтовані на застосування фактичних знань для набуття нових, забезпечують досягнення результату (тобто створення проекту) шляхом самостійної роботи магістрів, яка 
діагностується та прогнозується у змінюваних умовах навчального процесу.

Таким чином, в якості об'єкта проектної технології ми обираємо навчальний проект, а предметом - діяльність для створення проекту, тобто проектну діяльність. Виходячи 3 особливостей професійної діяльності майбутніх фахівців з управління проектами і структури ключових компетентностей, у нашому дослідженні ми використовуємо типологію проектів, яка виокремлює інформаційні, дослідницькі, творчі, ігрові та практично-орієнтовані проекти. Сутність проектних технологій полягає в тому, що магістр під час роботи над проектом пізнає реальні процеси та об'єкти, проживаючи конкретні ситуації; проникає у глибину явищ, процесів, конструюючи нові продукти.

Наступною організаційно-педагогічною умовою ми розглядаємо цілеспрямоване використання в процесі навчальної діяльності рівневої диференціації та індивідуалізащії навчання, підвищення якості організаиії самостійної роботи з фахових дисичилін.

Розуміння диференційованого навчання полягає у вивченні індивідуальних особливостей магістрів. Ми вважаємо, що диференційоване навчання - це спеціально організована навчальнопізнавальна діяльність, яка, враховуючи вікові, індивідуальні особливості суб'єктів навчання, їхній соціальний досвід і загальний стан, спрямований на оптимальний фізичний, духовний i психічний розвиток студентів, засвоєння необхідної суми знань, практичних дій за різними навчальними планами і програмами.

П'ятою умовою ми виділяємо удосконалення організації навчально-виховного прочесу зі спеціальності "Управління проектами” з метою активізації самостійної пізнавальної діяльності магістра як необхідного фактора реалізації готовності до професійної та інноваційної діяльності фахівия з управління проектами. В процесі розробки експериментальної методики значну увагу ми приділили вивченню результативності самостійної роботи. Окрім виконання звичайного обсягу домашньої самостійної роботи, ми пропонували магістрам підготувати виступ, твір, презентацію за відповідною тематикою, які не є частиною обов'язкового домашнього завдання, але дуже ефективно сприяють підвищенню інтересу у вивченні фахових дисциплін. При організації самостійної роботи ми давали магістру можливість самому обирати (в межах теми, що вивчається) і презентувати той науковий матеріал, який його цікавить.

Конкуретноспроможний фахівець 3 управління проектами повинен також займатись і інноваційною діяльністю, адже інноваційна діяльність - це вид діяльності, пов'язаний із трансформацією наукових досліджень i розробок, інших науково-технологічних досягнень у новий чи удосконалений продукт, введений на ринок, в новий чи 
удосконалений технологічний процес, що використовується у практичній діяльності, чи новий підхід до соціальних послуг. В час передових технологій та статусу англійської мови, як міжнародної мови бізнесу та інновацій, - оптимальний спосіб це Інтернет та закордонні джерела. Тому навички самостійної роботи, знання англійської мови, роботи з Інтреннет - технлогіями сьогодні стають не бажаними, а необхідними.

Висновки та перспективи. В цілому розв'язання завдання формування готовності до професійної діяльності магістрів можливе шляхом ціленаправленого педагогічного управління оптимізацією навчального процесу, змінення технології отримання нового знання та становлення майбутнього фахівця на базі використання інноваційних освітніх технологій. Ефективне управління якістю підготовки фахівців можливе лише за ефективно підібраних організаційно-педагогічних умов, які безпосередньо впливають на якість професійної підготовки магістра з управління проектами. Основні підходами до реалізації організачійно-педагогічних умов у процесі професійної підготовки майбутніх фахівців 3 управління проектами такі: індивідуальний або особистісно-орієнтований підхід до магістрів у процесі проектної діяльності; проблемний підхід (створення проблемних ситуацій) 3 метою визначення тематики проектів; практично спрямований діяльнісний підхід (передбачення у темах проектів реальних проблем майбутньої професійної діяльності, що потребують вирішення); міждисциплінарний підхід (реалізація проекту передбачає використання та інтеграції знань, умінь та навичок 3 різних дисциплін).

\section{Література}

1. Ильин Е. П. Мотивация и мотивы / Е. П. Ильин. - СПб. : Изд. «Питер», 2000. - 512 с.

2. Підласий I. П. Діагностика та експертиза педагогічних проектів: навч. посібник / І. П. Підласий. - К. : Україна, 1998. - 343 с.

\begin{tabular}{lcccc}
\multicolumn{1}{c}{ Ирина } & Оксенюк. & Обоснование & \multicolumn{2}{c}{ организационно- } \\
педагогических & условий & формирования & \multicolumn{2}{c}{ готовности к } \\
профессиональной & деятельности магистров & по управлению \\
проектами. & & &
\end{tabular}

B cтатье проанализированы необходимые организационнопедагогические условия для формирования готовности к профессиональной деятельности магистров по управлению проектами в техническом университете. Представлено собственную трактовку понятия «организачионно-педагогические условия».

Ключевые слова: организационно-педагогические условия, дифференцированное обучение, инновационная деятельность, 
проектная технология, специалист по управлению проектами, самостоятельная работа магистра.

Iryna Okseniuk. Justification organizational and pedagogical conditions formation of readiness for professional activity Masters in Project Management.

In the article has been made the analysis of the required pedagogical conditions for the formation of readiness for professional activity masters in project management at the Technical University. Submitted own interpretation of the term "organizational and pedagogical conditions."

Key words: organizational and pedagogical conditions, differentiated learning, innovative activity, project technology, expert project management, independent work of master's degree.

Стаття надійшла до редакційної колегії 11.03.2014

УДК 378.334 .2

\section{Olena Oleksenko \\ S. Kuznets Kharkiv National University of Economics \\ PSYCHOLOGICAL AND PEDAGOGICAL ASPECTS OF CROSS-CULTURAL CONFLICT RESEARCH}

(C) Oleksenko O. O., 2014.

The article deals with the psychological and pedagogical aspect of the cross-cultural conflict research. Its functions, structure, stages are outlined. Influence of studying the psychological and pedagogical aspect of the crosscultural conflict on the efficiency of professional activity of future managers is proved.

Key words: cross-cultural conflict, manager, professional activity.

The modern state of social, economic and political changes in the society, global innovative processes in the system of higher education of Ukraine, as well as intensification of cross-cultural cooperation, influence the demands for a high professional level of managers of foreign economic activity. Practice has proved that future managers lack psychological training in the situation of the cross-cultural conflict. It brings forward the problem of the cross-cultural conflict research in the psychological and pedagogical aspect that will help future managers forecast, assess and choose the most effective ways of managing the cross-cultural conflict.

The cross-cultural conflict is largely interdisciplinary in nature. It has been researched by Ukrainian and foreign scholars in different fields of knowledge, including psychology (M. Leontjev, G. Berry, A. Putinga, M. Seagull and others) and pedagogy (G. Elizarova, K. Staroverova, P. Linell and others). Despite the numerous research there is a necessity in psychological and pedagogical analysis of the cross-cultural conflict for 
professional activity of future managers. As pedagogical activity is based on the process of effective communication and description of future managers' qualification emphasizes the capability to forecast and analyse potential cross-cultural conflicts, the research of this phenomenon on the basis of the psychological and pedagogical aspect is urgent. Studied at advanced undergraduate courses it becomes the foreground for effective work of future managers in the authentic cross-cultural interaction.

The aim of the article is to outline the results of the cross-cultural research on the basis of the psychological and pedagogical aspect.

The analysis of definitions allows us to define the cross-cultural conflict as clash of persuasions, values, ways of behaviour in relations of representatives of different cultures. Defining the basic structural components and stages of the cross-cultural conflict is grounded on the components and stages of conflicts outlined by psychologists (M. Leontiev, A. Karmin). Thus, the cross-cultural conflict consists of the subject, motives, participants, their views.

The subject of the cross-cultural conflict is the main opposition that provokes cross-cultural interaction. Defining the subject of the crosscultural conflict is the starting point for seeking ways to manage it effectively.

The motives of the cross-cultural conflict are some inner stimulating resources which urge both sides of the cross-cultural interaction to a conflict. They may be presented in the form of needs, interests, aims, ideals, persuasions etc. For example it is natural for partners of business communication to exaggerate distinctions between foreign organizations and minimize those which exist inside their own [4]. Exaggerating distinctions, corresponding simplification and groundless generalization often become the motives of the cross-cultural conflict [2, p. 170-180].

The participants of the cross-cultural conflict are presented by subjects of the cross-cultural interaction that are in the state of conflict or support either visibly or latently those who clash.

An important role in different stages of the cross-cultural conflict may be also played by other participants such as initiators, organizers, assistants, mediators. The scholars (J. Karaulov, G. Bogin, V. Furmanova) prove the necessity to form a language personality that masters the communication skills with representatives of other cultures and thus is able to manage the cross-cultural conflict effectively [3]. The process of conflictless cross-cultural interaction is to take place on the background of realizing one's own stereotypes and psychological reactions, showing tolerance, avoiding prejudice [2, p. 5].

The primary focus should be concentrated on the theoretical understanding and empirical analysis of the essence of the cross-cultural conflict stages. Therefore it helps foresee, assess and choose effective ways 
of its management. Among the stages of the cross-cultural conflict are exposition, development, climax and denouement.

The exposition is revelation of contradictions between participants of the cross-cultural conflict that take an active or passive part in the clash, public exposure of antagonism both for participants of the cross-cultural conflict and outside observers. Initiation of the cross-cultural conflict in business communication happens either "from above" (i.e. chief vs. subordinate) or "from below" (i.e. subordinate vs. chief) or horizontally (i.e. business partners equal in status, rights, power, freedom of actions etc). The cross-cultural conflict may be visible (participants announce their clash publicly), latent (its state is defined through corresponding extra- and nonverbal communication), blind (participants do not realize the situation of the cross-cultural conflict). The latent cross-cultural conflict can be transformed into a visible one if "the third side" does not intervene.

The duration of the latent and blind periods cannot be foreseen as their transformation into a visible one depends on the level of aggressiveness of the participants and outside irritants which destabilize self-regulation.

The climax of the cross-cultural conflict is the most critical clash. At this stage "the third side" can balance the conflicting participants. "The third side" can be presented either by an individual (for example a manager of a higher rank) or information that can either support one of the participants or disclaim the starting motive of the cross-cultural conflict or give new directions. The action of "the third side" is realized through management approaches, styles and strategies of managing behaviour. After the climax the cross-cultural conflict can be either solved or transformed into another state or its participants can be forced to part. The post-conflict syndrome is an optional stage of the cross-cultural conflict which is revealed in emotional and intellectual experience, physical state of the participants. The post-conflict syndrome can be presented in the form of frustration [1].

Thus, the cross-cultural conflict has cognitive, regulative, integral functions. It consists of the subjects, motives, participants, their views. The structural components include exposition, development, climax and denouement. The general analysis of the research results proves the high efficiency of the professional activity of future managers in conditions of studying the psychological and pedagogical aspect of the cross-cultural conflict. Realizing functions, structure, stages of the cross-cultural conflict will give the future managers the possibility to get ready psychologically for cross-cultural difficulties which arise from divergence (in culture-specific norms, values, world-outlook), prejudice, stereotypes. Realizing one's own cultural identity will intensify the unity inside the professional group. Reflexive understanding of the gained intellectual and emotional experience 
will help in the future control one's own behavior and manage crosscultural conflicts.

The prospect of the future research in this direction is economic aspect of the cross-cultural conflict.

\section{References}

1. Бэрон Р. Социальная психология группы: процессы, решения, действия / Р. Бэрон, Н. Керр, Н. Миллер. - СПб : Питер, 2003. - 272 с. - (Серия “Концентрированная психология").

2. Елизарова Г. В. Формирование межкультурной компетенции студентов в процессе обучения иноязычному общению: автореф. дис. на соискание уч. степени докт. пед. наук: спец. 13.00.02 “Теория и методика обучения и воспитания (иностранный язык, уровень профессионального образования)" / Г. В. Елизарова. - СанктПетербург, 2001. - 36 с.

3. Караулов Ю. Н. Русский язык и языковая личность / Ю. Н. Караулов. - М. : Наука, 1987. - 264 с.

4. Кросс-культурная психология. Исследования и применение / [Берри Дж. В., Пуртинга А. Х., Сигал М. Х., Дасен П. Р.] / Пер. с англ. - Х. : Изд-во Гуманитарный центр, 2007. - 560 с.

5. Linell P. Approaching dialogue: talk, interaction and context in dialogical perspectives / Per Linell. - Amsterdam: Benjamin, 2001. - 253 p.

Олена Олексенко. Психолого-педагогічний аспект дослідження міжкультурного конфлікту.

Розглянуто психолого-педагогічний аспект дослідження міжкультурного конфлікту. Виокремлено функиії, структуру, етапи міжкультурного конфлікту. Доведено необхідність вивчення психолого-педагогічного аспекту міжкультурного конфлікту для ефективної професійної діяльності майбутніх менеджерів.

Ключові слова: міжкультурний конфлікт, менеджер, професійна діяльність.

\section{Елена Олексенко. Психолого-педагогический аспект исследования межкультурного конфликта.}

Рассмотрен психолого-педагогический аспект исследования межкультурного конфликта. Выделены функиии, структура, этапь межкультурного конфликта. Доказана необходимость изучения психолого-педагогического аспекта межкультурного конфликта для эффективной профессиональной деятельности будущих менеджеров. Ключевые слова: межкультурный конфликт, менеджер, профессиональная деятельность.

Статья поступила в редакционную коллегию 15.05.2014 


\section{Осьмук Наталія Григорівна}

(с) Осьмук Н. Г., 2014.

Сумський державний педагогічний університет імені А. С. Макаренка

\section{ХАРАКТЕРИСТИКА ПРЕДМЕТНОГО КОЛА КЛЮЧОВИХ КОМПЕТЕНЦЙ СУЧАСНОГО ВЧИТЕЛЯ}

Кардинальні зміни сучасної освіти, щзо зумовлені розвитком інноваційного суспільства, значно посилюють інтерес до нових концептуальних орієнтирів щзод підготовки педагогічних кадрів. Особливої ваги набуває розробка і впровадження фахової освіти за компетентністним підходом. Визначенню предметного кола ключових компетенцій майбутнього вчителя, ̈̈х характеристиці та взаємозв'язку присвячено дану статтю.

Ключові слова: професійна підготовка вчителя, компетентністний підхід, компетентність, компетенція, ключові компетенції.

Сучасні завдання фахової освіти в будь-якій сфері детермінуються вимогами, що передбачають врахування суперечностей між потребами ринку праці в конкурентоспроможній активній особистості та системою підготовки переважно знаннєвоадаптивної орієнтованості. Модернізація професійної освіти передбачає підготовку спеціалістів, які не лише володіють певним обсягом знань, умінь, навичок, але й здатні виявляти готовність до активної, ініціативної, перетворюючої діяльності в швидкозмінюваних реаліях сьогодення. 3 огляду на вище зазначене набувають актуальності проблеми фахової підготовки за компетентісним підходом.

Метою статmі є спроба характеристики предметного кола ключових компетенцій вчителя.

Проблема підготовки вчителя як компетентного фахівця зумовила значний інтерес широкого кола вітчизняних і зарубіжних науковців. Серед них: О. Антонова, В. Байденко, О. Бермус, Н. Бібік, В. Болотов, Н. Волкова, Е. Зеєр, І. Зимня, О. Лавріненко, О. Локшина, А. Маркова, Н. Ничкало, О. Овчарук, О. Пометун, Л. Пуховська, Дж. Равен, С. Сисоєва, Л. Сігаєва, Л. Хоружа, А. Хуторський, А. Шелтен та ін.

Аналіз наукових досліджень 3 обраної тематики дозволяє стверджувати, що сучасним орієнтиром професійної підготовки майбутнього вчителя, під якою розуміють єдність цілей, змісту, структури навчання й виховання та способів реалізації набутих знань, навичок і вмінь, $є$ компетентісний підхід. Рівень професіоналізму 


\section{Збірник наукових статей}

особистості визначає іiі компетентність, досягнення якої відбувається через здобуття необхідних компетенцій.

Поняття „компетентність” є багатоаспектним і складним. Певна частина науковців (О. Бермус, І. Зимня, А. Хуторський) тлумачать їі як сукупність компетенцій, їх якісне та ефективне використання. При цьому під компетенціями розуміють характеристики поведінки, що сформовані на відповідних знаннях, навичках і вміннях особистості й надають можливість встановити зв'язок між знаннями і ситуацією, визначити суть проблеми і успішно їі розв'язати.

Поняття „компетентність” і „компетенція” співвідносяться як ціле і частина. Кожна окрема компетенція характеризує певний прояв особистості, що у своїй сукупності визначають компетентність. На відміну від компетенції, компетентість відображає кінцевий результат роботи певного рівня. За визначенням Дж. Равена компетентність - це спроможність особистості сприймати індивідуальні та соціальні потреби та відповідати на них, кваліфіковано будувати діяльність у будь-якому напрямі, виконувати певні завдання або роботу [3, с. 11]. А. Хуторський визначає компетентність як сукупність особистісних якостей, зокрема: ціннісних орієнтацій, знань, умінь, навичок, здібностей, що обумовлені досвідом діяльності в певній соціальній i особистісно-значущій сфері [4, с. 61]. Отже, компетентність можна охарактеризувати як комплексну (інтегровану) характеристику особистості, що являє собою сукупність професійних знань, умінь, навичок, здібностей, цільових настанов, самостійності, гнучкості i критичності, необхідних для успішного виконання професійних завдань.

Формування професійної (фахової) компетентності педагога визначається специфікою його діяльності й передбачає набуття комплексу педагогічних здібностей, можливостей, системи знань, умінь, навичок і досвіду, вмотивованої спрямованості й ціннісних орієнтацій. Педагогічна компетентність виявляється як сукупність загальних i спеціальних компетенцій, що розкривають здатність учителя успішно розв'язувати завдання різних напрямів професійної діяльності.

Наявні в педагогічній науковій думці класифікації (В. Байденко, Є. Зеєр, І. Зимня та інші) презентують полікритеріальність підходів визначення компетентностей і компетенцій учителя. Проте, напевно, можна говорити і про наявність визнаних педагогічних компетенцій, які створюють предметне коло ключових компетенцій учителя, що, в свою чергу, обумовлюють специфічність спрямування загальних i спеціальних компетенцій майбутнього педагога.

Наше розуміння предметного кола ключових компетентностей обумовлюється визнанням за певними компетенціями загального 
характеру, що відносяться до особистісних (соціально-психологічних), визначальної (спеціальної) ролі в професійній діяльності вчителя. Розглянемо дану гіпотезу на прикладах існуючих класифікацій. Так, А. Хуторським запропоновано сім груп ключових компетенцій: ціннісно-сутнісні, загальнокультурні, навчально-пізнавальні, інформаційні, комунікативні, соціально-трудові та особистісного самовдосконалення [4]. В. Пелагейченко ключовими компонентами професійної компетентності пропонує визначати: інформаційний, комунікативний, продуктивний, автономізаційний, моральний, психологічний, предметний, соціальний, математичний i особистісний [2]. Як видно, в обох представлених класифікаціях виокремлені як самостійні психологічні і перетворювальні риси вчителя, що мають гуманістичне спрямування.

Ще одним підтвердженням особливого характеру ключових компетенцій сучасного вчителя $є$ ті, що були визначені Асоціацією ректорів педагогічних університетів Свропи і знайшли відображення в Педагогічній Конституції Свропи [1]. За вказаним документом підготовка європейського вчителя XXI вимагає від нього оволодіння сукупністю комунікативних, лідерських, дослідницько-аналітичних компетенцій, а також, формування таких особистісних рис як справедливість, самоідентичність, емпатія, здатність навчатися протягом життя тощо [1, с. 114]. Представлений перелік вимог, також, демонструє відданість сучасної педагогічної спільноти гуманним соціокультурним цінностям.

Таким чином, провідною ознакою предметного кола ключових компетенцій було обрано їх особливу спрямованість. Аналіз класифікацій компетенцій засвідчів, що провідною характеристикою предметного кола ключових компетенцій вчителя виступає їх гуманістичний характер. Він виявляється як на рівні змістової сутності провідних компетенцій, так і в якості стратегічної ознаки сучасної педагогічної освіти.

\section{Література}

1. Педагогічна Конституція Свропи. Преамбула // Вища освіта України. - 2013. - № 3. - С. 111-115.

2. Пелагейченко В. Ключові компоненти компетентності вчителя / В. Пелагейченко // Відкритий урок: розробки, технології, досвід. -2009. - № 2. - С. 55-60.

3. Равен Дж. Компетентность в современном обществе: выявление, развитие и реализация / Дж. Равен; пер. с англ. - М. : Когито-Центр, 2002. - 396 с.

4. Хуторской А. В. Определение общепредметного содержания и ключевых компетенций как характеристика нового подхода к конструированию образовательных стандартов / А. В. Хуторской // 
Компетенции в образовании: опыт проектирования : сб. науч. тр. / под ред. А. В. Хуторского. - М. : Научно-внедренческое предприятие «ИНЭК», 2007. - 327 c.

Наталия Осьмук. Характеристика предметного круга ключевых компетенций современного учителя.

Кардинальные изменения в современном образовании, обусловленные развитием инновационного общества, значительно усиливают интерес $\kappa$ новым концептуальным ориентирам подготовки педагогических кадров. Особое значение приобретает разработка и внедрение профессионального образования за компетентностным подходом. Определению предметного круга ключевых компетениий будущего учителя, рассмотрению их характеристики и взаимосвязей посвящена данная статья.

Ключевые слова: профессиональная подготовка учителя, компетентностный подход, компетентность, компетенция, ключевые компетенции.

Natalia Osmuk. Characteristic of key competences of a contemporary teacher.

Crucial changes in nowadays education system, caused by the development of innovative society, draw precise attention to the conceptual aspects in teacher training. Working out and implementing professional education using competence approach gain much interest today. The article deals with defining key competences of future teacher, describing their characteristic and interconnection.

Key words: teacher training, competence-based approach, competence, key competences.

Стаття надійшла до редакційної колегії 14.05.2014

УДК 37.091.33-024.63-026.12:37.091.12-057.86

(C) Повстяна Ю. С., Радченко М. А., 2014.

Повстяна Юлія Славомирівна

Луцький національний технічний університет

Радченко Марина Аркадіївна

Східноєвропейський національний університет імені Лесі Українки

\section{ІНТЕРАКТИВНІ МЕТОДИ НАВЧАННЯ МАЙБУТНІХ ФАХІВЦІВ}

У статті розглянута характеристика інтерактивних методів навчання, їх значення та можливості використання в навчальному прочесі вищих навчальних закладах.

Ключові слова: інтерактив, інтерактивна технологія навчання, інтерактивні методи навчання. 
Зміни життя в сучасному світі вимагають і змін мети та призначення сучасної освіти. Знижується функціональна значущість i привабливість традиційної організації навчання, передача «готових» знань від учителя до учня перестає бути основним завданням навчального процесу. Формуються сучасні уявлення про фундаментальність освіти, отримавши яку, людина здатна самостійно працювати, вчитися і переучуватися.

Вчені вважають, що у центрі уваги сучасної освіти мають бути не стільки навчальні предмети, скільки способи мислення і діяльності майбутнього фахівця. Тобто, необхідно навчити студента критично мислити, вирішувати складні проблеми шляхом аналізу обставин i відповідної інформації, зважувати і враховувати альтернативні думки, приймати виважені рішення, дискутувати, спілкуватися 3 іншими людьми.

Тому для науковців і викладачів вищих навчальних закладів актуальним залишається питання, як викладати і навчати, як вчити i вчитися, щоб зробити ефективним процес навчання.

Mema cmammi - визначити особливості використання інтерактивних методів навчання.

Дуже серйозне та глибоке вивчення, використання інтерактивних технологій навчання у вищих навчальних закладах розглянуто в роботах В. П. Беспалько, В. І. Свдокимова, М. В. Кларіна, Е. Н. Пєхоти, Г. К. Селевко, В. В. Серікова, С. А. Сисоєвої, I. С. Якиманскої; теоретичні й практичні аспекти проблеми - в наукових працях Е. Н. Пєхоти, С. І. Пометун, Л. В. Пироженко, А. Панченкова, Т. Ремех, О. Саган, О. Стребной та інших вітчизняних і зарубіжних учених. Інтерактивні технології навчання, які сприяють соціальному становленню особистості, розглянуті в роботах Б. Г. Ананьєва, Л. С. Виготського та ін. Проблемам інтерактивного спілкування присвячені наукові праці М. М. Богомолової, Б. Ф. Ломова, Р. С. Немова, Л. А. Петровської, Л. І. Уманського та ін.

Сутність інтерактивних методів полягає в тому, що навчання відбувається завдяки взаємодії всіх учасників педагогічного процесу. Це суспільна діяльність, в якій викладач та студенти виступають суб’єктами навчання.

В основу класифікації інтерактивних методів навчання науковцями покладені ті чи інші ознаки цих методів.

Так, М. Кларін класифікує інтерактивні методи навчання за принципом активності: фізична; соціальна; пізнавальна.

Прикладами фізичної активності є зміна робочого місця, запис інформаційних матеріалів, участь в проведенні навчальних занять та ін. Учасники навчання проявляють соціальну активність тоді, коли ставлять запитання, відповідають тощо. Пізнавальна активність 


\section{Збірник наукових статей}

студентів виявляється в підготовці до занять, доповненнях, виступах, які в свою чергу виступають джерелом професійного досвіду, самостійному пошуку розв'язання проблеми [2]. Треба зазначити також, що всі три види прояву активності студентами взаємопов'язані між собою.

О. Пометун і Л. Пироженко об'єднують форми інтерактивного навчання у чотири групи, залежно від мети навчання та форм організації навчальної діяльності учнів:

- кооперативне навчання (робота в парах, трійках, карусель, робота в малих групах, акваріум тощо);

- колективно-групове навчання (мікрофон, незакінчені речення, мозковий штурм, «навчаючи - вчуся», «ажурна пилка» та ін.);

- ситуативне моделювання (імітаційні ігри, рольова гра, драматизація та ін.);

- опрацювання дискусійних питань (метод ПРЕС, «займи позицію», «дискусія» тощо).

М. Скрипник у свою класифікацію інтерактивних методів навчання поклала такий принцип навчання, як взаємодія - діалог. Дослідниця визначає наступні інтерактивні методи навчання:

- інформаційні ( «Перше знайомство», «Хвилина мого життя», «Паперові літаки», «Мені подобається...», «Іменні жетони»);

- пізнавальні («Від А до Я»);

- мотиваційні («Мої очікування», «Лист до самого себе», «Самооцінка», «Інтерв'ю»);

- регулятивні («Виробимо правила»).

Основна відмінність інтерактивних вправ i завдань від звичайних полягає в тому, що вони спрямовані на вивчення нового, а не на закріплення вже відомого. Серед них можна виділити наступні:

- творчі завдання;

- робота в малих групах;

- навчаючі ігри (рольові, ділові й освітні ігри, імітації);

- використання суспільних ресурсів (запрошення фахівця, екскурсії);

- соціальні проекти та інші поза аудиторні методи навчання (змагання, радіо, газети, фільми, вистави, виставки);

- вивчення і закріплення нового матеріалу (інтерактивна лекція, робота 3 наочною допомогою, відео- та аудіо- матеріалами, «студент в ролі викладача», «кожен навчає кожного», та ін.);

- обговорення складних і дискусійних питань, проблем («Займи позицію (шкала думок)», проектна техніка, «Один - удвох - всі разом», «Зміни позицію», «Дискусія в стилі телевізійного шоу», дебати, симпозіум); 
- вирішення проблем («Дерево рішень», «Мозковий штурм», «Аналіз казусів», «Переговори і медитація») та ін. [1].

Вчені вважають, що модель групового вирішення проблем за допомогою метафоричного мислення, яка має назву «синектика», також $\epsilon$ популярною та ефективною при застосуванні інтерактивних технологій навчання студентів. Синектика охоплює досвід застосування методу групової генерації ідей, який відомий як метод «мозкової атаки», або «мозковий штурм». «Мозкова атака» є одним із системних методів пошуку, який $\epsilon$ ефективним в активізації колективної творчої діяльності [1].

Наступний метод інтерактивного навчання - дискусія. Дискусію, як навчальну форму роботи зі студентським колективом, частіше використовують у формі:

- «круглий стіл» - бесіда, у якій на рівних беруть участь невелика група студентів, при цьому відбувається обмін думками між студентами;

- «засідання експертної комісії» - спільне обговорення висунутої проблеми учасниками групи (з визначеним заздалегідь головою) та обговорення доповіді (досить стислої, у якій кожен доповідач висловлюватиме свою позицію);

- «форум» - обговорення, у ході якого група «експертів» обмінюється думками з «аудиторією»;

- «дебати» - формалізоване обговорення, яке побудоване на основі виступів учасників-представників двох протилежних командсуперників та заперечень щодо цих виступів.

Теоретичне значення використання інтерактивних методів в процесі навчання у вищих закладах освіти виявляється в тому, що вони сприяють формуванню комунікативної культури студентів, розвитку толерантності, емпатії, взаємоповаги; стають ефективним засобом формування комунікативних умінь та навичок (висловлювання та доведення своїх ідей, думок тощо).

До інтерактивних методів навчання належать також ігрові методи, які дозволяють удосконалювати діяльність і створюють нові моделі професійної практики, що відповідає цілям актуалізації майбутнього професіоналізму в педагогічному процесі в умовах вищих навчальних закладів.

Широко відомі серед інтерактивних методів навчання так звані «ділові ігри». Ділова гра - це форма відтворення предметного і соціального змісту, професійної діяльності спеціаліста, моделювання відносин, характерних для цієї діяльності як цілого [3]. За допомогою ділових ігор можливе формування у студентів цілісного бачення професійної діяльності, її динаміки; розвиток проблемно-професійного 


\section{Збірник наукових статей}

i соціального досвіду, теоретичного і практичного мислення в майбутній професійній сфері.

В нашій роботі ми використовували рольові ігри для залучення уваги студентів до конкретної проблеми, формування комунікативних навичок. Рольові ігри - це прояви поведінкового компоненту діяльності студентів. Вони можуть набувати різних форм: від простих дій до складного їх ряду, допомагають формувати такі важливі ключові якості фахівців, як комунікативність, толерантність, вміння працювати в малих групах, самостійність мислення та ін.

Ефективним методом інтерактивного навчання є «портфоліо», який націлений на формування певного стилю розумової діяльності, самооцінки та атестації студентів [4, с. 12].

При використанні технології портфоліо, студент повинен дотримуватися наступних вимог:

- в основному змісті навчального портфоліо - показати все, на що студент спроможний, продемонструвати свої найбільш сильні сторони, максимально розкрити творчий потенціал;

- особливо важлива форма оцінки, яка полягала у зміщенні акценту 3 того, що студент не знав й не вмів, на те, що він найкраще знає й уміє з теми, в інтеграції якісної оцінки, i, нарешті, у переносі педагогічного наголосу з оцінки навчання на самооцінку;

- прищеплювання навичок аналізу майбутньої професійної діяльності, самоорганізації, самоконтролю, самооцінки, позитивного ставлення до сторонньої критики своєї діяльності;

- самоусвідомлення результатів навчання студентом і розуміння ним їхньої динаміки.

Використання інтерактивних методів в навчальному процесі вищих навчальних закладів дає змогу: підвищити ефективність занять, розвивати інтерес студентів до майбутньої професійної діяльності.

Перспективи подальших досліджень полягають у необхідності 3'ясування впливу використання інтерактивних методів навчання на професійне самоусвідомлення майбутніх фахівців.

\section{Література}

1. Задоя С. С. Використання можливостей нетрадиційних технологій у підготовці майбутнього вчителя // Технології неперервної освіти : проблеми, досвід, перспективи розвитку / Є. С. Задоя. Миколаїв : МФ НаУКМА, 2002. - С. 92-95.

2. Занков Л. В. Избранные педагогические труды / Л. В. Занков. - М. : Педагогика, 1990. - 416 с.

3. Пидкасистый П. И., Х Хайдаров Ж. С. Технология игры в обучении и развитии / П. И. Пидкасистый, Ж. С. Хайдаров. - М. : Роспедагенство, 1996. - 268 с. 
4. Пометун О. I. Енциклопедія інтерактивного навчання / О. І. Пометун. - К., 2007. - 144 с.

Юлия Повстяная, Марина Радченко. Интерактивные методы обучения будущих специалистов.

В статье раскрывается сущность интерактивных методов обучения их характеристика и значение для формирования личностных $u$ профессиональных качеств будущих профессионалов.

Ключевые слова: интерактив, интерактивная технология обучения, методи и приёмы интерактивных технологий обучения.

Yulia Povstiana, Marina Radchenko. Interactive teaching methods future specialists.

The article reveals the essence of interactive learning technologies, its importance in the formation of professional skills of future professionals. Possibilities of the influence on the formation of personal and professional qualities and skills of future professionals in the process of teaching and learning activities through the use of interactive learning technologies are shown.

Key words: interactive, interactive teaching technology.

Стаття надійшла до редакційної колегії 14.05.2014

УДК 37.014.6:005.6-027.561-021.412.1]-043.83-027.561:116-057.86

(C) Погорєлова Т. Ф., 2014.

Погорслова Тетяна Феодосіївна

Український державний університет фінансів та зовнішньої торгівлі

\section{ПРОФЕСІЙНО ВАЖЛИВІ ЯКОСТІ ЯК КЛЮЧОВИЙ ФАКТОР У ФОРМУВАННІ ПРОФЕСІЙНОЇ КОМПЕТЕНТНОСТІ МАЙБУТНЬОГО ФАХІВЦЯ}

У статті розглядається проблема важливості розвитку професійно значимих якостей саме в період вузівської підготовки майбутнього спеціаліста. Визначено тісний зв'язок професійних якостей із професійною компетентністю фахівия, що забезпечує його здатність ефективно виконувати професійну діяльність. Представлено результати експериментального дослідження щуодо визначення змісту психограми випускника вищого юридичного навчального закладу.

Ключові слова: професійно важливі якості, професійна компетентність, психограма випускника вищього навчального закладу.

Питанню формування професійних якостей фахівця 3 віщою освітою завжди приділялась належна увага. Незважаючи на значний інтерес науковців до цієї теми, вона й досі залишається достатньо актуальною, оскільки відповідні наукові дослідження не отримали 


\section{Збірник наукових статей}

належного теоретичного осмислення та практичного застосування в аспекті створення та реалізації системи формування професійно значущих якостей студентів в процесі професійної підготовки у вищому навчальному закладі.

Мета дослідження полягає у визначенні змісту системи формування професійно важливих якостей майбутнього фахівця в період підготовки у закладі вищої професійної освіти.

Завданням дослідження $\epsilon$ вивченні особливостей розвитку професійно важливих якостей як основи формування професіональної компетентності спеціаліста з вищою освітою.

Проблема професійної підготовки та розвитку професійно важливих якостей досліджувались такими педагогами і психологами, як К. А. Абульханова-Славська, А. А. Бодальов, А. А. Деркач, Н. Н. Дяченко, Е. Ф. Зеєр, І. А. Зимова, А. М. Зимичев, І. А. Зязюн, Є. А. Клімов, А. К. Маркова, Н. В. Кузьмина, Л. Г. Лаптева, Є. А. Смірнова, А. М. Столяренко, В. Д. Шадриков, М. В. Черпінський та ін.

На основі узагальнення різних тлумачень поняття професійно важливі якості, можливо визначити його як стійкі характеристики особистості, що включені в процес діяльності i впливають на ефективність іiі виконання за основними параметрами (продуктивністю, якістю, надійністю).

Формування особистості спеціаліста 3 вищою освітою $\epsilon$ складним діалектичним процесом, який пов'язує різні аспекти соціального, психологічного та суто педагогічного.

В соціальному розумінні - це засвоєння особистістю майбутнього професіонала програмно-цільових вимог даного суспільства, формування соціально-значущих мотивів діяльності.

Психологічний аспект пов'язаний із внутрішніми процесами розвитку та удосконалення особистісних якостей майбутнього професіонала.

Педагогіка вивчає ті умови, які роблять цей процес ефективним, керованим, а також визначає засади, прийоми, методи та форми професійного розвитку майбутнього фахівця.

Професійно - розвиваюча діяльність вищої школи має бути спеціально організованою та програмованою системою, за допомогою якої формуються внутрішні механізми поведінки особистості, які $\epsilon$ скерованими на саморегулювання іï професійної діяльності. Цей процес має свій суб'єкт, об'єкт, цілі та завдання, свою програму та засоби її реалізації, своє об’єктивне середовище.

Отже, для того, щоб ефективно працювати у сучасних економічних умовах необхідно володіти не тільки суто спеціальними 
знаннями, вміннями та навичками, а й мати добре розвинені особистісні якості, які відповідають вимогам професії.

Нажаль вищі професійні заклади освіти України, які готують фахівців на рівні бакалавра та магістра, у більшості випадків не звертають належної уваги на питання професійного становлення майбутнього фахівця, не мають чіткої моделі розвитку його професійно важливих якостей, що часто призводить до професійної некомпетентності випускника.

Таким чином, основні професійно значущі якості раціонально розвивати у майбутніх спеціалістів під час навчання у вищому навчальному закладі, оскільки саме на цьому етапі в рамках базової професійної підготовки розпочинається розвиток професійно важливих якостей, які $\epsilon$ фундаментом подальшого формування професійної компетентності фахівця.

Термін "компетентність" (від лат. сошреtentia) $є$ поняттям, яке пов’язане $з$ характеристикою особистості, що здатна досягати високих результатів у своїй професійній діяльності. Поняття "професійна компетентність" увійшло в психолого-педагогічну термінологію у вісьомдесяті роки минулого століття 3 праць Ю. К. Бабанського, С. П. Баранова, В. О. Сластьоніна, але і досі вважається важливою складовою професіоналізму. Більшість вітчизняних та зарубіжних дослідників, розкриваючи зміст поняття компетентність, говорять про знання, уміння, мотиви, цінності професіонала. Отже, реалізація компетентнісно зорієнтованого навчання спрямована на формування цілісної інтегральної індивідуальності, яка виражається через набуття різноаспектних якісних характеристик.

Оскільки професійно важливі якості характеризують інтелектуальну, емоціонально-вольову та мотиваційну сторони особистості, вони суттєво впливають на формування професійної компетентності працівника. Таким чином, добре розвинені професійні якості сприяють активації пізнавальної та інтелектуальної діяльності особистості, підвищують мотивацію до професійного розвитку та творчого підходу до розв'язання фахових завдань.

Дослідження щодо вдосконалення якості підготовки майбутніх фахівців в галузі права, яке поводилось нами протягом кількох років, підтвердило необхідність оновлення підходу до системи фахової підготовки майбутнього фахівця в галузі права та довело, що фундаментом його професійного розвитку має стати формування професійно значимих якостей. Важливою умовою є i те, щоб процес підготовки спеціаліста у вищому навчальному закладі мав в своїй основі професійну модель майбутнього фахівця та регулювався відповідними програмними положеннями. 
Результати проведеного дослідження дали можливість визначити наступну структуру та зміст психограми випускника вищого юридичного закладу освіти.

Гносеологічний рівень: глибокі знання положень чинного законодавства, нормативно-правової бази, керівних матеріалів та вміння правильно застосовувати їх у своїй навчальній і відповідно майбутній професійній діяльності.

Рівень інтелектуальних властивостей: добре розвинена пам'ять, висока концентрація уваги, логічність, конструктивність, гнучкість та творчий характер процесу мислення, уміння ефективно працювати з різними джерелами інформації, робити іiї аналіз, синтез та узагальнення.

Рівень емоційно-вольової сфери: розсудливість, врівноваженість, висока ступінь самоконтролю, здатність здійснювати вольову регуляцію власних психічних процесів.

Рівень комунікативних якостей: поважне ставлення до людини, ввічливість, толерантність, доброзичливість, тактовність, уміння логічно, аргументовано та переконливо викладати свою думку.

Рівень розвитку особистих якостей: цілеспрямованість, відповідальність, дисциплінованість, уважність, самостійність щодо прийняття виважених рішень, працьовитість, витримка.

Рівень сформованості організаторських здібностей: здатність обирати пріоритетні напрямки роботи, планувати та ефективно організувати свій робочий час та дозвілля, вміння ефективно діяти в складі студентської групи, курсу, навчального закладу залежно від характеру та складності завдань, самоорганізованість, пунктуальність, прагнення до постійного вдосконалення свого культурного та професійного рівня.

Мотиваиійні характеристики: повага до закону, домінування у професійній діяльності соціально-важливих мотивів, прагнення досягти успіху у навчанні та роботі та завоювати повагу й авторитет.

Сочіальні характеристики майбутнього юриста: високий рівень правосвідомості, соціальної відповідальності та нормативність поведінки.

На цій основі завданням педагогічного колективу кожної кафедри вищого навчального закладу має стати чітке визначення переліку найбільш значимих властивостей особистості майбутнього юриста та методів їх формування в процесі викладання відповідних дисциплін та плануванні змісту виховної роботи.

Усвідомлення майбутнім фахівцем своєї професійної місії сприятиме більш ефективному формуванню його професійної ідентифікації як члена професійного співтовариства, носія професійної 
культури, певних норм, правил, традицій, тобто значно полегшить процес його професійної адаптації.

Результати проведеного дослідження дали можливість зробити наступні висновки:

1. Система професійної підготовки спеціаліста з вищою освітою повинна відповідати особливостям майбутньої професійної діяльності та мати в своїй основі професійну модель випускника вищого навчального закладу.

2. Науково-педагогічний колектив кожної кафедри на основі психограми випускника має визначити власні методи формування особистих та професійних якостей майбутнього спеціаліста.

3. Ефективність системи професійного розвитку майбутнього спеціаліста в період підготовки у вищому навчальному закладі має визначатись на основі читко розроблених критеріїв оцінки рівня сформованості його професійно значимих якостей.

1. Котикова О. М. Практико-зорієнтована психологопедагогічна підготовка майбутніх юристів: Монографія / О. М. Котикова. - К. : КНЕУ, 2010. - 343 с.

2. Савіщенко В. М. Дисципліни психолого-педагогічного циклу як важливий засіб формування професійно значущих якостей юриста / В. М. Савіщенко // Педагогіка i психологія формування творчої особистості: проблеми і пошуки : зб. наук. пр. / редкол. Т. І. Сущенко (голов. ред.) та ін. - Запоріжжя, 2008. - Вип. 48. - С. 279-287.
3. Столяренко А. М.
Психология
И
педагогика

А. М. Столяренко. - М. : ЮНИТИ ДАНА, 2006, - 527 с.

4. Трубачева С. Е. Умови реалізації компетентнісного підходу в навчальному процесі / С. Е. Трубачева // Компетентнісний підхід у сучасній освіті: світовий досвід та українські перспективи (Бібліотека 3 освітньої політики) / під заг. ред. О. В. Овчарук. - К. : "К.І.С", 2004. $112 \mathrm{c}$.

Татьяна Погорелова. Профессионально значимые качества как ключевой фактор в формировании профессиональной компетентности будущего специалиста.

Статья посвящена проблеме формирования профессионально значимых качеств будущчих специалистов при получении ими высшего образования. Определена тесная связь между профессионально значимыми качествами и профессиональной компетентностью, что обеспечивает способность специалиста эффективно осуществлять профессиональную деятельность. Результатом исследования, проведенного автором, стало определение структуры и содержания психологического портрета будущего юриста. 
Ключевые слова: профессионально значимые качества, профессиональная компетентность, психологический портрет, высшее профессиональное образование.

Tetiana Pogorielova. Professionally Significant Qualities as a Key Factor in Formation of Professional Competence of a Future Specialist.

The article deals with the problem of formation of professionally significant qualities by future specialists while getting higher education. Close connection between professionally significant features and professional competence of a specialist that provides his ability to effectively carry out professional activities is identified by the author. The result of the research to determine the content of the psychological portrait of a future lawyer is presented in the article.

Key words: professionally significant qualities, professional competence, psychological portrait, higher education.

Стаття надійшла до редакційної колегії 12.05.2014

УДК 81’243:37.018.43:004.738.5

\section{Полежаєва Олена Вікторівна}

(C) Полежаєва О. В., 2014.

Харківський національний економічний університет імені С. Кузнеця

\section{ВПРОВАДЖЕННЯ НОВІТНІХ ЗАСОБІВ У ПРОЦЕС НАВЧАННЯ ІНОЗЕМНИМ МОВАМ: ДИСТАНЦЙНЕ НАВЧАННЯ}

3 кожним роком все більше навчальних закладів впроваджують дистаниійне навчання, як найбільш прогресивний, економний та ефективний метод, оскільки застосування інформаційних технологій допомагає викликати інтерес до засвоєння матеріалу, розкрити творчий потениіал кожного студента.

Ключові слова: дистанційне навчання, інформачійні технології, комп 'ютерні телекомунікаиії.

Останнім часом поряд 3 традиційним навчанням набуває популярність дистанційне навчання. Актуальність теми дистанційного навчання полягає у тому, що дистанційна освіта активно розвивається в усьому світі та перебуває на етапі становлення в Україні. 3 розвитком Інтернет технологій з явилась нова форма навчання, яка передбачає нові методи, засоби та взаємодії викладача і студента. Впровадженню даного виду навчання сприяє, по-перше, стрімкий розвиток інформаційних технологій, а, по-друге, сучасні концепції освіти. 
Mema cmammi полягає в обгрунтуванні необхідності запровадження дистанційної освіти як наступного етапу еволюції традиційної системи освіти, тому що змінюється сама парадигма освіти.

Дистанційна освіта через Інтернет вигідно відрізняється від заочного навчання принципово іншим підходом до подачі знань. Інтернет підтримує постійний контакт між студентами та викладачами. Всесвітня павутина послужила основою для розвитку мережних технологій поширення знань, надав студентам та викладачам електронні підручники та бібліотеки, зручні системи тестування, а також засоби спілкування.

Дистанційне Інтернет навчання - це можливість навчатись у зручний для себе час у зручному місці, пройти навчання без відриву від виробництва; отримувати консультації та брати участь в процесі навчання в режимі on-line; підвищити творчій та інтелектуальний потенціал за рахунок самоорганізації, прагнення до знань,уміння самостійно приймати відповідальні рішення та інше. У дистанційному навчанні змінюється роль і вимоги як до студентів так і до викладачів. Процес навчання орієнтує студентів на творчий пошук інформації, вміння самостійно набувати необхідні знання і застосовувати їх у вирішенні практичних завдань 3 використанням сучасних технологій. Завдяки засобам дистанційного навчання створюється нове навчальне середовище [1]. Викладачі повинні володіти методами створення i підтримки такого навчального середовища, розробляти стратегії проведення цієї взаємодії між учасниками навчального процесу, підвищувати творчу активність і власну кваліфікацію.

Стандартне середовище дистанційної освіти характеризується тим, що студенти віддалені від викладача у просторі або у часі, але, щонайменше, мають можливість для спілкування,активного обміну, використовуючи інформаційні технології i комп'ютерні телекомунікації, супутниковий зв'язок та навчальні системи. Разом 3 традиційними інформаційними ресурсами, що зберігаються у системі державної дистанційної освіти, нові інформаційні ресурси такі як бази даних, комп'ютерні навчальні та контролюючі системи, відео-та аудіотеки, електронні бібліотеки, відео-телеконференціїта, створюють унікальну середу навчання, доступну найширшій аудиторії [3].

Ефективність будь-якого виду дистанційної освіти визначається такими складовими як: 1) організація ефективної взаємодії викладача і студента, фізично розділених відстанню, 2) якість використовуваних освітніх технологій, 3) структурна організація навчального матеріалу, 4) ефективність розроблених методичних матеріалів, способів їх доставки, методів реалізації, 5) ефективність зворотного зв'язку та системи контролю знань, 6) доступність та гнучкість системи 
навчання, 7) вибір часу та місця для навчання, 8) заощадження вільного часу, 9) вдосконалення навичок роботи з комп'ютером.

Дистанційне навчання розширює i оновлює роль викладача, який повинен координувати пізнавальний процес, постійно удосконалювати курси, підвищувати творчу активність і кваліфікацію відповідно до нововведень і інновацій [2].

\section{Література}

1. Клокар Н. Дистанційне навчання вчителів у вимірі сучасних моделей підвищення кваліфікації / Наталія Клокарю - Київ : Рідна школа. - 2006. - № 5. - С. 14-18.

2. Семенець В. Впровадження технологій дистанційного навчання у навчальний процес / В. Семенець, В. Каук, О. Аврунін. Київ : Вища школа. - 2009. - № 5. - С. 40-57.

3. Переваги дистанційної освіти в Україні [Електронний ресурс]. - Режим доступу : http://tcs.kharkov.ua. - Назва с титул. екрану.

Елена Полежаева. Внедрение нових технологий в процесс преподавания иностранных языков: дистанционное обучение.

Дистанциионное обучение - это обучение, которое полностью или частично осуществляется с помощьюю компьютера $u$ телекоммуникационных технологий и средств.

Ключевые слова: дистанциинное обучение, информационные технологи, компьютерные телекоммуникации.

Elena Polezhaeva. Implementation of New Technologies in Foreign Language Learning.

Distance learning refers to any kind of learning done with a computer and Internet connection. It is used to meet needs of special groups of students and allows them to adapt the material to meet their individual learning requirements.

Key words: distance learning, information technologies, computer telecommunications.

Стаття надійшла до редакційної колегії 15.05.2014

УДК 159.942.6-053.6

Поліщук Валерій Миколайович

(C) Поліщук В. М., 2014.

Глухівський національний педагогічний університет імені Олександра Довженка

\section{НОРМАТИВНІ I НЕНОРМАТИВНІ КРИЗИ У ВІКОВОМУ РОЗВИТКУ}

У руслі авторської концепиії симптомокомплексів переживань вікових криз наводяться окремі (фрагментарні) досліднищькі результати розгалуженого емпіричного вивчення підліткового і юнацького віку, які 
$\epsilon$ базовою інформачійною основою для вивчення кризових періодів у дорослому віці. Як наслідок, актуалізується потреба встановлення особливостей дорослості в цілому на основі зіставлення 3 конкретними вузькими віковими інтервалами.

Ключові слова: вікова нормативна криза, вікова ненормативна криза, переживання, симптом.

Формування доказових знань про віковий розвиток особистості $\epsilon$ необхідною умовою самопізнання та пізнання навколишньої дійсності. Зрештою, це результативність будь-якого професійного становлення в контексті розв'язання таких завдань як 1) управління своєю діяльністю та поведінкою, а також побудова оптимальних взаємин 3 оточенням, 2) зіставлення психологічних особливостей людини 3 конкретними віковими періодами.

Mema cmammi. Довести необхідність доказового диференційованого впливу на особистість будь-якого віку, який базується на конкретних знаннях про життєві періоди (зокрема кризові), виокремлених на основі не лише теоретичного (часто споглядального), а передусім емпіричного аналізу.

Актуалізація пізнання вікового кризового розвитку особистості (особливо - в дорослості) посилює значущість психологічної просвіти у вищій школі та забезпечує будь-яку індивідуальну особистіснупрофесійну самореалізацію, а значить, групову продуктивну діяльність, спрямовану на зміцнення національної безпеки держави.

Аналіз публікаиій. Це наукові видання 3 проблем життєвого шляху особистості як циклу стабільних і кризових (перехідних) періодів (Л. Виготський, 1983; К. Поліванова, 2000, 2006; В. Поліщук, 2012, 2013; Т. Титаренко, 2006, 2010). Нерозв'язана проблема: зміст вікового розвитку після кризи „входження в дорослість“ (однаково стосується обох названих періодів, оскільки досі вивчається, як правило, лише на рівні теоретичного аналізу).

Виклад основного матеріалу, обтрунтування результатів дослідження. Нами розроблено концепцію симптомокомплексів переживань вікових криз, згідно з якою зокрема: 1) їх фіксовані позитивні $і$ негативні симптоми є трансформаційними світоглядними перетвореннями в ставленні до себе й навколишньої дійсності; 2) вікові кризи $\epsilon$ нормативними (психогенний чинник) i ненормативними (результат несприятливої соціалізації і властиві будьякому віковому періоду); 3) зв'язок між симптомами здійснюється через негативні симптоми; 4) негативні зміни в особистості $€$ тіньовим, зворотним боком позитивних перетворень [1]: апріорі позитивний симптом перебуває під потужним адресним впливом певного для себе негативного симптому. 


\section{Збірник наукових статей}

Для прикладу вкажемо деякі змістові характеристики симптомів:

1. Це позначення окремого переживання, що вказує на клінічну фрагментарну картину перебігу вікового розвитку.

2. Симптоми нормативних криз: 1) загальні (усі можливі симптоми); 2) основні (базові) - типові, супутні та фонові; 3) типові це пікові та домінантні, які збігаються за силою і частотою виявів; 4) супутні, або домінантні: не збігаються з піковою симптоматикою в певному кризовому періоді та детермінують у ньому типову симптоматику (окремо - позитивну i негативну), причому частота виявів, як правило, домінує над їх силою; 5) нетипові, або фонові (тлосимптоматика): найменші частота i сила виявів (антипод типової симптоматики, який, однак, є прихованим активним стимулом типових і супутніх симптомів); 6) пікові: найбільше виявляються в окремому віковому інтервалі порівняно 3 іншими віковими інтервалами кризового періоду; 7) домінантні: порівняно 3 іншими симптомами мають найбільший вияв в окремому віковому інтервалі кризового періоду; 8) провідні домінанти: властиві більше, ніж одному інтервалу в певному кризовому періоді; 9) «домінанти-лідери»: серед провідних домінант мають максимальні вияви в будь-якому віковому періоді i, взаємодіючи із симптомами ненормативних криз, послаблюють позитивні або стабілізують негативні;

3. Симптоми ненормативних криз: 1) основні (базові), або лише ситуативні комбіновані негативні симптоми; 2) домінантні, або типові: порівняно з іншими симптомами мають найбільші вияви в окремому віковому інтервалі вікового періоду; 3) провідні домінанти: властиві більше, ніж одному інтервалу в певному віковому періоді (в одному перехідному, або двох - перехідному і суміжному з ним стабільному); 4) нетипові, або фонові (тло-симптоматика): негативні симптоми 3 найменшими виявами (антипод домінантних).

Спільність базових симптомів обох криз визначила розробку динамічної психологічної моделі для 9-23-річного віку з потенційним прогнозуванням наступних кризових періодів - нормативних i ненормативних (див. рис.).

Висновки. 1. Нормативні кризи мають унікальні базові динамічні позитивні і негативні симптоми переживань (типові, супутні, фонові) зі схожою структурою, але різним змістом. 2. Комбінований негативний симптомокомплекс ненормативних криз стабілізується в несприятливих суспільно-економічних умовах, кризах світогляду, дитинства та педагогічної свідомості. Перспективи: наступні наукові розвідки мають спрямовуватися зокрема на встановлення в дорослому віці нових та поглиблення структурно-функціональних особливостей вже відомих симптомів. 


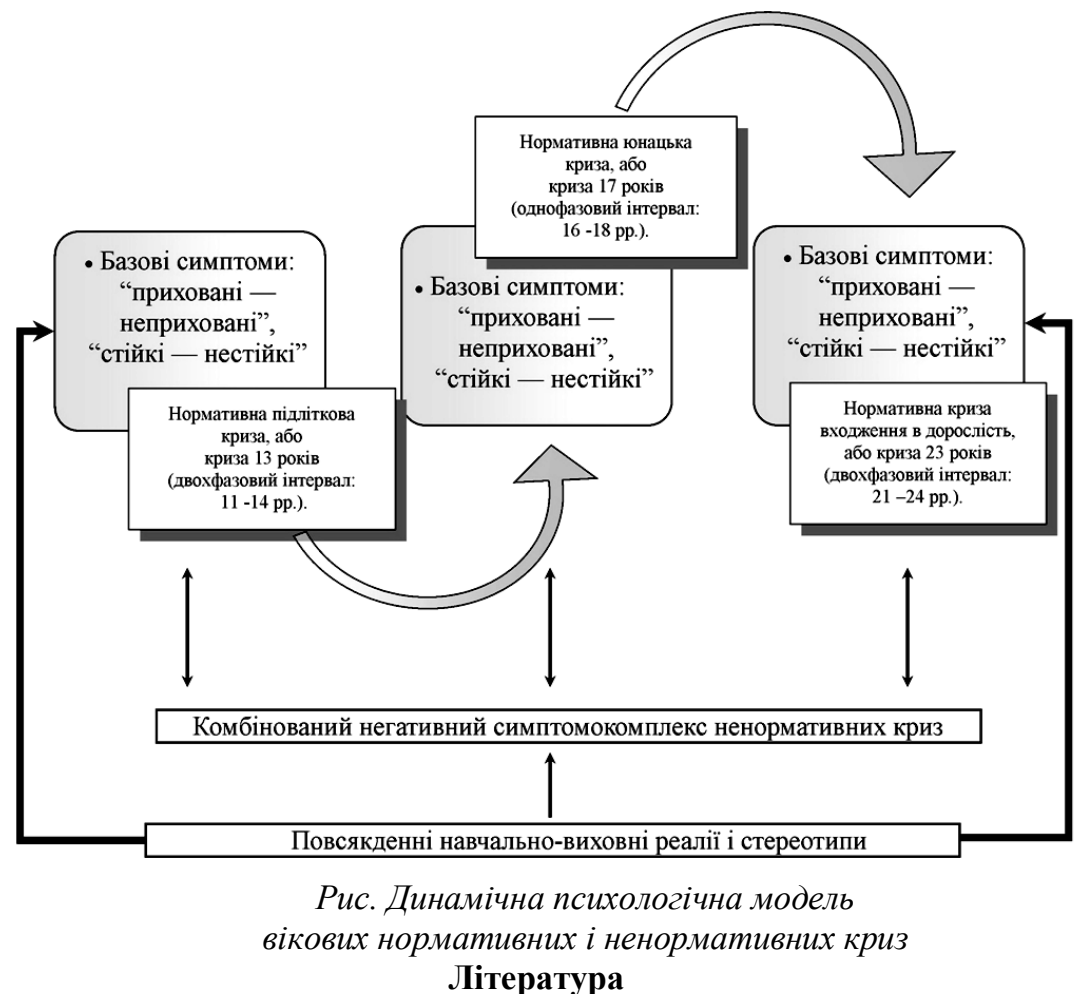

1. Выготский Л. С. Собр. соч. : в 6 т. / Л. С. Выготский; под ред. Д. Б. Эльконина. - М. : Педагогика, 1984. - Т. 4. Детская психология. $432 \mathrm{c}$.

2. Поліщук В. М. Від кризи 7 років до кризи входження в дорослість : [монографія] / В. М. Поліщук. - Суми : Університетська книга, 2013. - $156 \mathrm{c.}$

3. Поліщук В. М. Вікові кризи в підлітковому і юнацькому віці : базові симптомокомплекси : [монографія] / В. М. Поліщук. - Суми : Університетська книга, 2012. - 478 с.

Валерий Полищук. Нормативные и ненормативные кризисы в возрастном развитии.

В русле авторской конщепџии симптомокомплексов переживаний возрастных кризисов приводятся отдельные (фрагментарные) исследовательские результаты разветвленного эмпирического изучения подросткового и юношеского возраста, которые являются базовой информаиионной основой для изучения кризисных периодов 6 взрослом возрасте. Как следствие, актуализируется необходимость 
Збірник наукових статей

установления особенностей взрослости в целом на основе сопоставления с конкретными узкими возрастными интервалами.

Ключевые слова: возрастной нормативный кризис, возрастной ненормативный кризис, переживания, симптом.

Valeriy Polishchuk. Normative and non-normative crisis in the age development.

In accordance with the author's conception of age crisis overcoming symptom complex some (fragmentary) research results of general empirical investigation of teenagers' and adolescence are adduced. They are a basic informative base for critical periods' exploration in adulthood. As a result, the necessity of adulthood features setting is updated generally on the basis of the definite short age range comparison.

Key words: age typical crisis, age peculiar crisis, experiencing, symptoms.

Стаття надійшла до редакційної колегії 14.05.2014

УДК 168.1:[008-024.63:316.28-043.83]81'243:392.73-057.875

(C) Пономарьова Л. Ф., Осадча О. В., 2014.

Пономарьова Лілія Федорівна,

Осадча Олена Володимирівна

Дніпропетровський національний університет імені Олеся Гончара

РОЛЬ МІЖКУЛЬТУРНОГО КОМПОНЕНТУ У ФОРМУВАННІ НАВИЧОК ІНШОМОВНОГО СПІЛКУВАННЯ СТУДЕНТІВ

Проаналізовані сучасні підходи до формування навичок міжкультурної комунікації студентів. Визначені основні компоненти міжкультурної комунікації: афективний, когнітивний та стратегічний. Розглядається поняття ситуативного моделювання як основної форми навчального процесу.

Ключові слова: компоненти міжкультурної комунікації, афективний, когнітивний, стратегічний, ситуативне моделювання.

Процес інтеграції нашого суспільства до європейського простору, збільшення мобільності спеціалістів різної спрямованості суттєво впливають на підходи до підготовки сучасного фахівця. Особлива увага приділяється формуванню його іншомовної компетенції та підвищенню рівня володіння іноземною мовою. Традиційні підходи до викладання іноземних мов недостатньо враховують потреби спілкування та системи норм та цінностей носіїв мови, яка вивчається. Спостерігаються суттєві протиріччя між вимогами підготовки спеціалістів, здатних до міжкультурної комунікації та змістом навчальних програм, між орієнтацією навчального процесу на міжнародні стандарти та умовами викладання 
іноземних мов, між необхідністю формування міжкультурної компетенції та недостатньою розробленістю завдань та вправ.

Метою статті є аналіз сучасних підходів до формування навичок міжкультурної комунікації студентів та системи завдань, що можуть успішно застосовуватися на занятті 3 іноземної мови для формування навичок іншомовного спілкування.

Останнім часом проблема формування міжкультурної компетенції розглядалася у роботах вітчизняних та зарубіжних педагогів та психологів. Так, проблеми міжкультурної комунікації та діалога культур висвітлювалися у роботах М. М. Бахтіна, В. Г. Костомарова, Н. Г. Гальськової, $\quad$ В. В. Сафонова. Проблеми використання автентичних країнознавчих матеріалів на заняттях були проаназізовані у роботах Є. М. Верещагіна, Р. П. Мільруд, Є. В. Носонович.

Методи організації взаємодії на заняттях 3 іноземної мови, навчального співробітництва, застосування колективних, групових та інтерактивних форм роботи детально розроблялися Л. В. Ампілоговою, Т. В. Асламовою, А. Ш. Гусейновою. Були також досліджені проблеми формування міжкультурної професійної компетенції на основі іншомовного тексту (О. В. Сиром'ясов), формування мовленнєвої особистості нового типу (Ю. Н. Караулов, Г. І. Богін), застосування автентичних відеоматеріалів у процесі формування міжкультурної компетенції (Г. В. Єлізарова).

Аналіз наукових джерел та практичних розробок дозволяє зробити висновок, що формування міжкультурної компетенції здійснюється під час ознайомлення з умовами життя в інших країнах, набуття знань про повсякденну культуру, знайомства зі студентською субкультурою, критичного аналізу соціальних проблем та тенденцій, емоційного сприйняття та інтелектуальної роботи зі зразками культури. Отже у формуванні навичок іншомовної комунікації все більшої важливості набуває міжкультурний компонент.

А. Кнапп-Поттхофф виділяе афективний, когнітивний та стратегічний компоненти міжкультурної комунікації. В основі афективного компонента лежать емпатія та толерантність. Толерантність - це принцип міжособистісної взаємодії, моральна цінність та якість людини, яка має настанову на діалог, розуміння та прийняття іншого. 3 поняттям толерантності пов'язане поняття емпатії, здатність перевтілення в іншу людину 3 ціллю розуміння іiі думок та вчинків. Формування емпатії у студентів пов'язане 3 розвитком умінь співвідносити своє та чуже, приймати на себе нові ролі, відчувати впевненість у різних сферах діяльності іншого лінгвокультурного суспільства. В основі другого компонента когнітивного - лежать знання про рідну культуру та культуру країни, 
мова якої вивчається, а також загальні знання про культуру та комунікацію. Стратегічний компонент містить вербальні, навчальні та дослідницькі стратегії студента; принципи навчання (діалог культур, культурознавча обумовленість навчання, особістисно-діяльнісна стрямованість); форми та методи навчання (проблемно-пошукові, дискусійні, дослідницькі, творчі); форми занять (лекції, групові дискусії, рольові ігри); засоби навчання (основні - автентичні художні тексти; додаткові - відеофільми, таблиці, ілюстрації).

Формування міжкультурної компетенції стає можливим тільки на основі розвитку всіх видів мовленнєвої діяльності. Цей процес тісно пов’язаний $з$ розвитком комунікативної компетенції. Г. В. Слізарова підкреслює, що компоненти міжкультурної компетенції співвідносяться 3 компонентами іншомовної комунікативної компетенції: лінгвістичним, соціолінгвістичним, дискурсивним, стратегічним, соціокультурним та соціальним. При цьому зазначається, що міжкультурна компетенція може бути притаманна тільки медіатору культур - мовленнєвій особистості, яка вивчає будьяку мову як іноземну. Найважливішим результатом формування міжкультурної компетенції студентів стає здатність до удосконалення у напрямку полікультурності.

Основною формою організації навчального процесу у цьому контексті має стати ситуативне моделювання міжкультурних ситуацій, де студенти використовують необхідні елементи МК з ціллю успішної комунікації. При цьому важливо не ідентифікувати себе як носія мови, яка вивчається, а через усвідомлення своєї власної культури досягти взаєморозуміння. Існує певний досвід розробки спеціальних навчальних посібників. 3 урахуванням таких задач у ДНУ імені Олеся Гончара було створено навчальний посібник для студентів «Психологічні особливості культур», який містить тексти англійською мовою, присвячені проблемам національного характеру та особливостям спілкування американців, англійців, німців та французів. Тексти супроводжуються глосарієм та вправами, які спрямовані на формування умінь пошукового читання, монологічного та діалогічного мовлення. Тематика текстів має професійну спрямованість. Так студенти дізнаються, що ставлення до часу у представників різних культур відрізняється. Люди з індустріально розвинених країн (США, Японія) на питання «Якщо у вас призначена зустріч із другом, то як довго ви збираєтесь чекати його?» давали відповідь 3 точністю до хвилини. У Греції, Італії - в годинах, а в деяких культурах Африки і Латинської Америки - до кількох діб. Студенти також дізнаються, що у британському бізнесі існує певний ритуал спілкування. Про ділову зустріч треба домовлятися письмово, а не по телефону. Переговори ведуться 3 використанням значного фактичного та статистичного 
матеріалу. Прораховується кожна позиція контракту, фіксується кожна деталь. Ця інформація є дуже корисною для студентів, на основі таких текстів можна розробити систему вправ та завдань, які сприяють навчанню успішного міжкультурного спілкування.

Отже, у процесі формування навичок іншомовного спілкування міжкультурний компонент відіграє важливу роль. Недостатня увага до цього аспекта навчання може привести до проблем у професійному спілкуванні майбутніх фахівців, підготовкою яких займається ВУЗ. Тому необхідно шукати нові підходи та розробляти ефективну систему завдань, що відповідає вимогам до підготовки сучасного фахівця.

\section{Література}

1. Гальскова Н. Д., Гез Н. И. Теория обучения иностранным языкам. Лингводидактика и методика / Н. Д. Гальскова, Н. И. Гез. М. : Издательский центр «Академия», 2007. - 336 с.

2. Елизарова Г. В. Культура и обучение иностранным языкам / Г. В. Елизарова. - СПб. : КАРО. 2005. - 352 с.

3. Плеханова М. В. Роль и место межкультурной компетенции в структуре общей компетентности студентов технического вуза / М. В. Плеханова // Бюллетень «Вестника ТГУ»: «Актуальные вопросы современной филологии: теоретические и прикладные аспекты». 2006. - Томск : Изд-во «ТМЛ-Пресс», 2006.

Лилия Пономарева, Елена Осадчая. Роль межкультурного компонента в формировании навыков иноязычного общения студентов.

Проанализированы современные подходы к формированию навыков межкультурной коммуникации студентов. Определены основные компоненты межкультурной коммуникации: аффективный, когнитивный и стратегический. Рассматривается понятие ситуативного моделирования как основной формы учебного прочесса.

Ключевые слова: компоненты межкультурной коммуникации, аффективный, когнитивный, стратегический, ситуативное моделирование.

Liliia Ponomariova, Olena Osadcha. The role of the crosscultural component in forming students' foreign language communication skills.

The analysis of the approaches to forming students' foreign language communication skills has been made. The main components of crosscultural communication (affective, cognitive and strategic) have been defined. The concept of situation modeling as the basic form of the educational process has been considered.

Key words: components of cross-cultural communication, affective, cognitive, strategic, situation modeling.

Стаття надійшла до редакційної колегії 14.05.2014 


\section{Попович Наталія Михайлівна}

(c) Попович Н. М., 2014.

Київський університет імені Бориса Грінченка

\section{ВЗАЕМОДІЯ ДІЯЛЬНІСНОЇ І ПРАКТИЧНОЇ СКЛАДОВИХ У СТРУКТУРІ ПРОФЕСІЙНО-ОСОБИСТІСНОГО ДОСВІДУ МАЙБУТНЬОГО ФАХІВЦЯ}

У статті проаналізовано сутність діяльнісно-практичного компоненту професійно-особистісного досвіду майбутнього вчителя музики. Розглянуто основні принципи діяльнісного підходу, що акумулюють у своєму змісті фундаментальні закономірності навчання. Обтрунтовано зміст практичної підготовки студентів в умовах вищого навчального закладу, щяо забезпечується наступними принципами: неперервність педагогічної освіти, ї̈ демократизація, орієнтація на творчу діяльність $і$ неповторність особистості кожного фахівия, забезпечення диференційованого й індивідуальнотворчого підходу до його формування.

Ключові слова: професійно-особистісний досвід, діяльніснопрактичний компонент, майбутній вчитель музики, професійнопрактична підготовка.

У період оновлення усіх аспектів життєдіяльності суспільства та розширення міжнародних зв'язків рівень фахової підготовки майбутнього вчителя музики у системі неперервної освіти визначається сформованістю його особистісних якостей та професійних умінь, серед яких особливе місце займає професійноособистісний досвід. Цільова установка на взаємодію діяльнісної і практичної складових передбачає орієнтацію на здобуття майбутнім фахівцем знань та практичного досвіду, пов'язаного із музичнотворчою та професійно-педагогічною діяльністю; навичок як свідомого володіння процесом власного професійного становлення, так і музично-творчого розвитку своїх майбутніх учнів; вмінь не лише обирати i застосовувати потрібні методи, прийоми i способи удосконалення власної майстерності, а й користуватися ними в процесі професійної діяльності.

У науковій літературі дослідження проблеми формування досвіду як сукупності якостей, що визначають ефективність діяльності особистості охоплювали наступні напрями: індивідуальний досвід (Л. Большакова, Л. Воробйова, Т. Добудько, Н. Кузьміна, О. Лактіонов, А. Маркова, К. Платонов, Р. Рогожнікова, О. Савченко, В. Стрельніков, А. Хуторський та ін.), особистісний досвід 
(Д. Барашева, О. Музика, К. Тороп та ін.), естетичний досвід (І. Зязюн, Г. Карась, Т. Скорик та ін.), художньо-естетичний досвід (О. Шевнюк, Т. Сердюк та ін.), морально-естетичний досвід (О. Олексюк, С. Хлєбік та ін.), музично-естетичний досвід (Т. Завадська та ін.).

Мета статmi - здійснити аналіз сутності діяльніснопрактичного компоненту професійно-особистісного досвіду майбутнього вчителя музики.

Педагогічне керівництво процесом формування діяльніснопрактичного компоненту у структурі професійно-особистісного досвіду майбутніх фахівців передбачає створення оптимальних умов для активної позиції суб'єкта діяльності, завдяки чому відбуватиметься свідоме й грунтовне набуття ним певного рівня досвіду. Підвищення якості професійно-практичної підготовки майбутнього вчителя музики забезпечується використанням в умовах вищої школи таких принципів навчання як: неперервність педагогічної освіти, іiі демократизації, орієнтація на творчу діяльність i неповторність особистості кожного фахівця, забезпечення диференційованого й індивідуально-творчого підходу до його формування.

Практична діяльність як стрижневий аспект професійноособистісного досвіду майбутнього фахівця набуває видової своєрідності у різноманітних сферах реалізації активності особистості, у зв'язку з чим виникає проблема розкриття специфіки конкретного прояву діяльнісної активності, у тому числі музично-навчальної, професійної, педагогічної, мистецької діяльності тощо. Серед наукових праць щодо розробки поняття та моделей педагогічної практичної діяльності варто відзначити роботи Н. Кузьміної, В. Сластьоніна, О. Щербакова.

Н. Кузьміна 3 позицій загальної теорії систем та задачного підходу розглядає педагогічну діяльність як складну динамічну систему, яка характеризується специфічною структурою з численними взаємопов'язаними компонентами, серед яких основними є наступні: суб'єкт та об'єкт педагогічного впливу, предмет їх спільної діяльності, цілі діяльності та засоби педагогічної комунікації. Вони пов'язані між собою прямими та зворотніми зв'язками. До кожного з компонентів автор виокремлює групу відповідних функцій: конструктивних, організаторських, комунікативних. Така модель має певні переваги, оскільки враховує загальний характер педагогічної діяльності, що будується за законами спілкування [3, с. 42-46].

В. Сластьонін доповнив структуру практичної діяльності вчителя новою функціональною одиницею, якою є педагогічна дія як єдність мети та змісту. Автор наголошує, що будь-яка форма педагогічної діяльності вчителя являє собою складний психологічний 


\section{Збірник наукових статей}

процес, сукупність певних взаємопов'язаних елементів, що утворюють своєрідну структурну цілісність (систему і послідовність). Останнє характеризує особистість вчителя, його соціальну зрілість, професійну спрямованість, знання основ наук, уміння показати їх роль у суспільному та соціальному прогресі, знання психології та закономірностей розвитку дитини, зв'язок теорії з практикою навчання та виховання учнів, володіння педагогічною майстерністю, прагнення до неперервної самоосвіти [4, с. 176].

Діяльнісний і практичний підходи вчителя до процесу навчання музики i музичного виховання, розробка, запровадження нових методик, прийомів, оптимальне їх поєднання, сприяють створенню принципово нових систем навчання, виховання й музично-творчого розвитку особистості, що зумовлює ефективність формування професійно-особистісного досвіду. В свою чергу, одним 3 вагомих факторів, що забезпечуватиме ефективність формування діяльніснопрактичного компоненту досвіду майбутнього вчителя музики $\epsilon$ професійно-творча активність, яка виступає умовою й результатом музично-педагогічної діяльності, забезпечує нестандартний підхід i творче вирішення професійних завдань.

Для активізації діяльності студентів велике значення має використання у музично-педагогічній практиці активного діалогу, ділової гри, аналізу проблемних ситуацій, навчальних досліджень, спеціальних творчих вправ тощо. Сутність активності, на наш погляд, необхідно розглядати з урахуванням специфіки студентського віку й навчального процесу вищої школи. Адже, творча активність $\epsilon$ своєрідним прагненням студента проникнути у зміст досліджуваних процесів, явищ, прагненням до застосування нових прийомів подолання труднощів, здатність вносити елементи новизни у способи виконання навчального завдання, вирішення професійно-творчих завдань.

Рушійною силою діяльнісно-практичного процесу є потреба у творчості, заснована на усвідомленні невідповідності засвоєних алгоритмів, індивідуально-стильових особливостей особистості тій конкретної ситуації, що складається при виконанні особистістю професійних функцій $[1 ; 2 ; 5]$.

На всіх освітньо-кваліфікаційних рівнях у структурі підготовки майбутнього вчителя музики передбачена педагогічна практика, від змісту, форм і методів якої значною мірою залежить ефективність формування діяльнісно-практичного компоненту досвіду студентів та їх подальша адаптація до професійної діяльності.

Удосконалення підготовки вчителя музики знаходиться в прямій залежності не тільки від правильної орієнтації студента в процесі навчання на спеціальних заняттях, але й від загального 
методичного забезпечення та практичного досвіду, які він отримує 3 усієї різноманітності дисциплін на музично-педагогічному або мистецькому факультеті. Слабкість чи недостатність методичної підготовки негативно виявляється в ході проходження педагогічної практики та у майбутній професійній діяльності.

На нашу думку, для формування у майбутнього вчителя музики професійно-особистісного досвіду в умовах педагогічної практики необхідно:

- забезпечити умови для реалізації студентами-практикантами особистісних творчих якостей у навчально-виховному процесі загальноосвітньої школи (на уроці та в позаурочній роботі);

- надати можливість студенту-практиканту усвідомлювати власну індивідуальність; створити умови для виявлення рівня студента як музиканта-виконавця;

- розвивати у студентів уміння й навички самостійного добору музично-навчального репертуару для учнів різного віку;

- формувати уміння здійснювати самоаналіз рівня власної інтерпретації під час виконання музичного твору;

- здійснювати аналіз професійних якостей студента як режисера у процесі моделювання нестандартного уроку;

- створювати умови для розвитку педагогічного й виконавського артистизму майбутніх фахівців на прикладі змодельованих педагогічних ситуацій;

- розвивати у студентів вміння діалогової взаємодії формуючи навички комунікативної діяльності в музичному навчально-виховному процесі.

Підготовка студентів до проведення занять є складним i відповідальним етапом, оскільки така діяльність потребує максимальної концентрації зусиль i вияву сформованого рівня педагогічної майстерності. Цей процес вимагає тривалого часового терміну і передбачає не тільки написання конспекту заняття, а й психологічну підготовку до його проведення, глибоке осмислення мети заняття, зміст основних етапів і положень, власне творче бачення дисципліни, усвідомлення ऑii значущості, впевненості у власних знаннях; оволодіння майстерністю виступу і діалогічною взаємодією 3 аудиторією.

Таким чином, діяльнісно-практичний компонент професійноособистісного досвіду, як і процес його формування у майбутніх фахівців, слід розглядати як досить специфічну i складноструктуровану систему, що охоплює різноманітні елементи та ïx функціональні взаємозв'язки, які вимагають обгрунтованого виявлення i теоретичного моделювання, а також віднайдення системоутворювальних чинників для педагогічного управління 


\section{Збірник наукових статей}

процесами його формування та розвитку. Подальшого дослідження потребують питання забезпечення якості організації практичної діяльності студентів, від якої залежить реалізація основного завдання в тенденції модернізації освіти - активізувати мотивацію діяльності в ході вивчення навчальних дисциплін, формувати у майбутніх фахівців самостійне, креативне й професійне мислення, динамізувати потребу у творчій педагогічній діяльності, забезпечуючи цим самим високий рівень сформованості професійно-особистісного досвіду вчителя музичного мистецтва.

\section{Література}

1. Боднарук I. М. Педагогічна практика в системі методичної підготовки майбутнього вчителя музики / I. М. Боднарук // Науковий вісник Чернівецького університету (серія “Педагогіка та психологія”) : зб. наук. пр. - Вип. 128. - Чернівці : Рута, 2001. - С. 35-40.

2. Давыдов В. В. Теория Л. С. Выготского и деятельностный подход в психологии / В. В. Давыдов, Л. А. Радзиховский // Вопросы психологии. - 1980. - № 6. - С. 48-59; 1981. - № 1. - С. 67-80.

3. Кузьмина Н. В. Методы системного педагогического исследования : учеб. пособие / Н. В. Кузьмина, Е. Д. Григорьева, В. Я. Якунин и др. - Л. : ЛГУ, 1980. - 172 с.

4. Сластенин В. А. Педагогика : инновационная деятельность / В. А. Сластенин, Л. С. Подымова. - М. : Магистр, 1997. - 224 с.

5. Хекхаузен Х. Мотивация и деятельность / Хайнц Хекхаузен. М. : Педагогика, 1986. - 408 с.

\section{Наталья Попович. Взаимодействие деятельностной и практической составляющих В структуре профессионально- личностного опыта будущего специалиста.}

В статье проанализированы сущзность деятельностно-практического компонента профессионально-личностного опыта будущего учителя музыки. Рассмотрены основные принципь деятельностного подхода, аккумулируюшие в своем содержании фундаментальнье закономерности обучения. Обосновано содержание практической подготовки студентов в условиях высшего учебного заведения. Повышение качества профессионально-практической подготовки будущего учителя музыки обеспечивается использованием в условиях высшей школь следующих принципов обучения: непрерывность педагогического образования, его демократизация, ориентация на творческую деятельность и неповторимость личности, обеспечение дифференцированного и индивидуально-творческого подхода кее формированию.

Ключевые слова: профессионально-личностный опыт, деятельностно-практический компонент, будущчий учитель музыки, профессионально-практическая подготовка. 
Natalia Popovych. Interaction of activity-based and practical components in the structure of professional and personal experience of the future specialist.

The article analyzes the nature of the action-based and practical component of professional and personal experience of the future music teacher. The basic principles of the activity-based approach accumulating the fundamental laws of learning in its content were considered. The content of practical training of students in high school was substantiated. Improvement of the quality of vocational and practical training of the future music teacher is provided by the use of such learning principles as continuity of pedagogic education, democratization, focus on creative work and unique personality of each specialist, and provision of differentiated and individual creative approach to its formation in high school.

Key words: professional and personal experience, activity-based and practical component, future music teacher, professional and practical training.

Стаття надійшла до редакційної колегії 12.05.2014

УДК 37.091.214:811.1

(C) Посудиевская О. Р., 2014.

\section{Посудиевская Ольга Ростиславовна}

Днепропетровский национальный университет имени О. Гончара

\section{РАЗВИТИЕ «ЧУВСТВА ЯЗЫКА» КАК КОМПОНЕНТ ОБУЧЕНИЯ ИНОСТРАННОМУ ЯЗИКУ}

Статья посвящена исследованию «чувства языка» как необходимого компонента овладения иностранным языком. Анализируются два подхода $к$ определению явления как бессознательно-интуитивного феномена и сознательно-интеллектуального процесса. Проводится сопоставление понятия «чувства языка» $с$ «языковой интуицией» $u$ «коммуникативной компетенцией».

Ключевые слова: «чувство языка», «языковая интуиция», «коммуникативная компетенция», интуитивное овладение языком, сознательный уровень овладения языком.

Необходимость логической организации лексического и
грамматического материала, способствующей не просто
механическому запоминанию студентами новых структур иностранного языка, а выработке «чувства языка» - интуитивному выбору языковых единиц в зависимости от языковой ситуации, - 


\section{Збірник наукових статей}

актуальная проблема в современной методике преподавания иностранного языка. К примеру, О. Ю. Дигтяр критикует современные школьные учебники английского языка за отсутствие в них «автономного», «собственно лексического» раздела по обучению лексике при традиционном делении учебника на темы устной речи [1]. Исследовательница призывает к обстоятельной работе преподавателя и студентов с каждой новой лексической единицей (в особенности, с абстрактной лексикой). Одним из видов такой работы, по мнению методиста, должно стать «создание максимума ассоциаций» вокруг нового слова или словосочетания: эти ассоциации могут быть неречевыми, так как в дальнейшем овладении языком они все равно послужат опорой для быстрого нахождения нужных лексических эквивалентов [1].

Тем не менее, Н. Ю. Николаева высказывает несколько иную точку зрения, опираясь на принципы коммуникативного подхода к обучению иностранному языку: новые лексические единицы должны вводиться в контекстах, приближенных к реальным ситуациям общения и соответствующих интересам данной возрастной группы учащихся [3]. По мнению исследовательницы, заучивание наизусть списков иностранных слов без примеров употребления не является целесообразным и противоречит цели обучения иностранному языку. Поэтому, как утверждает Н. Ю. Николаева, необходимо с самого начала обучения вводить студентов в реальные ситуации общения, показывая на практике, как употребляется новая лексика. Ведь только в этом случае учащиеся имеют возможность «прочувствовать» новый для них язык и развить языковую догадку [3].

Согласно выводу Н. Ю. Николаевой, подача нового языкового материала должна осуществляться таким образом, чтобы учащиеся получили максимальную возможность для развития «языковой догадки», «языковой интуиции» и «чувства языка». Указанные понятия становятся распространенными темами современного методического исследования, наряду с терминами «языковое чутье», «речевая интуиция» и «коммуникативная компетенция». Тем не менее, наиболее обобщенным и часто используемым термином является «чувство языка».

Согласно определению, данному в психологическом толковом словаре, чувство языка - это «феномен интуитивного владения языком, проявляющийся в понимании и использовании идиоматических, лексических, стилистических и прочих конструкций еще до целенаправленного овладения языком в обучении», который формируется «в результате стихийного овладения речью и базовыми когнитивными операциями» [5]. Утверждения о бессознательноинтуитивном уровне возникновения чувства языка находим в работах 
многих ученых. Исследователи рассматривают чувство языка как «обобщение...неясных впечатлений» (Л. И. Божович); как «некую сумму знаний о языке, полученную в результате бессознательного обобщения многочисленных актов речи»; как «интеллектуальную эмоцию» - «эмоциональное переживание», которое сопровождает речевой акт и порождает реакцию неудовольствия при встрече с непривычным языковым оформлением высказывания (М. М. Гохлернер, Г. В. Ейгер). По мнению О. А. Лебедевой, чувство языка дает возможность действовать в языковой ситуации «по чувству», в случае отсутствия необходимых, однозначно сформулированных знаний о языковых структурах и их функциях. А Е. А. Авакумова приходит к выводу, что чувство языка является частным случаем интуиции, наряду с «чувством формы» и «чувством цвета», причем эмоциональная реакция - сопутствующий ему элемент.

Тем не менее, 3. П. Овчаренко придерживается иного мнения: бессознательно-интуитивное определение чувства языка исследовательница соотносит с «языковым чутьем» как способностью к «ощущению», «угадыванию», «обнаружению» и с «языковой интуицией» - «безотчетным неосознанным чувством» (т.е. процессами, происходящими на бессознательном уровне) [4]. Как утверждает методист, «чувство языка» следует противопоставить «языковому чутью» и «языковой интуиции» как мыслительную деятельность, направленную на «осознанное восприятие реальности» (т.е. процесс, происходящий на уровне сознательного контроля). О сознательном приобретении совокупности знаний и навыков, обеспечивающих «способность к грамотному общению в разных социально-культурных сферах, к оценке произведений вербальной культуры», упоминает и О. А. Лебедева. Однако, по мнению исследовательницы, в данном случае речь идет о развитии коммуникативной компетенции - «способности человека адекватно... организовать свою речевую деятельность... соответствующими каждой конкретной ситуации языковыми средствами и способами». А бессознательно-интуитивное чувство языка становится одним из главных механизмов, повышающих уровень коммуникативной компетенции, которая является «определяющей характеристикой языковой личности» [2, с. 154].

Как утверждают современные психологи, в процессе длительного использования языка (родного или иностранного) в сознании человека вырабатываются некие компактные логические модели, которые управляют выбором нужной буквы, знака препинания или речевого оборота. Такая компактность порождает быстродействие, дающее ощущение «врожденной грамотности», когда человек не задумывается над выбором языковых единиц, соответствующих 


\section{Збірник наукових статей}

речевому акту. А в случае недостатка теоретических знаний о языке именно логические модели управляют выбором правильного варианта языковой единицы, соответствующей речевой ситуации. Необходимость формирования логических языковых закономерностей - системных свойств языка, связанных с развитием осмысленного «чувства языка» (этапа, на котором язык структурируется как система), акцентирует и 3. П. Овчаренко. Исследовательница приходит к выводу о том, что бессознательное «языковое чутье», «приведенное в сознание грамматикой», становится осознанным «чувством языка» «генетическим продуктом знания» [4].

В контексте всего этого следует отметить, что в процессе изучения иностранного языка чувство языка все же формируется на сознательном уровне - через поэтапное овладение новыми языковыми единицами, через логическое усвоение новых языковых структур и правил их употребления. Формирование коммуникативной компетенции в сфере иностранного языка, безусловно, отличается от автоматической имитации речевых оборотов окружающих людей и бессознательной ориентировки «в системе типичных для той или иной формы значений и в системе форм, позволяющих передавать одни и те же значения с различными смысловыми...оттенками» (Е. Д. Божович), что характерно для носителей языка, постоянно пребывающих в языковой среде.

\section{Литература}

1. Дигтяр О. Ю. Организация лексического материала и его усвоения как фактор, соопределяющий эффективность обучения иноязычной лексике: английский язык, средняя ступень школьного обучения / О. Ю. Дигтяр. - Диссертация на соискание ученой степени кандидата педагогических наук. - Специальность 13.00.02. - 2009 // Научная библиотека диссертаций и авторефератов DisserCat. [Электронный pecypc]. - Режим доступа: http://www.dissercat.com/content/organizatsiya-leksicheskogo-materiala-iego-usvoeniya-kak-faktor-soopredelyayushchii-effekti\#ixzz317h06x8B. Название с титул. экрана.

2. Лебедева О. А. Чувство языка как компонент коммуникативной компетенции (в аспекте соотношения понятий) / О. А. Лебедева // Вестник Томского государственного университета. 2008. - Вып. 311. - С. 153-154.

3. Николаева Н. Ю. Условия развития «чувства языка» при обучении лексике на уроке иностранного языка / Н. Ю. Николаева. [Электронный ресурс]. - Режим доступа : http://www.lotime.ru/chyaz.html - Название с титул. экрана.

4. Овчаренко 3. П. О феномене «чувства языка» и проблеме его развития при обучении языку / 3. П. Овчаренко // Молодой ученый. - 
Психолого-педагогічні проблеми становлення сучасного фахівця

Випуск 2014 2013. - № 5. - С. 461-464. [Электронный ресурс]. - Режим доступа : http://www.moluch.ru/archive/52/6850/ - Название с титул. экрана.

5. Чувство языка // Психологический толковый словарь. [Электронный pecypc]. - Режим доступа: http://magazine.mospsy.ru/dictionary/dictionary.php?term=1085000. Заголовок с экрана.

Ольга Посудісвська. Розвиток «відчуття мови» як компонент навчання іноземній мові.

Стаття присвячена дослідженню «відчуття мови» як необхідного компонента оволодіння іноземною мовою. Аналізуються два підходи до визначення явища як несвідомо-інтуїтивного феномена та свідомоінтелектуального прочесу. Проводиться співставлення понять «відчуття мови» 3 «мовною інтуїиією» та «комунікативною компетенцією».

Ключові слова: «відчуття мови», «мовна інтуїція», "комунікативна компетенція», інтуїтивне оволодіння мовою, свідомий рівень оволодіння мовою.

Ol'ga Posudiyevs'ka. Development of «language feeling» as the component of foreign language teaching.

The article is dedicated to the investigation of «language feeling» as the necessary component for foreign language acquisition. The analysis concentrates on two approaches to definition of the notion as unconsciously intuitive phenomenon and consciously intellectual process. The article dwells upon the comparison of «language feeling» with «language intuition» and «communicative competence».

Key words: «language feeling», "language intuition», «communicative competence», intuitive language acquisition, conscious level of language acquisition.

Статья поступила в редакционную коллегию 15.05.2014

УДК 159.947:[001.892:167.1]::001:159.947.3

Поуль Валентина Станіславівна

Донецький обласний інститут післядипломної педагогічної освіти

\section{РОЗРОБКА ПРОБЛЕМИ ВОЛІ В СУЧАСНІЙ НАУЦІ: КОНСТРУЮВАННЯ ВОЛЬОВОЇ ПОВЕДІНКИ}

Стаття присвячена аналізу досліджень щодо розробки проблеми волі в сучасній науиі, на основі якого уточнюеться поняття «конструювання вольової поведінки». Звертається увага на один із 
шляхів розвитку волі: формування мовленнєвих умінь, щзо оптимізують становлення плануючої та регулюючої функиій мовлення.

Ключові слова: воля, вольова поведінка, конструювання вольової поведінки.

Проблема становлення волі особистості залишається актуальною в сучасній науці, оскільки передумови iï становлення включають розвиток здатності до оволодіння своєю поведінкою та своїми психічними процесами в зв'язку з необхідністю успішного інтегрування в суспільні відносини та самореалізації.

Сутність волі науковці вбачають у рефлекторній природі психіки людини, у залежності іiі вольової поведінки від організації взаємодії з навколишнім середовищем, а вищім регулятором цієї взаємодії є процес мовлення, завдяки якому вона свідомо керує своєю діяльністю (I. М. Сеченов, І. П. Павлов, С. Л. Рубінштейн). Особлива увага вчених звертається на розвиток мовлення, бо саме у формуванні усвідомлення власних дій найбільше значення має їх відпрацювання в мовленнєвому плані.

Мовлення розглядається дослідниками як носій повідомлення про дію і як засіб, завдяки якому дії, що здійснюються зовні, переводяться до внутрішнього плану, а процес формування цього засобу є психологічною умовою свідомого конструювання моделей власної поведінки (Л. С. Виготський, О. Р. Лурія, О.О.Леонтьєв, О. В. Запорожець [62], С. В. Фонарева (Яковлєва), Р.С. Левіна, $\begin{array}{llll}\text { I. П. Лаужикас, } & \text { В. І. Лубовський, } & \text { А. В. Піменов). Водночас у }\end{array}$ дослідженнях не має чіткого визначення поняття «конструювання вольової поведінки», хоча його застосовування можна зустріти в низці наукових праць, автори яких вкладають свій зміст.

Meта статті полягає в аналізі наукових праць щодо уточнення поняття «конструювання вольової поведінки».

У вітчизняній науці воля визначається, як свідома саморегуляція людиною своєї поведінки і діяльності, специфіка якої лежить у здатності наполегливо досягати поставленої мети, долаючи зовнішні і внутрішні перешкоди на шляху до неї (О. В. Запорожець, В. К. Котирло, Б. Н. Смирнов, П. А. Рудик, П. В. Симонов та інші). Вченими також було визначено та розширено понятійний апарат у межах проблеми волі, а саме: «довільність», «довільна поведінка» (О. В. Запорожець, О. О. Смирнова, С. Н. Рубцова та інші); «вольова» і «довільна» регуляція» (В. К. Калін, В. І. Селіванов, В. А. Іванников, T. I. Шульга та інші); «саморегуляція поведінки» (М. Й. Боришевський). Частіше зустрічаються поняття «управління своїми діями» (С. Л. Рубінштейн, О. В. Запорожець， В. І. Селіванов, 
В. І. Іванніков), «оволодіння своєю поведінкою» (С. Л. Виготський), «вольове управління поведінкою» (С. Є. Кулачківська).

Пізніше стали застосовувати поняття «конструювання вольової поведінки», яке вперше почало зустрічатися в працях зарубіжних психологів і розумілося ними як формування навичок здійснення контролю над поведінкою шляхом самоінструктування (П. Массен [4]), або як визначення (планування) напрямку своєї діяльності чи дій (Е. Еріксон [5]). Вітчизняні науковці поняття «конструювання вольової поведінки» також розуміють як планування людиною своїх майбутніх дій i здійснення саморегуляції при їх реалізації.

Так, наприклад, М. Й. Боришевський [1] «конструювання поведінки» визначає як планування дій, при цьому плануюча i прогностична функції саморегуляції поведінки включають моделювання можливих ситуацій діяльності. А в роботі Н. Е. Веракси і О. М. Дьяченко [2] в якості способу саморегуляції розглядається створення дитиною правил за допомогою мовлення, при дотриманні яких у іiі регуляції поведінки автори виділяються дві сторони: конструювання норми і наслідування ії̈ у реальних обставинах. Тобто на перше місце вчені висувають саме прогнозування і програмування моделей власних дій, що, на думку О. О. Леонтьєва [3], є одним 3 основних механізмів конструювання діяльності (у тому числі i мовленнєвої), на друге - реалізацію цих моделей відповідно до реальних умов, засвідчуючи взаємодію мовлення (його функцій) та волі в цьому процесі.

Отже, виходячи $з$ аналізу вищезазначених досліджень, поняття «конструювання вольової поведінки» можна розглядати як взаємодію плануючої і регулюючої функцій мовлення у процесі організації і здійснення особистістю своєї діяльності і поведінки.

Науковцями також відмічається залежність становлення регулюючої і плануючої функцій мовлення від умінь самостійно будувати висловлювання (Л. С. Виготський, О. Р. Лурія, В. І. Лубовський). Оволодіння вміннями визначати конкретну мету i предмет мовлення на кожному етапі роботи, планування його змісту i вибір відповідної структури активізує розвиток плануючої функції мовлення, а аналіз, оцінка та корекція свого висловлювання регулюючої. Таким чином, формування вищезазначених мовленнєвих умінь оптимізуватиме процес освоєння ними плануючої та регулюючої функцій, що сприятиме розвитку навичок конструювання вольової поведінки.

Висновки, перспективи: 1. Конструювання вольової поведінки визначається взаємодією плануючої і регулюючої функцій мовлення в процесі організації і здійснення особистістю своєї діяльності і 
поведінки. 2. Дослідження проблеми волі в цьому аспекті має наукове і практичне значення: 3'ясування, яким чином рівень сформованості мовленнєвих умінь сприяє розвитку волі на кожному етапі онтогенезу, дає можливість розробити рекомендації щодо формування вольової поведінки в природних умовах освітньо-виховного процесу в навчальних закладах.

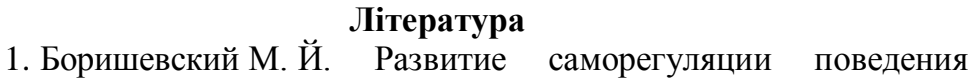
школьников : автореф. дис. ... д-ра психол. наук : 19.00.07 / М. Й. Боришевский. [КГПИ им. М.П. Драгоманова]. - К., 1992. - 32 с.

2. Веракса Н. Е. Способы регуляции поведения у детей дошкольного возраста / Н. Е. Веракса, О. М. Дьяченко // Вопросы психологии. - 1996. - № 3. - С. 14-27.

3. Леонтьев А. А. Психолингвистические единицы и порождение речевого высказывания / А. А. Леонтьев. - М. : Наука, 1969. - $307 \mathrm{c}$.

4. Mussen P. H. Readings in Child Development and Personality / P. H. Mussen, J. J. Conger, J. Kagan. - N.Y. : Harper Paw, 1970. - P. 385405.

5. Silverman R. E. Psychology. The Development of the Individual / R. E. Silverman. - N.Y. : Prentice-Hall, 1985. - P. 292-325.

Валентина Поуль. Разработка проблемы воли в современной науке: конструирование волевого поведения.

Статья посвящена анализу исследований по разработке проблемь воли в современной науке, на основании которого уточняется понятие «конструирование волевого поведения». Определяется один из путей развития воли: формирование речевых умений, которые оптимизируют становление планирующей и регулирующей функиий речи.

Ключевые слова: воля, волевое поведение, конструирование волевого поведения.

Valentyna Poul. Development of a problem of will in modern science: designing of volitional behavior.

Article is devoted to the analysis of researches of development of a problem of will (volition) in modern science, on the basis of which the concept "designing of volitional behavior" is specified. Determined by one way of development the will: the formation of verbal skills that optimize the formation of planning and regulatory functions of speech.

Key words: will (volition), volitional behavior, designing of volitional behavior.

Стаття надійшла до редакційної колегії 10.05.2014 
Птахіна Ольга Миколаївна

(C) Птахіна O. М., 2014.

Луганський національний університет імені Тараса Шевченка

\section{ВИКОРИСТАННЯ ІНФОРМАЦЙНОЇ ТЕХНОЛОГІЇ ШЕВ 2.0 В НАВЧАЛЬНОМУ ПРОЦЕСІ ВИЩОГО НАВЧАЛЬНОГО ЗАКЛАДУ}

Застосування інформаизйних технологій в будь-якої сфері діяльності $\epsilon$ необхідною умовою сучасного розвитку суспільства. Використання інформаційних технологій y діяльності вищзого навчального закладу дає можливість майбутнім фахівцям більи швидчого адаптування до навколичнього середовища та професійної мобільності. Технологія Веб 2.0. сприяє активної взаэмодї всіх учасників навчального прочесу (викладачів та студентів) та дає змогу вирішувати найрізноманітніші освітні завдання.

Ключові слова: інформаційні технологї, технологія Веб 2.0, переваги та недоліки технології Веб 2.0.

Інтенсивний розвиток інформаційних технологій ставить нові вимоги до професійної підготовки фахівців, оскільки сприяє переходу до інформаційного суспільства. Інформатизація вищої освіти - це сукупність взаємопов'язаних організаційних, управлінських, економічних, науково-технічних, навчальних, виховних процесів, що спрямовані на створення умов для задоволення інформаційних потреб всіх учасників освітнього процесу (студенпв, викладачів, ствробітників ВН3). Цей процес $\epsilon$ особливо актуальним у зв'язку 3 розвитком інформаційних технологій та залученням інтерактивних методик у діяльності вищих навчальних закладів .

Mema cmammi. Використання інформаційних технологій в навчальному процесі вищого навчального закладу полягає в створенні, впровадженні та розвитку комп'ютерно-орієнтованого освітнього середовища на основі інформаційних систем, мереж, ресурсів i технологій, що сприятиме комплексній перебудові педагогічного процесу, підвищення його якості та ефективності.

Використання в процесі підготовки фахівців різного профілю інформаційно-комунікаційних технологій представлено в працях таких дослідників, як Р. Гуревич, Є. Данильчук, Г. Ковальчук, Ю. Машбиць, Н. Морзе, Л. Положенцева, І. Роберт, В. Стрельніков, Т. Поясок, Г. Чаплицька, Г. Чусавитина, О. Філатов, Т. Шепеленко. та ін., але сьогодні особливо актуалізується необхідність удосконалення навчально-виховного процесу підготовки фахівців на основі 


\section{Збірник наукових статей}

інформаційних технологій. Проблемами використання Інтернет, соцільних сервісів (сервіси Веб 2.0), в освіті присвячені дослідження В. Бикова, М. Бухаркіної, Р. Гуревича, І. Захарової, Н. Морзе, С. Полат, Б. Ярмака та ін.

Об'єктивною реальністю сьогодення $\epsilon$ впровадження в усі сфери життя сучасних інформаційних технологій. Інформатизація навчального процесу, заснована на органічному поєднанні традиційних і новітніх технологій навчання.

Використання інформаційних технологій в навчанні забезпечує підтримку у створенні та підвищенні ефективності освітніх ресурсів, вносить значний внесок у стійкість та відкритість процесу навчання, його сталість, розширює можливості участі в ньому студентів. Отже застосування інформаційних технологій в навчальному процесі - це об'єктивна реальність, зумовлена сучасним етапом розвитку матеріально-технічної бази суспільства [4, с. 41].

До чинників, які зумовили необхідність використання інформаційних технологій можна віднести можливість успішного й більш швидшого адаптування до навколишнього середовища, які відбуваються під впливом глобальної інформатизації, тобто сприяння до професійної мобільності майбутніх фахівців, випускників вищих навчальних закладів. Існує кілька сучасних перспективних вебтехнологій, використання яких дає змогу вирішувати найрізноманітніші освітні завдання. Однією 3 таких технологій $€$ технологія Веб 2.0 (Web 2.0) - друге покоління мережних сервісів, що останнім часом стали основою розвитку мережі Інтернет.

Технології Веб 2.0 називають соціальними сервісами мережі Інтернет, оскільки їх використання зазвичай здійснюється спільно в межах відповідної групи користувачів (які утворюються відповідно до спільних інтересів). До особливостей технології Веб 2.0 відносятяся: об'ектно-оріентований інтерфейс; керована, вибірка і вивід даних на сторінці за багатьма параметрами, що вибирає користувач; розмщення великої кількості інформації на одній сторінці; перезавантаження тільки тієї частини сторінки, що змінюється; вивід різнотипової інформації в одному вікні; можливість поповнення сервісів, визначення стратегії розвитку ресурсів в цілому.

За допомогою технології Веб 2.0. стає можливим: забезпечення простоти у спілкуванні та співпраці всіх учасників навчального процесу за допомогою мережних технологій, створення соціальних спільнот, засобів колективного спілкування та обміну знаннями; впровадження особистісно-орієнтовані технології навчання за умов докорінної зміни ролі викладача з основного джерела отримання знань до фасилітатора навчального процессу; не нав'язлива допомога групі чи окремій людині в пошуку способів виявлення розв'язування 
проблем, налагодженні комунікативної взаємодії між суб'єктами діяльності.

Слід зауважити, що використання сучасної інформаційні технології Веб 2.0 з метою контролю навчального процесу дає змогу: накопичувати та аналізувати статистику навчальних досягнень студентів, яка може використовуватися викладачем в режимі реального часу; стандартизувати навчальний процес, а саме електронні курси можуть супроводжувати декілька викладачів, при цьому зміст його не змінюється, змінюється методика навчання; впроваджувати систему атестації навчальних ресурсів через забезпечення дотримання певних вимог до їх подання та складу; надавати або анулювати доступ студента до необхідного курсу; забезпечувати систематичну та відкриту взаємодію викладача та студента, студентів між собою на всіх етапах навчального процесу (при вивченні теоретичного матеріалу, його закріпленні, при виконанні практичних завдань, обговоренні проблемних ситуацій та питань, спільному виконання навчальних проектів та їх оприлюдненому захисті); контролі результатів навчальної діяльності, рефлексії та самооцінюванні навчальних досягнень студентів; установлювати зворотній зв'язок, завдяки використанню нових форм співтворчості (взаємодії) викладачів і студентів.

В Луганському національному університеті імені Тараса Шевченка на кафедрі державної служби, управління та адміністрування використовується технологія Веб 2.0 для навчання магістрантів за спеціальністю «Управління соціальними закладами». Однією $з$ форм роботи зі студентами $є$ використання в навчальному процесі блогів. Блог (англ. blog, від web log, «мережевий журнал або щоденник подій») - це веб-сайт, основний вміст якого - записи, що регулярно додаються, зображення або мультимедіа. У даному випадку блог використовується в навчальному процесі як джерело навчальної інформації, що була попередньо опублікована викладачем; для організацції дискусії (семінарів) за темами навчальної програми; для організації дистанційного навчання; для контролю за діяльністю на основі публікацій, обговорення контрольних робіт й завдань студентів, які вони розміщують на блогах. Блогі викладачів мають навчальнометодичне забезпечення, що дає змогу користувачу в повному обсязі вивчати дисципліни та виконувати практичні завдання згідно 3 навчальним планом курсу.

За результатами використання технології Веб 2.0 можна зробити висновок, що до переваг для викладачів застосування у навчальному процесі $\epsilon$ : можливість розміщення матеріалів (лекцій, практичних та семінарських занять, питань до контрольно-модульних робіт) та посилань на веб-ресурси, а саме використовування блогу для 
розповсюдження навчальних матеріалів або посилань на них; наявність он-лайн дискусії (залишаючи коментар до повідомлення у блозі, відвідувачі (студенти) стають учасниками справжньої дискусії); застосування засобів мультимедіа (вбудовані відеоматеріали, презентації, гіперпосиланні, аудіо лекції істотно підвищують інтерес до навчання); можливість активізувати пізнавальну діяльність студентів та виявити проблемні питання; індивідуальна підтримки викладачем навчальної діяльності кожного студента; отримання сучасних інтерактивних веб-сайтів, які дають можливість використовування для студентів різних форм навчання.

До переваг використання технології Веб 2.0 для студентів відноситься: вільний доступ до інформації; наявність зворотнього зв'язку (створення партнерських відносин взаємодії, що базуються на співробітництві, відкритості, довірі, особистісній участі, підтримці); активна участь у навчальному процесі; можливість постійного консультування (надання викладачем консультацій та додаткових завдань студентам).

Але існують певні недоліки користування технологіями Веб 2.0 - це залежність від наявності з'єднання з Інтернетом (зникає зв'язок інформація стає недоступною або незручною у використанні); залежність від якості роботи сервісу; здатність користуватися інформаційними технологіями. Розглядаючи недоліки та переваги застосування інформаційної технології Веб 2.0 у навчанні, слід наголосити, що в освіті важливою умовою успішної інтеграції технологій $\epsilon$ професійна підготовка викладачів $\mathrm{i}$ фахівців, які здійснюють експлуатацію систем і засобів нової інтегрованої технології навчання. Кожний учасник процесу, включаючи адміністрацію установ освіти, має володіти необхідною інформаційною грамотністю і розумінням важливості використання інформаційних технологій, отже необхідною умовою ефективності використання інформаційної технології Веб $2.0 €$ підвищення кваліфікації викладачів і фахівців, які здійснюють експлуатацію систем і засобів нової інтегрованої технології навчання.

Висновки. Перехід на новий рівень мережевої спільноти надає можливості не тільки ефективно впроваджувати інформаційні технології у життя, а й розширити кругозір; оволодіти вміннями спілкуватися, використовуючи мережу Інтернет; організовувати міжособистісну взаємодію; співпрацювати у групі; систематично підвищувати рівень власної загальнокультурної, інформаційної компетентності.

Отже, використання інформаційної технології Веб 2.0 в навчальному процесі сприяє: вільному розповсюдженню навчальних матеріалів та спільному використанню їх в навчальному процесі; 
самостійному створенню мережевих навчальних матеріалів (як для студентів так і для викладачів), де кожен учасник навчального процесу має можливість не тільки одержувати доступ до цифрових колекцій, а й брати участь у створенні власного мережевого змісту; дає можливість брати участь у нових формах діяльності (за умови наявності базових знань i навичок 3 інформатики); автоматизації діяльності усасників процесу; спілкуванні у формі взаємного спостереження за діяльністю користувачів в мережі.

\section{Література}

1. Балик Н. Р. Використання соціальних сервісів WEB 2.0 в галузі вузівської та післявузівської педагогічної освіти з інформатики / Н. Р. Балик // Наукові записки Тернопільського нац.пед.у-ту ім. В. Гнатюка. Серія: Педагогіка. - 2008. - № 7. - С. 88-90.

2. Коваль Т. І. Підготовка викладачів вищої школи: інформаційні технології у педагогічній діяльності : навч.-метод. посіб. / Т. І. Коваль. - К. : Вид. центр НЛУ, 2009. - 380 с.

3. Поясок Т. Б. Система застосування інформаційних технологій у професійній підготовці майбутніх економістів: монографія / Т. Б. Поясок. - Кременчук : ПП Щербатих О. В., 2009. - 348 с.

4. Співаковський О. В. Теорія і практика використання інформаційних технологій у процесі підготовки студентів математичних спеціальностей : монографія / О.В.Співаковський. Херсон : Айлант, 2003. - 249 с.

5. Співаковський О. В., Федорова Я. Б., Глущенко О. О., Кудас Н. А. Управління інформаційними технологіями вищих навчальних закладів: Навчальний посібник. Видання трете, доповнене / О. В. Співаковський, Я. Б. Федорова, О. О. Глущенко, Н. А. Кудас. Херсон : Айлант, 2010. - 302 с.

\section{Ольга Птахина.}

Использование

информационной технологии Веб 2.0 в учебном процессе высшего учебного заведения.

Применение информациинных технологий в любой сфере деятельности является необходимым условием современного развития общества. Использование информацчионных технологий в деятельности высших учебных заведений дает возможность будушим специиалистам более быстро адаптироваться к окружающей среде и профессиональной мобильности. Технология Веб 2.0 способствует активному взаимодействию всех участников учебного процесса (преподавателей $и$ студентов) $u$ дает возможность решать различные образовательные задачи.

Ключевые слова: информационные технологии, технология Веб 2.0, преимущества и недостатки технологии Веб 2.0. 
Olga Ptakhina. Use of information technology Web 2.0 in the educational process of higher educational establishmen.

Application of information technologies in any sphere of activity is the necessary condition of modern development of society. Use of information technologies in activity of higher educational institutions gives the chance to future specialists more quickly to adapt oneself to the environment and professional mobility. Technology Web 2.0 is the instrumental in active cooperation of all participants of educational process (teachers and students) and enables to decide different educational tasks.

Key words: information technologies, technology Web 2.0, advantages and shortcomings technology Web 2.0.

Стаття надійшла до редакційної колегії 14.05.2014

УДК 159.923:37.015.3

(С) Россова М. М., 2014.

Россова Марія Михайлівна

Волинський національний університет імені Лесі Українки

\section{ПРАКТИЧНІ РЕКОМЕНДАЦІЇ ПСИХОЛОГАМ, АДМІНІСТРАЦЇ̈ ШКОЛИ ТА ВЧИТЕЛЯМ ЩОДО ОСОБЛИВОСТЕЙ ЗАСТОСУВАННЯ ІМПЛШЦИТНОГО ПСИХОЛОГІЧНОГО ВПЛИВУ В НАВЧАЛЬНО-ВИХОВНОМУ ПРОЦЕСІ}

В статті представлено теоретичні аспекти та практичні вказівки психологам, адміністрації школи та вчителям щзоо особливостей застосування імпліцитного психологічного впливу в навчальновиховному прочесі.

Ключові слова: психологічний вплив, імпліцитнний психологічний вплив, система «вчитель-учень», практичні рекомендації, моніторинг, розвиток навичок впливу.

Одним 3 головних завдань створення умов для розвитку професійної компетенції вчителів молодших класів $\epsilon$ розробка практичних рекомендації психологам, адміністрації школи та вчителям щодо особливостей застосування імпліцитного психологічного впливу вчителем на учнів в навчально-виховному процесі.

Проблеми формування та розвитку навичок застосування імпліцитного впливу в навчально-виховному процесі потребують нагального вирішення шляхом впровадження в практику роботи шкільного психолога заходів науково-методичного характеру. Застосування психологом в педагогічному колективі різноманітних 
методів та способів навчання певним вмінням та навичкам й корекції особистісних властивостей-якостей вчителів дає можливість підвищити рівень здійснення ними професійної діяльності.

Meта статmі полягає у висвітленні практичних рекомендацій психологам, адміністрації школи та вчителям щодо особливостей застосування імпліцитного психологічного впливу в навчальновиховному процесі.

Одним 3 найважливіших аспектів професійної діяльності в системі «вчитель-учень» виступає особистісне спілкування. В процесі консультацій між викладачами та спеціалістами психологами можуть бути вирішені наступні завдання: виявлення психологічних властивостей-якостей особистості вчителя, які перешкоджають (сприяють) ефективній взаємодії 3 учнями в процесі здійснення професійної діяльності; виявлення основних проблемних моментів у практичному застосуванні імпліцитного впливу вчителем (зокрема об'єктивні та суб'єктивні умови, які заважають (сприяють) ефективності його застосування); підбір та впровадження індивідуально орієнтованих заходів психологічної корекції поведінки вчителя в процесі роботи з учнями.

Виходячи 3 вищевикладеного корекційна діяльність психолога щодо особливостей застосування імпліцитного психологічного впливу в навчально-виховному процесі адміністрацією школи та вчителями повинна бути спрямована на: а) формування позитивного ставлення вчителів до учнів, що сигналізує про професійну компетентність вчителя; б) корекцію ціннісних орієнтацій у бік альтруїстичних та високоморальних; в) формування професійної установки на професійну самосвідомість до дії або вчинку; г) аналіз рефлексії вчителів щодо власного досвіду професійної педагогічної діяльності); д) розвиток позитивного емоційного ставлення вчителів до власної професійної діяльності; ж) створення умов для розвитку адекватної самооцінки вчителів; з) корекція форм емоційного реагування вчителів в стресових ситуаціях; i) розвиток комунікативних вмінь вчителів. Враховуючі напрями спрямування корекційної діяльності психолога в навчально-виховному процесі практичні рекомендації поділено на дві основних блоки, а саме: психодіагностичний та психокорекційний.

До психодіагностичного блоку практичних рекомендацій відноситься комплекс методик психодіагностики компонентів імпліцитного психологічного впливу, а саме: 1) методики виявлення педагогічних та соціально-психологічних установок щодо особистісного ставлення вчителів до учнів (тест «СОУО» (система оцінних установок особистості), методика «Виховні реакції i установки вчителів» Е. Шеффера і Р. Белла адаптована Т. Нещерет) [1, c. 3-5]; 2) методики, спрямовані на виявлення структури ціннісних 
орієнтацій вчителів (методика «Ціннісні орієнтації» М. Рокича, методика «Ціннісні орієнтації» О. Моткова та Т. Огнєвої (варіант 2), методика діагностики реальної структури ціннісних орієнтацій особистості С. С. Бубнова) [1, 3]; 3) методики виявлення особливостей прояву емоцій та емоційних станів вчителів в процесі здійснення професійної діяльності (опитувальник для оцінки синдрому психічного вигорання, шкала депресії за Т. Балашовою, О. Єлісєєвим, тест «Визначення типового стану» Е. Ейдеміллера, В. Юстіцького, методика оцінки психологічної активації, інтересу, емоційного тонусу, напруги i комфортності (за Н. Курганським i Т. Немчиним), тест тривожності Ч. Спілбергера - Ю. Ханіна) [3]; 4) методики виявлення особливостей прояву мотиваційного та поведінкового компонентів особистості вчителів в процесі здійснення професійної діяльності у міжособовій взаємодії 3 учнями: (методика вимірювання рівня макіавеллізму особистості (МАК-ШКАЛА) розроблена Р. Крісті і Ф. Гейс, методика діагностики соціально-психологічних установок особистості в мотиваційно-потребовій сфері О. Потьомкіної, методика діагностики мотиваційної структури особистості В. Мільмана) [2; 3].

Другий блок практичних рекомендацій містить рекомендації щодо корекції когнітивного, емоційного та поведінкового компоненту імпліцитного психологічного впливу вчителя на учнів.

Здійснюючи психокорекційну діяльність, спрямовану на когнітивний компонент імпліцитного психологічного впливу вчителя на учнів психолог повинен: 1) здійснювати моніторинг професійної педагогічної діяльності вчителів молодших класів, спрямований на виявлення методів, способів та прийомів професійного психологічного впливу на учнів, якими користуються вчителі в процесі взаємодії 3 учнями, дії на них, та від яких залежить ефективність педагогічної діяльності в цілому, а саме: ступінь застосування вчителями імпліцитного психологічного впливу та ступінь застосування вчителями деструктивних (маніпулятивних) технік прихованого психологічного впливу в процесі педагогічної діяльності; 2) застосовувати заходи, спрямовані на розвиток практичних навичок 3 подолання негативних наслідків застосування деструктивних (маніпулятивних) технік прихованого психологічного впливу учнів на вчителів в процесі взаємодії;

На основі отриманих в процесі здійснення моніторингу даних вбачається проведення психологом тренінгів для вчителів молодших класів, спрямованих на розвиток асертивності, участь в яких забезпечує учасникам-вчителям: 1) оволодіння ефективними формами комунікації; відпрацювання проблемних ситуацій в спілкуванні 3 учнями, їхніми батьками, колегами, адміністрацією школи; 2) розвиток позитивного емоційного ставлення до професійної діяльності та 
оволодіння навичками емоційної саморегуляції при роботі 3 негативними та позитивними емоціями; 3) розвиток навичок заміни негативних психічних станів на позитивні, конструктивні, продуктивні, допомога у розкритті перспектив i сенсів щодо майбутнього та розвиток стійкого позитивного ставлення до здійснення професійної діяльності; 4) корекція поведінкових актів через закриття негативного досвіду минулого і створення нових форм поведінки в сьогоденні завдяки отриманню професійної упевненості; 5) стимулювання процесів особистісного зростання завдяки перенесенню навичок і цінностей спілкування в сферу щоденних комунікацій.

Зміст вказаного спектру роботи психолога сприяє руйнуванню деструктивних когнітивних, емоційних та поведінкових стереотипів вчителя та неупередженому, безпосередньому сприйняттю, глибшому i неспотвореному розумінню вчителями самих себе, своїх колег та учнів. При цьому у вчителів виникає прагнення приймати i реалізовувати нестандартні, творчі ідеї, виробляти конструктивні вирішення міжособових розбіжностей і проблем, підвищується іхня самооцінка, посилюються почуття емпатії і близькості до інших людей і навколишнього світу в цілому [4].

Отже, психолог повинен: здійснювати моніторинг професійної педагогічної діяльності вчителів молодших класів, спрямований на виявлення і відповідність методів, способів та прийомів професійного психологічного впливу на учнів, якими користуються вчителі в процесі взаємодії з учнями, в процесі дії на них не тільки при навчанні наукам, a i при формуванні ціннісних орієнтацій; проводити індивідуальні бесіди 3 вчителями, тестувати за допомогою стандартизованих психодіагностичних методик, запроваджувати виконання комплексу вправ, тренінгів, завдань практики, і аналіз рефлексії вчителів щодо досягнутих результатів; здійснювати роботу зі студентами в період педагогічної практики та молодими вчителями в період попередньої професійної адаптації, якими мають бути усвідомлені професійні труднощі та основні напрямки їх подолання.

Рекомендації адміністрації загальноосвітніх навчальних закладів повинні забезпечувати психолого-педагогічний супровід вчителів в освітньому просторі, а саме: створення умов передачі професійного і творчого досвіду між колегами; створення умов для розвитку прагнення до професійного зростання; стимулювання мотивації суб'єктів педагогічного процесу на саморозвиток культури (умов розвитку здібностей самопізнання, самоспостереження, самовдосконалення і самореалізації, творчої активності); впровадження консультативних заходів щодо навчально-методичного забезпечення освітнього процесу при аналізі нормативних, наукових і 
методичних джерел; надання рекомендацій вчителям відповідно до проблем, що виникають в професійній діяльності, деталізація та роз'яснення рекомендацій щодо організації навчальної діяльності 3 метою полегшення їхнього впровадження в реальну практику; допомога в аналізі і узагальненні педагогічного досвіду; забезпечувати поточну методичну допомогу.

Рекомендації вчителям молодших класів містять наступні аспекти:

1. Врахування вчителями в професійній діяльності принципу «зони найближчого розвитку» (обгрунтовано Л. С. Виготським для навчання дітей), в якій вчитель за допомогою своїх колег, учених, літератури, може вирішити проблеми, які виникли в професійній діяльності. Реалізація цього принципу припускає: вивчення професійних труднощів, виявлення проблем у власній діяльності; актуалізація необхідних для професійного зростання знань і умінь (надання допомоги педагогові в усвідомленні своїх професійних труднощів і проблем); визначення індивідуальних завдань підвищення педагогічної кваліфікації; складання програми професійного зростання педагога; систематична самооцінка вирішення поставлених завдань i реалізації програми, їх корекція.

2. Діяльність вчителя, спрямована на вирішення проблеми при здійсненні професійної діяльності включає: формулювання проблеми; побудову системи, в якій вона виникає і ідентифікацію ключових змінних; збір даних про обстановку i висунення припущень; формування образу майбутнього з використанням моделі і сценаріїв; ухвалення стратегічних рішень.

Педагогічна діяльність вчителя молодших класів повинна грунтуватися на наступних принципах: пошуку шляхів вдосконалення проведення уроків, реалізації організаційної чіткості кожного уроку від першої до останньої хвилини, використання цікавих завдань для учнів, що включають їх в роботу 3 першої хвилини уроку та застосовування різних способів фронтальної прискореної перевірки, підвищення пізнавальної самостійності і творчої активності учнів, оптимізації учбово-виховного процесу, забезпеченні міжнаочних i внутрішньонаочних зв'язків [5].

Висновки. Отже, реалізація заходів щодо оволодіння вчителями навичками застосування імпліцитного психологічного впливу в навчально-виховному процесі можлива завдяки спільній спрямованій діяльності шкільних психологів, адміністрації та педагогічного колективу, зацікавленого в забезпеченні якісними освітніми послугами відповідно до умов сьогодення. 


\section{Література}

1. Борисов, В. Н. Практическая психодиагностика : сборник тестов / В. Н. Борисов ; под ред. и с предисл. Ю. А. Алферова. - М. : РИПК МВД России, 1995. - 122 с.

2. Мильман, В. Э. Практикум по психодиагностике. Психодиагностика мотивации и саморегуляции / В. Э. Мильман. - М., 1990. - $144 \mathrm{c}$.

3. Фетискин, Н. П. Социально-психологическая диагностика развития личности малых групп / Н. П. Фетискин, В.В.Козлов, Г. М. Мануйлов. - М. : Изд-во Ин-та психотерапии, 2002. - 490 с.

4. Особенности копинг-поведения педагогов с разным уровнем эмоционального выгорания / Практические рекомендации [Електронний ресурс]. - Режим доступу : http : //www.psyhologyworld.ru/plws-423-1.html. - Назва с титул. екрану.

5. Современные образовательные технологии [Електронний pecypc]. - Режим доступу : http : //www.gimnazia22.ru/pedagogam/kafedru/rekomen dacii.html. - Назва c титул. екрану.

Мария Россова. Практические рекомендации психологам, администрации школы и учителям относительно особенностей применения имплицитного психологического влияния в учебновоспитательном процессе.

В статье представлены теоретические аспекты и практические указания психологам, администрачии школь и учителям относительно особенностей применения имплицитного психологического влияния в учебно-воспитательном процессе.

Ключевые слова: психологическое влияние, имплицитное психологическое влияние, система «учитель-ученик», практические рекомендации, мониторинг, развитие навыков влияния.

Maria Rossova. Practical recommendations to the psychologists, administration of school and teachers in relation to the features of using of implicate psychological influence in an educational process.

In the article are presented the theoretical aspects and practical pointing to the psychologists, administration of school and teachers in relation to the features of using of implicate psychological influence in an educational process.

Key words: psychological influence, implicate psychological influence, the system «teacher-pupil», practical recommendations, monitoring, development of skills of influence.

Стаття надійшла до редакційної колегії 07.05.2014 
Савицька Лариса Володимирівна

(С) Савицька Л. В., 2014.

Харківський національний економічний університет імені С. Кузнеця

\section{ФОРМУВАННЯ У СТУДЕНТІВ-ЕКОНОМІСТІВ МІЖКУЛЬТУРНОЇ КОМПЕТЕНТНОСТІ НА ОСНОВІ АНАЛІЗУ КЛЮЧОВИХ КУЛЬТУРНИХ КОНЦЕПТІВ БРИТАНСЬКОЇ КАРТИНИ СВІТУ}

У статті розглянуто ключові культурні концепти британської картини світу, які дозволяють краще розуміти представників англомовної культури під час міжкультурної комунікації.

Ключові слова: міжкультурна комунікація, концепт, культурний конияепm.

Формування комунікативної компетентності майбутнього фахівця є невід'ємною частиною формування його професійної компетентності. Основу комунікативної компетентності складають комунікативні здатності, які $є$ передумовою опанування студентом комунікативних знань, умінь та навичок.

Вивчення іноземної мови у повному обсязі неможливо без міжкультурного спілкування. Саме тому студенти повинні набути ввміннями міжкультурної компетентності.

Міжкультурна компетентність сприяє виробленню практичних навичок спілкування із представниками інших культур. У контексті загальної інтеграції та інформатизації суспільства міжкультурна компетентність може тлумачитись як здатність студента до ефективного вирішення завдань під час міжкультурного спілкування, яке передбачає діалог і взаєморозуміння представників різних культур.

У процесі розвитку міжкультурної компетентності під час іншомовного спілкування дослідники загострюють увагу на стимулюванні зацікавленості студентів до вивчення іншої культури та підтримці бажання накопичувати знання про іншу культуру шляхом вивчення іншомовних національно-культурних особливостей. Знання про культуру іншої країни сприяють розвитку загальної ерудиції, що $\epsilon$ однією 3 важливих передумов забезпечення здатності до міжкультурного спілкування і досягнення у ньому взаєморозуміння. Соціокультурні знання допомагають краще адаптуватися до іншомовного оточення, а пізніше і до полікультурного оточення.

Культурний (лат. cultura - догляд, освіта, розвиток) концепт (лат. conceptus - думка, поняття) - умовна ментальна одиниця, спрямована на комплексне вивчення мови, свідомості та культури. 
Концепт - це ніби згусток культури в свідомості людини; те, у вигляді чого культура входить до ментального світу людини. I, з іншого боку, концепт - це те, засобом чого людина... сама входить до культури, а в деяких випадках і впливає на неї [2].

Свідомість - це місце перебування концепту, культура детермінує концепт (тобто концепт - ментальна проекція елементів культури), мова або мовлення - сфери, в яких концепт вербалізується [1].

Мета статmі - висвітлити особливості ключових культурних концептів британської картини світу, які дозволяють краще розуміти представників англомовної культури під час міжкультурної комунікації.

Англія - це частина Сполученого Королівства Великої Британії та Північної Ірландії (разом із Шотландією, Уельсом та Північною Ірландією). Велика кількість назв, які вживають на позначення жителів Британських островів, свідчить, що англійці не є однорідною расою, а походять від багатьох далеких за походженням етносів - іберійців, кельтів, бриттів, данців тощо.

Для формування англійського національного характеру вирішальним виявилось острівне розташування країни: англійцям властиве відчуття відокремленості від решти світу, замкнутість, що віддзеркалюється також у мові (наприклад, про поїздку в країни континентальної Європи кажуть: поӥхати до Європи, тобто на континент). Океанічний клімат 3 великою кількістю опадів, туманів, сильними вітрами сприяе формуванню твердості характеру, загартованості тіла й духу, стриманості у висловлюванні почуттів. Малі розміри країни поєднуються 3 різноманіттям природного ландшафту.

Англійці схильні дивитися на світ так, начебто вони перебувають у його центрі, що пов'язано з тим, що тут проходить нульовий меридіан у Гринвічі, від якого здійснюють відлік часу; користуються традиційними мірами ваги та довжини, відмінними від європейських, лівобічним рухом на автошляхах, своєрідними формами розеток для електроприладів тощо.

Розглянемо особливо значимі для англійської картини світу культурні концепти.

Конщелт «домашнє вогнище», найближчий за значенням до українського поняття «Батьківщина». Рідна земля асоціюється 3 домом. Англійське уявлення про дім - цегляна будівля з кімнатами на першому та другому поверхах, із садком, за яким ретельно дбають та показують гостям. Англійське «house with a fence» - це мікромодель світу: відокремленість від інших у власному затишно облаштованому 


\section{Збірник наукових статей}

просторі. Англія заселена компактно, але це не заважає англійцям жити відокремлено.

Концеепт «свобода», зумовлений геополітичним положенням країни. Свобода пов'язана 3 особистою свободою, особистими правами, особистою незалежністю, тобто свобода, згідно з уявленнями англійців, - можливість робити, що хочеш, і не робити того, чого не хочеш.

Зміст концепту «здоровий глузд» охоплює певні практичні принципи, необхідні для формування моралі. В англійській мові багато виразів, що ілюструють особливу прихильність англійців до точного факту, очевидності: it's a fact, in actual fact, as a matter of fact фактично, насправді, дійсно; actually, really, obviously - насправді, точно, очевидно. Концепт «здоровий глузд» лежить в основі законослухняності, яка властива англійцям, $\epsilon$ основою їхньої соціальної стабільності та консерватизму. Він тісно пов'язаний 3 іншими концептами, які характеризують англійця: «джентльмен», «стриманість», «чесна гра», «відданість традиціям».

Кониеепт «приватне життя, приватність», тобто бажання захистити особистий простір, котрий англійці сприймають майже фізично як продовження власного тіла. «Приватний» означає наявність психологічно безпечної відстані між окремою особистістю та іiі оточенням.

Конщепт «джентльмен», який з'явився у XIII ст. і позначав людину благородного походження. Однак у XVI ст. цей концепт набуває іншого значення: «цивілізована людина, котра вёміє себе поводити спокійно, стримано, 3 повагою до оточуючих». Цивілізованість та культурність - важливі елементи англійської національної концептосфери. Цивілізованості властива скромність. Щоб не поставити співрозмовника у недвозначну ситуацію, джентльмен повинен уміти стримувати свої почуття, володіти собою, зберігати спокій за будь-яких обставин. Окрім цього, справжній джентльмен має бути добре освіченим, гучно оперувати словом.

Кониеет «стриманість», тобто вміння демонструвати витримку. Англійці особливо цінують уміння не виказувати своїх почуттів, сприймати поразку без демонстрування невдоволення тощо. Ці якості вважають типовими для будь-якого англійця. Протиставлення почуття та його відображення в англійській мові має певну специфіку: тут мало неперехідних дієслів, що виражають емоції: worry (хвилюватися), grieve (горювати), деякі з них мають негативні конотації: sulk (дутися), fret (нервувати, дратуватися), rave (біситися), fume (кипіти, дратуватися), а окремі дієслова зникають із вжитку: rejoice (радіти). Замість дієслів для вираження емоцій та почуттів переважно використовують прикметники. 
Схильність англійців до стриманості у вираженні емоцій можна проілюструвати такими мовними фактами:

1) для висловлення як позитивних, так і негативних емоцій вони використовують «пом'якшувальні» слова: quite (достатньо), about (приблизно), quite nice (досить гарний), quite awful (досить жахливий);

2) англійці віддають перевагу гіперболам при вираженні позитивної оцінки звичайних речей: одягу, предметів, але не серйозних моральних чеснот, у той час як російська мова вживає гіперболізацію при висловлюванні будь-яких оцінок.

Концеет «чесна гра» спочатку застосовували для характеристики спортивних змагань та поведінки джентльменів, які брали в них участь, пізніше розширив смислову сферу, що охоплює чесні правила гри в житті, повагу до інших. В англійському національному світі англійської культури важливу роль відіграє дотримання писаних та неписаних правил, при цьому правил гри дотримуються як переможці, так i переможені. В основі цього концепту лежить особливість англійської ментальності джентльменська угода, тобто усна домовленість, що грунтується на взаємній довірі. У національній свідомості англійців чесним є те, що не суперечить здоровому глузду, справедливості, законності.

Концепт «традиція» у широкому смислі означає, що щось пройшло перевірку часом і його слід зберегти. Він пов’язаний із концептом «спадок» (цінні об'єкти, обряди, традиції; предмети мистецтва, культурні досягнення тощо). Тобто основною ознакою $є$ сприйняття спадку як чогось цінного, що належить усім та має зв'язок 3 історією (акцент на зв'язку поколінь).

Концеет «гумор», що належить до якостей англійського національного характеру, яким особливо пишаються англійці. Відмінними ознаками англійського національного гумору є іронія та дотепність. Це інтелектуальний гумор, який спирається на феномен слова, при цьому смисл слід шукати в підтексті. Багато жартів побудовано на омонімах, буквальному прочитанні ідіом тощо. Уміння посміятися над собою англійці вважають ознакою зрілої цивілізації. Інший вияв англійського гумору - терпимість до людських слабкостей.

Підсумовуючи, зазначимо, що успішна міжкультурна професійна комунікація передбачає поряд із володінням іноземною мовою, вміння адекватно інтерпретувати комунікативну поведінку представника іншого культурного соціуму, готовність учасників спілкування до сприйняття іншої форми комунікативної поведінки, розуміння іiі відмінностей і варіювання від культури до культури. Кожна культура має в своїй основі власну систему соціальних стереотипів, образів i когнітивних схем. За кожним культурним концептом стоїть фрагмент образу світу конкретної культури. До 
ключових культурних концептів британської картини світу відносяться: концепт «домашнє вогнище», концепт «свобода», концепт «здоровий глузд», концепт «приватне життя, приватність», концепт «джентльмен», концепт «стриманість», концепт «чесна гра», концепт «традиція», концепт «гумор».

\section{Література}

1. Карасик В. И. Языковой круг: личность, концепты, дискурс / В. И. Карасик. - Волгоград : Перемена, 2004. - С. 8-171.

2. Степанов Ю. С. Константы: Словарь русской культуры / Ю. С. Степанов. - М. : Академпроект, 2000. - 824 с.

Лариса Савицкая. Формирование у студентов-экономистов межкультурной компетентности на основе анализа ключевых культурных концептов британской картины мира.

B cтатье рассматриваются ключевые культурные концепты британской картины мира, которые позволяют лучше понимать представителей англоязычной культуры при межкультурной коммуникации.

Ключевые слова: межкультурная коммуникация, концеепт, культурный кониепт.

Larysa Savytska. Formation of student-economists' crosscultural competence by means of analyzing key cultural concepts in British world picture.

The article deals with key cultural concepts in British world picture, which allow better understanding of English-speaking culture representatives at cross-cultural communication.

Key words: cross-cultural communication, concept, cultural concept.

Стаття надійшла до редакційної колегії 15.05.2014

УДК 612.821:378.091.212

(C) Самохвалов В. Г., Булынина О. Д., Васильева О. В., 2014

Самохвалов Валерий Гаврилович,

Булынина Оксана Дмитриевна,

Васильева Оксана Васильевна

Харьковский национальный медицинский университет

\section{ОСОБЕННОСТИ КОММУНИКАБЕЛЬНОСТИ СТУДЕНТОВ С РАЗЛИЧНЫМ ТИПОМ ФУНКЦИОНАЛЬНОЙ АСИММЕТРИИ}

Исследована зависимость между типом функииональной асимметрии и коммуникабельностью у студентов Харьковского национального медицинского университета. Установлено, что наибольщее число лич с левосторонним типом функииональной асимметрии являются 
идеальными слушателями, замечательными ораторами являются лицуа с соцчиально-измененным типом асимметрии. Лицуа со смешанным и соцчиально-измененным типом асимметрии наиболее непреклонны и упрямы, а лица с левосторонним типом асимметрии наиболее терпимы. Лица со смешанным типом и с социальноизмененньм типом функциональной асимметрии имеют наименьшую коммуникабельность.

Ключевые слова: функциональная асимметрия, коммуникабельность, студенты.

Основа коммуникативной компетентности основана на специфике мыслительных процессов и эффективном реагировании, способности понимать самого себя, других людей, их взаимоотношения и прогнозировать межличностные события. Сегодня, как никогда, ценится умение людей вести беседу на профессиональном уровне. Обязательным профессиональным качеством для каждого выпускника медицинского ВУЗа должно стать умение общаться, устанавливать и развивать отношения с людьми [1; 2].

Умение общаться, или коммуникативная компетентность, обеспечивает взаимопонимание, доверие в отношениях, эффективность в решении поставленных задач [3].

Следует отметить, что единой концепции в понимании профессиональной коммуникативной компетентности врача до сих пор не существует, а исследования касаются частных вопросов данной проблемы.

Цель исследования: выявить возможную зависимость между типом функциональной асимметрией и коммуникабельностью у студентов ХНМУ.

Объект и методы исследования. Обследовано 54 студента медицинского университета II курса лечебного и стоматологического факультетов, которые добровольно согласились принять участие в эксперименте. Контрольную группу составляли лица с правосторонним типом функциональной асимметрии (ПРТФА) - 21 человек, экспериментальную группу составили лица с левосторонним типом функциональной асимметрии (ЛВТФА) - 12 человек, лица со смешанным типом функциональной асимметрии (СМТФА) - 8 человек и лица с социально-измененным типом асимметрии (СИТФА) - 13 человек Разделение на группы проводилось на основе наибольшего количества набранных процентов при ответах на 10 вопросов. Отметка в каждой колонке (3 колонки: «всегда правой», «какой-либо», «всегда левой») оценивалась как 10 процентов [4]. Коммуникабельность оценивали с помощью тестов [5]. 


\section{Збірник наукових статей}

Результать и их обсуждение. Анализ результатов теста "Ваша коммуникабельность" у лиц с разным типом функциональной асимметрии показал, что они все относятся к одной группе (9-13 баллов): 12,2 ПРТФА; 12,1 ЛВТФА; 11,8 СМТФА и 10,8 СИТФА (они очень общительны, порой даже излишне; разговорчивы, любят высказываться по разным вопросам, охотно знакомятся с новыми людьми; любят бывать в центре внимания, никому не отказывают в просьбах, хотя не всегда могут их выполнить, однако им не хватает усидчивости, терпения и благоразумия при столкновении с серьезными проблемами).

Установлено, что среди них, наименьшее количество баллов (48) имеют: 9,5\% ПРТФА; 8,3\% ЛВТФА, 25\% СМТФА и 30,1\% СИТФА (они часто бывают причиной различных конфликтов в своем окружении через вспыльчивость, обидчивость и необъективность). Следует отметить, что среди них, наибольшее количество баллов (3032) не имеет ни одна из групп.

Таким образом, наибольшее число лиц с ЛВТФА и с СИТФА являются идеальными слушателями (25\% и 23,1\% соответственно). Замечательными ораторомы являются лица с СИТФА (53,9\%), а лица со СМТФА имеют неудовлетворительный результат (75\%). Лица со СМТФА и лица с СИТФА наиболее непреклонны и упрямы $(12,5 \%$ и $7,7 \%$ соответственно), а лица с ЛВТФА наиболее терпимы (41,7\%). Лица со СМТФА $(25 \%)$ и с СИТФА $(30,1 \%)$ имеют наименьшую коммуникабельность.

\section{Bblводbl.}

1. Лица с ЛВТФА являются идеальными слушателями $(25 \%)$ и наиболее терпимы $(41,7 \%)$.

2. Лица с СИТФА являются замечательными оратороми $(53,9 \%)$, но при этом наиболее непреклонны и упрямы $(7,7 \%)$ и имеют наименьшую коммуникабельность $(30,1 \%)$.

3. Лица со СМТФА не обладают ораторскими способностями (75\%), наиболее непреклонны и упрямы $(12,5 \%)$ и имеют низкую коммуникабельность (25\%).

\section{1. Горицнова Н. К. Jитература}

1. Горшунова Н. К. Формирование коммуникативной компетентности современного врача / Н. К. Горшунова, Н. В. Медведев // Успехи современного естествознания. - 2010. - № 3 - C. 36-37.

2. Васильева Л. Н. Коммуникативная компетентность в профессионально-личностном становлении будущего врача / Л. Н. Васильева : дисс. канд. психол. наук : Кострома, 2010. - 219 с. 
3. Каирова М. Б. Некоторые аспекты формирования коммуникативной компетентности / М. Б. Каирова // Вестник Моск. ун-та. - 2007.- № 6 (32). - С. 142-143.

4. Брагина Н. Н. Функциональные асимметрии человека / Н. Н. Брагина, Т. А. Доброхотова. - М. : Медицина. - 1994. - 230 с.

5. Пугачев В. П. Тесты, деловые игры, тренинги в управлении персоналом: Учебник для студентов вузов / В. П. Пугачев. - М. : Аспект Пресс, 2000. - 180 с.

Самохвалов В. Г., Булиніна О. Д., Особливості комунікабельності студентів 3 різним типом функціональної асиметрії.

Досліджено залежність між типом функиіональної асиметрії та комунікабельністю у студентів Харківського національного медичного університету. Встановлено, що найбільше число осіб з лівостороннім типом функиіональної асиметрії є ідеальними слухачами, чудовими ораторами є особи з сочіально-зміненим типом асиметрії. Особи зі змішаним і соиіально-зміненим типом асиметрї найбільш непохитні й уперті, а особи з лівостороннім типом асиметрії найбільш терпимі. Особи зі змішаним типом $i$ з соціально-зміненим типом функиіональної асиметрії мають найменшу комунікабельність.

Ключові слова: функиіональна асиметрія, комунікабельність, студенти.

Samokhvalov V. G., Bulynina O. D., Vasylieva O. V. The features of students' communicability with different types of functional asymmetry.

The dependence between the type of functional asymmetry and communication skills of the students of the Kharkiv National Medical University was studied. The greatest number of students with left-sided type of functional asymmetry are ideal listeners, speakers are wonderful people with socio- modified type of asymmetry were found. Individuals with a mixed socio-modified type of asymmetry most adamant and stubborn, and those with left-hand type of asymmetry most tolerant. Individuals with a mixed type and socio-modified type of functional asymmetry have the lowest communication skills.

Key words: functional asymmetry, communication, students.

Статья поступила в редакционную коллегию 23.04.2014 


\section{Святенко Тетяна Павлівна}

(C) Святенко Т. П., 2014.

\section{Харківський національний університет імені В. Н. Каразіна \\ ДОСЛІДЖЕННЯ ЦІННОСТІ «ВЛАДА» У ПРАЦІВНИКІВ, ЩО ЗАЙМАЮТЬ КЕРІВНУ ПОСАДУ В КОМПАНІЯХ СФЕРИ ІНТЕРНЕТ-ТЕХНОЛОГІЙ}

В статті розглядаються види спрямованості мотивації влади, зокрема конфліктний та иільовий ї̈ аспекти. Розглянуто иінність «влада» та ї̈ залежність від рівня задоволеності базових потреб особистості серед прачівників, щуо займають керівні посади в сфері інтернет-технологій, де иіннісна політика компанії нівелюе конфліктний підхід до розподілу ресурсів. За умов високого показника мотиву влади та прояву середнього соціального інтелекту у більшості досліджуваних, нами не знайдено статистично значущих зв'язків між рівнем мотиву влади та соиіальним інтелектом, а отже гіпотеза про наявність взаємозв'язку не підтверджується.

Ключові слова: мотив влади, сочіальний інтелект, конфліктний та изільовий типи мотивації влади.

В даному огляді ми зосереджуємося на визначенні проблеми концепції індивідуальної влади в зарубіжних теоріях, концентруючись на зарубіжному підході до визначення поняття, що має деякі розбіжності із вітчизняною теорією цього питання.

Актуальність даного огляду полягає в окресленні типів індивідуальної влади у вигляді мотиваційного утворення та можливості розгляду гіпотези про продуктивність реалізації влади відносно цінностей та позицій інших людей у вимірі ставлення до оточуючих особистості з реалізованою цінністю влади.

Таким чином, нами також поставлено завдання провести структурний аналіз індивідуальної влади (мотивації влади), яка розглядається теоретиками як потреба, мотив, цінність та ідеал. Відповідно до концепції про взаємозв'язок психологічних категорій А. В. Петровського та М. Г. Ярошевського, ми пропонуємо розглядати сукупність потреби, мотиву, цінності та ідеалу влади як інтегроване поняття влади як мотиваційного утворення та визначити дане поняття як об’єкт нашого дослідження.

У вітчизняному підході рівень потреби розглядається (виходячи 3 розуміння С. Д. Максименко про особистісні риси як мотиванти в неопредметненому вигляді) як риса «домінантність», рівень мотиву влади (за Ш. Шварца, Є. П. Ільїним), рівень ціннісної орієнтації (за 
визначенням В. О. Ядова про найвищий рівень соціальної регуляції, визначений в концепції О. Ф. Потьомкіної) та рівень ідеалу (на рівні нормативних ідеалів, яким виступають цінності в концепції Ш. Шварца). Сукупність даних мотиваційних явищ складає мотивацію влади.

У зарубіжному підході, наприклад, за визначенням С. Вятра, що розглядав типологізацію індивідуальної влади $€$ [3] наголос на ії двох аспектах: конфліктному та цільовому, які залежать від стану суспільства. У разі нерівномірного розподілення благ особистість більш схильна до конфліктного прояву влади, але у разі спрямування до загальної мети йдеться про цільовий прояв влади. Умови прояву цих аспектів індивідуальної влади формуються відповідно до певного рівня мотиваційного утворення. Таким чином, якщо ми говоримо про мотив «влади», то в першу чергу іï визначення формується через загальний стан обмеженої певним фактором групи, в якій перебуває особистість (компанія, де людина працює) та процесів в ній, що стосується цінності «влада» даний простір поширюється на такі угрупування як професійна галузь. Також, мотиви, що лежать в основі прагнення до влади, можуть бути егоцентричними та соціоцентричними (суспільними). Під егоцентричними розуміють мотиви, які концентруються навколо власної особистості, під соціоцентричними - на благо широкої групи людей: нації, класу, суспільства, людства. Ці мотиви не обов'язково мають виключати один одного, адже на різних рівнях мотивації влади можуть існувати специфічні спрямування утворень мотивантів (на рівні потреби, мотиву, цінності та ідеалу).

В свою чергу Б. Рассел зазначив, що без влади не може обійтися ні якась окрема особистість, ні суспільство в цілому. Влада носить природний характер і має визначатися як продукування намічених результатів. Тому він запропонував таку класифікацію людей за типами ставлення до влади:

1. Тi, що мають такі визначаючі риси характеру, як настирність в досягненні мети, віру у власні сили, цілеспрямованість, та тих, що відкрито проявляють своє прагнення до влади;

2. Ті, що сором'язливі, схильні до підпорядкування іншим, невпевнені в собі, у власних силах та можливостях;

3. Ti, що поводять себе ситуативно: в одних випадках прагнуть до влади, в інших - до підпорядкування іншим;

4. Тi, що мають мужність відмовитися від покірності іншим, не бажаючи при цьому керувати, намагаючись відійти від політики та не брати у ній участь. Вони шукають та знаходять застосування власних сил в науці, мистецтві, творчості. 


\section{Збірник наукових статей}

Насправді, провладними типами в даному випадку $є$ лише перший та третій тип. У випадку першого типу тут можуть актуалізуватися як потреба, мотив, так і цінність-ідеал влади, тобто на всіх рівнях регуляції соціальної поведінки за В. О. Ядовим; у випадку третього типу може актуалізуватися мотив влади, який ефективний у малій середній групі, але відсутня цінність влади, у випадку чого людина може не цікавитися владними стосунками на рівні, наприклад, держави чи певного регіону.

Д. МакКлелланд визначає мотив влади як потребу, по-перше, відчувати себе сильним, по-друге, виявляти свою могутність в дії. Вплив на інших людей є лише одним з багатьох способів задоволення потреби відчувати себе сильним.

Дослідник означив стадії розвитку мотивованості владою:

1. Асиміляція;

2. Автономність;

3. Самоствердження;

3. Продуктивність.

Вказані чотири етапи мають являти собою послідовні стадії дозрівання, які проходить людина в процесі свого розвитку. Досягнення більш високої стадії не анулює попередні досягнення, вони залишаються у розпорядження суб'єкта і можуть актуалізуватися в певних умовах. Стадія 1 - концепція «дещо надає мені сили», це відносини матері та дитини. 3 позицій орієнтації на владу в наступні роки життя вона означає відносини з людьми, які можуть підтримати, захистити, надихнути, тобто збільшити у індивіді відчуття власної сили. Стадія 2 - концепція «я сам надаю собі сили», відповідає середньому періоду дитинства, коли відбувається процес сепарації від матері. Стадія 3 - концепція «я справляю враження на інших» характеризує підлітка, для якого перестали існувати авторитети, чия участь у змаганнях визначається можливість взяти верх над іншими. Стадія 4 - концепція «мені хочеться виконати свій обов'язок» відповідає дорослому стану, тобто зрілій особистості. Аналогічні концепції розробляли також Дж. Та Дж. Б. Вероффи [2]. 3 точки зору моральної мети стадія 3, з ії орієнтацією на власні цілі, протилежна стадії 4, для якої характерна діяльність спрямована на благополуччя суспільства.

В сучасних дослідженнях питання індивідуальної влади, тобто потреби, мотиву, цінності та ідеалу влади розглядається як концепція прихованої та відкритої мотивації влади. В свою чергу дослідники також виокремлюють міфи про прагнення до влади, тобто про існуючу негативну конотації поняття влади у суспільстві. Зокрема, С. Люкс та М. Лоренчі вказують на те, що суспільство схильне вважати, що досягнення влади вимагає сили, обману, маніпуляції і примусу. В той 
же час виходячи з результатів сучасних досліджень американського та західноєвропейського наукових товариств показано, що застосування влади найбільш ефективно, коли вона використовується відповідально, людьми, які налаштовані на потреби та інтереси інших, тобто прагнення до влади корелює із соціоцентричністю особистості. Однак вони вказують, що, як тільки особистість отримує можливість реалізовувати владу, вона стає схильною діяти більш егоїстично, імпульсивно i агресивно, перестає розглядати точку зору іншої особистості. Таким чином, виникає певний парадокс прагнення до влади: навички найбільш важливі для отримання влади і ефективні для іiі здійснення, відкидаються як тільки влада концентрується в руках людини. Тому в сучасному суспільстві для втримання влади необхідна наявність розвиненого соціального інтелекту, що також сприяє соціоцентричному спрямуванню реалізації влади.

Тому ми провели пілотажне дослідження, де в першу чергу розглядається взаємозв'язок цінності «влада» із іншими цінностями та базовими потребами у спеціалістів на керівних посадах в сфері Інтернет-технологій.

Дослідження проведене серед працівників галузі розробки програмного забезпечення, що ми вважаємо цікавою соціальною групою, адже існує суспільно орієнтована модель роботи на керівних посадах в компаніях саме такого спрямування. Таким чином, об'єктом нашого пілотажного дослідження виступає влада як мотиваційне утворення.

Предметом дослідження постає цінність «влада» у працівників сфери Інтернет-технологій.

Мета роботи полягає у визначенні характеру взаємозв'язку цінності із іншими цінностями та базовими потребами.

Методи дослідження: методика дослідження базових потреб А. Маслоу, ціннісний опитувальник Ш. Шварца (мотиваційний профіль).

Характеристика вибірки: для проведення дослідження було залучено 34 особи віком від 24 до 30 років, що працюють на керівних посадах в компаніях сфери інтеренет-технологій, 3 них 9 жінок та 25 чоловіків.

Для виконання поставленої задачі ми використали метод непараметричного кореляційного аналізу за Спірменом.

За висновками дослідження базових цінностей досліджуваних (безпека, належність до суспільства, почуття власної гідності та самореалізація) встановлено, що ці потреби мають невисоке значення серед досліджуваних, що вказує на задоволеність даних потреб в достатній мірі у групі в середньому. Так, показник безпеки має середнє значення 13 (тобто такий, що не має особливого значення), показник 
належності - 15 (менш важливі мотиви), почуття гідності - 17, та самореалізація - 17. Тобто, ми бачимо, що потреби першого рівня задоволені в достатній мірі, інші гармонійно співіснують, досить задоволені.

Що стосується цінності «влада», вона займає досить низьке, дев'яте місце, у ранговому співвіднесенні інших цінностей особистості (доброта, універсалізм, конформність, безпека, влада, самостійність, гедонізм, досягнення, стимуляція).

Використовуючи метод непараметричного аналізу Спірмена нами було виявлено, що немає статистично значущих зв'язків між базовими потребами особистості та цінностями в даній групі, що свідчить про досить сильний відрив рівня цінностей від рівня потреб, адже вони задоволені в достатній мірі.

3 іншого боку виявлені статистично значущі кореляції між цінністю «влада» та цінностями досягнення та доброти у даній групі, що мають прямий характер.

Таким чином, ми бачимо, що чим вищий рівень прагнення до влади, тим сильніше актуалізується бажання досягнень, тобто особистісний успіх відповідно до соціальних стандартів. В той же час, чим вищий рівень влади, тим сильніше актуалізується цінність «доброта», тобто збереження та підвищення благополуччя оточуючих людей.

Цей факт вказує нам на наявність 4 стадії розвитку мотивації влади за Д. МакКлелландом по першому типу за Б. Расселом.

\section{Література}

1. Ильин Е. П. Мотивация и мотивы / Евгений Петрович Ильин. - СПб. : Питер, 2000. - 502 с.

2. МакКлелланд Д. Мотивация человека / Дэвид МакКлелланд. СПб. : Питер, 2007. - 708 с.

3. Максименко С. Д. Генеза здійснення особистості / Сергій Дмитрович Максименко. - К. : «КММ», 2006. - 240 с.

4. Маслоу А. Мотивация и личность / Абрахам Маслоу. - СПб. : Евразия, 1999. - 275 с.

5. Практический интеллект / Р. Дж. Стернберг, Дж. Б. Форсайт, Дж. Хедланд и др. - СПб. : Питер, 2002. - 272 с.

Татьяна Святенко. Исследование ценности «власть» у работников, занимающих руководящую должность в компаниях сферы Интернет-технологий.

В статье рассматриваются виды направленности мотивации власти. Например, аспекты целевой и конфликтной власти. Рассмотрена ценность «власть» $u$ гипотеза ее зависимости от уровня удовлетворенности базових потребностей личности среди сотрудников занимающих руководящие должности в сфере 
Психолого-педагогічні проблеми становлення сучасного фахівця Випуск 2014 интернет-технологий, где управление происходит по социализированным западноевропейским стандартам и нивелируется борьба за ресурсы по конфликтному типу.

Ключевые слова: ценность «власть», конфликтный и целевой типь мотивации власти.

Tetiana Sviatenko. Research the value of "power" of workers occupying management positions at the field of Internet technologies. In this study we looked through species of power motivation. We analyzed the dependence between level of satisfaction of basic needs and value of power at managers staff in internet-technologies area, where the value politic of companies provide non-conflict type of management.

Key words: value of power, conflict and objective type motivation of power.

Стаття надійшла до редакційної колегії 12.05.2014

УДК 159.9:37.011.32:004

\section{Сергіснко Ольга Володимирівна}

(C) Сергієнко О. В., 2014.

Харківський національний економічний університет імені С. Кузнеця

\section{ОСНОВНІ КОМПОНЕНТИ ІННОВАЦІЙНОӦ ПОВЕДІНКИ СТУДЕНТІВ СПЕЦАЛЬНОСТІ “ТЕХНОЛОГІЇ ЕЛЕКТРОННИХ МУЛЬТИМЕДІЙНИХ ВИДАНЬ"}

У статті проаналізовано поняття інноваційної поведінки студентів, описані основні компоненти інноваційної поведінки студентів на прикладі спеиіальності "Технологї електронних мультимедійних видань”. Також у статті надано авторське визначення поняття інноваційна поведінка студентів, інноваційна компетентність студентів, визначено патерн інноваційної поведінки.

Ключові слова: інноваційна поведінка студентів, інноваційна компетентність студентів, якості інноваційної особистості студента, патерн інноваційної поведінки.

Одним із завдань, яке сьогодні стоїть перед вищими навчальними закладами $\epsilon$ формування творчої інноваційної особистості студента, який здатен створювати та розповсюджувати інновації у сфері своєї професійної діяльності. Вищі навчальні заклади перетворюються з “ретрансляторів” знань у заклади, що формують та виховують інноваційну особистість. Саме така особистість здатна проявляти інноваційну поведінку та діяти швидко та креативно у невизначених ситуаціях, здатна створювати нові продукти, процеси та підходи у професійній діяльності, приносити прибуток своєму підприємству та самореалізовуватися у своїй професії. 


\section{Збірник наукових статей}

Поняття інноваційної поведінки розглядали у зарубіжній літературі такі вчені, як: V. A. West, J. L. Farr, O. Janssen, S. G. Scott, R. A. Bruce, N. King, N. Anderson та ін. Серед вітчизняних вчених слід зазначити таких, як: Е. В. Галажинський, В. Е. Клочко, О. М. Краснорядцева, А. В. Антонова, А. А. Гарипова, Г. П. Максимова, Н. Ю. Молостова, Т. А. Вауліна, І. О. Логінова, О. В. Шелехова, Т. С. Борисова, С. Б. Куликов.

Інноваційна поведінка дуже складний багатоаспектний феномен, на який впливають безліч факторів. В. Вест і Дж. Фарр, як приклад інноваційної поведінки розглядають пошук нових технологій, розробку та представлення нових шляхів досягнення цілей, застосування нових методів у професійній діяльності, вивчення нових ресурсів для застосування нових ідей [Ошибка! Источник ссылки не найден.]. 3 точки зору системної антропологічної психології інноваційну поведінку такі вчені, як В. Е. Клочко та Е. В. Галажинський розглядають, як таку, що здійснюється шляхом виходу за межі сформованих установок і поведінкових стереотипів і виникає тоді, коли сходяться такі фактори, як: можливості людини, представлені іiі потенціалом; середовище, що відповідає цим можливостям, в якому можлива самореалізація; готовність людини реалізувати свої можливості «тут і тепер» [0]. Т. А. Вауліна визначає інноваційну поведінку як комплексний феномен, який базується, як на здатності і готовності людини до генерування і втілення нових ідей, так і на здатності розкривати та реалізовувати свій творчий потенціал [0].

А от поняття інноваційної поведінки саме студентів ВНЗ було розкрито лише О.В. Шелеховою. За ii визначенням інноваційна поведінка - це ініціативний тип поведінки особистості, що включає здатність сприймати, створювати, реалізовувати нововведення, своєчасно позбавлятися від застарілого, недоцільного досвіду, а також творчі прагнення особистості з перетворення існуючої реальності [0].

Беручи до уваги дані визначення слід сказати, що більшість вчених дотримуються позицій детермінізму, тобто визначають інноваційну поведінку 3 точки зору взаємозумовленості явищ $\mathrm{i}$ процесів, націлюючи дослідження на виявлення причин i закономірностей виникнення інноваційної поведінки. 3 точки зору системної методології дане поняття розглядають рідше. Крім того дослідженню інноваційної поведінки саме студентів у вищих навчальних закладах приділяється мало уваги.

Тому метою даної статті є розгляд інноваційної поведінки, як системи, визначення поняття інноваційної поведінки студентів та опис iii основних компонентів, формування яких дозволить виховати 
інноваційну особистість, здатну проявляти інноваційну поведінку, як у процесі навчання, так і в професійній діяльності.

Інноваційна поведінка студентів має свої особливості:

- вона повинна бути орієнтована на створення інновацій не лише у процесі навчання, а й в подальшій професійній діяльності;

- формування інноваційної поведінки студентів повинно здійснюватись 3 врахуванням особливостей спеціальності, яку опановують студенти та особливостей навчального плану;

- повинна бути побудована на сформованих викладачами у процесі навчання цінностях та потребах інноваційної особистості студента;

- повинна включати знання, вміння та навички створення інновацій у професійній діяльності;

- повинна мати свій основний патерн (шаблон) поведінки, який буде алгоритмом дій у ситуаціях, що потребують такої поведінки.

Таким чином, інноваційну поведінку студента можна визначити, як систему дій та вчинків студента, направлену на розробку та впровадження інновацій під час навчання та орієнтовану на подальшу професійну діяльність, яка включає: систему потреб та цінностей студента, його інноваційну компетентність, інноваційні особистісні якості та закріплений у свідомості патерн поведінки.

Розглянемо більш детально визначені складові інноваційної поведінки студентів на прикладі спеціальності «Технології електронних мультимедійних видань». Система потреб та цінностей це складова інноваційної особистості студента, яка $є$ основою його інноваційної культури та без якої не можлива ініціація інноваційної поведінки. Будь-який вчинок людини завжди ініціюється певною потребою. Це може бути потреба у визнанні, або потреба в самостійності та незалежності. Кожна людина має майже однакові фізіологічні потреби, але дуже різні соціальні потреби. Виходячи 3 особливостей інноваційної особистості можна виділити ті потреби, які найчастіше виникають у особистостей, що проявляють інноваційну поведінку. За Г. Мюрреєм автором виділені основні потреби інноваційної особистості студента, серед них:

- потреба досягнення - бажання подолати, побороти, випередити інших; зробити щось швидко і добре, досягти висот в якійнебудь справі, бути послідовним, цілеспрямованим;

- потреба незалежності - втеча від будь-якого обмеження, бажання звільнитися від опіки, режиму, порядку, регламентації важкої роботи;

- потреба протидії - відрізняється від потреби досягнення акцентом на самостійність у діях; 


\section{Збірник наукових статей}

- потреба в розкритті - бажання “завоювати” інших, привертати увагу до себе, дивувати своїми досягненнями і якостями особистості; - потреба в чуттєвих враженнях - шукати чуттєві враження і радіти їм.

Спеціальність «Технології електронних мультимедійних видань» $\epsilon$ багатовекторною, саме тому на перший план виходять потреби досягнення та потреби в розкритті у різних напрямках даної спеціальності. Навчаючись на даній спеціальності студент повинен знаходити себе у різних видах діяльності - в дизайні, чи програмуванні, в технологіях та в економіці, а це набагато складніше ніж розвиток в одному напрямку.

Будь-яка поведінка ініціюється не лише накопиченим досвідом та потребами, але й тими цінностями, які притаманні певній культурі, певному суспільству та конкретній людині зокрема та, які заставляють людину діяти певним чином. Інноваційна особистість - це особистість для якої найбільш важливими цінностями $є$ свобода, задоволення (насолода від життя), духовний розвиток, прагнення до новизни, самоповага, творчий пошук, самодисципліна, самостійність, визнання, авторитетність, цілеспрямованість, толерантність до невизначеності та інші цінності, що спонукають до прояву інноваційності. Студенти, що вивчають мультимедійні технології повинні вбачати основною цінністю творчий пошук та прагнення до новизни, адже технології розвиваються дуже стрімко i потрібно бути завжди готовим до опанування нових технологій та їх самостійної розробки.

Наступний компонент інноваційної поведінки - інноваційна компетентність студента - це його знання, вміння, комунікативні навички та особистісні якості, які він готовий використовувати для створення та реалізації інновацій в процесі навчання та в подальшій професійній діяльності. У таблиці 1 представлено основні компоненти інноваційної компетентності студентів спеціальності «Технології електронних мультимедійних видань».

Таблиияя 1

Компоненти інноваційної компетентності студентів спеціальності «Технології електронних мультимедійних видань»

\begin{tabular}{|l|l|}
\hline Компетентність & інноваційна компетентність. \\
\hline Знання & $\begin{array}{l}\text { знання, набуті у процесі навчання на рівні новітніх досягнень мульти- } \\
\text { медійних технологій, які є основою для оригінального мислення та } \\
\text { інноваційної діяльності, знання про існуючі інновації в сфері } \\
\text { мультимедійних технологій, знання про способи генерації нових ідей. }\end{array}$ \\
\hline Уміння & $\begin{array}{l}\text { уміння розв'язувати складні задачі, що потребують інтеграції знань, } \\
\text { часто в умовах неповної або недостатньої інформації, уміння } \\
\text { використовувати методики творчості, уміння генерувати нові ідеї. }\end{array}$ \\
\hline Комунікація & $\begin{array}{l}\text { здатність доносити власні ідеї до колективу та керівництва, } \\
\text { здатність генерувати ідеї в процесі спілкування в колективі. }\end{array}$ \\
\hline $\begin{array}{l}\text { Автономність і } \\
\text { відповідальність }\end{array}$ & $\begin{array}{l}\text { здатність приймати рішення в умовах неповної або недостатньої } \\
\text { інформації. }\end{array}$ \\
\hline
\end{tabular}


Серед основних якостей інноваційної особистості студента можна виділити такі, як: креативність, оригінальність, лідерські якості, відкритість новому, гнучкість, ініціативність, емоційна стабільність, стресостійкість. Саме ці якості дозволять студентам йти в ногу з часом та добиватись успіхів в своїй професійній діяльності.

Наступний компонент інноваційної поведінки: закріплений у свідомості патерн поведінки. Даний патерн інноваційної поведінки визначає систему дій, які виконує студент в процесі реалізації інноваційної поведінки, він складається з таких етапів:

1. Визначення необхідності реалізації інноваційної поведінки, згідно з отриманим навчальним (професійним) завданням.

2. Формування задуму і мотивів необхідних інновацій.

3. Проектування системи дій та вчинків.

4. Процес реалізації нововведень (створення або застосування, нових або вдосконалених продуктів, процесів або підходів у професійній діяльності).

5. Оцінка результатів впровадження інновацій.

Процес реалізації нововведень в мультимедійній галузі - це не лише розробка нових мультимедійних продуктів, але й вдосконалення існуючих технологій та способів їх розробки, а також пошук нових дизайнерських рішень в оформленні мультимедійних продуктів.

Таким чином, в даній статті були визначені основні компоненти інноваційної поведінки студентів та описано їх специфіку для спеціальності «Технології електронних мультимедійних видань». Знання про основні компоненти дасть можливість створити модель формування інноваційної поведінки студентів спеціальності «Технології електронних мультимедійних видань» та обрати необхідні засоби, форми, технології та методи навчання та виховання інноваційних студентів, які проявляють інноваційну поведінку у процесі навчання та в професійній діяльності, врахувавши особливості та специфіку даної спеціальності.

\section{Література}

1. Ваулина Т. А. Современные подходы к определению понятия «инновационное поведение» / Т. А. Ваулина // вестн. Том. Гос. Ун-та. 2010. - № 340. - С. 168-171.

2. Клочко В.Е. Психология инновационного поведения / В.Е. Клочко Э.В. Галажинский. - Томск : Томский государственный университет, 2009. - 240 с.

3. Шелехова О. В. К проблеме сущности понятия «инновационное поведение» студентов вуза / О.В.Шелехова, Е. Н. Коньшина // Вестник науки ТГУ. - 2011. - № 4 (7). - С. 312-315. 
Збірник наукових статей

4. West V. A., Farr J. L. Innovation and creativity at work: Psychological and organizational strategies / West, Michael; Farr, James L . Chichester : John Wiley \& Sons, 1991. - 364 p.

Ольга Сергиенко. Основные компоненты инновационного поведения студентов специальности "Технологии электронных мультимедийных изданий".

$B$ статье проанализировано понятие инновационного поведения студентов, описаны основные компоненты инновационного поведения студентов на примере специальности "Технологии электронных мультимедийных изданий". Также в статье приведено авторское определение понятия инновационное поведение студентов, инновационная компетентность студентов, определен паттерн инновационного поведения.

Ключевые слова: инновационное поведение студентов, инновационная компетентность студентов, качества инновационной личности студента, паттерн инновационного поведения.

Olga Sergiienko. The main components of innovative behavior of students of specialty "Technologies of electronic multimedia publications".

The paper explores the concept of innovative behavior of students, describes the main components of the innovative behavior of students on example of specialty "Technologies of electronic multimedia publications". The article provided the author's definition of innovative behavior of students, innovative competence of students, defined pattern of innovative behavior.

Key words: innovative behavior of students, innovative competence of students, qualities of innovative student, student's pattern of innovation behavior.

Стаття надійшла до редакційної колегії 08.05.2014

УДК 378.147-043.83-027.561-047.22:116-057.86

() Скринник I. O., 2014.

Скринник Ірина Олександрівна

Харківський кооперативний торгово-економічний коледж

ДОСВІД ВИКОРИСТАННЯ МЕТОДУ ПРОЕКТІВ У ФОРМУВАННІ ПРОФЕСІЙНОЇ ТА КЛЮЧОВИХ ОСВІТНІХ КОМПЕТЕНТНОСТЕЙ МАЙБУТНІХ ФАХІВЦІВ (НА ПРИКЛАДІ ХАРКІВСЬКОГО КООПЕРАТИВНОГО ТОРГОВО-ЕКОНОМІЧНОГО КОЛЕДЖУ)

Проаналізовано досвід використання методу проектів у Харківському кооперативному торгово-економічному коледжі, доведено його 
ефективність як дидактичного та виховного засобу для активізації навчально-пізнавальної діяльності та утвердження гуманістичних цінностей у світогляді студентства. Розкрито роль методу проектів як інтегруючого фактора у прочесі формування професійної та ключових освітніх компетентностей майбутніх фахівців.

Ключові слова: метод проектів, навчальний проект, професійна компетентність, ключові освітні компетентності..

У “Національній стратегії розвитку освіти в Україні на 20122021 роки” зазначено, що “сучасний ринок праці вимагає від випускника не лише глибоких теоретичних знань, а здатності самостійно їх застосовувати в нестандартних, постійно змінюваних життєвих ситуаціях, переходу від суспільства знань до суспільства життєво компетентних громадян"[1]. Саме компетентісний підхід здатен подолати одну 3 головних проблем сучасної української системи освіти - відірваність системи освіти від потреб життя, що постійно змінюється, - i досягнути розумного балансу між академічними знаннями і прагматичними вміннями студентства.

Під компетентністю розуміють інтегральну якість особистості, яка виявляється у здатності до самостійної та успішної діяльності, що спирається на знання та досвід, отримані у процесі навчання та соціалізації. Головною у підготовці фахівця зазвичай виступає його професійна компетентність як показник готовності випускника до виконання професійної діяльності на якісному рівні [3, с. 5]. Але національна освітня доктрина України також наголошує на необхідності розвитку гармонійно розвинутої особистості, здатної до продуктивної соціальної взаємодії та самовдосконалення, i, отже, висуває вимоги щодо формування ключових (універсальних) освітніх компетентностей: ціннісно-смислової, загальнокультурної, навчальнопізнавальної, інформаційної, комунікативної, соціально-трудової, особистісного вдосконалення тощо [2].

Одним 3 ефективних засобів навчання, який відповідає сучасним вимогам модернізації української системи освіти, і органічно вписується у парадигму компетентісного підходу, є метод проектів. Його сутність полягає у самостійному пошуку студентами шляхів розв'язання досить складної проблеми, що вимагає від них творчої дослідницької активності та інтегрованих знань для досягнення корисного практичного чи теоретичного результату.

Питаннями впровадження проектів у навчальний процес займаються такі педагоги як Н. Альохіна, В. Докучаєва, І. Срмакова, Л. Сохань; аналіз деяких аспектів підготовки студентів вищих навчальних закладів через проектну діяльність $є$ у працях К. Баханова, В. Веселової, М. Елькіна, О. Ільяшевої, Ю. Кірімової, Т. Рєзник. Проте питання щодо використання методу проектів 3 метою формування 
професійної та ключових освітніх компетентностей потребує подальшого вивчення.

Метою дослідження є аналіз ефективності практичної реалізації методу навчальних проектів у формуванні професійної та ключових освітніх компетентностей майбутніх фахівців. Аналіз спирається на матеріали студентських проектів, проведених за останні три навчальних роки цикловою комісією гуманітарної та соціальноекономічної підготовки Харківського кооперативного торговоекономічного коледжу. До уваги взято також результати анкетування студентства на тему: “Що Ви знаєте про навчальні проекти, які проводяться у нашому коледжі?”.

Три роки тому у коледжі стартував мега-проект "Ми українці”, в рамках якого були визначені основні напрями майбутніх навчальних проектів. За результатами анкетування "Бути українцями це...” студенти відповіли, що українці мають: досконало володіти українською мовою, знати історію України, прагнути духовної та інтелектуальної досконалості, бути корисними для народу України, дотримуватися здорового способу життя, бути європейцями, цікавитися культурною спадщиною України. Кожний з цих напрямів мав визначити вектори цікавих для студентства тем. Отже, тематичний напрям - один з головних критеріїв класифікації наших проектів.

Іншим вагомим критерієм класифікації реалізованих нашими студентами проектів може слугувати домінуюча у проекті навчальна дисципліна, хоча всі проекти $є$ міждисциплінарними. Першу групу складають проекти, в яких левову частку займають соціологічні мікродослідження. В усіх цих проектах велику роль відіграло вивчення точок зору студентства щодо актуальних для них проблем та аналіз шляхів їх розв'язання. Для цього були застосовані методи мозкового штурму, дискусій, анкетування, інтерв'ювання. Представлення результаттів проектів також було досить широким: доповіді на конференціях та семінарах, дискусії з елементами міні-лекції на виховних годинах, колоквіуми, флешмоби, мультимедійні презентації і стіннівки.

Одним 3 найбільш цікавих видався проект "Гендерні стереотипи у студентському середовищі: шляхи подолання”, що реалізовував тематичний напрям “...бути європейцями”. Робота над проектом тривала більше року і була різноплановою: соціологічне опитування серед студентства, викладачів та батьків; створення інформаційного блоку "Народна мудрість/дурість про жінку”; проведення серії флешмобів 3 антисексистської тематики. Результати були представлені на Науково-практичній конференції “Европейські та традиційні цінності очима сучасної української молоді” у Харківському національному університеті будівництва та архітектури (2012р.). 
Другу групу навчальних проектів становлять історикокультурологічні проекти, які представляють напрями “...3нати історію України” та “...цікавитися культурною спадщиною України”. Багато 3 них спрямовано переважно на встановлення, опис та аналіз біографічних даних людей, чиє життя було пов'язано 3 війною. Виховний вплив таких досліджень важко переоцінити, бо у студентів, що беруть участь у таких проектах, виникає відчуття причетності до тих далеких від нас трагічних часів, великої шани до людей, на долю яких випали тяжкі випробування. Серед навчальних вмінь: робота 3 першоджерелами - документами, фотоматеріалами, мемуарами; формування комунікативних навичок - інтерв'ювання, співпраця 3 іншими учасниками проекту; аналіз інформації; ораторська та акторська майстерність під час представлення результатів проектів; оформлювальна майстерність - створювання мультимедійних презентацій, фотовиставок, альбомів тощо.

Найбільш успішним серед історико-культурологічних творчих проектів стала робота “Пам'ять серця, чуєш, не згасай: спогади моїх близьких". Вона посіла II місце на XIV Молодіжній історикокраєзнавчій конференції "Воєнне минуле рідного краю”, що проводилася у 2012 році у Харківському національному університеті ім. В. Н. Каразіна. За матеріалами цієї роботи, яка містила не тільки історично-біографічні факти, але й літературно-поетичний блок, була створена театралізована музична постановка.

Серед історико-культурологічних проектів є також присвячені вивченню i популяризації визначних пам'яток України. Таким дослідженням передували тематичні екскурсії, на яких ставилися проблемні питання, розв'язання яких потребувало дослідницької роботи, а презентація результатів - творчої фантазії. Деякі з таких проектів були тісно пов'язані з майбутньою професією студентів. Так, після подорожі до м. Львів, студенти спеціальності "Ресторанне обслуговування" представили свій творчий проект “Львів для гурманів”, який у гумористичній формі оповідав про незвичайні ресторації міста i включав міні-лекцію 3 демонстрацією мультимедійної презентації та фотовиставку. Такий проект може бути віднесений також і до наступної групи проектів, основною ознакою яких $є$ професійне спрямування проектної діяльності студентства.

Такі проекти представляють напрям “...бути корисними народу України”. Зокрема, це проект “Роль суспільно-гуманітарних дисциплін у формуванні професійної компетентності молодшого спеціаліста”, який проходив у вигляді конкурсу на кращу творчу роботу (есе, плакат, мультимедійна презентація, вірш тощо). Найкращою була визнана робота: "Роль навчальної дисципліни "Правознавство" у формуванні професійної компетентності майбутнього бухгалтера”, яка 


\section{Збірник наукових статей}

була презентована на Обласній студентській науково-практичній конференції, присвяченій 80-річчю коледжу переробної та харчової промисловості "Професіоналізм молодих: від теорії до практики" (2011 р.). Корисний ефект такого роду проектів $є$ очевидним: студенти починають більш відповідально ставитися до вивчення як фахових, так i суспільно-гуманітарних дисциплін, які допомагають сформувати майбутнього спеціаліста.

Отже, використання методу проектів $\epsilon$ ефективним для розв'язання багатьох дидактичних та виховних завдань. Але чи $є$ проектна діяльність цікавою і корисною з точки зору студентства? 3 цією метою нами було проведене анкетування "Що Ви знаєте про навчальні проекти, які проводяться у нашому коледжі?” В анкетуванні взяли участь студенти всіх спеціальностей - загальною кількістю 510 осіб, а також 84 випускники. Результати проведених досліджень дали змогу зробити висновки:

1. Студенти, що взяли участь у навчальному проекті, демонструють високий рівень зацікавленості, мають бажання брати участь в них і у подальшому. Вони впевнені, що завдяки участі у проекті отримали багато корисних вмінь та навичок, а це призвело до підвищення успішності у навчанні. Охоплені анкетуванням випускники зазначили, що здобутий ними у проектній діяльності досвід допомагає їм як у професійній, так і у громадській діяльності.

2. Студенти, що не мали нагоди взяти участь у проектній діяльності, виявили зацікавленість у цьому, спілкуючись з учасниками проектів. Вони демонструють прагнення, перш за все, до отримання комунікативних навичок: спілкування 3 однолітками і цікавими людьми, вміння висловлювати власні думки, аргументовано відстоювати свої переконання.

3. Учасники дослідження запропонували широке коло актуальних для студентства тем (щодо майбутнього працевлаштування, молодіжних рухів, перспектив використання соціальних мереж для професійної діяльності тощо) і виявили бажання до співпраці зі студентами з інших навчальних закладів.

Враховуючи результати теоретичного та практичного сегментів дослідження треба сказати, що навчальний проект $€$ ефективним дидактичним та виховним засобом для активізації навчальнопізнавальної діяльності та утвердження гуманістичних цінностей у світогляді студентства. Можна також стверджувати, що проектна діяльність виступає інтегруючим фактором у процесі формування професійної та ключових освітніх компетентностей майбутніх фахівців. Отже, навчальний проект потребує подальшої популяризації, щоб якомога більше студентів мали можливість спробувати власні сили у навчально-дослідницькій діяльності. Також проектна діяльність 
Психолого-педагогічні проблеми становлення сучасного фахівця

Випуск 2014 потребує тематичного урізноманітнення i виходу на міжвузівський рівень. Так, наступного навчального року у нашому коледжі розпочнеться навчальний проект: “Критерії професіоналізму”, який має охопити студентів декількох ВН3 I-II рівнів акредитації України економічної спеціалізації.

\section{Література}

1. Національна стратегія розвитку освіти в Україні на 2012 2021 роки [Електронний ресурс] / Режим доступу : http://www.mon. gov.ua/images/files/ news/12/05/4455.pdf. - Назва с титул. екрану.

2. Новые педагогические и информационные технологии в системе образования. Учеб. пособие для студ. пед. вузов и системы повыш. квалиф. пед. кадров / Е. С. Полат, М. Ю. Бухаркина, М. В. Моисеева, А. Е. Петров. Под ред. Е. С. Полат. - М. : Издательский центр «Академия», - 2012. - 272 с.

3. Царькова Е. А. Компетентность в контексте модернизации профессионального образования / Е. А. Царькова // Профессиональное образование. 2004. - № 6. - С. 5-6.

Ирина Скрынник. Опыт применения метода проектов в формировании профессиональной и ключевых образовательных компетентностей будущих специалистов (на примере Харковского кооперативного торгово-экономического колледжа).

Проанализирован опьт применения метода проектов в Харьковском кооперативном торгово-экономическом колледже, доказана его эффективность как дидактического и воспитательного средства для активизачии учебно-познавательной деятельности и утверждения гуманистических ценностей в мировоззрении студенчества. Раскрыта роль метода в прочессе формирования профессиональной и ключевых образовательных компетентностей будущих специалистов.

Ключевые слова: метод проектов, учебный проект, профессиональная компетентность, ключевые образовательные компетентности.

Iryna Skrynnyk. Experience of using the method projects in the formation of professional competence and basic education of future specialists (by Kharkov cooperative trade and economic college).

Analyzed the experience of using the method projects in Kharkov cooperative trade and economic college, proved its effectiveness as a didactic and educational tools for intensify learning and cognitive activity and approval of humanistic values in the worldview of students. Was revealed the role of project method in the formation of professional and basic educational competencies of future specialists.

Key words: method of projects, learning project, professional competence, basic educational competencies.

Стаття надійшла до редакційної колегії 07.05.2014 
(c) Станин Д. М., Ехалов В. В., Сединкин В. А., 2014.

\section{Станин Дмитрий Михайлович}

Государственное учреждение

«Днепропетровская медицинская академия МЗО Украины»

\section{Ехалов Василий Витальевич}

Государственное учреждение

«Днепропетровская медицинская академия МЗО Украины»

Сединкин Владислав Анатольевич

Государственное учреждение

«Днепропетровская медицинская академия МЗО Украины»

\section{ИСПОЛЬЗОВАНИЕ ЮМОРА \\ В ПРОЦЕССЕ ПОДГОТОВКИ СПЕЦИАЛИСТА-МЕДИКА}

В статье рассматривается идея использования юмора в процессе обучения. Подчеркивается значение психологических функций юмора в процессе подготовки интернов медииинского профиля.

Ключевые слова: последипломное образование, интерны, педагогика, методика обучения, юмор.

Одним из самых малоизученных вопросов в педагогике высшей школы является вопрос использования юмора в учебном процессе. Особенно это малоизученно в области подготовки специалистов медиков.

Целью работь является обоснование использования юмора в процессе обучения и его особенностей при подготовке молодых специалистов медицинского профиля.

Конечно, медицина - это та область знаний, где юмор мало ожидаем. Какой юмор может быть при обсуждении страданий, болезни, смерти. Тем не менее, во многих литературных источниках можно встретить, что в беседах с больными и родственниками (не говоря уже о беседах с коллегами) медики часто используют, пусть грубоватый, но юмор. По мнению известного анестезиолога А. П. Зильбера «смех, юмор, ирония, используемые умело и уместно, могут быть действенными лечебными средствами». Если удается пусть не рассмешить пациента, то хотя бы вызвать у него улыбку, шанс у такого пациента на выздоровление весьма высок.

И уж конечно, при подготовке молодого специалиста, который еще не обременен всеми знаниями опытного медика, исключить юмор просто нельзя.

«Оксфордский словарь английского языка» так определяет юмор: «Это такое качество действия, речи или литературного 
произведения, которое вызывает веселье; причуда, шутка, курьез, комизм, забава». Далее в словарной статье говорится, что юмор - это также «способность воспринимать смешное или забавное или выражать это в речи, а также в письменной или другой форме; шутливый образ или трактовка объекта» (Simpson \& Weiner, 1989). Из этих определений очевидно, что юмор - это широкое понятие, которое относится ко всем словам и действиям людей, воспринимающимся как забавные и обычно вызывающие смех у других, а также к психическим процессам, которые участвуют в генерации и восприятии такого забавного стимула, и к эмоциональной реакции, связанной с получением удовольствия от него.

Психологические функции юмора можно разделить на три категории:

1. Когнитивные и социальные выгоды положительной эмоции радости. влияния.

2. Использование юмора для социальной коммуникации и

3. Снятие напряжения и совладание с неприятностями.

При обучении студентов все три функции юмора крайне важны. Чаще всего во время преподавания используется функция социальной коммуникации и влияния. И вот здесь наиболее часто могут возникнуть ошибки. Согласно данным Д. Лонг и А. Грассера выделяют 11 категорий, которые различаются между целями или способами применения юмора. И наиболее часто в процессе обучения используются ирония, сарказм, преувеличение и преуменьшение. При этом далеко не во всех случаях использование элементов юмора адекватно. Как правило, преподаватель, для того чтобы привести группу студентов к порядку и показать, что он ведущий, использует сарказм или преувеличение ошибок, допущенных студентами. Конечно, некоторое время это работает, студент собирается, начинает усиленно работать. Однако при бесконечном использовании этих приемов вместо возможности продолжать плодотворно работать у студентов возникает чувство собственной неполноценности, теряется темп обучения, группа становится неуправляемой. Использование этих приемов постоянно категорически недопустимо, хотя многие преподаватели (особенно молодые) с целью самоутверждения очень широко используют эти приемы.

С нашей точки зрения использование этих элементов допустимо в момент первого контакта, когда группа присматривается к преподавателю, ищет его слабые стороны, чтобы в дальнейшем использовать это. Но в ходе обучения эта категория юмора для постоянного использования не годится. 


\section{Збірник наукових статей}

Для поддержания связи со студентами в принципе годны все формы юмора. Поддразнивание и самоирония могут прекрасно поддержать тесный контакт с группой, ирония позволит в мягкой необидной форме показать студенту, что он использовал неправильное направление решения клинической задачи.

C нашей точки зрения юмор может быть очень важным элементом в познавательном аспекте. Согласно Д. Риду, чтобы генерировать юмор, человек должен мысленно обработать информацию, поступающую из окружающей среды или из памяти, играя мыслями, словами или действуя творческим способом и таким образом производя остроумное высказывание или смешное невербальное действие, которое воспринимается другими как забавное. При восприятии юмора мы получаем информацию (то, что кто-то говорит или делает или, что мы читаем) через наши глаза и уши, понимаем смысл этой информации и оцениваем ее как несерьезную, игривую и юмористическую. И здесь большое значение имеют анекдоты и забавные случаи, которые происходили в практике любого клинициста. Рассказывая тот или иной случай из врачебной практики, придавая ему некоторую юмористическую окраску, преподаватель в шутливой форме предлагает слушателям решить возникающую клиническую ситуацию. Возникающая при этом форма игрового обучения не воспринимается студентами как тяжелая непреодолимая задача, а в игровой форме заставляет слушателей легко и быстро находить необходимое решение. Более того, возникающие в этот момент случаю использование иронии, сарказма преувеличения или преуменьшения не в такой агрессивной форме воспринимаются студентами.

Конечно, в этих случаях юмор должен быть заранее продуманным, все ситуации, которые приводятся как пример должны быть заранее продуманными. Юмористические ситуации также должны использоваться для снятия напряжении во время занятия. В этом случае следует помнить, что хотя элементы юмора годятся в любое время занятия, использование его для релаксации лучше всего после 20-30 минут напряженной работы, чтобы после этого была возможность продолжать работу в прежнем темпе.

Подводя итоги, следует сказать:

Предпочтение следует отдавать юмору с элементами доброжелательности.

При кажущейся спонтанности возникновения условий для юмора в процессе обучения, в действительности необходима тщательная подготовка условий, примеров юмористических рассказов, ситуаций и т.д. 


\section{Литература}

1. Мартин Р. Психология юмора / Р. Мартин, пер. с англ. под ред. Л. В. Куликова. - СПб. : Питер, 2009. - 480 с.

2. Рубинштейн С. Л. Основы общей психологии С. Л. Рубинштейн. - СПб. : Питер, 2002. - 720 с.

3. Long D. L., Graesser A. C. (1988). Wit and humor in discourse processing / D. L. Long, A. C. Graesser // Discourse Processes. - 1988. - V. 22 (1). - P. 35-60.

Дмитро Станін, Василь Єхалов, Владислав Седінкін. Використання гумору в процесі підготовки фахівця-медика.

У статті розглядається ідея використання гумору в процесі навчання. Підкреслюється значення психологічних функиій гумору в прочесі підготовки інтернів медичного профілю.

Ключові слова: післядипломна освіта, інтерни, педагогіка, методика навчання, гумор.

Dmitriy Stanin, Vasiliy Yekhalov, Vladislav Sedinkin. Using humor in the process of preparing medical specialist.

This article discusses the idea of using humor in the learning process. Emphasizes the importance of the psychological functions of humor in the process of preparing interns medical profile.

Key words: postgraduate education, interns, pedagogy, methods of teaching, humor.

Статья поступила в редакционную коллегию 12.05.2014

УДК 61:378.147

(C) Стоєва Т. В., Кравченко Л. Г., Кривда Г. Ф., 2014. (C) Лотиш Н. Г., Папінко Р. М., 2014.

Стоєва Тетяна Вікторівна

Одеський національний медичний університет

Кравченко Лілія Григорівна

Одеський національний медичний університет

Кривда Григорій Федорович

Одеський національний медичний університет

Лотиш Надія Григорівна

Одеський національний медичний університет

Папінко Роман Мар'янович

Одеський національний медичний університет

ІНТЕРАКТИВНІ МЕТОДИ

У ПРОФЕСІЙНІЙ ПІДГОТОВЦІ ЛІКАРІВ-ІНТЕРНІВ

У роботі обговорюються інтерактивні інновачійні методи навчання („Телеконференція”, „Тематична презентачія” та ін.), котрі впроваджуються у прочес професійної підготовки лікарів-інтернів. 


\section{Збірник наукових статей}

Звертається увага на правові аспекти медичної сфери. Методи сприяють посиленню практичної спрямованості навчального процесу, активують самопідготовку, креативний потенціал лікарів-інтернів.

Ключові слова: лікарі-інтерни, інтерактивні технології, післядипломна освіта.

Сучасна фаза розвитку вищої медичної освіти пов'язана 3 актуалізацією проблеми підготовки лікарів первинної ланки надання медичної допомоги, а саме лікарів-педіатрів, сімейних лікарів, що обумовлено завданнями реформування практичної медицини [3]. На сьогодні існує освітньо-кваліфікаційна характеристика як стандарт підготовки лікаря, спрямована вирішувати завдання формування професійної компетентності, клінічного мислення, втім вона не включає інноваційні навчальні технології [4]. Успішне вирішення завдання підготовки висококваліфікованих фахівців значною мірою залежить від якості викладання і вимагає нових форм раціональної організації навчального процесу. Інтерактивне навчання передбачає багатосторонню комунікацію, високу зовнішню та внутрішню мотивацію, баланс між традиційними та інноваційними методами навчання [1-3].

У зв'язку з цим на кафедри педіатрії № 2 поставлена мета удосконалення практичної спрямованості педагогічного процесу та самопідготовки інтернів шляхом впровадження інтерактивних інноваційних методів навчання.

Для досягнення мети на кафедрі проводяться наступні інтерактивні інноваційні форми навчання:

- метод „Мозковий штурм” дозволяє використовувати знання, вміння та навички інтернів щодо діагностики та невідкладної допомоги при загрозливих станах у дітей, тренує вміння швидко приймати рішення;

- метод „Телеконференція” - користується особливою популярністю, дозволяє заслуховувати та бачити виступи ведучих фахівців сучасної медицини, виходити за межі свого ВУЗу, своєї країни, вести відеоінтерактивний діалог;

- однією 3 активних форм навчання лікарів-інтернів $\epsilon$ „Ділова гра”, яка проходить у формі „Сюжетно-рольовоі” або у формі „Консиліум”. Метод формує комунікативні навички, здатність вести дискусію, аргументовано відстоювати свою позицію, дотримуючись при цьому лікарської етики та деонтології, підвищує професійну компетентність;

- метод „Тематична презентація” дозволяє підвищити активність інтернів та наочність під час семінарських занять, сприяє розкриттю 
особистісних характеристик інтернів, стимулює вміння виступати перед аудиторією;

- метод «Проектів» надає можливість самостійного отримання знань 3 науково-дослідної роботи інтернів, поглиблювати розділи щодо орфанної патології, дозволяє збільшити їх зацікавленість до дослідницької діяльності;

- метод „Проблемного навчання” пропонує рішення конкретної ситуації, яка може зустрітися в практичній роботі лікаря-педіатра, сприяє розвитку клінічного мислення лікаря.

Враховуючи те, що лікарі-інтерни (педіатри, сімейні лікарі) більш наближені до реалій медичної діяльності, у процесі очного та заочного навчання стикаються 3 проблемами взаємовідносин лікаря і пацієнта, лікаря і батьків пацієнта, інтерни повинні вміти надавати правову оцінку в певних ситуаціях та самостійно приймати правомірні рішення, працювати 3 нормативно-методичною літературою, належним чином оформляти офіційні медичні документи та ін.

Чітке уявлення про правове регулювання медичної діяльності та відповідальності за порушення законодавства - необхідна складова робота кожного лікаря. Основні поняття з цих питань закладаються ще студентам 4 курсу медичного факультету при вивченні дисципліни „Медичне правознавство”. Тематика включає три змістові модулі: медичне правознавство в системі вищої медичної освіти; правові основи організації охорони здоров'я; визначення несприятливих наслідків у медичній практиці, правопорушення та юридична відповідальність у галузі охорони здоров’я.

Анкетування інтернів показало недостатньо високий рівень збереження знань щодо деяких питань з основних правових аспектів медичної сфери. У зв'язку 3 цим на семінарських заняттях ми включаємо додаткові юридичні розділи, прив`язані до тем, що розглядаються. Наприклад, тему „Раціональна антибіотикотерапія” супроводжуємо питаннями ятрогенної патології, тему „Вірус імунодефіциту людини (ВІЛ)” - юридичними аспектами профілактики та лікування ВІЛ/СНІДУ. На практичні заняття виносимо конкретні ситуаційні завдання з акцентом на визначення правопорушень в сфері охорони здоров'я дітей та юридичної відповідальності.

Таким чином впровадження різноманітних інтерактивних інноваційних методів в процес навчання лікарів-інтернів оптимізує педагогічний процес, підвищує професійну компетентність, сприяє активації самостійності, відповідальності, творчого підходу до роботи, вмінню приймати правильне рішення в складних професійних ситуаціях, а також комунікативності.

Інтерактивне навчання наближує вирішування головного завдання університетської освіти - формування гармонійно 
Збірник наукових статей

розвиненої, професійно підготованої та науково орієнтованої особистості.

\section{Література}

1. Агейко О. В. Инновационная игра как ведущий активный метод обучения слушателей / О. В. Агейко // Управление в социальных и экономических системах: материалы международной научнопрактической конференции, г. Минск, 20.05.2011 г. - Минск : Изд-во МИУ, 2011. - С. 185-186.

2. Терентьєва Н. О. Основні тенденції розвитку сучасної університетської освіти: європейський вимір / Н. О. Терентьєва // Педагогіка і психологія, 2012. - № 3 (76). - С. 22-27.

3. Удосконалення засвоєння практичних навичок $\mathrm{i}$ методик студентами та лікарями-інтернами - важлива складова кадрової перебудови первинної ланки медичної допомоги населенню України / О. П. Волосовець, Ю. П. П'ятницький, І. С. Вітенко та ін. // Медична освіта, 2012. - № 3. - С. 5-6.

4. Типовий навчальний план та програма спеціалізації (інтернатури) випускників вищих медичних закладів освіти III-IV рівнів акредитації зі спеціальності „Педіатрія”. - К., 2006.

Татьяна Стоева, Лилия Кравченко, Григорий Кривда, Надежда Лотыш, Роман Папинко. Интерактивные методы в профессиональной подготовке врачей-интернов.

В работе обговариваются интерактивные инновационные методы обучения („Телеконференция”, „Тематическая презентация” и др.), которые внедряются в прочесс профессиональной подготовки врачейинтернов. Обращается внимание на правовые аспекты медицинской сферы. Методы способствуют усилению практической направленности учебного процесса, активизируют самоподготовку, креативный потенцииал врачей-интернов.

Ключевые слова: врачи-интерны, интерактивные технологии, последипломное образование.

Stoieva T. V., Kravchenko L. G., Kryvda G. F., Lotysh N. G., Papinko R. M. Interactive methods in professional training of medical interns.

The interactive innovative methods of training ( $T V$-conference, thematic presentation and other), which are implemented in process of professional training of interns-pediatricians are discussed in this research. Considerable attention is given to the legal aspects of medical scope. These methods improve practical orientation of educational process, activate selftraining and creativity of medical interns.

Key words: medical interns, interactive technologies, postgraduate courses. Стаття надійшла до редакційної колегії 14.05.2014 


\section{Тесля Роман Віталійович}

(C) Тесля Р. В., 2014.

Черкаський національний університет імені Богдана Хмельницького

\section{ВИЩА ОСВІТА ФРАНЦІЇ В АСПЕКТІ ОСВІТИ ДОРОСЛИХ}

У статті проаналізовано рівневу структуру вищої освіти Франизї та діяльність французької освітньої структури для дорослих ГРЕТА. Узагальнено досвід діяльності ГРЕТА в галузі змісту навчання 3 метою обгрунтувати педагогічні можливості використання ідей зарубіжного досвіду у вітчизняній сучасній системі освіти дорослих.

Ключові слова: освіта дорослих, вищза освіта Франиї, неперервна освіта, освітня програма ГРЕТА, зміст навчання.

Нині людство усвідомлює, що шкільної i навіть університетської освіти недостатньо для розв'язання нових проблем, скажімо, таких, як стрімкий демографічний процес, виснаженість ресурсів, соціальні і національні конфлікти, екологічна криза, ядерна небезпека тощо. Пріоритетним завданням освіти дорослих $\epsilon$ забезпечення людини комплексом знань і вмінь, необхідних для іiі активного повноцінного життя.

Історіографія наукових досліджень свідчить, що впродовж останнього десятиріччя зарубіжними та українськими науковцями активно здійснювалися педагогічні дослідження проблем безперервної освіти та освіти дорослих (Н. Бірюкова, С. Вершловський, О. Владиславлєв, Б. Вульфсон, О. Даринський, Т. Десятов, О. Джуринський, І. Зязюн, Д. Кідд, М. Коуді, В. Кремень, П. Ленгранд, 3. Малькова, Н. Мукан, Н. Ничкало, О. Новиков, В. Онушкін, Н. Рухадзе, Г. Селман, С. Сисоєва, Л. Сігаєва, Е. Фор та інші). Однак у пропонованому аспекті поставлена проблема не розглядалася.

Mema cmammi полягає в розкритті та аналізі системи вищої освіти Франції у системі неперервної освіти загалом та освіти дорослих зокрема.

Завданнями статmі є наголосити на тому, що вища освіта, особливістю якої $є$ відносно самостійний вибір освітніх цілей та засобів їхнього досягнення, передбачає гуманістичний тип стосунків учасників освітнього процесу, саморозвиток тих, хто навчається; $€$ шляхом і засобом творчого зростання особистості, конструктивного подолання ситуацій соціальної та професійно-життєвої кризи.

Вища освіта є вагомою складовою освіти дорослих у Франції. Найбільш суттєвих змін вища освіта зазнала після подій студентської революції у травні 1968 р. Міністром освіти Едгаром Фором було 


\section{Збірник наукових статей}

запропоновано проект реформи вищої освіти, що отримав назву «Закон про орієнтацію вищої освіти», а 12 листопада 1968 р. затверджено урядом. Новий закон зберіг традиційну форму вступу в університет, тобто без іспитів при наявності диплома бакалавра. Структурні зміни полягали у зникненні факультетів. Створювались нові плюридисциплінарні університети, які отримали цифрові найменування. Так, у 1971 р. п’ять факультетів Сорбонни були перетворені на 13 університетів.

Відповідно до закону, університети отримали деяку адміністративно-фінансову і навчальну самостійність. Структурна ж перебудова не змінила нічого у формі навчання. Як і до реформи, процес навчання ділиться на три цикли. Перший цикл триває два роки (УНО філологічних і гуманітарних, природничих, юридичних i економічних наук) і дає студенту базову загальноосвітню підготовку 3 присудженням Диплома про загальну університетську освіту (DEUG Diplome d'etudes universitaires generales) із вказівкою відповідної галузі знань. Двохрічна підготовка в університетських технологічних інститутах, що стосується першого циклу, базується на вивченні спеціальних дисциплін із врученням диплома про університетську технологічну освіту (DUT - Diplome universitaire de technologie).

Другий цикл дає більш глибокі знання. Студенти УНО природничих, гуманітарних і філологічних наук після першого року навчання за умови успішного складання іспитів отримують диплом ліценціата, а після другого року і відповідних іспитів - диплом метріз, який дає право на участь у конкурсі на звання викладача середньої школи. В УНО юридичних та економічних наук диплом ліценціата видається після двох років навчання на другому циклі. Тривалість другого циклу УНО медичних і фармакологічних наук різна, але не більше чотирьох років.

Третій цикл відповідає поглибленій спеціалізації з елементами наукових досліджень в УНО філологічних, природничих, юридичних та економічних наук. Після першого року вручається диплом про поглиблену освіту (DEA - Diplome d'etudes approfondies), а після другого - доктора третього циклу. В УНО медичних i фармакологічних наук у цьому циклі повністю завершується професійна підготовка спеціалістів з отриманням державного диплома доктора медицини чи фармакології. Така традиційна організація навчального процесу у французьких університетах нині замінюється новою моделлю освітніх циклів, яка відповідає вимогам Болонського процесу та відображена в реформі LMD (Licence-Master-Doktorat). Модель LMD (ліценціат-магістратура-докторантура) включає три освітні цикли, які, відповідно до Болонської декларації, складають загальноєвропейський стандарт вищої освіти, 3 тією різницею, що 
перший ступінь має назву не бакалаврат, а ліценціат. Ліценціат розрахований на три роки навчання, магістратура - на два роки, докторантура - на три роки навчання.

У 1984 р. був прийнятий новий закон про вищу освіту (так званий закон Саварі), який $\epsilon$ нині діючим. Цей закон надав максимальну адміністративну, фінансову, педагогічну та наукову автономію університетам. Він визначив провідні функції університетів: освіта, науково-технічні дослідження, поширення культури та результатів досліджень серед громадськості, міжнародна співпраця, визнання персональних досягнень дослідників.

У Франції не існує університетської освіти окремо для дорослих. Проте відповідно до закону про освіту дорослих, прийнятого у 1971 р., працедавці зобовязані сплачувати податок на фонд підготовки та удосконалення освіти дорослих. Кожен працюючий має право «скористатися коштами 3 добродійств цього закону й отримати допомогу на підвищення власної кваліфікації», зазаначає дослідник Т. В.Дрожжина. Найчастіше цим правом користуються чоловіки у віці 25-40 років, які вже мають одну вищу освіту та престижну роботу, але також звертаються і безробітні 3 метою набути чи змінити фах.

Більшість вищих навчальних закладів організує багато вільних $\mathrm{i}$ платних лекційних курсів актуального змісту для дорослих. Поряд із вечірнім навчанням є й дистанційне (понад 30000 студентів у 23-х університетах i Національному центрі заочної освіти), а також специфічні форми фахової підготовки в таборах або майстернях різної тривалості влітку чи у вечірній час під егідою Національної консерваторії мистецтв і ремесла. Наполегливість у виконанні програм цих таборів може привести до отримання престижного диплома інженера.

Цікавою особливістю Франції є поширеність «вільних слухачів» - дорослих осіб, які за символічну плату (за користування бібліотеками, лабораторіями тощо) можуть відвідувати за власним бажанням академічні програми університетів, але без права складати іспити й отримувати диплом про вищу освіту.

Освіта дорослої людини $є$ цінністю, що визначає якість особистості, безпосередньо впливає на зміцнення здоров'я, як самої людини, так і пї нащадків, збільшення тривалості життя, покращення стосунків у сім’і, громаді та суспільстві. Освіченість дорослих громадян позначається на піднесенні якості освіти суспільства в цілому й добробуту майбутніх поколінь.

Система неперервної професійної освіти дорослих у Франції базується на концепції, що охоплює безліч різноманітних перспектив, напрямів і форм навчання, завдяки чому кожний учень може повністю 
розкрити свої здібності та задовольнити свої освітні потреби. Система професійної підготовки і підвищення кваліфікації спеціалістів у рамках мережі ГРЕТА $\epsilon$ першою і нині основною структурою системи неперервної професійної освіти у Франції. У наш час у центрах мережі ГРЕТА функціонують три основні види освітніх програм: формальні освітні курси, індивідуалізоване навчання і навчання у формі навчальних одиниць. Комплекс освітніх установ ГРЕТА $є$ головною ланкою, яка об'єднує як людські, так і матеріальні ресурси, основною метою якої стала організація освітнього процесу для дорослого населення країни. Серед основних завдань ГРЕТА необхідно виокремити здійснення допомоги дорослим учням у профорієнтації, надання допомоги у визначенні профілю і безпосередньо організацію освітніх програм.

Висновки. У більшості документів щодо вищої освіти йдеться про те, що виховна роль вищих навчальних закладів полягає в залученні академічної спільноти до світової культурної спадщини та формування національної складової світогляду. Це включає формування високого рівня освіченості, вихованості, духовності, виховний процес має базуватися на універсальних людських цінностях та мати яскраво виражений національний характер. Розробка концепції освіти дорослих як складової неперервної освіти впродовж життя зумовлюється необхідністю оновлення й осучаснення соціальноекономічних й духовних умов розвитку суспільства. Наразі актуалізувалася нагальність розширення сфери освітніх послуг, що надаються дорослому населенню, проведення спеціальних досліджень, здійснення комплексного аналізу ринку освітніх послуг. Ці процеси відбуваються із урахуванням особливостей і потреб дорослої людини на акмеологічних принципах, що передбачає врахування закономірностей і механізмів розвитку людини на етапі ії зрілості, й особливо при досягненні найбільш високого ступеня цього розвитку.

Перспективи подальших досліджень вбачаємо в розкритті проблем, пов'язаних з освітою дорослих, найбільш актуальними з яких $€$ : дослідження можливостей досвіду Франції в українській системі освіти дорослих; виявлення тенденцій розвитку систем освіти дорослих в об'єднаній Європі; дослідження результативності міжнародних програм у галузі освіти дорослих.

\section{Література}

1. Гавриков А. Л. Образование взрослых в XXI веке: роль университетов в его развитии / А. Л. Гавриков, Н. П. Литвинова. - М. : Издательство Исследовательского центра проблем качества подготовки специалистов, 2001. - 170 с.

2. Дрожжина Т. В. Освітня система Франції: сучасний погляд / Т. В. Дрожжина // Управління школою. - 2010. - № 5. - С. 21-25. 
3. Auduc J.-L., Bayard-Pierot J. Le systeme educative francais / J.L. Auduc, J. Bayard-Pierot. CDRP, Academie de Greteil, 2000. - 192 p.

Роман Тесля. Высшее образование Франции в аспекте образования взрослых.

В статье проанализирована уровневая структура высшего образования Франции и деятельность франиузской образовательной структуры для взрослых ГРЕТА. Обобщен опыт деятельности ГРЕТА в отрасли содержания образования $c$ иелью обоснования педагогических возможностей использования идей иностранного опыта в отечественной современной системе образования взрослых.

Ключевые слова: образование взрослых, высшее образование взрослых, непрерывное образование, образовательная программа ГРЕТА, содержание образования.

\section{education.}

Roman Teslya. higher education in france in the aspect of adult The article gives an analysis of the level structure of adult education and the activity of the French educational structure for adults GRETA (Groups of Local Public Institutions of Education). There has been generalized the work experience of GRETA in the sphere of the content of education with the aim of the substantiation of pedagogical possibilities of using the ideas of foreign experience in the modern system of national education.

Key words: adult education, higher education of France, continuous education, educational program GRETA.

Стаття надійшла до редакційної колегії 19.04.2014

УДК [81'243:81'276.6:33]:37.09

\section{Тинкалюк Оксана Володимирівна}

(C) Тинкалюк О. В., 2014.

Львівський національний університет імені Івана Франка

\section{ВІДБІР ЕФЕКТИВНИХ МЕТОДІВ ОРГАНІЗАЦІЇ НАВЧАННЯ ІНОЗЕМНОЇ МОВИ ПРОФЕСІЙНОГО СПІЛКУВАННЯ}

Здійснено відбір методів навчання іноземної мови для студентів економічних спеціальностей. Охарактеризовано традиційні та інновачійні методи (ділова та рольова ігри, метод вправ, метод портфоліо, кейс-метод, метод асоиіативних карт, “круглий стіл"), щзо сприяють активізації навчального прочесу, оновленню, розвитку, підвищенню інтенсивності та урізноманітненню видів та способів комунікації між суб' єктами навчального прочесу. Зазначені методи застосовувалися під час вивчення студентами-майбутніми економістами іноземної мови професійного спілкування. 
Ключові слова: методи навчання, рольова гра, метод портфоліо, кейс-метод, метод асоиіативних карт, “круглий стіл", майбутні економісти.

В умовах входження нашої держави до світового економічного, освітнього і культурного простору гостро постає питання переходу від традиційних репродуктивних методик викладання іноземної мови на індивідуально-творчий підхід, застосування інтерактивних форм i методів навчання, які допоможуть студентам набути знання, сформувати вміння, навички та готовність до професійного іншомовного спілкування, яка $\epsilon$ необхідною для майбутньої професійної діяльності майбутніх фахівців. Важливе місце у системі формування готовності майбутніх економістів до професійного іншомовного спілкування займає відбір ефективних методів організації навчання іноземної мови. Ця проблема є актуальною, адже від іiї розв'язання залежить успішність процесу навчання.

Окремі аспекти проблеми досліджено у таких напрямах: використання ділових ігор у підготовці студентів до іншомовного спілкування (Л. Волкова, М. Воровка, Ю. Друзь та ін.); шляхи підвищення рівня підготовки фахівців до професійного (ділового) спілкування (І. Берман, О. Куліш та ін.).

Керуючись підходами Ю. Бабанского, Н. Волкової, С. Гончарова, В. Гуріна, В. Ягупова та інших, принципами навчання, власним досвідом роботи у ВНЗ, ми здійснили відбір ефективних методів навчання іноземної мови для студентів економічних спеціальностей. При цьому враховувались такі чинники: цілі професійної іншомовної підготовки; змістове наповнення навчального матеріалу та час, відведений для його вивчення; особливості навчальної дисципліни; цілі навчальних занять; можливості студентів; наявність засобів навчання; рівень майстерності викладача тощо.

Беручи за основу класифікацію методів навчання Ю. Бабанського [1, с. 34-35], у процесі формування готовності студентів до професійного іншомовного спілкування ми використовували такі групи методів:

1) методи організаиії та здійснення навчально-пізнавальної діяльності (словесні, наочні та практичні, індуктивні та дедуктивні, репродуктивні, проблемно-пошукові методи тощо);

2) методи стимулювання та мотивації навчальної діяльності (методи формування пізнавальних інтересів у студентів; методи, спрямовані на формування почуття обов'язку і відповідальності в навчанні тощо).

Так, з практичних методів навчання іноземної мови ми особливу увагу приділяли виконанню студентами вправ. 3 метою формування у 

студентів зазначеної готовності ми уклали навчальний посібник, в якому розробили дотекстові (pre-reading), текстові (reading) i післятекстові (post-reading) вправи для опанування студентами фаховою термінологічною лексикою [4].

Вагоме значення у формуванні готовності майбутніх економістів до професійного іншомовного спілкування надаємо інноваційним методам навчання (ігровим, методу портфоліо, кейсметоду, методу “круглого столу” тощо).

У виборі ігрових методів навчання дотримуємося думки, що ці методи дають змогу найповніше врахувати професіографічні вимоги до обраної спеціальності та створити ситуації, включаючись у які, студенти оволодівають мистецтвом швидко й ефективно вирішувати управлінські завдання, опановують прийоми професійного іншомовного спілкування, вдосконалюють економічне мислення [3, c. 5].

Л. Волкова зазначає, що при визначенні ділової гри увага акцентується на професійному спрямуванні та позитивному впливові на формування ділових якостей фахівця. Для рольових ігор, найбільш доцільною $є$ соціально-побутова тематика та розвиток аналітичних здібностей студентів [2, с. 7].

Високий навчальний та розвивальний потенціал для формування готовності студентів до професійного іншомовного спілкування має метод аналізу конкретних ситуац̧ій - кейс-метод, який дозволяє моделювати реальні ситуації майбутньої професійної діяльності фахівця, а спрямованість навчального процесу на майбутню професійну діяльність дозволяє сформувати професійну іншомовну комунікативну компетенцію.

Важливу роль у формуванні готовності студентів до професійного іншомовного спілкування відіграє метод портфоліо (італ. “папка 3 документами”, “папка фахівця”). Під час занять студенти виконують:

- рефлексивне портфоліо, що допомагає з'ясувати динаміку особистісного розвитку студентів та спостерігати за результативністю їхньої навчальної діяльності (таке портфоліо передбачає виконання студентами домашніх завдань, модульних робіт, тестів, диктантів, творів, презентацій, проектів);

- проблемно-дослідне портфоліо, пов'язане 3 написанням рефератів, магістерської роботи, підготовкою до обговорення в групі, виступу на конференції ( студенти наводять цитати, аналізують результати тощо);

- тематичне портфоліо, створюється у процесі вивчення великої теми або цілої навчальної дисципліни та передбачає 


\section{Збірник наукових статей}

презентацію під час захисту портфоліо за результатами роботи над нею.

Мета застосування методу “круглий стіл", у контексті розв'язання завдань нашого дослідження, полягає в моделюванні науково-дослідницької діяльності студентів-майбутніх економістів. На заняття з використанням цього методу, в основі якого лежить принцип колективного обговорення проблеми, ми виносили навчальні теми, які визначають якість професійної іншомовної підготовки майбутніх фахівців.

Метод асоиіативних карт - сприяє розвиткові аналітичного, логічного, мислення студентів-майбутніх економістів, осмисленню ними концептосфери професійного мовлення, завдяки введенню до їхнього активного індивідуального лексикону нового словникового запасу.

Отож, зазначені інноваційні методи дозволяють сформувати стійкий інтерес студентів до вивчення іноземної мови, оцінити рівень їхніх знань, умінь та навичок, готовності до спілкування. Від їхньої ефективності залежить результат професійної підготовки фахівців загалом.

\section{Література}

1. Бабанский Ю. К. Методы обучения в современной общеобразовательной школе / Ю. К. Бабанский. - М. : Просвещение, 1985. $-208 \mathrm{c}$.

2. Волкова Л. В. Педагогічна технологія застосування ділової гри у процесі формування іншомовної комунікативної компетентності майбутніх спеціалістів фінансово-економічного профілю : автореф. дис. на здобуття наук. ступеня канд. пед. наук : спец. 13.00.04 "Теорія i методика професійної освіти” / Л. В. Волкова. - К., 2006. - 25 с.

3. Клименко Е. В. ормирование иноязычной профессиональной коммуникативной компетентности будущих финансистов : дис. ... канд. пед. наук : 13.00.08 / Клименко Елена Васильевна. - Калуга, 2004. - 200 с.

4. The World of Economics (Світ економіки) : [навч. посіб. для студентів-економістів 1-2 курсів] / [Г. Крижанівська, Н. Курташ, О. Тинкалюк та ін.]. - Львів : Видав. центр ЛНУ імені Івана Франка, 2007. - 300 c.

Оксана Тынкалюк. Отбор эффективных методов организации обучения иностранного языка профессионального общения.

Осуществлен отбор эффективных методов обучения иностранного языка для студентов экономических специиальостей. Охарактеризованы традиционные и инновационные методы (деловая и ролевая игры, метод упражнений, метод портфолио, кейс-метод, 
Психолого-педагогічні проблеми становлення сучасного фахівця

Випуск 2014

метод ассоцчиативных карт, метод “круглого стола”), способствующих активизации учебного прочесса, обновлению, развитию, повышению интенсивности и разнообразию видов $и$ способов коммуникации между субъектами учебного прочесса. Указанные методы применялись при изучении студентами будущуими экономистами иностранного языка профессионального общения.

Ключевые слова: методы обучения, ролевая игра, метод портфолио, кейс-метод, метод ассоичативных карт, метод “круглого стола”, будущзие экономисты.

Oksana Tynkalyuk. The selection of effective methods of teaching a foreign language for professional communication.

The selection of effective methods of teaching a foreign language to students of economic specialties is carried out. The traditional and innovative methods (business games and role play, method of exercises, portfolio method, case-method, method of associative maps, "roundtable" method) to facilitate the activation of educational process, renewal and development, improving the strength and diversification of the types and models of communication between the subjects of educational process are described. These methods were used in the process of study of foreign language for professional communication by the future economists.

Key words: methods of teaching, role play, method of portfolio, casemethod, method of associative maps, "round table", future economists.

Стаття надійшла до редакційної колегії 14.05.2014

УДК $811.111-048.24$

\section{Торяник Леонид Борисович}

Харьковский национальный экономический университет имени Семена Кузнеца

\section{КАК ПОНИМАТЬ УМЕНИЯ, НАВЫКИ, ЗНАНИЕ ИНОСТРАННЫХ ЯЗЫКОВ}

В статье рассматриваются актуальные вопросы научного понимания умений, навыков и знаний иностранных языков в контексте сущцости внешнего независимого тестирования по иностранным языкам. Приведена характеристика европейской системы уровней владения иностранным языком. Сделаны выводы, что внешнее независимое тестирование по иностранным языкам только на 50\% определяет уровни языковой подготовки, остальные 50\% должны определяться при помощии проверки и возможности осуществлять непосредственное общение.

Ключевые слова: внешнее независимое тестирование, знания, умения, навыки, иностранные языки. 


\section{Збірник наукових статей}

В практике преподавания английского языка в высшей школе часто приходится сталкиваться с определением уровня знаний студентами иностранного языка. Это необходимо постоянно делать, потому что не смотря на то, что многие абитуриенты сдают успешно внешнее независимое тестирование (укр.: зно) по иностранным языкам и получают высокие рейтинговые балы, их реальные знания не соответствуют сути европейской системы уровней владения иностранными языками.

По мнению разработчиков, внешнее независимое оценивание [1] (укр.: зно) - это комплекс организационных процедур (прежде всего тестирование), направленный на определение уровня знаний выпускников средних учебных заведений при их поступлении в высшие учебные заведения.

Цель внешнего независимого оценивания - обеспечение реализации конституционных прав граждан на равный доступ к качественному образованию, осуществления контроля за соблюдением Государственного стандарта базового и полного среднего образования и анализа состояния системы образования, прогнозирование ее развития.

C 2004 г. при поддержке международных и общественных организаций система внешнего независимого оценивания формируется в Украине.

Участники внешнего независимого тестирования в 2013 году по английскому языку получили следующие результаты (табл. 1):

\section{Таблииа 1.}

Результаты участников ВНО по английскому языку в 2013 году

\begin{tabular}{|l|c|c|}
\hline \multicolumn{1}{|c|}{ Результат } & $\begin{array}{c}\text { Количество } \\
\text { участников }\end{array}$ & $\begin{array}{c}\text { В \% от количества принявших } \\
\text { участие в тестировании }\end{array}$ \\
\hline от 100 до 123,5 баллов & 7225 & 8,64 \\
\hline от 124 до 150 баллов & 33477 & 40,03 \\
\hline от 150,5 до 180 баллов & 36247 & 5,34 \\
\hline от 180,5 до 190 баллов & 4555 & 2,50 \\
\hline от 190,5 до 199,5 баллов & 2093 & 0,04 \\
\hline 200 баллов & 32 & \\
\hline
\end{tabular}

баллов до 180 получили 43,4\% участников тестирования.

Если эти результаты перевести в бальную систему оценок вуза, то это неплохой результат.

Однако у большинства преподавателей иностранных языков справедливо возникает вопрос: знают ли выпускники школ иностранный язык, соответствуют ли их знания современным требованиям научно-технического прогресса, или, в конце концов, сути европейской системы уровней владения иностранным языком. Напомним, что эта система предусматривает такие стандарты [2]: 
А - Элементарное владение (Basic User);

A1 - Уровень выживания (Breakthrough) Elementary;

A2 - Предпороговый уровень (Waystage) Beginner;

В - Самостоятельное владение (Independent User);

B1 - Пороговыйуровень (Threshold) Pre-Intermediate;

В2 - Пороговый продвинутый уровень (Vantage) Intermediate;

C - Свободное владение (Proficient User);

$\mathrm{C} 1$ - Уровень профессионального владения (Effective Operational Proficiency) Upper-Intermediate;

C2 - Уровень владения в совершенстве (Mastery) Advanced.

Теперь раскроем суть названных уровней.

A1: Понимаю и могу употребить в речи знакомые фразы и выражения, необходимые для выполнения конкретных задач. Могу представиться / представить других, задавать / отвечать на вопросы о месте жительства, знакомых, имуществе. Могу участвовать в несложном разговоре, если собеседник говорит медленно и отчетливо и готов оказать помощь.

A2: Понимаю отдельные предложения и часто встречающиеся выражения связанные с основными сферами жизни (например, основные сведения о себе и членах своей семьи, покупках, устройстве на работу и т.п.). Могу выполнить задачи, связанные с простым обменом информации на знакомые или бытовые темы. В простых выражениях могу рассказать о себе, своих родных и близких, описать основные аспекты повседневной жизни.

B1: Понимаю основные идеи четких сообщений, сделанных на литературном языке на разные темы, типично возникающие на работе, учебе, досуге и т.д. Умею общаться в большинстве ситуаций, которые могут возникнуть во время пребывания в стране изучаемого языка. Могу составить связное сообщение на известные или особо интересующие меня темы. Могу описать впечатления, события, надежды, стремления, изложить и обосновать свое мнение и планы на будущее.

В2: Понимаю общее содержание сложных текстов на абстрактные и конкретные темы, в том числе узкоспециальные тексты. Говорю достаточно быстро и спонтанно, чтобы постоянно общаться с носителями языка без особых затруднений для любой из сторон. Я умею делать четкие, подробные сообщения на различные темы и изложить свой взгляд на основную проблему, показать преимущество и недостатки разных мнений.

C1: Понимаю объемные сложные тексты на различную тематику, распознаю скрытое значение. Говорю спонтанно в быстром темпе, не испытывая затруднений с подбором слов и выражений. Гибко и эффективно использую язык для общения в научной и 


\section{Збірник наукових статей}

профессиональной деятельности. Могу создать точное, детальное, хорошо выстроенное сообщение на сложные темы, демонстрируя владение моделями организации текста, средствами связи и объединением его элементов.

С2: Понимаю практически любое устное или письменное сообщение, могу составить связный текст, опираясь на несколько устных и письменных источников. Говорю спонтанно с высоким темпом и высокой степенью точности, подчеркивая оттенки значений даже в самых сложных случаях.

Обратите внимание, что во всех уровнях главное - это участие в разговоре, говорение, возможности создать сообщение на английском языке, говорить спонтанно.

Еще в 2010 году Украинский центр оценки качества образования разъяснил, что в приказе Министерства образования и науки Украины «О внешнем независимом оценивании лиц, которые выразили желание поступать в высшие учебные заведения Украины в 2010 году» от 26.09.2009 г. № 570, и в приказе Министерства образования и науки Украины «Об утверждении Условий приема в высшие учебные заведения Украины» от 18.09.2009 г. № 873 [3], не предусматривалось установление соответствия тестовых баллов, полученных участниками внешнего оценивания по иностранным языкам, и среднего балла аттестата как уровням владения иностранному языку (A1, А2, В2, В2, C1, С2) в соответствии с Общеевропейскими рекомендациями по языковому образованию, так и уровням сформированности языковых умений и навыков (начальный, средний, достаточный, высокий).

О каких же знаниях выпускников средних учебных заведений идет речь?

Учитывая разъяснения Министерства образования и науки создается впечатление, что открывается дорога для «натаскивания» основной массы абитуриентов, чтобы те успешно сдали зно и без проблем поступили в университеты.

«Натасканность» - это умение выполнять определенные действия (решать, доказывать, формулировать, определять и т.п.) без устойчивой внутренней потребности в их правильности и, как следствие этого, без внутреннего желания вырабатывать объяснения, удовлетворяющие эту потребность. Соответственно, «натаскивание» это способ обучения, который полностью игнорирует и/или подавляет внутреннюю потребность обучаемого в правильности выполняемых им действий.

Хороший преподаватель должен дать такое объяснение, которое смогло бы удовлетворить внутреннюю потребность обучаемого, а не было бы простой компиляцией текста учебника. 
Таким образом, для того, чтобы разобраться, определяет ли зно уровень знаний выпускников средней школы, необходимо, прежде всего, понимать, что такое умение, навыки, знания иностранных языков.

Знание - это результат нашей познавательной деятельности независимо от того, в какой форме эта деятельность совершалась: чувственно или внечувственно, непосредственно или опосредованно; со слов других, в результате чтения текста, при просмотре кино или телефильма и т.д.

Знания могут быть донаучными; житейскими; художественными (как специфический способ эстетического освоения действительности); научными (эмпирические и теоретические).

Житейские знания, основывающиеся на здравом смысле и обыденном сознании, являются важной ориентировочной основой повседневного поведения человека.

Научное знание представляет собой систематизированные обобщенные разряды знаний, формирование которых основано не только на опытных, эмпирических, но и на теоретических формах отражения мира и закономерностей его развития. Научные знания, получаемые учеником в школе, зачастую расходятся и даже противоречат житейским представлениям и понятиям ребенка в силу ограниченности или односторонности опыта, на который последний опирается.

Согласно В. И. Гинецинскому [4], учебное знание существует в трех формах: в форме учебной дисциплины; в виде учебного текста; в форме учебной задачи.

Адаптированная форма научного знания образует учебную дисциплину, которая включает, с одной стороны, предметную область знания, a c другой - знание закономерностей познавательной деятельности. Языковая форма выражения учебного знания образует учебный текст.

Любое знание, в том числе и учебное, субъективно по форме своего существования, и поэтому его нельзя механически передать «из головы в голову», подобно эстафетной палочке, передаваемой из рук в руки. Знания могут быть усвоены только в процессе познавательной активности самого субъекта. Именно своей субъектностью научное или учебное знание отличается от научной или учебной информации, представляющей собой объективированную форму знания, зафиксированного в различных текстах.

Таким образом, проведенный анализ существующих современных понятий «что такое знания, умения и навыки иностранных языков» позволяет сделать вывод, что предлагаемые тесты зно современного образца не могут определить уровень 
владения иностранным языком, если не проверяется уровень владения говорением и пониманием речи на слух. Наибольшие трудности при общении человек испытывает, когда он говорит на иностранном языке. Овладеть навыками общения (говорением и аудированием) неотъемлемая часть языковой компетентности. Предлагаемые тесты зно могут определить уровни языковой подготовки на $50 \%$, остальные $50 \%$ должны определяться при помощи проверки и возможности осуществлять непосредственное общение, то есть говорение и понимание на слух. Поэтому с каждым годом уровень умений, навыков знаний по иностранным языкам у выпускников школ становится все хуже и хуже. Обучаемые ни имеют внутренней потребности в знаниях, а просто занимаются простой их компиляцией.

\section{Литература}

1. Зовнішнє незалежне оцінювання - Wikipedia. [Электронный pecypc]. - Режим доступа : http://uk.wikipedia.org/wiki. - Назва с титул. екрану.

2. Общеевропейские компетенции владения иностранным языком: Изучение, преподавание, оценка [Электронный ресурс]. Режим доступа : http://lang.mipt.ru/articles/european_levels.html. - Название с титул. экрана.

3. Про затвердження Умов прийому до вищих навчальних закладів України у 2010 році. Наказ Міністерства освіти і науки України від 18.09.2009 р. № 873 [Электронный ресурс]. - Режим доступа : // http://search.ligazakon.ua/1_doc2.nsf/link1/RE22214Z.html. Назва с титул. екрану.

4. Гинецинский В. И. Основы теоретической педагогики: Учеб. пособие / В. И. Гинецинский. - Спб. : Изд-во С.-Петербургского унта, 1992. - 154 c.

Leonid Toryanik. How to understand skills, abilities, knowledge of foreign languages.

The article deals with current issues of scientific understanding of foreign languages skills and knowledge in the context of the school-leavers state testing in foreign languages. The characteristic of the European system of levels of proficiency in foreign language is considered. It is summed up that only $50 \%$ of foreign language knowledge is determined with the schoolleavers state testing. The remaining 50\% must be determined by checking and exercising oral communication.

Key words: school-leavers state testing in foreign languages, knowledge, skills, foreign languages.

Статья поступила в редакционную коллегию 05.05.2014 


\section{Федорук Галина Миколаівна}

(C) Федорук Г. М., 2014.

Вінницький державний педагогічний університет

імені М. Коцюбинського

\section{МОТИВАЦІЙНИЙ АСПЕКТ В СТРУКТУРІ ІНФОРМАЦІЙНО- КОМУНІКАЦІЙНОЇ КОМПЕТЕНТНОСТІ МАЙБУТНІХ УЧИТЕЛІВ ТЕХНОЛОГІЙ}

У статті проведено аналіз результатів застосування інформаційнокомунікаційної технологій навчання показує, щзо мотиваційноціннісний компонент інформаційно-комунікаційної компетентності майбутніх учителів технологій характеризує визначення професійної спрямованість студентів на формування інформаційно-комунікаційної компетентності; постановку $і$ усвідомлення цілей інформаційної діяльності майбутніх учителів технологій.

Ключові слова: інформаційно-комунікаційной компетентності, технологї навчання,економічні знання,економічна компетентність, технологія.

Сьогодні в Україні через цілу низку причин соціального, політичного, економічного характеру суттєво змінилися вимоги, які висуває суспільство до підготовки вчителя технологій. Важко переоцінити роль інформаційно-комунікаційної компетентності у професійній діяльності майбутніх учителів технологій. Така професійна якість - здатність орієнтуватися в інформаційному просторі, отримувати інформацію, оперувати нею, володіти відповідним рівнем знань, умінь $і$ навичок стосовно інформаційнокомунікаційних технологій займає провідне місце, оскільки саме ця здатність є базовою для розвитку інших, більш складних, зокрема, професійної компетентності.

У Законі України «Про Основні засади розвитку інформаційного суспільства в Україні на 2007-2015 роки» [1] наголошено, що Україна готує i має значну кількість висококваліфікованих фахівців 3 інформаційних технологій, ринок інформаційних технологій перебуває у стані активного становлення та за певних умов може стати фундаментом розвитку інформаційного суспільства в Україні.

Проблемам упровадження й ефективного застосування інформаційно-комунікаційних технологій в освіті присвячено чимало теоретичних та експериментальних праць вітчизняних i зарубіжних педагогів, психологів, зокрема: В. Безпалька, В. Бикова, М. Варія, 
С. Гончаренка, Р. Гуревича, Ю. Дорошенка, М. Жалдака, М. Кадемії, М. Козяра, Ю. Машбиця, Є. Полат, І. Роберт, С. Сисоєвої, П. Стефаненка, Н. Тализіної, О. Тихомирова, С. Трапезникова, А. Шматко та інших. Удосконалення системи підготовки майбутніх учителів технологій, зокрема, в аспекті формування їхньої інформаційно-комунікаційної компетентності, потребує попереднього з'ясування дійсного іï стану в сучасному педагогічному досвіді вищих навчальних закладів.

Поліпшення якості освіти $є$ необхідною умовою формування інформаційного суспільства та конкурентоспроможної економіки. На сучасному етапі інтенсивне впровадження інформаційнокомунікаційних технологій у сферу освіти $€$ національним пріоритетом. У світовій освітній практиці інформаційно-комунікаційні технології розглядаються як якісно нові засоби поширення та акумулювання знань. При цьому актуальною $\epsilon$ проблема їх раціонального використання у навчально-виховному процесі, управлінській діяльності, підвищенні кваліфікації педагогічних працівників та самоосвіті. В умовах становлення i розвитку високотехнологічного інформаційного суспільства постає необхідність у стовідсотковому впровадженні у навчально-виховний процес загальноосвітніх навчальних закладів інформаційно-комунікаційних технологій [4]. Це, на наш погляд, є особливо важливим у контексті формування інформаційно-комунікаційної компетентності майбутніх учителів технологій.

У контексті дослідження педагогічних умов формування інформаційно-комунікаційної компетентності майбутніх учителів технологій актуальною $\epsilon$ проблема визначення структурних компонентів цього складного інтегративного утворення.

Науковці по-різному визначають структуру інформаційнокомунікаційної компетентності фахівця. Так, наприклад, I. Молодоженя визначає структуру ІКТ-компетентності у єдності чотирьох компонентів. Ціннісно-мотиваційний компонент включає мотиви, мету, потреби в професійному навчанні, вдосконаленні, самовихованні, саморозвитку, ціннісні установки актуалізації в професійній діяльності, стимулює творчий прояв особи в професійній діяльності. Він припускає наявність інтересу до професійної діяльності, який характеризує потребу людини в знаннях, в оволодінні ефективними способами організації професійної діяльності. Також ціннісно-мотиваційний компонент включає мотиви здійснення педагогічної діяльності, спрямованість на передачу суми знань і розвиток особистості учнів. Когнітивний компонент повинний забезпечити вільне володіння вчителем навичками опрацювання інформації та роботи 3 інформаційними об'єктами, які відповідно 
впливають на навички вдосконалення професійних знань і умінь, знання міжпредметних зв'язків і т.д. Рівень розвитку когнітивного компоненту визначається повнотою, глибиною, системністю знань вчителя в його предметній області. Діяльнісний компонент - це активне застосування інформаційних технологій i комп'ютера в професійній діяльності як засобів пізнання i розвитку IКТкомпетентності, самовдосконалення і творчості, а також виховання подібних якостей у своїх учнів. Комунікативна складова цього компоненту виявляється в умінні встановлювати міжособистісні зв'язки, вибирати оптимальний стиль спілкування в різних ситуаціях, опановувати засобами вербального i невербального спілкування. Сфера рефлексійного компонента IКТ-компетентності вчителя визначається відношенням вчителя до себе i до світу, до своєї практичної діяльності та її здійснення. Вона включає самосвідомість, самоконтроль, самооцінку, розуміння власної значущості в колективі i розуміння результатів своєї діяльності, відповідальності за результати своєї діяльності, пізнання себе i самореалізації в професійній діяльності через засоби IKT. Розвиток кожного компоненту IКTкомпетентності пов'язаний 3 формуванням його характеристик i властивостей як частини цілісної системи [2]. Ми погоджуємося 3 науковцем у тому, що ціннісно-мотиваційний компонент, 3-поміж інших, обов'язково має бути присутній в структурі інформаційнокомунікаційної компетентності особистості.

Стосовно мотивації в структурі компетентності заслуговують на увагу наступні твердження Дж. Равена [3]:

- мотивація $€$ інтегральною частиною компетентності, тобто компетентності будуть з'являтися i розвиватися лише в процесі виконання цікавої для людини діяльності;

- формування цінностей, можливостей розвитку та оволодіння новими компетентностями залежать від конкретної ситуації в якій опиняється індивід;

- важливо врахувати поєднання всіх трьох змінних поведінки індивіда;

- вплив на поведінку людини відношення до ситуації, в якій вона знаходиться, розуміння нею стилю роботи в даній організації та очікування певних реакцій з боку інших осіб;

- лише щодо значимих для особистості завдань можуть оцінюватись компоненти компетентності;

- компетентність людини проявляється лише тоді, коли ситуація, яка склалася, сприймається нею як придатна для заняття цікавою діяльністю.

На наш погляд, компоненти сформованості інформаційнокомунікаційної компетентності майбутніх учителів технологій мають 


\section{Збірник наукових статей}

достатньо повно відображати основні аспекти їхньої професійної компетентності. Аналітичний огляд психолого-педагогічної літератури, теоретико-експериментальних досліджень 3 проблеми привів нас до висновку, що в структурі інформаційно-комунікаційної компетентності майбутніх учителів технологій можна виділити такі компоненти: мотиваційно-ціннісний, інформаційно-пізнавальний та технологічно-результативний.

Мотиваційно-ціннісний компонент інформаційнокомунікаційної компетентності майбутніх учителів технологій характеризує визначення професійної спрямованість студентів на формування інформаційно-комунікаційної компетентності; постановку i усвідомлення цілей інформаційної діяльності майбутніх учителів технологій. Мотиваційно-ціннісний компонент виражає готовність майбутнього вчителя технологій до актуалізації інформаційнокомунікаційної компетентності.

Показниками мотиваційно-ціннісного компонента інформаційно-комунікаційної компетентності майбутніх учителів технологій $\epsilon$ : наявність інтересу до оволодіння IКТ; сформованість потреби в IКК; усвідомлення особистісного сенсу та значущості IКК; характер установок на використання IKT в майбутній професійній діяльності.

Сутність розвитку інформаційно-комунікаційної компетентності майбутніх учителів технологій полягає в кількісній і якісній зміні цієї інтегративної властивості в цілому і окремих її елементів, у тому числі й мотиваційно-ціннісного компонента.

Таким чином, сучасна епоха актуалізувала потребу в новому типі особистості майбутнього вчителя технологій, здатного орієнтуватися в інформаційному просторі, отримувати інформацію, оперувати нею; володіти відповідним рівнем знань, умінь і навичок стосовно інформаційно-комунікаційних технологій та ефективно використовувати інформаційно-комунікаційні технології в педагогічній діяльності. Існуюча система вищої педагогічної освіти не в змозі повною мірою реалізувати це соціальне замовлення. Як свідчать спостереження, майбутні вчителі технологій не мають достатніх знань, умінь i навичок стосовно інформаційнокомунікаційних технологій й не готові їх використовувати у майбутній професійній діяльності. Сприятливі можливості для подолання цих недоліків і підвищення рівня інформаційно-комунікаційної компетентності майбутніх учителів технологій створюються, на наш погляд, при вивченні фахових дисциплін.

\section{Література}

1. Закон України „Про Основні засади розвитку інформаційного суспільства в Україні на 2007-2015 роки" [Електронний ресурс] / 
Режим доступу до ресурсу : http: http://zakon.rada.gov.ua/cgi-bin/laws/ main.cgi?nreg=537-16. - Назва с титул. екрану.

2. Молодоженя I. IKT як умова формування інноваційної компетенції / I. Молодоженя [Електронний ресурс] / Режим доступу до pecypcy : http://molirina74.blogspot.com/2012/02/blog-post_6615.html. Назва с титул. екрану.

3. Равен Дж. Компетентность в современном обществе: выявление, развитие и реализация [Пер. с англ.] / Дж. Равен. - М. : «Когито-Центр», 2002. - С. 396.

4. Розпорядження від 27 серпня 2010 р. № 1722-р Київ Про схвалення Концепції Державної цільової програми впровадження у навчально-виховний процес загальноосвітніх навчальних закладів інформаційно-комунікаційних технологій "Сто відсотків" на період до 2015 року [Електронний ресурс] / Режим доступу до ресурсу: http://zakon2.rada.gov.ua/laws/show/1722-2010-p/print1320911820915270. - Назва с титул. екрану.

Галина Федорук. Мотивационный аспект в структуре информационно-коммуникационной компетентности будущих учителей технологий.

В статье проведен анализ результатов применения информаџионнокоммуникационной технологий обучения показывает, что мотивационно-ценностный компонент информационнокоммуникаиионной компетентности будущих учителей технологий характеризует определение профессиональной направленности студентов на формирование информационно-коммуникачионной компетентности; постановку и осознание целей информационной деятельности будущих учителей технологий.

$\begin{array}{lll}\text { Ключевые } & \text { слова: } \\ \text { компетентности, } & \text { технологии }\end{array}$ знания, экономическая компетентность, технология.

Galina Fedoruk. Motivational aspects of the structure of information and communication technology competence of future teachers.

In the article the analysis of results of application of informationcommunication technologies of training shows that motivational and values component of information and communication competence of future teachers of technology characterizes the definition of professional orientation of students in the formation of information-communication competence; production and the realization of the goals of the information activities of the future teachers of technology.

Key words: information and communication competence, learning technologies, Economics, economic expertise, technology.

Стаття надійшла до редакційної колегії 26.03.2014 


\author{
Фрицюк Валентина Анатолиевна \\ (C) Фрицюк В. А., 2014.
}

Фрицюк Валентина Анатолиевна
Винницкий государственный педагогический университет

имени Михаила Коцюбинского

\title{
ПРОФЕССИОНАЛЬНАЯ САМОАКТУАЛИЗАЦИЯ БУДУЩЕГО УЧИТЕЛЯ
}

B статье осуществлен анализ специфики педагогической деятельности учителя $u$ раскрыты возможности его самоактуализации в процессе профессиональной подготовки.

Ключевые слова: самоактуализация, профессиональная самоактуализачия, будущий учитель, профессиональная подготовка.

Важным условием успешной интеграции человека в общество является развитие внутренне и внешне согласованной системы социально-психологических средств организации собственной жизни, то есть стиля жизни. Одним из механизмов перехода индивидуальных качеств к интегрированной системе саморегуляции личности есть процесс ее самоактуализации. Это касается, в частности, и будущего учителя.

Иногда утверждают, что самоактуализированная личность - это скорее исключение, чем правило. Иногда, что процесс самоактуализации - это как восхождение на Эверест, которое не каждому нужно, не каждый может (всегда можно сорваться вниз) и не каждый хочет осуществить. Мы соглашаемся с мыслью, что самоактуализация - это вершина (идеал), которая достойна того, чтобы к ней стремиться.

В разные исторические периоды ученые уделяли внимание самоактуализации личности. Например, О. Бандура, С. Сысоева, О. Рудницкая, как и другие исследователи, подчеркивают важность и признают необходимость содействия самоактуализации личности будущего учителя в процессе профессиональной подготовки $[1 ; 2 ; 3]$.

Самоактуализация - это процесс актуализации человеком собственных потенциалов и использования их как средств реализации смысла жизни. Актуализация потенциалов определяется как осознание и принятие (,Я" - концепции) ранее неосознаваемых собственных возможностей и психических смыслов (мыслей, чувств, моделей поведения, свойств, способностей и др. - как субъективно приятных, так и субъективно неприятных, как социально одобряемых, так и социально неодобряемых). По мере актуализации смыслов они становятся психологическими ресурсами, доступными сознательному 
волевому контролю и использованию субъектом. Актуализация потенциалов является естественным процессом, однако в условиях развития современного человека он легко блокируется. Эффективнее всего такой процесс стимулируют психотерапия и психокоррекционные технологии групповой работы, предназначенные для содействия личностному росту участников [1].

Процесс самоактуализации личности переплетается с процессом жизнетворчества, выступая иногда в качестве предпосылки, а иногда результата. В этом контексте самоактуализация, по мнению О. Бандуры, начинает действовать как механизм саморегуляции социального поведения личности таким образом:

1. В процессе самоактуализации формируется и осознается специфическая система ценностных ориентаций, которые определяют характер содержания и средств достижения ведущих жизненных целей личности и потому составляют основу саморегуляции ее социального поведения.

2. B

процессе

самоактуализации жизненная позиция,

развивается социальноконструктивная предусматривает осознание необходимости которая взаимодействия с социальной средой на основе принятия личностью ответственности за построение собственной жизни, отношения к окружающим как к субъектам жизни, а не средствам достижения собственных целей, других ценностей самоактуализации.

3. В процессе самоактуализации образуется компетентность личности во времени. Она предусматривает такое единство часовой перспективы в сознании человека, при котором прошлое воспринимается лишь как источник опыта, будущее, - лишь как сфера целеполагания, а нынешнее - как единственно доступное активности часовое измерение [1].

Таким образом, одним из результатов самоактуализации является формирование субъективно и объективно согласованного, такого, что субъективно удовлетворяет определенную личность, стиля жизни - индивидуально избранной системы средств взаимодействия с социальной средой.

Самоактуализация личности - это естественное стремление человека к самораскрытию, сугубо индивидуальный творческий путь к собственному ,Я”.

Мы придерживаемся точки зрения, что творчество играет в процессе самоактуализации личности важную роль (как характеристика самоактуализации). Творческий процесс понимаем как проекцию внутренних личностных процессов на внешнюю деятельность путем самоактуализации. Рассмотрев основные психологические характеристики самоактуализированной личности, 
Збірник наукових статей

остановимся на рассмотрении творчества как показателя самоактуализации.

На основании анализа литературы по проблеме исследования, мы стремились дать ответ на вопрос - какие личностные характеристики способствуют эффективности процесса самоактуализации и какое место занимает творчество в этом процессе. В результате выяснилось, что творческой (креативной) и самоактуализованной личности свойственны похожие личностные характеристики: высокая степень сформированности системы ценностных ориентаций, спонтанность, независимость от влияния извне и др. Таким образом, можно утверждать, что творчество является существенной, хотя и не определяющей характеристикой процесса самоактуализации личности.

В процессе самоактуализации творчество играет двойную роль. Оно обеспечивает оригинальность процесса самоактуализации, которая предоставляет возможность признать существование творчества самоактуализации.

В нашем исследовании можем утверждать о 25\% респондентов, у которых был зафиксирован высокий уровень развития личностных черт, как следствие раскрытия личностного потенциала, и достаточно высокий уровень развития творческих способностей (креативности), при этом не обязательно личность стремится реализовать свою креативность в творческой деятельности (в результате отсутствия потребностей или наличия неблагоприятных условий). Творчество выступает лишь как стимул к развитию, как источник самоактуализации (в таком случае главным становится не практические достижения человека, а его личность).

Во-вторых, творчество может выступать как средство компенсации личностной, или любой другой недостаточности. Именно в данном случае можно наблюдать самоактуализацию в творчестве когда достигаются определенные успехи в творческой деятельности, но при этом является слабо выраженной личносная самоактуализация как следствие нераскрытия собственных резервов. Здесь уже самоактуализация, как стремление к удовлетворению потребностей, выступает в качестве источника творчества, а не наоборот, как было отмечено выше. Следовательно, можно сделать вывод, что существует отличие между творчеством самоактуализации и самоактуализацией в творчестве.

В последние годы сложилось ряд предпосылок, которые определили необходимость новых подходов к подготовке учителя. Анализ социальных, практических и теоретических предпосылок обновления высшей педагогической школы позволяет утверждать, что в настоящее время накопился значительный потенциал, использование 
которого способствует кардинальной перестройке профессиональной подготовки учителя и созданию условий для самоактуализации его личности.

Процесс обучения - это главный и решающий источник систематического влияния на будущего учителя, его мысли и чувства, мотивы поведения и учебу, сферу мышления, психических состояний и свойств личности. В этом процессе следует особенно подчеркнуть значение содержания учебных дисциплин, форм и методов обучения, отношения преподавателей к студентам, а также желание, готовность и умение самостоятельной работы самих студентов.

Содержание любого учебного предмета может в той или другой степени усиливать желание студентов самостоятельно углублять и расширять знания и умения, при условии осознания ими важности этого материала для собственного развития. Эффективность процесса обучения и воспитания во многом зависит от того, насколько быстро и успешно студент превращается из объекта дидактичных влияний на субъект познавательной деятельности.

Содержание, заложенное в учебные предметы, обогащает студентов научными фактами и обобщениями, вооружает приемами самостоятельной деятельности, стимулирует непрерывную самоактуализацию и интеллектуальное самосовершенствование.

Для того, чтобы подготовка будущих учителей происходила эффективно, адекватно требованиям современного этапа развития общества, необходимо учитывать, что именно личность педагога имеет творческий потенциал относительно интеграции всех видов ее деятельности.

Одним из наиболее доступных и проверенных практикой путей повышения эффективности занятий, активизации студентов на занятиях есть соответствующая организация самостоятельной учебной работы. Она занимает важное место в подготовке к будущей профессиональной деятельности, потому что студент приобретает знания только в процессе личной самостоятельной учебной деятельности.

Развитие навыков самостоятельной работы побуждает студента к самоактуализации, поскольку от него требуется получение совсем нового, ранее неизвестного ему знания, или углубление и расширение сферы действия уже полученных знаний. Любопытство к выполнению работы повышается, если задание носит проблемный характер.

Создание во время занятий проблемных ситуаций побуждает студентов к самостоятельному овладению дополнительными знаниями и использованию их в процессе творческого труда. Проблемные ситуации для развития могут быть смоделированы через: столкновение учеников с жизненными явлениями, фактами, которые требуют 
теоретического объяснения; организацию практических работ; предоставление ученикам жизненных фактов, которые противоречат бывшим жизненным представлением об этих явлениях; формулировку гипотез; побуждение учеников к сравнению, сопоставлению и противопоставлению имеющихся у них знаний; побуждение учеников к предыдущему обобщению новых фактов; опытные задания.

Следует отметить, что от личности преподавателя, от его научной эрудиции и увлеченности, создания в коллективе творческой среды, удачного привлечения студентов к самостоятельной, познавательной деятельности в значительной степени зависит уровень самоактуализации студентов. По-другому воспринимают студенты своего педагога, если это интересный, грамотный, эрудированный человек, который стремится внести разнообразие в сложный процесс обучения и воспитания. Такой педагог повышает интерес студентов к учебной деятельности, способствует совершенствованию профессионализма будущего педагога, его энтузиазма, творческому подходу к работе, а следовательно, его самоактуализации.

Bblвoдbl. Теоретический анализ проблемы самоактуализации личности и тенденций усовершенствования современного педагогического образования позволяет нам прийти к заключению, что профессиональная самоактуализация обусловлена всем процессом профессиональной подготовки будущих учителей и выступает как важный элемент готовности к педагогической деятельности.

Таким образом, при систематическом руководстве все составляющие: и содержание, и методы, и формы, и средства обучения при условии должного и целеустремленного использования их в учебном процессе, могут влиять на побуждение и развитие стремления студентов к профессиональной самоактуализации.

\section{Литература}

1. Бандура О. Самоактуалізація як механізм формування інтегрованого стилю життя особистості / О. Бандура // Кроки до компетентності та інтеграції в суспільство: науково-методичний збірник / Ред. кол. Н. Софій (голова), І. Срмаков та ін. - К. : Контекст, 2000. $-336 \mathrm{c}$.

2. Педагогічні технології у неперервній професійній освіті: Монографія / За ред. С. О. Сисоєвої. - К. : ВІПОЛ, 2001. - 502 с.

3. Рудницька О. П. Педагогіка загальна та мистецька: Навч. посіб. / О. П. Рудницька. - Тернопіль : Богдан, 2005. - 360 с.

\section{майбутнього вчителя.}

Валентина Фрицюк. Прифесійна самоактуалізація

В статті розглядається специфика діяльності учителя й розкриті можливості його самоактуалізаиії в прочессе професійної підготовки. 
Психолого-педагогічні проблеми становлення сучасного фахівця

Випуск 2014

Ключові слова: самоактуалізаиія, професійна самоактуалізація, майбутній учитель, професійна підготовка. teacher.

Valentine Frytsyuk. Professional self-actualization of the future

In the article "Professional self-actualization of the future teacher" are considered the main conditions of person's self-actualization. Their influence is studied on self-actualization of future teacher in pedagogical university. The pedagogical conditions of person's self-actualization help to realize its possibility in a process of the professional training.

Key words: conditions of self-actualization, self-actualization, future teacher, professional training.

Стаття надійшла до редакційної колегії 12.05.2014

УДК [378.14.015.3:811]:316.7

Хачатрян Єва Левонівна

(C) Хачатрян Є. Л., 2014.

Харківський національний економічний університет імені С. Кузнеця

\section{РОЗВИТОК МОТИВАЦЇ̈ ЩОДО ВИВЧЕННЯ ІНОЗЕМНОЇ МОВИ НА ОСНОВІ ВИКОРИСТАННЯ СОЦІКУЛЬТУРНОГО КОМПОНЕНТА}

Для формування мотивації у студентів ВНЗ при вивченні іноземної мови, розглянуто соціокультурний компонент як основа. Проаналізовано два типи мотиваціїзовнішніми $i$ внутрішніми мотивами. Зазначено важливість підвищення рівня мотиващії учнів. Проаналізовано також інтегративна та інструментальна мотивація. Визначено, щуо соиіокультурноспрямоване використання Інтернет-технологій у навчальному прочесі з іноземної мови підвищує мотивачію учнів до вивчення культури краӥни мови, щяо вивчається.

Ключові слова: мотивачія, сочіокультурний компонент, інтегративна та інструментальна мотиваџія.

Економічні й соціально-культурні зміни, що відбуваються у сучасному світі, сприяють росту обсягів міжкультурної комунікації, розширенню співробітництва у міжнародних освітніх проектах, професійних контактів між представниками різних культур. Все це потребує від фахівця професійної компетентності, невід'ємними показниками якої $\epsilon$ вільне володіння іноземною мовою й нормами міжкультурного спілкування. У цьому зв'язку при навчанні іноземної мови пріоритетного значення набуває проблема підготовки студентів до міжкультурної комунікації що $є$ важливою умовою для їхнього інтегрування у полікультурне суспільство. Виникає необхідність 


\section{Збірник наукових статей}

підвищення рівня викладання іноземних мов для забезпечення готовності студентів до життя і діяльності у багатомовному світі.

Іноземна мова як навчальний предмет зможе повноцінно виконувати свої функції лише за умови, якщо всі аспекти процесу навчання розглядатимуться на рівних умовах, що означає їх рівноправність у плані значущості для формування особистості студента.

Грунтуючись на даних прагмалінгвістіки і беручи до уваги зміни у статусі іноземної мови як засобу спілкування і взаєморозуміння у світовому співтоваристві, у сучасній методиці особливо наголошується на необхідності посилення прагматичних аспектів у вивчення мови. Це означає, що у навчанні важливо не тільки досягнення якісних результатів в оволодінні іншомовним спілкуванням, але й їх практичне застосування 3 урахуванням особливостей іншої культури.

Мова йде не просто про знання мови, а про вміння використовувати іiі в реальному спілкуванні, тобто про практичне володіння мовою i, отже, про розвиток практичної міжкультурної компетенцї.

При цьому навчання іншомовної культури використовується не тільки як засіб міжособового спілкування, але й як засіб збагачення духовного світу особистості на основі набуття нових знань про культуру країни мови, що вивчається (історія, література, музика те що), знань про структуру мови, її систему, особливості тощо.

Оскільки основним об'єктом $є$ не країна, а фонове знання носіїв мови, їх невербальна поведінка в актах комунікації, в узагальненому вигляді їх культура, то правомірним було б ввести соціокультурний компонент навчання іноземної мови, на базі якого студенти формували б знання про реалії та традиції країни, включалися б у діалог культур, знайомилися 3 досягненнями національної культури у розвитку загальнолюдської культури.

Основний вектор сучасних лінгводидактичних досліджень спрямований на теоретичне обгрунтування найбільш оптимальних шляхів розвитку у студентів здатності реалізувати i розуміти іншомовні лексико-граматичні конструкції, що відповідають нормам комунікативної діяльності індивіда іншої лінгвоетнокультурної спільноти та іншої національної мовної картини світу. Для цього студенти повинні бути мотивовані.

Управління мотивацією вивчення іноземної мови є однією 3 центральних проблем навчання у ВНЗ. Іноземна мова як навчальний предмет має низку специфічних рис, однією 3 яких $є$ оволодіння іноземною мовою комунікативними методами. У зв'язку з цим перед викладачем стоїть завдання створення умов для іншомовного 
мовленнєвого спілкування у процесі навчання мови, максимально наближених до природних умов.

Для оптимальної організації навчального процесу важливо, в першу чергу, глибоке знання мотивів навчання студента i, по-друге, вміння правильно виявляти їх і розумно керувати ними. У зв'язку 3 цим необхідно звернутися до теоретичних досліджень із проблем мотивації, а також визначити піi зв'язок зі змістом навчання іноземної мови. У галузі навчання іноземної мови психологічні питання щодо мотивації розглядаються в роботах І. О. Зимної, О. О. Леонтьева та інших науковців.

Аналіз наявної вітчизняної і західної літератури показав, що на даний момент немає єдиної думки, що ж таке мотивація навчальної діяльності. На думку І. О. Зимньої: «Мотив - це те, що пояснює характер мовної дії, тоді як комунікативний намір виражає те, яку комунікативну мету переслідує мовець, плануючи ту або іншу форму впливу на слухача» $[1 ; 2]$.

Взявши за основу зазначені вище роботи, мотивацією можна назвати систему спонукальних імпульсів, що спрямовують суб'єкта навчальної діяльності на більш глибоке вивчення іноземної мови, його вдосконалення і прагнення розвивати потреби пізнання іншомовної мовленнєвої діяльності [1;2].

Для оптимальної організації мовленнєво-розумовоі діяльності необхідно знати типи мотивації. Мотивація навчання може визначатися зовнішніми і внутрішніми мотивами.

Зовнішні мотиви (мотив відповідальності, обов'язку, мотив оцінки особистого благополуччя, відсутність бажання вчитися) не пов'язані зі змістом навчального матеріалу.

Внутрішні мотиви, навпаки, пов'язані зі змістом навчання. До них належать мотиви оволодіння загальними способами дій, виявлення причинно-наслідкових зв'язків у навчальному матеріалі, що вивчається.

Таким чином, 3 метою збереження інтересу до предмета викладач іноземної мови повинен розвивати в учнях внутрішні мотиви. При цьому ключовими i вирішальними параметрами вважаються: особистий досвід, контекст діяльності, інтереси і схильності, емоції і почуття, світогляд. Виникає цілий ряд завдань, основні 3 яких полягають у використанні міжособистісних відносин i створенні емоційно сприятливої атмосфери, що в свою чергу забезпечить ефективний розвиток мотивації.

Пізнавальні мотиви в оволодінні іноземною мовою розрізняються наступним чином: 1) інтерес до іноземної мови (як такої) сприяє формуванню мотивів до аналізу мовних явищ, всіляких за формою і змістом, а також до розвитку лінгвістичного мислення; 
2) можливість використання іноземної мови як засобу обміну інформацією; 3) отримання знань про культуру, історію країни мови, що вивчається.

Розширення кругозору формує мотив ставлення до іноземної мови як до необхідного засобу пізнавальної діяльності [3].

Мотиваційний аспект має вирішальне значення також і для активізації всіх психологічних процесів: мислення, сприйняття i розуміння іншомовного матеріалу. Для цього необхідно підвищувати рівні мотивації, сприяючи розвитку пізнання й інтелектуальної діяльності учнів, прагнучи в остаточному підсумку підвищити ефективність процесу навчання.

Оскільки навчання іншомовного мовлення відбувається за допомогою спілкування, що є суто особистісним процесом, в якому здійснюється обмін ідеями, інтересами, передача рис характеру, то при комунікативному навчанні врахування особистісних властивостей учня має першорядне значення. Без урахування зазначених вище факторів мовленнєві дії студентів відриваються від їхніх реальних почуттів, думок, інтересів. Саме врахування особистісних якостей приводить до виникнення ситуаційної комунікативної мотивації, тобто забезпечує ініціативну участь студента в навчальному та реальному спілкуванні.

Успішність засвоєння іноземної мови в ії когнітивній функції сприяє формуванню мовного чуття; задоволення власне пізнавальних мотивів при вивченні іноземної мови формує стійку мотивацію; використання іноземної мови для отримання інформації (читання журналів, газет тощо) робить дану мову незамінною у пізнавальній діяльності учня.

Психологи першими почали серйозні дослідження мотивації у вивченні мови, у поєднанні із соціальними і культурними аспектами. Найбільш впливові моделі мотивації розроблені Р. К. Гарднером. Так, Р. К. Гарднер визначає мотивацію як поєднання зусиль, а також прагнення до досягнення мети вивчення мови плюс позитивне ставлення до іiі вивчення [5]. Учений поділяє мотивацію на два основних типа: інтегративна та інструментальна. Вважається, що студенти, які найбільш успішні при вивченні мови, - це ті, хто любить людей, які розмовляють цією мовою, захоплюються культурою і у них є бажання познайомитися або навіть інтегруватися в суспільство, в якому використовується мова. Така форма мотивації відома як інтегративна.

Інструментальна мотивація відноситься до більш функціональних причин для вивчення мови, а саме: читання різноманітних матеріалів, їх переклад або досягнення більш високого соціального статусу. Інструментальна мотивація більш характерна для 
вивчення іноземної мови. Було встановлено, що в цілому студенти обирають інструментальні причини для вивчення мови частіше, ніж інтегративні. Ті, хто підтримує комплексний підхід до вивчення мови, як правило, мають більш високий рівень мотивації й у цілому є більш успішними у вивченні мови.

Учені, яки досліджують мотивацію до засвоєння іноземної мови, виділяють низку видів мотивації з урахуванням індивідуального розвитку потреб. На думку Р. К. Гарднера, оптимально підібраний матеріал зміцнює основні складові мотивації: потреби, емоції, інтереси [5]. Необхідно відзначити, що соціокультурноспрямоване використання Інтернет-технологій у навчальному процесі з іноземної мови підвищує мотивацію учнів до вивчення культури країни мови, що вивчається. Серед переваг Інтернет для розвитку соціокультурної компетенції вважаються наступні:

1) умови віртуального соціокультурного середовища країни мови, що вивчається;

2) автентичність матеріалів,представлених у мережі;

3) гіпермедійне подання матеріалу, що сприяє наочності, варіативності та індивідуалізації засвоєння знань, що здобуваються;

4) мотивація учнів до самостійної пізнавальної діяльності;

5) можливість комунікації з реальними носіями мови і культури за допомогою сучасних телекомунікаційних можливостей Інтернет;

6) підвищення інформаційної культури як необхідної складової загальнокультурної компетенції сучасної особистості [3].

Стимулюють розвиток мотивації студентів і рольові ігри. Вони викликають жваву зацікавленість і активність у підготовці і проведенні занять. Під час проведення гри студенти набувають необхідний досвід діяльності у різноманітних ситуаціях. При цьому цей досвід потім обговорюється, і на відміну від реальної дійсності, людина бачить, що можна змінити. Як результат, у реальній комунікації іiї дії стають більш ефективними. Якщо до рольової гри додати ще елементи конкурсу, змагання, - то процес стає більш інтригуючим та цікавим.

Обов'язок викладача - мотивувати зацікавленість студентів: створити таке середовище в аудиторії, яке заохочує їх ділитися власними ідеями, знаннями і досвідом, брати участь в аналітичному процесі. Обов’язком студента $є$ активна участь у навчальному процесі.

У даний час зростає роль іноземної мови як предмета в навчанні не тільки самої мови, але також іншомовної культури носіїв цієї мови.

Найефективнішим засобом навчання іншомовної соціокультурної компетенції $\epsilon$, безумовно, перебування в країні вивчаємої мови. Проте, враховуючи відсутність такої можливості у більшості студентів, необхідні засоби, що сприяють розвитку компонентів соціокультурної компетенції студента позамовного 


\section{Збірник наукових статей}

середовища. Таким засобом ми разглядаємо світову комп'ютерну мережу Інтернет. Використання в навчально-виховному процесі 3 іноземної мови культурологічного матеріалу створює умови, які мотивують суб'єкта навчального процесу, а також сприяють розширенню сфери його пізнавальної діяльності.

Таким чином, навчання міжкультурної комунікації охоплює різні аспекти навчання іноземної мові, культури іншої й рідної країн. Перед викладачами вузів поставлено завдання зі створення таких умов, у яких студенти за стислі терміни могли засвоювати максимально можливу кількість знань разом із набуттям навичок творчої діяльності. Самомотивація - це основний засіб, який дасть змогу підвищити рівень зацікавленості студентів до навчального процесу, дозволить підвищити їхній особистий, науковий, творчий потенціал та дозволить використовувати в своїй професійній діяльності.

\section{Література}

1. Зимняя И. А. Психологические аспекты обучения говорению на иностранном языке / И. А. Зимняя. - М. : Просвещение, 1978. $159 \mathrm{c}$.

2. Леонтьев А. А. Психофизиологические механизмы речи / А. А. Леонтьев // Общее языкознание. - М. : Наука, 1970. - 315 с.

3. Можаева А. Н. Формирование социокультурной компетенции при обучении английскому языку с использованием Интернеттехнологий / А. Н. Можаева // Филол. науки. - 2009. - № 16. - С. 110116.

4. Райхштейн А. Д. Лингвистика и страноведческий аспект в преподавании иностранного языка / А. Д. Райхштейн // ИЯШ. - 1992. № 3. - С. 10-14.

5. Gardner R. C. Motivation and Second Language Aqcuisition / R. C. Gardner. - New York : Peter Lang, 2010. - 244 p.

Ева Хачатрян. Развитие мотивации при изучении иностранного языка на основе использования социокультурного компонента.

Для формирования мотивации у студентов вузов при изучении иностранного языка, сочиокультурный компонент рассмотрен как основа. Проанализировань два типа мотивации $c$ внешними $и$ внутренними мотивами. Отмечена важность повышения уровня мотивации студентов. Проанализирована интегративная $u$ инструментальная мотивачия. Определено, что в социокультурнонаправленное использование Интернет-технологий в учебном прочессе по иностранному языку повыиает мотивацию студентов к изучению культуры страны изучаемого языка.

Ключевые слова: мотивачия, сочиокультурный компонент, интегративная и инструментальная мотивация. 
Eva Khachatryan. Development of motivation regarding language learning through the use of socio-cultural component.

Socio-cultural component is considered as a base for the formation of motivation among university students during a foreign language acquisition. Two types of motivation are analyzed with external and internal reasons. The importance of increasing the level of students' motivation is emphasized. Also there are analyzed the integrative and the instrumental motivations. It is determined that the socioculturally directed use of Internet technologies in the learning process of a foreign language increases the motivation of the students studying the culture of the country of the language studied.

Key words: motivation, sociocultural component, integrative and instrumental motivations.

Стаття надійшла до редакційної колегії 15.05.2014

УДК 37.01-027.561

\section{Ципіна Діана Савеліївна}

( С Ципіна Д. С., 2014.

Харківський національний економічний університет імені С. Кузнеця

\section{КОНЦЕПТУАЛЬНІ ЗАСАДИ ПЕДАГОГІЧНОГО ДОСЛІДЖЕННЯ ФОРМУВАННЯ РИТОРИЧНОЇ КОМПЕТЕНТНОСТІ МАЙБУТНІХ МЕНЕДЖЕРІВ}

Розглянуто концептуальні засади педагогічного процесу формування риторичної компетентності майбутніх менеджерів в умовах магістерської підготовки. Проаналізовано сучасні наукові парадигми знаннєва, культурологічна, гуманістична. Обтрунтовано доцільність застосування концепиії особистісно-орієнтованого навчання, компетентнісного та комунікативно-діяльнісного підходів.

Ключові слова: риторична компетентність, парадигма, компетентнісний підхід, комунікативно-діяльнісний підхід, особистісно-орієнтоване навчання.

Гарантією отримання вірогідних результатів вивчення конкретного педагогічного процесу формування риторичної компетентності (РК) майбутніх менеджерів в умовах магістерської підготовки є аналіз концептуальних засад, зокрема, наукових парадигм та підходів.

Метою статті $€$ висвітлення концептуальних засад педагогічного дослідження формування риторичної компетентності майбутніх менеджерів в умовах магістерської підготовки. 


\section{Збірник наукових статей}

Методологічні засади наукового дослідження формування РК майбутніх менеджерів забезпечують сучасні парадигми розвитку педагогічної науки. Вони дають можливість спроектувати педагогічну систему, визначити іiї особливості, розробити педагогічну технологію, а також провести педагогічний експеримент та перевірити висунуту гіпотезу.

Парадигма - (від грецьк. paradeigma - приклад, зразок) - це визнана наукова теорія, яка впродовж певного часу задає модель наукової діяльності [3, с. 29].

При розробці цілісної системи формування РК майбутніх менеджерів необхідно перш за все спиратися на традиційну знаннєву парадигму. Магістранти мають опанувати необхідні знання стосовно філософського, культурологічного, психологічного, лінгвістичного аспектів риторичної діяльності, а також засвоїти закономірності комунікації в економічній сфері. Крім того, їм необхідно опанувати способи здобуття нових знань риторичної спрямованості, включаючи пошук, систематизацію та аналіз інформації.

Проте, центральним завданням сучасної вищої освіти $\epsilon$ формування особистості студента, адекватної актуальним соціальноісторичним реаліям. Тому педагогічний процес має бути спрямований не лише на здобуття певних знань, а й на всебічний розвиток цілісної особистості, іiі інтелектуальної, вольової та емоційної сфер. Провідною освітньою парадигмою стає гуманістична, концептуальним принципом якої є ідея про пріоритет інтересів особистості, повноцінна реалізація внутрішнього потенціалу студента [1].

Основними характеристиками навчання у ВНЗ за гуманістичної парадигми $\epsilon$ систематичність i системність, творча активність, формування наукового мислення, самопізнання, самоідентифікація, суб'єкт-суб'єктний характер діяльності викладача і студентів [1].

Перелічені характеристики знаходять втілення в універсальних риторичних законах, завдяки яким риторика може виступати інтегратором НВП і розглядатися як засіб навчання.

У нашому дослідженні ми спираємося також на культурологічну парадигму, провідною ідеєю якої $є$ виховання культурної людини на основі діалогу культур. Культурологічна парадигма спрямована на засвоєння універсальних елементів культури і цінностей у процесі навчання і виховання. На їх основі майбутньому менеджеру необхідно набути певний рівень власної культури мовлення, комунікативної поведінки, інформаційної культури, залучитися до відповідної організаційної культури тощо.

Для реалізації зазначених вище парадигм як «зразків», «моделей» організації педагогічного процесу викладачеві необхідно 
спиратися на певні підходи, які б могли їх звузити та конкретизувати для певної ситуації.

У державній національній програмі «Освіта України. XXI століття» проголошено, що одним із провідних напрямів освітніх реформ вважається компетентнісний підхід до навчання. У зв’язку 3 цим, головним результатом діяльності ВНЗ стає готовність майбутніх фахівців змінюватися та пристосовуватися до нових потреб ринку праці, оперувати інформацією, активно діяти, швидко приймати рішення, навчатись протягом усього життя.

Особливого значення також набуває застосування особистісноорієнтованого підходу до навчання, головним положенням якого $\epsilon$ визнання унікальності кожної особистості, а також індивідуальність іiі розвитку та навчання. За твердженням Т. Колбіної, урахування особистісних якостей студентів потребує відповідного відбору всіх компонентів педагогічної системи [2]. Реалізація цього підходу здійснюється через застосування проблемних ситуацій, творчих завдань, діалогічної співпраці. Оскільки риторична компетентність знаходить своє втілення в діяльності й здійснюється під час комунікації, вважаємо за доцільне дотримуватися у нашому дослідженні комунікативно-діяльнісного підходу.

Отже, аналіз сучасних наукових парадигм у педагогічній науці дозволив визначити теоретичні, методологічні та аксіологічні орієнтири щодо реалізації цілісного педагогічного процесу формування РК майбутніх менеджерів. Обгрунтовано доцільність застосування концепції особистісно-орієнтованого навчання, а також компетентнісного та комунікативно-діяльнісного підходів.

\section{Література}

1. Зыбина Т. М. Риторика в вузе как средство обучения / Риторика и культура речи в современном обществе и образовании: сборник материалов X Международной конференции по риторике / науч. ред.-сост. В. И. Аннушкин, В. Э. Морозов. - М. : Флинта : Наука, 2006. - С. 135-139.

2. Колбіна Т. В. Формування міжкультурної комунікації майбутніх економістів: теоретико-методологічний аспект : моногр. / Т. В. Колбіна. - Х. : ВД Інжек, 2008. - 392 с.

3. Пушкарь А. И., Потрашкова А. В. Основы научных исследований и организация научно-исследовательской деятельности: Учебное пособие / А. И. Пушкарь, А. В. Потрашкова. - Х. : ИД «ИНЖЭК», 2008. - 2-е изд., стереотип. - 280 с. 
Диана Цыпина. Концептуальные основы педагогического исследования формирования риторической компетентности будущих менеджеров.

Рассмотрено концептуальные основы педагогического процесса формирования риторической компетентности будущих менеджеров. Осуществлен анализ современных научных парадигм - знаниевой, культурологической, гуманистической. Обосновано применение конщепции личностно-ориентированного обучения, компетентностного и коммуникативно-деятельностного подходов.

Ключевые слова: риторическая компетентность, парадигма, компетентностный подход, коммуникативно-деятельностный подход, личностно-ориентированное обучение.

Diana Tsypina. Conceptual grounds (bases) of pedagogical research of forming future managers' rhetorical competence.

The article deals with the conceptual grounds (bases) of pedagogical research of forming future managers' rhetorical competence. The analysis of knowledge, cultural, humanistic paradigms is realized. The using of personality oriented teaching, competence, communicative and action approaches is grounded.

Key words: rhetorical competence, paradigm, competence approach, communicative and action approach, personality oriented approach.

Стаття надійшла до редакційної колегії 15.05.2014

УДК 378.147.03

\section{Черниш Людмила Миколаївна}

(C) Черниш Л. М., 2014.

Харківський національний економічний університет імені С. Кузнеця

\section{РОЗВИТОК ОСОБИСТІСНИХ ЯКОСТЕЙ МАЙБУТНІХ ФАХІВЦІВ В СФЕРІ ЕКОНОМІКИ}

У статті визначені мовні засоби які впливають на формування особистості майбутніх фахівців у сфері економіки, проаналізовано використання ігрових технологій, які сприяють поліпшенню комунікативній компетениї студентів та формують якості необхідні їх подальмій професійній діяльності.

Ключові слова: ділова гра, комунікативна компетенція, тренінг.

Формування будь-якої особистості є складним процесом, який залежить від соціальної структури, політичних, соціальних, економічних, культурних та етнічних умов. На всіх етапах розвитку суспільства необхідним набуттям будь-якого управлінця має бути не 
тільки високий рівень професійної, але й загальнокультурної підготовки. Інтегрування України в європейський освітній простір вимагає суттєвих змін у системі освіти і ставить метою підготувати висококваліфікованого фахівця економічного фаху з добрим знанням іноземної мови. Адже саме вона є засобом спілкування та механізмом віддзеркалення картини світу, соціальних та психологічних процесів. Отже сучасні європейські стандарти освіти вимагають від кожного європейця володіння двома іноземними мовами та здійснення повноцінного спілкування з носіями мов.

Meта статmі. Окреслити коло особистісних якостей майбутніх фахівців розвиток яких можливий засобами іноземної мови та визначити найбільш ефективні види завдань для розвитку тих чи інших якостей особистості.

Аналіз цієї проблеми представлений в роботах Е. А. Хруцького, А. А. Вербицького, И. А. Зимньої.

Досягти високого рівня комунікативної компетенції в англійській мові, не перебуваючи в колі їі носіїв, - справа складна. Тому важливою задачею викладача $є$ створення на уроці англійської мови реальних і уявних ситуацій спілкування, використовуючи для цього різні прийоми роботи. Одним із таких прийомів є навчальна гра. Гра на уроці іноземної мови - простий і природний спосіб пізнання людиною навколишньої дійсності, найбільш доступний шлях до оволодіння знаннями, уміннями, навичками. Сам факт, що гра пробуджує інтерес і активність студентів, дає їм можливість проявити себе в цікавій для них діяльності, сприяє більш швидкому і надійному запам'ятовуванню іноземних слів та речень, особливо, якщо знання цього матеріалу є обов'язковою умовою активної участі, а в окремих випадках - обов'язковою умовою виграшу. Ретельно продумана й добре проведена гра полегшує вивчення й закріплення мовного матеріалу та сприяє формуванню відповідних умінь i навичок. Необхідність раціональної побудови, організації і застосування ігор у процесі навчання i виховання засобами іноземної мови вимагає ретельного і детального вивчення цього питання, що й обумовило актуальність вивчення обраної проблеми.

Ділова гра - це наближена до дійсності форма імітаційного моделювання діяльності особистості, яка охоплює інструментальний та емоційно-рольовий аспекти вирішення проблеми [1, с. 5]. Мета ділової гри - закріплення знань, стимулювання навчально-пізнавальної діяльності, формування практичних умінь i навичок щодо застосування знань, розвиток творчого мислення, відпрацювання навичок спілкування у процесі програвання конкретних ситуацій [3, c. 28]. 


\section{Збірник наукових статей}

Використання ігрових технологій навчання менеджерів у процесі підготовки їх до професійної комунікації дозволяють досягати таких лінгводидактичних цілей: формування умінь вести розгорнутий монолог із фахової проблематики, а також ефективну конструктивну розмову на теми,що цікавлять культурну високоосвічену людину; створення умов щодо володіння полемічним мистецтвом, культурою конструктивного діалогу та полілогу (диспут, полеміка, дискусія), технологіями формування індивідуального образу, власного мовленнєвого стилю; удосконалення умінь та навичок роботи 3 текстовим матеріалом, дотримуючись основних законів риторики, складання доповіді, інформаційно-аналітичного повідомлення, виступу тощо; формування вміння працювати 3 різними видами інформації, використовуючи методи соціально-психологічного аналізу, проводити прогноз поведінки підлеглого, між групових та групових взаємовідносин у діловому спілкуванні, обирати оптимальні риторичні методи і прийоми у процесі ділового спілкування; відпрацьовувати навички вирішення проблем в умовах, максимально наближених до реальних ситуацій професійного спілкування.

Ігрові технології як засіб організації навчального процесу майбутніх менеджерів охоплюють такі компоненти: ігрові ролі та їх прийняття, побудова за певними правилами ігрових дій, моделювання ігрового процесу та емоційної напруги. Важливими ознаками ігрових технологій науковці вважають поведінкову комунікацію учасників гри; взаємодію двох або більше суб'єктів, тобто колективну, групову взаємодію; складність і взаємопов'язаність завдань, які вирішуються у процесі гри; імітацію комунікаційної ситуації; багатофункціональність разом із функцією діагностики якостей i ознак комунікативної поведінки учасника гри, вона може виконувати функції навчання, тренінгу та виховання ії учасників, а також вирішувати дослідницькі завдання.

Такі реальні проблеми для вирішення пропонує Давид Коттон, автор багатьох підручників з бізнесу, за якими ведеться викладання мови ділового спілкування.

За функцією та цільовим призначенням ділові ігри є такими, де запропоновано вирішити практичне завдання у сфері професіональної діяльності:пошук оптимального рішення, наприклад під час реорганізації бухгалтерського відділу або моделювання проекту угоди 3 рекламним агентством на розробку реклами нового товару фірми, набір на роботу нового персоналу, досягнення домовленості 3 іноземними партнерами щодо термінів поставок та вирішення інших реальних проблем. Під час тренінгів студенти набувають вміння щодо колективної підготовки прийняття управлінських рішень 3 урахуванням великої кількості факторів, які впливають на конкретну 
ситуацію. За ступенем свободи рішень та дій учасників відокремлено: ігри $є$ м'якими, тобто учасники гри за умов дотримування загальних правил гри діють вільно, їх рішення не регламентовані встановленим набором альтернатив. Але $\epsilon$ і жорсткі ділові ігри за ступенем свободи рішень, де допускається лише обмежений, попередньо заданий спектр можливих рішень і відповідних альтернатив поведінки.

Характер комунікації учасників гри,що виступає одним із важливих показників динамізму гри, відбиває залежність або незалежність дій ії учасників одне від одного. Згідно з цим критерієм виділяють: інтерактивні ігри,які необхідні для імітації відносин конкуренції (наприклад, при відборі фахівців на певну посаду). Не інтерактивні зумовлюють прийняття самостійних рішень учасниками, незалежних одне від одного.

Автентичні тексти провідних американських та британських фахівців з економіки, які використовуються на заняттях 3 ділового спілкування, та запропоновані в них рольові ігри дають можливість студентам моделювати ситуації та вирішувати проблеми, з якими вони зустрінуться, коли переступлять поріг підприємницької організації. Досвід, отриманий на заняттях, надасть їм змогу ефективно управляти своєю комунікативною поведінкою під час діяльності за фахом. Вони будуть готові робити презентації та вести дискусії 3 іноземними партнерами, тому що за допомогою навчальних ситуацій студенти "відточують" свої навички ефективно взаємодіяти на ділових заходах. $\mathrm{Ti}$, що навчаються тренують навички, для того щоб брати слово та робити промови, підтримувати думку, реагувати на пропозиції та подавати свої, щоб вести переговори на іноземній мові. За допомогою серії сфокусованих вправ студенти покращують володіння словником ключових термінів, ідіоматичними висловлюваннями та граматичними конструкціями. Студенти беруть участь у рольових переговорах зростаючої складності, покращуючи свої здібності та навички.

Комунікативна компетенція не обмежується лише навичками мовлення та аудіювання. Не менш важливою для майбутнього менеджера $є$ комунікативна компетенція в галузі ділового письмового спілкування. Потреба у письмових контактах із зарубіжними колегами та партнерами зумовлює необхідність розвитку умінь та навичок письма як виду мовленнєвої діяльності.

Наприклад, студентів необхідно підготувати для вирішення такої ситуації ділового спілкування,як отримання менеджером листа скарги від покупця або написання запита щодо отримання інформації про нові товари та послуги, складання контракту 3 іноземною партнерською фірмою, складання листів щодо запропонування свого товару. 
Такі завдання стимулюють не лише навички ділового письмового мовлення, а й здатність взяти відповідальність на себе та кваліфіковано вирішити професійну проблему, таким чином розкрити талант майбутнього керівника.

Отже, можемо зробити висновок, що одним із найбільш ефективних і доцільних прийомів при роботі зі студентами під час вивчення іноземної мови є гра. Використання ігрової діяльності як засобу підвищення ефективності навчання іноземної мови, таким чином, має ряд переваг: навчання засновується на повазі особистості кожного студента та відбувається в атмосфері доброзичливості та взаєморозуміння. Атмосфера розкутості допомагає розкритися різним сторонам особистості майбутнього менеджера, звільнитися від багатьох психологічних бар'єрів, наприклад, від скутості, сором'язливості, невпевненості у собі. Гра активізує творчі здібності майбутніх фахівців, розвиває уяву, пам'ять, мислення та надає змогу студентам не тільки сприймати іноземну мову як засіб спілкування, а й сприяє формуванню соціально-важливих якостей особистості.

\section{Література}

1. Николаєва С., Шерстюк О. Сучасні тенденції у викладанні іноземних мов для спеціальних цілей / С. Николаєва, О. Шерстюк // Іноземна мова. - № 2. - 2002.

2. Трейсі Д. Менеджмент з погляду здорового глузду / Д. Трейсі. $-1993 .-65$ c.

3. Хруцкий Е. А. Организация проведения деловых игр / Е. А. Хруцкий. - М. : Высшая школа, 1991. - 102 с.

Людмила Черныш. Развитие личностных качеств будущих специалистов в сфере экономики.

В статье определены языковые средства, которые влияют на формирование личности будущих специилистов в сфере экономики, проанализировано использование игровых технологий, которые способствуют улучшению коммуникативной компетенции студентов u формируют качества необходимые их дальнейтей профессиональной деятельности.

Ключевые слова: деловая игра, коммуникативная компетенция, тренинг.

Ludmila Chernysh. The development of personal traits of specialists in the field of economy.

The article emphasizes the language influence on personality forming of specialists in the field of economy. It details the usage of game technologies which contribute to language perfection of students as well as give them an opportunity to develop traits to be used in their professional field.

Key words: training, case study, a letter of complaint.

Стаття надійшла до редакційної колегії 15.05.2014 


\section{Шаповал Никита Владимирович}

Харьковский национальный университет имени В. Н. Каразина

\section{Заика Евгений Валентинович}

Харьковский национальный университет имени В. Н. Каразина

\section{ПАМЯТЬ В УЧЕБНОМ ПРОЦЕССЕ: ОСОБЕННОСТИ ПРОЯВЛЕНИЯ ИНТЕРФЕРЕНЦИИ}

В статье представлены данные об особенностях и закономерностях проявления интерференции в памяти. На основе экспериментальных исследований показано деструктивное влияние ретроактивной интерференции на запоминание различных видов разрозненного материала при произвольном и непроизвольном запоминании. Представленные материаль важны для оптимизации учебного прочесса в школе и ВУЗе с иелью снижения отрицательного влияния интерференции в памяти.

Ключевые слова: произвольная память, непроизвольная память, интерференция, ретроактивная интерференция.

Интерференция - это одно из универсальных проявлений памяти. Она интенсивно изучается как в зарубежной когнитивной психологии, так и в отечественных направлениях исследования памяти, в том числе и харьковской психологической школе. В общем случае под интерференцией в психологии понимают взаимное влияние двух действий. Одним из проявлений интерференции выступает изменение мнемического эффекта одного из таких действий: результат запоминания, к которому привело выполнение этого действия, оказывается при наличии другого соседнего действия иным по сравнению с ситуацией, когда оно отсутствует. Поскольку в реальной жизни человек обычно выполняет не изолированные действия, а их последовательности, то интерференция в памяти имеет место достаточно часто и тем самым существенно влияет на результат запоминания. Влияние интерференции на память, особенно в учебном процессе, чаще всего бывает отрицательным, т.е. она ухудшает результат запоминания.

При этом, несмотря на значительное количество исследований интерференции, до настоящего времени остаются недостаточно изученными (или же на них имеются противоречивые ответы в литературе) такие вопросы: в чем специфика возрастных особенностей интерференции (усиливается ли она с возрастом? и если да, то в основном на сходный или несходный материал?), имеют ли место 


\section{Збірник наукових статей}

половые различия в проявлении интерференции (с учетом различия видов запоминаемого материала), имеют ли место корреляции между величиной интерференции при воспроизведении разных видов материала? Какова ее специфика в произвольном и непроизвольном запоминании и другие.

Цель исследования - определить ряд психических закономерностей проявления интерференции в памяти.

Задачи исследования: определить возрастные особенности проявления интерференции в памяти, половые особенности проявления интерференции в памяти, связь между разнообразными показателями памяти и интерференцией, связь интерференции с психофизиологическими особенностями человека.

Методы исследования: для исследования интерференции в произвольной памяти: 1) методика «Двойной счет» Мучника и Смирнова, 2) методика исследования интерференции Лактионова; в непроизвольной памяти: 1) последовательное выполнение заданий с буквами и цифрами Середы и Файера, 2) методика «Напоминание посредством близких предметов» Ю. В. Идашкина (подробное описание методик смотри в [1]). Для исследования психофизиологических особенностей человека: a) исследование свойств нервной системы 1) сокращенный вариант опросника Стреляу; б) для исследования функциональной асимметрии полушарий головного мозга: 1) тесты положения рук и отведения глаза.

Испытуемые являются представителями разных социальнодемографических и профессиональных групп: студенты, работники умственного труда, офисные работники и компьютерщики, цеховые работники различных специальностей (внутри каждой из групп мы пытались поддержать их приблизительный баланс). Всего в эксперименте учувствовало 140 испытуемых, из них:

- в первую выборку вошли 80 человек, которые составили четыре группы: 1) мужчины до 40 лет (20 человек); 2) мужчины старшие 40 лет (20 человек); 3) женщины до 40 лет (20 человек); 4) женщины старшие 40 лет (20 человек);

- во вторую выборку вошли 60 человек, которые составили четыре группы: 1) мужчины от 20 до 40 лет (15 человек); 2) женщины от 20 до 40 лет (15 человек); 3) мужчины от 40 до 65 лет (15 человек); женщины от 40 до 65 лет (15 человек).

Кратко перечислим полученные результаты:

1. Имеет место отчетливое возрастное снижение у подавляющего большинства испытуемых показателей памяти - как у мужчин, так и у женщин примерно в равной степени как в произвольной так и в непроизвольной памяти. 
Обращает на себя внимание факт практически точно пропорционального снижения показателей слов и цифр во всех ситуациях: и вне интерференции, и при интерференции со стороны как сходного, так и несходного материала. Средне-групповые показатели старших возрастных групп составляет от $83 \%$ до $92 \%$ от показателей младших групп. При этом внутри каждого вида материала (слова и цифры) четко сохраняется эффективность запоминания: вне интерференции всегда лучше, при использовании несходного материала интерференция проявляется слабее, и при использовании сходного всегда сильнее. Так, во всех группах показатели интерференции материалом несходным составляют 84-91\% от показателей вне интерференции, а показатели интерференции материалом сходным - 73-85\% от вне интерференции (и 82-90\% от интерференции несходным).

На этот факт мы обращаем особое внимание, так как в литературе отмечены два разных представления о возрастной динамике интерференции: a) пропорциональной основным показателям памяти и б) ускоренного снижения по сравнению с основными показателями памяти. Наши данные четко свидетельствуют о факте именно пропорцииональной, а не ускоренной динамике интерференции (разумеется в пределах изучаемого нами возрастного диапазона, т.е. как минимум до 55-65 лет; в более старшем возрасте картина может быть и иной).

Также о возрастной динамике испытуемых в ситуации непроизвольного запоминания можно сказать, что больше всего корреляционных связей показателей интерференции между собой замечены среди старших групп испытуемых. Это характерно для обеих ситуаций и произвольной, и непроизвольной запоминания, что свидетельствует о том, что с возрастом количество связей показателей интерференции между собой увеличивается, то есть можно сделать вывод, что с возрастом интерференция в памяти начинает работать как единый механизм.

2. Различия между мужчинами и женщинами как по отдельным показателям, так и по их возрастной динамике минимальны. Однако обнаружен факт заметно лучшего воспроизведения у мужчин для материала "цифры-цифры", причем это преимущество мужчин сохраняется в обеих возрастных группах. Однако явно наблюдаются отличия между мужчинами и женщинами как по отдельным показателям, так и по их возрастной динамике для ситуации непроизвольной памяти:

а) женщины оказались более стойкими к влиянию интерференции на эффективность запоминания в ситуации непроизвольного запоминания, чем мужчины, средние показатели 


\section{Збірник наукових статей}

женских групп по воспроизведению знаков всегда больше, чем у мужчин;

b) больше всего связей показателей интерференции в ситуации непроизвольного запоминания между собой было замечено у мужчин. Это позволяет сделать вывод, что показатели интерференции у них являются более взаимоувязанными.

3. Относительно характера связей показателей памяти в ситуации интерференции.

В ситуации произвольного запоминания таких связей почти нет. То есть каждый отдельный случай проявления интерференции в произвольной памяти предоставляет особенный некоррелирующий с другими результат, явление интерференции здесь разнообразно по своему существу.

Однако в ситуации непроизвольного запоминания такие связи есть, и их немало, что свидетельствует о том, что интерференция проявляет себя как единое явление в памяти. В этом заключается противоречивый характер проявления интерференции в произвольной и непроизвольной памяти.

4. О связи интерференции с особенностями психофизиологической организации человека, то есть со свойствами нервной системы и функциональной асимметрией полушарий головного мозга можно сказать следующие: связи минимальны, имеются лишь единичные взаимосвязи в единичных группах, т,е. проявление интерференции в непроизвольной памяти практически не связаны с этими индивидуальными показателями человека.

Полученные результаты могут быть использованы для рациональной организации и оптимизации функционирования памяти в учебном процессе.

\section{Литература}

1. Заика Е. В. Экспериментальные исследования памяти / Е. В. Заика. - X : Гуманитарный центр, 2013. - 396 с.

2. Заика Е. В., Шаповал Н. В. Интерференция B кратковременной памяти взрослых на различных видах разрозненного материала / Е. В. Заика, Н. В. Шаповал // Вестник ХНПУ имени Г. С. Сковороды. Психология. - Харьков : ХНПУ, 2012. - Вып. 44. Часть II. -249 с.

Микита Шаповал, Свгеній Заїка. Пам'ять в учбовому процесі: особливості прояву інтерференції.

У статті представлені дані про особливості $і$ закономірності прояву інтерференції в пам'яті. На основі експериментальних досліджень показан деструктивний вплив ретроактивної інтерференції на запам'ятовування різних видів розрізненого матеріалу при довільному $i$ мимовільному запам'ятовуванні. Представлені матеріали важливі для 
оптимізації учбового процесу в школі $i$ ВНЗ з метою зниження негативного впливу інтерферениіі в пам'яті.

Ключові слова: довільна пам'ять, мимовільна пам'ять, інтерференція, ретроактивна інтерференція.

Nikita Shapoval, Eveheniy Zaika. Memory in educational process: features of the display of interference.

The issue represents the data about features and conformities to law of the interference display in memory. On the basis of experimental researches there was shown the destructive influence of the retroactive interference on memorizing of different types of separate material at the arbitrary and involuntary memorizing. The presented materials are important for optimization of educational process at school and Institution of higher learning in order to decline the negative influence of interference in memory.

Key words: arbitrary memory, involuntary memory, interference, retroactive interference.

Статья поступила в редакционную коллегию 12.05.2014

УДК $378+371 ; 147: 54$

\section{Швець Ольга Григорівна}

(С) Швець О. Г., 2014.

Сумський національний аграрний університет

\section{ФОРМУВАННЯ АГРОЕКОНООСФЕРНОЇ СВЦДОМОСТІ СУЧАСНОГО СПЕЦАЛІСТА АПК ПРИ ВИВЧЕННІ ДИСЦИПЛІН ХІМІЧНОГО ЦИКЛУ}

У статті досліджено роль хімічної освіти в формуванні агроеконоосферної свідомості студентів сільськогосподарських спеціальностей. Визначено ї̈ основні рівні: професійний та загальнокультурний. В якості основного підходу до ноосферної освіти обрано системний. У змісті хімічної освіти виділено 5 світоглядних категорій: якість життя та здоров'я людини, хімізація сільськогосподарського виробництва, екологічна безпека та екологічні проблеми, взаємозв'язки в довкіллі, прогнозування майбутнього співіснування людства і природи.

Ключові слова: агроеконоосферна свідомість, спечіаліст сільського господарства, викладання хімії

На сучасному етапі існування людської цивілізації концепція стійкого розвитку суспільства набуває пріоритетного значення. Усвідомлення людиною того, що світ природи $є$ середовищем іiі 


\section{Збірник наукових статей}

існування, зумовлює зацікавлення в його збереженні. Підготовка фахівців, здатних покращити управління природними ресурсами та знизити екологічний ризик потребує реформування вищої професійної освіти, зокрема, аграрної.

Екологізація підготовки фахівців для сільського господарства відображає соціальне замовлення і може бути реалізована на засадах ноосферної освіти.

Mema cmammi: визначення можливостей хімічної науки у формуванні агроеконоосферної свідомості студентів сільськогосподарських спеціальностей.

Проведений аналіз публікацій $з$ екологічної психопедагогіки дозволив виділити іiі основний методологічний принцип: „чітка відповідність педагогічного процесу екологічної освіти та виховання психологічному процесу формування екологічної свідомості" [1, с. 319]. У цій же роботі визначено і структуру екологічної свідомості, як сукупність уявлень, особистісного ставлення до природи, відповідних технологій взаємодії з нею, життєвих цінностей етичного плану, забезпечити формування яких має екологічна освіта та виховання.

Одним із основних напрямків реформування освіти, який виділений у Державній національній програмі “Освіта” (Україна XXI століття) є формування „екологічної культури” особистості.

Проте, тенденції останніх 5 років у реалізації освіти в аграрному вузі свідчать про необхідність деталізації цього поняття у формі інтегрованої агроеконоосферної свідомості майбутнього фахівця.

У публікації О. С. Симбірських, визначено шість компонентів хімічної науки, що мають агроеконоосферний потенціал: природничонауковий, коеволюційний, футурологічний, екологічний, духовноморальний, естетичний і ноосферо-розвиваючий, який розглядається, як найбільш значущий [3].

Більшість проаналізованих нами літературних джерел стосуються в першу чергу реалізації ідей ноосферної освіти в професійній підготовці екологів та агрекологів, водночас, практично відсутні подібні дослідження щодо студентів інших сільськогосподарських спеціальностей (агрономів, ветеринарів, механіків, спеціалістів з переробки продукції тваринництва).

На нашу думку, потрібен універсальний підхід до ноосферізації вузівського курсу хімічних дисциплін, який можна було б застосувати під час хімічної освіти студентів вищезгаданих спеціальностей.

Вважаємо, що ноосферна освіта повинна реалізовуватись на основі міждисциплінарних зв'язків між природничими та спеціальними дисципліна у межах системного підходу, що забезпечує цілісне світорозуміння. 
Системоутворюючим фактором даного процесу вважаємо формування агроеконоосферної свідомості майбутнього спеціаліста на фаховому (передбачає хімічну підготовку, вміння здобувати та застосовувати знання у професійній діяльності) та загальнокультурному рівнях.

Хімічні поняття, закони i теорії забезпечують фундаментальність хімічної освіти в аграрному вузі, а факти конкретну емпіричну основу, практичну направленість, зв'язок теорії 3 життям. Ілюстрація теоретичних положень на прикладі об'єктів, пов'язаних із майбутньою спеціальністю студентів, посилює інтерес до хімії та мотивацію до іiі вивчення, сприяє свідомому засвоєнню хімічних знань на основі розвитку рефлексії.

Детальніше зупинимось на ноосфер них ідеях у вивченні яких беруть участь хімічні знання. У публікації О. П. Мітрясової виділено 8 „ключових категорій” [2]. Ми дотримувались, запропонованої класифікації, проте дещо змінили та доповнили їі.

Отже, до світоглядних категорій у змісті хімічної освіти фахівця сільського господарства відносимо:

1) якість життя та здоров'я людини, що пов'язане із якістю продукції рослинництва i тваринництва, впливом мікро- i макроелементів на живий організм, токсикологічними характеристиками речовин;

2) хімізація сільськогосподарського виробництва передбачає врахування ідеї про зростання потреби в продукції сільського господарства у зв'язку з ростом населення на планеті. Поняття про хімізацію сільськогосподарського виробництва $\epsilon$ частиною узагальнюючої ідеї про хімічне оточення людини і забезпечує збільшення врожайності сільськогосподарських культур, зростання продуктивності тваринництва, підвищення біологічної повноцінності продукції, захист рослин і тварин від шкідників і хвороб, зниження собівартості продукції тощо;

3) екологічна безпека та екологічні проблеми сільського господарства розглядається, як будь-який шкідливий вплив дій людини на агросистему: деградація грунтів, забруднення залишками мінеральних добрив та пестицидів, несприятливі зміни гідрологічного режиму та ін.

4) взаємозв'язки в довкіллі це одне 3 провідних понять у створенні уявлень про хімічну картину світу. У межах неорганічної хімії - генетичний взаємозв'язок між класами неорганічних речовин, органічної - причини різноманітності органічних сполук, взаємозв'язок між ними;

5) прогнозування майбутнього співіснування людства і природи 3 урахуванням перспектив сталого розвитку передбачає ознайомлення 
3 напрямками використання хімічних знань у розв'язанні проблеми збереження рівноваги в довкіллі.

Враховуючи вищенаведене можемо зробити наступні висновки: викладання хімічних дисциплін студентам сільськогосподарських спеціальностей повинно розкривати необхідність хімічних знань для професійного становлення спеціаліста АПК та формувати агроеконоосферний тип свідомості. Для забезпечення цього завдання потребують розвитку та удосконалення форми, методи i засоби навчальної діяльності, що застосовуються в методиці викладання дисциплін хімічного циклу.

\section{Література}

1. Дерябо С. Д. Экологическая педагогика и психология / С. Д. Дерябо, В. А. Ясвин. - Ростов-на-Дону : Издательство “Феникс”, 1996. $-480 \mathrm{c}$.

2. Мітрясова О. П. Стратегічні засади конструювання змісту хімічної освіти у вищій школі / О. П. Мітрясова // Педагогіка і психологія. - 2009. - № 2 (63). - С. 104-111.

3. Симбирских Е. С., Молоткова Н. В., Анкудимова И. А. Ноосферный подход к обучению химии в аграрном вузе / Е. С. Симбирских, Н. В. Молоткова, И. А. Анкудимова // Вестник МичГАУ : научно-производственный журнал / отв. ред. Г. В. Климанов. - Мичурнск : ФГБОУ ВПО МичГАУ, 2010. - № 2. C. 240-243.

Ольга Швец. Формирование агроеконоосферного сознания современного специалиста АПК при изучении дисциплин химического цикла.

В статье исследована роль химического образования в формировании агроеконоосферного сознания студентов сельскохозяйственных специиальностей. Определень ее основные уровни: профессиональный и общекультурный. $B$ качестве основного подхода к ноосферному образованию избран системный. $B$ содержании химического образования выделено 5 мировоззренческих категорий: качество жизни и здоровья человека, химизация сельскохозяйственного производства, экологическая безопасность и экологические проблемы, взаимосвязи в окружающей среде, прогнозирования будущего сосуществования человечества и природы.

Ключевые слова: агроеконоосферное сознание, специалист сельского хозяйства, преподавание химии.

Olga Shvets. Formation of agroeconoosferical consciousness of modern agrarian specialist in the study of disciplines of chemical cycle. The article explored the role of chemical education in the formation of agroeconoosferical consciousness of students of agricultural specialties. Determined its fundamental levels: professional and general cultural. 
Психолого-педагогічні проблеми становлення сучасного фахівця Випуск 2014 Systemical approach is selected as a main in noosphere education. Five philosophical categories such as: quality of life and human health; use of chemicals in agricultural production; ecological safety and environmental issues; the relationships in the environment, forecasting of the future coexistence of humanity and nature are determined the content of chemical education.

Key words: agroeconoosferical consciousness, specialist of agriculture, teaching chemistry.

Стаття надійшла до редакційної колегії 13.05.2014

УДК 378.013-051

\section{Шендерук Олена Борисівна}

(с) Шендерук О. Б., 2014.

Чернігівський національний педагогічний університет

ім. Т. Г. Шевченка

\section{СУЧАСНІ ПІДХОДИ ДО ВИЗНАЧЕННЯ ПОНЯТТЯ "ВИКЛАДАЧ"}

В даній статті проведено аналіз концепту “викладач”. Проаналізовано стан досліджуваної проблеми в науковій літературі. Охарактеризовано теоретичний аспект цьього поняття. Розкрито основні критерї, компоненти вищезгаданої понятійної категорії. Наведено різні визначення цүього поняття, починаючи з довідковословникової літератури $i$ закінчуючи нормативно-правовими документами. Означено вимоги до посади “викладач”, окреслено основні його функиії та виділено сучасні підходи до визначення изього поняття.

Ключові слова: викладач, вчитель, функція викладача, сучасні підходи.

Вивчення наукової літератури, а також нормативно-правових документів переконливо засвідчує, що існує суттєва різниця між поняттями “викладач” і “вчитель”. Одночасно аналіз психологопедагогічних джерел демонструє, що деякі дослідники не диференціюють ці два поняття, а відтак є плутанина щодо сутності терміну “викладач” і відповідно некоректно, на нашу думку, вживається цей концепт. Тому метою нашої статті $є$ аналіз поняття “викладач" у науковій літературі, визначення основних складових цього феномену, виділення його провідних функцій та доведення відмінності між поняттями “викладач” і “вчитель”.

Дослідженням кваліфікаційних вимог до посади викладача займались дослідники I. Мікульонок, О. Стукало, Н. Тализіна. 


\section{Збірник наукових статей}

Труднощі викладацької діяльності досліджувала Х. Мелько. А функції викладача вивчали Н. Волкова, А. Кузьмінський, І. Підласий. Проте проблема визначення сутності поняття “викладач" вимагає, на нашу думку, більш грунтовного теоретичного осмислення.

Відразу хотілося б відмітити, що порушене нами питання не $є$ новим. Воно було предметом досліджень багатьох вчених ще в минулих століттях. Так, ще німецькій вчений Вільгельм Оствальд на підставі швидкості розумових реакцій ділив вчених на "класиків", що здійснюють наукову діяльність поволі, але глибоко і “романтиків”, які творять швидко, але поверхнево і зацікавлені в оточені, яке сприймало б їхні ідеї. А видатний французький математик та фізик Жюль Анрі Пуанкаре класифікував викладачів на “аналітиків" і “геометрів". Російський науковець 60-х рp. XX ст. В. Волгін розподіляв їх за стилем роботи на: теоретиків, експериментаторів та організаторів. За стилем наукової творчості він поділяв їх на “галузевиків" та “систематиків" [1].

По-перше, з'ясуємо хто ж такий викладач? Відповідно до ст. 48 Закону України "Про вищу освіту” на посаду науково-педагогічних працівників обираються за конкурсом особи, які мають наукові ступені або вчені звання, а також випускники магістратури, аспірантури та докторантури.

Які ж вимоги до посади викладача ВНЗ? Це особи, які відповідають п. ХХ положення та:

- мають науковий ступінь за профілем кафедри або

- мають вчене звання за профілем кафедри або

- $\epsilon$ випускниками докторантури чи аспірантури за відповідною спеціальністю і мають стаж педагогічної роботи не менше як 1 рік у BH3 III-IV рівнів акредитації або

- закладах післядипломної освіти з оплатою праці не менше як 0,25 посадового окладу (ставки заробітної плати) або

- мають стаж педагогічної роботи не менш як 2 роки у ВНЗ IIIIV рівнів акредитації за профілем кафедри з оплатою праці не менше як 0,25 посадового окладу, а також наукові праці або мають вищу освіту освітньо-кваліфікаційного рівня магістра за відповідною спеціальністю, стаж роботи за профілем кафедри не менше як 4 роки, а також наукові праці і схильність до науково-педагогічної роботи [4].

Словниково-довідкова література дуже примітивно, на нашу думку, окреслює повноваження викладача. Так, у словнику української мови знаходимо наступне визначення: "Викладач - той, хто читає лекції, веде уроки в учбових закладах”. В Педагогічній енциклопедії наводиться таке визначення: "Викладач в широкому сенсі слова це працівник вищої, середньої спеціальної, професійно-технічної або загальноосвітньої школи, ведучий який-небудь учбовий предмет. У 
вузькому сенсі - штатна посада у вузах, середніх і професійнотехнічних учбових закладах".

В Вікіпедії знаходимо наступне визначення: “Викладач вищого навчального закладу - це посада, займаюча проміжне місце між асистентом і старшим викладачем. На таку посаду призначаються педагоги без вченого ступеня і з досвідом роботи". Але це визначення повністю суперечить ст. 48 Закону України "Про вищу освіту".

Цікаві думки 3 порушеного питання знаходимо на сайті Difference.ru. Завдяки проведеному аналізу понять “викладач” i “вчитель”, ми встановили, що викладачем вважається той, хто займається питаннями інформації, контролю, приймає участь в науково-дослідній та науково-методичній роботі. А також зазначається, що викладач не займається питаннями виховання, хоча ми 3 цим не згодні.

“Викладач ВНЗ - це особливий соціальний тип особистості. Це активний соціальний діяч, який здійснює свідомо керовану, цілеспрямовану та організовану соціалізацію студентів, їхнє навчання і виховання." - зазначає дослідниця О. Стукало.

Цікаві думки 3 приводу визначення поняття “викладач” ми знаходимо у російських дослідників В. Кікоть, А. Столяренко, які вважають, що викладач виконує обов'язки 3 підготовки молодих кадрів в системі вищої професійної освіти. Вони наголошують, що діяльність викладача суттєво відрізняється від діяльності вчителя. Це пояснюється віком студентів, а також цілями, задачами і змістом навчання і виховання в вищій школі.

В ході нашого дослідження ми побачили, що деякі дослідники, такі, наприклад як О. Стукало, вважають, що нині в Україні взагалі не існує стандартного шляху чи єдиного соціального інституту, який би забезпечував підготовку викладачів ВНЗ. А дослідниця Н. Ф. Тализіна вважає, що протиставлення викладачів вищої і середньої школи $\epsilon$ невиправданим.

Українська дослідниця X. Мелько вважає, що діяльність викладача ВН3 є більш різноманітною, ніж праця вчителя, тому що, окрім педагогічної вона включає i науково-дослідну сторону, яка вимагає спеціальних здібностей.

По структурі наукової діяльності і тому, які саме здібності розвинені, науковці вважаються “відкривачами”, “генераторами ідей”, “класиками” та “систематиками” - зазначає вона.

Які ж функції має виконувати викладач? А. І. Кузьмінський виділяє наступні:

- продукування знань (наукові дослідження, впровадження їх в практику); 


\section{Збірник наукових статей}

- передача знань (розмаїття форм, методів, засобів, технологій у навчальному процесі);

- формування в того, хто навчається, уміння й усвідомлення необхідності навчатися упродовж життя [3, с. 139].

I. П. Підласий вважає, що основна функція викладача вищої школи - це управління процесами навчання, виховання, розвитку i формування особистості студента. "Не вчити, а направляти”,-наголошує він.

На думку Н. П. Волкової та А. І. Кузьминського, викладач ВНЗ має задовольняти такі вимоги:

- висока професійна компетентність - глибокі знання і широка ерудиція в науково-предметній галузі, нестандартне мислення, креативність;

- педагогічна компетентність - знання педагогіки і психології, володіння сучасними методами, засобами і технологіями навчання;

- комунікативна компетентність - володіння іноземними мовами, культура усної і писемної форм літературних мов.

Соціально-економічна компетентність - знання глобальних процесів розвитку цивілізації та функціонування сучасного суспільства, основ соціології, економіки та права [2].

Таким чином, вивчення і осмислення провідних ідей науковці, дає нам змогу виділити провідні сучасні підходи до визначення поняття "викладач":

- це штатна посада в вищих навчальних закладах;

- викладач не займається питаннями виховання;

- це особа, яка приймає участь в науково-дослідній та науковометодичній роботі.

Ми робимо висновок: викладач - це особа, яка закінчила магістратуру та здійснює навчально-виховний процес у вищому навчальному закладі. Ніякого відношення до загальноосвітньої школи чи до середніх спеціальних закладів освіти викладач не має. В останніх працюють вчителі, діяльність яких кардинально відрізняється від діяльності викладачів.

\section{Література}

1. Волгин В. Н. Молодежь в науке / В. Н. Волгин. - М. : Феникс, 1964. $-135 \mathrm{c}$.

2. Волкова Н. П. Педагогічні комунікації / Н. П. Волкова. Дніпропетровськ : ДНУ, 2005. - 128 с.

3. Кузьмінський А. І.Педагогіка вищої школи : Навчальний посібник / А. І. Кузьмінський. - К. : Знання, 2005. - 486 с.

4. Мікульонок I. Про професійно-кваліфікаційні вимоги до посад науково-педагогічних працівників ВН3 / I. Мікульонок // Вища школа. - 2013. - № 12. - С. 15-22. 
Елена Шендерук. Современные подходы к определению понятия "преподаватель".

В статье рассматривается понятие “преподаватель". Автор анализирует разнообразные подходы относительно этого концепта. Представлены различные точки зрения отечественных и зарубежных ученых касательно этого термина. Определены основные функиии преподавателя.

Ключевые слова: преподаватель, учитель, подходы, концепция преподавания.

\section{Olena Shenderuk. Modern approaches to defining the notion "teacher".}

This article deals with the essence of the concept "teacher". The author analyses the modern approaches to this notion. Special aspects of teaching understanding by local and foreign scientists are studied. The main teacher's functions are performed.

Key words: teacher of a high school, teacher of a secondary school, approaches, teaching conceptions.

Стаття надійшла до редакційної колегії 03.04.2014

УДК 159:331.101.3

\section{Штученко Ірина Свгенівна}

(C) Штученко I. Є., 2014. Національний технічний університет «Харківський політехнічний інститут»

\section{ОСОБЛИВОСТІ ПРОФЕСІЙНОЇ МОТИВАЦІЇ СТУДЕНТІВ ТЕХНІЧНИХ ВНЗ У ПЕРІОД НАВЧАННЯ}

В даній статті розглянуто основні підходи у вітчизняній $i$ зарубіжній психології, пов'язані з проблемою професійної мотивації. Проаналізовано результати досліджень джерел професійної мотивації студентів технічних ВНЗ та їх вплив на ухвалення кар'єрного рішення в прочесі навчання у ВНЗ. В групах досліджуваних iз різним кар'єрним спрямуванням виявлено взаємозв'язок між джерелами професійної мотивачії та кар'єрною орієнтацією.

Ключові слова: потреба, професійна мотивачія, кар'єрна спрямованість.

У нинішній час проблема становлення висококваліфікованих спеціалістів має велике значення. Сучасне суспільство висуває перед випускником ВНЗ особливі вимоги, серед яких важливе місце посідають високий професіоналізм, активність, творчість. Професійна 


\section{Збірник наукових статей}

діяльність забезпечує самореалізацію особистості, актуалізацію всіх їі можливостей, $є$ основою самоствердження у суспільстві. Правильний вибір професійного майбутнього - достатньо складний i тривалий мотиваційний процес. На етапі навчання у ВНЗ питання, пов'язані 3 професійною діяльністю, набувають особливого значення. Під час підготовки майбутніх спеціалістів важливо знати вимоги до професії, виділяти в ній найсуттєвіші особливості, що можуть показати людині, яка вибирає рід діяльності, чи підходить для неї ця праця, чи відповідає внутрішнім потребам людини, нахилам та здібностям. Вивчення структури професійно-орієнтованої мотивації студентів технічних вузів, знання мотивів, що спонукають людей до роботи в тій чи іншій сфері, дозволить планувати професійну кар'єру, психологічно обгрунтовано розв'язувати завдання підвищення ефективності професійної діяльності. Проблема мотивів професійної діяльності є на сьогодні одним 3 актуальних аспектів професійної підготовки, пов'язаної 3 вищою освітою. Аналіз вітчизняних та зарубіжних досліджень свідчить, що проблематика професійної мотивації молодого покоління $\epsilon$ актуальною, але недостатньо дослідженим залишається аспект професійної мотивації студентів технічних вузів із різною кар'єрною спрямованістю. Ця проблема потребує більш детального дослідження, оскільки під час навчання у ВНЗ формуються джерела професійної мотивації, а також існують можливості впливу на них.

Mema ųiє̈ cmammi: проаналізувати основні наукові підходи до проблеми професійної мотивації; виявити особливості професійної мотивації у студентів технічних вузів із різною кар'єрною орієнтацією.

Професійне становлення студентів включає процес розвитку самосвідомості: самовдосконалювання професійно важливих якостей особистості, формування мотиваційно-особистісного ставлення до майбутньої професії. Шлях до ефективної професійної діяльності людини перебуває у прямому зв'язку з їі мотивацією. Схильність до певного типу діяльності може виявлятися в різних видах праці, а отже, сама ця схильність іще не передбачає вузькоспрямованого професійного вибору. Професійна мотивація - це дія конкретних спонук, що зумовлюють вибір професійної сфери діяльності та відповідну кар'єрну спрямованість у цій сфері. Вибір кар'єрної орієнтації тісно пов'язаний із реалізацією професійних мотивів.

Різним аспектам професійної мотивації присвячені дослідження О. М. Леонтьєва, А. К. Маркової, Л. І. Божович, Е. Ф. Зєєра та інших.

Мотиви професійної діяльності, на думку А. К. Маркової, виражають сформовані раніш потреби особистості, актуалізовані при взаємодії з професією [4]. 
Опис найтиповіших мотивів професійної діяльності містить теорія Ф. Херцберга, згідно з якою мотиви розрізняються за спрямованістю. Перша група спрямована на розв'язання виробничих завдань: можливість досягнення успіху в роботі, наявність шансів просування по службі, визнання результатів роботи, добра оплата праці, підвищення рівня професійної компетентності. До другої групи належать мотиви - «чинники гігієни»: умови праці, добрі стосунки зі співробітниками, гнучкий графік роботи [5].

Професійної сфери також стосується теорія мотивації Д. Мак Клелланда, в якій розглядаються три групи потреб людини: потреби влади, потреби успіху, потреби причетності [1].

$€$ Є. І. Ільїн до мотивів професійної діяльності відносить спонуки суспільного характеру: приносити користь суспільству, надавати допомогу іншим людям, отримувати визначні матеріальні блага, задовольняти потреби самоактуалізації, самореалізації [3, с. 270].

Ю. М. Орлов говорить про взаємозв'язок мотивів та цінностей у студентському віці. Ціннісні орієнтації - це орієнтири, на основі яких людина виконує свою професійну діяльність. За класифікацією О. Ф. Потьомкіної такими ціннісними орієнтаціями $є$ : «воля», «праця», «влада», «гроші» [4].

Таким чином, теоретичний огляд матеріалів щодо цієї проблеми показав, що аспект професійної мотивації майбутніх інженерів із різною кар'єрною спрямованістю залишається недостатньо дослідженим. Перспективною видається необхідність вивчення причин мотивації професійної діяльності студентів технічних ВН3 у період навчання 3 метою коригування для подальшого збільшення ефективності майбутньої трудової діяльності.

Завдання дослідження:

- визначити спрямованість кар'єрних орієнтацій майбутніх інженерів;

- визначити та проаналізувати особливості ієрархії джерел професійної мотивації у студентів технічних ВНЗ із різною кар'єрною спрямованістю.

Для визначення кар'єрної спрямованості студентів, а також особливостей професійної мотивації нами здійснено емпіричне дослідження, у якому брав участь 271 студент НТУ «ХПІ» (юнаки і дівчата у віці 18-20 років). В якості діагностичних інструментів були використані такі теоретичні методи: аналіз, систематизація наукових даних; емпіричні методи: опитувальник «Якорі кар'єри» (Е. Шейна), «Опитувальник для визначення джерел мотивації» (Джон Барбуто, Ричард Сколл); статичні методи: метод середніх арифметичних.

За результатами методики Е. Шейна «Якорі кар'єри» усі досліджувані були поділені на 4 групи: 1) група осіб, у яких переважає 
спрямованість «професійна компетентність» 2) група осіб, у яких переважає спрямованість «менеджмент»; 3) група осіб, у яких переважає дві спрямованості одночасно - «професійна компетентність» та «менеджмент»; 4) невизначена частина студентів.

За результатами тесту «Визначення джерел мотивації» визначено особливості професійної мотивації в усіх групах досліджуваних: професійна компетентність - 48 осіб, менеджмент - 97 осіб, професійна компетентність та менеджмент одночасно - 75 осіб, невизначена частина студентів - 51 особа.

В усіх групах досліджуваних найвагомішим джерелом мотивації $\epsilon$ бажання бути самостійними, мати можливість ухвалення рішень. У групах студентів, у яких переважає спрямованість «менеджмент», а також у групах, у яких переважають дві спрямованості одночасно: «професійна компетентність» та «менеджмент» друге місце посідає бажання матеріальних винагород за працю, третє місце - бажання задоволення від процесів діяльності. У групі 3 переважанням спрямованості «професійна компетентність», а також у групі досліджуваних із невизначеною кар'єрною спрямованістю потреба задоволення від праці посідає друге місце, що свідчить про більшу вагомість цієї потреби відносно потреби володіння матеріальними цінностями. В усіх групах досліджуваних четверте місце посіла потреба досягнення цілей, що відповідають внутрішнім цінностям, а п’яте місце - потреба визнання та схвалення.

На підставі здійсненого дослідження можна стверджувати, що існує взаємозв'язок між джерелами професійної мотивації у студентів технічних ВНЗ та кар'єрною спрямованістю.

Отже, можна зробити такі висновки:

- серед професійних потреб існують потреби, пов'язані 3 необхідністю приносити користь суспільству, отримувати визначні матеріальні блага, задовольняти потреби в самоактуалізації, самовираженні, в суспільному визнанні, в повазі з боку інших людей, що спонукає до ухвалення відповідного кар'єрного рішення;

- серед досліджуваних виділено групи 3 різним провідним кар'єрним спрямуванням: «професійна компетентність», «менеджмент», «професійна компетентність» та «менеджмент» одночасно, а також група досліджуваних із невизначеною кар'єрною орієнтацією;

- особливістю професійної мотивації у досліджуваних із різним кар'єрним спрямуванням є: потреба бути самостійними перевищує інші в усіх групах досліджуваних; потреба матеріального добробуту має більш вагоме - відносно потреби задоволення від праці - значення в осіб із переваженням спрямованості «менеджмент», а також у групах, у яких переважають одночасно дві спрямованості - 

«професійна компетентність» та «менеджмент», - порівняно з групами досліджуваних із перевагою спрямованості «професійна компетентність» та 3 невизначеною частиною досліджуваних: у цих двох останніх групах потреба задоволення від праці перевищує вагомість матеріального добробуту. Потреба здобуття поваги, схвалення, визнання посідає останнє місце в ієрархії мотивів в усіх групах досліджуваних.

Подальшою перспективою $є$ розроблення системи психологічного супроводу студентів у період навчання у ВНЗ: вивчення мотивів професійної діяльності, вплив на механізми їх формування, визначення кар'єрної спрямованості, усвідомлення та уточнення кар'єрного рішення.

\section{Література}

1. Дорофеев В. Д., Шмелева А. Н., Шестопал Н. Ю., Менеджмент: Учебное пособие / В. Д. Дорофеев, А. Н. Шмелева, Н. Ю. Шестопал. - М. : Высшее образование, 2008. - 440 с.

2. Зеер Э. Ф. Психология профессий. Учебное пособие для студентов вузов / Э.Ф. Зеер. - 2-е изд., перераб., доп. - М. : Академический проект, 2003. - 336 с.

3. Ильин Е. П. Мотивация и мотивы / Е. П. Ильин. - СПб. : Питер, 2008. - 512 с.

4. Маркова А. К., Матис Т. А., Орлов А. Б. Формирование Мотивации учения / А. К. Маркова, Т. А. Матис, А. Б. Орлов. - М. : Просвещение, 1990. - 192 с.

5. Ф. Херцберг, Б. Моснер, Б. Блох Снидерман. Мотивация к работе / Ф. Херцберг, Б. Моснер, Б. Блох Снидерман. - М. : Вершина, 2007. - 240 c.

Ирина Штученко. Особенности профессиональной мотивации студентов технических вузов в период обучения.

В данной статье рассмотрены основные подходы в отечественной и зарубежной психологии, связанные с проблемой профессиональной мотивации. Проанализировань результатьл исследований источников профессиональной мотивации студентов технических вузов и их влияние на принятие карьерного решения в прочессе обучения в вузе. $B$ группах испьтуемых с разной карьерной направленностью выявлена взаимосвязь между источниками профессиональной мотивации $и$ карьерной ориентацчией.

Ключевые слова: потребность, профессиональная мотивация, карьерная направленность. 
Збірник наукових статей

\section{Irina Shtuchenko. The peculiarities of the professional motivation of the students from higher technical educational institutions during their studies.}

The article deals with the main approaches of home and foreign psychology, connected with the problem of the professional motivation. The results of the investigations of professional motivation sources displayed by the students from higher technical educational institutions and their influence on approving career decisions while their studying at institutes of higher education have been analysed. The interconnection between professional motivation sources and career orientation has been revealed in the groups, tested according to different career trends.

Key words: necessity, professional motivation, career orientation.

Стаття надійшла до редакційної колегії 09.05.2014 


\section{АВТОРИ}

Абасалісва Оксана Миколаївна - практичний психолог, викладач, Красноградський коледж Комунального закладу «Харківська гуманітарно-педагогічна академія» Харківської обласної ради.

Абраменко Павло Олексійович - кандидат сільськогосподарських наук, доцент, Харківський національний аграрний університет імені В. В. Докучаєва.

Алекссєва Марія Ігорівна - кандидат педагогічних наук, доцент, Харківський національний економічний університет імені С. Кузнеця.

Багаліка Тетяна Михайлівна - доцент, Інститут Управління державної охорони України Київського національного університету імені Тараса Шевченка.

Безугла Ірина Валентинівна - старший викладач, Харківський національний економічний університет імені С. Кузнеця.

Бондар Оксана Євгеніївна - старший викладач, Дніпропетровський національний університет імені Олеся Гончара.

Борисенко Денис Володимирович - аспірант, Українська інженернопедагогічна академія.

Борова Тетяна Анатоліївна - доктор педагогічних наук, професор завідувач кафедри іноземних мов, Харківський національний економічний університет імені С. Кузнеця.

Бугайчук Костянтин Леонідович - кандидат юридичних наук, доцент, провідний науковий співробітник, Харківській національний університет внутрішніх справ.

Булиніна Оксана Дмитріївна - асистент кафедри фізіології, Харківський національний медичний університет.

Васильсва Оксана Василівна - кандидат медичних наук, асистент кафедри фізіології, заступник декану 6 факультету по роботі 3 іноземними студентами, Харківський національний медичний університет.

Верховська Марина Володимирівна - аспірант, викладач, Дніпропетровський національний університет імені Олеся Гончара.

Вільчинська Тамара Володимирівна - старший викладач, Хмельницький національний університет.

Вознюк Оксана Миколаївна - кандидат педагогічних наук, доцент, Львівська філія Дніпропетровського національного університету залізничного транспорту імені акад. В. Лазаряна.

Волошина Ірина Василівна - аспірант, Хмельницький національний університет.

Газизова Регина Расиховна - старший преподаватель, Стерлитамакский филиал Башкирского государственного университета, Россия. 
Громова Наталия Михайловна - кандидат психологических наук, доцент, Киевский университет имени Бориса Гринченко.

Груша Ляля Олександрівна - кандидат педагогічних наук, Національний медичний університет імені О. О. Богомольця, м. Київ.

Давидова Жанна Вадимівна - доцент кафедри іноземних мов та перекладу, Харківський національний економічний університет імені С. Кузнеця.

Дмитренко Тамара Олександрівна - доктор педагогічних наук, професор, Херсонський державний університет.

Дубниченко Варвара Юрьевна - кандидат философских наук, Донецк.

Дубовицкая Татьяна Дмитриевна - доктор психологических наук, профессор, Башкирский государственный педагогический университет им. М. Акмуллы, Россия.

Дядечко Алла Миколаївна - кандидат філологічних наук, доцент, Сумський державний університет.

Єрастова-Михалусь Інна Борисівна - аспірант, викладач, Харківський національний економічний університет імені С. Кузнеця.

Єрохов Роман Олександрович - кандидат біологічних наук, докторант, Міжрегіональна академія управління персоналом.

Свдокімова-Лисогор Леся Анатоліївна - викладач, Харківський національний економічний університет імені С. Кузнеця.

Єхалов Василь Віталійович - кандидат медичних наук, доцент, Державний заклад «Дніпропетровська медична академія MO3 України».

Заварусва Інна Іванівна - кандидат філологічних наук, доцент, Дніпропетровський національний університет залізничного транспорту Заїка Євген Валентинович - кандидат психологічних наук, професор кафедри загальної психології факультету психології Харківського національного університету імені В. Н. Каразіна.

Золотова Світлана Григорівна - старший викладач, директор Лінгвістичного центру, Сумський державний університет.

Іваніга Орина Валеріївна - старший викладач, Харківський національний економічний університет імені С. Кузнеця.

Ірчишина Марина Віталіївна - викладач, Дніпропетровський національний університет ім. О. Гончара

Кайдалова Лідія Григорівна - доктор педагогічних наук, професор, завідувач кафедри педагогіки i психології, Національний фармацевтичний університет.

Калашник Любов Сергіївна - кандидат педагогічних наук, доцент, докторант, Інститут вищої освіти Національної академії педагогічних наук України. 
Камишний Олександр Михайлович - доктор медичних наук, доцент, завідувач кафедри мікробіології, вірусології та імунології, Запорізький державний медичний університет.

Ключка Світлана Іванівна - кандидат педагогічних наук, доцент, Черкаський державний технологічний університет.

Коваль Аліна Сергіївна - викладач, Харківський національний економічний університет імені С. Кузнеця.

Ковальчук Дарія Василівна - аспірант, національний педагогічний університет імені М. П. Драгоманова.

Колбіна Тетяна Василівна - доктор педагогічних наук, професор, завідувач кафедри іноземних мов та перекладу, Харківський національний економічний університет імені С. Кузнеця.

Кондрацька Людмила Анатоліївна - доктор педагогічних наук, професор, Тернопільський національний педагогічний університет імені Володимира Гнатюка.

Копилова Світлана Вікторівна - кандидат педагогічних наук, доцент, Херсонський державний університет.

Костикова Ольга Владимировна - старший преподаватель, Харьковский национальный педагогический университет имени Г. С. Сковороды.

Костюченко Олена Вікторівна - кандидат психологічних наук, доцент, Київський національний університет культури і мистецтв.

Кравченко Лілія Григорівна - доктор медичних наук, професор, Одеський національний медичний університет.

Крайнова Тетяна Іванівна - керівник Секції науковопсихотерапевтичних досліджень та Секції психоаналітичної психотерапії Харківського відділення Українського союзу психотерапевтів; Центр сучасної наукової психотерапії.

Кривда Григорій Федорович - доктор медичних наук, професор, завідувач кафедри судової медицини та медичного законодавства, Одеський національний медичний університет.

Лаврик Тетяна Володимирівна - кандидат педагогічних наук, завідувач лабораторії педагогічних інновацій, Сумський державний університет.

Лаппо Віолетта Валеріївна - кандидат педагогічних наук, доцент, Коломийський інститут ДВНЗ «Прикарпатський національний університет імені Василя Стефаника».

Ластовець Ігор Володимирович - начальник курсу факультету підготовки спеціалістів експертно-криміналістичних підрозділів, Національна академія внутрішніх справ, м. Київ.

Лотиш Надія Григорівна - кандидат медичних наук, доцент, Одеський національний медичний університет. 
Лукашова Людмила Василівна - старший викладач, Харківський національний економічний університет імені С. Кузнеця.

Луніна Марина Леонідівна - викладач, Харківський національний економічний університет імені С. Кузнеця.

Лютвієва Ярослава Павлівна - старший викладач, Харківський національний економічний університет імені С. Кузнеця.

Малинівська Людмила Іванівна - кандидат педагогічних наук, доцент, Житомирський державний університет імені Івана Франка.

Малихіна Олена Євгенівна - кандидат психологічних наук, доцент, Харківський національний педагогічний університет імені Г. С. Сковороди.

Мельник Юрій Борисович - кандидат педагогічних наук, доцент, практичний психолог-методист, професор кафедри військового навчання та виховання, Академія внутрішніх військ МВС України; Голова Правління ХОГОКЗ.

Митроченко Ольга Євгенівна - кандидат психологічних наук, старший викладач, Харківський національний університет імені В. Н. Каразіна.

Морозова Ірина Анатоліївна - старший викладач, Сумський державний університет.

Нагаєв Віктор Михайлович - доктор педагогічних наук, професор, Харківський національний аграрний університет імені В. В. Докучаєва. Оксенюк Ірина Леонідівна - аспірант, начальник сектора якості та аудиту Авіаційного навчально-тренувального центру, Національний авіаційний університет, м. Київ.

Олексенко Олена Олексіївна - аспірант, викладач, Харківський національний економічний університет імені С. Кузнеця.

Осадча Олена Володимирівна - старший викладач, Дніпропетровський національний університет імені Олеся Гончара.

Осьмук Наталія Григорівна - кандидат педагогічних наук, доцент, Сумський державний педагогічний університет імені А. С. Макаренка.

Папінко Роман Мар'янович - кандидат медичних наук, асистент, Одеський національний медичний університет.

Повстяна Юлія Славомирівна - асистент, Луцький національний технічний університет.

Погорслова Тетяна Феодосіївна - доцент, Український державний університет фінансів та зовнішньої торгівлі.

Полежаєва Олена Вікторівна - старший викладач, Харківський національний економічний університет імені С. Кузнеця.

Поліщук Валерій Миколайович - доктор психологічних наук, доцент, завідувач кафедри практичної психології, Глухівський національний педагогічний університет імені Олександра Довженка. 
Пономарьова Лілія Федорівна - кандидат філологічних наук, доцент, завідувач кафедри іноземних мов для інженерно-технічних та природничих спеціальностей, Дніпропетровський національний університет імені Олеся Гончара.

Попович Наталія Михайлівна - кандидат педагогічних наук, доцент, докторант, Київський університет імені Бориса Грінченка.

Посудиевская Ольга Ростиславовна - кандидат филологических наук, доцент, Днепропетровский национальный университет имени О. Гончара.

Поуль Валентина Станіславівна - завідувач відділу методичного забезпечення оздоровчої функції освіти, Донецький обласний інститут післядипломної педагогічної освіти.

Птахіна Ольга Миколаївна - кандидат педагогічних наук, доцент, Луганський національний університет імені Тараса Шевченка.

Радченко Марина Аркадіївна - кандидат педагогічних наук, доцент, Східноєвропейський національний університет імені Лесі Українки.

Россова Марія Михайлівна - викладач, Академія внутрішніх військ МВС України; здобувач, Волинський національний університет імені Лесі Українки.

Савицька Лариса Володимирівна - кандидат філологічних наук, доцент, Харківський національний економічний університет імені С. Кузнеця.

Самохвалов Валерій Гаврилович - доктор медичних наук, професор, завідувач кафедри фізіології, Харківський національний медичний університет.

Святенко Тетяна Павлівна - аспірант, Харківський національний університет імені В. Н. Каразіна.

Сединкин Владислав Анатольевич - кандидат медичних наук, асистент, Державний заклад «Дніпропетровська медична академія MO3 України».

Сергіснко Ольга Володимирівна - аспірант, Харківський національний економічний університет імені С. Кузнеця.

Скринник Ірина Олександрівна - викладач, Харківський кооперативний торгово-економічний коледж.

Станін Дмитро Михайлович - кандидат медичних наук, доцент, Державний заклад «Дніпропетровська медична академія MO3 України».

Стоєва Тетяна Вікторівна - доктор медичних наук, професор, Одеський національний медичний університет.

Тесля Роман Віталійович - методист, аспірант, Черкаський обласний інститут післядипломної освіти педагогічних працівників.

Тинкалюк Оксана Володимирівна - асистент, викладач, Львівський національний університет імені Івана Франка. 
Торяник Леонид Борисович - старший викладач, Харьковский национальный экономический университет имени Семена Кузнеца.

Федорук Галина Миколаівна - аспірант, викладач, Вінницький державний педагогічний університет імені М. Коцюбинського.

Фрицюк Валентина Анатоліївна - кандидат педагогічних наук, доцент, Вінницький державний педагогічний університет імені М. Коцюбинського.

Хачатрян Єва Левонівна - викладач, Харківський національний економічний університет імені С. Кузнеця.

Ципіна Діана Савеліївна - аспірант, викладач, Харківський національний економічний університет імені С. Кузнеця.

Черниш Людмила Миколаївна - старший викладач, Харківський національний економічний університет імені С. Кузнеця.

Шаповал Микита Володимирович - магістр, Харківський національний університет імені В. Н. Каразіна.

Швець Ольга Григорівна - кандидат педагогічних наук, доцент, Сумський національний аграрний університет.

Шендерук Олена Борисівна - аспірант, старший викладач, Чернігівський національний педагогічний університет імені Т. Г. Шевченка.

Штученко Ірина Євгенівна - асистент, Національний технічний університет «Харківський політехнічний інститут». 


\section{Вимоги до оформлення статті}

\section{в науковому збірнику}

\section{ПСИХОЛОГО-ПЕДАГОГІЧНІ ПРОБЛЕМИ}

СТАНОВЛЕННЯ СУЧАСНОГО ФАХІВЦЯ

Матеріал подається на одній 3 робочих мов конференції: українською/російською/англійською/німецькою/французькою.

Форматування тексту статmі. Обсяг статті: від 3 до 7 повних сторінок, включно зі списком цитованої літератури (не більш 5 джерел), формату А 4. Розмір полів: ліве, праве, верхнє, нижнє - 20 мм. Міжрядковий інтервал - 1,5. Шрифт "Times New Roman”, кегль 14. Текст без переносів, без колонтитулів, вирівнювання по ширині. Всі ілюстрації, схеми, таблиці мають бути розташовані у відповідному місці, а не наприкінці статті.

Текст статті повинен мати такі елементи. 1. Проблема, їі зв'язок із важливими науковими чи практичними завданнями. 2. Ціль статті, постановка завдання. 3. Аналіз публікацій (виділення невирішених проблем). 4. Виклад основного матеріалу, обгрунтування результатів дослідження. 5. Висновки, перспективи. 6. Література.

\section{Порядок оформлення:}

- індекс УДК (ліворуч, жирно, кегль 14);

- прізвище, ім'я та по-батькові автора/авторів, якщо їх декілька, відомості про кожного подаються окремими рядками (по центру, жирно, кегль 14);

- назва організації без скорочень (по центру, кегль 14);

- назва статті (після пропуску 1 рядка, по центру, жирно, кегль 14);

- анотація (мовою статті, після пропуску 1 рядка, без слова анотація, без абзацного відступу, по ширині, курсив, не виділяти жирним, кегль 14), текст анотації повинен мати об'єм 400-500 знаків;

- ключові слова (від трьох до восьми, по ширині, курсив, не виділяти жирним, кегль 14);

- основний текст (після пропуску 1 рядка, по ширині, абзацний виступ 1,25 , кегль 14 , переноси слів не допускаються, по тексту використовуються однакові лапки „,' та апостроф ');

- література (по центру) оформлюється згідно з ДСТУ ГОСТ 7.1:2006 "Система стандартів з інформації, бібліотечної та видавничої справи. Бібліографічний запис...";

\section{На 3-х мовах (рос., укр., англ.)}

- ім'я та прізвище автора/авторів та назва статті (англійською мовою, після пропуску 1 рядка, по ширині, жирно, кегль 14);

- текст анотації (англійською мовою, без слова анотація, без абзацного відступу, по ширині, курсив, кегль 14);

- перелік ключових слів (англійською мовою (Key words), по ширині, курсив, кегль 14). 


\title{
Наукове видання
}

\section{ПСИХОЛОГО-ПЕДАГОГІЧНІ ПРОБЛЕМИ СТАНОВЛЕННЯ СУЧАСНОГО ФАХІВЦЯ}

Збірник наукових статей

Харківського національного економічного університету імені Семена Кузнеця

Матеріали міжнародної науково-практичної конференції (Україна, Харків, 11 - 12 червня, 2014 р.)

\section{PSYCHOLOGICAL AND PEDAGOGICAL PROBLEMS OF MODERN SPECIALIST FORMATION}

\author{
Collected articles
}

Materials of international scientific and practical conference

(11 - 12 June, 2014, Kharkiv, Ukraine)

\section{Друкується в авторській редакції}

(відповідальність за достовірність інформації несе автор роботи)

Видано за кошти авторів. Видано при сприянні ХОГОКЗ.

Відповідальний за випуск

Мельник Юрій Борисович

Технічний редактор Ю. Б. Мельник

Художній редактор Н. Е. Крюкова

Коректура Л. П. Мельник

Комп’ютерне складання та верстання С. М. Свячена

При дизайні обкладинки використано:

фотографії з офіційного сайту ХНЕУ http://www.hneu.edu.ua/

Підп. до друку 26.05.2014 р. Формат 80х64\% $\frac{1}{6}$

Гарн. «Times». Папір для мн. ап. Друк ризограф.

Ум. друк. арк. 22. Обл. вид. арк. 8. Зам. № 1-7

Тираж 110 пр.

Харківський національний економічний університет імені С. Кузнеця Україна, 61166, Харків, пр. Леніна, 9-а

Харківська обласна громадська організація "Культура Здоров'я"

Україна, 61105, м. Харків - 105, пров. Забайкальський, 6/6.

E-mail: CultureHealth@ukr.net; KOSOCH@gmail.com;

http://www.culturehealth.org; тел./факс: (057)775-75-23.

Свідоцтво про державну реєстрацію видавництва

ДК № 4387 від 10.08.2012 